


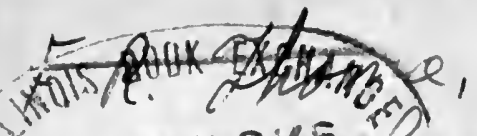

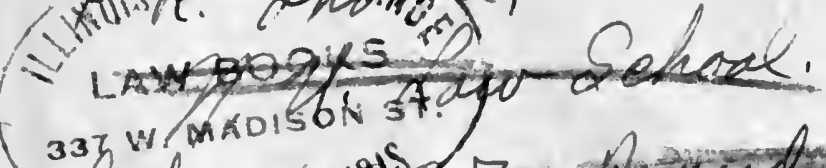
337w manisok st.

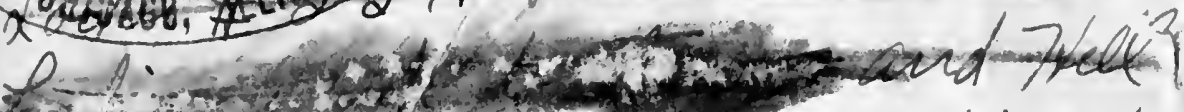
terou

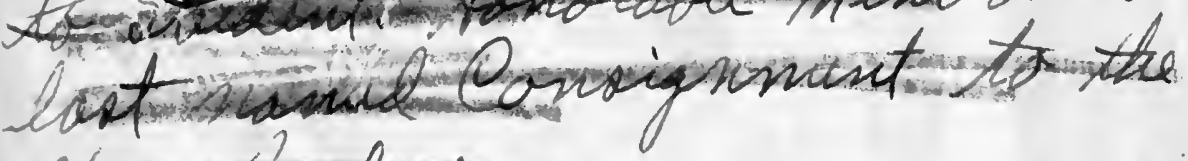

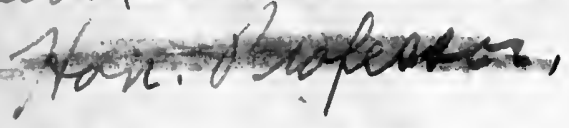

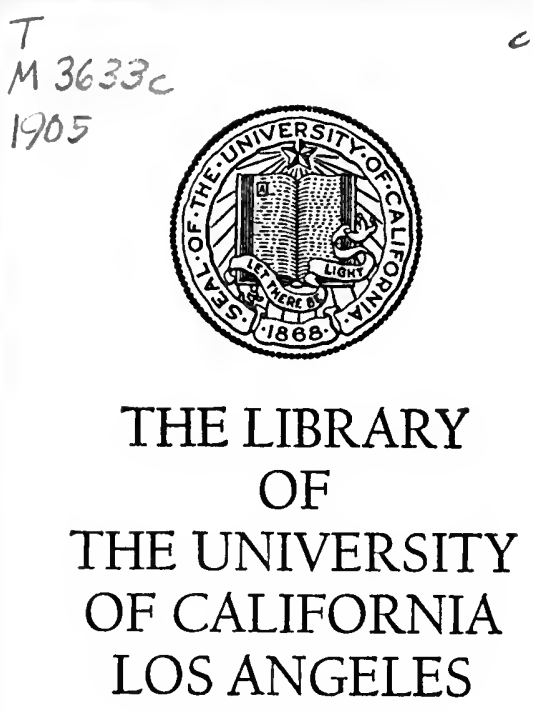

SCHOOL OF LAW

6.3 


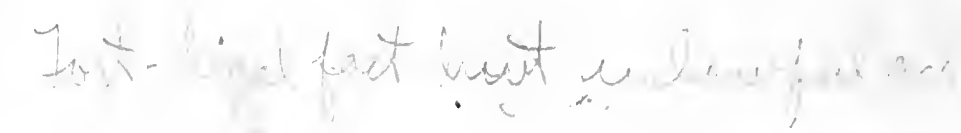<smiles>C1[As][As]1</smiles> 



\section{CIVIL PROCEDURE AT COMMON LAW.}


Digitized by the Internet Archive in 2007 with funding from Microsoft Corporation 


\title{
CIVIL PROCEDURE
}

$\mathbf{A T}$

\section{COMMON LAW.}

\author{
BY \\ ALEXANDER MARTIN, LL.D. \\ DEAN OF THE DEPARTMENT OF LAW IN THE CiNIVERSITY OF THE \\ STATE OF MISSOURI.
}

"The substantial rules of pleading are founded in strong sense an'i the soundest and closest logic." - Lord Massfield.

S'T. PAUL

WEST PUBLISHING CO.

1905 
Copyright, 1899 ,

Bx Alexander Martin.

All rights reserved.

$T$

$M 3633 \mathrm{C}$

1905 


\section{MARY H. MARTIN,}

xִaife of the Zuthor,

THIS WORK IS AFFECTIONATELY INSCRIBED. 



\section{PREF ACE.}

Authons on code procedure in the United States usually advise students commencing its study to first familiarize themselves with the principles of common law as well as equity procedure.

As an instructor for ten years in code, common law, and equity. procedure, I have been impressed with the truth and propriety of this advice, and have endeavored to make it as effective as possible, in the instruction which it has been my duty to impart.

I would not be understood as urging the student of code procedure to achieve that critical mastery of the common law system of procedure, which was a necessary accomplishment of a success. ful barrister; but that he should aequire such passable knowledge of its history and principles as will enable him to understand thoroughly the reformed system which has supplanted it. All the more necessary is such knowledge to the student of the modificd systems of common law procedure which prevail in some of the States.

The work which I now submit to the profession has been prepared during the years in which $I$ have been engaged as an instructor in civil procedure, with the view of meeting the requirements of the modern student in law for a more thorough and extended acquaintanee with the common law system of procedure. It has been prepared more especially for students, and is written from the standpoint of an instructor, who commenecd to practisc. as an attorney under the system which he is now engaged in teaching.

If a practitioner under code procedure, or under the modified systems of common law procedure, should find it necessary to go 
back to the common law system to bring any of its principles to lis assistance, it is believed that this presentation of the systcm may prove as useful to him in an emergency as to the student in his class work.

A general sketch of the system, or an exposition of some fragmentary parts of it, would fail in my judgment to ineet the requirements of higher education on this important branch of jurisprudence. Accordingly I have endeavored to present in a concise form, and within reasonable compass, the history, principles, and leading features of the system, without burdening the presentation with details and conflicting deductions, which tend to discourage and bewilder the student.

The work consists of fourteen chapters arranged somewhat in the orde: in which an action at law makes its way through the courts. Commencing with the primordial conceptions which underlie every rational system of procedure, I have defined and explained the elementary parts of an action at law : the original and judieial writs; appearance; scheme of actions personal and real; parties to actions; joinder and election of actions; scheme of defences, dilatory, in bar and in estoppel; rules of pleading; trial ; instructions ; verdict; judgment and execution.

As the most important part of every system of procedure consists in the pleadings which disclose the issues between the litigating parties, I have devoted the greater part of the work to their exposition.

My aim has been to present to the student in a concise and orderly method the common law system as it existed in its day, as it was recognized, classified, and interpreted by the courts and judges controlling its application and enforcement.

Beliering that a true knowledge of legal principles must be derived from historical sources, I have paid considerabie attention to the origin of the system and the various phases of its development, noting the changes in it, whether emanating from judicial precedents, court orders, or legislative enactments.

For authority in support of the text, I have followed and cited the masterly works and decisions of the most eminent authors and jurists who have dereloped and illustrated the system. 
In reference to the formulated rules governing pleadings and parties to actions, I have followed the guide of Stephen and Dicey, - presenting them for the most part in the language in which they have been formulated; feeling that it would be all injustice to the student to substitute anything else in the place of these incomparable expressions in remedial law.

Appreciating the importance attributed by the system to form, $I$ have included in an Appendix a large collection of writs, declarations, demurrers, pleas, and replications, being satisficd that they will greatly assist the student in thoroughly understanding the substance and life of the system.

The two actions of replevin and ejectment have come down to modern times, and still contain many of their ancient features, even in States in which code procedure has displaced that of common law. I have recited in the Appendix of Notes and Forms the ancient proceedings in these two actions as prevailing under the common and statute law of England.

In the fourth chapter I have given a condensed account of the ancient real actions. This chapter, which was prepared for my own use, was not contained in the original plan of this publication; but after some hesitation I decided to incorporate it, although covering a part of procedure at common law which has been obsolete for several hundred year's.

I was induced to do this from two considerations: first, the original connection between these actions and the substantive law of real estate ; second, the fact that the books explaining them are all out of print, and unavailable to students in large classes. No one can hope to have a thorough understanding of the law of real estate as contained in the common law, without some acquaintance with these actions, and the theory of rights in land upon which they are based.

Some embarrassment is experienced in citing standard works which have been issued in numerous editions by the press. I lare furnished a list of authors consulted in the preparation of this work, and the citations in the foot notes are made from the editions indicated in the list, unless the citations point to some other edition. 
When the edition cited contains the marginal paging of some previous issue, that paging is the one intended in the citation.

Having described in a general way the nature of this publication, and explained the purpose of its preparation, I now commit its fortune to the charitable judgment and generous disposition of all who may have occasion to use it.

ALEXANDER MARTIN.

Columbia, Mo., September 1, 1899. 


\section{CONTENTS.}

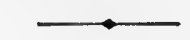

PAge

Names of most Publications Consulted and Cited . xxiii Table of Cases . . . . . . . . . . . . . xxvii

\section{CHAPTER I.}

I NTRODUCTOR Y.

ARticle I. . . . . . . . . . . . . . . 1-6

\section{Primordial Conceptions.}

Sec. 1. Iaw.

" 2. Duties and Rights.

“ 3. Wrougs. $\mid \begin{gathered}\text { Sec. 4. Damage. } \\ \text { “ 5. Damage implied. } \\ \text { “ } 6 . \text { Damage actual. }\end{gathered}$

ARTICLE II. . . . . . . . . . . . . . 6-9

Sec. 7. Defined.

Civil Actions.

| Sec. 8. General Classification of Actions. Sec. 9. Classification of Personal Actions.

Article III. . . . . . . . . . . . . . . . . 9-10

Original Writs.

Sec. 10. General Description. I Sec. 11. Abolishment of.

Article IV. . . . . . . . . . . . . . . . . 10-12

Appearance.

Sec. 12. Necessity of Appearance. I Sec. 13. Change in the Law.

ARTICle V. . . . . . . . . . . . . . 12-14

Pleadings.

Sec. 14. Defined. $\quad$ Sec. 15. History.

Sec. 16. Immediate Object. 
Article VI. . . . . . . . . . . . . . 14-21

Courts.

Sec. 17. Prefatory.

“ 18. King's Bench.

“ 19. Common Pleas.

Sec. 23. Courts Baron.

\section{ARTicle VII. . . . . . . . . . . . . 21-25 \\ Attorneys and Barristers.}

Sec. 24. Origin.

“ 25. General Duties. Sec. 26. Qualifications, Responsibility, and
Discipline.

ARTICLE VIII. . . . . . . . . . . . . . 25-30

Declaration.

Sec. 27. Prefatory.

"28. Title of Court.

“ 29. Entitlement of Term.

Sec. 33. Conclusion.

Sec. 30. Venue.

" 31. Commencement.

“ 32. Statement.

Article IX. . . . . . . . . . . . . 30-32

Profert.

Sec. 34. Defined.

"35. Relaxation.

Sec. 38. Effect of Profert.

Sec. 36. Extensiou.

" 37. Limitation.

CHAPTER II.

PERSONAL ACTIONS EX CONTRACTU.

ARTICLE I. . . . . . . . . . . . . . 33-42

Debt.

Sec. 39. Defined.

"40. History.

“ 41. History.

Sec. 44. Judgment.

Article II.

Covenant.

Sec, 45. Defined.

“ 46, 47. History.

Sec. 48. Essential Features.
“49. Declaration.
Sec. 50. Judgmeut. 
Assumpsit.

Siec 51. Defined.

" 52-53. History.

" 54. Nature and Features.

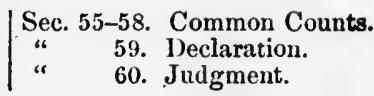

ARticle IV. . . . . . . . . . . . . . . 62-65

Account.

Sec. 61. Defined.

"62. History.

"63. Nature and Characteristics.

Sec. 66. Declaration.

Sec. 64. Case on Refusal to account.

" 65. Assumpsit on Accouut stated.

Sec. 67. Judgment.

ARTICLE V. . . . . . . . . . . . . . 65-67

Annuity.

Sec. 68. Defined.

Sec. 70. Nature and Characteristics.
“71. Judgment.

“ 69. History.

ARTICle VI. . . . . . . . . . . . 67-68

Scire Facias.

Sec. 72. Definition and History.

\title{
CHAPTER III.
}

\section{PERSONAL ACTIONS EX DELICTO.}

Alticle I. . . . . . . . . . . . . . . 69-74

Trespass vi et Armis.

Sec. 73. Defined.

74. History.

Sec. 80. Juigment.

Sec. 75-78. Nature and Characteristics. 79. Declaration.

\section{ARTICle II.}

Sec. 81. Defined.

“ 82. History.

Detinue.

\author{
Sec. 85. Jndgment. \\ Sec. 83. Nature and Characteristic Fea- \\ tures. \\ 84. Declaration.
}

ArTicle III.

Trespass on the Case.

Sec. 86. Defined.

" 87. History.

Sec. 88-94. Nature and Characteristics.
Sec. 96. Judgment. 
Trover.

Sec. 97. Defined.

" 98-101. History.

$\mid \begin{array}{ll}\text { Sec. 102. Qualifications and Distinctions. } \\ \text { “ 103. Declaration. }\end{array}$ Sec. 104. Judgment.

\section{Article V.}

$92-101$

Replevin.

Sec. 105. Defined. Sec. 113. Characteristic Features.
“ 114. Declaration.

" 106-112. History.

Sec. 115. Judgment.

Article VI.

Action for Mesne Profits.

Sec. 116. Definition and Nature.

\section{CHAPTER IV.}

\section{ANCIENT REAL ACTIONS.}

ARTiCle I.

\section{Introductory.}

Sec. 117. Prefatory.

" 118. Defined.

" 119. Historical.

“ 120. Classification.

Sec. 121, 122. Theory of Rights in Land.

" 123, 124. Distinction between proprietary and possessory Actions.

Article II.

\section{Ancient Real Actions - Proprietary.}

Sec. 125. Division of them.

" 126. Writs of Right proper.

" 127. Writs in the Nature of Writs of Right.

“ 128. The Writ of Right Close in an-

cient Demesne.
"129. Writ of Right De rationabili “ 135. Writ of Quod ei deforceat.
“ 136. Other Writs in nature of, etc. parte.

Sec. 130. Writ of the Right of Advowson.

" 131. Writ of the Right of Dower.

" 132. Writ of Dower Unde nihil habet.

“ 133. Writ of Quod permittat.

134. Writs of Formedon.

135. Writ of Quod ei deforceat.

“ 137. Writ of $\mathrm{Ne}$ injuste vexes.

ARticLe III.

\section{Ancient Real Actions - Possessory.}

Sec. 138. Writs of $\Lambda$ ssize.

"139. Writs of $A$ ssize continned.

“ 140. Assize of Nnisance.

“ 141. Assize of Darrein Presentment.

“ 142. Assize of Juris utrum.

Sec. 143. Assize of Mort d'Ancestor.

“ 144. Writs of Entry.

“ 145. Writs of Fntry sur disseisin.

“ 146. Writ of Fntry sur alienation.

“147. Writ of Entry sur intmion. 
Sec. 148. Writ of Entry sur abatement. Sec. 153. Writ of Quare ejecit infra ter-

" 149. Writ of Entry Ad terminum

qui præteriit.

“ 150. Writ of Causa matrimonii prælocuti.

“ 151. Writs of Entry as affected by Feoffment and Descent.

“ 152. Writs Ancestral possessory. ninum.

154. Writ of Quare impedit.

155. Writ of Waste.

156. Writ of Ejectione firmæ.

157. Writ of leceit.

"158. Writ of l'artition.

“ 159. Writs of Warrantia chartæ and Curia claudenda.

Article IV.

Forcible Entry and Detainer.

Sec. 160. Introdnctory.

161. Defined. $\mid \begin{aligned} & \text { Sec. 162. Forcible Fntries at Common Law. } \\ & \text { " 163. History after the Statute. }\end{aligned}$ Sec. 164. History cuntinued.

\section{CHAPTER V.}

\section{MODERN REAL ACTIONS.}

Article I.

I. .

\section{Ejectment.}

Sec. 165. Prefatory.

Sec. 168. Declaration

\begin{tabular}{l|ll} 
“ 166. Causes leading to the Action. & " 169 . Jurlgment. \\
“ 167. Defined.
\end{tabular} Sec. 171. Ejectment in the United States.

A RTICLE II. . . . . . . . . . . . . . . . . 145-146

Trespass to try Title.

Sec. 172. Trespass to try Title.

I Sec. 173. In Texas.

ARTicLe III.

Writs of Entry and of Disseisin.

Sec. 174. Writs of Entry.

| Sec. 175. Writ of Disseisin.

Article IV.

Dower and Partition.

Sec. 176. Dower.

| Sec. 177. Partition.

Article V. .

Forcible Entry and Detainer.

Sec. 178. Introductory.

| Sec. 179. Characteristic Features. 


\section{CHAPTER VI. \\ PARTIES TO ACTIONS.}

Article I.

Parties Plaintiff in Personal Actions ex contractu.

Sec. 180. Prefatory.

“ 181. General Rule.

“ 182. As to Bonds and leeds inter. partes.

“ 183. As to Deeds Poll.

“ 184. As to Simple Contracts.

“ 185. As to Contracts with Carriers of “ 190. As to Joinder of I'arties I'lain-

Goods.

Sec. 186. As to Assiguees of Choses in: Aetion.

187. $\Lambda$ s to Agents.

"188. $\Lambda$ s to Corporations.

" 189. As to Executors and Administrators.

Article II.

Parties Plaintiff in Personal Actions ex delicto.

Sec. 191. General Rule. Sec. 196. Injuries to Real Property 111.

" 192. Injuries to the $\Lambda$ bsolute Rights of Person.

“ 193. Injuries to Relative Rights. "

“ 194. Injuries to Rights appertaining trators. to Personal (Chattels.

“ 195. Injuries to Real Property Cor- “ 200. As to Joinders of Parties I'laiiporeal, tiff.

Article III.

Parties Defendant in Personal Actions ex contractu.

Sec. 201. The General Rule.

“ 202. As to Agents.

* 203. Trinstees, Cestuis que Trust, Partners, and 'Tenants in Common as between each other.

Sec. 204. Assignees.

" 205. Executors and Administrators.

" 206. Heirs and Derisees.

“ 207. Infants.

“ 208. Corporations.

Secs. 209, 210, and 211. Joinder of Parties.

ArTiCle IV.

$173-179$

Parties Defendunt in Personal Actions ex delicto.

Sec. 212. General Rule.

"213. Injuries to absolute Riglits of P'ersoll.

“ 214. Injuries to relative lights of Person.

“ 215. Injuries to Rights appertaining to Land.

“ 216. Injuries to Rights appertaining to personal Chattels.

Sec. 224. Joinder of Parties.

Sec. 217. Injuries resulting from Management and Control of real ant? personal Property.

“ 218. I'rincipal aut $\Lambda$ gent.

“ 219. Husband and Wife.

“220. Infants and insane l'ersons.

“ 221. Executors and $\Lambda$ dministrator.

“ 222. Assignees.

“ 223. Corporations.

ARTICLE V

Purties Plaintiff and Defendant in Real Actions.

Sec. 225 Ancient Real Actions.

( Sec 226. Plaintiff in Modern Real Actions. Sec, $22 \pi$. I) Jendants in silme. 


\section{CHAPTER VII. \\ JOINDER AND ELECTION OF ACTIONS.}

Article I.

Joinder of Actions.

Sec. 228. Joinder of Actions.

| Sec. 229. Cunsequences of Misjoinder. Changes in tlie Law.

ARticle II. . . . . . . . . . . . . . 185-186

Sec. 230. Election of Actions.

\section{CHAPTER VIII.}

\section{MOTIONS OF DEFENDAN'T AFTER DECLARATION AND BEFORE PLEA.}

AR'TICLE I.

Sec. 231. Demand of Oyer.

Article II. • • • . . . . . . . . . . . 188-189

Sec. 232. Demand of Particulars.

ARTICLE III. . . . . . . . . . . . . . . . 189-190

Sec. 233. Views, Aid-Prayer, Voucher of Warranty.

Article IV. . . . . . . . . . . . . . . . 190-191

Sec. 234. Imparlance.

\section{CHAPTER IX.}

\section{DEFENCES.}

Article I. . . . . . . . . . . . . . . . 192-194

Sec. 235. Classification of Defences.

Article II. . . . . . . . . . . . . . . 194-204

Demurrer.

Sec. 236. Defined.

“ 237. History.

“ 238. Causes for Demurrer.

“239. Effects and Conseruences.

Sec. 240. Effect of pleading over without Demurrer.

Martin Civil Procedure-b 


\section{CHAPTER X.}

\section{DEFENCES BY WAY OF DILATORY PLEAS.}

Article I.

Sec. 243. Introductory.

Prefatory.

Article II. . .

I Sec. 244. Defined and Classified.

\section{Pleas to the Jurisdiction.}

Sec. 245. Defined and Classified.

| Sec. 246. Requircments.

Article III. . . . . . . . . . . . . . . . 209-210

Pleas in Suspension.

Sec. 247. Pleas in Suspension.

Article IV.

Pleas in Abatement.

Sec. 248. Defined and Classified. Sec. 251. Pleas to the Connt or Declara-

" 249. Pleas to the Person of Plaintiff. tion.

“ 250. Pleas to the Person of Defend- "252. Pleas to the Writ or Bill. ant

“ 253. Statutory Restrictions.

Article V.

Conclusion of and Judgment on Dilatory Pleas.

Sec. 254. Conclusion of Dilatory Pleas. | Sec. 255. Judgment on.

\section{CHAPTER XI.}

\section{DEFENCES IN BAR BY WAY OF TRAVERSE.}

ARTICLE I. .

\section{Defined and Classified.}

Sec. 256. General Nature of Pleas in Bar. Sec. 258. General Traverse Defined.

“ 257. Specific 'Traverse Defiued.

ARTiCLE II. .

General Traverse - Application thereof.

Sec. 260. In Debt

261. In Covenant.

"262. In Assumpsit.

" 263 In Accomnt.

"264. In 'lrespass.

Secs. 270, 271. General Traverse De Injuria by way of Replication.
219-23:?

Sec. 265. In 'Trespass on the Case.

" 266. In 'Trover.

“ 267. In J)etinue.

“ 268. In Replevin.

" 269. In Ejectment. 
Specific Traverse - Application thereof.

Sec. 272. General Rule.

" 273. In I)ebt.

“ 274. In Covenant.

“ 275. In Assumpsit.

“276. In Account Render.
Sec. 277. In Trespass.

" 278. In 'Trespass on the Case.

“ 279. In Irover.

“ 280. In 1)etinue.

“ 281. In Replevin.

\section{Article IV.}

Special Traverse. - Application Thereof.

Sec. 282. Hlistory.

" 283. Essential Requisites.

“ 284. Rules for determining its Sufficiency.

Sec. 285. Special 'Traverse, abnormal Form. Sec. 288. Principles relating to Traverses in general.

\section{CHAPTER XII.}

\section{DEFENCE IN BAR BY WAY OF CONFESSION AND AVOIDANCE.}

Article I.

- Defined, Classified, and Explained.

Sec. 239. Defined and Classified.

Sec. 291. Confession or Color expressed.

290. Coufession or Color implied.

Sec. 293. Pleas in Justification or Excuse defined.

Article II.

Pleas in Justification or Excuse applied.

Sec. 294. In Debt.

“ 235. In Covenant.

“ 296. In Special $\Lambda$ ssumpsit.

“ 297. In General Assumpsit.

Sec. 302. In Case.

$$
\begin{array}{|c}
\text { Sec. 298. In Trespass. } \\
\text { “ 299. In Trover. } \\
\text { “ } 300 \text {. In Detiuue. } \\
\text { 301. In Replevin. }
\end{array}
$$

Article III.

Pleas in Rar by Way of Estoppel.

Sec. 303. Pleas in Estoppel.

252-263 
Rules which tend simply to the Production of an Issue.

sec. 305. Recital of the Rules and Pur-|Sec. 307. Manner of Reaching an Issue pose of them.

" 306. Forin of producing an Issue by

Demurrer or 'Traverse. by lea in Confession and Aroidance.

Sec. 309. Exceptions to Rule I.

Article III

Rules which tend to secure the Materiality of the Issue.

Sec 310. Rule. All Pleadings must con- See. 311. Subordinate Rules. tain Matter pertinent and material.

Article IV.

Rules which tend to produce Singleness or Unity of the Issue.

Sec. 312. The Vice of Duplicity.

" 3I3. Extent of Rule I.

“ 314. Suhordinate Rules.

" 315. Cumulative Traverses.

Sec. 316. Relaxations of Rule I. in respect to Declarations.

Sec. 318. Rule II. Against Pleading and Demurring to the same Matter.

ARticle V. .

Rules which tend to produce Certainty or Particularity in the Issue.

Sec. 319. Rule I. The Pleading must have Certainty of Place.

" 320. Rule II. "The Pleading must have Certainty of Time.

“ 321. Rule III. 'The Pleading must specify Quality, Quantity, and Value.

“ 322. Rule IV. The Pleading must specify the Names of Persous.

“ 323. Rule V.. 'The l'leadings must show Title.

“ 324. Ilow to allege Title in himself or another whose Authority ho Pleads.
Sec. 325. Exceptions.

"326. How to allege Title in an Adversary.

“ 327. Exceptions.

“ 328. Rule VI. The Pleadings must show Authority.

“ 329. Rule VII. In general, whatever is alleged in leading must be alleged with Certainty.

" 330. Subordinate Rules limiting and restrictiug the general Rules which tend to Certainty.

ARticle VI.

Rules which tend to prevent Obscurity and Confusion in Pleading.

Sec. 33I. Rule I. l'leading must not be Sec. 333. Rule III. Pleading must not be Insensilule or Repuguant.

“ 332. Rule II. l'leading must not be Ambiguous or Donbtful, and when two different Meanings 'present themselves that Construction shall be adopted which is most unfavorable to the l'arty pleading.

\section{Argumentative.}

"334. Rule IV. Pleading must not he Hypothetical or in the Alternittive.

“ 335. Rule V. Pleadings must not be by way of Recital, but mu:t le jositive in their form.

"336. Rule VI. Things are to l,e 
pleaded according to their legal Effect or Uperation.

Sec. 337. Rule VII. Pleadings should observe the known and aucient Forins or Expressions, as contained in approved Prece. dents.

Sec. 338. Rule VIII. I'leadings should have their proper formal Commencements and Conclusious.

Sec. 339. Rule LX. Pleading which is Bad in Part is Bad altogether.

PAge

Artiche VII.

Rules which tend to prevent Prolixity and Delay in Pleading.

Sec. 340. Rule I. There must be no De- Sec. 341. Rule II. Whire a Plea parture in Pleacling.

amounts to tlie General Issuc, it sliould be so l'leacled.

Sec. 342. Rule III. Surplusage is to be avoided.

Article VIII.

297-301

\section{Of Certain Miscellaneous Rules.}

Sec. 343. Prefatory.

“ 344. Rule I. Declaration must conform with the Writ.

“ 345. Rule II. Declaration must have proper Commencement, and in its Conclusion lay 1)amages and Production of Suit.

“ 346. Rule III. Pleas must be pleaded in due Order.

“ 347. Rule IV. Pleas in Abatement mnst give the Plaintiff a better Writ or Declaration.

“ 348. Rule V. Dilatory Pleas must be pleaded at a Preliminary Stage of the Suit.

Sec. 349. Rule VI. All affirmative Plealings which do not conclude to the Country must conclude with a Verification.

“ 350. Rule VII. Profert must be made of a Deed alleged iu the lleading.

“ 351. Rule VIIIt. All Pleadings must be properly entitled.

“ 352. Rule IX. All l'lealings must be 'True.

Sec. 353. Rule X. Which relaies to Exceptions in Statutes and Contracts.

\section{CHAPTER XIV.}

TRIAL, VERDICT, JUDGMENT, AND EXECUTION.

Anticle I. • . . . . . . . . . . 302-309

Trial.

Sec. 354. Prefatory.

" 355. Trial by Inspection without “358. Trial by Wager of Battle Witnesses.

“ 356. Trial by Witnesses withont “ 360 . Trial by Record. Jury.

“ 361. Trial by Jury extraordinary.

See 362. Trial by Jury ordinary.

ARTICLE II. . . . . . . . . . . . . . 309-314

Verdict.

Sec. 363. Form and Tenor.

"364. Variance.

“365. Demnrrer to Fvidence.

“ 366. Special Verdict.

“ 367. Special Case.

Sec. 372. Motion for Repleader.

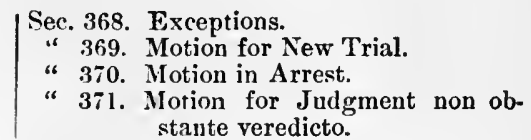
stante veredicto. 
Article III. . . . . . . . . . . . . 314-324

\section{Judgment.}

Sec. 373. I'refatory.

“374. Defined.

“ 375. Interlocutory Judgments.

“ 376. Final Judgments.

\begin{tabular}{|l} 
Sec. 377. Signing and Enrolment. \\
" 378. Audita Querela. \\
" 379 . Writs of Error. \\
“ 380 . Writs of Error, continned.
\end{tabular}

\section{Article IV.}

\section{Execution.}

Sec. 381. Defined.
" 382. Execution for the Recovery of Sec: 383. Executions in Actions for the Recovery of Money.

Conclusion • • • • • • • . . . . • • 331-339

Sec. 384. Conclusion.

\section{APPENDIX.}

Note I. . . . . . . . . . . . . . . . . 341-349

General Assumpsit for Part Performance of Express Contracts.

Note II. . . . . . . . . . . . . . . 350-357

Proceedings in Replevin after Issue of Writ or Making of Plaint.

Note III. . . . . • . . . . . . . . . . . 358

Writs abolished by $3 \& 4$ Wm. IV., c. 27, s. 36.

Note IV. . . . . . . . . . . . . . . . 359-364 Proceedings in Ejectment.

Forms in Pleading . . . . . . . . . $365-392$

Table of English Regnal Years . . • • . . . 393

INDEX . . . . . . . . . . . . . 395-416 


\section{NAMES OF MOST PUBLICATIONS CONSULTED AND CITED.}

Adams on Fjectment, 1846.

Adams's Equity, 1890.

American and English Encyclopædia of Law, 1st ed.

American Law Review, si. Louis.

American Leading Cases, 1871.

Ames's Cases on Pleading, 1875.

Annual Practice, 1897. By Snow, Burney, \& Stringer.

Atherton's Personal Actions, 1833.

Austin's Jurisprudence, 1869

Bacon's Abridgment, 1868. By T. \& J. W. Johnson \& Co.

Bigelow's History of Procedure in England, 1880.

Bispham's Principles of Equity, 1893.

Blackstone's Commentaries, 1884. Cooley.

Bliss on Code Pleading, 1887.

Booth on Real Actions, 1808.

Bouvier's Law Dictionary, 1858.

Bracton De Legibus, 1640.

Brooke's Abridgment, 1586.

Broom's Legal Maxims, 1868.

Browne on Actions at Law, 1844. (Law Library.)

Buller's Nisi Prius, 1788 and 1817.

Chitty on Pleading, 1st vol., 1844. (9th Am. from 6th Lond. ed.)

Chitty on Pleading, 2d and $3 d$ vols., 1872.

Chitty on Pleading, 2d vol., 1809.

Chitty's General Practice, 1st and 2d vols., 1834.

Chitty's General Practice, 3 vols., 1836.

Chitty's General Practice, 4th vol., 1839.

Coke upon Littleton, 1853.

Common Law Procedure Act of 1852. By Morris \& Finlason.

Comyn's Digest, 1824.

Crabb's English Law, 1831.

Cruise's Digest, 1834.

Central Law Journal. St. Louis. 
Dalton's Country Justice, 1746.

Dicey on Parties to Actions, 1879.

Encycloprdia of Pleading and Practice. By Edward Thompson Co. Espinasse's Nisi Prius, 1808.

Evans on Pleading, $18 S 6$.

Finlason's Leading Cases, 1847.

Fitzherbert's Natura Brevium, 179:3. Dupiu.

Freeman on Judgments, 1886.

Freeman on Executions, 1885.

Gilbert's Tenures, 1796.

Gilbert's History and Practice of Common P'leas, 1779.

Gilbert on Distress and Replevin, 1757.

Glanville, Laws and Customs of England, 1812. Beames.

Gould on Pleading, 1861.

Greenleaf on Evidence, 1st vol., $18 t 4$.

Greenleaf on Evidence, 2d and 3d vols., 1868.

Hale on Torts, 1896.

Hale's History of Common Law, 1521

Hale's Pleas of the Crown, 1847.

Hawkius, Pleas of the Crown, 1795.

Harvard Law Review. Cambridge, Mass.

Hammond's Nisi Prius, 1823.

Hepburn on Code Pleading, 1897.

Holmes's Common Law, 1881.

Howe's Studies on Civil Law, 1896.

Indermauer's Manual of Practice, 1888.

Jackson on Real Actions, 1828.

Jacob's Law Dictionary, 1811.

Jaggard on Torts, 1895.

Keener on Quasi Contracts, 1893.

Kerr's Action at Law, 1854.

Langdell on Equity Pleading, 1883.

Langdell's Select Cases, 1971.

Langdell's Summary of the Law of Contracts, 1880.

I awson on Contracts. 1893.

Leigh's Nisi Prius, 1838.

Lilly's Entries, 1791.

Mansel on Demurrer, 1839. (Law Library.)

Mason's Practice in New Eugland, 1880. 
Mclielvey on Common Law Pleading, 1894.

Mirror of Justice, 1768.

Minor's Institutes, 1883.

Morris on Replevin, 1869.

Perry on Common Law Pleading, 1897.

Piggott on Torts, 1885.

Pollock \& Maitland, History of English Law, 1895.

Pollock on Torts, 1894.

Pollock's First Book of Jurisprudence, 1896.

Pomeroy's Equity Jurisprudence, 1881-1883.

Rastall's Entries, 1596.

Reeves's History of English Law, 1869. By W. F. Finlason.

Richardson's C. P. Practice, 1792.

Rolle's Abridgment, 1668.

Roscoe on Actions relating to Real Property, 1840. (28 and 29 Law Library.)

Rumnington on Ejectment, 1795.

Saunders on Pleading and Evidence, 1829.

Saunders's Reports, 1846. Gould Banks \& Co.

Sedgwick \& Wait on Trial of Titles, 1886.

Sellon's Practice, 1813.

Selwyn's Nisi Prius, 1857. Wheaton.

Scribner on Dower, 1867.

Shipman's Common Law Pleading, 1895.

Smith on Actions, 1848. (Law Library).

Smith on Landlord and Tenant, 1871.

Smith's Leading Cases, 1839. (23 Law Library.)

Spence on Equity Jurisprudence, 1846.

Stearns on Real Actions, 1831.

Stephen on Pleading, 1867. Heard.

Stephen's Nisi Prius, 1844.

Taylor on Private Corporations, 1894.

Thompson on Corporations, 1895.

Tidd's Practice, 1840.

Tidd's Appendix, 1819.

Tyler on Ejectment, 1870.

Wait's Actions and Defences, 1885.

Wait's Law and Practice, 1867.

Walker's American Law, 1887.

Warren's Law Studies, 1846.

Wharton on Evidence, 1879.

Wilkinson on Replevin, 1834. (Law Library.)

Villiams on Personal Property, 1866. 



\title{
TABLE OF CASES.
}

\author{
[References are to pages.]
}

A.

Ahern v. Boyce

Alcorn v. Westbrooke

Alilen's Case

Alexander $v$. Mawman $v$. Rundle

Algeo $v$. Algeo

Allen's Fix. v. Harlan's Adm'r

Allell $v$ Flood

$$
\begin{aligned}
& v \text { Sharp } \\
& v \text {. Spencer }
\end{aligned}
$$

Aller $v$. Aller

Alsager $v$. Close

Anderson $v$. Smith

Andrae $v$. Heinritz

Angel $v$. Hamna

Anstice $r$. Holmes

Appleby $v$. Brown

A rcliard $v$. Horner

Arcent $v$. Durrant

Arundell $v$. 'Trevill

Atkins $v$. Barnstable

Alkyns $v$. Horde

Atty.-Gen. $v$. Brown

Asliby $v$. White

Aslifurd $v$. 'Thornton

B.

Badkin v. Powell

Bitiley $v$. Clay

Bainloridge $v$. Downs.

Baker $v$. Gray

Baldwin $v$. Cole

Bank of Columbia $v$. Patterson

I3arber $v$. Fox

Barnes $v$. Hunt

liarnet $v$. Ihrie

Barnewall $v$. Williams

liarrett $v$. Trainor

$v$. Warren

Bartlett $v$. Wills

Basten $v$. Butler

Baten's Case

Bates $v$. Hinton

iatterman $v$. Pierce

Baylies $v$. Fettyplace

Batylis $v$. Le Gros

\begin{tabular}{|c|c|}
\hline & Beckman $v$. Knight \\
\hline & Bedell $v$. Lull \\
\hline 345 & Bedow v. Tonkin \\
\hline 342 & Beebe $v$. Lyle \\
\hline 105 & Beeclier $v$. Parmele \\
\hline 194 & Begole $v$. McKenzie \\
\hline 90 & Beha v. Ottenberg \\
\hline 345 & Bellant $v$. Brown \\
\hline 77 & Bender $v$. Fromberger \\
\hline 84 & Benjanin $v$. Stremple \\
\hline 93 & Bennett $v$. Allcott \\
\hline 91 & v. Filkins \\
\hline 48 & Berkeley $v$. Hardy \\
\hline 90 & Bernard v. Dickens \\
\hline 260 & Betts $v$. Lee \\
\hline 152 & Bicker $v$. Vrooman \\
\hline $34 b^{\circ}$ & Billings $v$. Tucker \\
\hline 8,261 & Bird $v$. Randall \\
\hline 82,63 & Bishop $v$. Montague \\
\hline 345 & Blakeslee $v$. Holt \\
\hline 236 & Block v. Elliutt \\
\hline 98 & Blood $v$. Williams \\
\hline 346 & Bonzi $v$. Stewart \\
\hline 142 & Boone $v$. Eyre \\
\hline 93 & Boyce $v$. Whitaker \\
\hline 5 & Bradhurn r. Botfield \\
\hline 303 & Bradyl v. Ball \\
\hline & Bray v. Bray \\
\hline & Breck $v$. Blanchard \\
\hline & Breckenridge $v$. McAfee \\
\hline 225 & Breech $v$ White \\
\hline 254 & Brilge 3. Grand Junction Ry. \\
\hline 167 & Briggs $v$. Dorr \\
\hline 89 & Brind $v$. Dale \\
\hline 88 & Bristol v. Burt \\
\hline 342 & Britton $v$. Turner \\
\hline 200 & Brooks v. Stuart \\
\hline 233 & Broomfield $v$. Smith \\
\hline 326 & Brown $v$. Hartzell \\
\hline 8,260 & v. Perry \\
\hline 153 & Browne $v$. Davis \\
\hline 72 & Browne's Case \\
\hline 295 & Browning $v$. White \\
\hline 3,344 & Bruen $v$. Roe \\
\hline 117 & Burkingham $r$. Ludlum \\
\hline 47 & Burk 1. Plare \\
\hline 343 & Burnet $v$. Lynch \\
\hline 343 & Burton $\ell$. Stewart \\
\hline 143 & Butchier $v$. Butcher \\
\hline 62 & Butler $v$. Manny \\
\hline
\end{tabular}

Beach $v$. Hotchkiss 
C.

Calvert $r$. Gordon

Camp r. Barker

Campbell $r$. Jones

Carrett v. Snallpage

Chanc. Oxford

Cheesman $v$. Exall

Chírae $v$. Reinecker

Choppel $v$. Hicks

Chouteau $v$. R R.

Christy $v$. Price

Churchman $v$. Tunstal

Clafliu v. Boston, etc.

Clark $v$. Fairchild $v$. Terry

Clarke v. Gray

Clearwater $v$. Meredith

Clements $v$. Fliglit

Closson $v$. Means

Clue $v$. Bailey

Cochran i' 'Tatum

Cockrill v. Armstrong

Cohen $v$. Stein

Colens $v$. Virginia

Cole $v$. Hawkius

Colgan $v$. Sharpe

Collet $v$. Flinn

Collins $v$. Blantern $v$. Gibls

Com'w. v. Shattuck

Conklin $v$. Buslı

Cooke v. Munstune

Coolbangh $v$. Porter

Cooper $v$. Chitty $v$. Monks

Cornwallis $v$. Savery

Colthirst $v$. Bejustin

Cotton v. Browne

Courtney $v$. Satchwell

Cowper $v$. Garbett

Crandall $v$. Gallup

Crews r. Garneau

Crugate's Case

Cross Keys Co. $v$. Rawlings

Crouch $v$. Lomion and N. W. Ry. Co. $246^{\circ}$

Crousillat v. M'Call

Culliford $v$. Blanford

Curtis v. Curtis

Cutter v. Powell

D.

Dakin $v$. Williams

Dalston $v$. Jianson

Dameron $v$. Janieson

Dane $v$. Gilmore

Dirtuall $v$. Howard

Dilvies $v$. Benton

Davis ". Davis $\boldsymbol{v}$. Iledges

Dawson ". McGill

Dean $v$. McLean

Dearborn $v$. Dearborn

[References are to pages.]

Ex parte Chamberlain

Ex yarte Wall

E.
59,342

238

90

149

276

209

255

43

86. !1

238,260

71,82

225

181

181

138

93

250

139

229

194

293

Earl of Mancliester $v$. Vale

251,258

60,349

Edwards $v$ Mckee

lifland $v$. Efland $\quad 149$

Elkinton $v$. Feunimore 343

Elsee v. Gatward 82

Emery $v$. Fell $\quad 58$

Erhart $v$. Bass 140

Erwin $v$. Clark $\quad 88,90$

Estey $v$. Smith $\quad 81$

Evans $v$ Elliott $\quad 98,18$

F.

254, 255, 341 Fallowes $v$. Taylor

(1) Farmers', etc. 'Turnpike Co. v. Mc-

8:3 Farnswortl $v$. Garrard $v$. Taft

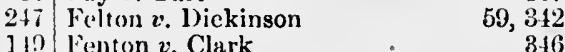

$\begin{array}{lll}119 & \text { Penton } v \text {. Clark } & 346 \\ : 3 ! 1 & \text { lerrar's Case } & 118\end{array}$

1'.2) Fitch $v$. Casey 343

8:3 Fitzgerald $r$. Jlayward 345

83, V'leischman $v$. Niller $\quad 346$ 
Y":etcher $v$. Wilkins

Fortescue $v$. Holt

Franklin $v$. Miller

lirankum $v$ Earl of Falmouth

Frazer $v$. How

Freenuan v. Ayler n. Blewitt

Fulur $\boldsymbol{v}$. Dean

Fuller $\boldsymbol{v}$. Rounceville

liursden $v$. Weeks

G.

Gage $v$. Sanborn

Galway $v$. Rose

Gardner $v$. Weber

George $v$. Chambers $v$. Tate

Gerard $v$. Baden

Gibbons $v$. Pepper

Gibbs $v$. Bryant $v$. Stone

Gidley $v$. Lord Palmerston

Glacius $v$ Black

Glazebrooke $v$. Woodrow

Gledstane $v$. Hewitt

Glover $v$. Henderson

Godfrey $v$. Saumlers

Goodchild $v$. Pledge

Gordon $v$. Bruner $v$. Martin

Gould $x$. Lasbury

Graham $v$. Peat

Grannis $v$. Clark et al.

Grant $v$. Button

$v$. King

v. Vaughan

Gregg $v$. Duwn v. Wells

Gregory $v$. Paul

Griffin $v$. Farwell $v$. Yates

Griffith $v$. Willing

Grocery Co. v. Archbishop

Gwin $v$. Smur

H.

Hiddix $v$. Einstman

IIall $v$. Robinson

IIalpin $v$. Manny $v$. School Dist.

Hardy v. Beaty

Ifarman $v$. Kingston

Hatrrington $x$. Stratton

Harris v. Miner $v$. Turner

Harrison $v$. Cotgreave

$$
v \text {. Dixon }
$$

$v$. Luke

Harrow $v$. Baker

Hart $v$. Longfield

Hartshorn $v$. Day

[References are to pages.]

90

56

257

346

$2+3$

196

237

\begin{tabular}{r|lr}
131,135 & Iledges $v$. Sandon \\
224 & Heineman $v$. Heard
\end{tabular}

231 Heman $v$. Compton Hill Imp. $\quad 340^{\circ}$

Heulerson's ('ase 134

Heskett $v$. Fawcett 251

Ilickam $v$ Hickam 5 ?

153

Hill $v$. Wriglst

Hilllouse $v$. Mix

Hillyard $v$. Crabtree

256 Huiton $v$. Rossey

93 Holtham $v$. East Ind. Co

222 Honnegger $v$. Wettstein

66 Horn $v$. Lewin

259 Hoskins $v$. Robins

34.2 Houck $v$. Frishee

255

167

Houston $v$. Spruance

Hudson $v$. Jones

59, 254, 256 Huglies $v$. Carson

Huish $v$. Philips

75,77

345

64

$37,41,234,235$,

250,251

185

$59,341,342$

248,251

73

48

343

91

90

346

238

160

79

232

62,63

246

ulle $v$. Heightman

Humplireys $v$. Bethily v. Churchman

Hunneman $v$. Grafton

Hunter $v$. Britts

$$
\text { v. Gibson }
$$

$v$. Neck

Huntington $v$. Claflin

Hutchinson $v$. Brock

Hutton $v$. Arnett

Huy $v$. Brown

Hyatt $\imath$. Wood

\section{I.}

In re Bowman

Ireland $v$. Chauncy

Isaac $v$. Belelier v. Farrar

Ish $v$. Chilton

Ives $v$. Ives

181

346

252

254,256

60,348

211

99

52

234

248

$102,10:$

241, 245

$59,311,342$

274

274

342

102

$60,3+8$

2118

60,348

207

86

254

134

Jaekson $v$. Bradt

v. Cummins

v. Dieffendorf

Jones $v$. Axen

v. Barkley

$r$ Brown

r. Chapman

$v$. Dowle

$v$. Jolinson

r. Kitchin

59,311 
Joslyn $v$. Taylor Justice $v$. Vermilion County

K.

Kaulleen ". Tillman

Kelly $v$. Bradford $v$. Foster $v$. Rowane

Kemble $v$. Mills

Kemuerly $v$. Summerville

Kettle $c$ : Bromsall

Kier $v$. Leeman

Kincaid $v$. Logue

King $v$. Boston

$v$. Coke

$v$. Jones

v. Oakley qui tam v. Bolton

$\boldsymbol{c}$. Welcome

v. Willianıs

Kingdon $v$. Nottle

Kingman :. Pierce

Kingston $v$. P'reston

Kipp $v$. Bell

Knapp v. Salsbury

Krevet $v$. Myer

L.

Lambert $v$. Stroother

Lane $v$. Cotton $v$. Tewson

Latham $v$. Rutley

Leake $v$. Lovedily

Lecompt $v$. Wash

Lee $v$. Ashibrook $v$. Bauman

Leigliton $v$. Sargant

Lerinard $v$. I yer

Lewis $v$. Alcuck

Lilley $v$. Jilwin

Lillie $v$. Price

Lindley $v$. Miller

Linnenkolıl $v$. Winkelmeyer $60,346,348$

Lloyd $v$. Williams

Lock wood $v$. Barnes

London $v$. London

$\begin{array}{lr}\text { London } v \text {. London } & 1+8 \\ \text { Lonilon \& Westin. Loan Co, v. Drake } 8.1\end{array}$

Loverlay $v$. Mitcliell

Low n. Burrows

Lidwig $v$. Kuippenger

Lumley $v$. Guy

Lyall $v$. Higgins

Lyne $v$. Moody

Lyon $v$. Fairbanks

M.

Macfadgen $v$. Olivant

Malbon v. Birney

Mansur v. Botts

Margetts $v$. Bays

Marsh v. Richarils

Marshall $v$. Haney

[References are to pages.]

139,152

346

59,342

345

257

342

134

48

15:2

343

245

252

139,161

244

$34 \overline{5}$

304

43

91)

59,341

274

$258,26: 3$

1335

(

Mitchell $v$. Gila

Mixer $v$. Coluirn

236

8.2

238, 260

256

238

348

10:3

83

$60,345,348$

$227,2: 37$

345

$2 \cdot 26$

199

196

345

$8 !$
239

243

348

84

256,257

90

236

342

218

:3t.) O'Brien v. Cavanaugh

2.31 v. Saxon

N.

Nasl v. Breeze

O.
254 Marston $v$. Baldwin

254 Mason $v$. Ditchbourne v. Farnell

Mather $v$. Church

Maund's Case

77, 228, 238

139,152

91

242

$252,343,344$

235,251

152

$346^{\circ}$

345

$345^{\circ}$

$346^{\circ}$

39

347

41, $2 \angle 3$

346

342

98

93

83

254,255

152

$: 43$

345

87

342

$3+3$

295

344

60,348

222

153

342

73

256

$53,54,56$

90

345

26, 2118

345

$21 \% 2$

346

88

148

Naylor $v$. lall River Iron Works

257

348

346

143

345

200

347

344

47 
Owen $v$. Knight

Oystead $v$. Shed

\section{P.}

Packwood $v$. Tho p

Page $"$. l)wight v. Freema:

Palmer $v$. Ekins

Parcell $v$. Combe:

Parker $v$. Parmlee

P'arks $v$. Heman

Parmliain $v$. Pacey

Parry $v$. Frame

Partington $v$. W $s$ msutta Mills

Partridge v. I)artmouth Col.

Pearson $v$. lioberts $v$. Rogers

Pendleton $v$. Dyett

Penn $v$. Ward

People $v$. Gray $v$. Rowland

l'erkins $v$ Hart

Petree ". Duke

Pett $v$. Russell

Plielps ". Decker

Phillips $v$. Bacon $v$. Gallant $v$. Robinson

Planche $r$ Colburn

Pole $v$. 'T'wolieff

Pond $v$. Wyman

Pordage $v$. Cole

Potts $r$. Point Pleas.

Poulter $v$. Cornwall

Poulion v. Lattimore

Powdick $r$. Lyon

Poyser v. Minors

l'resillent etc. $v$. Rife

Preston ". Am. Lin. Co.

Prim $v$. Walker

J'rinieton Co. $v$. Grelick

Proprietors $v$. Taylor

Pulliam v. Burlingame

Pullman v. Corning

I'urchell v. Salter

\section{R.}

Radford $v$. Harbyn

Randall's Case

Ray $v$. Young

Raymond $v$ Andrews

Read $v$. Broskman

v. Hutchinson

$$
v \text {. Ran }
$$

Reader ". Purdy

Jeal Istate Sav. Inst. $v$. Collonious

Re Cruwilv

Regina $v$. Nyer

Renno $v$. Bennett

Rensliaw $v$ loyd

Rex $r$. Burgess $v$. Fawcet

[References are to pages.]

\begin{tabular}{r|lr}
238,259 & Rex $v$. Sadler & 138 \\
242 & $v$. Storr & 134 \\
& $v$. Wilson & 134 \\
& Rice $v$. Hollenbeck & 90 \\
& Richards $v$. Frankum & 228 \\
153 & Richardson $v$. Mayor of Oxford & 214 \\
153 & Ring $v$. Kelly & 48 \\
178 & Ringliam $v$. Clements & $238,25 !$ \\
242 & Rivers $v$. Griffiths & 282 \\
346 & Roberts $v$. Havelock & 345 \\
254 & $v$. Long & 153 \\
254 & $v$. Marriett & $24: 3$ \\
270 & Robinson $v$. Rayley & 240,243 \\
90 & Rogers $v$. Arnold & 70 \\
348 & Roo $v$. Apsley & 42 \\
91 & Roosevelt $v$. Fulton & 234 \\
92 & Rose $v$ Bates & 160 \\
245 & Roy $v$. Parkers & 138 \\
256 & Rude $v$. Mitchell & 345
\end{tabular}

\section{S.}

\section{Sampson $v$. Henry}

Sanford $v$. Rogers

Saunders $v$. Crawley

Scarborough $v$. Arrant

Sicattergood $v$. Sylvester

Scliee $v$. Hassinger

Schnerr ". Lemp

-cott $v$. Parker

Seraggs $v$. Hill

Searle $v$. Long

Selby $v$. Bardons

Sendicor $v$. Leach

Sesson $v$. Willard

Shannon $v$. Shannon

195,294

235

348

181

342

349

162

347

232

Searer $v$. Jewett

Sherman $v$. N. Y. Cent. R. R.

Shipp $v$. Snyder

Silsbury ". McCoon

Sims $v$. Mcliwen

Sister $v$. Hodgson

Skinner $r$. Kilby

Slade's Case

Smart v. Hyde

Sinitl, $\because$ Dovers v. First Cong. M. H.

v. Hayward

$v$. Milles

\section{v. Parsuns}

v. I'slius

v. Smith

$v$. Welib

Snow i. Alley

Spalding $v$. Vandercook

spence $v$. McGowan

Snencer $v$. Blackman

Spieres ". Parker

Stafford $v$. Mayor of Albany

Stancliffe $v$. Hardwick

Stanley $v$. Bircher

Staple $v$. Haylen

Stark $v$. Parker
Sprarhawk $v$. Bagg
232

244

$2 i 4$

146

90

64

317

345

255

132

232

342

257

93,98

312

345

149

90

345

47

243

$5 \mathrm{l}$

256

244

39

345

87

235

66

47

39

90

344 
Starr $v$. Jackson

State $v$. Hoefiner

$$
\text { v. Kemp }
$$

$v$. Richards

v. Vansickle

$$
\imath \text {. Wilson }
$$

Stavers $v$. Curling

Stearns $v$. Stearus' Adm'r

Steiner $x$. l'riddy

Stennel $v$. Hogg

Stephens $v$. Eiwall

Stevenson $r$. Lambard $v$. Newham

St. Louis ". St. Louis Gas Light Co.

Stonc $v$. Dennis $v$. Stone

Straddling $v$. Morgan

Street $v$. Blay

Strong $v$. Smith

Stroud $v$. Springfield

Studdy $v$. Saunders

Strutter $v$. Harlock

Sutherland $v$. Pratt

Sullivan $v$. Campell

Syms $v$. Chaplin

T.

Taunton $v$. Costar

Taylor $v$. Cole

$v$. James

v. Markham

Templar $v$. McLachlan

Thomas $v$. Cadwallader v. Morgan

Thomas Co. $v$. Watson

Thomasson $v$. Wilson

Thompson $v$. Burhams v. Thompson

Thorn $v$. Shering

Thornton $x$. Place

Thorp $v$. Thorp

Thurber $v$. Conners

Thurston $v$. Percival

Tilton $v$. Beecher

Timberlake $v$. Thayer

Titus $v$. Johnson

Todd $v$. Summers

Torrenee $v$. Giblins

Trapaud $v$. Mercer

Traver $v$. Halstead

Trevelian $v$. Seccomb

Trubee $v$. Miller

Tucker $v$. Groves

Turner $v$. Neymott

Turnpike Co. $v$. Rife

Tuttle $v$. IIanlon

Underwood $v$. Sparks

Union Cotton Mfg. $v$. Lobdell

Unwin $r$. Wolseley

Utter $\because$. Vance

[Keferences are to pages.]

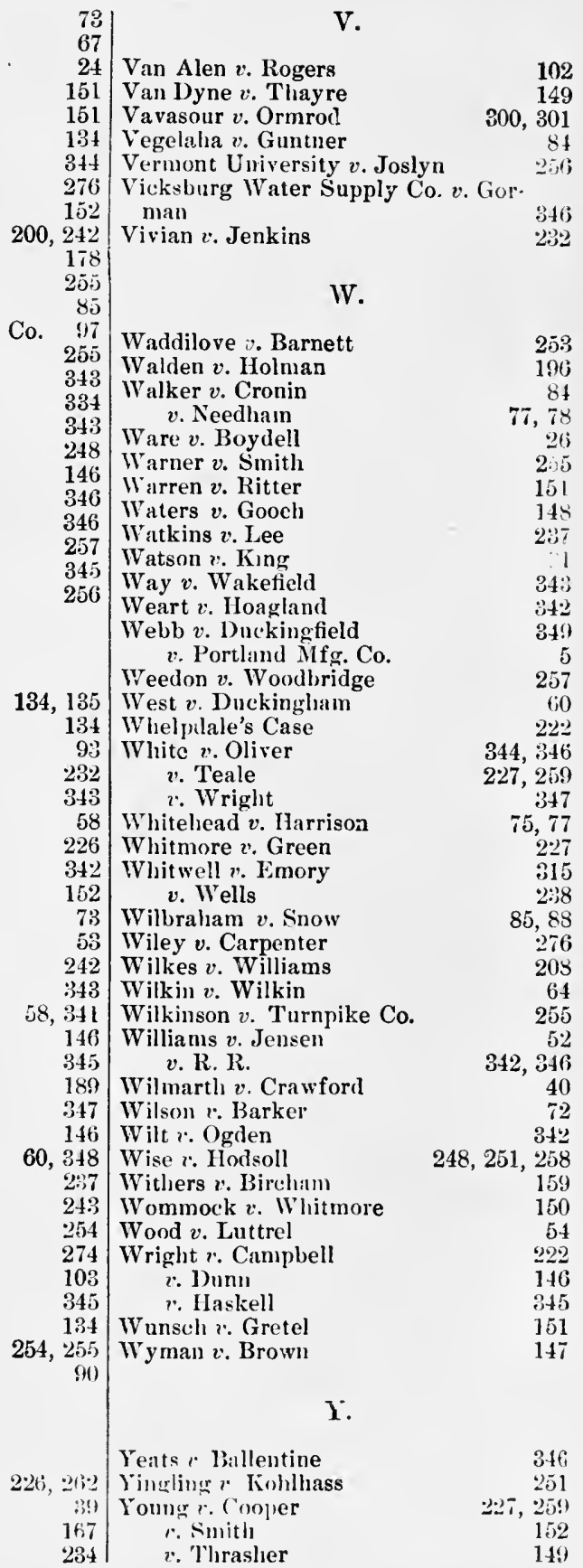




\section{CIVIL PROCEDURE.}

\section{CHAPTER I.}

\section{INTRODUCTORY.}

Article 1. Primordial Concoptions.

" II. Civil Actions.

“ III. Originai

“IV. Appearance.
Article IX. Profert.

Article V. Pleadings.

"VI. Courts.

“ VII. Attorneys and Barristers.

"VIII. Declaration.

\section{ARTICLE I.}

\section{Primordial Conceptions.}

Sec. 1. Law.

"2. Duties and Rights.

“ 3. Wrongs.
Sec. 4. Damage.

“ 5. Danage implied.

“ 6. Damage actual.

Section 1. Law. In commencing the study of any science or art, it is necessary that the student should have a more precise understanding of the general conceptions which underlie it than can be derived from crdinary definitions. To help him in doing this in respect to the science of civil procedure, I will consider briefly the meaning and import of the terms at the head of this article.

It may be said without contraciiction that the law of a State consists in the existing rules and principles o human conduct binding on its members as such. The binding effect of these rules and principles is derived from the command or sanction of the sovereign power of the State. This command or sanction is contained in the positive enactments of the State, or ix the recognition by the State of such rules and principles as have originated with the members of the State, and possess their common assent.

SEc. 2. Duties and Rights. The law cannot be studied or dealt with as a collection of abstract principles or propositions. It can be understood and appreciated only in its application to the 
acts and events of human life. In such application it manifests itself in reciprocal duties and rights of the members of the State, as to the State itself, and as between each other, and in wrongs which result from a breach or invasion of such duties and rights respectively. Criminal wrongs result from a breach of duty to the State ; civil wrongs from a breach of duties existing between members of the State. Civil procedure concerns itself chiefly with a breach of duties and violation of rights existing between the members of the State; and what is contained in this treatise relatez to them only.

Duties and rights are correlative terms. No duty can rest upon any member of the State, without a corresponding right in some other member or members to have that duty kept and performed, whether it be a duty sanctioned by the State because it has been assumed by the members, or is imposed by the express or implied sanction of the State, irrespective of the consent of the member in the particular case. The very existence of a right in behalf of one member of a State against another member implies a duty on that other to do or refrain from doing something which will beneficially or injuriously, as the case may be, affect the possessor of the right.

Wrong is nothing more than a breach of duty, which necessarily zonstitutes at the same time a violation of right. Duties, rights, and wrongs are only aspects or phases of law, as it is applied to the acts and events of human life. The whole body of the law of any State nay be intelligently classified under any one of these aspects or phases, so closely are they blended together.

The word duty in its legal sense, and as used in this article, includes not only the natural and positive duties imposed by law, but also such duties as have been assumed by the members of the State as between each other, by virtue of contracts, which the law sanctions and enforces in behalf and against the parties thereto.

SEc. 3. Wrongs. As already stated, wrong in a legal sense is the violation or infringement of a right. There can be 110 wrong for remedial redress where there is no right. The conception of a wrong implies the existence of a right. Wrong and injury (injuria) are convertible terms in their primary and legal signification. Every injury implies not only the existence of a right, but also a violation or infringement of it. Damage or loss which results from the wrong is distinguishable from the wrong itself. .The worl injury is sometimes used in a popular sense to represent the dam. 
age or loss resulting from the injury. A person's injuries are sometimes alluded to, when nothing is meant beyond his actuai damage or loss. ${ }^{1}$

I have said that positive or municipal law manifests itself in re. ciprocal duties and rights. These duties and rights are supposed in law to be known to the members of the State. Liability of some kind for a breach of duty or violation of right is a logical consequence of the act, and springs from the sanction of the Srate which gives to law its binding effect. This liability is usually measured by the damage or loss consequent upon the breach of duty or violation of right. The State enforces its command or sanction embodied in every law, by compelling redress of some kind from every wrongdoer.

I do not deem it necessary in this treatise to inquire whether there exists any uniform theory or basis upon which it may be affirmed that this liability is enforced by the State, although I am convinced that in some doubtful cases near the border of legal responsibility an appeal to some underlying theory or basis of liability must be made to settle the question of legal liability. In such appeal the philosophy underlying all municipal and positive law is involved, and it will be found on examination that the authorities bearing on the point of inquiry are in conflict, especially in respect to liability for acts which in themselves do not constitute the infraction of any right, but which eventuate in such result, without any blameful conduct of the defendant. It is sufficient for the purposes of this treatise to refer the reader to some of the best sources of information. ${ }^{2}$

SEc. 4. Damage. The common law system of procedure as

1 Dicey, 28, n. $a$.

2 Austin's Jurisprudence ; Holland's Jurisprudence ; Hare on Contracts; Pollock on Torts; Holmes on Common Law. It is contended that assent upon consideration is the basis of liability for breach of duty springing from contract; and that cuipability is the basis of liability for breach of duty constituting a tort.

The first generalization is almost universally conceded. The second one does not seem to furnish a satisfactory basis for the liability imposed by law for certain torts, irrespective of any culpable conduct of the defendant.

it is possible that, in the course of time, liability may not be recognized or enforced for torts in the face of innocent conduct on the part of the defendant, unless he has in some way agreed to such a result. Until that time comes, the second proposition falls short of a perfect generalization: of the basis of liability in torts, al. though it accounts for liability in the greater portion of them. 
finally developed does not assume to enforce duties or maintain rights, by affirmative commands directing performance of the one or enjoining infraction of the other, but only in a negative way, ky means of compensation or restitution, after wrongs have been inflicted. The duty to make restitution or compensation for the wrong suffered from a breach of duty is a supplemental duty, and is implied in the binding force of the duty which has been broken, - that binding force which springs from the necessary sanction of the sovereign to all law. The right to have such compensation or restitution belongs to the possessor of the right which has been violated by the breach of duty. To him the courts in a common law proceeding awarded compensation in money or a restitution of the thing wrongfully taken or withheld. Compensation or restitution was not awarded for every damage or loss, but only for such as resulted from the infraction of a right. When the damage or loss was not the proximate effect of the infraction of a right sanctioned by law, it was irremediable in the courts; a condition of things which gave rise to the maxim Damnum absque injuria, that is, a damage or loss without a wrong.

SEc. 5. Damage implied. It was a principle of the common law that whenever the direct and immediate effect of the act of any one constituted a violation or infringement of a distinct legal right of another, damage necessarily followed; for which the possessor of the right was entitled to compensation or restitution according to the nature of the wrong and extent of the damage. This conclusion was justified by the maxim Ubi jus ibi remedium. In most acts of direct violation of distinct legal rights, actual damage usually results. But in some instances a legal right may be airectly violated withont resulting in any actual or appreciable damage. Nevertheless, the law in such cases conclusively presumes damage, and, in absence of proof of any actual damage, awards a nominal sum which usually operates to carry costs. The reason for this conclusive presumption and award of damages is derived from the full aim of common law procedure, which is to discourage the future violation of rights, as well as to furnish compensation for the actual violation thereof. On this account, a person is not at liberty to violate the rights of another, and escape legal condemnation for his wrongful conduct by the accidental fact that no actual or appreciable damage has been suffered. It, may therefore be asserted as a universal proposition that damage either actual or 
implied attends the violation of every legal right, ${ }^{1}$ and is an essential ingredient in every proceeding to obtain redress therefor.

On these three aspects or manifestations of law, viz. right, wrong, and damage, rests the whole fabric of common law procedure. Accurately speaking, there is no such thing as wrong in a legal sense without damage actual or implied, and the maxim Injuria sine damno, which was imported at an early day from the Roman law, fails to command the assent of modern jurists. ${ }^{2}$ It will be found, on examination of the cases to which this latter maxim has been applied, that in some of them the violated right in question belonged to the public, and the citizen had no interest in the right or the damages, except in common with the public, in which event the remedy for redress must be invoked by and in the name of the State $;^{3}$ in others, the right to recover damages for the apparent violation of right has been denied or suspended on grounds of public policy. ${ }^{4}$

SEc. 6. Damage actual. While it is true that the law presumes damage from the direct violation of absolute and possessory rights, and from the violation of rights created by contract, it is also true that there is a large variety of cases in which actions for the infraction of rights, consequent upon acts not wrongful in their nature, cannot be maintained without proof of actual damage. In these cases it may be said that no right has been substantially violated until actual damage or loss is suffered. There being nothing wrongful in the nature of the act from which actual damage has been suffered, there would seem to be nothing in it from which the law can presume damage. Hence the plaintiff is compelled to allege and prove actual damage in order to establish the facts which constitute a violation of right. No invasion of right is perceptible before actual damage or loss is suffered. ${ }^{5}$ It is perhaps impossible to submit a decisive test by which to distinguish these cases from those in which damage is necessarily implied and need not be proved to maintain the action. The distinction may be sufficiently understood by allusion to a few examples; as where a master sues for assault on his servant by reason of which he has

1 Pollock on Torts, 214.

2 Ashby $v$. White, 2 Ld. Raym. 938; Webb v. Portland Manuf. Co., 3 Sum. 189 ; S. C. Fed. Cas. 17322; Ad. on Torts, 1, 9 ; Pig. on Torts,
126 ; Innes on Torts, 16; Hale or. Torts, 54.

3 Broom, Leg. Max. 203, 204.

- Ibid., 207, 208, 209.

5 Pollock on Torts, 215. 
lost his service; where a reversioner sues for trespass on land, whereby the imheritance has been damaged; where the plaintiff sues one for setting out a fire or maintaining a nuisance by reason of which he has been damaged; where the plaintiff sues for the utterance of false words, which may, but do not necessarily, cause harm or loss. In all these, as well as in many similar cases, it may be said that one's right to immunity from harm in respect to his person, property, or reputation, is not violated until the harm or damage has been done. Actual damage is therefore a necessary ingredient of the action. But, as we have seen, it is otherwise when the right to immunity from harm is violated by a direct assault or trespass upon the person or possessory rights of the plaintiff; damage is implied and need not be proved.

Right, wrong, and damage must, however, appear in every statement of a cause of action, either by express averment or necessary implication from the averments made.

\section{Article II.}

\section{Civil Actions.}

Sec. 7. Defined.

I Sec. 8. General Classification of Actions. Sec. 9. Classification of Personal Actions.

SEc. 7. Defined. By civil procedure is meant "the mode of proceeding by which a legal right is enforced as distinguished from the law which gives or defines the right." ${ }^{\prime}$ A civil action at common law is a proceeding in a court of justice for the purpose of obtaining redress for the violation of a legal right.

The definition of the Mirror, that "an action is nothing else but the demand of right," which has been so often commended, is too meagre, in leaving out a distinctive feature of either an action at law or a suit in equity, viz. that the demand must be in a court of justice and according to its forms of procedure. ${ }^{2}$ A person may demand his right in many ways; but unless he demands it in a court of justice and through the forms of its procedure his demand will not constitute a civil action or suit. A demand of one's right outside of a court and its forms of procedure is in some cases necessary to give a right to bring and maintain an action in court.

1 Poyser $v$. Minors, 7 Q. B. Div. 329, 333; Lush, L. J. 408.

2 Cohens $v$. Virginia, 6 Wheat. 407 , 
In common law procedure, as already stated, wrong consists, in the violation of some legal right. ${ }^{1}$ The ordinary action at common law was an adversary proceeding in a court of justice, in which one party sought to render another party liable by judgment of court for the infringement of some legal right. ${ }^{2}$ This infringement constitutes the right of action or right of recovery as known at common law and is embraced in the nodern term cause of action $^{3}$ The definition here given covers the ordinary actions at common law, to which its system of pleading was eventually applied. After the brevia anticipantia (anticipatory or preventive writs) became obsolete, there was no proceeding at law which had for its distinct purpose the prevention of a threatened wrong. Chancery assumed jurisdiction in such cases and administered relief in proceedings peculiar to that jurisdiction which do not accord with the definition or immediate purpose of an action at law. A slight extension of the definition so as to include redress for threatened wrongs would be sufficient to cover ordinary suits in equity. ${ }^{4}$

I may add here that there have always been, and still continue in increasing numbers, proceedings in equity and under statutes which have for their immediate object the establishment or preservation of rights independent of any actual or threatened infringement thereof. Among sueh may be mentioned suits by trustees invoking the advice of the court, probate of wills, and proceedings to secure rights under the power of eminent domain. For a more complete enumeration of such proceedings I will refer to 1 Encyc Pl. \& Pr. 112, 113. The definition of a common law action or an ordinary suit in equity would have to be broadened to include them. Anciently the term action at law applied only to the proceedings which terminated with the judgment. But in modern times it includes all the proceedings from the writ to the enforcement and satisfaction of the judgment.

I may add in this connection, that the rights for violation of which actions lay at common law were rights at common law or under statutes, as distinguished from rights recognized only in equity.

$13 \mathrm{Bl}$. Com. 2.

2 Dicey on Parties, $2 S$.

Encyc. Pl. \& Pr. 116, 117.

"An action is an ordinary pro- ceeding in a court of justice by which in party prosecutes another party for the redress or prevention of a wrong:" Bliss on Code Pl, sec. 1. 
SEc. 8. General Classification of Actions. Actions at common law, according to the subject matter of them, were distinguished into three kinds, - personal, real, and mixed. ${ }^{1}$ Personal actions are for the recovery of a debt, or damages for the breach of a contract, or dainages on account of injuries to the-absolute or relative rights of person, or to rights appertaining to personal or real property, or for the recovery of specific personal chattels. ${ }^{2}$ Real actions are for the specific recovery of lands, tenements, and hereditaments. ${ }^{3}$

Mixed actions partake of the nature of the other two, being for the recovery of specific lands, tenements, and hereditaments, and also for damages on account of injuries thereto. ${ }^{4}$

A real action in its primary signification lay only to recover the freehold in lands, tenements, or hereditaments claimed in fee simple, fee tail, or for life. ${ }^{5}$ Mixed actions, in which freeholds were recovered as well as damages given by common law or by statutes, came to be treated in common acceptation as real actions, and will be found scheduled and treated under that head by most authors. ${ }^{6}$ The mixed action of ejectment, in which a less estate than a freehold could be recovered along with damages, was in its origin a personal action; but in modern times it has displaced the use of the ancient real actions, and is now properly designated as a real action. ${ }^{7}$ The fact that it lies for a less estate than a freehold, and that damages are also recoverable, does not divest it of its proper character as a real action. Mixed actions have never been treated as a distinct class by themselves, and I will follow the popular usage in this respect, and consider all common law actions under the two heads of personal and real; the latter head including all actions for the recovery of realty, whether with or without damages.

SEc. 9. Classification of Personal Actions. Personal actions are divided into two general classes, designated as actions $e x$ contractu, and actions ex delicto; in other words, actions for breach of contract and actions for wrong, not exclusively dependent upon or limited by contract. In these actions the party complaining is

13 Bl. Com. 117.

21 Chit. Pl. 97.

8 Steph. Pl. 3.

41 Chit. Pl. 97 ; 3 Bl. Com. tion, D. 4. 118.

5 Jackson on Real Actions, 1; 3 I3I Com. 117.

- Roscoe, 1, 3 ; Comyn, Dig. Ac-

7 Tyler, Eject. 36. 
called the plaintiff, and the party proceeled against the defendant. The first pleading on the part of the plaintift is the declaration, and the first on the part of the defendant the demurrer or plea. Personal actions ex contractu consisted of debt, covenant, assumpsit, account, and annuity. Personal actions ex delicto consisted of trespass $v i$ et armis, trespass on the case, detinue, trover, and replevin.

The classification of all personal actions as ex contractu or $e x$ delicto is not supported on principle, for we shall find that there are many duties imposed by law, a breach of which constitutes neither a tort nor the violation of a genuine contract, - as, for instance, the failure to pay a debt imposed by custom, judgment, or statute. In some of these cases the classification has been maintained by treating the action as if arising on contract, although clearly not so arising. In others, the duty imposed by law so resembles the duty assumed by contract that they have for convenience been included in actions ex contractu. The subdivision of real actions will be considered when they are taken up.

\section{ARTICle III.}

\section{Original Writs.}

Sec. 10. General Description.

| Sec. 11. Abolishment of.

Sec. 10. General Description. Original writs were such as were used in the institution of actions at law. The forms of action recognized in the courts of general jurisdiction took their names from these writs, which were anciently essential to the exercise of jurisdiction in the case. ${ }^{1} \quad$ At quite an early day the practice obtained in all the courts of exercising jurisdiction in personal actions without an original writ, which will be explained in connection with our account of the jurisdiction of the respective courts. But this practice did not do away with the use of the original writ in proper cases, if the suitors saw fit to invoke it. An account of the office, nature, and variety of these writs would fall but little short of a history of the ancient Common Law. It is sufficient for our purpose here to remark, that these writs were in the nature of mandatory letters issuing out of the Court of Chancery, under the Great Seal, in the King's name, and generally directed to the sheriff of the county in which the injury or wrong was alleged to have been committed.

1 Steph. Pl. 5, 6. 
They contained a summary statement of the cause of complaint, and fell into two general classes, which were designated and known as eptronal and peremptory. In the optional writ the sheriff was required to command the defendant to do a particular thing, and in the event of his failure to do it, to summon him into the King's Court to show cause for his failure or refusal. In the peremptory writ the sheriff was relieved from the requirement of commanding the defendant to do anything, and was required merely to enforce his appearance by summons or such other process as could be employed for that purpose. ${ }^{1}$

Whatever may have been the original connection between the writ and the form of action, it came in the course of time to control the cause and form of action, which were required to be stated in the writ ${ }^{2}$ and repeated in the declaration. ${ }^{3}$ The original writ from very early times served three very material purposes: it defined and determined concisely the form of the action; it gave the court in which the defendant was required to appear jurisdiction of the action, and it enjoined or enforced his appearance.

SEc. 11. Abolishment. After the abolishment of original writs in personal actions, and the substitution of judicial writs therefor by the Uniformity of Process Act of 1832, it was sufficient to state in the judicial writ by name only the form of action which the defendant was required to answer; as "in an action of debt" or "in an action of trespass on the case." 5 All personal actions in England since 1832 have been commenced by judicial writ of summons. By the Supreme Court of Judicature Act of 1873 all actions are now commenced by a judicial writ of summons indorsed with a statement of the nature of the claim made or of the relief or remedy sought. ${ }^{6}$ Only judicial writs are used in the United States.

\section{Article IV.}

\section{Appearance.}

Sec. 12. Necessity of Appearance.

| Sec. 13. Change in the Law.

SEC. 12. Necessity of Appearance. The plaintiff submitted himself to the jurisdiction of the court by suing out either origi-

1 Steph. Pl. 5, 6; 3 Bl. Com. 273.

21 Chit. Pl. 94, 95.

3 Tidd, Pr. 433.

1 Chit. Pl. 95.
52 Wm. IV. c. 39 ; 1 Chit. Pl. 94.

6 Order 2, 1875; An. Pr. 1897, p. 218. 
nal or judicial process returnable to it, without any formal appearance. No pleading was required from him before appearance of defendant. ${ }^{1}$ After that, if he failed to appear and prosecute his action, he was liable to judgment of nonsuit at the instance of defendant after demand in writing that he should plead, which carried costs enforceable against him and his pledges for prosecution. $^{2}$ If the plaintiff failed to appear and plead within one year after the return of the writ, he was deemed out of court by the Hilary rules, as well as by the Common Law Procedure Act of $1852 .^{3}$

The doctrine of appearance and the dilatory and cumbersome means of enforcing it relate entirely to the appearance of the defendant. The actual presence of the defendant, by himself or attorney, was required as a condition precedent to any pleading, trial, or judgment in the case. ${ }^{4}$ The court was not regarded as having jurisdiction over his person by service of summons upon him. If after service of summons he failed to appear or to authorize his formal appearance, he was treated as acting in contempt of court, and the process of attachment of his property and arrest of his person was originally invoked in some cases, and subsequently by fiction in all, to compel his appearance. If the use of this process did not result in compelling his appearance, there could be no step taken or judgment rendered against him on the cause of action $;^{5}$ except in real actions, in which the demandant was in a general sense conducting proceedings against land within the jurisdiction of the court. ${ }^{6}$

SEc. 13. Change in the Law. In later times the plaintiff was authorized by statute, upon affidavit of personal service of summons or writ of distringas, to enter the appearance of defendant, if he failed to appear within a certain time, and to proceed to judgment in like manner as if he had entered appearance for himself. ${ }^{\top}$ This practice did away with the process of attachment and arrest for the purpose of bringing the defendant into court; except when personal service could not be obtained, in which case the ancient mesne process to outlawry remained in force. ${ }^{8}$ By the Common

13 Chit. Gen. Pr. 437.

2 ? Chit. Gen. Pr. 448, 449.

3 Hilary Rules, 2 IVm. IV. r. 35: Com. Law Procedure Act, 1852, 8. 58 .

43 Chit. Gen. Pr. 141.
53 Bl. Com. 281; 3 Chit. Gen. Pr. 142.

- Roscoe, 168; Booth, 13.

73 Bl. Com. 287; Tidd, Pr. 241, 242 ; 3 Chit. Gen. Pr. 141.

83 Chit. Gen. Pr. 142. 
Law Procedure Act of 1852 the writ of distringas was abolished, also the practice of the plaintiff entering appearance of defendant. On proof of service the defendant was in default, and the plaintiff might proceed to final judgment by following the requirements of the act. ${ }^{1}$

The intricacy and inconvenience of the ancient mesne process to compel appearance brought a merited reproach upon the remedial procedure of English jurisprudence. If any of my readers should be curious enough to learn how the simple act of compelling a legal appearance to an action was misconceived and perverted by the process employed, he should read a full account of it in Tidd's Practice. $^{2}$

\section{Article V.}

\section{Pleadings.}

Sec. 14. Defined. Sec. 16. Immediate Object.

Sec. 15. History.

SEc. 14. Defined. Some of the most eminent writers on the subject concur in defining pleadings to be " a statement in a logical and legal form of the facts which constitute the plaintiff's cause of action or the defendant's ground of defence." 3 It will be observed that this definition excludes from the classification any allegations made with the intent of raising issues of law, as contained in demurrers and motions. The demurrer was excluded by them on the ground that it constitutes in fact and in form only an excuse from further pleading, and is not a plea of any kind. ${ }^{4}$ But as it admits the facts well pleaded and tenders an issue of law, taking its place on the record like other pleadings, there is no substantial reason for excluding it. The definition would therefore seem to be a little too narrow. The term pleading in its modern sense and usage represents the statement in legal form of the grounds on which the parties to an action respectively claim the decision of the court in his favor, whether of law or fact. ${ }^{5}$

1 Com. I. P. Act, 1852, s. 17, 18, man, 3 T. R. 159 ; 3 Bl. Com. 292; $24,26,27,28$.

Steph. Pl. 23.

2 Tidd, Pr. c. 9-13; 3 Chit. Gen. Pr. c. 5.

3 Bl. Com. 314 ; Gould, Pl. ch. ii.

31 Chit. Pl. 2, 13; Read v. Brooks. 43.

5 Bliss, Code Pl. s. 135. 
SEc. 15. History. The alternate statements of the parties, which constitute the pleadings (placita) of an action were originally expressed by the parties or their attorneys in open court before the judges, minutes of which were entered on the record when they were finally settled. These minutes were made by the clerk under the immediate direction of the judges. This method of proceeding continued into the reign of Henry VIII., ${ }^{1}$ when it became the universal practice of the parties or their advocates to deliver the pleadings to the court in writing. ${ }^{2}$ The pleadings as entered never speak in the first person, a fact which seems to corroborate their oral origin, when the clerks made minutes of what the respective parties had said before the judges.

Immediately, or very soon, after the Conquest, the oral pleadings were conducted in Norman French, while the record of them was written up by the prothonotaries in Latin. ${ }^{3}$ This continued until 1348 , when it was enacted that the pleadings (meaning oral pleadings) should be in English, but should continue to be entered or enrolled in Latin. ${ }^{4}$ On the introduction of written pleadings in the reign of Henry VIII., the pleadings as written and delivered followed the language and style of the recorded pleadings in Latin. ${ }^{5}$ This practice continued till 1731 , when it was enacted that both the pleadings and the record of them should thenceforward be framed in English, ${ }^{6}$ which remains the prevailing practice in England and the United States.

It may be remarked in this connection that reports of what passed in court were still taken and published in Norman French, and so continued for hundreds of years after the reign of Edward III. The statutes of Parliament since the reign of Richard III., including the statutes of that reign, are in English. Before that reign they were in Norman French or Latin.

SEc. 16. Immediate Object. The grand object contemplated by the system was the production of a certain and material issue between the parties, upon some important part of the subject matter of dispute between them. ${ }^{7}$ When the parties had reached in their pleadings a specific point or matter affirmed on the one side and

1 1509-1547; 2 Reeves, 219. See an example of oral pleading from the Year Books in the reign of Edw. II. in 2 Reeves, 220, 221.

2 Steph. Pl. 24.

8 Steph. Pl., App., n. 14.
436 Edw. III., Stat. 1, c. 15; 2 Reeres, 316.

5 Steph. Pl., App., n. 14.

64 Geo. II. c. 26.

71 Chit. Pl: 213. 
denied on the other, they were said to be at issue. This issue was the exitus or outcome of the pleadings, and a decision of this issue disposed of the whole case, without proof or trial on the previous allegations of the parties. ${ }^{1}$

It was according to its nature an issue of fact or of law. If it was an issue of fact, the court awarded a trial according to the prevailing modes of trial as applicable to the issue. If it was an issue of law raised by demurrer or motion, it was determined by the judges, after argument of counsel, if argument was deemed necessary. Issues of fact were known as general or special, according to the mode in which they were raised on the record. They will be considered in connection with the rules governing traverses.

In this feature of the production of a single issue, and disposition of the whole controversy by a trial of that issue only, the Common Law systein of procedure differed from all other known systems. In the Roman system the complaining party was not relieved from proving the facts of his complaint by the trial of subsequent exceptions. Nothing but an admission of its truth in open court operated to relieve the libellant from establishing the truth of his libel. ${ }^{2}$

\section{Article VI.}

\section{Courts.}

Sec. 17. Prefatory.

“ 18. King's Bench.

“ 19. Common Pleas.

Sec. 23. Courts Baron.

Sec. 20. Exchequer.

“ 21. Commission of Assize.

" 22. County Court.

SEc. 17. Prefatory. To understand the pleadings and process of common law procedure, some information of the Superior Courts of Common Law in which it was adninistered is necessary. To furnish the requisite information it will not be necessary to give anything beyond a brief recital of the original and acquired jurisdiction of these courts, which will include some general reference to the original and judicial writs by virtue of which that jurisdiction was exercised.

SEc. 18. KRing's Bench. The Court of King's Bench, so called because the sovereign used formerly to sit there in person, was the Supreme Court of Common Law in the kingdom, and latterly con-

$$
\text { ' Steph. Pl. 24, } 25 . \quad 2 \text { Langdell, Eq. Pl. s. } 7 .
$$


sisted of a chief justice and three puisne justices. ${ }^{1}$ It had a supervisory jurisdiction-over all inferior tribunals, magistrates, and corporations, which was exercised by its writs of mandamus, prohibition, and quo warranto. It had two sides to its jurisdiction, known as the Crown (or criminal) side, and the plea (or civil) side. On the Crown side it exercised jurisdiction in all criminal proceedings, from high treason down to the most trivial misdemeanors. Of this jurisdiction nothing need be said in this treatise. On the plea side its jurisdiction was originally limited to wrongs committed vi et armis or contra pacem, and which savored of a criminal nature, although furnishing a cause of civil action. This jurisdiction was commensurate with the limits of the kingdom, and was exercised by virtue of original writs issued out of Chancery. ${ }^{3}$ Anciently it was held that no action of debt or detinue, or other mere civil action, could by common law be prosecuted in the court by any subject by original writ ont of Chancery, ${ }^{3}$ except the action of debt given by statute. ${ }^{4}$ But by degrees it came to exercise in later times jurisdiction by virtue of original writs in all personal actions against all persons, excepting prisoners in custody of the marshal and officers or attorneys of the court, ineluding peers of the realm and members of the House of Commons. ${ }^{5}$

It has exercised from a very ancient date jurisdiction without original writ in all personal actions by or against its attorneys or officers. The proceeding commenced by exhibiting in court a bill setting forth the cause of action, which in substance resembled,a declaration. Members of the House of Commons were by statute made subject to be sued by bill and summons. ${ }^{6}$

It likewise entertained from the earliest times jurisdiction without original writ in all personal actions against prisoners in actual or constructive custody of the marshal. ${ }^{7}$ The proceeding was by bill.

The judges of the Court of King's Bench were the sovereign judges of gaol delivery and of oyer and terminer, also conservators of the peace throughout the whole realm, and supreme coroners of all England. ${ }^{8}$ Its jurisdiction was so high that it superseded the powers of all justices of oyer and terminer, gaol delivery,

$11 \mathrm{Wm}$. IV. c. 70.

23 Bl. Com. 42, 285; 1 Spence, Eq. Jur. 114.

34 Inst. 72 ; 3 Bl. Com. 42.

- Culliford $v$. Blanford, Carth. 234.
61 Tidd, $\mathrm{Pr} .37$.

612 \& 13 Wm. III. c. 3, s. 2.

71 Tidd, Pr. 37.

${ }^{8} 3$ Bl. Com. 41; Crabb's Eng. Law, 550 ; Spence, Eq. Jur. 114. 
and of Eyre in the county wherein it sat, during the time of its sitting. ${ }^{1}$

We have seen that by its fundamental constitution it had power to determine all trespasses by the common law and custom of the realm, which it took cognizance of by original writ. ${ }^{2}$ But by virtue of its power as conservator of the peace, and the necessity imposed on it of inmediate action by reason of a suspension of the authority of the justices as recited, no original writ was deemed necessary to give it cognizance of misdemeanors in the county in which it sat. Accordingly it exercised its jurisdiction there in all cases of forcible injury, upon plaint made to it, by judicial process of its own, wherein it commanded the sheriff to take the defendant and bring him before the court to answer the trespass complained of. This process was called a Bill of Middlesex, because the court, with few exceptions, always sat in that county. If the sheriff made return of non est inventus, then a second writ could be issued to the sheriff of any other county upon suggestion that the defendant lurks or wanders in that county, which was known as a latitat, being in substance like the first writ. After the defendant was brought into court he was liable as a prisoner, as we have seen, to be sued in any form of personal action by any subject.

Upon this proceeding, which in the beginning was real, the court founded its usurpation of jurisdiction in all personal actions between subjects. This was done by permitting the plaintiff to sue out the Bill of Middlesex, or latitat, which contained the recital of a feigned or supposed trespass, and commanding the defendant to answer the same, and also any other personal action suggested in the writ. When the defendant appeared he was required to plead solely to the other personal action suggested in the writ, and exhibited by the plaintiff by bill or declaration. In this manner the court extended its jurisdiction to all personal actions. And it was probably after this extension that writs from chancery came to be issued in all personal actions, as stated by $\mathrm{Mr}$ Tidd. $^{3}$ It remained optional with the plaintiff whether he would commence by this judicial process of the court, or sue out an original writ. But the more usual method was by judicial process without original writ. ${ }^{4} \mathrm{Al}$ though the first pleading against an artual prisoner was by exhibiting a bill stating the cause of action, in cases of feigned or

1 Crabb's Eng. Law, 550.

23 BI. Com 254.
31 Tidd, Pr. 37.

4 Bl. Com. 283. 
supposed custody it was more usually called a declaration. After passage of the Uniformity of Process Act of 1832 it ceased to be slecessary to resort to this fiction to maintain the jurisdiction of the court. ${ }^{1}$

The King's Bench was also a court of appeal, into which might be removed by writ of error the judgments of the Common Pleas and of all inferior courts of record. ${ }^{2}$ An appeal from the King's Bench was to the Court of Exchequer Chamber, or to the House of Lords. ${ }^{3}$ But in later times it was first to the Court of Exchequer Chamber, and thence to the House of Lords.

SEc. 19. Common Pleas. The Court of Common Pleas, which in modern times consisted of one chief and five puisne-justices, ${ }_{-}^{4}$ exercised original jurisdiction in all civil actions whatever between subject and subject.

As already stated, the jurisdiction of the King's Bench became concurrent with it in all personal actions and three or four mixed actions. Its jurisdiction in distinctively real actions, and in the greater part of mixed actions, was exclusive of the other superior courts. ${ }^{5}$ It was also exclusive in certain actions provided for by statute.

Its jurisdiction was anciently exercised by original writs issuing out of Chancery. In later times a practice prevailed of commencing actions by judicial process of capias founded upon the return of a supposed original writ, which was not actually issued unless outlawry of defendant was contemplated. If in other cases the plaintiff was called upon to produce the original, he could satisfy the demand by exhibiting a fictitious original with a fictitious return. ${ }^{6}$ In the reign of William IV. the judicial writ was substituted for the original in all personal actions. ${ }^{7}$

It was customary for this court from the earliest times to entertain jurisdiction of personal actions by bill instead of writ in favor of and against attorneys and officers of the court, in like manner as in the King's Bench.

SEc. 20. Exchequer. The Court of the Exchequer in its origin had jurisdiction only of cases in which the defendant was liable to the Crown for non-payment or withholding of the revenue due

$12 \mathrm{Wm}$. IV. c. 39

23 Bl. Com. 43.

$33 \mathrm{Bl}$. Com. 43.

431 \& 33 Vict. c. 125.
51 Tidd, Pr. 38.

$63 \mathrm{Bl}$. Com. 282.

$72 \mathrm{Wm}$. IV. c. 39.

Martin Civil Procedure-2 
to it. The Crown could prosecute in this court its claims for collection of the revenue by procedure after the forms of law or equity, according to the nature of the case.

In the progress of time this court developed into two general divisions; one in which the royal revenue was managed, known as the Receipt of the Exchequer, and which need not be further noticed; the other the judicial part of the court proper, in which suits were prosecuted, and which was known as the Court of the Exchequer of Pleas.

The judicial division of the Exchequer of Pleas was a court of equity as well as a court of law, having two sides, one in which common law actions were tried, the other in which.suits in equity were entertained. ${ }^{1}$ The Crown employed both sides in the enforcement of its rights of revenue $;^{2}$ and of course no original writ was necessary for these proceedings in the name of the King.

From the earliest times the Exchequer of Pleas, in like manner with the other Superior Courts, entertained jurisdiction in personal actions by and against its officers and attorneys, to whom was accorded the privilege of suing and of being sued only in their own court in all personal actions. ${ }^{3}$ This jurisdiction was exercised without original writ, but upon bill as in the other courts.

The privilege of suing and being sued was further extended to the accountants of the King and the farmers of his revenue.

It was next extended to any subject who was indebted to the Crown, upon the assumption that, by reason of the default of the subject's debtor, the subject himself was less able to meet his obligations to the King. The suggestion of indebtedness on the part of the plaintiff to the Crown, as disclosed in the judicial writ and repeated in the bill or declaration, came in the course of time to be a non-traversable fact in the case. Nevertheless, upon this mere fiction the court exercised jurisdiction between subjects in all personal actions. The jurisdiction to entertain suits in equity between subject and subject was assumed by the court upon a like fiction. ${ }^{4}$

The equity side of the court was held before the Lord Treasurer, the Chancellor of the Exchequer, a chief baron, and three puisne barons. The common law side was conducted by the chief baron

13 Bl. Com. 44, 45 ; 2 Chit. Gen. Pr. 430 .

2 Smith, Ac. 6.
83 Bl. Com. 45.

42 Chit. Gen. Pr. 451; Smith. Ac. 6 . 
and puisne barons alone. In the reign of William IV., the barons were increased to five, ${ }^{1}$ and afterwards to six in the present reign. ${ }^{2}$

By the Uniformity Process Act of 1832 the usurped jurisdiction just recited was confirmed by act of Parliament; the fiction upon which it had rested was abolished, and judicial process by summons was substituted in all personal actions. ${ }^{3}$ In 1842 the jurisdiction of this court in equity was confined to the mere collection of the revenue of the Crown, and its other jurisdiction in equity as between subjects was transferred to the Court of Chancery. ${ }^{4}$

To this account of the Superior Courts of common law I may add an allusion to some of the changes effected by the Judicature Acts of 1873 and 1875, in which the business and jurisdiction of the King's Bench, Common Pleas, and Exchequer were transferred to the Supreme Court of Judicature created by said acts. ${ }^{5}$ It will be noticed that in the composition of that court the autonomy of these ancient tribunals was substantially preserved in the divisions of the new tribunal, known as the Queen's Bench Division, the Common Pleas Division, and the Exchequer Division, to which divisions were distributed the cases and proceedings which the old courts had previous thereto respectively entertained. $^{6} \quad$ By order of Council of Dec. 16, 1880, the Common Pleas and Exchequer Divisions were reduced and consolidated into one Division, namely, the Queen's Bench Division, of which the Lord Chief Justice of England is President, and who is now possessed of the powers heretofore belonging to the Lord Chief Justice of the Common Pleas and the Lord Chief Baron of the Exchequer. ${ }^{7}$ To understand the jurisdiction of the present Queen's Bench Division, it is necessary to know something about the ancient jurisdiction of the three courts to which it has succeeded, under the Judicature Acts and orders and rules made in pursuance thereof.

SEc. 21. Commission of Assize and Nisi Prius. This commission or court was an auxiliary of the Superior Courts, and was composed of a justice of one of said courts-associated with one or two discreet knights of each county in which the commission sat.

$11 \mathrm{Wm}$. IV. c. 70 .

$231 \& 32$ Vict. c. 125.

$32 \mathrm{Wm}$. IV. c. 39.

15 Vict. c. 5.
$536 \& 37$ Vict. c. 60.

6 An. Pr. 1897, 51.

7 Jud. Act, 1881, s. 25. 
Besides its jurisdiction in criminal matters, it was authorized by act of Parliament to visit the counties of the kingdom, and to take the verdict of a peculiar species of jury called an assize, which was summoned for the trial of landed disputes; also to try all questions of fact issuing out of the Superior Courts and appointed to be tried at Westminster by a jury summoned from the county in which the cause of action arose, with a proviso in the venire to this effect: nisi prius (unless before) the return day at Westminster the judges of assize come into the county in question; in which event the issue was tried by the judges of assize so visiting the county, an event which was certain to happen. ${ }^{1}$

SEc. 22. County Court. This court was continued from Saxon times. It was incident to the jurisdiction of the sheriff, and was not a court of recerd. It anciently held pleas of debt or damages under the value of forty shillings.

By virtue of a special writ called a justicies, in which the sheriff was commanded to do justice between the litigants, he exercised jurisdiction in this court in many real actions, and in personal actions to any amount. ${ }^{2}$

The sheriff also held his court as auxiliary to the Superior Courts in assessing damages in writs of inquiry, or in trying issues sent to lim by the courts for that purpose.

Although the jurisdiction of the County Court has been greatly changed by the County Court acts passed at different times, the changes have upon the whole resulted in increasing its powers, extending its usefulness, and adding to its dignity. ${ }^{3}$

SEc. 23. Courts Baron. These courts were incident to every manor in the kingdom. They were of a twofold nature.

One was the customary Court Baron, and was held by the steward of the manor. It entertained jurisdiction of the transfer and surrender of copyhold estates, and the admittance of copyholders to tenancy, and of other matters relating to their tenures.

The other was a court of common law termed the Freeholder's Court Baron, in which writs of -right to land within the manor - were determined. How these writs came to be made returnable in the King's court in derogation of the ancient jurisdiction of

13 Bl. Com. 57, 58, 59.

13 Vict. c. 101 [1849] : 13 \& 14 Vict.

23 Bl. Com. 35, 36; Fitz. N. B. c. 61 [1850]: $15 \& 16$ Vict.c. 54 [1852]; $85,119$.

30 \& 31 Vict. c. 142 [1867]; 51 \& 52

$39 \& 10$ Vict. c. 95 [1816]; 12 \& Vict. c. 43 [1888]. 
the Courts Baron will be explained in our sketch of the ancient real actions. ${ }^{1}$

It also had jurisdiction of personal actions where the debt or damages did not reach the amount of forty shillings. The court was held before the freeholders of the manor, the steward acting in the capacity of registrar rather than judge. Courts Baron fell into disuse, and were practically abolished or superseded by the County Court Acts of 1846 and $1867 .^{2}$

\section{Article VII.}

Attorneys and Barristers.

Sec. 24. Origin.

“ 25. General Duties. Sec. 26. Qualifications, Responsibility, and
Discipline.

SEc 24. Origin. Attorneys at law grew up from attorneys in fact.

By the ancient common law no one could appear for another in court except by special authority of the King, evidenced by writ or letters patent. ${ }^{3}$ Attorneys were first expressly recognized by statute as a body or class in 1273 , when the judges were required to select in each county the most learned and able attorneys and apprentices to do service in court. ${ }^{4}$ These selections were made from such persons as had been in the habit of going to court with suitors, and assisting them in their business in court. Naturally men with some learning and experience in the counties would be called on by suitors for this kind of service, and the value of their assistance would be increased by the frequency of their visits and extent of their service. Their constant appearance with suitors would naturally attract the attention of the courts, and recommend them to the acquaintance and friendly regard of the judges. The statute of Edward I. recognized this condition of affairs, and enabled the judges to help these assistants, or attorneys in fact, by selecting the best of them to do service for suitors in court. This selection gave superior value to their work, and increased their emoluments. The selection made them quasi officers of the court, and rendered them amenable to its superintending control.

1 Sec. 126.

230 \& 31 Vict. c. 142 , s. 28.
81 Tidd, Pr. 60.

42 Edw. I. 
By a subsequent statute of the same reign, all persons were enabled to appear in court and to prosecute and defend by attorney. ${ }^{1}$ Prior to this statute the normal relation of the attorney was that of an experienced adviser or spokesman acting in behalf and always in the presence of the suitor. It seems to be clear that prior to this statute a suitor might, if he had appeared to an action in person, appoint with the consent of the court a responsalis (who was in substance an attorney) to represent him in the subsequent progress of the suit. ${ }^{2}$

SEC. 25. General Duties. In the course of time these selected attorneys came to be divided into two well defined classes, designated as attorneys and barristers. The general business of the attorney was to attend personally to such parts of an action as were conducted outside of court, while the barrister exercised the exclusive right of audience before the judges in open court. "The barrister was also a counsellor to the attorney, and important steps in a cause were not usually taken without his advice. Pleading and conveyancing alse belonged to the business of a barrister. The conduct of every action in a superior court required the employment of a barrister as well as an attorney. By professional courtesy, the barrister was excluded from communication with his client, except through the intervention of an attorney; and the attormey from communication with the judges except through the intervention of a barrister.

\section{SEc. 26. Qualifications, Responsibility, and Discipline.} The qualifications for enrolment of attorueys in the courts were prescribed by rule of court or fixed by statute. They were not members of the Inns of Court, but at one time were required to be members of the Inns of Chancery. ${ }^{3}$ Solicitors in Chancery corresponded with attorneys at law, and took rank with them. ${ }^{4}$

By rule of court, and afterwards by statute, students were required to serve for five years as articled clerks to practising attorneys or barristers before applying for enrolment as attorneys. This term of service was reduced to three years in the case of graduates of certain universities. They also were subjected to examination by examiners appointed by the courts, or the duly constituted authorities having charge of such matters. ${ }^{5}$

1 Westm. II. [13 Edw. I.], c. 10 [1285].

2 Steph. Pl., App., n. 5 ; 1 Reeves, Hist. 217.
31 Tidd, Pr. 60, 61.

42 Chit. Gen. Pr. 2.

5 Tidd, Pr. 60, 61 . 
In 1845 was established a corporation named "The Society of Attorneys, Solicitors, Proctors, and others [not being barristers], practising in the Courts - of $\mathrm{Eaw}$ and Equity of the United Kingdom," the operations of which, combined with the-Attorneys' and Solicitors' Act of $1843,{ }^{1}$ have conferred important advantages on the profession of law and the public at large. This society took a superintending interest in the competent and faithful discharge of duty by attorneys, solicitors, and proctors, and participated in the examination and admission of them to enrolment in the courts.

Since 1843 numerous acts have been passed relating to attorneys and solicitors, which, along with certain sections of the Judicature Acts, have extended their rights, privileges, and responsibilities, prescribed their qualifications, and helped greatly to maintain proper discipline over their conduct. ${ }^{2}$. By the Judicature Act of 1873 the name of attorney at law was abolished, and the name of solicitor substituted in its place. ${ }^{3}$ By the Solicitor's Act of 1888 , the roll of solicitors was given into the custody of the Incorporated Law Society. Complaints for misconduct were referred to a committee of the council of said society, appointed by the Master of the Rolls, which committee was authorized to report their findings to the High Court of Justice, upon which it rendered judgment. ${ }^{4}$ While great deference is paid to the findings of the committee, the court is not conclusively bound by them. ${ }^{j}$

Barristers were always members of the Inns of Court. Their entrance to the bar depended upon the suggestion and examination of the benchers or regents of the Inns, who prescribed the requisite qualifications, which consisted of a membership of five years' standing and a satisfactory examination. In the case of graduates of certain universities, a membership of three years' standing was sufficient. ${ }^{6}$

A student qualified to become a barrister could accept a certificate enabling him to become a practitioner under the bar in pleading and conveyancing.

Sergeants at law were barristers of an advanced degree, and were called to the order at the pleasure of the King by writ issuing out of Chancery. ${ }^{7}$ From the barristers and sergeants the King selected

$16 \& 7$ Vict. c. 73.

22 Ann. Pr. 1897, p. 315.

8 Jud. Act, 1873. s. 87.

42 Ann. Pr. 1897. p. 318.
5 Re Crowdy, 11 Times Rep. 406.

61 Tidr, Pr. 41, 42.

71 Tidd, Pr. 42. 
his Attorney General and Solicitor General, who took first rank at the bar. He also appointed a limited number of barristers and sergeants as King's Counsel, which appointment conferred on them only an honorary right of precedence over the ordinary barristers and sergeants.

The sergeants were members of Sergeants' Inn, and until 1845 enjoyed a monopoly of business in the Court of Common Pleas. It was then thrown open by act of Parliament to all barristers. In 1877 the Sergeants' Inn was disposed of by its members, and its proceeds distributed to them; and no one has been called to the order since 1868.

Barristers are officers of the courts, and amenable to their rules, which frequently prescribe their duties and fix their compensation. The name counsel has in recent practice been substituted for barrister. ${ }^{1}$

In the United States the functions of attorney and barrister are very generally united in the same person under the name of attorney at law or attorney and counsellor at law.

In modern as well as in ancient times the law imposes on these special agents of suitors the duty of exercising the utmost good faith, as well as reasonable diligence and professional skill, in attending to matters committed to their care, for breach of which they are liable in a civil action for damages. They always have been and still continue to be subject to suspension and dismissal for breach of duty, or for any misconduct in their professional capacity. Proceedings to that end are of a summary nature, and not according to procedure in ordinary civil or criminal actions. Such summary proceedings will be treated as sufficiently legal, if, in the absence of statutes directing special procedure, they give to the delinquent a hearing before final action on his case. ${ }^{2}$

While admission to the bar has always been regulated by law, and has usually been exercised by the courts in pursuance of authority conferred upon them from the earliest times, the right of discipline over attorneys when once admitted is inherent in the courts to which they belong. Although such discipline has been directed by statutes, commencing in the reign of Edward I., ${ }^{3}$ they

12 Ann. Pr. 1897, p. 3Ј6; Order 19 (1875), r. 4.

2 Randall's Case, 11 Allen, 473 ; Ex parte Wall, 107 U. S. 265; In re
Bowman, 8 Cent. L. J. 250; State $v$. Kemp, 82 Mo. 213.

3 Westm. I. (3 Edw. I.) c. 29. 
have been regarded as only in aid of the common law. The inherent power to discipline exists in the courts unless expressly or impliedly restricted by statute law. ${ }^{1}$

\section{ARTICLE VIII.}

\section{Declaration.}

Sec. 27. Prefatory.

" 28. Title of Court.

“ 29. Entitlement of Term. (

Sec. 33. Conclusion.

SEC. 27. Prefatory. The first pleading on the part of the plaintiff in personal actions is called a declaration, in the ancient real actions a count. It was the next step in order after appearance of the defendant.

The declaration was originally an expansion of the writ, - a more particular and circumstantial statement of the cause of action, which the writ indicated in general terms. Its requisite parts differed somewhat in form according to the form of action pursued and the custom and practice of the court in which it was filed. All declarations were alike in containing the following parts, viz.: title of the court, title of term or time of filing, venue, commencement, statement of cause of action, and the conclusion.

SEc. 28. Title of Court. In the King's Bench, when the pro. ceedings were in pursuance of an original writ, the declaration in ordinary cases was superscribed with the name of the court, as "In the King's Bench." If the proceedings there were commenced by judicial process in the nature of a capias respondendum, called a Bill of Middlesex, the declaration was entitled with the name of the prothonotary or chief clerk. Declarations in the Common Pleas and Exchequer were entitled like declarations on original process in the King's Bench, as "In the Common Pleas," "In the Exchequer of Pleas." By the rules of Michaelmas Term, 1832, all declarations were required to be entitled in the proper court having the case. ${ }^{2}$

SEc. 29. Entitlement of Term, or Time of Filing. Anciently, when the pleadings were oral, a memorandum of the time when the plaintiff and defendant came into open court and held

111 Allen, 476.

\& Ev. 411; Gen. Reg. Mich. T., 3

21 Chit. Pl. 263; 1 Saund. Pl. Wm. IV., I. reg. 15. 
their mutual altercations was cntered in the minutes of the proceedings by the clerk. When the pleadings came to be written, and were filed in court by the attorneys, which was always in term time, it was sufficient if the declaration was entitled as of the term to which the writ was returnable, or at which the defendant made his appearance. By the Hilary rules of 1834 it was required to be entitled of the year and day of the month in which it was filed or delivered. As this requirement applied only to personal actions commenced in the Superior Courts, it necessarily left declarations in real actions, ejectment, and scire facias to be entitled as before. ${ }^{2}$

SEc. 30. Venue. It was_anciently the rule that every_traversable allegation of fact in a pleading should state the place at which the fact transpired. A rigorous enforcement of the rule required the parish, town, or hamlet in which it transpired to be stated, as well as the-connty. But when local description was not a necessary ingredient of the action, the name of the county was sufficient. ${ }^{3}$ Under this rule it was customary also to state in the margin of the declaration the county in which the facts or some principal part of them happened. ${ }^{4}$ The venue thus laid in the margin was called the venue of the action, and indicated the county into which the writ issued, and in which the action was to be tried. It is unnecessary to consider in this connection the cases in which the venue must be truthfully stated, or those in which an accurate statement of venue was anciently excused or evaded in practice. ${ }^{j}$ By the Hilary rules of 1834 it was ordered that the name of the county should be stated in the margin, and that as thus stated it should be taken as the venue intended by the plaintiff, and that no venue should be stated in the body of the declaration or in any subsequent pleading; provided that,' in cases in which local description was required, it should be given in the body of the declaration. ${ }^{6}$ In the enforcement of this rule it was very generally held that a correct venue was not necessary except in local actions; and that in transitory actions the venue could be laid in any county, subject to compulsory change on a showing of the adverse party. In cases in which

11 Saund. Pl. \& Ev. 411 ; 1 Chit. 1 Chit Pl. 274, 275; 1 Saund. Pl. \& Pl. 263, 264.

23 Chit. Gen. Pr. 463.

3 Mostyn v. Fabrigas, Cowp. 176, 177; Ware $v$. Boydell, 3 M. \& S. 145; Ev. 506.
4 Steph. Pl 281.
51 Chit. Pl. 278.
61 Chit. Pl. 279.
7 Stepl. Pl. 289, 290. 
local description is required, the rule directing a statement of the name of the county in the margin does not dispense with a statement of the necessary local description in the body of the pleading. ${ }^{1}$

SEc. 31. Commencement. The commencement of the declaration follows the venue inserted in the upper margin, and precedes the more circumstantial statement of the cause of action.

It formerly contained, 1st, a statement of the names of the parties to the suit, and if they sued or were sued otherwise than in their own right or liability, or in a political capacity, then a statement of the character or right in respect of which they were parties to the suit; 2d, a statement of the mode in which the defendant had been brought into court; $3 \mathrm{~d}$, a recital or repetition of the original writ or form of action. ${ }^{2}$ Anciently it was the practice to repeat the whole writ in the declaration; but in 1654 the Common Pleas and King's Bench made a rule forbidding the repetition in actions on the case, and on general statutes other than debt, and directing in place of it a statement of the nature of the action. ${ }^{3}$ By regulations of Hilary Term, 1832, this rule was extended to all personal and mixed actions in the three Superior Courts. ${ }^{4}$ Soon after the promulgation of this rule, all original writs in persenal actions were abolished by the Uniformity of Process Act of May 23, 1832. But in mixed actions, and in actions removed from inferior courts, the form of commencement was not affected by this statute. No positive rule about the form of commencing actions was made by the courts after the passage of this act; but in the forms of declarations prescribed for personal actions, the commencement thereof recited the effect of the process against defendant, as that he had "been summoned," or "arrested," or "detained." As this form of commencement concluded with an " \&c." it was thought that a recital of the form of action was intended by the rule, and this intention was carried out in subsequent practice. ${ }^{5}$ Accordingly the forms of declaration used thereafter recited not only the effect of the process by which the defendant appeared in court, but also the form of action as mentioned in the judicial writ, as follows:" "was summoned" [or "attached," or "arrested" as the case might be] to answer the said A. B. in an action of trespass." 6 But it seems quite clear 460 .

1 Steph. Pl. 291; 3 Chit. Gell. Pr.

2 Saund. Pl. \& Ev. 415; 1 Chit. Pl. 280.

4 Reg. 4 Hil. Term, 2 Wm. IV.; 1 Chit. Pl. 283.

53 Chit. Gen. Pr. 465-467.

61 Chit. Pl. 285.

31 Tidd, Pr. 433 ; 1 Chit. Pl. 283. 
that it was not intended by the rule to require in the commencement of a declaration any statement of the form of action mentioned in the judicial writ. ${ }^{1}$ It was sufficient if it appeared in the body of the declaration. ${ }^{2}$ Both statements were omitted in the form of commencement prescribed by the Common Law Procedure Act of $1852 .^{8}$

SEC. 32. Statement of Cause of Action. The statement disclosed the right which the defendant had violated, whether founded on contract or tort, (unless it was judicially recognized by the court, ) the infringement or violation of the right, and the damages consequent upon the violation or infringement thereof. ${ }^{4}$ The facts thus constituting the cause of action should be stated with certainty and precision, and in their logical and natural order, so as to disclose the three elements necessary in every cause of action, viz. the right, the injury, and the damages. ${ }^{5}$

It was considered essential after enactment of the Uniformity of Process Act that the cause of action stated in the body of the declaration should correspond with the form of action stated in the judicial writ, although the objection could be taken advantage of only by motion, and not by demurrer. ${ }^{6}$ If an inducement was necessary to make out the cause of action, this was the proper place for stating it. The nature of an inducement, and in what actions it was necessary, will be considered in a subsequent part of this treatise. ${ }^{7}$ When the declaration contained more than one cause of action, each was required to be stated in a separate count.

SEc. 33. Conclusion. The conclusion of the declaration differed somewhat in form, according to the court in which it was made and the form of action employed.

In the King's Bench in suits for damage it concluded "to the damage of the plaintiff of $\mathbf{f}-$, and therefore he brings his suit"; in the Common Pleas, "wherefore the said plaintiff saith that he is injured and hath sustained damages to the value [or amount] of $£$ - and therefore he brings his suit"; in the Exchequer, "to the damage of the said plaintiff of $£-$, whereby he is the less able to satisfy our said lord the King the debt which he owes

13 Chit. Gen. Pr. 467.

23 Chit. Gen. Pr. 467; 1 Chit. Pl. 254.

3 Com. Law Proc. Act of 1852,
41 Chit. Pl. 287.

5 Saund. Pl. \& Ev. 416.

- 1 Chit. Pl. 254, 287.

7 Sec. 95, 265. s. 59. 
his said Majesty at his Exchequer, and therefore he brings his suit." 1

After the abolishment of original writs, the declaration in all the courts in personal actions concluded as in the form given in the rules of Trinity Term, $1 \mathrm{Wm}$. IV., viz. "to the plaintiff"s damage of $\mathfrak{E}$ suit of husband and wife, executors, administrators, or assignees. ${ }^{2}$

By the Common Law Procedure Act of 1852, the following form was prescribed: "and the plaintiff claims $£$ action is brought to recover specific goods] the plaintiff claims a return of the said goods or their value, and $\mathfrak{f}-$ for their detention." 3

The allegation in all the old forms relating to the bringing of suit is a relic of an obsolete practice of very ancient law, by which the complainant was required to establish the truth of his declaration in the first instance, and before it was called into question upon the pleading, by the simultaneous production of his secta, that is, a number of persons prepared to confirm his allegations. The averment continued in all declarations except counts in dower. 4

The names of the two pledges for prosecution of the suit were anciently appended to the declaration, but the omission of them was not material after they ceased to be the names of real persons; and the 15th rule of Michaelmas Term, $3 \mathrm{Wm}$. IV., expressly prohibits the addition of them to declarations in personal actions. ${ }^{5}$

Signature of counsel, it is believed, was never required at common law. It was so expressly declared by the Common Law Procedure Act of $1852 .{ }^{6}$

By the present rules, it is customary for the solicitors or parties to sign the pleadings. But when they have been settled by counsel, such counsel must add their signature. ${ }^{7}$

Declarations differed from each other, according to the forms of action adopted by the pleader in each case. In considering actions and the forms of action, the varying features of the declaration as suited to each form will be noticed.

11 Chit. Pl. 419.

51 Chit. Pl. 420, 421; 3 Chit. Gen.

23 Chit. Gen. Pr. 472 ; 1 Chit. Pl. Pr. 473. 419,420 .

${ }^{3}$ Com. Law Proc. Act of 1852 , s. 85. 59 .

4 Steph. Pl. 429, 430.

${ }^{6}$ Com. Law Proc. Act of 1852, s.

${ }^{7}$ Order $19[1875]$, r. 4. 
In this connection it is proper to refer to a feature which characterized declarations or other pleadings in which the right of action or defence was founded on instruments under seal, and which was known by the name of profert.

\title{
Article IX.
}

\author{
Profert. \\ Sec. 34. Defined. \\ " 35. Relaxation. \\ Sec. 36. Extensiou.
}

Sec. 38. Effect of Profert.

SEc. 34. Defined. It was a general rule of common law pleading that, when the plaintiff or defendant alleged a contract under seal executed by his adversary as a party, or binding on him as a privy thereto, and presumed to be in the pleader's possession, upon which he founded his right of action or rights of defence, it was incumbent on him to make profert of the same, which was usually done in the following words : "which said writing obligatory, sealed with the seal of the defendant [or plaintiff] the plaintiff [or defendant] now brings lere into court, the date whereof is the day and year aforesaid." 1

SEc. 35. Relaxation of the Rule. Anciently this rule was without exception, a fact which rendered it necessary to invoke the jurisdiction of equity when a party was unable to make actual profert by reason of loss or destruction of the instrument. 2 To maintain their jurisdiction, the courts of law in the eighteenth century first permitted the pleader to substitute in the place of actual profert certain excuses for his inability to make it, and to recover on secondary evidence of the instrument. ${ }^{3}$ If the instrument was presumably in the pleader's possession, and as a matter of fact he could not produce it, it became sufficient for him to allege a valid excuse for the omission, as, for instance, that it was lost, destroyed, or in possession of the opposite party $;^{4}$ which excuse was a traversable fact, and had to be proved when put in issue.

Sec. 36. Extension and Qualification of the Rule. The rule requiring profert was extended to letters testamentary and of .

11 Chit. Pl. 365.

2 Bispham, Eq. s. 177 (5th ed.).
${ }^{3}$ Read $v$. Brookman, 3 T. R. 151; 9 Harv. Law Review, 50.

41 Chit. Pl. 365. 
administration, when pleaded by executors and administrators in actions brought by them: ${ }^{1-}$ Strictly speaking, they were neither deeds nor sealed instruments; but being under official authentication by seal, they were included in the rule, because they furnished the foundation for the right of action, somewhat in the manner of sealed instruments.

The rule did not extend to records which were regarded as public; nor to wills or awards, though under seal, because a seal was not an essential part of them. ${ }^{2}$ When a party could make title under a deed without pleading it, profert was unnecessary. ${ }^{3}$ Neither was profert necessary when sealed instruments were pleaded merely by way of inducement to the action or defence ; or when the party pleading had no right to possession of them. ${ }^{4}$

SEc. 37. Limitation. The rule was never extended to bills of exchange or negotiable promissory notes, which continued to be treated in respect to profert as simple contracts, although partaking strongly of the nature of specialties. Why the extension was never made may be briefly explained. The rule of profert rested on the fundamental law of evidence, that the best evidence must always be produced. Profert became a perfected doctrine or rule long before negotiable instruments were received into the common law as a part of the law merchant. When profert was first established, deeds and records were the only evidence susceptible of being proved by production. The publicity of a record rendered it unnecessary to plead profert. All other contracts were required to be established by witnesses. Any written evidence of them did not at that time constitute special instruments upon which actions were founded as on sealed instruments, but served as memoranda only for assisting the memory of witnesses. When negotiable instruments were received into the common law along with the law merchant, although in their nature they constituted a new species of specialty, they were nevertheless unwarrantably excluded from the common law classification of specialties by the courts, for the reason only that they were devoid of a seal. The practice which grounded profert on sealed instruments was too strong to admit within the requirements of profert another form of specialty unknown to the conmon law. The same rule was ap-

11 Chit. Pl. 365; Gould, Pl. ch. viii. s. 43 .

2 Gould, Pl. ch. viii.s. 41.
8 Gould, Pl. ch. viii. s. 44.

41 Chit. Pl. 365, 366; Gould, Pl. ch. viii. s. 48 . 
plied to other unsealed contracts in writing, when in the progress of time they became susceptible of enforcement as effectually as covenants under seal.

In the United States the required filing of instruments, which has very generally taken the place of profert, usually includes all written instruments executed by the opposite party upon which suit or defence is founded, whether sealed or unsealed.

SEc. 38. Effect. The effect of profert was to enable the opposite party to obtain oyer, or hearing of the instrument, before he was required to plead, if he chose to do so. His action in exercising his rights in this respect was called demand of oyer, and will be considered in connection with defences.

Although the language of a profert obviously implies the fact of an actual production in court of the instrument pleaded, it nevertheless remained in the custody of the pleader, and was exhibited to the attorney on the other side upon his written request. ${ }^{1}$

By the Common Law Procedure Act of 1852, profert and oyer were abolished without making any substitute therefor. ${ }^{2}$ Inspection and copies of deeds could be obtained only in like manner with other documentary evidence.

1 Steph. Pl. 67, 68.

Com. Law. Proc. Act of 1852, s. 55 
CHAPTER II.

PERSONAL ACTIONS EX CONTRACTU.

Article I. Debt.

"II. Covenant.

" III. Assumpsit.
Article IV. Account.

"V. Annuity.

* VI. Scire Facias.

\section{Article I.}

\section{Debt.}

Sec. 39. Defined.

"40. History.

" 41. History.

Sec. 44. Judgment. $\begin{gathered}\text { Sec. 42. Essential and Incidental Fea. } \\ \text { tures. } \\ \text { Declaration. }\end{gathered}$

SEc. 39. Defined. The action of debt as finally established lies for breach of a duty on the part of one person to pay to another a certain sum of money, whether the duty to pay arises from contract or is imposed by record of court, legislative enactment, common law, or custom. ${ }^{1}$

Whenever the duty is imposed, a corresponding right in some one to have the money is conferred by the same authority which imposes the duty. Viewed from the standpoint of rights, it may be said that the action lies whenever the right to have the money is violated by failure or refusal to pay. The act which constitutes a breach of duty is also an infraction of the right.

In line with this general definition, Chitty says that the action lies to recover money, in a certain sum or capable of being reduced to a certainty, due upon simple contracts, express or implied (implied in fact or in law), whether verbai or written, upon contracts under seal, upon records and statutes, and upon common law and customs. $^{2}$

1 The cases are not numerous in which debt lies upon a common law liability, because the instances are few in which the common law imposes the liability to pay a certain sum. Suit for rent by a lessor against the assignee of the term is one of

them. Liability to pay a judgment is another. In most actions on quasi contract the liability is for unliquidated amounts, and assumpsit is the appropriate remedy. Keener, Quasi Contract. 159-267.

21 Chit. Pl. 108, 109. 
The greater number of actions in debt were employed to redress breaches of duty assumed by contract, and on that account it is probable the action has been classed with actions arising $c x$ contractu. The action, when arising from duties imposed by julgments, statutes, common law, and custom, independent of any genuine contract, has nevertheless been classed with actions ex contractu, rather because it more nearly resembles such actions than actions in.tort; and it may be added that the classification was maintained in many such cases by treating the duties arising therefrom as if they had been assumed by contract. ${ }^{1}$

SEc. 40. History. Debt is among the oldest actions known to the common law, and is found in the most ancient register of writs." An eminent American anthor furnishes convincing proof that it unfolded from the ancient writ of right for services due by virtue of tenure, from which it was but a short step to the writ of right for a money debt by express contract of tenure, and a step quite as short to the writ of right for debt on account of money loaned; from which latter writ the formed writ of debt comes by lineal descent. ${ }^{3}$

This descent seems to be supported by the form of the writ, the form of the ancient declaration, and the form of the judgment; all of which indicate its origin as a droitural or proprictary action. In some of the first known writs the sheriff is required to command the defendant to render to the plaintiff so many marks or shillings, "which, so the plaintiff says, the defendant owes him and whereof he unjustly deforces him." The creditor is being deforced of his money in like manner as a demandant in a writ of right is deforced of his land. ${ }^{4}$ After Glanville's time the word deforces was supplanted by the word detains, which more nearly represents a simple refusal to pay money, 5 but which nevertheless implies something like a proprietorship in the money detained.

While the writ may have been first employed for the return of money loaned, it was more frequently resorted to in the case of sales for the agreed price of chattels sold and delivered, for the reason that money loaned was generally evidenced by sealed instruments which greatly reduced the occasion for dispute or controversy.

1 Keener, Quasi Contract, 14.

2 Fitz. N. B. 119.

8 Jig. Hist. Proc. 160-160.
42 Pol. \& Mait. 203.

5 2. Pol. \& Mait. 171, 172. 
It was conceived that the seller acquired a proprietary right in the price as completely as the purchaser did in the chattels sold and delivered, provided it was for a fixed sum of money. If it was for money generally, irrespective of any fixed amount, the conception was admitted to be untenable, and the action would not lie. This species of ownership rested upon the doctrine that the defenclant had acquired a title to something delivered to him by the plaintiff, and that in return for it he had invested the plaintiff with a title to a certain amount of his money. In detaining the money, he was regarded as unjustly keeping the plaintiff out of his own property. Judgment was asked for recovery of this property, and damages for detention of it.

In its origin these damages were not nominal. The plaintiff alleged the amount, which was often very high, and if the defendant invoked trial by wager of law and failed to make his law, the plaintiff recovered the amount of damages claimed by him without reduction or mitigation. ${ }^{1}$

Upon the strength of this conception of proprietary right, it was natural to extend the remedy by action of debt to the recovery of specific chattels belonging to the plaintiff and detained by the defendant. Accordingly, we find that it was so employed in the reign of Henry II. ${ }^{2}$ The action as applied to the recovery of chattels was more plainly in accord with its original proprietary nature, and was perhaps quite as ancient as the action for money.

It is needless to say that the conception of proprietorship in a sum of money due from a debtor was in contradiction of the actual relation between debtor and creditor as now understood, which is of a contractual rather than a proprietary character. A shadow of the misconception evidently lingers in the popular mind at the present time. It is not unusual to hear one speak of another person having his money, when the person is only indebted to him for money loaned, in like manner as for goods sold.

An excuse exists for thus attributing ownership to a mere contractual right, and pressing into service for its enforcement the forms of a proprietary action. Except as to covenants under seal, there was no form of action for the enforcement of contracts. The action of covenant would not lie on a parol contract of any kind. Hence the necessity of employing some existing form to

12 Pol. \& Mait. 213, 214.

2 1154-1189. 2 Reeves, Hist. 208, 374; 3 Bl. Com. 155. 
serve the purpose of enforcing such a manifest right as a man must have for money loaned, or for the price of goods which he has sold and delivered to another. When the writ of right came to be em. ployed in this way, any parol contract which culminated in a debt for money loaned, goods sold, or actual benefits received, became binding on the debtor. ${ }^{1}$ But it was not regarded as binding because of any contract, but because it was conceived that the plaintiff had a title to the money due him, and was wronged by its detention. ${ }^{2}$

The modern doctrine of contract, as resting solely on consideration, was not developed in English jurisprudence for hundreds of years after the origin of the action of debt. ${ }^{3}$ And no other parol contracts were binding until, in the reign of Henry VI., ${ }^{4}$ another form of action was pressed into service, from the domain of tort, to enforce them under the name of trespass on the case on promises. ${ }^{5}$

It is true that the ecclesiastical courts exercised jurisdiction in many parol contracts which were not enforceable at law. This fact of itself was an inducing cause to the establishment of the new action of assumpsit.

SEc. 41. Fistory continued. The conception of proprietorship which was at war with the contractual relation of debtor and creditor, as now understood, commenced at a very early day to give way. The form of writ as first developed alleged that the defendant owes and detains the money. It was said to be in the debet and detinet. But when it came to be employed to recover specific chattels, the debet was dropped and it ran in the detinet alone. ${ }^{6}$ It was thus felt that a person could not owe a chattel, while he might owe a debt. When an executor was sued in debt, the writ ran in the detinet only, because it was apparent that the executor owed nothing, for want of privity. ${ }^{7}$ This retention of the word debet in all cases for money, and its omission in all cases for chattels, tended to the development of two distinct forms - of action, one suited to the enforcement of a particular obligation arising on contract, the other to enforcement of the rights of proprietorship. The writ for chattels was in line with the original conception of the action of debt, while that for money

12 Pol. \& Mait. 2ก9, 210.

22 Pol. \& Mait. 203-214.

8 Holmes. Com. Law. 265.

1 1422-1461.

52 Reeves, Hist. 509, 605, 606. 607,608 .
62 Reeves, Hist. 208, 374; Browne, Ac. 331 .

Y Fitz. N. B. 119, note; 3 Bl. Com 155. 
commenced to depart from it. While in the Common Pleas the form for money continued in the debet and detinet, the one issued before the justices itinerant was in the debet only, if for money, and in the detinet for chattels. ${ }^{1}$ The word detinet in the writ of debt for money came in the course of time to be a mere form, for the reason that it was prima facie implied in the word debet, ${ }^{2}$ while it remained to be the one word necessary in the writ for chattels.

In the reign of Edward I., ${ }^{3}$ these two forms of writ, one in the debet and detinet, the other in the detinet only, unfolded into two distinct forms of action, in which the writ of debt in the debet, or in the debet and detinet, was confined to the recovery of money, while the writ of debt in the detinet only was confined to the recovery of specific chattels. ${ }^{4}$ The writ for money remained under the name of debt, while the writ for chattels came in the course of time to be known as the writ of detinue, which is identical with the ancient writ of debt for chattels. ${ }^{5}$ The general issue in debt on simple contract was nil debet (owes nothing) till the Hilary rules. of 1834, when nunquam indebitutus (never indebted) was substituted. In detinue the general issue was non detinet (does not detain).

Notwithstanding this restriction of the action of debt to the enforcement of particular contract rights for the payment of money, the form of the writ in the Superior Courts retained its ancient proprietary features, although in modern times they were gradually dropped from the action itself. While the modern declaration recited the writ according to its ancient form of owing and dctaining the money, in its statement of the cause of action, the contract is set forth, and non-payment or refusal to pay after demand or request is the breach for which redress is sought. ${ }^{6}$

The ancient distinction between the judgments in debt and assumpsit when money was recovered was expressly abolished by the Common Law Procedure Act of 1852.7 Thus it may be said that debt, as finally settled, is in substance an action to obtain redress for the breach of a personal obligation to pay a certain sum of money. The obligation really rested on contract when the

12 Reeves, Hist. 379. 363.

${ }^{2}$ Goodchild $v$. Pledge, 1 M. \& W. 171, 172.

8 1272-1307.

62 Chit Pl. 387, 398, ed. 1847.

715 \& 16 Vict. c. 76 , s. 95 .

42 Reeves, Hist. 208, 374, 379. 
action first originated, although it was not put on that ground. The necessary averment to sustain the action contained what was known as the causa debendi (the canse of being indebted); which has been regarded by some writers as the forerunner of consideration. ${ }^{1}$

The obligation inposed by record, statutes, common law, and custom, to pay a certain sum of money, was held to be within the scope of the action, as heretofore defined, because of its resemblance to the obligation contained in a contract to pay the same thing. The damages given are not for detention of the plaintiff's property, but for a breach of the defendant's obligation or duty to pay the principal, and interest when interest is allowed by law. Out of courtesy to the ancient form, promises to pay were carefully exclnded from the declaration; ${ }^{2}$ but as evidence, they often operated towards sustaining the cause of action, as indirect acknowledgments of indebtedness, and as tending to fix its maturity.

The action of debt was supplanted-for a time-in-its application to simple contracts by the action of assumpsit, when that action was developed as shown hereafter, for the reason that the defendant in the latter action could not invoke trial by wager of law as in debt on simple-contracts. It remained in use principally in actions on specialties under seal. ${ }^{3}$ But after abolishment of trial by wager of law in the reign of William IV., ${ }^{4}$ it came again into use on simple contracts. ${ }^{5}$

The action of debt has been very generally retained in the United States where the common law system of pleading has not been supplanted by the codes, or radical modifications of the common law system. Such is the case in Maine, New Hampshire, Vermont, New Jersey, Delaware, Rhode Island, Maryland, West Virginia, Virginia, Florida, Alabama, Mississippi, and New Mexico. ${ }^{6}$

SEc. 42. Essential and Incidental Features. The action as settled at an early day lies only to recover money in a certain

2 Harv. Law Review, 1.

21 Chit. Pl. 114.

8 Bl. Com. 155.

- 1830-1837. 113.

5 Browne, Ac. 334; 1 Chit. Pl. 485.

618 Am. \& Eng. Encyc. Law, 479-

Before adoption of the Code in Missouri, the legislature passed an act prescribing a special form of ac- tion denominated "petition in debt," which was created for the speedy recovery of debts due on bonds and notes. It is curious to note that, in the form prescribed, the prayer for judgment resembled the ancient proprietary form, in which the plaintiff "demands judgment for his debt and damages for the detention thereof." Rev. Stat. Mo. 1845, ch. 135. 
sum due upon legal liabilities, irrespective of their nature. If a sum certain was indicated in a contract, the action would lie, although the obligation might have been discharged by the payment of property. ${ }^{1}$ From its origin down to the time of Blackstone the sum sued for was required to be certain, and not subject to subsequent valuation or settlement, ${ }^{2}$ and the plaintiff was defeated if he failed to prove the exact sum sued for. But a rather general qualification was added in modern times, to the effect that it would lie if the amount of money sued for could be readily reduced to a certainty. ${ }^{-}$- tt thus came to be used to recover the price of property sold, or the compensation of services rendered, although the price or compensation was not expressly agreed on by the parties. The action in such cases was helped out by the inference of fact that the parties must have intended the market price or the customary compensation, which was said to be capable of being reduced to a certainty by proof of such price or custom. The price or compensation was said to be certain under the maxim Id certum est quod ccrtum reddi potest.

The common counts of quantum meruit and quantum valebant, which were peeuliar to the action of assumpsit, came rather questionably to be employed in the action of debt, their phraseology being slightly changed to suit the form of the action, by substituting in place of a promise the allegation that the defendant agreed to pay what the goods were worth, or what the plaintiff deserved for his services. ${ }^{4}$ The indebitatus counts followed suit, and were held to be maintainable whenever the indebtedness could be readily reduced to a certainty. These extensions were manifest departures from one of the essential requisites, which separated debt from all other actions, and helped to break down the distinction between debt and assumpsit, which is fully consummated in code procedure.

Debt would not lie against an executor on a simple contract made with the testator, unless in the Court of Exchequer, where wager of law was not allowed, or in those cases in which the

1 Edwards $v$. McKee, 1 Mo. 123.

$23 \mathrm{Bl}$. Com. 154.

31 Chit. Pl. 108.

4 Saund. Pl. \& Ev. 403, 409; Warren's Law Studies, 293; Union Cotton Manufactory $v$. Lobdell, 13 Iohns. 462; Smith v. First Cong. M.
H., 8 Pick. 17S; 2 Chit. Pl. 385; Walker, An. Law, 612; 2 Greenl. Ev. 269, note 1 (10th ed.); McGinnity v. Laguerenne, 5 Gil. 101 (Ill.); Smith v. Webb, 16 Ill. 105; 1 Chit. Pl. 342. 
testator if living could not have wagered his law. ${ }^{1}$ But by statute in the reign of William III. the action was given against an executor or administrator on the simple contract of the decédent in any court of common law. ${ }^{2}$ The executor was always liable on his own contract.

Debt is maintainable for rent against a lessee, whether reserved by demise under seal or by parol. After assignment of the term, it is maintainable against the assignee by virtue of his privity of estate; and it is no longer maintainable against the lessee, if rent has been accepted from the assignee. If the lessee remains liable for the rent, it is by virtue of his privity of contract only; and covenant, not debt, is the proper action. ${ }^{3}$ On account of some doubt as to whether a personal action could be maintained for arrears of rent on a freehold estate, the action was not used for such purpose till after the statutes of 8 Anne, c. 14, and 5 Geo. III. c. $17 .^{4}$

The action of debt on bills of exchange and promissory notes was first admitted as between the original parties thereto, and was denied as between remote or mediate parties. ${ }^{5}$ But after the negotiability of these instruments came to be recognized by the common or statute law, the action has been entertained in behalf of remote as well as immediate parties. Want of privity of contract is no longer a valid objection to the action; the money promised by the acceptor or maker being in judgment of law and by terms of the instruments payable to any one who is indorsee or bearer. ${ }^{6}$

Debt is often designated as the appropriate action for the re covery of statute penalties of a fixed pecuniary sum; and it is generally held to lie, in the absence of any designation of remedy.7

Debt lies for taxes due by authority of law, unless some other mode of collection is designated. And even in such cases the action will lie, according to some authorities, unless it is apparent that the designated mode is intended to be exclusive. ${ }^{8}$

SEc. 43. Declaration. The pleader in his declaration alleged the ultimate fact of indebtedness, and mentioned so much of the

11 Chit. Pl. 113.

$23 \& 4$ Wm. IV. c. 42 , s. 14.

31 Chit. Pl. 113.

43 Bl. Com. 231, 232; 4 Minor, Inst. 130.
51 Chit. Pl. 109.

Wilmarth $v$. Crawford, 10 Wend 341.

7 5 Encyc. Pl. \& Pr. 907.

85 Encyc. Pl. \& Pr. 908, 909. 
contract as disclosed a legal liability or undertaking to pay a certain sum of money. This allusion to the contract or transaction was known among-pleaders-as-the causa debendi, an importation from Roman procedure. If the action was based on simple contract, the consideration had to be mentioned in order to impose the legal liability to pay. ${ }^{2}$ If brought on specialties or records, it was sufficient to describe them, no averment of consideration being required unless performance of a consideration is made a condition precedent to the liability, in which case it must be averred. ${ }^{3}$ If the action is brought on a statute, the facts constituting a violation of the statute had to be stated with a reference to it. ${ }^{4}$ If the plaintiff wanted damages for breach of the obligation, it was necessary for him to ask for more than inerely nominal damages. ${ }^{5}$ If founded on a judgment, the judgment and court in which it was rendered should be concisely stated, without recital of previous proceedings in the case. ${ }^{6}$

The statement of the defendant's failure or refusal to pay was generally regarded as essential to the action, as it constituted a formal averment of the breach of the obligation sued upon. But it has been sometimes treated as mere matter of form, not essential to the validity of the declaration, upon the assumption that non-payment is necessarily implied in the statement of an obligation or promise to pay money when it appears that the time for payment has arrived. ${ }^{7}$

SEC. 44. Judgment. Judgment, if for the plaintiff, was to the effect that he recover $h$ is debt, and, in general, nominal damages for the detention thereof. When more than nominal damages were wanted in the shape of interest, the damages at the conclusion of the declaration should be stated in a sum sufficient to cover the interest incident to non-payment of the principal as allowed by law. ${ }^{8}$

On penal bonds given to secure performance of a covenant, the plaintiff was entitled at common law to judgment and execution for the full penalty and costs. But under the statute of $8 \& 9$ Wm. III. c. 11, while judgment was entered for the full penalty, actual damages were assessed aud execution was awarded for

1 Steph. Pl. 35 ; Browne, 335.

21 Chit. Pl. 114.

1 C'it. Pl. 114.

Saund. Pl. \& Ev. 830.

1 Chit. Pl. 114.
6 Saund. Pl. \& Ev. 607, 608.

7 Goodchild $v$. Pledge, 1 M. \& W. 363 ; McKyring $v$. Bull, 16 N. Y. 297.

81 Chit. Pl. 114. 
only such damages. ${ }^{1}$ This statute has been very generally reenacted in the United States.

If the defendant suffered a default, the judgment in most cases was final, and not interlocutory, an inquiry for assessment of damages not being necessary on account of the liquidated nature of the demand. ${ }^{2}$

A writ of inquiry for assessment of damages was necessary in a few cases, such as debt for the recovery of foreign money, for tithes under the statute of Edward VI., and for recovery on penal bonds. ${ }^{5}$ In some cases in which dannages are a mere question of ealculation, the court will refer them for computation to a master, for the purpose only of informing the conscience of the court, or will assess them without such reference or writ of inquiry. ${ }^{4}$ The rule to compute in such cases was abolished by the Common Law Procedure Act of 1852 , but it was retained by the same act in a class of cases to which it did not formerly apply. It was provided by the act that, "when it shall appear to the court or a judge that the amount of damages sought to be recovered by the plaintiff is substantially a matter of calculation, it shall not be necessary to issue a writ of inquiry, but the court or a judge may direct that the amount for which final judgment is to be signed shall be ascertained by one of the masters of the -said court." 5

When an assessment of damages in debt was not a matter of calculation, a writ of inquiry was necessary, and the amount assessable was ascertained and found by a jury. ${ }^{\circ}$

For the writ and declaration in debt consult forms 1, 2, and 3 in the Appendix.

\section{Article II.}

\section{Covenant.}

Sec. 45. Defined.

" 46,47 . History.

Sec. 50. Judgment.

Sec. 45. Defined. Covenant is an action to recover damages for the breach of a covenant or contract under seal. ${ }^{7}$

11 Chit. Pl. 115; Browne, 335; Com. Law Proc. Act, 1852, s. 96.

2 Browne, 335; Com. Law Proc. Act, 1852 , s. 93.

8 Browne, 335.

42 Saund. 107; Roo v. Apsley, 1553. 94.

5 Com. Law, Proc. Act, 1852, s. 92, Com. Law Proc. Act, 1852, s. 97.

71 Chit. Pl. 115; Browne, 352, Sid. 442. 
It lies only against a person who has executed a deed or-othercontract under seal. By special custom of London and Bristol, the action lies although the contract be not under seal. So also it could be maintained against the lessee or patentee of the Crown, although he did not seal the lease or any counterpart of it. ${ }^{1}$

The action lies on covenants expressed in deeds, or implied from the nature and-terms of the instruments. It lies on covenants under seal to pay money, or to do or omit-doing any thing else which is lawful. The breach of covenants retrospective in their nature, to the effect that the covenantor had done or refrained from doing something, was remediable in this action in like manner with the breach of covenants in futuro. ${ }^{2}$ According to some ancient authorities the action could not be maintained upon a covenant in prosenti, as that the covenantor is seised, or that a certain chattel is yours or the property of another. ${ }^{3} \quad$ But the distinction has not been generally recognized. ${ }^{4}$

SEC. 46. History. The modern action of covenant is descended from the ancient breve de conventione, which was a writ for the enforcenent of the agreements or covenants which most usually occurred in the twelfth and thirteenth centuries. It is found in the register of writs, ${ }^{5}$ and is met with in the latter years of the reign of Richard I., ${ }^{6}$ and in the first years of the reign of John. ${ }^{7}$ It is not mentioned by Glanville, who wrote in the reign of Henry II., ${ }^{8}$ but is described by Bracton in the reign of Henry III., ${ }^{9}$ when it could be had as of course; at all events, when the tenement to which it related was of small value. ${ }^{10}$ Its form is given in the statute which introduced English law into Wales in the reign of Edward I. in A. D. 1284.

The writ in substance ordered the sheriff to command the defendant that justly and without delay he keep with the plaintiff the agreement made between them concerning (certain land), and that unless he shall do so, he [the sheriff] summon him to show. wherefore he hath not done it."

11 Chit. Pl. 118.

2 Comyn, Dig. Cov. A. 1. A. 1 .

3 Plow. 308; Comyn, Dig. Cov.

42 Saund. $181 \mathrm{~b}$; Browning $v$. Wright, 2 B. \& P. 13; Kingdon $v$. Nottle, 4 M. \& S. 53; Dickson $v$. Desire's Adm'r, 23 Mo. 151.
5 Fitz. N. B. [145].

6 1189-1199.

7 1199-1216. 2 Pol. \& Mait. 214.

8 1154-1189.

9 1216-1272.

102 Pol. \& Mait. 214.

1 Stat. Wall. 12 Edw. I. c. 6; 2 Reeves, Hist. 158. 
It will be observed that this writ is modelled on the type of droitural writs, and suggests a specific observance of the rights conferred by virtue of the agreement, rather than damages for breach of it. Wherever the writ appears in the thirteenth and early fourteenth centuries the subject matter of the conventio is usually land, or some profit issuing out of land as homage, services, and the like. ${ }^{2}$ But according to the statute of Wales movables as well as immovables could be demanded ${ }^{3}$ a declaration which would seem to leave the remedy without bounds so far as the subject inatter of the agreement is concerned. ${ }^{4}$ Accordingly, in the reign of Edward I., ${ }^{5}$ and probably some time before, the writ assumed a flexible nature, and was invoked for redress in miscellaneous agreements. ${ }^{6}$ The ancient form of the writ contained a suggestion or threat of compulsory specific performance, but the common law courts never exercised such power directly, but they reached substantially the same end in certain cases, by awarding recovery of the thing covenanted to the use and enjoyment of another, instead of giving damages for breach of the covenant. In this use it discharged the functions of a real or mixed action.

There seems to have been a period of hesitation by the courts in limiting the action of covenant to contracts under seal, during which it was occasionally maintained on a simple contract. ${ }^{7}$ But the period was of short duration, and the cases few in number; the rule being established before the end of the reign of Edward I. ${ }^{8}$ in the King's Court, that the only conventio enforceable by action must be expressed in a written document sealed "by the party to be charged therewith." 9 Thenceforward the words conventio and covenant imply sealed instruments among English lawyers. ${ }^{10}$ This conclusion of the courts was an unfortunate one to English jurisprudence, and left simple contracts other than for the payment of a certain sum of money unenforceable by action at law, until the action of assumpsit was eventually established for that purpose in the reign of Henry VI.11

1 Pollock, 6 Harv. Law Rev. 399.

2 Crabb's Hist. 214 ; 2 Pol. \& Mait. 215.

- Crabb's Hist. 214; 2 Reeves, Hist. 158; 2 Pol. \& Mait. 216.

4 2 Pol. \& Mait. 217; 2 Reeves, Hist. 158.

6 1272-1307.
62 Pol. \& Mait. 216.

72 Pol. \& Mait. 217, 218.

8 1272-1307.

92 Pol. \& Mait. 217.

102 Pol. \& Mait. 217. 607.
11 1422-1461. 2 Reeves, Hist. 606. 
While it originated in the enforcement of agreements relating to land, the specific want it met in its early life was an action on a lease. ${ }^{1}$ The lessee when evicted by the lessor could in an action of covenant recover back his leasehold term, and damages for the time of his eviction. ${ }^{2}$ This was his sole protection until his remedy was extended in the reign of Henry III.," by introduction of the writ of quare ejecit infra terminum, in which he was permitted to recover his term, and damages for dispossession, against any one ejecting him by virtue of title derived from his lessor. ${ }^{4}$ By an extension of the remedy in the action of ejectione firma, he was enabled to recover his term and damages against any ejector. ${ }^{5}$

SEc. 47. History continued. A freehold was sometimes demanded in a writ of covenant; as when land was demised upon a certain rent with a condition that, should the rent not be paid, the person demising might enter and hold the land. In such case, should the demisor not be able to make entry upon default of payment, he might recover the land together with damages by writ of covenant. ${ }^{6}$

Likewise upon a covenant to convey or dispose of land, the remedy was by special writ of covenant if the covenantor failed to make the conveyance, in which writ the covenantor, who was designated as a deforciant, was commanded to keep his covenant. If he had the lands, the covenantee was entitled to recover them in the action, as well as damages. ${ }^{7}$ Such covenant however could not be enforced by recovery in specie, if the covenantor had enfeoffed another with the lands. ${ }^{8}$

A great many of these actions on covenants were brought in order to be compromised. They related to the conveyance of lands; and it was on the basis of this proceeding that fines were levied at coinmon law, ${ }^{9}$ and constituted a form of conveyancing until its use for that purpose was displaced by the deed of disentailment in the reign of William IV. ${ }^{10}$

This ancient use of covenant gave to it the occasional character

12 Pol. \& Mait. 106, 215.

23 Bl. Com. 157 ; 2 Reeves, Hist. 389 ; 2 Pol. \& Mait. 106; Adams, Eject. 3, 4.

3 1216-1272.

4 Adams, Eject. 3, 4; 2 Pol. \& Mait. 107.

5 See Sec. 156
62 Reeves, Hist. 159.

73 Bl. Com 157: 2 Reeves, Hist. 159: 2 Pol. \& Mait. 215.

82 Pol. \& Mait. 216: 2 Reeves. Hist. 159

92 Bl. Com. 349 ; 3 Bl. Com. 156;

2 Pol. \& Mait. 214.

$103 \& 4$ Wm. IV. c. 74. 
of a real or mixed action. When land could be recovered in a writ of covenant, it was held to be a real or mixed action;-when employed to recover damages - only, it was regarded as a personal action; ${ }^{1}$ when used to bar estates tail by levy of fines, it was always a real or mixed action. ${ }^{2}$

The use of it as a real action, except in conveyancing, disappeared at an early day, being supplanted by the actions at law of quare ejecit infra terminum and ejectione firmo, and by the more perfect remedies afforded in equity by way of specific performance. Although its employment as a real or mixed action had long become obsolete, it was expressly included in the statute of William IV., which formally abolished all real actions except four. ${ }^{3}$

As a personal action it has continued down to modern times, and is classed with actions ex contractu, in which damages are alone recovered on a money jndgment. ${ }^{4}$ It appears not to have been used prior to the seventeenth century to enforce a contract to pay a certain sum of money, although evidenced by a sealed instrument, the sole reason for this delay being that debt could be employed for that purpose. ${ }^{5}$ Covenant has been retained in all of the American States professing to follow the common law system of procedure, such as Maine, New Hampshire, New Jersey, Delaware, Vermont, Rhode Island, Maryland, Florida, Virginia, West Virginia, Alabama, Mississippi, and New Mexico. ${ }^{6}$ It has been consolidated with debt and assumpsit under the name of contract in Massachusetts, and under the name of assumpsit in Pennsylvania. ${ }^{7}$

SEC. 48. Essential and distinguishing Features. Covenant is distinguished from debt in that it lies only on sealed instruments, and may be brought for payment of uncertain as well as certain sums of money, and for the non-performance of covenants to do any other lawful thing. It is a concurrent remedy with debt on all sealed instruments for the payment of a certain sum of money. It is not concurrent with assumpsit in any case, as covenant will not lie on an unsealed contract and assumpsit will not lie on a sealed one. ${ }^{8}$ It is the sole and exclusive remedy on sealed instruments for payment of an uncertain sum of money, or for the

12 Reeves, Hist. 159.

22 Sellon, Pr. 467.

3 3 \& 4 Wm. IV. c. 27, s. 36.

4 Reeves, Hist. 402.

5 2 Pol. \& Mait. 217.

618 Am. \& Eng. Encyc. of Law, $479-485$.
7 Pub. Stat. Mass. 1882, p. 964; Purdon's I)ig. 2369; Mason's Pr. 4; $18 \mathrm{Am}$. \& Eng. Encyc. of Law, 485, 486.

81 Chit. Pl. 117, 118. 
performance of other things. It was always essential that the defendant should have executed the covenant under seal, with exception of the local customs hereinbefore noticed; but it was never essential that the covenantee should have sealed the instrument. ${ }^{1}$

The obligation of the defendant to keep his covenant or promise was anciently conceived to spring from the deliberation and solemnity of the act of sealing the instrument. ${ }^{2}$ The seal was recognized as sufficient to give to the instrument its binding force. The courts of law declined to go back of the seal and allow the binding force of a sealed instrument to be impeached for mere want of consideration. This was the doctrine of the common law, anterior to the date at which consideration came to be regarded as giving to contracts a binding force of its own. Long after the recognition of this truth - after consideration came to be recognized as the binding force of contracts - the courts of law, in pursuance of the doctrine, adopted the rule that the seal conclusively implied a consideration, ${ }^{3}$ and they continued to forbid a sealed instrument to be impeached by evidence of an actual want of consideration. This holding has continued down to comparatively recent times. ${ }^{4}$

Naturally a person would not assume burdensome obligations without consideration of some kind. The courts of law accepted this truth, and said or implied that, after the sealing and delivery, it was too late to inquire about consideration. The solemnity and deliberation of the act of sealing furnished internal evidence of a sufficient consideration, which operated as an estoppel on any efforts to impeach the verity of the act. ${ }^{5}$

In the course of time the consideration of a contract, as already stated, came to be regarded as the most important element in it, while the ensealing of it lost much of the solemnity and deliberation which were incident to a mere nechanical act. The courts of equity, in bills for specific performance and for the aid of defective conveyances, went back of the seal and declined to observe the rule of estoppel as prevailing in the courts of law. ${ }^{6}$ The binding

1 Browne, 352.

22 Bl. Com. 446; 1 Greenl. Ev. s. 19 .

3 Fallowes $v$. Taylor, 7 T. R. 471; 2 Whart. Ev. 1045.

4 Hartshorn v. Day, 19 How. 211;
Dorr $v$. Munsel, 13 Johns. 430 ; Bates v. Hinton, 4 Mo. 78.

52 Bl. Com. 446.

6 Smith v. Smith, 36 Geo. 184; Northern Kansas 'T. Co. v. Aswald, 18 Kans. 336; Sister $v$. Hodgson, 
effect of a contract in modern times is believed to spring with greater force from the consideration than from the seal. ${ }^{1}$ This has led to a modification of the doctrine of estoppel as resting on the conclusive effect of the seal. The seal is still accepted as prima facie evidence of a consideration; but the ancient conclusive character of its import has been in recent times very generally denied in law as in equity, and in most contracts the defendant in a proper plea is permitted to make the defence of a want of consideration. ${ }^{2}$ This modification has been brought about in England and in many of the American States by legislation. ${ }^{3}$ Perhaps this modification might not apply in legal proceedings on contracts under seal, which were intended to be gratuitous. ${ }^{4}$

SEC. 49. Declaration. It was necessary that the declaration in this action should show a contract or covenant under seal, and should make profert thereof or furnish a valid excuse for the omission. ${ }^{5}$

In general it was not necessary to state the consideration of the defendant's covenant, inasmuch as the seal of the defendant inported a consideration. If however the delivery or performance of a consideration constituted a condition precedent to the covenant sued on, the fact of delivery or performance had to be alleged or its omission excused. ${ }^{6}$ The pleader was required to set out in hoc $v e r b a$, or according to its legal effect, only so much of the deed and covenant as was essential to the cause of action. ${ }^{7}$ Covenants not expressed, but only implied from those expressed or from the legal tenor of the instrument, may be set forth in like manner as if expressed. ${ }^{8}$ Several distinct breaches of the covenant could be assigned in the same count, a practice which was authorized by $8 \& 9$ Wm. III. c. 11 , s. 8 , and was also permitted by the Hilary rules of $1834 .^{9}$

SEC. 50. Judgment. The judgment in covenant was that the

Law Rep. 4 Eq. 30, 36 ; Adams, Eq 78.

1 The seal has been abolished in some of the States. Sess. Acts Mo. 1893 , p. 117.

2 Kier r. Leeman, 9 Q B. 371 ; Lawson, Cont. s. 65.

3 Com. Law Proc. Act, 1854, s. 83; 2 Rev. Stat. N. Y. 4n\%, s. 75 ; 1 Rev Stat. Mo. 1889, s 2090; Ring v. Kelly, 10 Mo. App. 411. 446.

4 Aller $v$. Aller, 40 N. J. (L.)

5 Rrowne, 357 ; 1 Chit. Pl. 120.

61 Chit. Pl. 120.

71 Chit. Pl. 120; Browne, 357.

8 (irannis v. Clark et al., 8 Cow. 36; 1 Chit. Pl. 302.

9 Browne, 357; Rules Hil. T. 4 IVm. IV.r. 5. 
ART. III.] PERSONAL aCtions EX CONTRACTU. - assumpsit.

plaintiff recover a named sum for his damages which he hath sustained by reason of the breach or breaches of the covenant, together with costs of suit. ${ }^{1}$

The forms of writ and declaration will be found in the Appendix. ${ }^{2}$

\section{Article III.}

\section{Assumpsit.}

Sec. 51. Defined.

“ 52,53 . History.

"54. Nature and Features. \begin{tabular}{|cc} 
Sec. $55-58$. & Common Counts. \\
“ & 59. Declaration. \\
& 60. Judgment.
\end{tabular}

SEc. 51. Defined. Assumpsit lies for the recovery of damages for the non-performance of all simple contracts; that is to say, all contracts not under seal nor of record, whether express or inplied, oral or written, for the payment of money, or for the performance or omission to perform any other act. ${ }^{3}$ The sole object of the action is to recover damages for the breach of simple contracts expressed by the parties, or implied by the law from their acts. ${ }^{4}$

SEc. 52. History. The modern action of assumpsit does not appear in the register of writs. It is derived from the action of trespass on the case, which latter action originated substantially in the Statute of Westminster II, and is found in the register of writs. ${ }^{5}$

It is a singular fact that prior to the reign of Henry VI. ${ }^{6}$ the common law courts furnished noredress for the mexe non-performance of a simple contract, unless it was a contract for the payment of a certain sum of money, for the recovery of which the action of debt was employed. ${ }^{7}$ If the delinquent party to a contract had commenced to perform his undertaking, and in his work of part performance had done it so negligently or imperfectly as to inflict an injury on the other party in respect to his person or property, an action on the case would lie, which was derived from the statute to which I have alluded, and which was denominated an action of trespass on the case on promises. The action as thus entertained sounded unmistakably in tort, although the tort was dimly associ-

11 Chit. Pl. 120.

2 See forms 4 and 5 .

31 Chit. Pl. 98, 99 ; Browne, 318.

4 Browne, Actions, 318. Martin Civil Procenure-4
513 Edw. I. c. 24 [1285]; Fitz. N. B. $[94]$.

6 1422-1461.

72 Reeves, Hist. 509, 605, 606, 607,608 . 
ated with contract; but not with contract as subsequently developed, as being founded on consideration.

In the declaration of trespass on promises, the defendant was represented as undertaking or promising to do something, and inflicting some positive wrong while carrying out his undertaking. The conception of a consideration as necessary to give to the undertaking its binding force, was not fully recognized, and it was not alleged in the declaration; neither was it necessary in the action which sounded in actual tort. ${ }^{1}$ A promise to do something, whether binding or not, might well serve the means or inducement to a tort.

This action was repeatedly denied in the reign of Henry IV., 3 as applying to cases of mere non-feasance or non-performance of contracts. ${ }^{3}$ In the reign of Henry VI. ${ }^{4}$ it was finally held by the courts to include such cases. ${ }^{5}$ The mere failure of - a person to keep his promises was thus regarded and treated as a tort, and the action of trespass on the case on promises was classed with other actions of trespass on the case, sounding in tort. ${ }^{6}$

In the language of Chief Baron Gilbert, "The gist of the action is the fraud and delusion that the defendant hath offered the plaintiff in not performing the promise he had made, and relying on which the plaintiff is hurt." 7 The act of the defendant in breaking his promise was originally conceived of as a deceit, remediable by action as in any tort. ${ }^{8}$ A relic of this conception was continued down to comparatively modern times in the form of the declaration, which affects to represent the defendant as contriving and frandulently intending craftily and subtly to deceive and defraud the plaintiff in and by his mere act of disregarding his promise. ${ }^{9}$

When the action disclosed no tort except the mere failure to perform a contract or promise, it then was felt that the contract or promise must be binding in law to form the basis of an actionable wrong. To make it so, a consideration was necessary and had to bo alleged in the declaration. ${ }^{10}$ This is the distinguishing feature of modern assumpsit. ${ }^{11}$

1 Holmes, Com. Iaw, 196.

2 1399-1413.

82 Reeves, Hist. 509 . ।

4 1422-1461.

52 Reeves, Hist. 606, 607.

61 H. Bl. 55I; 1 Chit. Pl. 99 ; Browne, 318.
7 Gilb. Com. Pleas, 65; 2 Harr. Law Rev. 16.

82 Harv. Law Rev. 13.

92 Chit. Pl. 324.

10 Holmes, Com. Law, 196, 197.

11 Selw. N. P. 42, 43. 
There does not seem to have been any distinction between express and implied promises. Nevertheless its application to simple contracts for the payment of money was not fully conceded until the decision of Slade's Case, in the 44th year of Elizabeth's reign, on the notion that, as the action of debt applied to such contracts, there was no necessity, and therefore no right, to resort to the action of trespass on the case. ${ }^{1} \quad \Lambda$ fter the decision in this case, it came to be more generally used than the action of debt in the enforcement of money demands on simple contracts. ${ }^{2}$

SEc. 53. History continued. It was perhaps a strained construction which found the elements of a tort in a mere failure to perform a contract. It had for its excuse the necessity of sorne remedy in such case, and the further inducement to escape trial by wager of law, which could be invoked in the action of debt on simple contract. ${ }^{3}$ After the action of trespass on the case on promises had been established, and had been extended to the nonperformance of all simple contracts, it was impossible to retain and classify it with other actions of trespass on the case, for the reason that it was manifestly wanting in the ex delicto element, which had from the beginning characterized that kind of action. Accordingly, we find that the ex delicto phase, which had been unwarrantably imposed upon it, was gradually dropped, and it took its present name of assumpsit, and has in modern times been classed and recognized as an action ex contractu, being designated both in the writ and declaration as an action on promises, instead of an action of trespass on the case on promises. ${ }^{4}$

The artion of assumpsit has been very generally retained in the States adhering to the common law system of pleading; although other actions ex contractu have been consolidated with it in some instances.

SEc. 54. Nature and characteristic Features. It is seen that assumpsit is the appropriate and favorite remedy for the breach of all contracts not-under seal nor of record, whether express or implied. The promise of the defendant in modern assumpsit, whether ex pressed or fictitious, must be supported by a consideration of some kind. The quid pro quo, or consideration, which imposed a liability on the defendant in debt was limited to actual benefits

1 Slade's Case, 4 Co. 74, 91, 95.

21 Chit. Pl. $99 ; 3$ Reeves, Hist. 750 .
83 Reeves. Hist. 750.

4 Steph. Pl. 40 ; 1 Chit. Pl. 99 ; Browne, 318. 
received by him. Mere detriment to the plaintiff was not a sufficient consideration to support that action. ${ }^{1}$ But in assumpsit the conception of consideration came finally to include detriment to the plaintiff as promisee. ${ }^{2}$ All considerations of parol contract have been aptly generalized as some detriment to the promisee incurred at the instance or request of the promisor. ${ }^{3}$ Mere detriment to the promisee, however, will not support general assumpsit on quasi contract, which rests upon equitable grounds, and requires a consideration of actual benefits received by the promisor in like manner as in debt on simple contract. ${ }^{4}$

A contract is express, when the parties have in definite terms expressed their intention. It is also express, when that intention can be inferred as a matter of fact from the acts and doings of the parties, which coustitute the contract, although devoid of any written or oral expression embodying that intention. The distinction between these two kinds of express contracts consists only in the manner of proof. In the former, it is proved by the language used. In the latter, by circumstances from which it may be inferred as a matter of fact. ${ }^{5}$ The latter kind of express contract has been frequently confounded with implied or constructive contracts, now generally referred to as quasi contracts, hereafter defined. The distinction between them consists in the difference between an inference of fact which a jury or court is justified in drawing, and a conclusion of law implied from the existence of certain facts and declared by the court, for the purpose of administering justice between the parties. They have been treated under the designation of contracts implied in fact, to distinguish them from the latter, which are said to be implied by law. ${ }^{6}$ When the action is based on express contracts, it is generally denominated specral assumpsit, because of the actual and special contract set forth in the count, to which the parties have assented.

The law implies obligations or quasi contracts from the acts and doings of the parties; although no inference of an actual contract could be drawn as a matter of fact; the hostile attitude of the parties to each other in many cases forbidding the existence of an

1 Holmes, Com. Law, 269, 271.

2 Holmes, Com. Law, 271; 1 Chit. Pl. 293, 294; Block v. Elliott, 1 Mo. 275 ; Williams $v$. Jensen, 75 Mo. 681 ; Houck $v$. Frisbee, 66 Mo. App. 16; Hare, Cont. 134, 135.
3 IIarv. Law Rev. 18.

4 Keener, Quasi Cont. 253.

5 Keener, Quasi Cont. 222.

6 Keener, Quasi Cont., 3-6. 
actual aggregatio mentium. ${ }^{1}$ Obligations thus implied by law, and existing independent of actual agreement, were sometimes designated in ancient as well as in modern law as quasi contracts. ${ }^{2}$ The variety of these obligations and the grounds upon which they are raised by law could not be considered in a treatise of this character. ${ }^{3}$ It is sufficient to say that assumpsit was' employed to enforce a great many of them. When the action was founded on the obligation raised by law independent of express contract, it was-usually denominated general assumpsit,-and-the-counts-of the declaration embodying it were denominated common counts.

There is a marked distinction between special and general assumpsit. In special assumpsit, the plaintiff grounded his action on some actual express undertaking or promise to pay money, or to do or omit doing some particular thing. In general assumpsit, he ignored the express undertaking, if there was one, and grounded his action on certain facts happening or existing between the parties from which the law raised the implication of a promise, which, although fictitious, had to be alleged by the pleader. ${ }^{4}$

The courts were not always unanimous on the class of facts which would justify the implication of an obligation or contract sufficient to sustain the action of general assumpsit. The promise in some cases was implied by invoking the principles of equity or natural justice, thus giving to the action an equitable character. ${ }^{5}$ The field in which general assumpsit was employed is thus seen to be a wide one, and it will not be convenient to compass it in detail. I will, however, briefly as possible indicate the most us̀ual classes of facts upon which it was said the law raised an implied assumpsit, and enforced it in what I have referred to as the Common Counts. The right to enforce it, during the existence of an express contract covering the same subject matter, is a question about which there is great conflict of authority, as will appear in our note in the Appendix. ${ }^{6}$

SEC. 55. Common Counts, or General Assumpsit. These counts were generally used in connection with some count in special assumpsit preceding them in the same declaration. This was not 496.

1 Hickam $v$. Hickam, 46 Mo. App.

22 Bl. Com. 443; Browne, 384 ;

Saund. Pl, \& Ev. 337, 338.

83 Bl. Com. 158-164.

- Cutter $v$. Powell, 2 Sinith Id.
Cas. 61 ; Browne, 320 ; Gould, Pl. c. 3, s. 19.

53 Bl. Com. 162; Thompson $v$. Thompson, $5 \mathrm{~W}$. Va. 190 ; Moses $v$. Macferlan, 2 Burr. 1012.

6 See note 1. 
invariably the case. It appears that they were sometimes used independently of any count in special assumpsit, ${ }^{1}$ although such use was subject to the objection of inducing surprise at the trial, on account of the general and indefinite terms in which they disclosed the cause of action. ${ }^{2}$ Whenever, in the count on special assumpsit, the contract sued on contained in its nature the receipt of a consideration delivered or given at the instance of the defendant, upon which a promise to pay money had been expressed, or could be implied by law, one or more of the common counts might generally be added. They were always predicated upon a precedent and existing debt or executed consideration, for which the, law raised an implied promise to pay in money. ${ }^{3}$ They were all developed from the count on special assumpsit upon an express promise. The courts permitted the jury to infer an actual promise from circumstantial evidence. They next inferred the promise themselves in clear cases, when it was in accord with the natural and evident intention of the parties. In this manner a promise to pay on the facts constituting a debt became a reasonable and conclusive inference of fact. In other cases; as in quasi contract, it was often imposed upon the wrongdoer, in the face of any actual or presumed intention, upon the equitable principle that he ought to pay for an enrichment of his estate effected by unjust acquisitions from another. ${ }^{4}$

SEc. 56. Common Counts continued. I will give the name and form of these counts as found in the early reports, and afterwarls notice the distinction between them. According to the old classification there were four kinds of coinmon counts.

First. The count of indebitatus assumpsit, the inost comprelien. sive one of all, in which it was alleged that the defendant was indebted to the plaintiff in a certain sum of money; as for real property sold or used and occupied, or for persoual property sold ; or for personal services rendered; or for money loaned or paid and expented to defendant's use; or for money paid to and received by defendant to plaintiff's use; all of which was incurred in some way at his special instance and request; and that being so indebted, the defendant-promised-in consideration thereof to pay to

1 .Moses $v$. Macferlan, 2 Burr. 1010; 1 Chit. P1. 33:39.

2 Wood $v$. Lut trel, 1 Call. 239

81 Clit. Pl. 340, 341.
42 Harv. Law Rev. 66 : $3 \mathrm{Bl}$. Com 1fi2; Moses v. Macferlan, 2 Burr. 1012. 
ART. III.] PERSONAL ACTIONS EX CONTRACTU. - ASSUMPSIT.

the plaintiff the said money.1 Of the indebitatus counts, those relating to transactions based on the payment or receipt of money were called the money counts; as, money lent to defendant; money paid and expended for his use; and money had and received by defendant to plaintiff's use.

Second. The count of quantum meruit, in which it was alleged that in consideration that the plaintiff had done work, etc. at. the request and instance of defendant, he the defendant promised to pay plaintiff so much money as he reasonably deserved to have therefor, and that plintff deserved to have a named. sum $^{2}$

Third. The count of quantum valcbant, which resembled the quantum meruit count in every respect except that it related to the sale of goods-or-merchandise, and which, after alleging a delivery and acceptance of the goods sold, contained the averment of a promise on the part of defendant to pay what they were reasonably worth; ${ }^{3}$ and that they were reasonably worth a named sum.

Fourth. The count of insimul computasset, or account stated, in which it was alleged that the defendant on a day named accounted with the plaintiff of and concerning divers sums of money before then due to plaintiff, and that upon such accounting the defendant having been found to be in arrear and-indebted, he the defendant, in consideration thereef, promised the plaintiff to pay him the same on request. 4

In considering the language of these counts it will be seen that the counts of indebitatus assumpsit differ somewhat in form from the other counts, by alleging in the first instance the existence of a debt, and accompanying that allegation with the cause of the indebtedness. The promise is thus implied from the existence of a debt, and the existence of the debt from the binding cause or consideration. In the other counts the fact of services rendered, gonds and materials sold, premises occupied, all at the instance of defendant, or the finding of an indebtedness on an accounting for moneys, constitute the consideration of the promise, and give to it its binding force. The implied promise to pay rises directly from these

11 Chit. Pl. 341 ; Saund. Pl. \& Ev. 139.

21 Saund. Pl. \& Ev. 139, 140; 1 Chit. Pl. 341.
31 Sannd. Pl. \& Ev. 140; 1 Chit. Pl. 341, 34:.

41 Saund. Pl. \& Ev. 31; 1 Chit. Pl. 342 . 
facts of consideration, and not from any substantive allegation of indebtedness.

SEc. 57. Common Counts continued. These common counts were not in general use till the time of Lord Holt; ${ }^{1}$ but their use was approved by Lord Mansfield, ${ }^{2}$ and they have come to constitute a marked feature peculiar to common law pleading, and offset to a certain extent the disadvantages which sometimes attended the required particularity of special assumpsit. The count on an account stated was developed from the ancient action for arrearages on account, and the count for money had and received comes from the old action of account. ${ }^{3}$

They often served the purpose of enabling the plaintiff to recover upon a distinct element underlying the contract declared on in special assumpsit, but not necessarily disclosed in its terms. In illustration, let it be supposed that the plaintiff sues on a promissory note given towards payment for a sale of goods; the first count in the declaration would be a special assumpsit on the note. But this count would contain no allusion to the sale of goods which constituted the consideration of the note. By adding the count of indebitatus assumpsit, the plaintiff was at liberty to recover upon the promise implied from the debt, which independently of the note rose from the sale and delivery of the goods. If he failed in proof of the first count, he might often prevail on the second.

If the plaintiff declared upon an express contract for building a house, and failed to prove that it had been built in conformity with the contract, he was at liberty to recover on the quantum. meruit and quantum valebant counts, upon proof that defendant had received the benefit of his labor and the value of his materials in the house as actually completed by plaintiff and received by defendant. The law raised an implied assumpsit on the part of the defendant to pay what the plaintiff deserved for his labor, and what his materials were reasonably worth.

The plaintiff in all declarations in assumpsit for the recovery of money could recover on the count of account stated, by proof that the defendant had expressly or impliedly acknowledged the debt in an accounting for moneys involved in any transaction.

1 Hayes $v$. Warren, 2 Str. 933.

3 Finlason's Lead. Cas. 1, 2, 79.

${ }^{2}$ Moses v. Macferlan, 2 Burr. 1010. 
It was a cardinal rule that indebitatus assumpsit would not lie in any case in which the action of debt could not be maintained, because it was founded on a promise implied solely from the existence of a debt.

It was a leading feature of the action of debt that it must be for a sum certain. On that account it was formerly held, as I have already stated, that the action of debt could not be maintained on the facts of a quantum meruit or quantum valebant, by reason of the uncertainty of the sum. ${ }^{1}$ Hence the necessity of those counts in assumpsit which related as then supposed to uncertain sums. ${ }^{2}$ But after the action of debt was extended to such implied obligations, upon the maxim Id certum est quod certum reddi potest, and the indebitatus count in assumpsit followed suit in being maintained by evidence of sums possible to be reduced to a certainty, the counts of quantum meruit and quantum valebant came to be regarded by the profession in England as wholly unnecessary, ${ }^{3}$ their original purpose being finally attained in the indebitatus count in assumpsit and in debt.

The general regulations of Trinity Term in 1831 prescribed a form for the common counts of indcbitatus assumpsit and account stated, simplifying and relieving them from unnecessary verbiage. ${ }^{4}$ No mention is made of the quantum meruit or quantum valebant counts, a fact which has been treated as virtually abolishing them in England. 5

The count of account stated is in its nature an indebitatus count, resting as it were upon the implied promise to pay a certain sum found to be due on an accounting for money. It differed in form from the indebitatus count in omitting to allege the substantive fact of indebtedness, and in making the fact of accounting and finding of a sum due serve as the consideration of the implied promise, instead of the debt itself, the existence of which is only inferentially assumed from the allegation of the accounting and finding. ${ }^{6}$ In the forms prescribed in the rules last mentioned, this fine distinction disappears, and the count of account stated takes its place among the counts of indebitatus assumpsit, and is prefaced with the substantive allegation of indebtedness in like manner with them. ${ }^{7}$

$13 \mathrm{Bl}$. Com. 154.

23 Bl. Com. 154, 155, 161.

31 Chit. Pl. 342.

1 Chit. Pl. 726.
51 Chit. Pl. 342.

- Finlason's Leading Cases, 3, 5.

71 Chit. Pl. 726. 
An essential feature of the common counts is that the obligation attempted to be enforced is an implied promise to pay money, although the transaction may relate to the receipt of goods, services, or anything else of value. If the obligation according to the terms of the special contract was to be discharged in property, or anything else than money, implied assumpsit as a general rule could not be maintained. ${ }^{1}$

It may be repeated here that the common counts were also used in connection with the action of debt. This was always true of the counts of indebitatus assumpsit, and the account stated; and latterly became true of the counts of qurntum meruit and quantum valebant, although subject to some dissent. ${ }^{2}$ When used in debt, the phraseology was slightly changed so as to conform with the requirements of that action. ${ }^{3}$

SEC. 58. Common Counts continued. Under what circumstances an action may be maintained on an implied assumpsit, for part performance of an express contract relating to the same subject matter of the suit, is a question about which there has been great conflict in the decisions of the courts. In a note in the Appendix $I$ have endeavored to express the principal conclusions embraced in the controversy; and I will indicate here only the prospective outcome of it. ${ }^{4}$

The precise point of inquiry is this: When will the express contract defeat an action founded on an implied assumpsit to recover what has been actually done under or in pursuance of it? The law of implied assumpsit is evolved from the law of special assumpsit, and must be considered in connection with it.

It may be observed that anciently the courts were very liberal in allowing actions to be maintained on contracts, notwithstanding a failure on the part of plaintiff to perform the contract, or covenants of it, on his side. ${ }^{5}$ This liberal doctrine grew up in relation to covenants, by which mutual covenants were treated as separate and independent unless they were made dependent by express declaration. ${ }^{6}$

But the injustice to which this ancient doctrine led induced the

11 Chit. Pl. 346, 347.

21 Chit. Pl. 342 ; 1 Saund. Pl \& Ev. 31, 403, 405, 409; 2 Chit. Pl. $385 ; 1$ Chit. Pl. 109, note $q$ : Emery v. Fell, 2 T. R. 28; Finlason's I eading Cases, 131.
3 Sec. 42.

4 Appendix, note 1.

5 Langdell, Sum. Cont. 178.

6 Langdell, Sunı. Cont. 178; Thomas ". Cadwallader, Willes, 490 ; 'Thorp v. Thorp, 12 Mod. 455. 
courts in comparatively modern times to import into contracts, in which performance on one side constitutes a consideration for performance on the other, the implied condition precedent that the contract must be fully performed on the part of plaintiff before he can maintain an action on the contract for non-performance on the part of defendant. ${ }^{1}$ This rule may be regarded as still prevailing in its application to actions founded on the contract. ${ }^{2}$

But the courts did not stop with the rule forbidding action on the contract in such cases, but went a step further, and laid down a rule forbidding action upon an implied assumpsit for anything done under an express contract which remained open and unperformed. ${ }^{3}$

To this extension of the rule prohibitive of general assumpsit there have been so many well settled exceptions that it may be said to exist no longer as a general rule.

A generalization announcing the reverse of it, attended with two or three exceptions, represents more nearly the present condition of the law on this matter, which may be formulated as follows: when the plaintiff has performed part of an express contract existing between himself and defendant, and the part which has been performed and retained by the defendant is of value or benefit to him, he-(the plaintiff) is entitled to recover in general assumpsit the reasonable value to defendant of the part performance under the circumstances of the case; and the express contract will not operate to defeat his right of action, but may be used to reduce or limit the amount of recovery.

To this rule two well recognized exceptions may be noted.

1st Exception. When it is expressly provided in the contract, or is necessarily implied from the terms and nature of it, that the actuxt intention of the parties is that complete performance is a coudition precedent to the payment of all or any part of the consideration stipulated for, - or, in other words, that nothing is to be paid for part performance, however beneficial it may be to de-

1 Kingston $v$. Preston, cited in Martin, Fitzgibhon, 303; Hulle $v$. Jones v. Barkley, Douglass, 684, Heightman, 2 East, 145; Dernot Mansfield, C. J.

v. Jones, 23 How. U. S. 23.3; Felton

2 Glazebrook $v$. Woodrow, 8 T. R. $v$. Dickinson, 10 Mass. 287; Kelly $v$. 366. Foster, 2 Binn. 4; Camp v. Barker,

82 Smith L. Cas. 10 [Cutter v. 21 Vt. 460; Christy v. Price, 7 Mo. Powell, note of Smith]; Gordon v. 430. 
fendant, - the express contract will operate to defeat an implied assumpsit for part performance. ${ }^{1}$

$-2 d$ Exception. When the express contract is void for illegality, it will defeat an implied assumpsit for part performance. ${ }^{2}$ -In analogy with this exception, it has been held, on grounds of public policy, that wanton desertion by a seaman is punished with forfeiture of wages, ${ }^{3}$ and that bad faith toward his principal by an agent or servant will work a similar forfeiture of compensation for his services. ${ }^{4}$

The student is referred to note 1 in the Appendix for a more complete consideration of the law on this difficult and important question.

SEc. 59. Declaration. In special assumpsit the declaration should set forth all the material parts of the contract by which its nature is determined.

The consideration of the contract must be stated, except in suits on bills of exehange, promissory notes, and such other contracts as import a consideration. It may be necessary in some cases to recite in a general manner, by way of inducement, facts and circumstances to which the consideration and promise apply, for the purpose of making the contract intelligible and operative.

The promise of the contract nuust be alleged either in the usual form which made use of that word, or-in equivalent words. ${ }^{5}$ And any conditions, limitations, or restrictions on the promise should be set out, especially if occurring in the language disclosing the promise.

It was necessary that the declaration should show a performance of everything required of the plaintiff by the contract constituting the consideration of the defendant's promise, as also the performance of all conditions precedent, or allege a valid excuse for nonperformance. ${ }^{6}$

A breach of the contract must be alleged, with such particularity

1 Leonard v. Dyer, 26 Conn. 177 ; Todd $v$. Summers, 2 Grat. 167 ; Linnenkohl $v$. Winkelmeyer, 54 Mo. App. 570 ; Huntington $v$. Claflin, 10 Bosw. 262; S. C. 38 N. Y. 182 ; Monkham $v$. Shepherdson, 11 Ad. \& E. 411; Hunter v. Gibson, 3 Pich. S. C. 161 ; Crews $v$. Garneau, 14 Mo. App. 50 5.
2 Burk v. Place, 6 Cow. 431 ; Hon. negger $v$. Wettstein, 94 N. Y. 252.

s West $v$. Duckingham, 13 .Johns. 390 ; Edward v. Trevellick, 4 E. \& B. 59.

41 Wait's Actions and Defencer 271.

51 Chit. Pl. 301.

61 Cliit. Pl. 296, 320, 321, 326. 
as the nature of it may require It need not be set out in the exact language of the contract. It is sufficient that the language used shows that the contract has been violated.

The damages which legally and directly flow from the breach should be stated in a general sum. If damages have actually resulted, though not the direct consequence of the breach, the character of them should be specially stated. When the contract is general, and several distinct breaches thereof can, in fact, be committed, the declaration might at common law state in one count several breaches as different violations of the contract obligation; and the regulations of Hilary Term 1834 expressly permit the assignment of several breaches of the same contract or duty. ${ }^{1}$

In general assumpsit the nature of the declaration has been indicated in our description of the nature and form of the Common Counts, and need not be repeated. The essential averments of the declaration are the same as in special assumpsit; viz. the consideration of the promise, the promise of defendant, breach of the same, and damages. The allegations in general assumpsit differed from those in special assumpsit in being more general, and devoid of the particularity attributable to express contracts. The goods sold or services rendered for which the law imposed a liability need not be described as to kind, quality, or quantity; and averments of time and place were not deemed necessary. This indefiniteness of statement was recognized and continued in the forms of general assumpsit prescribed by the regulations of Trinity Term 1831. ${ }^{2}$

For writs and declarations see Appendix, forms 6, 7, and 8.

SEc. 60. Judgment. The judgment, when given in plaintiff's favor, is that he recover a specified sum assessed by a jury, or found on reference to a master for his damages which he hath sustained by reason of the defendant's non-performance of his promises and undertakings; and for full costs of suit, unless deprived of the right to costs by virtue of some statute or some default of his own in not proceeding in some inferior court having jurisdiction of the action. ${ }^{3}$

11 Chit. Pl. 336, 739.

21 Chit. Pl. 726.

s 1 Chit. Pl. 108. 


\section{Article IV.}

\section{Account.}

Sec. 61. Defined.

"62. History.

“63. Nature and Characteristics.

Sec. 64. Case on Refusal to account.

" 65. Assumpsit on Account stated.

Sec. 67. Judgment.

Sec. 61. Defined. Account is the name of a common law action which lies against one who, by reason of his office or business as bailiff, receiver, or guardian, ought to render an account to another, but refuses to do so. ${ }^{-1}$ It is sometimes designated as the action of account render. The immediate object of the action was to compel the defendant to come to an accounting with the plaintiff for profits and moneys received by him in his capacity as guardian, bailiff, or receiver, ${ }^{2}$ with the ultimate object of recovering the amount for which he should be found in arrears.

SEc. 62. History. The writ of account is of early origin, appearing first in the register of writs late in the reign of Henry III., in 1232. ${ }^{3}$ It was modelled on the proprietary writs, the plaintiff demanding an account of his moneys. ${ }^{4}$ It was regulated as to guardians in socage, bailiffs, and receivers by the statutes of Marlbridge and Westminster II., passed in 1267 and $1285^{5}$ Prior to these statutes, guardians in socage as well as in chivalry were not accountable for profits. ${ }^{6}$

In favor of merchants and for the advancement of trade, it was sanctioned between them in respect to joint partnership adventures, the plaintiff naming himself and defendant merchants, and charging the defendant as his receiver. ${ }^{\top}$ It was held not to 'lie if there were more than two partners. ${ }^{8}$ This action did not lie at common law in favor of an administrator or executor, for want of privity; ${ }^{9}$ but it was extended by statute in favor of executors; ${ }^{10}$ and in favor of the executor of an executor, and in favor of an adminis-

1 Fitz. Nat. Brev. 116, 117; Co. Litt. 172 a.

22 Reeres, Hist. 213, 214, 215.

\& 2 Pol. \& Mait. 219.

1 2 Pol. \& Mait. 219.

5 Marlb. c. 23 ; Westm. II. ; 2 Pol. \& Mait. 219.

- 1 Pol. \& Mait. 303.
7 Bacon, Abr. Accompt A.; 1 Binn. 191 ; Co. Litt. 172 a ; Co. Litt. 17.2 b, n. 34 .

8 Beach v. Hotchkiss, 2 Conn. 425; Appleby $v$. Brown, 24 N. Y. 143.

9 Co. Litt. 89 ; Griffith v. Willing, 3 Binn. 317.

10 Westm. II. (13 Edw. I.) c. 23. 
trator. ${ }^{1}$ In the reign of Queen Anne it was extended to joint tenants and tenants in common as against each other for receiving in the capacity of bailiff more than his share, and to and against executors and administrators of such tenants respectively. ${ }^{2}$ The action of account render gradually became obsolete, and was superseded in practice by the superior remedy of a bill in equity to compel and take an accounting. ${ }^{3}$ It has perhaps been employed to a greater extent in the United States, ${ }^{4}$ but in a way greatly modified by statutes.

SEc. 63. Nature and Characteristics. The first issue in the case involved the liability of the defendant to account. This liability rose as incidental to the relation of privity which he occupied to the plaintiff, and was independent of contract. ${ }^{5}$ His refusal to account was regarded as a breach of duty imposed by law. If the issue which involved his liability to account was decided in favor of the plaintiff, it was followed by an interlocutory judgment, that the defendant account. ${ }^{6}$

This account he was required to make before auditors appointed by the court. If after the accounting the defendant was found in arrears, another judgment was rendered for recovery of the amount thus ascertained to be due. ${ }^{7}$ The first issue in this action would seem to ally it with actions on the case for breach of duty; but as it is a duty which furnishes the elements of a quasi contract, it has at least in modern times been generally classed with actions ex contractu. ${ }^{8}$

The proceedings before the auditors were very dilatory and burdensome, for the reason that they had no power of passing at once on controverted items, but were obliged to refer each disputed item to the court or jury as a distinct issue of law or fact. ${ }^{9}$ Not until the reign of Queen Anne could the auditors examine the parties under oath $;^{10}$ and if the balance turned out to be in favor of defendant, the court could not give judgment in his favor for the amount.11

131 Fdw. III. c. 11.

24 \& 5 Anne, c. 16 , s. 27.

8 Bisphau's Prin. Eq. s. 482 ; Kerr on Actions, 127, note $n$.

4 Griffith $v$. Willing, 3 Binn. (Pa.) 317 ; Duncan v. Lyon, 3 Johns. Ch. 351 ; Conklin v. Bush, 8 Penn. 514; Closson v. Means, 40 Me. 337 ; Appleby $v$. Brown, 24 N. Y. 143.
52 Harv. L. Rev. 243.

62 Reeves, 388.

72 Reeves, 388.

82 Reeves, 387, 388, 408; 1 Chit.

Pl. 39; Conklin v. Bush, 8 Penn. 514.

9 Comyn, Dig. Accompt E. 11.

134 \& 5 Anne, c. 16.

11 Spence, Eq. 949; Crousillat $v$ M'Call, 5 Binn. 433. 
SEC. 64. Trespass on the Case for Refusal to account. To avoid the unsatisfactory methods of the action of account render, and to retain the business of accounting in mercantile matters in the common law courts, an action of trespass on the case on promises, for neglect or refusal to account was sanctioned by them, when founded on the breach of an express promise to account. ${ }^{1}$ It was claimed that on principle this action of trespass on the case would also lie where the obligation to account could be raised by implication of law. ${ }^{2}$ Whether the law raises an implied promise on the part of an agent or factor to account has been doubted, ${ }^{3}$ but not with any good reason. 4 In the old action of case for failure to account, the plaintiff recovered the damages resulting from the default or refusal of the defendant to render an account, but no account was taken in the action. ${ }^{5}$

SEc. 65. Assumpsit on an Account stated. The modern action of assumpsit always lies to recover the balance of an account stated. ${ }^{6}$ In the action of assumpsit on an account stated, the plaintiff recovers on the implied promise to pay the acknowledged amount, and no account is taken. ${ }^{7}$

SEc. 66. Declaration. In the declaration it was alleged that the defendant for a certain period of time was the bailiff or receiver of plaintiff, in respect to certain tenements or property, and that during the time aforesaid he had the care and management of said tenements or property as bailiff to take and receive the rents and profits of the tenements or property described with the appurtenances, and to render a reasonable account thereof to the said plaintiff when he should be thereunto requested. It next set forth a failure or refusal on the part of defendant to render such account upon request of plaintiff, and concluded with the averment that he was injured and had sustained damage to the amount of $£-$, and therefore he brings suit. ${ }^{8}$ A sum certain in arrears was not stated, the object of the suit being to ascertain the true sum. If an estimated sum was stated, the plaintiff was entitled to recover the balance found to be due, whether in excess of or below the estimated sum. ${ }^{9}$

1 Schee $v$. Hassinger, 2 Binn. 330; Wilkin $v$. Wilkin, 1 Salk. 9.

21 Chit. Pl. 135.

8 Schee $r$. Hassinger, 2 Binn. 321.

4 See argument of counsel in Schee $v$. Hassinger, 2 Binn. 321 ; Conklin $v$. Bush, 8 Penn. 514; Closson v. Means, $40 \mathrm{Me} .337$.

5 Poulter $v$. Cornwall, 1 Salk. 9; Wilkin $v$. Wilkin, 1 Salk. 9.

61 Chit. Pl. 100.

7 See Sec. 56, 57.

8 Godfrey $v$. Saunders, 3 Wils. 73, 94; 3 Chit. Pl. 1297.

${ }^{9}$ For writ and declaration see forms 9 and 10. 
SEC. 67. Judgment. As already stated, there were two judgments, - the first one an interloeutory judgment, in which the defendant was adjudged to account; the second one a final judgment, in which the plaintiff recovered the amount found in arrears by the auditors. If the amount was in-favor of defendant, thecourt could give no judgment in his favor:

\section{Article V. \\ Annuity.}

Sec. 68. Defined.

" 69. History.
Sec. 70. Nature and Characteristics.

" 71. Judgment.

SEc. 68. Defined. This is the name of an old personal action for recovery of an annuity. An annuity strictly speaking was in annual sum of money granted to another in fee for life or years, and chargeable only against the person of the grantor, and against his heirs when they were bound by the language of the grant.1 The grant had to be by deed, by words of express grant, in order to furnish the right of action at law. ${ }^{2}$

SEc. 69. History. This writ or action appears in the register of writs, and is among the oldest known. ${ }^{3}$ The report of an action of annuity from the Year Books in the reign of Edward II. is referred to by Reeves as disclosing an example of oral pleadings. ${ }^{4}$ It was superseded at an early day by the actions of debt and covenant, ${ }^{5}$ there being invariably, in later times, an express or an implied covenant in the deed to pay the annuity. ${ }^{6}$

SEC. 70. Nature and Characteristics. The original writ resembled the writ of debt, and was triable in the Common Pleas, or before the sheriff, by justicies writ. ${ }^{7}$ The action was theoretically a proprietary action. It proceeded upon the assumption that the defendant, or the person whom he succeeds as heir, had granted from his coffers a right to the plaintiff for an annuat sum of money, which intangible right the plaintiff had been dispos-

1 Co. Litt. 144 b.

2 Bacon, Abr. Annuity and Rent Charge B.; 1 Saund. Pl. \& Ev. 84.

3 Fitz. Nat. B. [152]; Bracton Folio, 203 b.

12 Reeves, 221.

Martin Civjl Procedure-5
51 Tidd, Pr. 3; 1 Saund. Pl. \& Ev. 84; 1 Chit Pl. 110, 116. .

6 Smith, Actions, 46.

7 Fitz. Nat. B. [152]; Comyn, Dig. Annuity D. 
sessed of by the refusal or failure of the defendant to pay a single instalment after the same was payable. This feature to pay was anciently regarded in the nature of a disseisin of the plaintiff's estate or interest in the annuity; and the action lay to recover back this intangible thing called an annuity, and incident thereto the iustalments in arrears. The action lay in favor of the grantee or his heirs, or their grantees, against the grantor himself or his heirs, when they were bound by the language of the grant. ${ }^{1}$

An annuity constituted eventually a peculiar species of property at common law. While it was a chose in action, it differed from other choses (excepting negotiable paper) in being assignable ${ }^{2}$ An inheritance could be created in it as in realty. ${ }^{3}$

A rent charge differed from an annuity, with which it was sometimes confounded, in being chargeable against land, either in the form of a reservation of annual rent, accompanied with the right of distress on land conveyed away, or in the grant of an annual rental with the right of distress chargeable on land remaining with the grantor. ${ }^{4}$

An annuity was enforced by the personal writ of annuity; while a rent charge, being in the nature of realty, was enforced by the remedies relating to land, such as distress and assize of rent. $^{5}$ There was nothing inconsistent in the annuity granted being chargeable against both the person and the land of the grantor; in which case the grantee had both the rights of an annuity and a rent charge. ${ }^{6}$ In such case, he was at liberty to invoke either the personal writ of annuity, or the remedies of distress and assize of rent against the land; but his choice of one remedy debarred him from exercising the other. ${ }^{7}$

SEc. 71. Judgment. In the personal action of annuity, the judgment, if for plaintiff, was that he recover the annuity and arrearages of the same up to the time of judgment. ${ }^{8}$ To recover the amount accruing after judgment, a scire facias was necessary. ${ }^{9}$

1 Co. Litt. 144 b : Comyn, Dig. Annuity 13. ; 1 Roll. 226, c. 25 .

2 Co. Litt. $144 \mathrm{~b}$; Gerard $v$. Baden, Hetl. 80 ; Maund's Case, 7 Coke, 112.

82 Bl. Com. 40; Smith v. Pybus, 9 Ves. 566.

4 Bacon, Abr. Annuity B.
5 Co. Litt. 144 b.

- Bacon, Abr. Annuity and Rent Charge.

7 Co. Litt. 144 b, 145 a ; Bacon, Abr. Annuity and Rent Charge C.; Com. Dig. Annuity C.

82 Tidd, Pr. 1107.

๑ 2 Tidd, Pr. 1107. 
If the term of the annuity had expired before issue of the writ, or if it expired pending the writ, debt was the proper remedy. ${ }^{1}$

For writ and declaration in account, consult Appendix, forms 11 and 12.

\section{ARTCLE VI. \\ Scire Facias.}

Sec. 72. Definition and History.

SEc. 72. Definition and History. This is a writ founded upon some matter of record. When brought to repeal a patent, it is an original writ issuing out of Chancery; in other cases it is a judicial writ issuing from the court in which the record on which it is founded is made. It is only the judicial writ necessary to be considered in this treatise.

The object of the judicial writ is to enforce judgments, recognizances, or other obligations of record, and to continue suits. On this account it has been classed with writs of execution; but it is so far in the nature of an original writ that the defendant may plead to it, and this element gives to it the character of an action at law, but not that of an ordinary action at law. ${ }^{2}$

Scire facias was necessary when the plaintiff in a judgment delayed taking out an execution within a year and a day from its date. In real actions it lay at common law because there was no other remedy for enforcement of judgment after expiration of that time. It did not lie at common law to revive a judgment in personal actions, because the plaintiff could sue again on them.-To prevent the oppression of such suits, the remedy of scire facias was extended to personal actions. ${ }^{3}$ It was also necessary when any new person is to be benefited or charged by the execution of the judgment. This necessity arose from the rule of law requiring executions to pursue and correspond with the judgments upon which they are issued.

The purpose of the proceeding is to revive the judgment, not to recover damages; and in the case of new parties to be benefited or charged, to include them; so that execution may be sued out upon the judgment as revived and enlarged.

The judicial writ recites the judgment upon which it is founded,

12 Hen. VI. 8 ; 1 Saund. Pl. \& Ev. 187; Kerr, Actions, 122, 152; State 84 ; Coke, 285 a.

2 Smith, Actions, 45 ; 2 Sellon, Pr. $\quad 32$ Sellon, Pr. 189.

$v$. Hoeffner, 124 Mo. 488. 
alleging that execution still remains to be had, and commands the sheriff to make known to the defendant that he be in court at the return day to show cause why the plaintiff ought not to have execution. ${ }^{1}$ Judgment in the proceeding revived the original judgment, so as to enable the plaintiff to sue out execution upon it at any time during a year and a day from the date of revival.

By the Common Law Procedure Act of 1852, a writ designated as a writ of revivor was made in many instances to serve the purpose of a scire facias in the enforcement of judgments. ${ }^{2}$ It was directed to the party, instead of the sheriff calling upon him to show cause within a certain time why the plaintiff should not have execution on the judgment. It was served like a summons, and was proceeded in as in ordinary actions. The writ of scire facias remained in all other cases as before, except that it was directed and served like writs of revivor. ${ }^{3}$ Judgments could also be revived upon suggestion of record and rule to show cause, when it was manifest to the court that a party was entitled to an execution. ${ }^{4}$

See writ in Appendix, form 13.

1 Smith, Actions, 209, 210.

2 Com. L. Pro. Act, 1852, s. 131.

3 Com. L. Pro. Act, 1852, ๙. 132.

4 Com. L. Pro. Act, 1852 , s. 129 , 130. 
CHAPTER III.

\section{PERSONAL ACTIONS EX DELICTO.}

Article I. Trespass vi et Armis.

" II. Detinue.

"III. Trespass on the Case.
Article IV. Trover.

"V. Replevin.

“ VI. Action for Mesne Profits.

\section{ARticle I.}

Trespass vi et Armis.

Sec. 73. Defined.

"74. History.
Sec. 75-78. Nature and Characteristics. 79. Declaration.

Sec. 80. Judgment.

SEC. 73. Defined. The term trespass, in an enlarged sense, includes every voluntary transgression or wrong: But the action which goes by that name lies only for the redress of wrongs committed with violence, either actual or implied, against the person or against tangible and corporeal property, whether personal or real. ${ }^{2}$ The wrong inflicted must be the direct effect of the act complained of, and not merely the consequence of it.

SEc. 74. History. While the early writers speak but little of this action, ${ }^{3}$ it nevertheless existed from a very early date in a somewhat nebulous form. It is said to be descended from the old writ of breve de transgressione. ${ }^{4}$ It was quite uncommon in its settled form in 1250, and became quite common in $1272 .{ }^{5}$ It is found in the register of writs, and is probably among the first which were reduced to form in the reign of Henry III. ${ }^{6}$ Full proceedings from the writ to the award of a venire, occurring in the reign of Edward I., ${ }^{7}$ are given in Reeves's History. ${ }^{8}$

It was originally of a semi-criminal nature, involving a breach. of duty to the King, as well as a violation of the rights of the sub-

13 Bl. Com. 208.

2 Steph. Pl: 16, $17 ; 1$ Chit. Pl. $126,127,166$.

3 2 Reeves, 216.

12 Pøl. \& Mait. 524.
52 Pol. \& Mait. 524.

6 1216-1272; Fitz. N. B. 85, 86.

7 1272-1307.

82 Reeves, $159,216$. 
ject. The defendant could be imprisoned and fined for his offence against the King, as well as compelled to pay damages for the wrong inflicted on the subject. ${ }^{1}$ These results were originally worked out in the proceedings had upon the civil writ.

In the course of time the wrong against the public came to be redressed by independent process, and proceedings on the writ of trespass were confined to compensatory damages to the plaintiff for the wrong against his rights. The writ, however, retained its semi-criminal form in describing the wrong as being done against the peace of the King.

Anciently, there were two forms of writs of trespass. In one the sheriff was commanded to compel appearance of defendant in the King's Superior Courts. It was returnable in said courts, and it always described the trespass as having been committed vi et urmis. ${ }^{2}$ The other was in the nature of a commission to the sheriff to try the case, and was not returnable in the Superior Courts. It omitted the words vi et armis, and thus confined the redress to compensatory damages. ${ }^{3}$

In all of the States retaining the common law system of pleading in a modified form, the action of trespass still prevails, although in some the distinction between trespass and case has been abolished, and either form may be used. ${ }^{4}$

SEc. 75. Nature and Characteristic Features. The force essential to this action might be actual or implied. An assault of the person by the use or offer of violence is an example of actual violence. A peaceable but wrongful entry upon land is an example of implied violence. ${ }^{5}$ The motive of the wrongdoer is immaterial as to sustaining the action, the negligent use of force being sufficient for that purpose. ${ }^{6}$

When the wrongful act is wilful, and the effect of the force immediate, trespass was the only remedy; except in cases which contain the facts upon which the trespass might be waived, and assumpsit, case, or trover maintained. ${ }^{7}$

An act might not constitiite a trespass in its inception, but might become such by the wrongful way in which it was carried

12 Pol. \& Mait. 165.

2 Fitz. N. B. [86].

8 Fitz. N. B 86.

426 Am. \& Eng. Encyc. Law, 709.

s Steph. Pl. 17.
62 Saund. Pl. \& Ev. 853, 851; 1 Chit. Pl. 171.

7 Saund. Pl. \& Ev. 336, 854; 1 Chit. Pl. 171 ; Rogers $v$. Arnold, 12 Wend. 39. 
out and performed; in which event the actor was treated as a trespasser $a b$ initio. ${ }^{1}$

-To maintain trespass, it was essential that the plaintiff should have not only a right or interest in the person or thing against which the force had been wrongfully exerted, but such a right or interest as could be and was immediately violated by such exertiou.

The essential and characteristic feature of the action consisted in the effect which immediately follows the wrongful exertion or projection of physical force. This feature will become more apparent when we consider it with reference to the persons and things subject to be affected by the wrongful infliction or application of such force.

SEC. 76. Nature and Characteristic Features continued. Rights of Body. Any-wrongful-infliction of force against one'sbody operated as a direct and immediate violation of the absolute rights of personal security guaranteed-by law-to every-one. The courts judicially recognized these rights, and the plaintiff was relieved from alleging them in his declaration or complaint. Menaces and offers of immediate bodily hurt, as well as batteries, were remediable by this action. ${ }^{2}$

It was likewise maintainable for wrongs occasioned by the infliction of force upon the wife, child, or servant of the plaintiff, in whose security of person he was possessed of only relative instead of absolute rights. Trespass was the preferable remedy. ${ }^{3}$. It was held in some instances that case was the proper remedy, on account of the damages being confined to the consequential loss of services, including expenses incurred for medical treatment, \&c. ${ }^{4}$ But in all wrongs of this description it may be said that trespass or case lay at the option of the plaintiff. ${ }^{5}$

SEc. 77. Nature and Characteristic Features continued. Personal Chattels. To maintain trespass in respect to personal chattels, it was essential that the plaintiff should have either actual possession thereof, or such general or special ownership 410.

12 Saund. Pl. \& Ev. 854 ; Browne,

22 Saund. Pl. \& Ev. 853; Browne, $395,396$.

${ }^{3} 1$ Chit. Pl. 167, 168; Ditchman v. Bond, 3 Camp. 525 ; 2 Saund. Pl. \& Ev. 854 .
42 Chit. Pl. 643, 644; Macfadgen $v$. Olivant, 6 East, 387 ; Bennett $v$. Allcott, 2 T. R. 166.

52 Greenl. Ev. 225 ; 2 Saund. Pl. \& Ev. 783; Ditchman $v$. Bond, 3 Camp. 525; 2 Chit. Pl. 654-657 [6th Lond. ed.]. 
therein as gave to him the immediate right of possession, which in contemplation of law drew along with it actual possession sufficient for the purposes of this action. On this account the gist or criterion of the action was said to consist in a forcible disturbance of possession. ${ }^{1}$ Hence came the terms actual and constructive possession. It was actual when the property was in the custody of the complainant or in custody of his agents or servants. It was constructive when the property was in possession of a bailee or carrier subject to the plaintiff"'s immediate right of possession. ${ }^{2}$

The bailor could maintain trespass against his bailee, although the latter was vested with the right of possession as incident to the bailment, if he violated his trust by damaging or destroying the-property held in bailment. This act of the bailee operated as a wrongful disturbance of the bailor's possession intrusted to him, and put an end to any right of possession in him incident to the bailment, and remitted the bailor to his immediate right of possession. ${ }^{3}$

It was also constructively in possession of plaintiff, if he had the right of immediate possession, although at the time of the trespass or injury it was in the actual hostile and wrongful possession of another. He could maintain this action against the second or subsequent taker, except possibly when the latter acquires possession by delivery and without fault, in which case trover was the proper remedy. ${ }^{4}$ In the early stages of common law procedure, there seemed to be no civil remedy against the subsequent taker for the reason that a right of property was erroneously ascribed to trespassers and even thieves. ${ }^{5}$

If, however, the plaintiff was without the right of immediate possession, he could not maintain trespass, whatever other rights he might have in the property. It could be maintained on a limited or special right of property, such as contained in the right of possession in a consignee or factor, although actual possession was in another. ${ }^{6}$ So could a person in actual though wrongful

11 Chit. Pl. 175; 2 Saund. Pl. \& Wilson v. Barker, 4 Barn. \& Adolph. Ev. 861 ; Browne, 402.

22 Saund. Pl. \& Ev. 862, 864; 1 Chit. Pl. 169, 173.

31 Chit. Pl. 169, 172; Browne, 404; 2 Saund. Pl. \& Ev. 862, 864.

4 Barrett v. Warren, 3 Hill, 348; 614.

5 ? Pol. \& Mait. 166, 167. In its origin the action fililed entirely against the subsequent taker. 11 Harv. I. Kev. 286.

62 Saund. Pl. \& Ev. 862, 863; Browne, 405. 
possession maintain this action against a trespassing stranger, but not against an owner with the right of immediate possession, or any one deriving that right from the owner. ${ }^{1}$

SEC. 78. Nature and Characteristic Features continued.Real Froperty. To maintain trespass for injuries respecting realty the plaintiff was required to have actual possession by himself or servants. Constructive possession was not sufficient, as in the case of personal property. This is the strict rule of the common law. ${ }^{2}$ But in most of the American States the action can be maintained upon a constructive possession, which arises from the right of immediate possession, and the absence of actual adverse posses- sion in any one else. ${ }^{3}$ But there can be no constructive possession of land which is in the actual and adverse possession of another. ${ }^{4}$

Actual possession of real estate is a fact from which title may be inferred, and it has been usually recognized and treated as property. ${ }^{5}$ A person in actual though wrongful possession of land could maintain this action against any trespasser not having the prima facie immediate right of possession. ${ }^{6}$

Tn some cases it may be maintained on possession by relation, after the plaintiff has gained actual possession. His possession is permitted to relate back for the purposes of an action. ${ }^{7}$ Thus, if a disseisee re-enter, such entry vests in him the possession $a b$ initio, and this action lies by him for any trespass after the disseisin and before such entry. ${ }^{8}$ Of course a disseisee can maintain this action for the trespass culminating in the disseisin, without re-entry, but not for damages subsequent to the disseisin. ${ }^{9}$

SEc. 79. Declaration. The declaration in this action was very simple, devoid of fiction, and of inducement other than that of title or relationship. It was necessary to mention the person or describe the property against which the force had been exerted;

11 Chit. Pl. 61, 169,170; 2 Saund. Pl. \& Ev. 861; Browne, 406 ; Graham c. Peat, 1 East, 244.

21 Chit. Pl. 62, 63, 175, 176; 2 Saund. Pl. \& Ev. 866, 868; Browne, 415, 416; Sparhawk v. Bagg, 16 Gray, 583.

3 Renshaw v. Loyd, 50 Mo. 500 ; Moore $v$. Perry, 61 Mo. 174; Brown v. Hartzell, 87 Mo. 564; Starr $v$. Jackson, 11 Mass. 519; Mather $v$. Church, Serg. \& R. 513, 514; Obrien
». Caranangh, 61 Mich. $368 ; 28 \mathrm{~N}$. IV. 127.

4 Thompson $v$. Burhams, 61 N. Y. 52 ; Td., 79 N. Y. 93.

5 Finch, Law, b. 2, c. 3 ; 2 Pol. \& Mait. 42.

6 2 Saund. Pl. \& Er. 866; 1 Chit. Pl. 176, 177; Browne, 412, 418.

7 Browne, 417.

8 Co. Litt. 257 a ; Com. Dig. Trespass, B. 2.

- Ham. N. P. 151. 
and in the case of property, to allege, in general terms, the plaintiff's right or title to the same and his possession thereof. ${ }^{1}$ In trespass clausum fregit the close or place upon which the defendant had entered was required to be designated by name or abuttals. $^{2}$ Then followed a statement of the wrongful act complained of, with an averment that it was done with force and arms.

In case of trespass against one's person, the court took cognizance of the plaintiff's absolute rights therein, which excused any averment thereof. If the trespass was against a person in whom the plaintiff had relative rights, it was sufficient to state the relationship in general terms. It concluded with an allegation that the wrong done was against the peace of the King and to the damage of the plaintiff in the sum claimed. ${ }^{3}$

SEC. 80. Judgment. The judgment, if for plaintiff, is for the damages assessed by the jury. ${ }^{4}$

Consult forms 14 and 15 in the Appendix.

\section{Article II.}

\section{Detinue.}

Sec. 81. Defined.

" 82. History.
Sec. 85. Judgment. $\begin{aligned} \text { Sec. 83. Nature and Characteristics. } & \text { Neclaration. }\end{aligned}$

SEc. 81. Defined. The action of detinue lies for the recovery of a personal chattel in specie in the possession of defendant and wrongfully detained by him. ${ }^{5}$ To maintain the action it was necessary that the plaintiff should have a general or special property in the chattel coupled with the right of immeditate possession at the commencement of the suit.

SEc. 82. History. In a previous chapter I have alluded to the action of detinue as being evolved from the ancient action of debt in the detinet, which was employed for the detention of chattcls instead of money. ${ }^{7}$ This seems to be the accepted history of its origin. ${ }^{8}$

The writ of detinue is mentioned among the forms of writs pre-

12 Saund. Pl. \& Ev. 85.5.

2 Hilary Rules, 4 Wm. IV. 1 Chit. Pl. 744.

81 Stephen, Pl. 38, 39.

41 Chit. Pl. 186.
51 Chit. Pl. 121, 122 ; Browne. 358. 35.9.

6 1 Chit. Pl. 122.

$7 \mathrm{Ch}$ II sec. 41.

82 Reeves, 158; 1 Chit. Pl. 121, 122; 2 Pol. \& Mait. 171. 
scribed for the inhabitants of Wales in the reign of Edward I., but it probably was used before it was prescribed in this statute. In its early form it presented a contractual aspect, as for the return of chattels bailed and to be delivered under the contract of bailment. 2 The wrong consisted in detaining them contrary to a contract express or implied. But the action was proprietary in its nature and manifest implication, in like manner witl debt. ${ }^{3}$ The allegation of a bailment was an argumentative averment of property in the plaintiff, because it implied a right of property in the bailor, a fact which the bailee was estopped from denying. It is easy to see how the plaintiff came to understand that his right of property was actually denied by the defendant in his breach of the bailment, and that he was entitled to his property as owner, as well as by contract. This obvious conception tended to enlarge the scope of the action, and to divest it of its contractual phase. ${ }^{4}$ It nay be conceded that in its early stages in the 13th and 14th centuries, the allegations of a bailment were usually held to be material and traversable. ${ }^{5}$ But in the course of time they became fictions, leaving the right of property and the wrongful detention as the only material issues for trial. ${ }^{6}$ When the wrongful detention of the plaintiff"s property became the material issue, the fiction of a finding instead of a bailment was often used. ${ }^{7}$

According to a recent eminent writer this final scope of the action was reached by gradual steps: first, in allowing the action to be maintained against the executor of the bailee when the property came to his hand; second, against a person acquiring possession from a bailee, or subsequent to a bailment; third, against the finder of property in the absence of any bailment, a conclusion which was approved in $1371 .^{8}$ I may add the fourth and final step in the trend of the action to its present scope as a proprietary remedy, which was established after some dissent; viz. that it lies not only when the property comes into the hands of the defendant lawfully, but when it has been tortiously taken by the defendant or any one else from the plaintiff. 9

1 1284; Statute Walliæ, 12 Edw.

I. ; 2 Reeves, 13 \& 14.

22 Pol. \& Mait. 175.

32 Pol. \& Mait 175, 176.

4 Pol. \& Mait. 176.

5 Year Book, 3 Edw. II. 78; Y. B. 6 Edw II. 192; 11 Harv. Law Rev. 375; 2 Pol. \& Mait. 174.
61 Chit. Pl. 121; Gledstane $v$. Hewitt, I Cr. \& J 565; Whitehead v. Harrison, 6 Q. B. N. S. 423 .

71 Saund. Pl. \& Ev. 434; 2 Pol. \& Mait. 174 : Brookes, Abr. Detinue, 10.

8 Ames, 11 Harv L. Rev. 377-382.

91 Chit. Pl. 123; Browne, 361; 1 Saund. Pl. \& Ev. 434. 
In England this action was supplanted by the action of trover, an action which was free from wager of law, and required a less degree of certainty in describing_the goods, and which fulfilled the same end, - an end which the defendant at his option could accomplish in the action of detinue; viz. a judgment in damages for the value of the goods detained. ${ }^{1}$

After abolishment of wager of law in the reign of William IV., it came again somewhat into use, ${ }^{2}$ but not to any great extent, being almost entirely superseded in practice by the action of trover. The issues for trial were identical in detinue and trover; viz. the right of possession and the fact of detention or conversion, every detention in detinue being a conversion in trover. They differed only in the character of recovery, trover being for damages only, while in detinue the plaintiff sought a return of the property in the first instance, and was compelled to accept damages as in trover when the defendant failed to return the property. But the fact that he recovered a judgment for the goods in specie operated to clothe it with the character of a proprietary action in so far as that character can be imputed to actions for the recovery of chattels, which could not properly be taken from it by a deficiency in the execution, ${ }^{3}$ which was sometimes supplemented with assistance from equity, until a specific enforcement of the judgment was more perfectly secured by the act of 1854 hereinafter referred to. ${ }^{4}$

Replevin was a concurrent remedy with detinue in only a very limited number of cases, and could not operate to supersede it generally in England. ${ }^{5}$ But in the United States, since the extension in recent times of the action of replevin in all cases of detention of chattels, it may be said to be practically superseded by the latter action, which has proved itself a more efficient remedy.

SEC. 83. Nature and Characteristic Features. The gist of the action as finally settled consisted in the wrongfuldetention of the goods or chattels of the plaintiff, irrespective of the manner in which the defendant came into possession. After some difference of opinion, the plaintiff's right to maintain the action was finally conceded, as we have seen, even when the defendant had come into possession by a tortions taking. ${ }^{6}$.

1 Browne, 425; Chit. Pl. 125.

2 Browne, 359.

32 Pol. \& Mait. 174.

4 Sec. 85.
51 Saund. Pl. \& Ev. 434.

61 Chit. Pl. 123; 1 Saund. Pl. \& Ev. 434; Browne, 361. 
It never lies against a person who was never in possession of the chattels $;^{1}$ but it lay although defendant had wrongfully parted with the goods before suit. ${ }^{2}$

After the contractual element which anciently allied this action with debt as an action ex contractu was dropped, the material issue of a wrongful detention of the plaintiff's goods would seem to ally it with actions in tort; and it is so classed in recent times by distinguished authors and jurists. ${ }^{3}$

Its classification with actions ex contractu is supported by great authority, ${ }^{4}$ but the admitted character of the action is against continuing it as an action ex contractu. The fact that it was unfolded from the action of debt, and that it continued to be susceptible of joinder in the same declaration with debt, ${ }^{5}$ are only relics of its former nature, and not very cogent arguments against classing it according to the ex delicto phase it finally assumed.

SEc. 84. Declaration. It was necessary to describe the chattel with more certainty than in trover or replevin. ${ }^{6}$ The declaration usually contained an allegation in general terms of a bailment, or of a finding of the chattel sued for, or of both. These facts, as already stated, ceased to be traversable, leaving the right of property and the wrongful detention as the only material issues in the case. ${ }^{7}$ In cases of special bailment it was customary to include one count on the bailment, setting it forth according to its terms, and alleging a special request for redelivery; in all other cases it was sufficient to declare on the supposed finding by defendant of plaintiff"s property and his detention thereof. ${ }^{8}$ Under the Common Law Procedure Act of 1852 these fictions were omitted. ${ }^{9}$ Although detinue is defined to be an action for the recovery of chattels in specie, no such element appeared in the declaration, which concluded with a claim of damages for the unjust detention. Its original character as a proprietary action is disclosed in the judgment.

1 Jones $v$. Dowle, 9 M. \& W. 19; Allen's Ex. v. Harlan's Adm'r, 6 Leigh, 42; 29 Am. Dec. 205; 1 Chit. Pl. 123.

2 Jones $v$. Dowle, 9 M. \& W. $19 ; 2$ Steph. N. P. 1309.

a Dicey, 23; Gledstane $v$. Hewitt, 1 Tyrw. 445; Mason v. Farnell, 12 M. \& W. 674; Whitehead $v$. Harrison, 2 Dow. \& I.. 122.
41 Chit. Pl. 131: Warren's Law Studies, 294 ; 1 Tidd, Pr. 5 ; Browne, 317,358 ; Walker $v$. Needham, 3 Man. \& Gr. 557.

51 Saund. Pl. \& Ev. 434.

61 Saund. Pl. \& Ev. 434.

i 1 Chit. Pl. 121.

81 Saund. Pl. \& Ev. 434; 1 Chit. Pl. 124 .

915 \& 16 Vict. c. 76. 
SEc. 85. Judgment. The judgment, if for plaintiff, was in the alternative that he recover his goods, or the value thereof if he cannot have his goods, and his damages for the detention thereof. The practical working of this juagment resolved the proceeding into an action for damages as far back as Bracton's time. ${ }^{1}$ The right of defendant to retain the goods was conceded upon his payment of the assessed value. The recovery in detinue could at the option of the defendant be also confined to damages, measuring the value of the goods by merely spiriting them away or otherwise disposing of them before or after judgment, for which wrong trover was a concurrent remedy. In such case the plaintiff had no other relief than enforcement of the alternative in the judgment for the assessed value. As the action generally resulted in a recovery of damages only, and in this respect resembled the action of trover, it is easy to see how it was superseded by that action, which was free from some objectionable features attendant upon detinue. ${ }^{2}$

This defective feature of the action was corrected to a certain extent by the Common Law Procedure Act of 1854, in which the court or judge, upon application of the plaintiff, had the discretion of awarding an execution for return of the chattel detained, without giving defendant the option of retaining it upon paying the assessed value. Upon failure to find the chattel, the sheriff had authority, unless otherwise ordered by the court or judge, to enforce return by distraining the defendant by all his lands and chattels; or, at the option of plaintiff, to make out of defendant's goods the assessed value of the chattel detained. ${ }^{3}$ The fact that the chattels could not be seized at the commencement of the proceeding impaired its efficiency as a proprietary action, and led to its disuse.

See writ and declaration in Appendix, forms 16 and 17.

\section{Article III.}

\section{Trespass on the Case.}

Sec. 86. Defined.

" 87. History.

\begin{tabular}{l|l} 
Sec. 88-94. Nature and Characteristics. \\
“" 95. Declaration.
\end{tabular}

SEc. 86. Defined. Trespass on the case, commonly called case, is the generic name of an action to recover damages for an injury

12 Pol. \& Mait. 173; Walker $v$. Needham, 3 Man. \& Gr. 557.
21 Chit. Pl. 125 ; Browne, 359.

${ }^{3} 17$ \& 18 Vict. c. 125 , s. 78. 
to one's rights in respect of his person, or the person of others in wholn he has relative rights, in respect of his health, reputation, privacy, and domestic comfort, or in respect of his property, real or personal, caused by the wrongful act of another, unaccompanied with force actual or implicd; or when the injury to said rights is the indirect or secondary effect of a wrongful act accompanied with iorce actual or implied. ${ }^{1}$

If the right affected by the wrongful act is intangible, incorporeal, in reversion, or disconnected with possession or the right of possession of property, it is incapable of being affected directly by the application of force, and the injury in such case, if any, must necessarily be the indirect or consequential effect of the wrongful act, if accompanied with force. If unaccompanied with force, the injury, if any, is consequential only.

SEc. 87. History. This form of action originated in the necessity of the plaintiff for a writ of some kind, when no form could be found in the register of writs adapted to the peculiar nature of his case. His right - to $a$ writ of some kind was recognized at common law by the maxim Ubi jus ibi remedium, but in many instances it was reluctantly and doubtfully conceded by the officers in Chancery. When issued it was classed among magisterial writs, so called from being framed by the masters or principal clerks of Chancery to suit the particular case. ${ }^{3}$ By the statute of Westminster II. ${ }^{4}$ the duty was enjoined upon the officers of Chancery to issue a proper writ in any case for which no writ could be found in the register of writs, but which was similar to cases for which writs could be found. As the cases in which new writs were usually wanted sounded in tort, and resembled somewhat the wrongs for which trespass $v i$ et armis was a proper remedy, the new writs under the statute naturally took on the form of that action, and appeared as an extension of it to a great variety of cases under the name of trespass on the case. ${ }^{5}$ It has been regarded as the appropriate remedy for injuries caused by misconduct for which the law has provided no other adequate remedy. ${ }^{6}$

The subtle and refined distinction between injuries effected immediately by force, and those resulting as the censequence of

11 Chit. Pl. 132, 133; 1 Saund. Pl. \& Ev. 335, 336, 337 ; Browne, 367 ; Walker, Am. Law, 617; $3 \mathrm{Bl}$. Com. 122.

21 Chit. Pl. 132, 133.
3 Bracton, fol. $413 \mathrm{~b}$; Crabb's Eng. Law, 547, 548 .

$413 \mathrm{Edw}$. I. c. 24 [1285].

5 Crabb's Eng. Law, 290, 291.

6 Griffin $v$. Farwell, 20 Vt. 151. 
wrongful acts, with or without force, was not well understood or preserved in the reign of Edward III., ${ }^{1}$ many of the writs of trespass on the case, like those of trespass vi et armis, containing the averment that the wrongful acts complained of were done with force and arms and against the peace. ${ }^{2}$ After the clause of $v i$ ct armis was omitted, the writ often continued the averment of contra pacem. ${ }^{3}$ The distinction came out clearly in the reign of Henry IV., ${ }^{4}$ and ever after constituted the test between trespass $v i$ et armis and the great variety of actions of trespass on the case. $^{5}$

In considering the action of assumpsit, I have explained how this form of action was extended to the breach of simple contracts under the name of trespass on the case on promises, when the breach consisted in malfeasance or imperfect performance $;^{6}$ also how it was further extended in the reign of Henry VI. ${ }^{7}$ to a breach which consisted in mere non-performance ${ }^{8}$ and how this last extension resulted in disconnecting the action of trespass on the case on promises from its classification with actions of trespass on the case, and in the establishment of the modern action of assumpsit, which takes its classification with actions ex contractu. ${ }^{9}$

The distinction between trespass and case has not been preserved in all the States in which common law pleading has been retained in a modified form. ${ }^{10}$ Of course it has ceased to exist in England under their new procedure, and it never had any countenance from the code procedure in the United States.

SEc. 88. Nature and Characteristic Features. This form of action as finally settled always sounds in tort, and is classed with actions ex delicto." Its nature, as disclosed in the practice of the courts prior to the Hilary rules of 1834 , is very pointedly alluded to in the following language of Lord Mansfield: "There is an essential difference in pleading between actions of trespass, and actions on the case; the former are actions stricti

1 1327-1377.

22 Reeves, 394, 396, 397.

3 Fitz. N. B. 92.

4 1399-1413.

52 Reeves, 508. See an exhaustive discussion of the distinction between the two actions in Comyn, Dig. Action, M. 2, note
A, Vol. I. 240, 241; also in Ham. mond, N. P. 4-23.

62 Reeves, 509.

7 1422-1461.

8 2 Reeves, 606, 607.

9 Sections 52, 53.

10 26 Am. \& Eng. Encyc. Law, 709.

111 Chit. Pl. 125, 133. 
juris, and therefore a former recovery, release, or satisfacton cannot be given in evidence (under the general issue), but must be pleaded; but an action on the case is founded upon the mere justice and conscience of the plaintiff's case, and in the nature of a bill in equity, and in effect so; and therefore a former recovery, release, or record and satisfaction ineed not be pleaded, but may be given in evidence; for whatever will in equity and conscience, according to the circumstauces of the case, bar the plaintiff's recovery may in this action be given in evidence by the defendant (under the general issue), because the plaintiff must recover upon the justice and conscience of his case and on that only." 1 Subsequent to the rules of 1834 the scope of this action was somewhat limited by the restrictions imposed upon the effect of the general issue; and it may be safely remarked that its equitable nature has never been recognized by the courts to the extent of giving to it the full effect or form of a bill in equity, as expressed by Lord Mansfield.

In applying its leading principles it may be conveniently considered as the appropriate remedy for certain injuries to the rights of person and property.

Rights of Person. It lies for injuries to the rights of personal security and personal liberty in the individual, when the injury is the consequential and not the immediate effect of the wrongful act. $^{2}$ Under this head may be classed the rights of life, liberty, immunity from bodily harm, - the rights of health, reputation, domestic comfort, and individual privacy. When these rights are affected by the negligence of others, case is the appropriate remedy. It also lies for injuries to these rights from mischievous animals; from public nuisances; from malicious prosecution, and arrest under regular process; from libel and slander.

SEC. 89. Nature and Characteristic Features continued. Rights in the Persons of Others. This action lies for injuries to what are usually denominated relative rights, - rights which one is permitted to have in the person of another by virtue of his relation, as parent, husband, or master. It may be maintained for seducing and harboring wives or alienating their affections, for enticing away or debauching daughters and servants. When injuries to these domestic relations are accompanied with force, or when force may be implied, trespass vi et armis may be maintained ${ }^{3}$ but

1 Bird v. Randall, 3 Burr. 1253.

31 Chit. Pl. 134; Browne, 374.

21 Chit. Pl. 133; Browne, 368.

Martix Civil Procenure-6 
it is optional with the complainant to found his action on the consequential effects of the force, in the loss of services and society, and to sue in case. ${ }^{1}$

SEC. 90. Nature and Characteristic Features continued. Personal Chattels. It lies for an injury to one's rights in personal chattels resulting from a wrongful act committed with force, provided the injury is the consequential and not the immediate effect of the act, or where the right affected is intangible, in reversion or disconnected with possession. ${ }^{2}$ Injuries to rights inhering in personal chattels are too numerous to mention. Neither possession nor the right of possession is necessary to maintain the action, as in trespass. It is sufficient that any right in the chattel disconnected with actual or constructive possession has been infringed.

SEC. 91. Nature and Characteristic Features continued. Contracts. 1. Non-performance. In respect to ordinary contracts it may be safely said that mere non-feasance or non-performance is no longer an injury for which this action is a remedy. Its ancient use for that purpose under the name of trespass on the case on promises, and how that use resulted in developing the modern action of assumpsit, have been explained. ${ }^{3}$ So far as ordinary contracts are concerned, there must be something more than mere non-performance to support this action. There must be-some breach of a duty imposed by law, as distinguished from the duty imposed by contracts.

Upon that class of persons who hold themselves out as conducting public occupations or callings, such as carriers, innkeepers, ferrymen, wharfingers, etc., the law, for reasons of public policy, imposes the duty of assuming the contracts implied in their occupations, upon the customary consideration, and for any refusal to comply with this duty case will lie. Mere refusal to assume the contract, or mere refusal to perform it when assumed, operates as a breach of the duty imposed by law.

\section{SEC. 92. Nature and Characteristic Features continued. -}

Contracts. 2. Misfeasance. If, however, a person commences

12 Greenl. Ev. 225 ; 2 Saund. Pl. \& Ev. 783 ; Ditchman $v$. Bond, 3 Camp. 526 , note.

21 Chit. Pl. 134 ; Browne, 376.

See Sections $52,53$.
41 Chit. Pl. 134-136; Browne, 375; 1 Saund. 312; Lane $v$. Cotton, 1 Salk. 17; Churchman $v$. Tunstal, Hardres, 162 ; Elsee $v$. Gatward, 5 T. R. 143. 
to perform a contract, even though it be gratuitous, the law imposes a duty on his part to perform it so far and in such a manner that the other party shall not be injured by his interference; and for a breach of this duty, case will lie upon the ground of misfeasance or mal-performance?

Whenever the common or statute law imposes duties or obligations upon parties to contracts, this action will lie for any violation of such duties or obligations, although they are incident to the contracts and expressly included in them. ${ }^{2}$ Thus, in all contracts in which acts are to be done by one party in possible connection or contact with the person, property, or rights of the other party, the law imposes the duty of reasonable care and diligence in performance; and case will lie for a breach of this duty by which damage ensues, even though the contract may have expressly provided for the payment of such damages. ${ }^{3}$

Physicians, attorneys, artificers, dentists, and other persons professing knowledge and skill in their respective professions and trades, are not bound to act when called upon, or to assume any contract relation, and are therefore not liable for non-feasance in that respect. But when they contract to act, the law imposes on them the duty of acting in good faith, and with the skill and diligence customarily exercised by parties under like circumstances; and any breach of this duty renders them liable in this action. ${ }^{4}$

The law imposes on agents in every line of business the duty of acting in good faith, and of exercising reasonable diligence, and such care and skill as are ordinarily possessed by persons of common capacity engaged in the same business, and for any breach of this duty resulting in damage to their principals, case will lie against them. ${ }^{5}$

Certain duties are imposed by law as incident to the relation of landlord and tenant, and this action will lie for breach of them, although the act complained of may in some cases constitute the breach of an express covenant. ${ }^{6}$

1 Browne, 375 ; Dartnall v. Howard, 4 B. \& C. 345 .

2 Browne, 375; Dartnall v. How. ard, 4 B. \& C. 350.

8 Jean $v$. McLean, 48 Vt. 412; 1 Chit. Pl 135.

Dearborn $v$. Dearborn, 15 Mass. 316; Leighton $v$. Sargant, 27 N. H. 460 ; 59 Am. Dec. 388.

5 Heineman v. Heard, 50 N. Y. 35.

61 Chit. Pl. 135 ; Burnet v. Lynch,

4 Burnet v. Lynch, 5 B. \& C. 589; 15 Wend. 169. 
The fact that a statutory remedy is given for these violations of duty does not exclude the common law action of case. ${ }^{1}$

These duties or obligations, although implied by law, have been very generally treated as furnishing the basis of fictitious and implied promises, sufficient to sustain actions ex contractu. In connection with this use, they have been designated in former as well as in recent times as arising from quasi contracts. ${ }^{2}$ If the law implies no duty, then there can be no ground for ease, nor-for implied assumpsit. The remedy in such case must be on the terms of the express contract.

SEc. 93. Nature and Characteristic Features continued. Contracts. 3. Interference. Case is the appropriate remedy for redress for..all unlawful interference in the performance of contracts by persons who are not parties to the same. Outside of the contracts of household servants, the authorities are in conflict as to the interference which becomes actionable for either preventing the contractual relation, or preventing a performance of its obligations when the relation is assumed. The subject has engaged the attention of the courts in recent days, and a reference to the adjudications will answer the purposes of this treatise. ${ }^{3}$

SEC. 94. Nature and Characteristic Features continued. Real Property. Case lies for wrongs to the corporeal rights of real estate committed without force, or where such-wrongs are the consequential and not the immediate effects of force; or where the rights affected are incorporeal or in reversion, and not connected with possession. ${ }^{4}$ Nuisances, obstruction of windows, waste, excavations endangering walls, etc., are remediable in this action. It also lies for wrongs affecting incorporeal realty, such as rights of common, rights of way, franchises, easements, licenses, and liens appertaining thereto. ${ }^{5}$

SEc. 95. Declaration. The declaration should disclose the circumstances under which the wrong was committed.

It should contain : 1st, a statement or description of the person or thing affected; $2 d$, a statement of the plaintiff's relation thereto

1 Bellant $v$. Brown, 44 N. W. 326 (Mich.).

2 Browne, 384; Keener, Quasi Contract, 6.

${ }^{8}$ Lumley $v$. Guy, 2 E. \& B. 216 ; Estey $v$. Smith, 45 Mich. 402; Cooley on Torts, 497; Walker $v$. Cronin, 107 Mass. 555; Allen $v$. Flood, Law Rep. 1898 , App. Cas. 1; Vegelaha v. Guntner, 167 Mass. 92.

41 Chit. Pl. 139 ; Browne, 388.

51 Chit. Pl. 142; Browne, 393, 394. 
or interest therein, which passed by the name of inducement; $3 \mathrm{~d}$, a statement of the act from which the injury flows; 4 th, a statement of the damages resulting therefrom, for which recovery is asked; 5th, the conclusion, according to the form used in the court.

It ought not to state anywhere that the act complained of was committed vi et armis, or contra pacem. ${ }^{1}$

In other respects, the declaration depends upon the particular circumstances on which the action is founded, a fact which gives rise to a greater variety of statements than in any other form of action. ${ }^{2}$ There are no fictitious allegations as in trover, and the declaration more nearly resembles a bill in equity or petition of the code pleader than any other declaration at common law.

SEc. 96. Judgment. The judgment is that the plaintiff recover a sum of money ascertained by the jury for his damages sustained by the committing of the grievances complained of.

See writ and declaration in Appendix, forms 18, 19.

\section{Article IV.}

\section{Trover.}

Sec. 97. Defined. “ 98-101. History.

Sec. 102. Qualifications and Distinctions.
“" 103. Declaration.
Sec. 104. Judgment.

SEc. 97. Defined. Trover lies to recover damages for the value of specific personal chattels wrongfully converted by defendant to his use. To maintain the action, it is necessary that the plaintiff should have at the time of the conversion a right of property in the chattel, either general or special, together with actual possession, or the right of immediate possession. ${ }^{3}$ The right of immediate possession, such as belongs to a carrier, factor, or consignee, irrespective of any other right of property, has been held suffcient to maintain the action. ${ }^{4}$ Indeed, bare possession, even though wrongful, is 'sufficient to maintain it as against every one but the rightful owner. ${ }^{5}$

11 Chit. Pl. 145.

21 Chit. Pl. 145.

31 Chit. Pl. 146, 148; 2 Saund.

Pl. \& Ev. 869; Browne, 426. 4 Browne, 430; Wilbraham $v$. Snow, Newham, 13 C. B. 285.
2 Saund. $47 \mathrm{~d} ; 2$ Saund. P]. \& Ev. 877,879 .

5 Browne, 426, 431 ; 2 Saund. 47 e; Saund. Pl. \& Ev. 878; Stevenson v. 
The owner of any special title, which includes the right of immediate possession, can maintain it against the general owner who has parted with or never had the right of possession. ${ }^{1}$

SEc. 98. History of its Origin and Development. Trover in its origin was a species of trespass on the case for the recovery of damages against a person who had found goods and refused to deliver them to the owner on demand, but converted them to his own use. ${ }^{2}$ A case of trover is reported in the reign of Edward VI. $;^{3}$ but it is believed that it came somewhat into use in the previous reign of Henry VIII. ${ }^{4}$ It has been maintained with much force and learning by an eminent author that trespass on the case for conversion - modern trover - developed from the ancient action of detinue sur trover, the first case appearing in $1479 .^{5}$

It is evident that the facts of losing by the plaintiff, and finding by defendant, were not in their nature essential ingredients of the wrongful conversion. Any other state of facts which furnished the defendant an opportunity to convert the plaintiff's property to his use would answer the purpose of these allegations quite as well. They were, at most, only allegations of inducement. ${ }^{6}$

In accordance with this truth, these allegations at a very early day came to be treated in the courts as immaterial and non-traversable, the gist of the action being regarded as contained in the wrongful act of conversion. Notwithstanding their fictitious character, they were not dispensed with by the Hilary Rules of 1834, but were continued in the forms of pleading down to the Common Law Procedure Act of 1852.7

SEC. 99. History, etc., continued. - Extension of the Action. In the course of time a gradual change took place in respect to the nature of the wrong which went by the name of conversion, which greatly broadened and extended the action. The theory of the action in its origin implied that the defendant in some manner had come lawfully into possession of the goods, and that he not only detained them from the plaintiff after demand, but had also converted them to his own use. ${ }^{8}$ It was not sufficient that he

1 Benjamin $v$. Stremple, 13 Ill. 466 ; Hutton $v$. Arnett, 51 Ill 198; Dilworth $v$. McKelvey, 30 Mo. 149.

21 Chit. Pl. 146.

8 1547-1553.

4 1508-1547. 3 Reeves, 406.
5 11 Harv. L. Rev. 382-384.

6 Esp. N. P. 587.

715 \& 16 Vict. c. 76.

8 Cooper v. Chitty, 1 Burr. 31;

S. C. 1 Bl. Rep. 68 . 
detained them wrongfully after demand: such an act might support detinue, but to maintain trover it was necessary to allege and prove that he had also converted them to his own use. "The form of the action contained an allegation of the date and fact of conversion, distinct from the allegation of a wrongful detention, and in addition to it.

When the goods of plaintiff came lawfully into the possession of defendant, and he had actually converted them to his own use by consuming or making use of them as his own, the act was not always easy to prove, as it was often within the secret and exclusive knowledge of the defendant. The most that could be done by plaintiff was to demand his goods, and govern his conduct by the action of the defendant in refusing to deliver them. He had a right to infer the very worst against the defendant if his refusal was not accompanied with lawful justification and excuse. The burden of explaining and establishing the justification would naturally fall on the defendant.

SEC.' 100 . History, etc., continued. - Extension of the Action, continued. To help the plaintiff from the embarrassment of proving in the first instance an actuat conversion, which the nature of the action at that time required, the courts adopted a rule at a very early day by which proef of a demand and refusal to deliver in answer to the demand was accepted as prima facie evidence that the defendant had converted them to his own use. Upon this evidence the jury was at liberty to find that the defendant had actually appropriated the goods to his own use. ${ }^{1}$ In this manner, the originat theory of the action, to the effect that an actual conversion as well as an unlawful detention had to be established, was maintained by the courts.

But in the course of time they became sensible of the fact that the plaintiff's injury actually consisted in being deprived of his property, and that this injury remained substantially the same whether the defendant, after so depriving him of his property, appropriated it to his own use by consuming it, or by destroying it, or by giving it over to another.

The logic of this perception naturally led to an extension of the meaning of the term conversion, which had been settled on as the gist of the action, by which it was held to represent every wrong-

1 Mires $v$. Solibay, 2 Mod. 242; 2 R. 475; Chanc. Oxford, 10 Coke, Roll. Abr. 693; Smith $v$. Milles, 1 T. 53, 56. 
ful act of depriving the plaintiff of his possession, or right of possession, over his personal chattels, irrespective of any distinct appropriation of it to the defendant's use. ${ }^{1}$

Its broadened use may be more easily understood by a simple classification of the wrongful acts for redress of which the action finally came to be employed.

First. It lies for every tortious taking or destruction of personal chattels in the actual or constructive possession of plaintiff; and for any tortious interference by which the actual or constructive possession of plaintiff has been displaced or denied. This division contemplates that the actual possession or custudy of the chattels at the time of the wrongful act should be in the plaintiff, or some third party for him, and not in the defendant. A demand was never necessary in this class of cases. ${ }^{2}$

Second. It lies for any wrongful detention of the personal chattels of plaintiff by defendant, after his right of possession has ceased, or any wrongful use by defendant of the plaintiff's personal chattels, of which he [defendant] had in the first instance acquired lawful possession, by which the plaintiff's right of property is denied by defendant, or which is inconsistent with the purposes for which it was bailed or delivered to him. ${ }^{3}$ In this division the lawful possession or right of possession is in the defendant, and remains unchanged until the wrongful act. In absence of any distinct act of appropriation to defendant's use, a demand was necessary to make out a prima facie case of conversion. A refusal to deliver without justifiable excuse came to be in itself a conversion, and not mere evidence of it. ${ }^{4}$

SEC. 101. Fistory, etc., continued. The ancient rule making demand and refusal mere evidence of a conversion was thus substantially superseded by the extension of the meaning of the term gonversion. Notwithstanding this, the original form of the declaration, which alleged an unlawful detention after demand, as well as an actual conversion, was continued unchanged down to the Common Law Procedure Act of 1852. According to that act, it was sufficient to allege that the defendant converted to his own

1 Wilbraham $v$. Snow, 2 Saund. Drew $v$. Spaulding, 45 N. H. 472; Lr$47 \mathrm{k} ., 47 \mathrm{l}, 47 \mathrm{~m}$. win $v$. Clark, 13 Mich. 10.

2 Bruen $v$. Roe, Sidf. 264 ; 3 Salk. 365.

8 Mulgrave v. Ogden, 1 Cro. Eliz. 219 ; Cooper v. Monks, Willes, 52, Robinson, 2 Comstock, 293. 
use or wrongfully deprived the plaintiff of the use and possession of plaintiff's goods. ${ }^{1}$ Conversion and deprivation of property had become for a long time convertible terms, and the last mentioned act recognized the fact. Although deprivation of property was implied in the term conversion, the act makes use of the term conversion probably in deference to the ancient state of things, or to repel the inference that it might not be included in the definition of the essential requisites of the action. ${ }^{2}$

After the action had thus become broadened-by the construction of the courts, it was more often employed. Although it remained in its nature an action of case, on account of its extension and frequent use it came to have a classification by which it was separated and distinguished from all other actions of case; and instead of being designated or classed as an action of trespass on the case for the trover and conversion of personal property, it was classed and known as an action of trover and conversion. ${ }^{3}$ It superseded to a great extent the action of detinue, - which usually resulted only in recovery of the value of the property detained, - on account of its exemption from the defence of wager of law, and on account of the less particularity permitted in its description of the property converted. ${ }^{4}$

SEC. 102. Qualifications and Distinctions. To the nature and leading features of this action as developed in our sketch of its origin and history, it is deemed proper to add a few well recognized distinctions'and qualifications, which have obtained in the extended uses for which it has been invoked.

It lies, as we have seen, for the wrongful deprivation of the plaintiff's dominion over his personal property. Dainages were not claimed or given on account of any trespass in the taking or detention, but only for the act of converting, as settled in its modern sense, which was implied in every tortious taking, as well as in every refusal, without legal excuse, to restore. The plaintiff, by bringing this action for the conversion of his gaods, Waived his right to damages for any forcible trespass which might have accompanied the act of conversion. ${ }^{5}$ The injured party being

115 \& 16 Vict. c. 76 ; Sched. B. 28.

2 London \& Westm. Loan Co. $v$. Drake, 6 C. B. N. s. 798 ; Baker $v$. Gray, 17 C. B. 462.
3 Bl. Com. 152.

4 Browne, 425.

5 Cooper v. Chitty, 1 Burr. 31; S. C. 1 Bl. Rep. 67, 68. 
always at liberty to qualify, but not to increase or magnify a tort. ${ }^{1}$ It thus became a rule that, for the taking and carrying away of his goods, the plaintiff could sue in trespass or trover at his option. ${ }^{2}$

It lies for the conversion of every kind of personal chattels possessing physical form and susceptible of manual caption. It lies for the conversion of promissory notes, checks, bonds, policies of insurance, certificates of stock, title deeds, account books, and copies of records. ${ }^{3}$

It could be maintained by the general owner as against a wrongdoer interfering with the actual possession of a carrier or other mere bailee, the possession of the bailee being in law the possession of the general owner or bailor as against all unlawful interference. ${ }^{4}$

It can be maintained not only against the original wrongdoer, but against every succeeding acquirer of the goods, even though he acquire them in good faith. ${ }^{5}$

The motive of the wrongdoer is not an essential ingredient of the action. A carrier or bailee's delivery by mistake, or under a forged order to the wrong person, will support the action; ${ }^{\circ}$ but a negligent loss by a bailee in taking care of the goods does not render him liable in this action. ${ }^{7}$

If the goods converted have been changed by the labor and skill of the wrongdoer into a different kind of property, the-owner can maintain trover for them in their changed form; but it is otherwise when the change has been effected by the labor and skill of an innocent acquirer of the property. ${ }^{8}$ A conversion of itself did

1 Bishop v. Montague, Cro. Eliz. 824 ; 2 Saund. Pl. \& Ev. 869.

2 Dalston $v$. Janson, 1 Salk. 10 , note; Lyne $v$. Moody, 2 Stra. 851; Phillips v. Bacon, 9 East, 298.

81 Chit. Pl. 167; Alsager v. Close, 10 M. \& W. 576 ; Grant v. Vaughan, 3 Burr. 1516; Kingman v. Pierce, 17 Mass. 247; Alexander $v$. Rundle, 75 Ill. 85; Snow $v$ Alley, 144 Mass. 516; Parry v. Frame, 2 Bos. \& P. 451; 6 Wait's Ac. \& Def. 155.

42 Saund. Pl. \& Ev. 873; Drake v. Redingtol, 9 N. H. 243.

52 Saund. Pl. \& Ev. 8i3; Scattergood $v$. Sylvester, 15 Q. B. N. s. 50l; ; Cheesman $v$. Exall, 6 Ex. 311 ; Breck- enridge $v$. McAfee, 54 Ind. 141 ; Tuttle $v$. Hanlon, 74 Mich. 652 ; 6 Wait's Ac. \& Deî. 130, 163.

6 Claflin $v$. Boston, \&c., 7 Allen, 341 ; Devereux v. Barclay, 2 B. \& Ald. 702 ; Hawkins $v$. Hoffman, 6 Hill, 586.

7 Moses $v$. Norris, 4 N. H. 304; Ilawkins $v$. Hoffnalı, 6 Hill, 586.

8 Cowen's Treatise, s. 579 ; Betts v. I.ee, 5 Johns. 348; Silsbury $v$. McCoon, 3 Coms. 379 ; Rice v. HolJenheck, 19 Barb. 664; Haddix $v$. Eiustman, 14 1ll. App. 443; Erwin v. Clark, 13 Mich. 10; Wait's Ac. \& Def. 170. 
not imply an acquisition of property by defendant, at least as against the owner, but only a wrongful deprivation of the plaintiff's right to it. ${ }^{1}$ It has been shown that, in archaic law, property was ascribed to the trespasser, and even to the thief, in like manner as to a disscisor. ${ }^{2}$ At the present time a wrongdoer in possession has a good title as against every one but the true owner.

Trover did not lie in favor of one cotenant as against another for conversion of an undivided interest in a chattel, unless the acts of conversion amounted to a destruction or sale of the property. ${ }^{3}$ In some cases it has been held that a refusal by one tenant to permit his cotenant to participate in the use of the chattel amounts to a conversion. ${ }^{4}$ If a conversion has once taken place, a return of the property is no defence, but is admissible in mitigation of damages. ${ }^{5}$

The owner of a special title with the right of immediate possession can maintain the action against the general owner, but in such case the interest of the general owner operates to reduce the damages to the value of the plaintiff's special title. ${ }^{6}$ Every one who aids or assists in the conversion of property is liable in this action, whether with knowledge of the plaintiff's right or in ignorance of it. ${ }^{7}$

SEc. 103. The Declaration. The declaration should contain a description of the chattels converted, which need not be as particular as in detinue or replevin; also, a statement of their value. ${ }^{8}$ It must also contain an averment of plaintiff's title or interest in the chattels, which may be in general words, as that he was lawfully possessed of the same as of his own property. ${ }^{9}$ It contained the fictitious and non-traversable allegations of a bailment or finding of the property, until abolished in England in 1852 by the Common Law Procedure Act. Then followed the allegation of a refusal to deliver on demand. After this came the gist or gravamen of the action as expressed in the allegation of conversion to

11 Chit. Pl. 146; Browne, 435; 2 Saund Pl. \& Ev 869.

23 Harv. L. Rev. 29.

8 IVatson $v$. King, 4 Camp. 272; 2 Saund. Pl. \& Fv. 887 ; I3rowne, 433 ; Mayhew $v$. Herrick, 7 C. B. 229.

4 Bray v. Bray, 30 Mich. 479.

56 Wait's Ac. \& Def. 220.

- Allen v. Spencer, 1 Edm. (N. Y.)
117: Partridge $v$. Dartmouth Col., 5 N. H. 286; Billings $v$. Tucker, 6 Gray, 368 ; Grant $v$. King, 14 Vt. 367 ; Dilworth $v$. McKelvey, 30 Mo. 149.

76 Wait's Ac. \& Def. 140, 175177.

y 2 Saund. Pl. \& Ev. 871; 1 Chit. Pl. 377.

92 Saund. Pl. \& Ev. 870. 
defendant's use, the date of which had to be alleged.' The conclusion was to the damage of plaintiff in a sum certain, which should be large enough to cover the value of the goods at the date of the conversion, and any other loss immediately consequent upon the conversion.

See declaration in Appendix, form 20.

SEC. 104. Judgment. The judgment is for damages as assessed by the jury and for costs.

\section{ARticle V.}

\section{Replevin.}

Sec. 105. Defined. "106-112. History.
Sec. 113. Characteristic Features.
" 114. Declaration.

Sec. 115. Judgment.

SEc. 105. Defined. The action of replevin lies in favor of the owner of specific chattels wrongfully taken from him, for the purpose of regaining possession thereof, and damages for the wrongful taking and detention ${ }^{2}$ - The original writ, which will be noticed hereafter more particularly, gave to the action a dual character. It furnished a speedy remedy for regaining possession of the chattels, and empowered the sheriff to entertain a proceeding incident thereto, for the purpose of determining the legality of the taking and detention, and awarding damages for the wrongful act. If the action is viewed from the first command of the writ alone, it would seem to be a proceeding to regain possession of personal property wrongfully taken and detained; and it has been so defined by some authors. ${ }^{3}$. If viewed from the second command of the writ and from the declaration, it would seem to be an action to recover damages for the unlawful taking and detention of personal property, and it has been so defined by other authors.4 But in reality the action always included both elements as expressed in our definition; and notwithstanding statements construed to the contrary, ne case of replevin has been found in the reports which has not been commenced with a writ requiring the sheriff to cause the goods to be replevied, or by plaint in the sheriff's court, followed

1 Saund. Pl. \& Ev. 871.

23 Bl. Com. 145; 1 Chit. Pl. 163 2 Greenl. Ev. 560.

- Bouvier, Law Dict., Replevin.
4 Steph. Pl. 20; 1 Tidd, Pr. 5; Saund. Pl. \& Ev. 760 .

5 Pearson $v$. Roberts, Willes, 668. 
by a precept to replevy the goods. ${ }^{1}$ The two proceedings were never distinct or independent of each other. A recovery of the goods under the first command of the writ was always provisional upon the result of the proceedings under the second command to do justice; and if the plaintiff failed in the proceedings under the latter command, the-goods had to be returned to defendant. It may be said that, if the sheriff failed to replevy the goods because they were eloined or withheld by defendant, the plaintiff was at liberty to go on with the remainder of the proceedings, or to bring a new replevin, or institute some other independent action. ${ }^{2}$

SEC. 106. History. - Origin and Scope. The authorities all agree that replevin originated in common law as a remedy against the wrongful exercise of the right of distress for rent. ${ }^{3}$ But it seems to have been occasionally employed at a very early day in other cases of a wrongful taking. ${ }^{4}$ The use of it in other takings was so rare for-several centuries that we find Blackstone asserting that it lies only against a distrainor. ${ }^{5}$ But this restriction of the remedy never existed even in theory, and was contradicted by occasional decisions; and after Blackstone wrote, his statement was challenged as erroneous, and the action was held to lie in all wrongful takings, ${ }^{6}$ except when done under process against the plaintiff.7 It has not been extended by judicial authority to-the wrongful detention or conversion of chattels distinct from or independent of a wrongful taking. ${ }^{8}$ This further extension, however, has been effected in many of the American States by legislative enactment, ${ }^{9}$ and in some by judicial authority. ${ }^{10}$

SEC. 107. History continued. - The Original writs. To understand the action thoroughly, it will have to be considered from the standpoint of its origin as a remedy against an illegal distress.

1 Wilk. RepI. 6; Fletcher $v$. Wilkins, 6 East, 286.

2 Wilk. Repl. 20; Fitz. N. B. 69 L.; Lutw. 1150 ; 2 Roscoe, Ac. 626.

8 Co. Litt. 145 b; 2 Roscoe Ac. 621 ; 3 Bl. Com. 145.

412 Co. Rep. 79 ; 5 Co. Rep. 107; 2 Selwyn, 1185, 1186; Atty. Gen. $v$. Brown, 1 Swanst. 30 ; Dore $v$. Spurvey, 2 Stark. 285 ; Taylor $v$. James, Godbolt, 150.

53 Bl. Com. 145; Mellor $v$. Leather, 1 E. \& B. 619.
6 Shannon $v$. Shannon, 1 Sch. \& Lef. 327 ; George $v$. Chambers, $11 \mathrm{M}$. \& W. 149 ; Allen $v$. Sharp, 2 Exch. 352 ; Comyn, Dig. Repl. A.

7 Comyn, Dig. Repl. D.

8 Mennie $v$. Blake, 6 E. \& B. 843 ; Evans v. Elliott, 5 Ad. \& E. 142.

9 Morris, Repl. 46, 47 ; Wait's Ac. \& Def. $455,456$.

10 Marston $v$. Baldwin, 17 Mass. 606. 
A landlord at common law had the right without writ or precept to take the chattels of his tenant and retain them in his possession as security for rents due him. A wrongful exercise of this right was regarded as a serious offence against the Crown, which could not be redressed by the inferior courts without special authority emanating from the sovereign. ${ }^{1}$

The remedy furnished by the common law to redress this wrong consisted in the writ of replevin, which issued out of Chancery. It was in use as early as the reign of Henry II. It appears in the register of writs; and its introduction was ascribed by the author of the Mirror to Glanville, Chief Justice of Henry II., in whose treatise it is mentioned. ${ }^{2}$

This writ was addressed to the sheriff, and commanded him to cause to be replevied to the plaintiff his cattle, goods, and chattels which the defendant had taken and unlawfully detains as he saith, and afterwards cause him to be brought to justice for the same, that no more complaint be heard for want of justice. ${ }^{3}$ Before the sheriff executed this writ he was required at common law to take pledges from the plaintiff that he would prosecute a suit for the purpose of determining the legality of the distress.

If the sheriff failed to execute this writ the plaintiff was entitled to an atias. Neither the original or alias were returnable to the Superior Courts. They operated only as commands to the sheriff to replevy, and afterwards determine the question of the unlawful taking in his court. But in the pluries writ, and sometimes in the alias, the clause vel causam nobis significes was inserted, which made them returnable processes. ${ }^{4}$ They then superseded the proceedings of the sheriff in his court, and practically removed them into the Superior Court, giving the defendant a day for his appearance there. ${ }^{5}$ It became usual to take out the alias and pluries at the same time. ${ }^{6}$

SEC. 108. History continued. - Statute of Marlbridge. The delay which attended the application to Chancery for an original writ in every case greatly impaired the efficiency of the

1 Morris, Repl. 48 ; 2 Pol. \& Mait. 575 ; Bracton, 155, 156.

2 1154-1189. Fitz. N. B. 69 ; Glanville [Beames], 294 ; Mirror, c. 2, s. 6 .

33 Bl. Com. 146, 147 ; Wilk. Repl. 143 ; Fitz. N. B. 68.
4 Fitz. N. B. 69, 70; 2 Inst. 189; Freeman $v$. Blewitt, 1 Salk. 410.

51 Ld. Raym. 617. 53.
${ }^{6}$ Dalt. Sheriff, 273 ; Morris, Repl. 
remedy. This inconvenience was obviated by the Statute of Marlbridge (52 Hen. III. c. 21, 1267), by which the sheriff acquired jurisdiction in replevin of any value in like nanner as possessed by him under an original writ. ${ }^{1}$ This jurisdiction was exercised upon plaint made to him by plaintiff, in pursuance of which he issued a precept to his bailiffs to take the property from the defendant and deliver it to the plaintiff, and to summon the defendant to allswer in the County Court an action for the unlawful taking-and detention.

At the present time actions of replevin may be commenced in the Superior or in the County Courts, and in both cases the registrar of the County Court, upon instance of plaintiff, without writ, grants replevin of the property upon securities furnished in compliance with the modern statutes. ${ }^{2}$

SFc. 109. History continued. - Pledges, etc. By the Statute of Westm. II. c. 2 (1285), the sheriff, whether acting in pursuance of a writ or upon plaint to him under the Statute of Marlbridge, was required before delivering the property to plaintiff to exact from-him, in-addition to the common law pledges for prosecution, security also for a return of the property to defendant if the plaintiff was defeated in his suit and a return was adjudged. By statute of 11 Geo. II. c. 19 (1738), the sheriff was required in cases of distress for rent to exact from plaintiff, before making replevy, a bond with two sureties in a sum double the value of the goods distrained, conditioned to prosecute the suit and make return of the property when return was adjudged. This bond took the place of the former pledges in the cases in which it was required. At the present time the powers and responsibilities of the sheriff have ceased, and the registrar of the County Court grants replevies and passes upon the sufficiency of the bonds, whether the suit has been commenced in the Superior or in the County Courts. ${ }^{3}$

SEC. 110. History continued. - Removal. As the sheriff could not try title to the property replevied without special authority to that end, and could not try an issue when the freehold came in question, it came to be the usual practice at a very early day to. remove all replevies of any importance, whether commenced by.

1 Wilk. Repl. 78.

219 \& 20 Vict. c. 108 , s. $63,64,65$, 66 ; C. L. P. Act, 1862 , s. 22 [23 \& 24 Vict. c. 126].
3 19 \& 20 Vict. c. 108 , s. $63-66$; C. L. P. Act, 1862 , s. 22. 
writ or plaint into the Superior Courts by writs from Chancery, which are particularly described in our note in the Appendix. ${ }^{1}$ The right of removal is still secured by late statutes. ${ }^{2}$ The ancient writs of removal either enjoined a summons to the opposite party, or gave him a day to appear in the Superior Court. ${ }^{3}$

SEc. 111. History continued. - Incidental Writs and Precepts. If, in executing the command of the writ to replevy the property, the sheriff neglected to perform his duty, or by reason of the defendant's claim of title to the property in himself or a stranger, or by reason of his eloinment or removal of it, so that it could not be found or taken by the sheriff, the courts and the legislature furnished various remedies in behalf of the parties, framed and contrived to work out complete redress to each of them. These remedies consisted in alias and pluries writs or precepts of replevin; writs de proprictate probanda (to try the title); writs of recaption; writs of second dcliverance; and writs or precepts of capias in withernam (to seize other property in lieu of that taken and withheld); all of which are set out particularly in our note disclosing the intricate and complicated proceedings in this anomalous action.

SEc. 112. History continued. - Avowry and Cognizance. If, as in ordinary cases of distress for rent due or damage feasant, the sheriff succeeded in taking the property or cattle and delivering them to the plaintiff upon the gages and pledges furnished by him, the usual defence consisted of a plea known as an avowry or cognizance. These pleas admitted property in the plaintiff, acknowledged the taking, and contained a counter declaration against the plaintiff for rent due, or damáges suffered from trespassing cattle, and prayed a return of the property, to remain with defendant as security for the rent or damages. In an avowry, the defendant justified the seizure in his own right. In a cognizance, he justified in the name of some one else from whom he derived his right to distrain. ${ }^{4}$

The distinguishing feature of an avowry and cognizance was that they not only justified the taking on account of rent or damages, but asked for a return of the property. ${ }^{5}$ Under certain statutes the defendant upon succeeding in an avowry for rent on demise could accept a judgment for rent to the extent of the value of the prop627.

13 Bl. Com. 149 ; 2 Roscoe, Ac.

29 \& 10 Vict. c. 95 , s. $121 ; 19$ \& 20 Vict. c. 108, s. 67.

3 Fitz. N. B. 70; Wilk. Repl. 31, $32,151,154$.

4 Wilk Repl. 52, 53; 3 Bl. Com. 149 .

52 Roscoe, Ac. 631, 632. 
erty replevied, as will be seen in our sketch of the judgment in this action. $^{1}$

The defendant might plead a mere justification by which he confessed the taking, but avoided the illegality of it, without seeking a return; the object of the plea being solely to exclude the plaintiff from damages. ${ }^{2}$ Such a plea- was-denominated-a-plea merely in justification, which as a general rule did not entitle the defendant to a return, because it affirmed property in the plaintiff. ${ }^{3}$ But there was one exception to this rule: when the defendant by way of justification pleaded property in himself or a stranger, he was entitled to a return without an avowry. 4

The action of replevin is in use in all the American States, although simplified by statute, and freed from the complexities of the ancient action. It has been extended in most of the States to the unlawful detention of chattels irrespective of the manner in which possession has been acquired. In a few States the taking must be tortious to support the action, while in one or two it is confined to distresses for rent. ${ }^{5}$ In other respects the characteristic features of the action as finally settled at common law have been retained.

A right on the part of defendant to retain the property taken under the replevin order until termination of the action, upon furnishing proper security, has been given him in some States, when it does not appear by affidavit of plaintiff that he acquired possession by a tortious taking. -

SEc. 113. Characteristic Features. The feature which distinguishes the action of replevin from all other actions at common law consisted in the restoration to plaintiff of possession of the property sued for, upon commencing the action, and before trial and judgment of his right to such possession. In this respect it differed from detinue, in which possession was not acquired until final judgment to that effect, and then only-if-the defendant failed. to elect to pay the assessed value. It is this feature which has rendered it such an efficient and popular remedy. The practice of exacting security from the plaintiff as a protection against an abuse of the remedy is analogous with that in equity when its extraordinary and summary jurisdiction is invoked. ${ }^{\top}$

1 Sec. 115.

22 Roscoe, Ac. 632; Gilb. Repl. 186.

2 Roscoe, Ac. 632.

12 Roscoe, Ac. 632.

Martin Civil Procedure-7
5 Morris, Repl. 47, 48.

62 Rev. Stat. Mo. 1889, s. 7482.

7 St. Irnuis v. St. Louis Gas Light Co., 8.2 Mo. 349 . 
Another feature which contributed to render the action anomalous at common law-was that in the plea of avowry or cognizance the defendant was a plaintiff in the case as well as a defendant. $\mathrm{He}$ prosecuted a counter demand and asked for an affirmative judgment against the plaintiff for return of the property and for damages. To his demand the plaintiff responded by plea as to a declaration. ${ }^{1}$

It has been remarked that the action of replevin has never been extended by judicial authority in England to a wrongful detention, distinct and independent of a wrongful taking. A tortious taking preceding the wrongful detention has generally been regarded as necessary to support the action there. It must be admitted, however, that there are some authorities tending to controvert this proposition. $^{2}$

The writ in replevin complains of a taking simply, and avers that the detention is unjust. And it was always held that the action would lie for a distress which was legal in the beginning, but which became unlawful because of a detention after gages and pledges. ${ }^{3}$ The great weight of authority is in support of the proposition; and it is argued that an unlawful detention after a legal taking makes the defendant a wrongdoer $a b$ initio; and that in this manner a legal taking may be treated as tortious by reason of the subsequent illegal act of detention, 4

SEc. 114. Declaration. When the action was instituted by plaint and removed to the Superior Court, the declaration conformed with the requirements of that court. If it was tried below, it resembled those used in the upper courts. ${ }^{5}$

It has been supposed by some that there were two kinds of replevin, - one in the detinuit and the other in the detinet. ${ }^{6}$ But this supposition originated in a reasonable variation in the declaration, depending upon the success or failure of the sheriff to find the property. If the property was found and delivered to the plaintiff, he declared in the detinuit, describing the wrong for which he claimed damages as an accomplished thing of the past. In this form of

I Bacon, Abr. Repl. and Avow. A.

2 Arundell $v$. 'Trevill, Sidf. 81, 82; Gilb. Repl. 131; Jacobsen v. Lee, Lilly's Entries, 349. 575.
43 Steph. Com. 524; Ex parte Chamberlain, 1 Sch. \& Lef. 320; Shannon $v$. Shannon, Ib. 324; Evans $v$. Elliott, 5 Ad. \& E. 142.

5 Wilk. Repl. 22, 23.

62 Sellon, Pr. 153. 
declaration it was alleged that the goods which had been taken "were detained until replevied by the sheriff," a phrase which came to be abbreviated by an averment that they were "detained until, etc.," which was called "declaring in the detinuit." 1 This was the more usual declaration, for the reason that the sheriff was successful in most cases, and the declaration was filed after the result of his efforts was known. Damages were given only for the wrongful taking and past detention. ${ }^{2}$ If, however, the sheriff did not succeed in finding and delivering the property, it was optional with the plaintiff whether he would declare and compel the defendant to answer for the wrongful taking and detention in damages, or resort to another writ for regaining possession. In the event of his choosing to proceed in damages, he declared in the detinet and recovered damages for the continued detention of the chattels, which would necessarily include the full value of the chattels taken and still detained, as well as damages for the wrongful taking. ${ }^{3}$ The same declaration could be a detinuit as to the part returned, and a detinet as to the residue not found or returned. ${ }^{4}$ Morris on Replevin contains a declaration in which the two forms are used. ${ }^{5}$

We have seen that there never was a distinct action of replevin in the detinet, ${ }^{6}$ although we meet with dicta to that effect, - sometimes coupled with the statement that such action became obsolete when replevin came to be brought by plaint before the sheriff. ${ }^{7}$ It is probable there never was a time when, after issue of the replevin writ, the plaintiff could not declare in the detinet if he thought best to do so after the sheriff failed to redeliver the goods. The necessity for such practice was not very common. But the older authorities are quite clear that, unless he did so, he could not recover the value of the goods. ${ }^{8}$

This variation in the forms, which has given rise to much discussion and comment, did not operate to effect any change in the action itself, but only in the measure of damages, and finally ceased

1 Ham. N. P. 460, 461.

2 Ham. N. P. 461 ; 1 Espin. N. P. 350 .

31 Chit. Pl. 162 ; Ham. N. P. 461; Browne, Ac. 447 ; Fitz. N. B. 69 I.; Morris, Repl. 54.

4 Co. Ent. 611 b, 613 a ; Comyn, Dig. Tit. Pleader, 3 K. 10.

5 Morris, Repl. 306 ; see one also in McKelvey on Com. Law Pleading, 49.

6 Sec. 105.

7 Browne, Ac. 447; Bull. N. 1'. 52 ; Chit. Pl. 162.

82 Roscoe, Ac. 645; Comyn, Dig. Pleader, 3 K. 29 b; Fitz. N. B. 69 L. c; Hoskins v. Robins, 2 Saund. 319. 
to be necessary for the latter purpose. A declaration in the detinuit implied that the plaintiff has his goods again, and that he seeks damages only for the taking. A declaration in the detinet implies that the defendant still has the goods, and the plaintiff is entitled to the value of his goods in his assessment of damages. ${ }^{2}$

It is possible that under the abbreviated form of a declaration in the detinuit, which came to be generally used in the sheriff's court before the success of the sheriff in finding the goods was actually known, the courts permitted the plaintiff to show that the goods were still detained, so as to bring their value into the assessment. And to that end the value was alleged in the declaration in the detinuit. ${ }^{3}$ In doing this there was no serious variance from the gist of the action. Present detention might with some show of reason be treated as a continuation of the original taking and detention, as it went only to the measure of damages, and not to the right of action. This practice rendered it unnecessary to declare in the detinet, and may well account for the dicta relating to its abandonment.

It may be added here that the writ was always in the detinet, and that the modern action in most of the American States, being instituted before issue of the writ or order, is usually in that form.

It was required that the place where the distress was taken should be described with certainty, also the character, number, and value of the goods taken. ${ }^{4}$

SEc. 115. Judgment. The judgment for plaintiff was, that he recover his damages for the taking and detention of the property, together with eosts. ${ }^{5}$ If the property has not been delivered to the plaintiff, he in that event recovers in damages also the value of the property still detained, as already stated. ${ }^{6}$

If the judgment was by default, and the damages were not confessed, a writ of inquiry issued to assess them, the amount of which depended upon the result of the sheriff's efforts to obtain the goods. ${ }^{7}$

The nature of the judgment when given for the defendant varied in different cases. At common law he was, as a general rule, adjudged return of the property, but without damages or $\operatorname{costs}^{8}$

1 Petree $v$. Duke, 2 Lutw. 468 [1150].

22 Roscoe, Ac. 645; Comyn. Dig. Plearley. 3 K. 29 b; Fitz. N. B. 69 I. c.

8 VeKelvey, Com. L. P. s. 69.
41 Chit. Pl. 165.

51 Chit. Pl. 166.

6 Wilk. Repl. 43

72 Roscoe, Ac. 645.

81 Espinasse, N. P. 375 ; 2 Roscoe, 646. 
ART. VI.] PERSONAL AC'CIONS EX DELICTO. - MESNE PROFItS. 101

repleviable in some cases, and irrepleviable in others. ${ }^{1}$ If tho defendant proceeded under the statutes of Henry VIII., ${ }^{2}$ he recovered, after verdict in his favor, his damages and costs, in like manner as the plaintiff should have done if he had recovered against the defendant. ${ }^{3}$ By a statute in the reign of Charles II., when judgment was given on demurrer for the defendant avowing or making cognizance for any rent, he was entitled to a writ of in. quiry as to the value of the distress, and a judgment for the arrears of rent admitted by the judgment to the amount of the value of the property distrained, together with costs. ${ }^{5}$ It was optional with the defendant whether he would take judgment under this last statute alone, or in addition to the common law judgment for a return of the property. But if judgment is taken under the statute along with the common law judgment for a return, it operates as a stay of the writ for return of the goods. ${ }^{6}$ When, under the twenty-first section of the same chapter and statute, the plaintiff was nonsuited before issue joined, the defendant was entitled to an inquiry as to the amount of rent in arrear and the value of the property distrained, upon which finding judgment went in his favor as on demurrer. In this case he had the option to sue out the writ of return, or have execution for the damages. ${ }^{7}$

See writ and declaration in Appendix, forms 21 and 22.

\section{Article VI.}

Action for Mesne Profits.

Sec. 116. Definition and Nature.

SEc. 116. Definition and Nature. This action is in form an action of trespass vi et armis, but in effect to recover the rents and profits of an estate from possession of which the plaintiff has been kept by a defendant in ejectment. ${ }^{8}$ The plaintiff in ejectment recovered possession and only nominal damages. By a subsequent action for mesne profits, he recovered substantial damages for the loss of rents and profits as the continuing consequences of the

1 Wilk. Repl. 90.

27 Hen. VIII. c. 4 , s. 3 ; 21 Hen. VIII. c. 19 , s. 3.

52 Roscoe, Ac. 646.

62 Roscoe, Ac. 647.

72 Roscoe, Ac. 649, 650.

81 Chit. Pl. 193.

417 Car. II. c. 7, s. 3. 
eviction. The previous judgment of nominal damages constituted no bar to the subsequent action for mesne profits. ${ }^{1}$ Being in its nature a peculiar species of trespass, it has come to be designated by a name which distinguishes it from all other trespasses. There does not seem to be any mention of it prior to the end of the reign of Elizabeth. ${ }^{2}$ It could be brought in the name of the nominal plaintiff in ejectment, or in the name of his lessor. It lies against the defendant in the ejectment suit, and against all found in possession at the time of recovery in that action. It also lies against a landlord in fact of the defendant in ejectment, who-reeeives the rents and profits, or against any one who in fact resists the recovery in ejectment by aiding and abetting the defendant in his defence, aithough not a party to the suit. ${ }^{3}$ It proceeded upon the assumption-that the plaintiff's right of possession had been vindicated by judgment in the ejectment case, and that the defendant and all entering under him, or during progress of the action, or assisting him to resist the suit, were parties to the continuing wrong, and liable for the profits received from the land during its detention from the plaintiff. The declaration, as in the usual form of trespass clausum fregit, must state the time when the defendant ejected the plaintiff, and the length of time he was kept out of possession. The premises were described as in the declaration of ejectment. It was next alleged that the defendant receired the mesne profits of the land, indicating their value, while the plaintiff was kept out of possession. The ordinary measure of damages is the rental value of the premises during that time. If any special damages to the land had been committed by the defendant, it was necessary that they should be stated in the declaration in order to be estimated by the jury and included in their verdict. The judgment is for damages. In ejectment by landlord against his tenant, it was optional with the plaintiff to have damages assessed in the nature of mesne profits in pursuance of the statute. ${ }^{4}$

In absence of statutes to the contrary, a subsequent action for mesne profits as at common law has been very generally recognized in the American States. ${ }^{5}$ The statutes relating to ejectment in

1 Van Alen $v$. Rogers, 1 Johns. Cas. 280; Tyler, Eject. 841; Hughes $v$. 281-283.

24 Reeves, Hist. 241 [ed. 1880]; Stearns, Real Ac. 402, s. 3. Carson, 90 Mo. 399.

41 Geo. IV. c. 87. s. 2.

5 Dawson $v$. McGill, 4 Whart.

${ }^{3}$ Hunter v. Britts. 3 Camp. N. P. 230; Van Alen v. Rogers, 1 Johns. 455; Chirac $v$. Reinecker, 11 Wheat. Cas. 281. 
ART. VI.] PERSONAL ACTIONS EX DELICTO. - MESNE PROFItS. 103

some of the States leave it optional with the plaintiff to include his claim for mesne profits in the ejectment suit, or to omit it there and bring a subsequent action after recovery of possession. ${ }^{\text {m }}$ Under the present practice in England, the plaintiff may join his claim for mesne profits with his action for recovery of possession. ${ }^{2}$ Where, as in some of the States, the language of the statutes is imperative in directing the plaintiff to include his claim for mesne profits in the ejectment suit, ${ }^{3}$ there would seem to be no right in him to omit his claim there, and burden the same defendants with a subsequent action. ${ }^{4}$ But in construction of such statutes it has been properly held that a person liable at common law for mesne profits, in a subsequent action therefor, may be pursued in such action, if he has not been a party to the ejectment suit. ${ }^{5}$

1 Trubee $v$. Miller, 48 Conn. 347; Act of June 11, 1879, Penn. Laws, p. 125 ; Code Civ. Proc. N. Y. s. 1496, 1497 [Banks \& Bros., 1885].

2 Ann. Pr. 1897 , p. 457.
8 Rev. Stat. Mo. [1889], s. 4638, $4640,4641$.

4 Lee $v$. Bauman, 55 Mo. 400.

5 Hughes $v$. Carson, 90 Mo. 399. 


\section{CHAPTER IV.}

\section{ANCIENT REAL ACTIONS:}

Article I. Introductory.

“II. Proprietary Actions.
Article III. Possessory Actions.

IV. 'Forcible Entry and Detainer.

\section{Article I.}

Introductory.

Sec. 117. Prefatory.

" 118. Defined.

“ 119. Historical.

“ 120. Classification.
Sec. 121, 122. Theory of Rights in Land. “ 123,124. Distinction between proprietary and possessory Actions.

SEc. 117. Prefatory. Before entering upon the subject of modern real actions, it has been thought advisable, for reasons expressed in the preface, to give a more definite and precise account of the ancient real actions than will be found in modern treatises.

SEc. 118. Defined. "A real action is one that is brought to recover the freehold in lands, tenements, or hereditaments claimed either in fee simple, fee tail, or for life, by one who is deforced, against him who is tenant thereof. ${ }^{1}$

The party bringing the action was called the demandant, the party against whom it was brought the tenant. The first pleading on the part of the demandant was called a count.

It will be observed that these actions existed only in favor of owners of at least a freehold. Grants of rights to possession, less than for life, were not construed as transferring any title to the land. ${ }^{2}$ The common law furnished a great variety of writs to determine the rights of property and the rights of possession in a freehold. They varied according to the title or seisin of the demandant, and the circumstances of ouster or deforcement.

SEc. 119. Historical. The writs were of feudal origin. They will be found in the register of writs, and were about sixty in number. The distinctions between them were technical and refined. 
The procedure under them became inconveniently long and costly. They prevailed for about five hundred years, going out of use in the reign of Elizabeth. ${ }^{1}$ The causes which led to their discontinuance and formal abolishment will be noticed in connection with the modern action of ejcctment, which supplanted them. ${ }^{2}$ They were all expressly abolished by a statute passed in 1833, excepting the writ of right of dower, writ of dower, quare impedit, and ejectment. ${ }^{3}$ By the Supreme Court Judicature Act of 1873 and acts amendatory thereof, and the rules promulgated in pursuance of them, the writs in the first three of these actions were necessarily superseded by the new system, and the action of ejectment was continued in a modified form. ${ }^{4}$

For enumeration of the writs abolished by the statute of William IV., see note 3 of Appendix.

SEc. 120. Classification. The ancient real actions were susceptible of classification according to the nature of the thing recovered. In one class only land or incorporeal hereditaments were recovered. These were regarded as purely real actions. ${ }^{\bar{j}}$ In the other class, not only lands or incorporeal hereditaments were recovered, but damages also, as incident thereto. This latter class answers to the definition of mixed actions; but as all of them are ordinarily classed and treated with real actions, ${ }^{6}$ and as recovery of the freehold was in most of them their leading feature, and recovery of damages incidental and secondary, I will notice them under the head of real actions, and not under the head of mixed actions.

A more generally accepted classification has been founded on the nature of the demandant's title. According to this division, real actions were either proprietary (droitural), in which the demandant sues on the strength of his mere right (jus merum) of property, after having lost his right of possession; or possessory, in which he sues in respect of his right of possession, which might belong to him in addition to his right of property or independent thereof. ${ }^{-}$ This general classification will be followed in our account of the ancient real actions.

To understand their nature, and especially the distinction between proprietary and possessory actions, it will be necessary to 105.

1 1558-1603. Alden's Case, 6 Rep.

2 Appendix, Note 4.

$33 \& 4$ Wm. IV. c. 27 , s. 36.

4 Ann. Pr. 1897, 215, 218, 458, 459.
51 Roscoe, Real Ac. 1.

6 1 Roscoe, Real Ac. 1, 3 ; Comyn, Dig. Actions D. 4.

71 Roscoe, Real Ac. 2. 
notice, as briefly as possible, the theory of rights in real estate as accepted by the courts and jurists of those early days.

SEc. 121. Theory of Rights in Land. It was held that a complete title to real estate consisted of three essential elements: viz. the jus proprietatis, or ultimate right of property ; the jus possessionis, or right of possession; and the actual present possession thereof. The right of property and the right of possession might exist in different persons, while the actual possession was in a third person. Actual possession was thus regarded as a right (or perhaps as implying a right) distinct from the right of property and the right of possession. ${ }^{1}$

If a person in the enjoyment of a complete title to land was wrongfully ousted from possession, he lost one of the constituents of his title, viz. actual possession. There remained in him still the right of possession and the right of property or general ownership. The wrongdoer who ousted him was known in law as a disseisor. As to all other persons, the disseisor was owner of the complete title. As to the person whom he had disseised, he was owner of the complete title, subject to be defeated by enforcement of the disseisee's superior right of possession or right of property. If those rights were not enforced within certain periods of time fixed by the common or statute law, his title became absolute and indefeasible as to all failing to show a better right of possession or right of property.

1 The treatment of actual possession as a right, or as implying a right distinct from the right of possession, has been misleading. Actual possession is a fact or status. As a fact it is prima facie evidence of the right of possession, because it is the natural manifest:tion of that right. As a fact or status it is protected by law for reasons of public policy against displacement, except by jurlicial process at the instance of some one having a superior right to possess. Peaceable possession therefore is not a right, but it is a foct or status which implies the right in the possessor to contiuue his possession until it is displaced by judicial process. This right of possession is provisional, and subject to determination at the suit of any one having an older and therefore superior right of possession. In imputing to the peaceable possessor a right in the fact of his possession, nothing. more could have been intended than to recognize in him a peculiar right of possession, which springs from and is implied from the present fuct of possession. This right of possession might coexist with a right of possession in some one else springing from a previous fact or status of peaceable possession. Thus we have two persons invested with rights of possession. One founds his right on a present peaceable possession, the other founds it on a previous peaceable possession, or a right of property which resolves itself ultimately into al1 older possession or seisin. 
The same condition of things existed in the case of an abatement where upon death of a person seised of an inheritance a stranger acquired possession of the freehold before actual entry of the heir or devisee; also in case of an intrusion where a stranger, after termination of a particular estate of freehold, acquired possession before entry of the remainderman or reversioner.

The necessary effect of a disseisin abatement or intrusion was to convert the estate of the disseisee, heir, devisee, remainderman, or reversioner, as the case might be, into rights of possession and rights of property. These rights might descend to their heirs, but they were incapable of being devised or assigned. While, on the other hand, the estate of the disseisor, abator, or intruder was capable of alienation, devise, and descent, being an estate in possession.

SEc. 122. Theory of Rights in Land continued. To vindicate these rights of possession and rights of property, when violated by wrongdoers, the ancient law furnished certain remedies, some of which were extra-judicial, and rested on the principle of self-help, others of which were judicial and constitute the scheme of real actions hereinafter defined and described.

Immediately after a disseisin, abatement, or intrusion, the disseisee, heir, devisee, remainderman, or reversioner, as the case might be, could obtain redress by entering into peaceable possession of the land, by which act his title became complete. If he could not make peaceable entry, then his only resort for legal redress lay in the courts, as he was forbidden by the law under penal restrictions to invoke the aid of force against any one in peaceable possession. An entry by force was a punishable offence, and the premises entered were subject to be restored to the occupant by the writ of forcible entry, irrespective of any right of possession or right of property, except that which is implied from the bare fact of peaceable possession.

If, however, the disseisee, heir, devisee, or remainderman failed to exercise the extra-judicial remedy of peaceable entry in the lifetime of the disseisor, abator, or intruder, but permitted him to die in peaceable possession of the land, his right to enter even peaceably without process of court was ended. The right of extra-judicial entry was thus taken away by the fact of a descent cast. The disseisor's estate descended to his heir, who, being innocent of the original disseisin, became invested with the apparent or presumptive right of possession, which could not be displaced except by an 
action to vindicate the disseisee's superior right of possession or right of property. ${ }^{1}$

It was anciently held that this right of extra-judicial entry was also taken away as against the feoffee of a disseisor, abator, or intruder, after he had been in possession a year and a day. ${ }^{2}$ But this holding became obsolete at a very early date; there had to be a descent from the feoffee to accomplish this result. ${ }^{3}$ It may be mentioned here that the descent of incorporeal hereditaments which lie in grant did not take away the right of entry. ${ }^{4}$

But the effect of a descent cast in taking away the right of extrajudicial entry could be defeated by the act of the disseisee in making claim to the lands of which he had been disseised. By making his claim at any time before the death of the disseisor, he saved his entry for a year and a day after such claim made. Continual claim had the same effect on his right as an entry, the continuance of the disseisor in possession after claim made being regarded as a new disseisin. ${ }^{5}$ By continual claim annually, the disseisee was enabled to keep alive his right of entry.

The right of entry was extended by the statute of 32 Henry VIII. c. 33 , by which it was provided that a descent from a disseisor should not have the effect of taking away the right of entry, unless the disseisor had peaceable possession five years next after the disseisin. In construction of this statute it was held that a descent from the heir of a disseisor, or from his feoffee, was not within the terms of the statute, and that such descents took away the right of extra-judicial entry, notwithstanding a want of five years' possession. Neither did it extend to abators or intruders. ${ }^{6}$

It may be added here that the right of entry, as against disseisors, abators, and intruders, never existed as an independent right in cases of discontinuance or deforcement of the freehold, - cases in which the wrongdoer had acquired possession lawfully, but had unlawfully detained it. In such cases the party entitled to possession by virtue of his estate could only invoke a proprietary action to establish his rights. He had neither possessory action nor remedy by self-help. ${ }^{7}$

1 Gilbert, Ten. 37.

2 Gilbert, Ten. 43.

3 Co. Litt. 237 b; Comyn, Dig. Descent, D. 1; Bac. Abr. Descent, G.
1 Co. Litt. 237 b.

51 Roscoe, Real Ac. 85, 86.

61 Roscoe, Real Ac. 87.

73 Bl. Com. 178. 
SEc. 123. Distinction between Proprietary and Possessory Actions. The common law, for reasons of public policy, deemed it necessary to protect a person in the quiet and peaceable possession of land irrespective of the means by which he acquired it. It accomplished this in three ways: 1 st, by refusing to enforce in the courts any one's claim to possession which was not superior to the right of the actual possessor; $2 \mathrm{~d}$, by summarily restoring to the ousted possessor his possession, when it was forcibly taken from him, irrespective of any right of possession in the party who had interrupted the possession; 3d, by punishing any one who attempted to elfforce his rights of possession, without process of the Courts. Under this state of things it is obvious that actual seisin or possession, however wrongful, gave a presumptive right of possession, which was valuable and beneficial according to the person against whom, and the mode of proceeding in which, it was asserted. The possessor thus had a species of property in the fact of his possession. ${ }^{1}$

After being disseised, the disseisee could vindicate by some possessory proceeding his right of possession, - founding his action on the simple fact of his actual seisin and the wrongful act of the disseisor in ousting him, The possessory remedies of writ of assize or writ of entry, according to the nature of his case, were at his conmand. In addition to these legal remedies he might effect his restoration and regain his seisin by extra-judicial. entry, if he could effect it in a peaceable manner. This remedy by extra-judicial entry served the purpose of a possessory action, but was liable to be lost if not carried out before descent cast or other limitation imposed by law or statute. After loss in this manner of his remedy by extra-judicial entry, his right to regain possession by some possessory action still remained to him for a period of time which varied according to the statute in force at the time his action was brought. ${ }^{2}$ The limitation of possessory actions was fixed in the reign of James I. at twenty years. ${ }^{3}$

If he failed to invoke redress by possessory action of some kind within the periods of time limited for such actions, or if he had been defeated in them, he might still recover possession by a pro-

12 Pol. \& Mait. 42.

2 Coke, 238, note 1 ; 1 Roscoe, Real Ac. 4; Jackson, Real Ac. 1,
2 ; 3 Bl. Com. 188, 189 ; 2 Pol. \& Mait. 51.

8 Browne, Ac. 28, 29; 1 Roscoe, Real Ac. 13. 
prietary action suited to the nature of his case, if brought within the periods of time limiting such latter action. ${ }^{3}$ The limitation of the writ of right remained at sixty years until the action was abolished. ${ }^{2}$ In this action he not only alleged the fact of his seisin or possession of a fee, but added that he or those under whom he claimed were seised "as of right"; thus bringing into the action the ultimate dominion, or right of ownership, which either included or implied the superior right of possession as incident to it or constituted that right itself. This dominion or ownership is generally alluded to as something very different in its nature from the right of possession. But when ownership in land is resolved into its essential elements, it becomes apparent that the fundamental one is the right of possession. It would seem, therefore, that the right of property enforced in the proprietary actions is nothing more than an older and superior right of possession. ${ }^{3}$

\section{SEc. 124. Distinction between Proprietary and Posses-} sory Actions continued. Property in its strict sense represents the right to possess and use a determinate thing, indefinitely in point of user, unlimitedly in point of duration, and unrestrictedly in point of alienation or disposition. ${ }^{4}$ It is probable that in English law there was no property in land which came up to this ideal of absolute property. ${ }^{5}$ But from the time of Practon, the rights of proprietorship have been ascribed to the tenant in demesne, notwithstanding the rights of seigniory remaining in the lord and ultimately in the sovereign. ${ }^{6}$ The right of the tenant in fee to possess and use the land, although subject to these seigniorial rights has always been regarded and treated as property in its highest sense, although manifestly falling somewhat sloort of the ideal of absolute property. No violence has been done to the philosophy or logic of property rights by ascribing them unqualifiedly to the rights of a tenant under English law, much less to a purchaser in fee under American law.

As already stated, the foundation of the right of ownership is the right of possession to which the other rights are primarily incidental. A person cannot use nor make perfect disposition of a thing which is in the adverse possession of another. When

13 Bl. Com. 193, 196.

21 Browne, Ac. 28; 1 Roscoe, Bl. Com. 447.

\section{Real Ac. 10.}

2 Pol. \& Mait. 77.
42 Austin, Jur. $818,823,866 ; 2$

52 Austin, Jur. 866.

62 Pol. \& Mait. 3-7 
the right of possession is once vindicated, these other rights are restored along with the possession. Indeed, it has been aptly remarked by an able author that there is "no action in the law of England by which property in goods or land [as distinguished from the right to possession either inmediate or future] is alone decided." 1 The reason of this is that the right of property in land or goods is only another name for the right of possession, and the other rights incidental to it. In all the real actions, whether proprietary or possessory, the right of possession was the material issue. "Every title to land has its root in seisin; the title which has its root in the oldest seisin is the best title." ${ }^{2}$ The superior right of possession, being the older one, was called the right of property, but only in comparing it with the right of possession, which came from subsequent adverse, enjoyment, and which had to be protected by the law for reasons of public policy. The defendant in his plea to a writ of right averred that he had more right to hold the lands than the demandant had to demand them.

It is probable that the scheme of ancient real actions would have been more readily understood and enforced, if the technical distinction between proprietary and possessory actions had never existed, and if they had all been known as possessory actions. However this may be, the outeome of remedial procedure relating to land has in modern times resulted in practically abolishing the distinction, and in furnishing a possessory action which serves all the purposes for which the proprietary actions were used. By $3 \& 4 \mathrm{Wm}$. IV. c. $27, \S 39,(1833$,) it was enacted that no descent cast, discontinuance, or warranty shall hereafter defeat any right of entry or action for the recovery of any land. The effect of this enactment was to render obsolete the learning of descent cast, discontinuance, and continual claim, and to convert all titles into possessory titles, which can be enforced in the modern action of ejectment. By the same statute, all the ancient real and mixed actions were expressly abolished, except four, one of which is ejectment; the other three (quare impedit, and two writs in dower) involving rights which could not, as it was supposed, be vindicated in that action.

A significant feature which disclosed the possessory nature of

1 Williams, Per. Prop. 26 (7th ed.); 22 Pol. \& Mait. 46. Dicey on Parties, 346. 
the proprietary actions is found in the fact that they were concurrent remedies with the possessory actions in which estates in fee simple were recoverable; but on account of the delay which attended them they were seldom resorted to, when the simpler and more speedy remedy by possessory action could be employed.

Having. considered the definition, history, and classification of real actions, and the distinction upon which the general classification rests, the different kinds of actions under the classification will next be rehearsed, with sufficient definiteness, it is hoped, to answer the wants of the modern student or practitioner. To help in this undertaking the reader is referred to the table compiled by Roscoe, and which is founded on the table of Chief Baron Comyn. ${ }^{1}$

\section{Article II.}

\section{Proprietary Actions.}

Sec. 125. Division of them.

" 126. Writs of Right proper.

"127. Writs in the nature of writs of right.

" 128. 'The writ of right Close in ancient demesne.

" 129. Writ of Right De rationabili parte.

Sec. 130. Writ of the Right of advowson.
" 131. Writ of the right of dower.

“ 132. Writ of dower Unde nilil habet.

" 133. Writ of Quod permittat.

134. Writs of Furmedon.

" 135. Writ of Quod ei deforceat.

" 136. Other writs in uature of, etc.

" 137. Writ of Ne injuste vexes.

SEc. 125. Division of Them. Proprietary or (droitural) actions are divided into two general classes: 1st, writs of right, properly so called; $2 \mathrm{~d}$, Writs in the nature of writs of right. ${ }^{2}$ Writs of right in the time of Glanville were used in manorial courts in trial of the rights of property in land, or of incorporeal rights therein, such as services due by reason of tenure. ${ }^{3}$

SEc. 126. Writs of Right Proper. The writ of right proper lies when the demandant has only the right of property (the jus proprietatis), the mere right (jus merum) as it has been called, and when his estate has been devested and put to a right. ${ }^{4}$ There were four species of this writ:-

I. The Writ of Right Patent, which lay for lands held of the King as of some honor or of some lord other than the King. It was called patent, because it was directed as an open letter to the

11 Roscoe, Real Actious, 3; Comyn, Digr. Action [I).] 2.

2 Booth, Real Ac. $86,87$.
8 Bigelow, Hist. Proced. 157.

41 Roscoe, Real Ac. 19. 
King's bailiffs, when the lands were held of the King as of some honor, and to the lord of the manor, when the lands were held of him, or to his bailiffs when he was absent from the realm. It was anciently brought in the Court Baron, but it could be and usually was removed to the County Court, by writ of tolt issuing therefrom, and thence by writ of pone to the Court of Common Pleas. ${ }^{1}$ They came to be orought in the first instance in the King's Court, in which case they were differently directed, and went by another name. $^{2}$

II. The Writ of Right Quia dominus remisit Curiam, which differed from a writ of right patent as hereinbefore defined only in being brought in the first instance in the King's Court (presumably by license of the lord of the manor), and in being directed to the sheriff instead of the lord of the manor. It took its name from a recital in it to the effect that the lord had remitted his right to entertain the suit to the King's Court. ${ }^{3}$ It was a writ close, being directed to the sheriff, - a feature which distinguished writs close from writs patent.

III. The Writ of Right of Precipe in Capite, which lay for the recovery of land held of the King ut de corona and not ut de honore,that is, of the King in chief as of his crown and not of the King, as of any honor, castle, or manor. ${ }^{4}$ This was a writ close, and was directed to the sheriff'of the county where the lands were, and was returnable into the Common Pleas $;^{5}$ and was in effect the same as the writ of quia dominus remisit curiam. ${ }^{6}$

IV. The Writ of Right Patent in London, which lay for lands in the city of London, and was directed to the mayor and sheriff jointly. ${ }^{7}$ The fact that it was directed to the mayor as well as the sheriff made it a writ of right patent. 8 It did not differ from the writ of right patent, except in being always for lands in the city of London.

The foregoing species of writs of right were the only proper and genuine writs of right; all other writs of that name were only writs in the nature of writs of right, and were so classified to distinguish them from the pure and proper writ of right for the recovery of land in fee simple. ${ }^{9}$ It was the appropriate remedy for the recovery of corporeal hereditaments. It lay only in favor of a tenant in fee

1 Booth, Real Ac. 89, 90.

2 See Writ and Count in Appen$\operatorname{dix}, 23,24$.

8 Booth, Real Ac. 91.

- Fitz. N. B. 5 G.

Martin Civil Procedure- 8
${ }^{5}$ Fitz. N. B. 5 H.

61 Roscoe, Real Ac. 21.

7 Booth, Real Ac. 117.

82 Reeves. Hist. 365.

9 Booth, Real Ac. 85, 86. 
simple, resting his title on the right of property only, arising from his own seisin or the seisin of his predecessor. ${ }^{1}$ It did not lie for incorporeal hereditaments. ${ }^{2}$ Neither did it lie in favor of a person claiming a less estate than a fee, - as tenant in tail or for life. ${ }^{3}$ The defendant, or, more technically speaking, the tenant against whom it was brought, had to be owner of at least a freehold. It could not be brought against a tenant for years, or by elegit, statute merchant, or statute staple. ${ }^{4}$

The judgment, if for the demandant, was that he recover his seisin against the tenant of the tenements, with the appurtenances, to hold to him and his heirs, quit of the tenant and his heirs forever. ${ }^{5}$ Neither damages nor costs were included in the judgment.

The writ of right proper was a necessary remedy principally in four kinds of cases: 1. Upon a discontinuance effected by an alienation by tenant in tail, whereby the right of possession was transferred to the alienee, leaving only the right of property in the issue or remaindermen; 2. In case of judgment by default against either party in a possessory action; 3. In case of judgment upon trial of the merits in any possessory action; 4 . In case the demandant is barred from possessory actions by length of time and the statute of limitations.

The extension of the remedy by possessory actions rendered, at an early day, resort to this writ necessary only in cases of a rare character, or where limitations forbade the possessory actions, ${ }^{6}$ until in 1833 it was formally abolished, along with nearly all the other real writs. ${ }^{\top}$

SEc. 127. Writs in the Nature of Writs of Right. There are some eighteen species of proprietary writs, said to be in the nature of writs of right, because in their process and proceedings they agree mostly with the writ of right, although wanting in some material or technical requirement of such writs. ${ }^{8}$ Some of them lie for the recovery of incorporeal hereditaments, while others lie for the recovery of a less estate than a fee. ${ }^{9}$ It will not be necessary to define them all, but only such, with some exceptions, as were in frequent use in their day.

11 Roscoe, Real Ac. 21; 1 Reeves, Hist. Eng. Law, 184.

21 Roscoe, Real Ac. 17-23.

31 Roscoe, Real Ac. 21.

41 Roscoe, Real Ac. 22.

51 Roscoe, Real Ac. 329.
6 2 Pol. \& Mait. 70.

73 \& 4 Wm. IV. c. 27.

8 Booth, Real Ac. 88.

9 Booth, Real Ac. 88 ; 3 Bl. Com. 194. 
SEC. 128. I. The Writ of Right Close in ancient demesne, or the Petty Writ of Right Close, as it was called, lies for tenants who hold lands or tenements in ancient demesne, - that is to say, tenants of manors which were in the hands of the Crown from the tine of the Conquest. The writ was directed to the lord of the manor, and the demandant might make protestation to pursue his action in the nature of a writ of right proper or of some possessory action. ${ }^{1}$ It lies for tenant in fee simple, fee tail, for life or in doiver, and the precept follows the nature of the process appropriate to the form of action selected. ${ }^{2}$

It was said that every writ sued upon the custom of a manor was called a writ of right close, which makes this writ an exception to the distinction already adverted to between writs patent and writs close, ${ }^{3}$ in that it was designated as a writ close in ancient demesne, but was directed to the lord of the manor and not to the sheriff.

SEC. 129. II. Writ of Right De rationabili parte. This is a writ in the nature of a writ of right, between privies in blood only; as between brothers in gavelkind, and sisters and other coparceners where one deforces another. If the ancestor leases for life, and after death of both ancestor and lessee one of the brothers or coparceners enters and keeps out the rest, he or she so kept out could invoke this writ. ${ }^{4}$ It was a writ patent directed to the lord of the tenancy, and lay only for lands in fee simple. ${ }^{5}$ It differed from the writ of right proper in the proceedings under it, the deforcing tenant, on account of privity in blood, being denied the right to vouch, to demand view, offer battle, or put himself upon the grand assize. ${ }^{6}$ It could be brought in, or removed into, the Court of Common Pleas in like manner with the writ of right proper.

SEC. 130. III. Writ of the Right of Advowson. This writ lay for usurpation of the rights of patronage to a church benefice. It was brought to recover back the right of presentation after the patron had been put to his mere right by the admission and institution of the clerk of the usurper. ${ }^{7}$ It was necessary that the demandant should have an estate of inheritance. ${ }^{8}$ After enactment of the statute of Westm. II. c. 5, and 7 Anne, c. 18, which allowed

11 Roscoe, Real Ac. 23.

2 See Appendix, form 25.

32 Reeves, Hist. 366.

4 Booth, Real Ac. 119 ; Fitz. N. B. 20.

Booth, Real Ac. 119.
- Booth, Real Ac. 120; 1 Roscoe, Real Ac. 25, 26.

71 Roscoe, Real Ac. 26 ; Booth, Real Ac. 121.

${ }^{8} 1$ Reeves, Hist. 194; Booth, Real Ac. 122 . 
the possessory writs of darrein presentment and quare impedit for the wrong, this writ became obsolete. ${ }^{1}$

SEC. 131. IV. Writ of the Right of Dower. This writ lay in favor of a widow who had acquired from the tenant by assent her dower in only a parcel of the land to which she was entitled to be endowed in the same time, and was deforced by him of her dower in tine residue. ${ }^{2}$ The writ was patent, and directed to the heir or alienee of the husband or to the guardian, commanding him to do right to the wife in his court, and was removable like other writs of right. ${ }^{3}$ It fell into disuse on account of the remedy afforded by courts of equity in cases of deforcement of dower, and by the courts of law, through the writ of dower unde nihil habet. It differed from the writ of right proper in the proceedings under it, but has been very generally classified with it. This action was excepted from the effect of the abolishing clause in the statute of $3 \& 4 \mathrm{Wm}$. IV. No damages or costs were recoverable. ${ }^{5}$

SEC. 132. V. Writ of Dower Unde nihil habet. This writ lay in favor of a widow who had not been able to acquire possession of any part of the land in which she was entitled to be endowed. ${ }^{8}$ It could be brought by the widow to recover dower in any lands or tenements, corporeal or incorporeal, of which her husband had been seised during coverture in fee simple or in tail and which the issue of the marriage might by possibility inherit. ${ }^{7}$ This writ was aimed at the tenant of the freehold, although addressed to the sheriff $;^{8}$ unless the husband had aliened in his lifetime, in which case it lay against his alienee. By the statute of Merton, 20 Hen. III. c. 1-31, damages were recoverable from the heir, if the husband had died seised, but not from the husband's alienee. ${ }^{9}$

Notwithstanding the remedy in cases of deforcement of dower afforded by equity, this writ remained in partial use till comparatively recent times, particularly when the title of the dowress was disputed and equity declined to interfere. ${ }^{10}$ This action was

11 Roscoe, Real Ac. 27, 28; Booth, Real Ac. 121 ; see Appendix, form 26.

21 Roscoe, Real Ac. 29; Booth, Real Ac. 118.

3 Booth, Real Ac. 118; 1 Roscoe, Real Ac. 29, 30 .

4 C. 27, s. 36.

51 Roscne, Real Ac. 30 ; Scribner on Dower, 656. See Appendix, form 27.
61 Reeves, Hist. Eng. Law, 199201 ; 1 Roscoe, Real Ac. 29 ; Booth, Real Ac. 166.

7 Booth, Real Ac. 166; 1 Roscoe, Real Ac. 39, 40.

81 Roscoe, Real Ac. 40.

9 Booth, Real Ac. 168.

101 Roscoe, Real Ac. 40. 
excepted from abolishment by the $3 \& 4$ Wm. IV. c. 27, s. $36 .^{1}$ The judgment and writs about possession: see Scribner, Roper, and Bright. ${ }^{2}$

SEC. 133. VI. Writ of Quod permittat. This writ lay for recovery of the right of common and other easements owned in fee or in fee tail. ${ }^{3}$ Whether it was to be regarded in the nature of a writ of right or in the nature of a possessory writ depended upon the recitals of the writ bearing on the possession. If it alleged actual possession or user in the demandant, it was treated as a writ of entry. If it omitted such allegations, averring merely a right in the debet only, it was treated as a writ of right. ${ }^{4}$

It lay in favor of the disseisee or his heir against the heir of the disseisor after entry, or the alienee of the disseisor after the disseisor's death. By statute of Westm. II. c. 24, the writ was extended to the successor of the disseisee as against the disseisor or his heirs. ${ }^{5}$ It could be brought in the Common Pleas, or in the County Court by a justicial writ. ${ }^{6}$

When this writ was brought in the form of a writ of right, it would seem that no damages were recoverable. But when prosecuted in the form of a possessory writ, damages for the disturbance or nuisance were recoverable. ${ }^{7}$ It was at an early day superseded by the actions of trespass and trespass on the case. ${ }^{8}$

SEC. 134. VII. Writs of Formedon. This was a writ by which a person recovered an estate which had been entailed, by virtue of his right to it under the entailment. It lay in favor of an issue in tail or remainderman or reversioner to recover possession, when the estate tail was discontinued, and the remainder or reversion displaced and turned into a right. ${ }^{9}$ Although the right to such a writ was recognized in the time of Bracton, no instance of it in the courts appears prior to the passage of the statute de donis conditionalibus. ${ }^{10}$ It was not given by the statute, but was evolved from common law doctrine and the practice of conveyancers. ${ }^{\text {.l }}$ It was founded on the equity of the statute. ${ }^{12}$

11833.

2 Writ: form No. 28.

3 1 Roscoe, Real Ac. 41, 42 ; Booth, Real Ac. 237, 238.

4 Booth, Real Ac. 238 ; 1 Roscoe, Real Ac. 41.

52 Reeves, Hist. Eng. Law, 368; 1 Roscoe, 41, 42.

- 1 Roscoe, Real Ac. 41.
7 Baten's Case, 9 Rep. 55 a ; 1 Roscoe, Real Ac. 309, 331.

81 Roscoe, Real Ac. 40; Booth, Real Ac. 239.

9 Booth, Real Ac. 139.

102 Pol. \& Mait. 24, 25; 1285.

112 Pol. \& Mait. 25.

123 Bl. Com. 192. 
It is in the nature of a writ of right in all respects, except that it is employed to recover an estate in lands or issues thereof less than a fee simple, and is the highest action which a tenant in tail can have, the writ of right proper being confined to such as claim in fee simple. ${ }^{1}$

There were three well recognized writs of formedon, as follows: formedon in descender, which lay in favor of the heir in tail after the tenant in tail had aliened the lands or been disseised of them and had died; formedon in remainder, which lay in favor of the remainderman in fee or in tail or his heir, when the first tenant in tail discontinues and dies without issue or not having made a discontinuance, dies without issue and a stranger abates and deforces the remainderman $;^{2}$ formedon in reverter, which lay in favor of the donor, his heirs or assigns, when the reversion fell to them after death of the donee in tail without issue of his body. ${ }^{3}$ The writ was necessary only when there was a discontinuance. ${ }^{4}$ It lay at common law before the statute of de donis if the donee aliened before issue, and died without any issue. ${ }^{5}$

SEC. 135. VIII. Writ of Quod ei deforceat. This writ was in the nature of a writ of right, and was given by the statute of Westm. II. ${ }^{6}$ to a tenant in dower by curtesy or for life, who had lost his lands by default or non-appearance in any real action, whether duly summoned or not. ${ }^{7}$ Having lost possession by judgment of court, their claim was turned into a mere right; and not having rights in fee, they could not at common law maintain a writ of right; hence the necessity for statutory relief. ${ }^{8}$ If they had lost their lands not by default, but after action tried, they had no remedy whatever. ${ }^{9}$

When the default was in consequence of a false return by the sheriff, it was a concurrent remedy with the writ of deceit. ${ }^{10}$

It lay against the demandant in the real action in which the default had been rendered or against his feoffee. ${ }^{11}$

The effect of it was to restore the tenant to his right to the

11 Roscoe, Real Ac. 53.

21 Roscoe, Real Ac. 57 ; 2 Reeves, Hist. 362. 363.

33 Bl. Com. 192; 2 Reeves, Hist.

41 Roscoe, Real Ac. 43.

s 3 Bl. Com. 192. See form No. 29.
613 Edw. I. c. 4.

7 Booth, 253.

81 Roscoe, 132.

91 Roscoe, 132, 133 ; Ferrar's Case, 6 Co. 8 b.

101 Roscoe, 136 ; Booth, 253.

111 Roscoe, 133. 
lands lost by the defnult, as in all other real actions of precipe quod reddut. ${ }^{1}$

SEC. 136. IX. Other Writs in the Nature of Writs of Right. There were some ten other writs in the nature of writs of right, some of which dropped entirely out of practice before express abolishment, and most of which were seldom ever used. Most of them concerned relief to be had for other things than the recovery of lands and hereditaments. They will be found scheduled in Booth and Roscoe, ${ }^{2}$ and were known by the following names: Ne injuste vexes, nativo habendo, quo jure, de rationabilibus divisis, de recto custodia, de consuetudinibus et servitiis, secta ad molendinum, de recto disclamando, cessavit, writ of mesne, and escheat. Only one of them will be noticed here, - the writ of ne injuste vexes, on account of its resemblance to the remedies of a court of equity.

SEC. 137. X. Writ of Ne injuste vexes. This was a very ancient common law writ which existed prior to Magna Charta and did not originate with it. ${ }^{3}$ It lay when the tenant and his ancestors had held of the lord and his ancestors by fealty and a fixed rent; and the lord had obtained seisin of a greater rent by the voluntary payment of the tenant, and afterwards continued to demand this greater rent and to distrain for it. ${ }^{4}$ The tenant could not avoid this as against an avowry in a replevin suit, but was driven to this writ, which was in the nature of a writ of right patent, for the purpose of restraining the lord from exacting the excess of rent over what was rightfully due under the holding. It lay at common law only for tenant in fee simple. Tenants in tail and for life could avoid by virtue of Magna Charta the excessive seisin suffered by their ancestors, in their plea to an avowry in replevin. ${ }^{5}$

This writ might be maintained quia timet before distress or molestation. ${ }^{6}$ Nearly all questions raised in it became triable in actions of trespass or trespass on the case, and it went gradually out of use at an early day.

It has been referred to as evidence of the flexibility of common law procedure in ancient times, showing that it was not confined to actions merely for compensation or restitution, but that it could

1 Booth, 25̄; 3 Bl. Com. 193. Writ: see form 29 a.

Booth, Real Ac. 125; 1 Roscoe, Real Ac. 3.

3 Booth, Real Ac. 126 ; 1 Roscoe, 100 a.
4 Booth, 126. 37.

- Booth, Real Ac. 126; 1 Roscoe,

61 Roscoe, Real Ac. 38 ; Co. Litt. lieal Ac. 37. 
reach out and enjoin the perpetration of threatened wrongs as subsequently done in chancery. ${ }^{1}$

It was the use of this and similar writs, such as curia claudenda, monstraverunt, warrantic charto, and estrepment, which enabled Blackstone to say, in alluding to the action of trespass on the case, - which was founded on the statute of Westm. II., - that " the provision of the statute (with a little accuracy in the clerks of the chancery, and a little liberality in the judges, by extending, rather than narrowing, the remedial effects of the writ) might have effectually answered all the purposes of a court of equity, except perhaps that of obtaining a discovery by the oath of the defendant."

\section{Article III.}

\section{Ancient Real Actions : Possessory.}

Sec. 138. Writs of Assize.

“ 139. Writs of A ssize continued.

“ 140. Assize of Nuisance.

“ 14l. Assize of Darrein presentment.

“ 142. Assize of Juris utrum.

“ 143. Assize of Mlort d'ancestor.

" 144. Writs of Entry.

“ 145. Writs of Entry sur disseisin.

"146. Writ of Entry sur alienation.

“ 147. Writ of Entry sur intrusion.

“ 148. Writ of Entry sur abatement.

“ 149. Writ of Entry Ad terminum qui præteriit.

\footnotetext{
Sec. 150. Writ of Causa matrimonii prælocuti.

“ 151. Writs of Entry as affected by feoffment and descent.

" 152. Writs ancestral possessory.

" 153. Writ of Quare ejecit infra ter. minum.

“ 154. Writ of Quare impedit.

“ 155. Writ of Waste.

“ 156. Writ of De ejectione firmæ.

“ 157. Writ of Deceit.

“ I58. Writ of Partition.

“ 159. Writs of Warrantia chartæ and Curia claudenda.
}

SEC. 13S. Writs of Assize. The number of possessory actions was very great. It will be sufficient to mention definitely only such as had been most in use. Of all possessory actions the writ of assize was the most ancient and favored. It originated in an edict of the Council known as the Assize of Clarendon in the reign of Henry II. in $1166 .^{3}$ It was distinctively a possessory action, contrived to protect the actual possessor of a free tenement, irrespective of the mode in which he acquired it, against every wrongful dispossession or disseisin, except by judgment of court. ${ }^{4}$ It was a summary proceeding in which the jury impanelled, answered the simple question, whether the demandant was

1 Bigelow, Hist. Pro. 166-168.

$23 \mathrm{Bl}$. Com. 51. See form 30.

31 Pol. \& Mait. 124, 125.
41 Pol. \& Mait. 125; 2 Pol. \& Mait. 49. 
seised or possessed of a free tenement, and had been disseised or dispossessed of it by the defendant. If the finding was in favor of the demandant, he was restored to the possession. All rights of property, except as flowing from the facts of actual seisin and disseisin, were excluded from consideration, and left to be vindicated in some proprietary action. Such was the original and primitive scope of the action; but a practice somewhat at variance with it gradually grew up of entertaining special issues founded on some right of the defendant to oust the plaintiff, which operated as a reason for not taking the assize. ${ }^{1}$

Within the meaning of this writ, disseisin was a wrongful ouster of a freehold, and it could only be accomplished by means adequate to transfer the freehold. ${ }^{2}$ Mere entry without process was not necessarily a disseisin - it had to be done presumably with the intention of ousting the true owner and claiming the freehold or by taking the profits. ${ }^{3}$ Whatever may be the act, it must be such that an intention to disseise can be reasonably inferred from it. ${ }^{4}$

The doctrine of disseisin by election is properly confined to those cases in which, either on account of the nature of the property, to which the injury is done (as, for instance, an incorporeal hereditament), or of the act which is committed (as, for instance, a feoffment by a tenant for years), no actual disseisin can take place. $^{5}$ In such cases the injured person may elect to treat the acts as equivalent in law to an actual disseisin. But where the property is susceptible of such an actual injury, and the acts had all the qualities necessary to constitute a disseisin, and no other inference can reasonably be deduced from them, it is not in the power of the injured party to elect whether or not he will consider himself disseised. ${ }^{6}$

The writ of assize lay only in the lifetime of the disseisor. $\mathrm{He}$ had to be a defendant in the action. His tenant or his people may be joined, but the writ must abate if the disseisor is left out as a party defendant. ${ }^{\top}$

SEc. 139. Writs of Assize continued. There were five species of these writs :-

I. Assize of Novel Disseisin: in which the owner of a freehold

1 Booth, 212, 213 ; 1 Roscoe, 228.

21 Roscoe, Real Ac. 61, 62.

81 Roscoe, Real Ac. 62.

1 Roscoe, Real Ac. 62.
51 Roscoe, Real Ac. 62.

61 Roscoe, Real Ac. 62.

71 Roscoe, 64; 2 Pol. \& Mait. 54,55 . 
has been disseised, or chooses to admit himself disseised of lands, tenements, or herditaments, by means of an ouster since the last visit of the justices in eyre. ${ }^{1}$ It could be maintained only in the lifetime of the disseisee and in his name. ${ }^{2}$ The demandant's estate must not be less than for life; but by statute of Westm. II. c. 18 , the remedy was given to tenant by elegit. ${ }^{3}$ At common law it lay only for lands and common of pasturage, but was by statute extended to other incorporeal property. ${ }^{4}$ In its origin it was intended as a summary remedy against a very recent disseisin not happening more than a year off; but the period of time was lengthened greatly, - a fact which tended to divest it somewhat of its original characteristics as a possessory action. ${ }^{5}$ By statute of 32 Hen. VIII. c. 2 , the disseisin had to be within thirty years.

Another phase at war with its original purpose as a remedy for redressing violated possession consisted in the practice of permitting special pleas, which resulted in introducing issues involving the right of the defendant to dispossess the plaintiff or a want of right in the plaintiff to be restored. ${ }^{6}$ These special pleas. superseded the general issue of nul tort, nul disseisin, and disposed of the case frequently upon an issue involving proprietary rather than possessory rights. ${ }^{7}$ The wrong complained of consisted in the disturbance done to an actual seisin as distinguished from a seisin in law. It could not be maintained on a mere seisin in law. ${ }^{8}$

This was the only writ by which at common law the demandant recovered not only the land itself, but damages from the disseisin and costs. ${ }^{9}$ In modern practice it has been entirely superseded by the action of ejectment. ${ }^{10}$

SEc. 140. II. Assize of Nuisance, in which the owner of the freehold sued for abatement of a nuisance. ${ }^{11}$ It was superseded by action on the case. ${ }^{12}$

SEC. 141. III. Assize of Darrein presentment. This writ lies in favor of a tenant in fee or in tail when he or his ancestors have presented to a church, and the clerk has been instituted, and the demandant, upon a subsequent vacancy, is afterwards hindered

11 Roscoe, Real Ac. 64, 65.

22 Pol. \& Mait. 64.

31 Roscoe, 64.

1 Roscoe, Real Ac. 65, 66, 67, 68.

52 Pol. \& Mait. 51.

61 Roscoe, 228; Booth, 212, 213.

71 Roscoe, 228 ; Booth, 213, 271 -
81 Roscoe, 65.

91 Roscoe, 64, 69.

10 Writ: see Appendix, form 31.

112 Pol. \& Mait. 53, 533.

121 Roscoe, 73, 74 ; 3 Bl. Com. 221.

Writ : form 32 . 
in presenting to the same church by a stranger who claims the right of presentation. ${ }^{1}$ It lay for tenant for life or years if he has himself presented.2 This writ was superseded by the writ of quare impedit, which lay for disturbance of presentment irrespective of any former presentment. ${ }^{3}$

SEc. 142. IV. Assize of Juris utrum. This, was called the parson's writ of right. It lay in favor of a parson or prebendary of a church, whose predecessor had died, and an abatement has taken place; or who had aliened the lands of the church, or lost them by default or reddition in a possessory real action, or by verdict upon trial, if the patron and ordinary were not party by aid prayer. ${ }^{4}$ This writ became useless after the statute of 13 Eliz. c. 10, which disabled all ecclesiastical persons from making alienations. ${ }^{5}$

SEC. 143. V. Assize of Mort d'ancestor. This writ furnished redress against disseisin by abatement or intrusion. It lay where the father, mother, brother, sister, uncle, aunt, nephew, or niece died seised of lands, rents, or hereditaments in fee simple, and a stranger after their death made entry upon them, thereby effecting an abatement. The heir was entitled to this writ. ${ }^{6}$ It thus appears that the demandant had to be not only an heir, but an heir of near relationship.

The writ is said to have originated in 1176 , ten years later than the writ of novel disseisin. ${ }^{\top}$ It was always regarded as a possessory writ, and contained the averment of a seisin in fact of the ancestor at the time of his death as of fee within the period of limitations, and the fact of a holding by the defendant. ${ }^{8}$ This adverse holding by a stranger constituted a disseisin of the heir by abatement or intrusion. This writ has been sometimes classed with writs ancestral possessory. ${ }^{9}$ At common law no damages were recoverable; but by statute of Gloucester, c. 1, damages were awarded in all cases of recovery in this action. ${ }^{10}$

It was superseded by the action of ejectment, ${ }^{11}$ and was included in the abolishing statute of $3 \& 4 \mathrm{Wm}$. IV. c. 27 , s. $36 .^{12}$

SEC. 144. Writs of Entry. Prior to the writ of assize it was

13 Bl. Com. 245; 1 Roscoe. Real Ac. 74 .

21 Roscoe, Real Ac. 74.

31 Roscoe, Real Ac. 74.

4 Fitz. N. B. 49; Booth, Real Ac. 221.

${ }^{5}$ Booth, 221.
6 Booth, $206 ; 3$ Bl. Com. 185.

- 1 Pol. \& Mait. 126.

8 Booth, 206.

${ }^{9}$ Comyn, Dig. Action, D. 2.

${ }_{10} 1$ Roscoe, Real Ac. 314.

111 Roscoe. Real Ac. 76.

1: Writ : form 33 . 
necessary, in every case where a person was deprived of his power of entry, to resort to a writ of right. ${ }^{1}$ The writ of assize, as already stated, furnished him a remedy only against the disseisor and his tenant and alienee during the disseisor's lifetime. ${ }^{2}$ The writ of entry became necessary as a remedy of similar though higher character against the heir of a disseisor and in favor of the heir of a disseisee..$^{*}$ Generally speaking, it lay in favor of a person who, having possession of lands as tenant in fee, fee tail, or for life, is ousted therefrom; or having the right of possession is deforced therefrom, to restore him to the possession. ${ }^{4}$ As a remedy distinct and different from the writ of assize, it first appears as a writ of course in 1205 and $1224 .^{5}$ Although anciently denied, it came to be a concurrent remedy with the writ of assize of novel disseisin, when it was brought against the original disseisor by the disseisee himself, in which case it was called a writ of entry in the nature of an assize or writ of entry in de quibus. ${ }^{6}$ Its original use and distinctive features made it a remedy against one coming into possession without fraud or tort, as by the deed of a disseisor or of one who had but a particular or defeasible estate. ${ }^{\top}$ But it came to be used when a disseisin was suffered by a demandant or his ancestor. ${ }^{8}$

The writ in most common use alleged substantially that the demandant had an inheritance in the messuages sued for; that the tenant in occupation had no entry into them but by a certain named ancestor of the demandant to whom demandant was heir, and that it was demised to the tenant by said ancestor for a term which had expired. In this manner the principal issue for trial was confined to the infirmity of title suggested in the writ, viz., entry under a right which had expired. ${ }^{9}$ There were some five forms of this writ, which were distinguished from each other according to the nature of the disseisin or dispossession and the degrees of descent or alienation between the demandant and the original disseisor. ${ }^{10}$

SEC. 145. I. Writ of Entry sur disseisin; where a disseisin had been suffered by the demandant or his ancestor.

SEC. 146. II. Writ of Entry sur alienation; as where the tenant

11 Roscoe, 88; Gilb. Ten. 47, 49.

21 Roscoe, 64 .

2 Pol. \& Mait. 64.

4 Bl. Com. 180.

6 2 Pol. \& Mait. 64.

- Booth, 172-174; 1 Roscoe, 91.
7 Booth, 172.

8 Booth, 175.

9 Booth, 172 .

10 See forms $34,35,36,37$, in Appendix. 
of a particular estate wrongfully aliens it, which operates as a deforcement of the reversioner.

SEC. 147. III. Writ of Entry sur intrusion. Where, on the expiration of a preceding estate of freehold, a stranger wrongfully intrudes, by which he affects a deforcement of the reversioner. ${ }^{1}$

SEc. 148. IV. Writ of Entry sur abatement; where, on the death of the ancestor, a stranger abates and deforces the heir. It seems to have been in this case a concurrent remedy with the writ of mort d'ancestor or writ of ayel..$^{2}$

SEC. 149. V. Writ of Entry Ad terminum qui præteriit. Where the owner of a freehold leases lands or tenements for life or years, and after the expiration of the term by efflux of time or surrender, the lessee or a stranger, either entering upon or continuing in, detains the possession from the lessor or his heir, thereby effecting a disseisin by deforcement. ${ }^{3}$

It was doubted whether this writ lay in event of an alienation in fee by the tenant during the lifetime of the tenant or his alienee; the remedy by assize of novel disseisin being expressly given by statute of Westm. II. c. 25.4 On account of this statute, which was construed as preserving the entry of the lessor or his heir, this writ was little in use. ${ }^{5}$ If both the tenant and his feoffee are dead, this writ was the proper remedy. ${ }^{6}$ It also lay in favor of the grantee of the reversion against the lessee, his heir or assignee. ${ }^{7}$ It was eventually superseded by the action of ejectment.

SEC. 150. VI. Writ of Causa matrimonii prælocuti, which lay in favor of a woman who has given lands in fee or for life to a man in consideration of a promised marriage, and he fails to keep his promise within a convenient time when required by her to do $\mathrm{so.}^{8}$ This writ became obsolete at an early day, no count on it being found in Rastall's entries. ${ }^{9}$

There are many other writs of entry found in the register of writs, which are only variations of the forms of those already defined; and which being of only occasional or limited use may be dismissed with a recital of their names and a reference to the authors by whom they are more fully defined and described.10

1 See form 37 .

21 Roscue, 88.

8 Booth, 195 ; Fitz. N. B. 201.

4 Booth, $195 ; 1$ Roscoe, 97.

5 Booth, 195.

- Booth, 195.
71 Roscoe, 97, 98.

8 Booth, 197 ; 1 Roscoe, 98.

9 Booth, 197.

10 Booth, 185-200; 1 Roscoe, 9298; Stearns, Real Ac. 139-274. 
They are as follows: dum non fuit compos mentis, dum fuit infra atatem, dum fuit in prisona, ad communem legem, in casu proviso, in consimili casu, cui in vita, cui ante divortium, sur cui ante divortium, sine assensu capituli.

SEC. 151. Writ of Entry as affected by Feoffment and Descent. The foregoing writs of entry defined by us (and probably all others) varied in form according to the number of degrees which the tenant was distant from the original wrongdoer by alienation or descent; and the particular degree in each case gave a technical name to the form used, as being a writ of entry in the per, in the per and cui, or in the post. To explain more fully: if the original wrongdoer had made a feoffment, or his estate had descended to his heir, the feoffee or heir was alleged to be in in the per, the writ going on to say "into which be had not entry save by (per) B," who demised to him, and who had disseised the demandant or his ancestor. If there was a second feoffment or alienation from the wrongdoer, the recital of the writ was: "into which he (the defendant) had not entry save by (per) C, to whom (cui) $\mathrm{B}$ demised it, who had disseised the demandant (or his ancestor)." 1 The writ at common law could not be maintained in the event of more than two alienations or descents, except when the defendant came in by intrusion or disseisin of his own, in which case he was said to be in in the "post," his wrongful entry not being counted as a degree. ${ }^{2}$ But by the statute of Marlborough a writ of entry was given where the entry of the tenant was lawful by descent or conveyance, notwithstanding any number of alienations or descents. ${ }^{3}$ In this latter writ it was alleged that the defendant had no entry into the land save after (post) the disseisin, which B had perpetrated upon the demandant or his ancestor. ${ }^{4}$

SEc. 152. Writs Ancestral possessory. We have seen that the assize of mort d'ancestor in favor of the heir was restricted to the seisin of an ancestor of near relationship, and did not lie in favor of remote heirs, such as grandsons and cousins. ${ }^{5}$ About a half-century later (21 Hen. III.) the justices, after a dispute with the magnates, succeeded in formulating the writs of aiel, besaiel, and cousinage to meet the shortcomings of the writ of mort

11 Roscoe, 89 ; 2 Pol. \& Mait. 64.

1 Roscoe, 90; Booth, 173.

Booth, 173.

42 Pol. \& Mait. 65. See Writs of
Entry, Appendix, forms 32, 34, 35, 36, 37.

$\checkmark$ Sec. 143. 
d'ancestor. ${ }^{1}$ In this purpose and effect they discharged the functions of a writ of mort d'ancestor to these remote relations, and were said to lie in favor of the heir in all cases of abatement by a stranger upon death of his aiel, besaicl, tresaiel, or cousin, more remote, with like effect as a writ of mort d'ancestor in favor of the heir upon abatement of his ancestors of a nearer relationship. ${ }^{2}$

The formulated writ does not follow closely the language of the writs of assize, but resembles in some respects the writ of entry, in calling for a delivery of the premises, instead of an inquiry as to the seisin of the ancestor, heirship of the demandant, and abatement implied in the adverse holding of the defendant. Like the writ of mort d'ancestor, the seisin was alleged to be as of fee.

The writs were distinguished in name by the degrees of kinship, -if brought on the seisin of a grandfather it was called an aiel; if on the seisin of a great-grandfather, a besaiel; if on the seisin a great-great-grandfather, a tresaiel ; if on the seisin of a collateral relation more distant than the degrees which entitled one to a writ of mort d'ancestor, a cousinage. ${ }^{3}$

Another ancestral possessory writ was known by the name of nuper obiit. It lay "when the grandfather, father, brother, uncle, or other ancestor of the demandant died seised in fee simple of lands, tenements, or rents, and after such death one of the heirs of the same ancestor enters and deforees the demandant, in which case the heir who is deforced may have a nuper obiit against the other parcener or coparceners." 4 The difference between this and the writ in the nature of a writ of right de rationabili parte consists in the distinction that the latter writ may be brought if the ancestor was seised at any time; while in a nuper obiit the ancestor must die seised. ${ }^{5}$

These ancestral actions passed out of use when the right of entry was preserved and continued notwithstanding the facts of an abatement, and have been supplanted by the modern action of ejectment. ${ }^{6}$

SEC. 153. Writ of Quare ejecit infra terminum. This writ lies in favor of a tenant for years to whom the owner of the fee has leased land for a term of years, and who afterwards makes a

12 Pol. \& Mait. 57.

2 Comyn, Dig. Assize D; Fitz. N. B. 221 ; Booth, 200.

Fitz. N. B. 221; 2 Pol. \& Mait.
57. Writ of aiel or besaiel; Appendix, form 34 .

1 Roscoe, 128.

5 Booth, 205.

6 Booth, 204. 
feoffment in fee or a lease for life of the same lands to a stranger, in pursuance of which the tenant has been ejected from the premises before the end of his term. ${ }^{1}$ It lay against the lessor or against his feoffee or lessee for life. ${ }^{2}$ The writ was first introduced in the reign of Henry III., about $1235 .^{3}$ The plaintiff recovered damages for the loss of so much of the term as the defendant had wrongfully withheld, and the sheriff put him in possession of the unexpired portion of the term. ${ }^{4}$ It has been classified with writs of entry, which it resembles in some respects, especially in its final outcome. But it is sharply distinguished from them in being a remedy for a mere termor, whose possession implied a seisin of his landlord and not of himself. It is the first remedy in the nature of a real action vouchsafed to a tenant for years to redress an injury to his actual possession by ouster, the remedy by assize, which existed in favor of his landlord against any one who without his consent dispossessed his tenant, being denied to the tenant himself. ${ }^{5}$ Accordingly I have treated it as a possessory writ sui generis.

Notwithstanding some insistence to the contrary, ${ }^{6}$ the better opinion as prevailing in later times is that this writ lay only against an ejector who was either the lessor himself or some one who derived title under him, and never against a mere stranger, the remedy in the latter case being supplied by writ of ejectione firmo, which was developed at a much later day. ${ }^{7}$ It is probable that the restricted recitals in the writ operated to limit it as a remedy against the lessor or those in privity with him. ${ }^{8}$ The writ alleges a feoffment by the lessor to a third person and an ejectment by reason of the feoffment. As the lessor had to make entry in order to effect his feoffment, he thereby became a party to the ejectment, although it may have been carried out by the feoffee himself.

It was supplanted by the writ of ejectione firmo, when that writ in the reign of Henry VII. ${ }^{9}$ was transformed by the courts into a writ for recovery of the term and damages against any ejector. ${ }^{10}$

11 Roscoe, Real Ac. 98.

21 Roscoe, Real Ac. 98.

32 Pol. \& Mait. 107.

- 3 Bl. Com. 199.

5 Pol. \& Mait. 105-107.

- Bracton, f. 220 ; 2 Reeves, Hist.

136 (ed. 1880).
71 Roscoe, Real Ac. 99; Adams, Eject. 45 ; 2 Pol. \& Mait. 109.

82 Pol. \& Mait. 107.

91499.

10 See form 38 . 
SEc. 154. Writ of Quare impedit. This writ appears early in the thirteenth century. ${ }^{1}$ It was possessory in its nature, and only lay at common law in favor of the patron of an advowson, who was hindered from presenting his clerk during a vacancy in the benefice, to restore him to the possession of his advowson and to his right of presentation. ${ }^{2}$ It did not lie after the disturber had succeeded in wrongfully filling it with his clerk, ${ }^{3}$ the patron in that case being remitted to the writ of right of advowson.

By statute of Westm. II. ${ }^{4}$ and 7 Anne, c. 18, it was given in every case of usurpation, whether the clerk of the usurper was instituted or not, provided the writ was brought within six months after the institution. ${ }^{5}$. By virtue of these statutes it superseded in practice the writ of the right of advowson, which lay after institution of the usurper's clerk, and came to be used in the trial of all disputed titles to advowsons. ${ }^{6}$

It could be brought against the disturber only or against the incumbent and disturber, or against the bishop, disturber, and incumbent. ${ }^{7}$ If the demandant succeeded, he had judgment for recovery of his presentation to the benefice and a writ to the bishop requiring him to admit a fit person on demandant's presentation with damages, where damages were recoverable. ${ }^{8}$ This action was one of the four actions excepted from the abolishing effect of the statute $3 \& 4$ Wm. IV.c. 27 , s. $36,{ }^{9}$ and has continued down to modern practice. ${ }^{10}$

SEc. 155. Writ of Waste. This was a possessory action which lay in favor of the reversioner or remainderman in fee simple or fee tail against the tenant of the particular estate for life for the spoil or destruction of lands or corporeal hereditaments held by him, to the disherison of. the reversioner or remainderman. ${ }^{11}$ It lay at common law only in favor of the immediate remainderman and reversioner, and not in favor of one between whom and the guilty tenant there existed a mesne estate. ${ }^{12}$ This disqualification operated only to prevent the action during the continuance of the mesne estate, and left the remainderman or reversioner at liberty after its

12 Pol. \& Mait. 138, note 1.

21 Roscoe, 100.

3 Booth, 223, 224.

$413 \mathrm{Edw}$. I.

5 Booth, 223; 1 Roscoe, 100.

6 Steph. Pl. 10.

Booth, 226.

Martin Civil Procedure-9
81 Roscoe, 106 ; Booth, 225.

9 18:33.

102 Sellon's Pr. 223; Steph. Pl. 10.

Writ : form 39 .

111 Roscoe, 107.

121 Roscoe, 107. 
termination to sue for any spoil or destruction happening during its continuance. ${ }^{1}$

There seems to be a conflict of opinion as to the persons who were punishable for waste at common law. ${ }^{2}$ It is probable that in the earliest times the tenant at life was not liable for waste. ${ }^{3}$ It came to be a recognized remedy at common law as against the guardian in chivalry, tenant in dower, and tenant by curtesy, whose estates were created by act or operation of law. ${ }^{4}$ Whether the ordinary tenant for life whose estate was created by act of the parties was liable for waste in the absence of a prohibitory covenant, prior to the statutes of Marlbridge and of Gloucester, may be open to question. ${ }^{5}$ But by these statutes the action was given as against all estates for life, whether rising by operation of law or acts of the parties. $^{6}$

In this action the estate of the guilty tenant, if unexpired, is forfeited and the demandant recovers the land wasted and damages; if it has expired, then only damages. ${ }^{7}$

At common law, if a tenant against whom a real or mixed action had been brought, committed waste after judgment and before execution, a writ of estrepment of waste lay in favor of the demandant restraining him, or commanding the sheriff to prevent him from committing waste by arrest and imprisonment. ${ }^{8}$ By the statute of Gloucester ${ }^{9}$ this writ was given to the demandant in a real action at any time during its pendency, as a remedy auxiliary to it. ${ }^{10}$ The writ of waste was superseded at law by action of trespass on the case, and the writ of estrepment of waste was supplanted by a more efficient remedy in equity. ${ }^{11}$

SEC. 156. Writ of De ejectione firmæ. This was in its origin an action of trespass for damages in favor of a termor against any one who had unlawfully entered and broken his "close," meaning his premises. ${ }^{12}$ At what precise time he became entitled to it in its effect as an action of trespass cannot be stated; possibly as early as the reign of Edward I. A specialized writ of this name was for-

11 Roscoe, 107.

2 Bractoll, 315-317; 1 Reeves, Hist. 58 , note 1.

2 Pol. \& Mait. 8, 9.

41 Roscoe, 109.

52 Pol. \& Mait. 9.

- 1 Roscoe, 110 ; Bispliam, Eq. 430;
Marlbridge, 52 Hen. III. c. 23; Gloucester, $6 \mathrm{Edw}$. I. c. 5 .

71 Roscoe, 123.

81 Roscoe, 124.

96 Edw. I. c. 13.

101 Roscoe, 124 ; 3 Bl. Com. 225.

11 Writ : form 40 .

122 Pol. \& Mait. 108. 
mulated to meet the case of a disturbance of the termor's possession by a stranger deriving no right whatever from the lessor. ${ }^{1}$ In its first use it is quite clear that only damages were given in the judgment of recovery, ${ }^{2}$ notwithstanding high authority to the contrary. $^{3}$ The first reported case in which the lessee in this action was allowed to recover his term as well as damages is found in the reign of Henry VII. in 1499. ${ }^{4}$ While this writ in its extended use supplied a remedy which the restricted writ of quare ejecit infra terminum denied, it is clearly distinguishable from it. It is probable that the writ of quare ejecit infra terminum, which appeared first in time, furnished a suggestion of the use to which the writ of ejectione forma, was turned. In this transformation it furnished to a real action of a possessory nature the simple and rapid procedure of a personal action. ${ }^{5}$

How the modern action of ejectment, which has superseded it, was developed from this ancient writ, is shown in our sketch of that. action. ${ }^{6}$

SEc. 157. Writ of Deceit. The ancient writ of deceit, in so far as it was employed for recovery of real estate, must be regarded in. the nature of a possessory writ. It was of rather limited application lying in favor of a tenant against whom judgment by default in a real action had been suffered in conseqnence of a false summons by the sheriff, or perhaps by covin of the attorney.' Although it was commonly issued as a judicial writ from the court in which the default had been rendered, an original writ for the same purpose was obtainable in Chancery. ${ }^{8}$

By means of this writ the defaulting tenant obtained a restoration of his land, and the mesne profits which were usually remitted. ${ }^{9}$ It lay also in favor of the heir of the defaulting tenant, but not in favor of the reversioner $;{ }^{10}$ and it could be prosecuted as soon as the judgment was rendered and before entry of the demandant. ${ }^{11}$ It lay against the demandant in the real action in which

12 Pol. \& Mait. 109.

2 Runnington, Eject. 5 ; $3 \mathrm{Bl}$. Com. 200.

82 Reeves, Hist 549, Finlason's note; 3 Reeves, Hist. 177, Finlason's note.

414 Hen. VII. Rast. Ent., folio 252 3 3 Reeves, Hist. 178.

- 3 Reeves, Hist. 178.
6 See note 4 in Appendix. See form 41 in Appendix.

7 Booth, Real Ac. 251; 2 Pol. \& Mait. 533.

81 Roscoe, Real Ac. 136; Fitz. N.

B. $97 \mathrm{c}$.

y 1 Roscoe, 139.

101 Roscoe, 137.

111 Roscoe, 136. 
the dereult happened and against his heir upon death of the demandant after recovery of judgment. Upon his alienation after recovery it lay against him and his alienee. If after recovery and alienation he died, it lay against his heir and alienee. The sheriff to whom the writ in the first action was directed and the summoners are parties defendant. ${ }^{1}$

This writ in case of deceit for non-summons is said to be in the nature of an audita querela $;^{2}$ and the purpose of it was more easily attained in later times by motion to set aside the judgment, supported by affidavits to the effect that the tenant had never been summoned. ${ }^{3}$

The tenant was not concluded by an adverse decision on this writ or motion; but if he was a tenant in fee he might resort to the writ of right; if a tenant for life only, to the writ of quod ei deforceat under the statute of Westm. II., the judgment by default for non-summons not being a bar to other appropriate actions. ${ }^{4}$

SEC. 158. Writ of Partition. Before closing our account of real actions it is proper to notice the writ of partition, which is a peculiar action relating to the realty, in that it is, strictly speaking, neither proprietary nor possessory, the party bringing it being in the possession and enjoyment of his rights of property and possession. The law giving this action recognized the right of a coparcener to possess and enjoy his share separately from his coparceners. The writ lay at common law from very remote tines in favor of a tenant in coparcenary against cotenants thereof for a partition of the lands so held by them. ${ }^{5}$

By statute of 31 Hen. VII. c. 1, and 32 Hen. VIII. c. 32, the remedy was extended to joint tenants and tenants in common, by inheritance or for life or years. ${ }^{6}$ The partition of copyhold lands was effected by a plaint in the lord's court in the nature of a partition. ${ }^{7}$

The writ of partition existed only as between parties in possession. Tenants in remainder were not competent parties to the proceeding and were not affected by it. When the partition could not be equally made, the court could adjudge payment of a sum of money to equalize the division, which was called owelty in partition.

11 Roscoe, 137.

21 Roscoe, 138.

8 Searle $v$. Long, 1 Mod. 248.

1 B w.. 132,133. See form 42 . Eq. s. 487.
52 Pol. \& Mait. 305.

61 Roscoe, 130.

7 Adams, Doc. Eq. 229 ; Bispham, 
There were two judgments in the action of partition : first, an interlocutory one that the demandant have partition, for which a writ issues; next, a final judgment on return of the writ. ${ }^{1}$ In case of default the proceedings are governed by the act of $8 \& 9 \mathrm{Wm}$. III. o. 31 .

The writ of partition was superseded by the superior remedy of bill in equity for partition, ${ }^{2}$ and both writ and plaint were abolished in the reign of William IV. ${ }^{3}$

SEC. 159. Writs of Warrantia chartze and Curia claudenda. There are two other writs relating to realty which, like the writ of partition, cannot be scheduled with either proprietary or possessory writs; viz. the writ of warrantia charta, which lies in favor of a person who wishes to take advantage oì a warranty in lieu of voucher, by judgment in which he binds the land of the warrantor and recovers damages $;^{4}$ the writ of curia claudenda, which lies in favor of a tenant of the freehold against the owner of land adjoining, who will not enclose his land as he ought..5

\section{Article IV.}

\section{Forcible Entry and Detainer.}

Sec. 160. Introductory.

“ 161. Defined.

\author{
Sec. 162. Forcible Entries at Common Law. \\ Sec. 164. History continued.
}

SEc. 160. Introductory. The civil remedy for a forcible entry or forcible detainer consisted in a summary restitution of the premises by the justices of the peace or by the King's Bench, after a verdict of a jury finding the fact of force in the entry or detention. This remedy was not anciently recognized as a civil action. It was authorized by statute law as an incident ${ }^{6}$ to a criminal prosecution for the public offence of making entry upon land by the use of overpowering force. As the proceeding under the statute might result in restoring the disseisee to his land again, and was employed at an early day as a substitute for real actions, greatly diminishing resort to them, ${ }^{7}$ some mention of it is proper in any complete account of the ancient remedies for recovery of land.

11 Roscoe, 131, 338.

21 Roscoe, 131.

s 3 \& 4 Wm. IV. c. 27 , s. 36 . See form 43.
- 1 Roscoe, 142.

51 Roscoe, 144.

6 Rex $v$. Fawcet, Yelv. 99.

7 Hale, Hist. Com. Law, c. viii. 
SEc. 161. Defined. A forcible entry consisted in violently taking possession of lands or tenements with menaces, arms, and force, and without authority of law. A forcible detainer consisted in keeping possession of lands and tenements with menaces, arms, and force, and without authority of law." Both were offences against the King, as well as wrongs against the person turned out or kept out of possession. A forcible entry might be complete without being followed by a forcible detainer. A forcible detainer might take place after a peaceable entry. But the better opinion is that the previous entry must have been unlawful, if it was not forcible. ${ }^{2}$

SEc. 162. Forcible Entries at Common Law. It has been laid down by high authority that a person having the right to enter upon land was permitted by the common law to do so by the use of overpowering force. ${ }^{3}$ This declaration cannot be accepted without qualification. It would seem that this right was anciently conceded, provided it was exercised within certain limitations of time. ${ }^{4}$ Outside of these limitations, when an entry culminated in something more than a mere trespass, and constituted a breach of the peace, there can be no doubt that the disseisor was always liable at common law to indictment as for a misdemeanor. ${ }^{5}$ A person without the right of entry was liable to indictment at common law for making entry, although it was unaccompanied with force. ${ }^{6}$ But this liability to a public prosecution did not directly affect the pos. session acquired by the disseisor entering with force. In the civil action of trespass quare clausum fregit the defendant could always plead liberum tenementum, and if he sustained this plea by proof of a freehold in him, the action would be defeated, notwithstanding his entry was made with actual violence, provided the violence was no more than necessary to accomplish his actual entry. ${ }^{7}$

It is true that a disseisee had his remedy in the real action of assize of novel disseisin, whereby he might regain possession and damages for the wrong, founding his action on the right flowing

14 Bl. Com. 148.

2 Chit. Gen. Pr. 238, 239; Rex v. Wilson, 3 Ad. \& El. 817.

- 4 Bl. Com. 148; 4 Bac. Abr. For. Ent. 321.

- Bract. 162, 163.

52 Chit. Gen. Pr. 232; 2 Pol. \& Mait. 44; Rex $v$. Storr, 3 Burr. 1698; Rex $v$. Wilson, 8 T. R. 357 ; Com'w. v. Shattuck, 4 Cush. 141 ; Hender- son's Case, 8 Gratt. 708 ; State $v$. Wilson, 3 Mo. 125.

6 Reg. $v$. Dyer, 6 Mod. 96.

7 Taylor $v$. Cole, 3 T. R. 292 ; Co. Litt. 257 a ; Taunton $v$. Costar, 7 'T. li. 431 ; Hyatt $v$. Wood, 4 Johus. 150; Dustin v. Cowdry, 23 Vt. 631: 'Turner $\because$ Neymott, 1 Bing. 158 ; lves $v$. Ives, 13.Johns. 235 ; Fulı $r$. Dean, $26 \mathrm{Mo}$. 116. 
from a peaceable possession. Undoubtedly the assize of novel dissisin in its origin was intended to redress the wrong of a forcible dispossession irrespective of title or right of entry, ${ }^{1}$ but.this intention was not always carried out by the courts. In the course of time the disseisor was permitted to make special pleas which took the case out of the primary issue of actual seisin and disseisin, and in one form or another interposed the right to make entry as a defence to the forcible ouster of the plaintiff. ${ }^{2}$

Moreover, an assize of novel disseisin would not lie against a disseisor who used an overpowering force to regain his possession immediately after he had been himself dispossessed. ${ }^{3}$ A person disseised with force, according to Bracton, was given four days within which to gather in his friends from the four points of the compass to help him to regain his possession. ${ }^{4}$ Further time was allowed him if he was dispossessed during his absence from the premises. The right to use force, except within these limitations, was never conceded by the common law, ${ }^{5}$ although it furnished no complete remedy in its scheme of civil actions when the forcible entry was made in pursuance of a legal right to enter. The right of entry could be exercised by force, subject only to indictment when it culminated in a breach of the peace. ${ }^{6}$ The scrious breaches of peace attending the archaic remedy of self-help suggested the necessity for the restraining acts of Parliament, which not only forbade and punished forcible entries and detainers as public offences, but added the summary remedy of restitution as a redress for the private wrong resulting from the public offence.

SEC. 163. History after the Statute. By the statute of 5 Rich. II. c. 7,7 it was provided that " none thenceforth make entry into any lands or tenements, but in cases where entry is given by the law; and in that case not with strong hand, nor with multitude of people, but only in a peaceable and easy manner; and if any man do to the contrary, and thereof be duly convicted, he shall be punished by imprisonment of his body and thereof ransomed at the King's will." 8

12 Pol. \& Mait.48.

Butcher v. Butcher. 7 B. \& C. 399 ;

2 Pol. \& Mait. 48; Booth, 212,213; Krevet v. Myer, 24 Mo. 107; Fuhr v. Roscoe, 228.

31 Reeves, Hist. 344.

42 Pol. \& Mait. 49 ; 4 Law Quar. Rev. 30.

52 Pol. \& Mait. 44.

Dean, 26 Mo. 116 ; Beecher $v$. Parmele, 9 Vt. 352 .

' 1381.

84 Bac. Abr. For. Ent. A. 321 ; 2 Reeves, Hist. 475.

6 Taunton v. Coster, 7 T. R. 431 ; 
This statute made no provision whatever against forcible detainers ; neither did it furnish any speedy remedy for its enforcement, but left the-party injured to the existing remedies by indictment or real action. The object of this statute was to put an end to forcible entries in all cases, including those which were permitted by the cornmon law, as heretofore mentioned, by subjecting the offenders to criminal process. The defects to which allusion has been made were remedied by subsequent legislation.

By statute of 15 Rich. II. c. $2,{ }^{1}$ it was enacted that the previous statute should be "kept and fully executed" as to those who forcibly held the premises after having forcibly entered them. The power of summarily punishing the offenders was given to one or mure justices of the peace. It provides that upon complaint to the justice of any forcible entry, the same justice shall take a posse of the county " and go to the place where the force is made; and if they find any that hola such place forcibly, after such entry made, they shall be taken and put into the next jail, there to abide, convict by the record of the same justices or justice, until they have made fine and ransom to the King."

The statute provided a speedy criminal remedy under the control of the justices of the peace. It will be noticed that this statute. gave no remedy as against a forcible detainer after a peaceable entry. Neither did it extend to offenders guilty of either forcible entry or forcible detainer, if they had departed from the premises before the coming of the justices to make record of the force by personal view. If there was no continuing force, there could be no conviction upon view, although the offenders remained subject to indictment at the sessions of the justices or at the assizes. ${ }^{2}$ After conviction by the justices on view or on indictment at sessions, there was no authority to restore the land, which had been entered or detained by force. Doubtless the framers of the statute assumed that after the offender was lodged in jail the injured party would be able to resume his possession without any assistance from the courts. But this favorable termination of the trouble was prevented in practice by the departure of the disseisor and the peaceable entry of his alienee.

The statute of $8 \mathrm{Hen}$. VI. c. $9,{ }^{3}$ recites the deficiencies of the foregoing statute, in that it did not extend to forcible detainers

11391.

3 1429.

22 Chit. Gen. Pr. 231. 
after peaceable entry, nor to offenders guilty of forcible entry who had removed from the premises before the coming of the justices. It also alludes to the conveyances made by disseisors for the purpose of defrauding "rightful possessors of their right and recovery forever." It then goes on to ordain that the statutes be fully executed of all such entries and alienations, and directs that the justice or justices of the county, upon complaint of either a forcible entry or a forcible detainer, shall cause the said statute to be duly executed at the costs of the party aggrieved. By this language the summary criminal process of the previous statute was extended to cases of forcible entry and forcible detainer held not to have been within its terms. The next clause of the statute adds for the first time the civil remedy of restitution on inquisition by a jury.

That clause provides that whether the persons making forcible entries are present or departed before the coming of the justices, the said justices or justice shall have authority and power to inquire by the people of the county as well of them that make such forcible entries into lands as of them who hold the same with force; that if it be found before any of them that any doth contrary to this statute, "then the said justices or justice shall cause to reseize the lands and tenements so entered or holden as aforesaid, and shall put the party so put out in full possession of the same lands and tenements so entered or holden, as before." The justices or justice were empowered to command the sheriff to summon a jury to make inquiry of the forcible entries, and the sheriff was required to execute the process subject to penalty and fine for neglect of duty.

This statute also directed that persons aggrieved by forcible entries and detainers might have redress by the real action of assize of novel disseisin or writ of trespass, in which, if they recovered, they should have treble damages against the defendants, who were also subject to fine and ransom to the King.

SEc. 164. History continued. In construing these statutes it was held that they might be enforced by indictment before the justices at quarter sessions, although no express authority to that effect is given, and restitution awarded with like effect as upon inquisition. ${ }^{1}$ Restitution might also be made by the King's Bench upon trial of an indictment removed thence by certiorari or certificate of the justices. ${ }^{2}$ But justices of oyer or general gaol deliv-

21 H. P. C. $171,213$. 
ery, while they might inquire of forcible entries and punish the offenders, were without authority to award restitution. ${ }^{1}$

By statute of 31 Eliz. c. 11, restitution upon indictment was forbidden when the party proceeded against had been in peaceable possession three years. The remedy of restitution under these statutes was, by construction of the courts, accorded only to tenants of freehold estates.

By statute of 21 Jac. I. c. 15, it was extended to tenants for years, by copyhold, by elegit, statute merchant, and staple.

A justice could not order restitution upon a record of his personal view. ${ }^{2}$ To justify a precept to the sheriff to that effect there inust have been an inquisition or an indictment by a jury, and in both cases an opportunity given to the defendant therein to traverse the fact of force disclosed in the presentment. Upon this traverse he was entitled to a jury trial. It was only when the issue raised by the traverse was decided against him or when he refused to make the traverse that the justices or the courts had authority to order restitution. ${ }^{3}$

If the injured party invoked the civil remedy of assize of novel disseisin or trespass as given to him by the statute of Henry VI., he was compelled to abide the contingencies incident to those actions. The defendant could plead not guilty or he might plead any special matter in bar and traverse the force. The plaintiff was required to answer the special matter and not the traverse. If the issue raised by the special plea in bar was decided in favor of the defendant, so that he had good title at law, he was excused from the force because the plaintiff could not recover in the action if he had no right outside of bare possession. ${ }^{4}$ But if he (plaintiff) prevailed on the plea in bar, the force had to be inquired of, and treble damages assessed against the defendant. But in the criminal proceedings the defendant might be punished, as we have seen, ${ }^{5}$ for a forcible entry under the statutes, although he had a right to enter; and restitution incident to the prosecution could be awarded to the person dispossessed.

It will be seen from these statutes that in the summary proceedings for fine and restitution the jury made inquiry of the fact

11 H. P. C. c. 64 , s. 51.

21 Vent. 308.

34 Bac. Abr. For. Fnt.G. 333; Com. Dig. For. Ent. D. 7 ; Domina R.g. v. Winter, 2 Salk. 587 ; Roy $v$. l'arkers,
1 Sid. 287 ; Rex $v$. Burgess, 1 Keble, $343 ; \operatorname{Rex} v$. Saller, 1 Keble, 427.

44 Bac. Abr. For. Ent. A. 32t;

Dalton, C. J. 129.

5 Sec. 163, 164. 
of actual force in the entry or detainer complained of, and that the merits of title had nothing to do with the issue. A forcible entry was a wrong against the right of possession as springing from the present fact of possession in the person aggrieved and not from what was regarded as the right of property. ${ }^{1}$ A forcible detainer was in like manner a wrong against the right of possession springing from the fact of an actual or constructive possession in the person aggrieved ${ }^{2}$ actual, when the forcible detainer followed a forcible or unlawful entry upon the plaintiff; constructive, when possession acquired under let or license of plaintiff was forcibly continued against the terms of the letting or license.

Whether the summary proceedings by fine and. restitution could be rightly invoked against forcible detainers in the absence of previous forcible entries has been doubted by eminent authority. ${ }^{3}$ This doubt, so far as restitution is concerned, is supported by the plain language of the statute relating to it in which the justice or justices are authorized " to put the party so put out in full possession of the same lands and tenements so entered or holden, as before."

It must be admitted, however, that by construction of the courts the summary remedy of restitution has been extended to forcible detainers preceded by entries which were merely unlawful and not forcible. ${ }^{4}$ It has also been extended as against tenants holding over forcibly after expiration of their terms. ${ }^{5}$ But in this latter case the ruling has been said to be in harmony with the requirement of a preceding unlawful entry, upon the theory that the continuance in possession by the tenant may in judgment of law amount to a new and an unlawful entry. ${ }^{6}$

The foregoing statutes have constituted a popular remedy in the language in which they were enacted for nearly five hundred years in England. The statute of 8 Hen. VI. c. 9, was repealed in 1879 , except as to its criminal features. ${ }^{7}$

These ancient statutes were very generally recognized or re-enacted with modifications in most of the American States. They constitute an important and popular remedy in modern procedure, which is particularly mentioned in connection with our sketch of modern real actions.

12 Pol. \& Mait. 41, 42, 43.

2 King $v$. Oakley, 4 B. \& Adol. 307 ; Kaulleen $v$. Tiliman, 69 Mo. 510 ; Dortch $v$. Robinson, 31 Ark. 296; May v. Luckett, 48 Mo. 472 .
82 Chit. Gen. Pr. 237, 239.

12 Chit. Gen. Pr. 238, 239.

54 Com. Dig. For. Det. B. 1, p. 55.

- King v. Oakley, 4 B. \& Adol. 307

$742 \& 43$ Vict. c. 59 . 


\section{CHAPTER V.}

\section{MODERN REAL ACTIONS.}

Article I. Ejectment.

"II. Trespass to try Title.

" III. Writs of Entry and of Disseisin.

Article IV. Dower and Partition.

V. Forcible Entry and Unlawful Detainer.

\section{ARTICLE I.}

\section{Ejectment.}

Sec. 165. Prefatory.

Sec. 168. Declaration.

“ 167. Defined. Sec. 171. Ejectment in the United States.

SEc. 165. Prefatory. Under this subdivision I shall notice only such real actions as have survived or succeeded the ancient actions, and are employed in modern times to redress wrongs constituting an ouster or disseisin as to real estate. They are few in number, and are very generally represented in the action of ejectment or in actions in the nature of ejectment.

.SEc. 166. Causes leading to the Action of Ejectment. The great number of writs in real actions, the refined and almost imperceptible distinctions between many of them, the long and dilatory proceedings under them, and the burdensome costs incidental to them, produced in the course of time convincing proof of their inadequacy as remedies for the redress of wrongs to the title or possession of real estate. The defects of the proceedings, and the abuses attending them had originated in the courts. Parliament made no effort to correct or reform them.

To preserve their jurisdiction in real actions, which was being encroached upon by the Court of Chancery, the courts of law were compelled to direct or sanction a relief of some kind demanded by the progressive spirit of a higher civilization. ${ }^{1}$ The reform, like most reforms in England, did not come in the discovery or creation of 
any proceeding new or unknown, but rather by adapting the well known process and proceedings of personal actions to the trial of issues relating to ouster and disseisin from real estate.

The writ of ejectment-was first-known in English Jaw by the name of ejectione firmo, and it lay in favor of a lessee for a term of years to recover damages for loss of his term. As early as 1499 it was made to serve the purpose of a real action by permitting the lessee to recover his unexpired term, along with his damages for the time it was withheld from him. ${ }^{1}$ The manner in which the more modern writ or action of ejectment for trial of titles to real estate has been evolved from the ancient personal action of ejectione firme is given in the note in our appendix, to which the reader is referred for further information in detail. ${ }^{2}$

SEc. 167. Defined. The action of ejectment as moulded and approved by the courts was employed for recovering the possession of real property, in which the lessor or the plaintiff has a legal interest or estate and a possessory right ${ }^{3}$

It was necessary that the lessor should have, at the commencement of the action, the right of entry, whether his title was in fee simple, fee tail, copyhold, for life or for years. ${ }^{4}$ It -lay for the recovery of land or buildings annexed to land, upon which an entry in point of fact might be made, and of which the sheriff could deliver actual possession. ${ }^{5}$ It lies to recover a chamber room, or upper story of a house, when the proprietorships of such divisions of the building are separated or severed from the realty by contract of the parties ${ }^{6}$ It will tie in favor of a tenant in common against his cotenant upon an actual ouster or denial of right. ${ }^{7}$

SEc. 168. Declaration. The declaration upon which the issues were tried set out a demise from the actual claimant by name, to the lessee by name, who was the nominal plaintiff, and who in the course of time came to have the well known name of John Doe. In the declaration the premises and the term demised were particularly described. It further alleged that the nominal lessee or plaintiff entered into the tenements and became possessed thereof for the term granted; that being so possessed the defendant (who as tenant on the land had been by rule of court substituted in the

1 See sec. 156.

2 Appendix, note 4.

31 Chit. Pl. 187.

11 Chit. Pl. 189.
51 Chit. Pl. 188.

6 Serg. \& Wait, s. 105, 106, 106 a.

; Tyler, Eject. 41. 
place of Richard Roe, the fictitious ejector and defendant in the original declaration) with force and arms entered into said tenements on a certain day (before expiration of the term) and ejected him the said John Doe out of his farm, and other wrongs there did against the peace, and to the damage of said John Doe in a sum stated. Neither possession of the land nor recovery of the. term was asked for. Such relief was added by the courts, - a feature which made the personal action serve the purpose of a real action.

SEc. 169. Judgment. The judgment in ejectment is that the plaintiff recover his term yet to come and unexpired, in the tenements with the appurtenances as described in the declaration. ${ }^{2}$ By virtue of this judgment the court by its writ of habere facias possessionem put the plaintiff in possession of the land covered by his unexpired term. If the term exists when the suit is brought the action is not defeated by its expiration before verdict, because the plaintiff in this action originally was entitled to compensation for the trespass and ouster including loss of mesne profits. ${ }^{3}$ But when the proceeding became fictitious and the plaintiff merely nominal, the damages assessed became nominal also, and another action for damages and mesne profits was necessary. ${ }^{4}$ But in the modern modified action the claim for damages and mesne profits can usually be prosecuted with the main action for possession, and in some cases it must be so included. ${ }^{5}$

In the modified form of the action in which it is divested of fictions the judgment is for possession, if the right of possession has not expired.

The effect of this judgment is the same in the original and in the modified action. "It is a recovery of the possession (not of the seisin or freehold) without prejudice to the right as it may afterwards appear even between the same parties. He who enters under it in truth and substance can only be possessed according to right. If he has a freehold he is in as a freeholder. If he has a chattel interest he is in as a termor. If he has no title he is in as a trespasser (disseisor). If he had no right to the possession then he takes only a naked possession." 6

1 Stephens, Pl. 33.

22 Roscoe, Real Ac. 601.

3 Adams, Eject. 34, 379.

- Sec. 116 ; Adams, Eject. 379.
5 Sec. 116.

- Jackson $v$. Dieffendorf, 3 Johns. 270 ; Atkyns $v$. Horde, 1 Burr. 114. 
SEC. 170. Recent Changes in England. The action as thus established by rules of court, having been accepted from the abolishing effect of $3 \& 4$ William IV. c. 39, continued unchanged until 1852. By the Common Law Procedure Act of 1852 and the amendatory acts of 1854 and $1860^{1}$ the action underwent material changes reforming and simplifying its procedure. Pleadings of all kind were abolished. The action was commenced by a judicial writ directed to the person in possession and to all persons entitled to defend the possession of the property claimed and described in the writ, and commanding them to appear and defend the possession of the property sued for, or such part thereof as they may think fit, and notifying them that in default of appearance they would be turned out of possession. In case of nonappearance of defendants or of an appearance for defending only a part of the property, plaintiff was entitled to a judgment of recovery of all or part of the land sued for, as the case might be. Appearance of itself constituted a defence to the writ, and the court made up an issue between the claimant of possession in the writ and the parties appearing to defend their possession. This issue was tried according to the general principles governing the former action of ejectment. These reforming acts were thought to authorize equitable defences to a limited extent. But the courts in construing them held that an equitable defence was not available in the action, for the reason that all pleadings had been abolished. ${ }^{2}$

The action continued in this form down to the "Supreme-Court of Judicature Act of 1873." 3

By this act the Superior Courts of Law and the Courts of Chancery were consolidated in one court, styled the "High Court of Justice," with five divisions; and the action of ejectment like all other actions is now commenced by a judicial writ of summons upon which the plaintiff indorses a statement of his claim with the relief asked for, to which the plaintiff makes a statement of his defence. The pleadings are governed by rules of court under general orders made in 1883. By rule 21 under order XXI. a defendant in possession is excused from pleading his title unless.

$115 \& 16$ Vict. c. $76 ; 17 \& 18$ Vict. c. 25 ; 23 \& 24 Vict. c. 126 , c. 154 .

2 Neave $v$. Avery, $7 \mathrm{~J}$. Scott's R. 328 ; S. C. 81 Eng. C. L. R. 327 ;
Baylis $v$. Le Gros, 2 J. Scott's R. x. s. 316.

$336 \& 37$ Vict. c. 66. 
his defence depends upon an equitable estate or right, or he asks relief on equitable grounds. Under this act and the rules madc in conformity with it, the remedy of ejectment has lost its name and distinctive features. But when a suit is brought for the recovery of land, the principles underlying the action of ejectment will never cease to be of use.

SEc. 171. Ejectment in the United States. The action of ejectment as prevailing at common law in England for several centuries was very generally introduced into the United States; but subject to statutes modifying its form and procedure. The extent to which it has been adopted in the several States could not be given with particularity in this treatise. It will be found in the valuable work of Tyler on Ejectment, to which the reader is referred for further information. ${ }^{1}$ In all the States, with one or two exceptions, it has been freed from the fictitious contrivance of lease entry and ouster. It has been extended in some States to rights of possession for vindication of which it would not lie at common law. It is sufficient in most States to allege in the pleading of the plaintiff that he is entitled to possession of the land, describing it, and that the defendant is in possession and wrongfully withholds it from plaintiff; concluding with a prayer for recovery and damages. In a few of the States the plaintiff is required to set out in his pleading the title upon which his right of possession rests. ${ }^{2}$ In most States it received its form and character from statutes which provided special procedure for it as distinguished from other actions. ${ }^{3}$ Upon adoption of the code pleading and practice in many of the States in which the action had been employed in a modified form, these statutes when not expressly repealed have been generally construed as affected by the code pleading in matters specifically covered by the code. Its ancient name and forms of procedure have in this manner to a great extent disappeared, and been supplanted by new forms of procedure. It would perhaps be more accurate to say that an action in the nature of ejectment prevails in most of the States for the trial of title to land, and that it is substantially governed by the principles which for centuries supported the common law action of ejectment.

1 Tyler, Eject. 611-837.

3 Rev. Stat. Mo. 1889 , c. 59.

2 Ark. Dig., 1884, sec. 2632. 


\section{ARTICLE II.}

\section{Trespass to try Title.}

Sec. 172. Trespass to try Title.

| Sec. 173. In Texas.

SEc. 172. Trespass to try Title. An action under this name has obtained recognition in three States, and prevails still in one of them.

It originated in Soutl Carolina, in pursuance of an act of the legislature, passed in 1791, and was adopted as a substitute for the action of ejectment. ${ }^{1}$

It seems to be derived from the old action of trespass quare clausum fregit. It will be remembered that in that action, when the defendant made plea of liberum tenementum, he was allowed to prove that he entered upon the close by virtue of an estate or title in himself or in some one else-under whose authority he acted, which gave him the immediate right of entry.

While bare possession was sufficient to support the action as against a mere wrong doer, it failed to sustain it against a person who had a superior title. In this manner the right of entry might constitute the controlling issue in the action of trespass. Recovery by the plaintiff resulted however only in a judgment for damages.

This statutory action of trespass to try title consisted in an extension of the old action of trespass to wrongs theretofore redressed by the action of ejectment. This extension was effected by indorsing on the writ of the action for trespass a notice to the effect that theaction was brought to try the title to the premises described, as well as for damages. When the entry constituting the trespass culminated in an ouster of the plaintiff, he was entitled, if successful, to a writ of habere facias possessionem as well as to damages.

It could be maintained upon evidence of a trifling and technical trespass, in which case no mesne profits were recoverable, but the title to the premises would be settled; and the plaintiff, if out of possession, would acquire it by virtue of his superior right, and if he was in possession, the defendant would be concluded of his title and right of possession.

This form of action prevailed in South Carolina till abolished in $1873 .^{2}$ It was introduced in Alabama in $1821,{ }^{3}$ where it prevailed

1 S. C. Stat. at Large, $17 n$. 3 Clay's Dig. 320-346.

2 Rev. Stat. S. C. 1873 , p. 586.

Martin Civil Procedure-10. 
under substantially the same conditions till superseded in 1852 by an action in the nature of ejectment. ${ }^{1}$

SEC. 173. In Texas. Trespass to try title has always been and still remains the exclusive form of action for trial of controverted titles in Texas. ${ }^{2}$ By a proper indorsement on the petition, the action of trespass upon land might be employed to try title as well as to recover mesne profits. ${ }^{3}$ The plaintiff was required to-state the interest he claimed to own, whether in fee simple or other estates. ${ }^{4}$ Proof of actual entry was dispensed with $;^{5}$ a constructive trespass by some character of adverse claim or assertion of title or interest by defendant being sufficient. ${ }^{6}$ The plaintiff may elect to consider himself evicted by reason of the adverse claim of the defendant, and sue him, although he has never made actual entry or been in possession. ${ }^{7}$ The judgment, if for plaintiff; was that he recover of defendant the title or possession, or both, as the case may be ${ }^{8}$ It has been held that the intent of the acts creating the action was to furnish a proceeding for the trial of disputed titles irrespective of actual occupancy or pedal possession. ${ }^{9}$ It is an action to vest and devest title and possession, and to quiet title. ${ }^{10}$ It also can be maintained on an equitable title. ${ }^{11}$ The trial is conformable to the principles of trial by ejectment, except as otherwise required by statute. ${ }^{12}$

It is thus seen that the action has a much broader scope than ejectment, not solely being a substitute for that action, but serving the purposes of what was known in Chancery practice as equitable ejectment, as well as the proceedings recognized in modern code pleading for reformation of deeds, devesting of title, and decreeing recovery of possession as incident thereto.

1 Ala. Code, 1852, s. 2209.

2 Paschal's Dig. Art. 5292.

3 Spence $"$ Mcfiowan, 53 Tex. 30.

4 Tex. Rev. Stat. 1895, Art. 5250.

5 O. \& IV. Dig. Art. 2042. 649.

6 Stroud $v$. Springfield, 28 Tex.

7 Titus $v$. Johnson, 50 Tex. 224; Thurber $v$. Conners, 57 Tex. 96 .
8 Tex. Rev. Stat. 4808.

9 Titus $v$. Johnson, 50 Tex. 224.

10 IJardy $v$. Beaty, 81 Tex. 562;

S. C. 19 S. W. 778 ; Wright $v$. lunn,

73 Tex. 293 ; S. C. 11 S. W. 330.

11 Scarborough $v$. Arrant, 25 Tex. 129 ; Erhart $v$. Bass, 54 Tex. 97.

12 Rev. Stat. Tex. 1879, Art. 4784; Thurber $v$. Conners, 57 Tex. 96. 
ARTICLE III.

Writs of Entry and of Disseisin.

Sec. 174. Writs of Entry.

| Sec. 175. Writ of Disseisin.

SEc. 174. Writs of Entry. The ancient possessory action under this name was retained, although in a greatly modified character, in Massachusetts, Maine and New Hampshire. ${ }^{1}$ In Massetrusetts and New Hampsire, to maintain the action the plaintiff must possess at least an estate for life. ${ }^{2}$ In Maine it lies also in behalf of a tenant for years. ${ }^{3}$ As a general rule, the action must be brought against a tenant of the freehold; but if the defendant has actually ousted the demandant he may at the election of the demandant be considered as a disseisor, for the purpose of trying the right, although he claims an estate less than a freehold. ${ }^{4}$ Damages by way of mesne profits were not formerly recoverable in Massachusetts in this action, ${ }^{5}$ but have since been made exclusively incident to it. ${ }^{6}$ In the other mentioned States in which it prevails damages are recoverable.

The pleadings and practice in the action are greatly simplified, corresponding with those in personal actions.

SEC. 175. Writ of Disseisin. In Connecticut, the action to recover real property is called an action of disseisin, which serves the purpose of the common law actions of writ of right, writ of entry and ejectment, with all the multifarious divisions into which they are branched. ${ }^{\top}$ It is commenced and prosecuted like a personal action, except that it must be commenced and tried in the county where the land or a part of it lies. ${ }^{8}$ It can be maintained only on a legal title; it resembles ejectment clesely, and is frequently called by that name. ${ }^{9}$ The action seems to be superseded by the preseut form of procedure. ${ }^{10}$

1 Jackson on Real Actions, 11 ; Tyler, Eject. 636, 641 .

2 Jackson, Real Ac. 25, 27 ; Fay $v$. Taft, 12 Cush. 448 ; Johnson $v$. Elliot, 26 N. H. 67 ; Tyler, Eject. 50.

3 Rev. Stat. ch. 104, sec. 1 ; Wyman o Brown, 50 Me. 139.

* Gen. Stat. Mass. 1860, c. 134, s. 3 , 4, 5, 6; Wyman v. Browu, 50 Me. 139.
5 Jackson, Real Ac. 27.

- Raymond $v$. Andrews, 6 Cush. 265.

7 Tyler, Eject. 654; Crandall $v$. Gallup, 12 Conn. 371.

8 Gen. Stat. Conn. 1865, tit. 1, c. $\overline{5}$, s. 80,81 .

9 Tyler, Eject. 654 .

10 Gen. Stat. 1888, s. 872. 


\section{Article IV.}

\section{Dower and Partition.}

Sec. 176. Dower.

| Sec. 177. Partition.

SEc. 176. Dower. We have seen that the common law writs of dower were excepted from the abolishing act of the reign of William IV. ${ }^{1}$ Nevertheless, resort to them became less frequent from the fact that the Court of Chancery had long before that time acquired, by judicial expansion, concurrent jurisdiction with the courts of law in the enforcement of dower rights, ${ }^{2}$ and the superior advantages of the proceeding in equity gave an increasing preference to it over the remedy at law.

When the marriage or seisin of the husband in a legal estate was disputed in a bill for dower, it was the practice of the Court of Chancery to direct the issue raised by the plea to be tried by a jury, or to stay the suit in equity until the plaintiff established her right at law. ${ }^{3}$ But this practice has not been invariably followed in the United States.

Although the right of dower arises by operation of common law, ${ }^{5}$ it has come to be so generally defined and enforced by statutes in the United States, that in some of them it has been treated as depending entirely on statute. ${ }^{6}$ But while the statutes may have superseded the common law in giving and defining the right, the courts go back to the common law and to equity for the remedies of enforcing it in the absence of statutes prescribing some exclusive mode to that end. Thus we find that in our early history the common law action of dower unde nihil habet has been followed with suitable modifications. ${ }^{7}$ In many States a petition for dower in conformity with code pleading, or resembling a bill in equity, has been adopted, in prosecution of which dower is assigned, damages assessed, and possession awarded. ${ }^{8}$

In all States in which the action of ejectment prevails in its

$13 \& 4$ Wm. IV. c. 27 , sec. 36 .

2 Srrib. Dow. 140 ; Mundy v. Mundy, 2 Ves. Jr. 122 ; S. C. 4 Bro. C. C. 294 .

8 Scrib. Dow. 148, 149 ; Curtis v. Curtis, 2 Bro. C. C. 631, 6:33.

47 Enc. Pl. \& Pr. 182, 183 ; London $v$ London, 1 IIumph. 1.
5 Scrib. Dow. 3 ; Lecompt $v$. Wash, 9 Mo. 551.

${ }^{6}$ Chouteau v. R. R. 122 Mo. 375.

7 Scrib. Dow. 106-121; Waters v. Gooch, 6 J. J. Marsh. 386: Jackson, Real Ac. 19, 300.

87 Enc. Pl. \& Pr. 184, 185; Rev. Stat. Mo. 1889, s. 4536, 4539. 
original or modified form, dower can be recovered in that form of action after assignment. ${ }^{1}$ In some States the widow is allowed by statute to recover in that form of action before assignment. ${ }^{2}$

The modern remedies for enforcement of dower rights in the American States are usually indicated in the statutes on dower, or are contained in the forms of civil procedure prevailing there.

In these statutes elements of the procedure in equity will be very generally encountered, allying the remedy with a suit in equity. ${ }^{3}$

But notwithstanding special modes of enforcement prescribed by statutes, it is very generally held in the United States that equitable remedies may be invoked concurrently with those of the statutes, in the absence of some express or implied exclusion of them."

Summary proceedings for assignment of dower have been vested in Probate Courts or Courts of Probate jurisdiction in some of the States ${ }^{\circ}$

It is held by the courts in some States, and is provided by statute in some others, that when the right of dower is disputed in an equitable or statutory proceeding, the parties to the controversy shall have the right of trial by jury. ${ }^{6}$

This conclusion is in accord with the ancient jurisdiction of equity in dower, which always took or waited for a verdict at law-on such issues. ${ }^{7}$ It is conceived that a trial by jury would be out of place, when the dower right is asserted against an equitable estate, since extension of dower to such estates. ${ }^{8}$

SEc. 177. Partition. The writ and plaint in the action at lawfor partition wero abolished, along with the other real actions, by act, of Parliament in the reign of William IV9 This statute left exclusive jurisdiction in the Court of Chancery in proceedings of partition, - a jurisdiction which it had exercised concurrently with the courts of law from the reign of Elizabeth. ${ }^{10}$

The action of partition at common law has been so effectually

1 Park, Dow. 283; Adams, Eject. $66 ; 7$ Encyc. Pl. \& Pr. 283.

2 Scrib. Dow. 110 ; 7 Encyc. Pl. \& Pr. 284.

87 Encyc. Pl. \& Pr. 174 ; Efland $v$. Efland, 96 N. C. 488 .

4 Scrib. Dow. 143, 144; Davis v. Davis, 5 Mo. 183 ; Devorse v. Snider, 60 Mo. 239; Young v. Thrasher, 115 Mo. 222; 7 Encyc. Pl. \& Pr. 175, 176.
57 Encyc. Pl. \& Pr. 186.

6 Shipp v. Snyder, 121 Mo. 155 ;

Code Civ. Proc N. Y. sec. 968.

7 Curtis v. Curtis, 2 Bro. C. C. 631, 632.

8 Van Dyne $v$. Thayre, 19 Wend.

162 ; Beebe $v$. Lyle, 73 Mich. 114.

93 \& 4 Wm. IV. c. 27 , sec. 36.

${ }^{10}$ Bispham, Eq. sec. 488. 
superseded in the United States by bill in equity and statutory proceedings, that it never obtained recognition in its ancient form. the statutes governing it having effected such changes that a comparison between it and the varied forms of the modern action would be of no practical use. ${ }^{1}$

In most of the modern statutory proceedings, possession actual or constructive in the joint or cotenant suing is the initial requisite of his suit as at common law or in equity. ${ }^{2}$ Of course this requirement does not apply to the partition of equitable estates. ${ }^{3}$ But in some States a right of entry or seisin in law is sufficient. ${ }^{4}$ Notwithstanding the breadth of the statutory proceedings in force in most of the States, it has been invariably held that in absence of express. or implied restrictions to that end, they do not divest the courts of equity of their jurisdiction over the subject of partition. ${ }^{5}$ Accordingly it will be found that equitable proceedings are constantly being maintained in pursuance of the concurrent jurisdiction of equity, in which the various rights and equities between the cotenants relating to the land, as well as the rights of mortgagees and remaindermen, are settled in the decree. In some States, how ever, the statutory proceeding has been regarded as excluding the concurrent jurisdiction of equity. In some the exclusion is made so by express provision. ${ }^{6}$ There was no action at common law for the partition of personal property. Equity assumed jurisdiction in such case. It is also very generally conferred by statute.

It is not within the scope of this treatise to define or discuss the protean forms of the American suit for partition, as it prevails at present in the different States.

\section{Article V.}

\section{Forcible Entry and Detainer.}

Sec. 178. Introductory.

| Sec. 179. Characteristic Features.

SEc. 178. Introductory. The nature and history of this summary proceeding has been given in connection with our account of

117 Am. \& Eng. Encyc. Law, 705, note $6 ; 707$, note 3 .

217 Am. \& Eng. Encyc. Law, 694; Wommock $v$. Whitmore, 58 Mo. 448.

8 Dameron $r$. Jamieson, 71 Mo. 97. 697.
517 Am. \& Eng. Encyc. Law, 705, 706 ; Real Estate Sav. Inst. v. Collonious, 63 Mo. 290. 707.

617 Am. \& Eng. Encyc. Law, 706,

717 Am. \& Eng. Encyc. Law, 681. 
the ancient real actions. As a civil proceeding its nature and scope lepended upon the statutes giving rise to it, and the construction of the same by the courts. The statutes furnished summary redress against the wrong of forcibly entering upon the peaceable possession of another, or of forcibly holding another out of his immediate right of possession, after a forcible or unlawful entry upon the same. ${ }^{1}$ Thus the remedy continued in England till a very recent period.

The ancient statutes found their way into the colonies along with the body of the common law. In some of the States the leading provisions of these statutes have been literally copied, but usually in connection witl enacted modifications. It will be found that in some form or another, the summary remedy of the ancient statutes has been continued in all the States. But the changes and modifications have been so numerous and varied, that it would not be within the purview of this treatise to describe the remedy definitely as it prevails at the present time. It will be sufficient to indicate the leading and general features which characterize it as a modern remedy in most of the States.

SEC. 179. Characteristic Features. - 1. It is no longer an incident of a criminal inquisition or indictment, but is entertained by the justices of the peace or courts of general jurisdiction, as a distinct civil remedy set on foot by the complaint or petition of the party aggrieved. ${ }^{2}$

2. It will be found that the modern statutes, when providing for criminal punishment, usually retain the ancient requirement of actual force as necessary to constitute the criminal offence of a forcible entry or detainer, ${ }^{3}$ but that when they provide against the civil wrong they sometimes omit this feature, and furnish the redress of damages and restitution for all entries and detainers made against the consent of the party in actual or constructive possession.4 In most of the States actual force, by virtue of statutes, is no longer an essential ingredient of the civil wrong redressed by this remedy. ${ }^{5}$

1 Com. Dig. For. Det. B. 1 ; 2 Chit. Gen. Pr. 238, 239 ; King v. Oakley, 4 B. \& Adol. 307 .

2 Mo. Stat. 1889, s. 5092 ; 2 Kans. Stat. 1889, s. 5014 ; Neb. Code, Civ. Proc. s. 1023; 9 Encyc. Pl. \& Pr. 25; Mass. Stat. 1882 , c. 175 ; Harrow v. Baker, 2 Greene, Iowa, 201.

s State v. Richards, 15 Mo. App.
331 ; State $v$. Vansickle, 57 Mo. App. 611 ; Mo. Stat. 1889, s. 3779.

4 Ish $v$. Chilton, 26 Mo. 256; Warren $v$. Ritter, 11 Mo. 354; Wunsch v. Gretel, 26 Mo. 580 ; Mo. Stat. 1889, s. 5102 ; 9 Encyc. Pl. \& Pr. 40.

5 Wunsch v. Gretel, 26 Mo. 580 ; Reader $v$. Purdy, 41 Ill. 279 ; 9 Encyc. P1. \& Pr. 42. 
3. In most of the States the action is regarded as a redress for a wrong against the right of possession, springing from the fact of possession actual or constructive. This right rests upon the necessity of sustaining the fact of peaceable possession against all persons asserting claims to it, except in the courts. A person in peaceable possession, actual or constructive, may maintain the action against the disturber of it. "His title is sufficient.

4. The civil remedy has been expressly extended to unlawful detainers by tenants after expiration of their terms, irrespective of the element of force. The American statutes in this respect furnish redress for an untawful detainer of a particular description, as well as for a forcible entry or a forcible detainer. ${ }^{2}$ It being the duty of the tenant to surrender the possession of the premises at the termination of his lease to his landlord, his failure to do so may well be summarily treated as an infraction of the landlord's right of possession, springing from his constructive possession during the lease, and which after its expiration has become exclusive of the tenant's rights. ${ }^{3}$

5. The summary remedy has been expressly given in most of the States to the heirs, devisees, and assignees of those entitled to maintain it at the time of their death or assignment.4

6. It has been held in some States that a person can maintain the action upon his occupation of a part of a tract under claim of ownership to the whole against any one entering on the vacant part so claimed. ${ }^{5}$ He has constructive possession of the vacant part.

7. A person may have such a constructive possession of wild and vacant lands, without actual occupation of them, as will support the action, - as where he has a title to them, has entered upon and done acts upon them or in reference to them, indicating a present proprietorship. But of course this constructive possession can exist only in the absence of adverse occupancy at the time the ownership and possession was thus asserted. ${ }^{6}$

19 Encyc. Pl. \& Pr. 42.

2 Steiner $v$. Priddy, 28 Ill. 179; Dudley v. Lee, 39 Ill. 339; Andrae v. Heinritz, 19 Mo. 310 ; Young $v$. Smith, 28 Mo. 65; Thomasson $v$. Wilson, 34 N. E. 432 (Ill.); Johnson $v$. West, 41 Ark. 535 ; Mass. Stat. 1882. c. 175.

3 May $v$. Luckett, 48 Mo. 472 ; Kaulleen $v$. Tillman, 69 Mo. 510; Ish v. Chilton, 26 Mo. 256 ; 'Ihomasson v. Wilson, 34 N. E. 432 (III.); Coolbaugh ". Porter, 33 Mo. App. 548.

1 Mo. Stat. 1989, s. 5120; 9 Encyc. Pl. \& Pr. 51.

5 McCartney $v$. Alderson, 45 Mo. 35; Kincaid $v$. Logue, 7 Mo. 167; Iarris $v$. Turner, 46 Mo. 438.

6 Miller $v$. Northup, 49 Mo. 397; 
8. There has been a disposition in recent legislation to extend this form of action to the trial of the right of possession in some cases, thus making it serve the purposes of ejectment. ${ }^{1}$ In some States the remedy of unlawful detainer has been extended to purchasers at foreclusure sales under mortgages and deeds of trust, as against the makers of the deeds or claimants under them, ${ }^{2}$ and to claimants of possession under land contracts, ${ }^{3}$ who have never had either actual or constructive possession. ${ }^{4}$ It is evident that these latter extensions carry the summary remedy far beyond its legitimate purpose of redressing the wrong of displacing or withholding possession. In some States the action has been denied to peaceable occupants who have been evicted by persons having title and right of possession, under statutes authorizing the action only in favor of "the person entitled to the premises." ${ }^{5}$ This limitation ignores the original nature and scope of the remedy as a redress for violated possession.

9. In some States restitution is given before trial as in replevin, upon bond being furnished by plaintiff to abide the results of the action, and to restore possession to defendant, if judgment goes in his favor. ${ }^{6}$

10. Three years' possession has been generally retained as a bar to the civil action, except perhaps in some States, in which the action has been extended beyond its primitive scope, as_a remedy for the protection of actual possession.

Packwood $v$. Thorp, 8 Mo. 636; Robert $v$. Long, 12 B. Mon. 195.

1 Mason's Practice in New England States, 21, 369.

2 Mass. Stat. 1882, c. 175; Barrett v. Trainor, 50 Ill. App. 420 ; Gage $v$. Sanborn, 64 N. W. 32 (Mich.); Mich. Comp. Laws, 6706.
8 Moody v. Seaman, 8 N. W. 711 (Mich.).

49 Encyc. Pl. \& Pr. 42, 43.

5 Page v. Dwight, 39 L. R. A. 418;

170 Mass. 29.

6 Stat. Ark. 1884, s. 3352. 


\section{CHAPTER VI.}

\section{PARTIES TO ACTIONS.}

Art. I. Parties Plaintiff in Personal Art. III. Parties Defendant in Personal Actions $e x$ contractu.

“ II. Parties Plaintiff in Personal “ IV. Parties Defendant in Personal Actions ex delicto. Actions ex delicto.

Art. V. Parties Plaintiff and Defendant in Ancient Real Actions.

\section{Article I.}

Parties Plaintiff in Personal Actions ex contractu.

Sec. 180. Prefatory.

"181. General Rule.

" 182. As to Bonds and Deeds inter partes.

“ 183. As to Deeds Poll.

“ 184. As to Simple Contracts.

‘ 185. As to Contracts with Carriers of Goods.
Sec. 186. As to Assignees of Choses in Action.

187. As to Agents.

188. As to Corporations.

189. As to Executors and Adminis. trators.

“ 190. As to Joinder of Parties Plaintiff.

SEc. 180. Prefatory. Having considered the forms of actions and the nature of the initial pleadings suited to them respectively, it is next in order to notice the rules by which the proper and necessary parties to actions may be ascertained and determined.

SEC. 181. General Rule. In actions on contracts the right of action is vested solely in the person having the strict legal title or interest in the contract as disclosed by its terms, in exclusion of the mere equitable rights of any one therein. ${ }^{1}$

This general rule may be understood best by considering its application to the different forms and kinds of contracts. Some difficulty is experienced in determining who are the legal parties in interest.

SEC. 182. As to Bonds and Deeds inter partes. Only the persons by whom or with whom such instruments are made were regarded as vested with the legal title or interest. They alone could maintain suit thereon. ${ }^{2}$ No one could sue on a covenant in an indenture, who was not mentioned among the parties to the

11 Chit. Pl. 3; Browne, $\Lambda$ c. $99 . \quad 21$ Chit. Pl. 4 ; Dicey, 101, 103. 
indenture, even though the covenant is made expressly with him. ${ }^{1}$ This was said to be a technical rule peculiar to the law of England. ${ }^{2}$ But this rule was changed in respect to indentures relating to tenements and hereditaments in $1845 .^{3}$

SEc. 183. As to Deeds Poll. In such an instrument there is, strictly speaking, but one party, who addresses it to the world generally, declaring the fact that he has made some conveyance to or entered into some covenant with a person or persons therein mentioned, without making them or any one else parties to the instrument. ${ }^{4}$ If the covenant in all poll is made with someone other than the person for whose sole benefit it is made, the covenantee is the proper person to sue on it, as being the legal party to the covenant. . $^{5}$ But if the covenant is directly or generally with the person for whose benefit it is made, he might sue although a stranger to the consideration, and no party to the deed. ${ }^{6}$

SEC. 184. As to Simple Contracts. In simple contracts the binding effect comes from the consideration, there being no seal. A simple agreement was regarded as nudum pactum in respect to persons who were strangers to the consideration. This gave rise to the rule that an entire stranger to the consideration cannot sue upon it, although it may be for his sole benefit? The person to sue for the breach of a simple contract must be the person from whom the consideration for the promise moves. ${ }^{8}$ He is the person with whom such a contract, in point of law, must be considered as made. ${ }^{9}$ In other words, he is the legal party to the binding contract. ${ }^{10}$ No formal recital of a person as a party can make him such in law, if he is an entire stranger to the consideration.

There were three well settled exceptions to the rule that an entire stranger to the consideration of a contract could not sue on it: first, in actions by a person appointed by statute to sue in behalf of others; second, in certain cases which could be brought by principal or agent; third, in actions for money had and received under circumstances which render the receipt of it a receipt by the defendant to the use of the plaintiff."

1 Dicey, 103.

2 Berkeley v. Hardy, 5 B. \& C. 100. 355.

38 \& 9 Vict. c. 106 , s. 5.

4 IV. Cruise, Dig. c. i. s. 19.

b 1 Chit. Pl. 4; Browne, 100; Dicey, 103.

- 1 Chit. Pl. 4; Dicey, 103; Browne,

7 Browne, 103.

8 Dicey, 81.

9 Dicey, 80; Browne, 103.

10 Dicey, 82; Browne, 103.

11 Dicey, 90, 91. 
SEc. 185. As to Contracts with Carriers of Goods. In the absence of express agreement to the contrary, the person at whose risk goods are carried is the person to sue the carrier for non-delivery, whether that person be consignee or consignor. ${ }^{1}$ Prima facie the consignee is possessed of the legal interest and right of action. ${ }^{2}$ But this may be rebutted by evidence of an express agreement between the consignor and the carrier, that the latter was employed on the consignor's account. ${ }^{3}$ It may also be rebutted by evidence that the property in the goods has not passed to the consignee, in which case the consignor is the proper party to sue, as being the person at whose risk the goods are being carried. ${ }^{4}$

SEc. 186. As to Assignees of Choses in Action. It was a general rule that the right of action on contracts or choses in action could not be assigned or transferred. Assignments were against the policy of the law. ${ }^{5}$ The rights of assignees were recognized only in equity. They could be enforced at law only in the names of the original parties :

There were several exceptions to this rule.

1st. Assignees of negotiable paper, which passed by indorsement and delivery under the law merchant and the statute of Anne, could sue in their own names. ${ }^{6}$ This was also true of all other contracts made assignable by statute. ${ }^{7}$

2d. Assignees of a debt assigned by agreement of all the parties. 8

$3 d$. Covenants annexed to an estate by the person creating it enured to the assignee of the estate under the common law, who by virtue of his privity of estate could maintain an action on the covenants in his own name against the original grantor. A like right belonged to any subsequent assignee of the estate. ${ }^{9}$

Implied covenants or covenants in law annexed to or running with the reversion passed to the grantee of the reversion, vesting in him the right of action on such covenants. ${ }^{10}$ But this effect was denied at common law to the assignee of the reversion in respect to express covenants. $\overline{\mathrm{He}}$ was neither benefited nor bound by them. None but parties or their heirs or devisees could sue upon

1 Dicey, 87.

21 Chit. Pl. 6.

3 Dicey, 89.

- Dicey, 88.

- Dicey, 115.

- 1 Chit. Pl. 15, 16; Dicey, 117.
7 Dicey, 117.

8 Dicey, 117.

91 Chit. Pl. 18; Dicey, 119, 120, 121.

101 Chit. Pl. 16. 
them. This defect was corrected by the statute of 32 Hen. VIII. c. 34 , sec. 1 , which transfers the reversioner's remedy and right of action to his assignee as against the lessee or his assigns, and gives the same remedy against the reversioner to the assignee of the tenant, which the tenant had against the original landlord. ${ }^{2}$

4th. Assignees by marriage, bankruptcy, and death could sue on the rights of action passing to them. ${ }^{3}$ In case of marriage, the husband became vested-with-the right, in case of bankruptcy, the assignee or trustee, and in case of death, the executors and administrators.

SEC. 187. As to Agents. In general an agent or servant with whoin a contract was expressed to be made on behalf of another could not maintain an action in his own name; the principal was the proper person to sue on it. 4

To this rule there were seven exceptions:-

1. When the agent was contracted with by deed in his own name. ${ }^{5}$

2. Where the agent is named as a party to a bill of exchange or promissory note. ${ }^{6}$

3. Where the right to sue on a contract is expressly restricted to the agent. ${ }^{7}$

4. Where the contract is made with the agent himself, - in other words, where the agent is treated as the actual party with whom the contract is made. ${ }^{8}$

5. Where the agent is the only known or ostensible principal, or where he has made a contract not under seal in his own name for an undisclosed principal. ${ }^{9}$

6. Where an agent has made a contract in the subject-matter of which he has a special interest or property. ${ }^{10}$

7. Where the defendant has paid away money of the principal's under circumstances which gave a right to recover it back. ${ }^{11}$

In this connection may be added the following rules applying to certain phases of agency in contracts:-

1. A person who enters into a contract in reality for himself, but apparently as agent for another person, whom he does not name, can sue on the contract as principal. ${ }^{12}$

11 Chit. Pl. 16; Dicey, 121.

${ }^{6}$ Dicey, 134.

21 Chit. Pl. 16, 17 ; Smith, L. \& T. 283, 285; Dicey, 122.

81 Chit. Pl. 20; Dicey, 128, 170, 188, 205.

41 Chit. Pl. 6; Dicey, 130.

5 Dicey, 134.

7 Dicey, 135.

8 Dicey, 136.

9 Dicey, 138.

10 Dicey, 139.

11 Dicey, 140.

12 Dicey, 143, 144. 
2. If he contracts in reality for himself, but apparently as agent for another, whose name he gives, he cannot sue on the contract as principal.:

SEC. 188. As to Corporations. Corporations must sue in their corporate names on all contracts. The ancient rule that it could not sue on a contract not under seal, came to have so many exceptions that it may be said to be obsolete as a general rule. ${ }^{2}$ They may sue in their corporate names on all contracts not under seal, whether express or implied, made or incurred by them within the scope of their powers, unless the nature of the contract requires_a seal for its validity. ${ }^{3}$

SEC. 189. As to Fxecutors and Administrators. As a general rule, the executors or administrators of a deceased person can sue on all contracts made with him, whether broken before or after his death. ${ }^{4}$

There are several exceptions to this rule, which will be merely recited : -

1. Contracts, the breach of which occasioned merely personal suffering to the deceased, and did not injuriously affect his personal estate. 5

2. Contracts limited to the lifetime of the deceased by reason of the personal consideration on which they are founded. ${ }^{6}$

3. Covenants real, broken during the lifetime of the deceased; but upon breach of which no substantial damage has accrued until after-decease. ${ }^{7}$ In such case the real representative is the proper person to sue.

4. Contracts on which the deceased must have sued jointly with other obligees, in which case the right of action passes to the surviving obligee or obligees. ${ }^{8}$

When an executor or administrator sued on contracts made with the deceased, he was required to sue in his-representative character. ${ }^{9}$

On contracts made with him as executor after death of the deceased, he might sue either in his personal character or in his representative character. 10

\section{SEc. 190. As to Joinder of Parties Plaintiff.}

1. In actions on contracts in favor of partnership, all the partners
1 Dicey, 144.
"Dicey, 209.
2 Dicey, 164 .
7 I)icey, 211.
3 Dicey, 164-170.
8 Dicey, 128, 214.
4 1)icey, 205.
9 Dicey, 216.
5 Dicey, 208.
10 Dicey, 216. 
must join, if living. Upon the death of a partner, the legal interest vests in the surviving partners, and ultimately in the last survivor or his representative, who must sue in behalf of the partnership.

2. In actions on contracts or covenants made jointly with several persons, all of them must join in a suit for the breach thereof, even though the covenants were expressed to be several as well as joint. ${ }^{2}$ $A$ contract could not be made so as to entitle several persons to sue both jointly and severally. They must be entitled to sue under it either jointly only or severally only. One and the same covenant could not be made both joint and several as regards the covenantees. ${ }^{3}$ As regards the liability of covenantors the rule was different. ${ }^{4}$.But when the legal interest and cause of action of the covenantees or promisees are several, each may and should sue separately for the particular damages resulting to him individually, although the covenant be in its terms joint. ${ }^{5}$ Upon death of one covenantee in a joint covenant, the right of action passes to the survivors, and on the death of the last, to his representatives. ${ }^{6}$

3. In actions for breach of covenants in favor of tenants in common of estates, all were required to join if the covenants arose from or were included in a joint demise. ${ }^{\top}$ When the rent accrued from separate demises or was reserved to them separately on a joint demise they were required to sue separately. ${ }^{8}$ Upon the death of one in case of a joint demise, the right of action upon covenants relating to the estate had to be enforced by the survivor or survivors and the representative of the deceased demisor, who sued in the character of joint owners of the reversion, and not as joint covenantees. ${ }^{9}$

4. Husband and wife - when to be joined. Husband and wife inust sue jointly on all-contracts of every description (with the exceptions hereinafter mentioned) made with her before marriage. ${ }^{10}$ This was also true of all contracts in which the wife claims not in her own right but in a representative character, as for example, as executrix.11

The husband may sue alone or jointly with his wife: -

11 Chit. Pl. 11; Dicey, 151.

21 Chit. Pl. 8.

( Dicey, 111 ; Bradburn v. Botfield, 14 M. \& W. 573.

4 Dicey, 112.

5 1 Chit. Pl. 10; 1 Saund. 153,n. 1;

Withers $v$. Bircham, 3 B. \& C. 254 .
6 Dicey, 128.

71 Chit. Pl. 12.

81 Chit. Pl. 12, 13.

9 Dicey, 128, 129.

101 Chit. Pl. 28; Dicey, 171, 179.

11 Dicey, $174 ; 179$. 
1st. On negotiable instruments given by her before marriage.

$2 d$. On contracts made with his wife after marriage.

3 d. On contracts made after marriage with himself and wife.

4th. On causes of action on leases or other contracts relating to the land of the wife, whether made before or during coverture, provided the cause of action accrued during the marriage. ${ }^{2}$

Neither husband nor wife can sue the other at law. 3

The wife may sue alone; -

1st. When the husband is civilly dead.

2 d. When he is legally presumed to be dead,

3d. When the wife has a judicial separation or protection -order under the English statutes.

4th. When the husband has deserted his wife and left the jurisdiction. This last cause prevails in some of the American States only. ${ }^{4}$

On death of the husband, the right of action on all contracts made with the wife before marriage survives to her, and she may either commence or continue an action upon them. ${ }^{5}$ The death of the husband produces no effect on the wife's right to sue on contracts made with her as executrix. ${ }^{6}$ On the death of the wife, her right of action on contracts made with her before marriage passes to her administrator; and her husband, if he survives her, has the right of administration, and must sue in the character of administrator. ${ }^{7}$

On contracts made with her as executrix, the right of action upon her death passes to the representative of her testator. ${ }^{8}$

The serious and often fatal effects of a non-joinder or misjoinder of parties plaintiff were relieved by the liberal authority to make amendments to that end by the Common Law Procedure Act of $1852 .^{9}$

1 Dicey, 181.

21 Chit. Pl. 30, 31.

3 Dicey, 174.

4 Gregory v. Paul, 15 Mass. 31; Rose $v$. Bates, 12 Mo. 31.

6 Dicey, 180.
- Dicey, 180.

7 Dicey, 180.

8 Dicey, 180.

9 Com. Law Proc. Act. 1852, s. $34,35,36$. 
Article II.

Parties Plaintiff in Actions ex delicto.

Sec. 191. General Rule.

" 192. Injuries to the Absolute lights of l'erson.

“ 193. Injuries to Relative Rights.

" 194. Injuries to Rights appertaining to Personal ('hattels.

" 195. Injuries to Real Property Corporeal.
Sec. 196. Injuries to Real Property Incorporeal.

197. As to Assignees.

198. As to Executors and Administrators.

199. As to Assignees in Bankruptcy. 200. As to Joinders of Parties Plaintiff.

SEc. 191. General Rule. Actions in form ex delicto lie for injuries to the absolute or relative rights of persons or to the rights of persons in respect of personal or real property, independent of contract. ${ }^{1}$ The general rule is analogous to that which has been laid down respecting actions on contracts. An action ex delicto must be brought in the name of the person whose legal rights have been violated. ${ }^{2}$ The application of this rule will be considered with reference to the violations of legal rights which most frequently occur and for which redress is usually sought by action at law.

\section{SEC. 192. Injuries to the Absolute Rights of Persons.} Every one is entitled in law to freedom of his person and exemption from injury to or wrongful interference with it; also to the enjoyment of health, reputation, and domestic comfort. These rights are commonly classified as the absolute rights of security to person, as distinguished from mere property rights. ${ }^{3}$ These absolute rights are violated by assault, battery, wounding, mayhem, false imprisonment, slander, libel, malicious prosecution, and interference with the enjoyment of health and domestic comfort. Actions for the redress of these wrongs must be brought in the name of the person whose absolute rights have been thus violated or invaded. 4

SEC. 193. Injuries to Relative Rights. One may have relative rights depending upon the relation which he holds to other persons, such as wife, child, and servant. An injury to the person of a wife is an injury to the right of a busband to the society and service of his wife. The right of a parent in his child is violated

1 Browne, 106.

21 Chit. Pl. 60 ; Browne, 106; 124 Dicey, 325.

Martin Civil Procedure-11
31 Chit. Pl. 60; 1 Bl. Com. 123,

41 Chit. Pl. 60; Browne, 106, 107; Dicey, 330, 331. 
by any wrong to its person which disables it from performing service due the parent, or imposes an expense on the parent in caring for it. A rnaster's rights in his servant are likewise violated by any wrong to the person of the servant, which disables him from discharging his duties. The husband, parent, or master, as the case may be, can sue for these wrongs. ${ }^{1}$ The wife, child, or servant may also sue for the same wrongs, which constitute a violation of their absolute rights as already expressed.

\section{SEC. 194. Injuries to Rights appertaining to Personal} Chattels. All injuries to the rights of any one in respect of personal chattels must resolve themselves into injuries against the actual possession of them (which in itself implies a right of possession as against all who have not a superior right) or against the right of immediate possession or against the right of future possession. $^{2}$ The respective owners of these rights, which constitute the so called rights of property, can sue for any invasion or violation of them. The bare possessor can sue for an interference with his actual possession. He has a sufficient right or title as against mere wrongdoers. ${ }^{3}$ Any one interfering with the rights implied by actual possession cannot defend on the ground that a superior right of possession belongs to a third person. To make his defence good he must show that he derived his authority to interfere from such third persan.4 Absolute or general ownership in goods implies the immediate right of possession, in the absence of any restriction as to the meaning of the term. ${ }^{5}$ The absolute or general owner of personal chattels who has not parted with the right of immediate possession may sue for any damage thereto, although he has never had actual possession. ${ }^{6}$ When he has parted with the right of possession for a definite term, he can sue for any damage thereto affecting his reversionary interest. ${ }^{7}$ The owner of personal chattels for a limited time, or for a particular purpose only, is said to have a special property in them, and can sue for injuries to them affecting his interest or title. Such is the right of bailees and carriers. ${ }^{8}$ The form of action and extent of recovery depend upon the right or interest affected

11 Chit. Pl. 60; Dicey, 326.

2 Dicey, 344, 354; 1 Chit. Pl. 61.

81 Chit. Pl. 61 ; Dicey, 354.

4 Dicey, 356; Pulliam v. Burlingame, 81 Mo. 41 .
5 Dicey, 349.

61 Chit. Pl. 61.

71 Chit. Pl. 62.

81 Chit. Pl. 61. 
by the injury, the person against whom redress is sought, and the fact as to whether the plaintiff, if not absolute owner, is bound to answer over to him for any portion of his recovery.

SEc. 195. Injuries to Real Property Corporeal. Whether a person can sue for damages to corporeal realty depends upon whether he has an interest or estate in it, and whether the act complained of is an injury to or a violation of his interest or rights. A person in actual-possession has an estate upon which he can maintain an action against any unlawful interferences with his possession. Actual possession is sufficient title against a stranger who cannot show a better right or title. ${ }^{1}$ If the act complained of operates as a permanent injury to the land, or interferes with the future enjoyment of it, any one possessed of the future interest or estate by way of remainder or reversion must sue for such injury. ${ }^{2}$ But in such cases it must appear that the land was in possession actual or constructive of the tenants having the particular estate. If it was held at the time of the injury adversely to the tenants of the particular or prior estate, neither they nor the reversioners or remainderman could sue for the injury, except as incident to a suit for possession and in the name of the person entitled to immediate possession. In this respect land differs from personalty. A trespass culminating in an ouster of possession constitutes a complete cause of action, which may be maintained irrespective of an action to recover possession. Such was the nature of the possessory action of ejectione firmce in its origin, ${ }^{3}$ and of the action of trespass quare clausum fregit. ${ }^{4}$

SEc. 196. Injuries to Real Property Incorporeal. As a general rule, owners of incorporeal realty have their rights of action for injuries thereto, in so far as their respective interests and estates have been affected by the acts complained of, in like manner with owners of corporeal realty. The appropriate action at law for redress of such injuries is trespass on the case. ${ }^{5}$

Skc. 197. As to Assignees. The right of action for torts to person or property, either real or personal, could not be assigned "at common law by voluntary act so as to vest in the assignee the right to sue. ${ }^{6}$

11 Chit. Pl. 62; Dicey, 332, 333, 334.

21 Chit. Pl. 63; Dicey, 340.

s Sec. 156.
4 Hammond, N. P. 151; Gilbert's Tenures, 45.

51 Chit. Pl. 142.

61 Chit. Pl. 66 ; Dicey, 382. 
SEC. 198. As to Executors and Administrators. By the ancient common law the right of action for a tort to person or property perished upon the death of the person injured, unless the facts of the tort furnished the basis of an action ex contractu, invokable at the option of the injured person. ${ }^{1}$ By statutes passed in the reign of Edward III., all actions survive to the executor or administrator for injuries to personal property by which it was rendered less beneficial to the owner, whatever the form of the action. ${ }^{2}$ These statutes have been very generally construed as not continuing to one's representatives any right of action for injuries to his person, character, or real estate. ${ }^{3}$ By a statute passed in the reign of William IV., rights of action for injuries to real property were continued to the representatives of the deceased. ${ }^{4}$ By a modern statute an action is given to certain relations of a person whose death lias been caused by the negligence of another. ${ }^{5}$

SEc. 199. As to Assignees in Bankruptcy. For injuries to either personal or real property all rights of action upon bankruptcy pass to the assignee. No right of action passes for mere personal torts. ${ }^{6}$

SEc. 200. As to Joinder of Parties Plaintiff. The general rule has been aptly formulated by Mr. Dicey as follows:-

1st. Persons who have a separate interest and sustain a separate damage must sue separately.

2d. If they have a separate interest but sustain a joint damage, they may sue either jointly or separately in respect thereof.

$3 \mathrm{~d}$. If they have a joint interest they must sue jointly for an injury thereto. ${ }^{7}$

It will be proper to notice the application of these rules to some of the parties who have interests in common with each other:-

1st. Joint Tenants and Tenants in Common. They must join in actions for injuries to their personal property. ${ }^{8}$ For injuries to their real property joint tenants and coparceners must join.

Tenants in common must join in actions for trespass and nuisance to their realty. ${ }^{9}$ They may sue separately for recovery of possession and mesne profits. ${ }^{10}$

11 Chit. Pl. 68; Dicey, 402.

24 Edw. III. c. 7; 15 Edw. III. c.

5; Dicey, 403 ; 1 Chit. Pl. 69.

${ }^{3} 1$ Chit. Pl. 69 ; Stanley $v$. Bircher,

78 Mo. 245.

$43 \& 4$ Wm. IV.c. 42 , s. 2 ; 1 Chit.

Pl. 70.

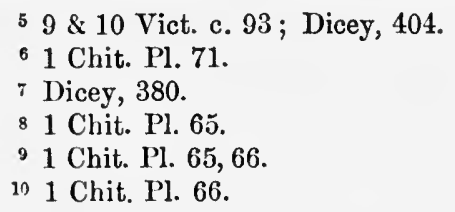


When two or more persons have a joint right of action for a tort, it passes on the death of each to the survivor, and upon the death of the last survivor to his representatives, if it is an action which survives death.

2d. Partners. All partners must join in an action for wrong done to the firm or firm property. ${ }^{2}$ They can join in an action for injuries to their business resulting from a libel or slander. ${ }^{3}$

3d. Husband and Wife. The rule of joinder in torts is analogous with that which applies to contracts. Husband and wife must join in actions for injuries: First, to the person, character, or property of the wife committed before marriage; second, to the person or character of the wife committed during coverture; third, to the property and rights of the wife as executrix or administratrix. ${ }^{4}$

When the husband has suffered special damages resulting from injuries to the person or character of his wife by depriving him of her company, aid, and assistance, or in subjecting him to expense, he must sue alone for them. ${ }^{5}$ For injuries to her personal chattels committed during coverture he must sue alone by reason of his sole ownership. 6 For damages to her realty during coverture the husband may sue either alone or jointly with the wife. The wife, however, is a necesscury party when the injury is a permanent one to her freehold. ${ }^{8}$ If the husband survive he may still sue for any injury to her person or property for which he might have sued alone during coverture. 9 In cases where the wife must join in suing, the right of action on death of the husband remains to the wife. On the death of the wife it passes to her husband, except in cases in which she is executrix or administratrix. ${ }^{10}$ The injurious effects of non-joinder and nisjoinder of plaintiffs, as prevailing at common law, were counteracted by the liberal power of amendment given to the courts by the Common Law Procedure Act of $1852 .{ }^{11}$

1 Dicey, 382.

2 Dicey, 384.

31 Chit. Pl. 64.

4 Dicey, 389 ; 1 Chit. Pl. 73.

51 Chit. Pl. 73 ; Dicey, 390, 391.

61 Chit. Pl. 74 ; Dicey, 394.
71 Chit. Pl. 74.

8 Dicey, 393.

91 Chit. Pl. 75.

10 Dicey, 392.

$1115 \& 16$ Vict. c. 76 , sec. $34,35,36$. 


\section{ARticle III.}

Parties Defendant in Personal Actions ex contractu.

Sec. 201. The General Rule.

“ 202. As to Agents.

" 203. 'Trustees, Cestnis que Trust, Partners, and 'Tenauts in Common as between each other.

Sec. 204. Assignees.

“205. Executors and Administrators.

“ 206. Heirs and Devisees.

" 207. Infants.

“ 208. Corporations.

Sec. 209, 210, and 211. Joinder of l'arties.

SEc. 201. The General Rule. The person to be sued for breach of a contract of any. kind must be a party to the contract by express undertaking or by implication of law. ${ }^{1}$ This rule is so general, that its application is usually directed in pursuance of subordinate rules of qualification or exception, depending on the nature and form of the contract sought to be enforced :-

1st. Upon deeds, whether deeds inter partes or deeds-poll, ineluding bonds, the action must be against the person contracting or covenanting, who executes the instruments. If he contracts or covenants in the deed and executes the instrument, he is liable on the contract or covenant, although not described in the deed as a party thereto. ${ }^{2}$ In this respect the rule differs from the one governing the right of action on the part of the covenantee, who could not sue on a covenent in a deed inter partes, unless he was mentioned as a party to the deed. If so mentioned, he could sue, although he had not executed the deed. ${ }^{3}$

$2 d$. In simple contracts, the person liable in an action for a breach thereof is the person who promises or who allows the credit to be given to him. ${ }^{4}$

3d. Some contracts implied by law, and which are known as quasi contracts, may be regarded as furnishing an exception to the preceding rule. Actions on them should be brought against the persons on whom the law imposes a legal liability from the particular facts of the transaction. ${ }^{5}$

4th. Persons appointed by statute to be sued on behalf of others furnish an exception to the general rule. ${ }^{6}$

The foregoing rules may be illustrated by considering them with

1 Dicey, 223.

4 Dicev, 225.

2 Browne, 111; 1 Chit. Pl. 33;

Dicey, 229, 230.

31 Chit. Pl. 34; Dicey, 228.

- Dicey, 228.

8 Ante, sec. 182. 
reference to the relation which different classes of persons may bear to contracts.

SEc. 202. As to Agents. The qualifying or subordinate rule is that a contract entered into by a principal through an agent is in law made by the principal, not by the agent; and the principal alone is liable to be sued on it. ${ }^{1}$

The following exceptions to this rule have been formulated by Mr. Dicey, in all of which the agent is liable: -

1st. When the agent contracts by deed in his own name.

2 d. Where an agent draws, indorses, or accepts a bill of exchange or negotiable note in his own name.

These first two exceptions are held not to apply to an officer of government acting in its behalf. ${ }^{2}$

$3 d$. Where credit is given exclusively to the agent.

4 th. Where an agent contracts for persons incapable of contracting.

5th. Where the agent is treated in the contract as the actual party by whom the contract is made.

6 th. Where the agent is the only known or astensible principal, or where a contract (not under seal) has been made by an agent in his own name for an undisclosed principal.

7th. Where' money received by an agent for his principal has. been paid under a mistake of fact, or obtained by means of a tort.

8th. Where the agent has signed certain contracts on behalf of a limited company_without using the word limited.

The first four of the foregoing exceptions, and probably the eighth, are cases in which the agent must be sued and the principal cannot be sued; the fifth, sixth, and seventh are cases in which either the principal or the agent may be sued.

SEc. 203. Trustees, Cestuis que Trust, Partners, and Tenants in Common as between each other. Trustees are not liable to be sued at law by their cestui qiie trust, unless they have admitted a balance due; the remedy for breach of trust being in equity. 4 Partners and tenants in common are likewise for the same reason not liable to their copartners or cotenants in actions at law in form ex contractu. ${ }^{5}$

11 Chit. Pl. 34 ; Dicey, 238.

21 Chit. Pl. 35; Unwin $v$. Wolseley, 1 T. R. 674; Gidley $v$. Lord Palmers. ton, 3 Brod. \& Bing. 275 ; Bainbridge v. Downs, 6 Mass. 257.
3 Dicey, 251.

41 Chit. Pl. 34.

51 Chit. Pl. 39. 
SEc. 204. Assignees. The general rule is that the liability to action on a contract cannot be transferred or assigned, and that the liability of the assignor remains, notwithstanding the assignment.

Liability is a burden and not a right of property. 1 In general, the assignee of a contract is not liable to action for its breach, nor does the assignor escape any liability by assignment.

There are some exceptions to this rule.

1st. When, by agreement of all parties, the original obligor is discharged and a new one substituted in his place.

$2 d$. Upon marriage, the husband becomes liable for the wife's debts.

3d. Upon death, the executor or administrator becomes liable for the debts of the deceased to the extent of the assets received.

4 th. Upon bankruptcy, the liability of the debtor ceases on his existing obligations, and they can be 'enforced only against the assets in the hands of the assignee. The same is true of debtors complying with the provisions of the insolvent act. ${ }^{2}$ The extent of the application of the fourth exception depends upon the provisions of the bankrupt and insolvent act, to which the reader is referred. ${ }^{3}$

5th. Upon covenants running with the land, whether express or implied, the assignee of the lessee is liable for all breaches accruing while the term is legally vested in him, but not for breaches happening before assignment to him nor after assignment of the term by him. His liability rests upon privity of estate, and not upon privity of contract. The original lessec remains liable to the lessor on the express covenants of the lease, notwithstanding his assignment of the term, even though his covenants run with the land, and the lessor has accepted the assignee as his tenant. 5 This liability of the original lessee does not, after assignment of his term and acceptance of the assignee as tenant, continue to any one but the original lessor, who is privy in covenant with him. It does not continue to the assignee of the lessor, with whom he has neither privity of contract nor estate. ${ }^{6}$ In absence of assignunent of his term by the lessee, his liability to the assignee of the lessor would

11 Chit. Pl. 47 ; Dicey, 2.34.

21 Chit. Pl. 53, 55, 56; Dicey, 306; 7 Geo. IV. c. 57 , sec. 40,$46 ; 1 \mathrm{IVm}$. IV. c. 38.

3 Dicey, 308.
41 Chit. Pl. 48; Dicev, 237.

5 Dicey, 226 ; 1 Chit. Pl. 49 ; Smith, L. \& T. 43 , note 19 .

${ }^{6}$ Iicey, 237; 1 Saund. 240, 241, c. 
continue by privity of estate. ${ }^{1}$ After assignment by the lessee and acceptance of his assignee as tenant, the lessee cannot be held in any description of action on covenants implied by law, - covenants which rest upon privity of estate. ${ }^{2}$

On assignment of the reversion by the original lessor, he now ceases to be liable on his covenants which run with the land. His assignment severs his privity of estate. By virtue of statute his privity of contract in respect to the covenants which run with the land, as well as his liability thereon, is transferred to his assignee. ${ }^{3}$

SFC. 205. Executors and Administrators. The executor or administrator of a deceased person is the proper party to be sued upon all contracts made with him, whether broken before or after deatli.4

There are three exceptions to this general rule which include:-

1st. Contracts limited to the lifetime of the deceased.

2d. Covenants in law running with land and limited to the duration of the lessor's estate, ceasing upon its determination. If broken after death of the lessor, no action lies against his executor or administrator. ${ }^{5}$

3d. Joint contracts in which the liability of the deceased as a party thereto is to be discharged by the surviving obligors. ${ }^{6}$

As a general rule, an executor or administrator must be sued in his represcntative capacity on all contracts made by the deceased, and in his personal character on contracts made by himself.?

There are two exceptions to this rule:-

1st. When he becomes liable as assignee of a term, he may be sued in his representative or personal capacity at the election of the lessor.

2 d. On promises made by him distinctly in his representative capacity, he may be sued-in-that character and held chargeable as upon a promise of the testator. ${ }^{8}$

SEc. 206. Heirs and Devisees. . The heir was liable to an action for breach of an express covenant under seal, provided the ancestor expressly bound his heir as well as himself by its terms, and the heir received legal assets by descent from the covenantor. ${ }^{9}$ He was also bound by his ancestor's contracts of record, such as judgments and recognizances. ${ }^{10}$

1 Dicey, 237.

21 Chit. Pl. 50.

332 Hen. VIII. c. 24 ; Smith, I. \&

T. 293 , note 19 .

4 Dicey, 313 ; 1 Chit. Pl. 51.

- Dicey, 315,316 .
6 Dicey, 317.

7 Dicey, 317, 318.

8 Dicey, 321.

91 Chit. Pl. 52; Dicey, 323.

10 Dicey, 323. 
An heir receiving a legal estate becomes liable as assignee to an action for breach of any covenant running with the land committed in his own time. A devisee of a freehold was not liable at common law on the contracts of the devisor. ${ }^{2}$ But by modern statutes he is bound under the same circumstances and to the same extent as the heir would have been bound if the land had come to him by descent. ${ }^{3}$

SEc. 207. Infants. An infant could not be sued successfully at common law on any contract made by him. His contracts were either void or voidable. ${ }^{4}$

This was the general rule, to which there were two exceptions:-

1st. He could be held liable on his contracts for necessaries.

2d. Also on contracts attached to, or incident to, permanent property accupied or possessed by him. ${ }^{5}$

He was liable to action on all contracts made during infancy, which he had ratified after reaching his majority.

Sec. 208. Corporations. An incorporated body must be sued by its corporate name. The ancient rule that it could not be sued on contracts not under seal may be said to have no application in modern times except as to such contracts as are required by law, or the provision of its charter, to be under seal. ${ }^{6}$

As to all contracts within its corporate powers made by its officers or agents it is liable like any other person in the absence of statutory provision to the contrary. ${ }^{7}$

It is generally laid down that a corporation cannot be sued on contracts ultra vires. ${ }^{8} \quad$ But in respect to private corporations the doctrine of estoppel may be successfully interposed to the plea of ultra vires in a great variety of cases furnishing the elements of equitable estoppel. ${ }^{9}$ Corporations in process of winding up under proceedings of court, or in the hands of receivers, cannot be sued except by leave of court; and actions pending against them may be stayed. ${ }^{10}$

SEc. 209. Joinder of Parties. It was a rule at common law that where several persons were jointly liable on a contract, they must all be sued in an action for the breach of it."

11 Chit. Pl. 53 ; Dicey, 323.

2 Dicey, 324.

3 Dicey, 324 ; 11 Geo. IV. and $1 \mathrm{Wm}$. IV. c. 47 , sec. $2,3,4$; Rev. Stat. Mo. 1889 , sec. 8839 .

4 Dicey, 28:3.

6 Dicey, 290.
6 Taylor on Private Corporations, sec. 218.

74 Thompson, Corp., s. 5015, 5017.

8 Dicev, 278.

95 Thompsoll, Corp., s. 6015.

10 Dicey, 280.

11 Chit. Pl. 42 ; Dicey, 230. 
This rule was subject to the following exceptions: ${ }^{1}$ -

1st. Where one of the joint contractors has become bankrupt, an action may be brought against his co-contractors alone.

$2 \mathrm{~d}$. Where the claim sued on is barred against one or more joint debtors, and not against the other or others suing.

$3 \mathrm{~d}$. Where one or more of several co-contractors are non-residents of the jurisdiction, they may be omitted from the suit.

4th. Where the defendant is sued as a common carrier, his cocontractors need not be joined.

5th. Where the suit is against a firm and the persons left out are nominal or dormant partners.

6 th. Where one of the co-contractors is an infant or married woman.

When the contractors, by the terms of their contract, were severally as well as jointly bound, they could be sued jointly or separately at the option of the plaintiff. The suit had to be against all or only one. ${ }^{2}$ In no case can an executor or administrator be joined as defendant with an heir or devisee. ${ }^{3}$ The same is true of contracts joint in form, but made several as well as joint by law.

SFC. 210. Joinder of Parties, continued. - Partnership. Snits against partnerships must be brought against the persons by name composing the firm. ${ }^{4}$ To this rule there are two exceptions :-

1st. Where a member of the firm is a nominal or dormant partner he may be joined or omitted. ${ }^{5}$

2 d. One partner must, or may be, sued alone, on contracts made by lim on behalf of the firm, in the same cases in which an agent must, or may be, sued on contracts made by him on behalf of his principal. ${ }^{6}$

Bankruptcy of the firm terminates_the right of action against the members thereof. On bankruptcy of one or mure partners, the solvent partner or partners remain liable to action. ${ }^{7}$

On the death of a partner, the surviving partuers, and ultimately, the last survivor or his representative, must be sued on contracts made with the firm. ${ }^{8}$

SEC. 211. Joinder of Parties, continued. - Husband and wife. It was a general rule that a wife could not be sued alone

1 Dicey, 231-233.

21 Chit. Pl. 43; Dicey, 233.

8 Dicey, 324.

4 Dicey, 266.
6 Dicey, 268.

6 Dicey, 271; see sec. 202.

7 Dicey, 272.

8 Dicey, 274. 
during coverture on-any contract or liability. ${ }_{\rightarrow}^{1}$ To this rule there were four exceptions :-

1st. When the husband is civilly dead by imprisonment, or transportation permanently or for a time.

-2d. When the husband is presumed in law to be dead after a lapse of seven years, with no account of him during his absence.

-3d. When the wife has a judicial separation or protection order under the statutes. ${ }^{2}$

4th. When the husband is an alien enemy. ${ }^{3}$

Husband and wife must be sued jointly:-

1st. On all contracts made by the wife before marriage.

$2 d$. On contracts in which a claim is made against the wife as executrix or administratrix. ${ }^{4}$

Upon death of the husband, the right of action on her contracts made before coverture survives against her as a feme sole. If the wife dies, the right of action on such contracts survives against her administrator. If the action has been brought against her and her husband, it abates as to both upon death of the wife, but may be revived as against her administrator. If the husband dies after action brought, it abates as to the husband, and may be continued as against the widow. If the husband dies after judgment recovered, the liability on the judgment remains against the wife. If the wife dies after judgment, the lusband remains liable on the judgment as for a debt of his own. ${ }^{5}$

In regard to contracts in which it is sought to charge her as executrix, the right of action survives as against the wife on death of the husband, and upon ber death it survives against the representative of the testator or intestate. ${ }^{6}$

A wife is not liable on contracts made by her during coverture. ${ }^{7}$ Her husband may be liable on such contracts when made by her as agent of her husband or when they have been made for necessaries. ${ }^{8}$ In the enforcement of such contracts the husband alone is liable, and he must be sued alone. ${ }^{9}$

The injurious consequences of a misjoinder of defendants in actions ex contractu were greatly mitigated by the Common Law Procedure Act of $1852 .^{10}$

1 Dicey, 296; 1 Chit. Pl. 57.

$220 \& 21$ Vict. c. 85, s. 26 and 21.

8 Dicey, 296, 297.

4 Dicey, 297.

5 Dicey, 298.

- Dicey, 299.
71 Chit. Pl. 5s; Dicey, 299.

8 Dicey, 300, 302.

9 Dicey, 299.

1 Com. Law Pr. Act, 1852, s. 37, 38,39 . 


\section{Article IV.}

\section{Parties Defendant in Personal Actions ex delicto.}

Sec. 212. General rule.

“ 213. Injuries to absolute rights of a person.

" 214. Injuries to relative rights of persons.

" 215. Iujuries to riglits appertaining to land.

" 216. Injuries to rights appertaining to personal chattels.
Sec. 217. Injuries resulting from manage. ment and control of real and personal property.

" 218. Principal and agent.

" 219. Husband and wife.

" 220. Infants and insane persons.

" 22l. Executors and administrators.

“ 222. Assignees.

“ 223. Corporations. Sec. 224. Joinder of Parties.

SEc. 212. General Rule. The general rule is that any one who violates the absolute or relative rights of persons, or the rights of persons in respect of their real or personal property, independent of contract, is liable to be sued. ${ }^{1}$ The person causing the injury to such rights, either wilfully or by neglect of legal duty, is liable to suit at the instance of the injured person.

In determining whether a person is liable under this rule as the cause of a wrong, the courts confine their inquiry to the natural and proximate consequences of his acts, and decline to consider remote consequences not clearly connected with the act complained of. ${ }^{2}$ Under the general rule, a person is not regarded as causing an injury to another, when the wrong complained of was caused partly by his negligence, and partly through the negligence of the complainant. ${ }^{3}$

An exception to the general rule exists in favor of persons protected by law, for acts done by them in their official capacity, such as judges, civil or ecclesiastical. Magistrates, constables, and police officers have a qualified protection. ${ }^{4}$ The application of the general rule will now be considered.

SEC. 213. Injuries to the absolute Rights of a Person. Under this head it may be said that all persons are liable to the injured party, by reason of assault upon, or imprisonment of, his person, or any act directly interfering with his liberty. ${ }^{5}$ This is equally true of injuries to his character in the form of libel and slander. ${ }^{6}$

SEC. 214. Injuries to the relative Rights of Persons. As we have seen, a person may have rights in the persons of others

11 Chit. Pl. 76; Dicey, 413.

2 Dicey, 410.

3 Dicey, 412.
41 Chit. Pl. 78 ; Dicey, 427, 430.

5 Dicey, 414.

6 Dicey, 415. 
to whom he holds the relation of husband, parent, or master. $\mathrm{He}$ has a right to their services and society. Any one who injures the person of a wife, child, or servant violates and impairs these rights, and may be sued by the husband, parent, or master, as the case may be. He may also be sued by the wife, child, or servant for the injury done to their absolute rights.

SEc. 215. Injuries to Rights appertaining to Land. A person committing a trespass upon land, interfering with its possession and enjoyment, or damaging its value, is responsible for his acts to all persons having estates in the land, to the extent of the injury suffered by them respectively. ${ }^{1}$ Actual possession is an estate sufficient to maintain an action against any one wrongfully interfering with the same. ${ }^{2} \mathrm{He}$ is also responsible for damages resulting to it, by reason of his negligence or misconduct falling short of actual trespass; as in case of a nuisance maintained or permitted near it. ${ }^{3}$

SEc. 216. Injuries to Rights appertaining to Personal Chattels. Any one who interferes with the possession, or riglit of possession, immediate or future, of personal chattels, may be sued in trespass, trover, or case according to the extent and character of his interference, and the interest therein of the complainant. ${ }^{4}$

SEC. 217. Injuries to the Rights of others proceeding from the Negligence or Misconduct of a Person in the Use, Management, and Control of his own Property, real or personal. A person is liable in tort, as the owner or occupier of land, for injuries to others resulting from malfeasance or want of care in the management and control of it. ${ }^{5} \mathrm{He}$ is likewise liable for injuries to others arising from his personal chattels, as long as they remain under his control, but not when they pass out of his control, unless control is lost by his fault. ${ }^{6}$ The fact that he keeps or harbors an animal known by him to be dangerous makes him the cause of injuries inflicted by the animal. ${ }^{\top}$

SEc. 218. Principal and Agent. A principal or master is liable to be sued for the torts of an agent or servant, either committed by the command of the principal or master, or subsequently assented to or ratified by him. ${ }^{8}$ There can be no exception to this rule, for

1 Dicey, 417.

21 Chit. Pl. 176.

3 Dicey, 422 ; 1 Chit. Pl. 83.

4 See sections $73,86,97$.

51 Chit. Pl. 83; Dicey, 422, 423.
- Dicey, 425 . 83.

' Dicey, 425, 426; 1 Chit. Pl. 82,

8 Dicey, 440. 
the reason that the act of the subordinate is made also the act of the principal or master, by his specific command or ratification.

A principal or master is also liable to be sued for the torts of his agent or servant, if committed in the course of his employment and in the service of the principal or master. ${ }^{1}$ There were three well recognized exceptions to this rule: 1st, where a servant is injured by a fellow servant; ${ }^{2} 2 \mathrm{~d}$, where the principal or master is compelled to employ a particular person ${ }^{8} 3 \mathrm{~d}$, where the employer is a public officer under government. ${ }^{4}$

In the third exception he is only a nominal principal, and the government is the real principal. His exemption is not affected by the fact that no action can be maintained against the government. It is generally held, that this third exception does not protect trustees or corporations, in the gratuitous performance of public works, from liability for the torts of their servants. ${ }^{5}$

An agent or servant is liable to the person wronged for acts of misfeasance or positive wrong in the course of his employment, but not for acts of non-feasance or mere omission. ${ }^{6}$ The nonfeasance or omission for which the servant or agent is not responsible must relate to the duty assumed by him to his principal or master, and not to any breach of duty due to third persons.

SEc. 219. Husband and Wife. A woman remains liable after marriage for her torts committed before marriage. But her husband must be joined with her as defendant in suits_brought against her for their redress. ${ }^{7}$ A married woman is responsible for torts actually committed by her during coverture; though she cannot be a trespasser by mere assent, either prior or subsequent. ${ }^{8}$ Her husband must be joined with her as defendant in all suits on account of such torts. ${ }^{9}$ When the tort is committed by her in the presence of her husband, he is prima facie liable for it as his own act, and she is exempt. ${ }^{10}$ But this liability and exemption will not prevail against evidence showing that the tort was committed by her in violation of his commands. ${ }^{11}$ Married women are not liable for torts committed during coverture in the nature of fraud connected with, or constituting an inducement to, a contract. ${ }^{2}$

1 Dicey, 445; 1 Chit. Pl. 81.

2 Dicey, 459.

8 Dicey, 461.

4 Dicey, 462.

5 Dicey, 462.

'Dicey, 463; 1 Chit. Pl. 83, 84.
71 Chit. Pl. 92; Dicey, 476.

81 Chit. Pl. 76, 92.

91 Chit. Pl. 92.

10 Cooley on Torts, 115, ed. 1879.

11 Cooley on Torts, 115, ed. 1879.

12 Dicey, 476, 477. 
Neither can she be made responsible for breaches of contracts made with her during coverture by being sued for such breaches in the form of an action of tort. ${ }^{1}$

Upon death of the wife her liability, if it is such as survives, passes to her representative, and her husband is no longer liable. ${ }^{2}$ After death of her husband, she remains liable for torts committed either before or during coverture. ${ }^{3}$ When a wife and husband commit a tort jointly, they may be sued jointly, or the husband may be sued alone. But no action can be maintained against her alone during coverture.

SEC. 220. Infants and Insane Persons. Infants are liable for torts committed by them. ${ }^{5}$ They cannot be held liable for breach of a contract by a suit, in form of a tort. If the action be in substance for breach of contract, the fact that it is in the form of an action in tort will not overthrow his plea of infancy. ${ }^{6}$

To his liability for tort there is one exception, where it consists of a fraud closely connected with or constituting an inducement to a contract. ${ }^{7}$ While insane persons are not liable criminally, they are responsible civilly for any tort they may commit. ${ }^{8}$

SEc. 221. Executors and Administrators. The general rule at common law was that executors and administrators of deceased persons could not be sued for torts committed by them. ${ }^{9}$ There were two exceptions, at common law to this rule: Ist, an action might be maintained against the executor of an ecclesiastical person for dilapidations $;^{10} 2 \mathrm{~d}$, when the tort contained the facts upon which an action ex contractu might be supported, the executor could be sued for it in the latter form of action. ${ }^{11}$

Exceptions to the common law rule have been effected by statute for the most part, in modern times. It may be noticed here that the statute of $4 \mathrm{Edw}$. III. c. 7 , which furnished a remedy for certain torts in favor of an executor or administrator did not give any remedy against them. By statute 30 Car. II. e. 7, explained and made perpetual by $4 \& 5$ W. \& M. c. 24 , s. 12 , the executor or administrator of any executor or administrator was made liable for the devastavit of his testator or intestate. ${ }^{12}$ By

1 Dicey, 476.

2 I)icey, 478.

8 Dicey, 478.

44 Dicey, 476.

51 Chit. Pl. 76 ; Dicey, 474.

6 Dicey, 474.
7 Dicey, 475.

81 Chit. Pl. 76 ; Dicey, 2.

91 Chit. Pl. 89; Dicey, 481.

10 Dicey, 482.

111 Chit. Pl. 69, 90; Dicey, 482.

121 Chit. Pl. 90, 91. 
statute of $3 \& 4 \mathrm{Wm}$. IV. c. 42 , s. 2 , actions might be brought against executors and administrators for an injury to property real or personal, committed by the testator or intestate within six months before his death, provided the actions were commenced within six months from the date at which these representatives assumed administration of the estate. ${ }^{1}$

Since the passage of these statutes, the representatives of a deceased person can be sued only for such torts of the decedent as constituted an invasion of property riglits. Liability for an infraction of those absolute rights which relate to the person, reputation, and domestic comfort of the claimant terminates with the death of the perpetrator. In the United States the modifications of the common law are in general accord with the statutes and result of the text. ${ }^{2}$

SEc. 222. Assignees. With the exceptions under the previous section, liability for a tort cannot be transferred or assigned. ${ }^{3}$ The liability of the husband to be joined with his wife in a suit for her torts is an apparent rather than a real exception. ${ }^{4}$ Liability for a tort is in no case transferred to an assignee in bankruptcy. The bankrupt remains liable after as before discharge. ${ }^{5}$ This may not be true of a claim substantially for breach of contract, although asserted in form of action ex delicto.

SEc. 223. Corporations. Corporations are liable to be sued for torts committed by their agents within the scope of their employment, or which have been authorized or ratified by the corporate body, or which arise from a breach of duty imposed by law. ${ }^{6}$ It is held that there are some wrongs which a corporation is incapable of committing, such as murder, adultery, seduction, slander, and corruption. It is now settled that they are liable for any malicious prosecution or libel authorized by them, and for frauds committed by their agents or servants in the course of their employment.

SEc. 224. Joinder of Parties Defendant. The general rule is that one or any or all of several joint wrongdoers may be sued by the injured party, for the reason that a tort is in legal contemplation the wrongful act of each individual, although another may have acted with him. ${ }^{8}$ To render a tort joint as against two or

11 Chit.Pl. 70, 91 ; Dicey, 481, 482.

2 Stanley $v$. Bircher, 78 Mo. 245.

3 Dicey, 439.

4 Dicey, 439.

Martin Civil Procedure-12
5 Dicey, 180.

61 Chit. Pl. 76, 77; Dicey, 470.

7 Dicey, 472, 473.

1 Chit. Pl. 85, 86; Dicey, 430. 
more persons, it must appear that they co-operated in some way in the acts, or some of the acts, constituting the tort by aid, assistance, or counsel, ${ }^{1}$ or that they were related to each other as principal and agent, or master and servant, in such manner as to make the acts of the agent or servant the acts of the principal or master, because done within the scope of their employment. ${ }^{2}$ All persons actually participating in any manner in a tort are liable to be sued jointly; and it is no defence that one was principal and the other an agent. As to the injured party they are all principals. ${ }^{3}$ This principle applies not only to trespasses $v i$ et armis against persons or property, ${ }^{4}$ but to a large class of torts which fall under the general head of case, such as conversion of personal property, malicious prosecution, libel, \&c. ${ }^{5}$ Indeed, it may be said that the liability to be sued jointly applies to all torts, except a few which the courts have held to be incapable of being committed by more than one person, such as verbal slander, debt on penal statute, bribery, and perhaps seduction. ${ }^{6}$

When a proceeding is in substance an action ex contractu, the plaintiff cannot by bringing it in form ex delicto escape the effect of either omitting or joining parties according to the rules governing actions ex contractu..$^{\top}$ But this rule does not apply when the action in tort conld be maintained without referring to the contract. ${ }^{8}$

One or more of the partners of a firm may be sued for a wrong committed by the members thereof, or by any partner of the firm, acting within the scope of the partnership business, or by any agent or servant in the course of his employment. ${ }^{9}$

There seems to be one exception to the general rule, that an action can be maintained separately against one of several wrongdoers, which relates to joint tenants and tenants in common of land.

If the action is brought against a person in respect of his interest or ownership in land for an injury arising from its condition, any one interested with him as joint tenant or tenant in common must

1 Dicey, 432 ; Page $v$. Freeman, 19 Mo. 421.

2 Dicey, 445, 463.

Dicey, 464; Stephens v. Elwall, 4 M. \& S. $259,261$.

11 Chit. Pl. 79.
51 Chit. Pl. 85, 86 ; Dicey, 432.

6 1 Chit. Pl. 86 ; Dicey, 436.

7 Dicey, 437, 438.

8 Dicey, 438.

- Dicey, 467. 
be included as co-defendant. ${ }^{1}$ This exception also applies when the land is owned in partnership. ${ }^{2}$

\section{Article V.}

\section{Parties Plaintiff and Defendant in Real Actions.}

Sec. 225. Ancient Real Actions. | Sec. 226. Modern Real Actions.

Sec. 227. As to Defendants.

SEc. 225. Ancient Real Actions. The proper parties to the ancient real actions have been indicated in our sketch of the various writs giving the nature and name of the actions. There were a few rules arising from the quantity and nature of the estate, or right in the demandant or tenant, which applied to all real actions in general, and which may be briefly stated. ${ }^{3}$

1. As to the Demandant. To maintain a real action, it was necessary that the demandant should have an estate in fee, fee tail, or for life. ${ }^{4}$ A right to a chattel interest, as a term of years, would not be sufficient. By statute of Westm. II.c. 18, an exception was made in favor of a tenant by elegit, who might maintain an assize of novel disseisin. Real actions being founded on the actual seisin of the demandant or his ancestor, for the purpose of redressing the wrong of deforcement in its various meanings, it was necessary that the demandant himself should have been actually seised to maintain an action brought upon his own seisin, and that his ancestor should have been actually seised to support an action brought on the seisin of such ancestor; a seisin in law not being sufficient. ${ }^{5}$ Joint tenants were required to sue jointly. But upon refusal of one to prosecute, a severance could be enforced, and recovery by the other of his moiety was then permitted. The same rule applied to coparceners, as long as their interests remained undivided. ${ }^{8}$ Ten. ants in common were required to sue separately, because they were regarded as having several freeholds, and claiming by several titles.?

2. As to the Tenants. In general all real actions had to be brought against the actual tenant of the freehold, and not against a tenan

1 Dicey, 438.

2 Dicey, 439, 468.

81 Roscoe, 6 .

4 Jackson, Real Ac. 1 ; 1 Roscoe, 6.

51 Roscoe, 6.
61 Roscoe, 6.

71 Roscoe, 6, 7.

81 Roscoe, 7.

91 Roscoe, 7, 8. 
for years, by elegit, statute staple, or others holding only chattel interests. ${ }^{1}$ But a seisin in law of the tenant was sufficient without an actual seisin. ${ }^{2}$ In an assize of novel disseisin, an actual disseisor, although not a tenant of the freehold, ought to be joined with such tenant. $^{3}$ The ordinary and clerk were joined with the patron in a quare impedit. ${ }^{4}$

Joint tenants had to be sued jointly, so likewise with coparceners, till partition or severance of their estate. ${ }^{5}$ Tenants in common had to be sued severally, as they were possessed of several freeholds. ${ }^{6}$

SEc. 226. Modern Real Actions. It will not be necessary under this head to go outside of the action of ejectment, which constitutes the type of modern real actions.

1. As to the Plaintiffs. As already explained, this action was in its origin a remedy in favor of a termor to recover damages for an ouster of his possession, to which was added by the courts a recovery of his unexpired term. Formally on the record he appeared as a tenant for years to some other person who was seised of a superior estate. The question of the plaintiff's right as a termor in possession at the time of the ouster depended upon the estate of the other person, who had vested him with the term. In this manner the estate of the lessor came in question, and especially his right, as incident to it, to make an entry upon the land and give possession thereof to his tenant. In the course of time the lessor mentioned in the pleadings became the substantial party to the proceeding and the termor a fictitious party, whose tenancy under the substantial party and whose ouster could not be inquired into, by reason of the consent rule adopted by the court.

To maintain the action in this form, the precise estate of the lessor was not a matter of consequence, whether in fee simple, fee tail, in copyhold, for life, or for years, provided it was a legal estate as distinguished from an equitable one, and contained the right of immediate possession at the time of the demise laid in the declaration. The modification effected under the Common Law Procedure Act of 1852 dispensed with the fictitious lessee, and made the lessor the nominal as well as the substantial party plaintiff; and this result is not changed by the Supreme Court Judicature Act of 1875 . It is only necessary that the plaintiff should have some legal estate

11 Roscoe, 8 .

21 Roscoe, 8.

- 1 Roscoe, 8 .
41 Roscoe, 8.

51 Roscoe, 9.

- 1 Roscoe, 9. 
or interest in the premises, and the right of entry into possession as incident to it. ${ }^{1}$

The same rules of joinder prevailed in ejectment which obtained in the ancient real actions; joint tenants were required to join in the suit. ${ }^{2}$ Coparceners were also required to join, so long as their estates remained undivided. ${ }^{3}$ They were allowed to sue separately in ejectment by alleging a several demise by one of the joint tenants, - that act constituting a severance of the joint tenancy and coparcenery. ${ }^{4}$ Tenants in common were required to sue separately. ${ }^{5}$ But this requirement of severance was evaded, while the proceeding was in the name of a fictitious plaintiff, by permitting him to allege several demises from several tenants in common. ${ }^{6}$

Since the Common Law Procedure Act of 1852, the general rule as to co-owners seems to be that they may sue jointly and recover all they are entitled to, or that one or more of them may sue without joining the rest, and recover his or their share or proportion of the whole. ${ }^{7}$ This modification of the common law prevails very generally in the United States. ${ }^{8}$

SEc. 227. 2. As to Defendants. The persons to be made defendants should include all the tenants in possession of the land sought to be recovered. ${ }^{9}$

In the early rules and practice of the courts the landlord of any tenant who was sued in ejectment might appear, and by leave of court defend the case as co-defendant with his tenant. ${ }^{10}$ But it seems that this leave was not granted unless the tenant appeared and consented to be a co-defendant in the case. ${ }^{11}$ This defect in the proceeding was corrected by statutes in England and in the United States, by which the landlord or other person in privity of estate with the tenant acquired the right to appear and be made a defendant irrespective of the appearance or consent of the tenant. ${ }^{12}$

By a provision in the Common Law Procedure Act of 1852, any other person not named in the writ shall by leave of court be

1 Dicey, 484.

21 Chit. Pl. 65.

31 Chit. Pl. 65.

4 Doe $v$. Pearson, 6 East, 173; Jackson $v$. Bradt, 2 Caines, 169.

51 Chit. Pl. 65, 66; Gould, Pl. c. iv. s. 52 .

${ }^{6}$ Doe $v$. Read, 12 East, 57 ; Jackson $v$. Bradt, 2 Caines, 169.
7 Dicey, 492.

8 Hillhouse $v$. Mix, 1 Root, 246 ; 4 Day, 298 ; Prim v.Walker, 38 Mo. 94.

9 Dicey, 494.

10 Adams, Eject. 255.

1. Adams, Eject. 255.

12 Adams, Eject. 255. 
allowed to appear and defend, on showing by affidavit that he is in possession of the land either by himself or his tenant. ${ }^{1}$ This improvement in the action prevailed in the United States in pursuance of statutes and practice to that effect. It may be added here, that, by modern statutes in some of the American States, the plaintiff is at liberty to include the landlord or other claimants in his suit. ${ }^{2}$

1 Dicey, 497.

2 Rev. Stat. Mo. 1889, sec. 1993. 
CHAPTER VII.

JOINDER AND ELECTION OF ACTIONS.

Article I. Joinder of Actions. | Article II. Election of Actions.

ARTICle I.

Joinder of Actions.

Sec. 228. Joinder of Actions.

| Sec. 229. Consequences of Misjoinder.Changes in the Law.

Sfc. 228. Joinder of Actions. The general rule of the common law is, that where several causes of action of the same nature exist between the same parties, all accruing to the plaintiff in the same right and against the defendant in the same character or capacity, they may all be joined by several counts in the same declaration. ${ }^{1}$ It may be added here, that such joinder was encouraged by the courts and enforced at their discretion by orders of consolidation. ${ }^{2}$

Some difficulty has been experienced in determining when two or more causes of action are so allied to each other in their nature as to admit of their joinder in the same declaration. Several tests of resemblance between the different forms of action have been urged as justifying such joinder, based on similarity of process, plea, or judgment; but none of these tests are universal. ${ }^{8}$ They may assist, but do not absolutely control the pleader.

The whole subject is resolved into a question of the joinder of forms of action, the nature of the action appearing only through the form in which it is stated. Certain conclusions of the courts, with a few attending exceptions, may be stated as governing the practice of joinder at common law.

1st. A party may join in the same declaration as many causes of action as he pleases, provided they can be and are expressed in the same form. ${ }^{4}$

1 Gould, Pl. c. iv. 8. 79; 1 Chit. Pl. 200; 1 Tidd, Pr. 12.

23 Chit. Gen. Pr. 643; Gould, Pl. c. iv. s. 103.

81 Tidd, Pr. 12 ; Gould, Pl. c. iv. s. 89 .

11 Chit. Pl. 200; Browne, 560. 
2d. No action in any of the forms ex contractu can be joined with an action in any of the forms ex delicto. ${ }^{1}$

$3 \mathrm{~d}$. None of the actions in form ex contractu can be joined with actions in any other form ex contractu except debt and detinue. This conclusion assumes that debt and detinue are treated as both ex contructu in nature. This anomalous exception of their joinder has probably resulted from the fact that anciently both were regarded as actions of debt, and were found embodied in the same writ in the register of writs. ${ }^{2}$ Notwithstanding the modification and modern use of detinue, which relegates it to the classification of actions $e x$ delicto, the courts have unaccountably continued the ancient practice of permitting its joinder with debt. ${ }^{3}$ It has been said that such joinder is permissible only when detinue is founded on contract. ${ }^{4}$

4th. No action in form ex delicto could be joined with any action in any other form $e x$ delicto except trespass on the case with trover. ${ }^{6}$ The exception rests upon the fact that trover is in its nature a speeies of trespass on the case. ${ }^{6}$

All joinders of actions were subject to the requirement that the causes of action should all exist in favor of the plaintiff in the same right, and against the defendant in the same capacity or character of liability. ${ }^{7}$ The plaintiff could not join in the same declaration an action in his individual right with one in his right as the executor or representative of another. Neither could a person be called to answer a suit containing an action against him as an individual, joined with an action against him as an executor or representative of another.

SEC. 229. Consequences of Misjoinder. - Changes in the

Law. The consequence of a misjoinder of actions was very serious, tending to impeach the validity of the whole declaration, on being brought to the attention of the court on demurrer, in arrest of judgment, or upon error. ${ }^{8}$ On timely application, the court will in general give the plaintiff leave to amend by striking out some of the counts on payment of costs. ${ }^{9}$

11 Chit. Pl. 201; Gould, Pl. c. c. iv. s. $86 ; 1$ Chit. Pl. 200; Kettle iv. s. 91 .

${ }^{2}$ Sec. $41 ; 1$ Chit. Pl. 200.

$r$. Bromsall, Willes, 118.

${ }^{3} 1$ Tidd, Pr. 11; 1 Chit. Pl. 200 ;

4 Minor's Inst. $366,367$.

6 Sec. 77.

71 Chit. Pl. 201, 202 ; Gould, I'l.

41 Tidd, Pr. 11; Browne, 560.

54 Minor's Inst. 366; Gould, Pl. c. iv. s. 93.

81 Chit. Pl. 205, 200.

91 Chit. Pl. 206. 
ART. II.] JOINDER AND ELECTION OF ACTIONS. - ELECTION.

By the Common Law Procedure Act of 1852, it was enacted that " causes of action of whatever kind, provided they be by and against the same parties and in the same rights, may be joined in the same suit ; but this shall not extend to replevin or ejectment." 1 It was further enacted that the court or judge might order separate trials and records, if a trial of different causes of action togethèr should be inexpedient.

By section 40 of the same act, in suits brought by the husband and wife for injuries to the wife, the husband was permitted to add thereto claims in his own right.

\section{Article II. \\ Election of Actions.}

Sec, 230. Election of Actions.

SEc. 230. Election of Actions. It appears from our account of the actions prevailing at common law, that two or more of them were often concurrent remedies for substantially the same wrong.

Thus debt and assumpsit were concurrent remedies in general on simple contracts dischargeable in money. Either debt or covenant could be employed to enforce a money demand secured by deed. Either case or assumpsit could be invoked when the defendant was guilty of a tort, and the tort also constituted a breach of contract, express or implied.

Where goods have been wrongfully taken and detained, the plaintiff might be said to have a choice of redress in four forms of action; viz. trespass, trover, detinue, and replevin. Redress by assumpsit was also recognized in some of the American States. ${ }^{3}$ If the goods thus wrongfully taken have been sold by the defendant or converted into money, the plaintiff might always sue in assumpsit for money had and received to his use; ${ }^{4}$ in which event he would have no remedy by replevin or detinue, which implied that the goods were still in defendant's possession.

A pronounced tort might contain the elements of recovery upon a quasi contract, which the plaintiff was at liberty to enforce, thereby

1 Common Law Procedure Act, 1852 , s. 41 .

2 Common Law Procedure Act,

3 Bliss, Code, Pl. 244; Gordon v. Bruner, 49 Mo. 570. 1852 , s. 40 . 
waiving the tortious ingredients of the transaction; an injured party generally having the right to qualify a tort by omitting some of its aggravating features.

Having chosen one form of redress, the plaintiff was debarred from invoking any other, without abandoning the one first chosen before verdict. ${ }^{1}$

Which form was the most advantageous to him depended upon the circumstances of the particular case, and the incidents in which one form differed from another.

Chitty has grouped under nine heads the considerations which might control a choice of forms under the common law system of pleading and practice.

It is sufficient to say, in a general way, that these considerations related to: 1st, the nature or extent of plaintiff's interest or right; $2 \mathrm{~d}$, to the security of bail in the action or process ; $3 \mathrm{~d}$, to the number of parties; 4th, to the number and joinder of causes of action; $5 \mathrm{th}$, to the nature and defence of the plea; $6 \mathrm{th}$, to the venue; $7 \mathrm{th}$, to the evidence ; 8 th, to the costs ; 9 th, to the judgment and execution. For a more particular account of these considerations, the reader is referred to Chitty's Pleadings. ${ }^{2}$

11 Chit. Pl. 212.

21 Chit. Pl. 207-212. 


\section{CHAPTER VIII.}

\section{MOTIONS OF DEFENDANT AFTER DECLARATION AND BEFORE PLEA.}

Article I. Demand of Oyer.

" II. Demand of Particulars. Article IV. Imparlance. Article III. Views, Aid-Prayer, and
Voucher of Warranty.

\section{Article I.}

Demand of Oyer.

Sec. 231. Demand of Oyer.

SEc. 231. Demand of Oyer. The first step by defendant after receipt of the declaration was a demand of oyer, provided the declaration contained profert of an instrument under seal upon which the plaintiff founded his right of action.

In response to the profert made, the defendant might crave oyer thereof; that is, he might pray to have the same read to him in open court, so that he might ascertain the authenticity of the instrument, and make use by demurrer or plea of such portions as were not set forth in the declaration $;^{1}$ the effect of granting oyer being to make the instrument read a part of the record. This right of oyer existed in all actions, whether real, personal, or mixed, and relieved the defendant, after exercising it, from pleading until it was granted.2 It was also demandable in response to profert made in any pleading subsequent to the declaration.

It was a right, however, which extended to only such instruments as were necessarily made profert of. If the plaintiff unnecessarily made profert of an instrument, the defendant was required to plead without the privilege of oyer. If profert was erroneously omitted, the defendant could only demur to the pleading. ${ }^{8}$

Oyer was not demandable of a record recognizance, private act of Parliament, letters patent, agreement, note, or other instrument not

11 Chit. Pl. 430-434.

${ }^{8}$ Gould, Pl. c. viii. s. 63.

21 Tidd, Pr. 587. 
under seal.1 It was anciently allowed of the original writ, in order to enable the defendant to demur or plead in abatement for any defect or variance between the writ and declaration; but that practice was abolished by rule of court, and the plaintiff was permitted to proceed as if no demand for oyer of the writ had been made. ${ }^{2}$

The demand for oyer was a species of plea made by note in writing before the time for pleading had expired. ${ }^{3}$ But in more recent times it became the practice to demand oyer by a written request on the attorney of the party making profert. This demand was complied with by furnishing a copy of the instrument, and exhibiting the original if desired. ${ }^{4}$

\section{ARticle II. \\ Demand of Particulars.}

Sec. 232. Demand of Particulars.

SEC. 232. Demand of Particulars. In actions of assumpsit or'debt for goods sold or work and labor done, when the declaration, as in most instances, failed to disclose the particulars of the demand, the defendant's attorney might take out a summons before a judge requiring the plaintiff's attorney to show cause why he should not deliver to the defendant's attorney the particulars in writing of the plaintiff's demand, for which the action is brought, and why all proceedings should not in the mean time be stayed. ${ }^{5}$ It seems that such a rule to show cause could be taken out in both the King's Bench and Common Pleas before appearance, to the end that the defendant might be advised of the full particulars of the demand, so that he might pay it. ${ }^{6}$ But it was usually taken out after appearance and declaration, and before plea. The practice is of comparatively modern date, and is believed to have come in with the introduction of the Common Counts. ${ }^{7}$

In compliance with the order for particulars, the plaintiff should deliver a particular account in writing of the items of the demand, and when and in what manner it arose ${ }^{8}$ If there has been an account current, the credits as well as debits should appear. After delivery of the bill of particulars the defendant had time for plearl-

11 Chit. Pl. 431.

21 Tidd, Pr. 588.

31 Tidd, Pr. 588.

- See Profert, sec. 34.

51 Tidd, Pr. 596.
63 Chit. Gen. Pr. 611; 1 Tidd, Pr. 596.

73 Chit. Gen. Pr. 612; 1 Tidd, Pr. 597.

81 Tidd, Pr. 597. 
ing, according to the rules of the court in which the case was pending. ${ }^{1}$

In special assumpsits, covenant, and debt on articles of agreement, or in actions on matters of record, an order for particulars would not seem to be necessary. ${ }^{2}$

In actions of tort, the wrong complained of is in general stated in the declaration, and an order for particulars was seldom demanded; but the circumstances of the tort may be of such a nature as to render an order necessary and proper. ${ }^{3}$ If the bill rendered was defective in disclosing the necessary particulars, another one could be obtained by order of court for further particulars. ${ }^{4}$

The plaintiff was in like manner entitled to an order for particulars from the defendant when he made plea of a set-off for goods sold. ${ }^{5}$

The effect of the delivery of a bill of particulars by a party was to incorporate it as a part of the declaration or plea containing the cause of action upon which it rested, and to exclude at the trial the submission of any evidence outside of the particulars delivered. ${ }^{6}$

By a regulation' of Trinity term, 1831, the plaintiff, in actions containing counts in indebitatus assumpsit or debt on simple contract, was required to deliver full particulars of his demand under those counts where this could be comprised within three folios, and if it could not be comprised in three folios, then a statement of the nature of his claim and balance due as may be comprised within that number of folios, without any order to that effect. ${ }^{7}$

\section{Article III.}

Views, Aid-prayer, etc.

Sec. 233. Views, Aid-prayer, Voucher of Warranty.

SEc. 233. Views, Aid-prayer, Voucher of Warranty. There were certain motions or movements at command of the defendant in the ancient real actions preliminary to making defence, which may be noticed sufficiently in this connection by name or definition.

The tenant might in some of these actions demand $a$ view of the land in order that he might know with certainty what the demand-

11 Tidd, Pr. 598.

21 Tidd, Pr. 597.

31 Tidd, Pr. 597 ; Tilton $v$. Beecher, 59 N. Y. 176.
41 Tidd, Pr. 598.

51 Tidd, Pr. 598.

61 Tidd, Pr. 599.

73 Chit. Gen. Pr. 612. 
ant sought to recover, and that he might thus be enabied properly to shape his defence. ${ }^{1}$

The tenant might also pray in aid, or call for assistance of another to help him to plead, because of the weakness of his own estate. This motion might be made by the life tenant, asking that the owner of the inheritance or remainder be joined with him, or that he should help to defend the title. ${ }^{2}$

By voucher to warranty is meant the calling in of some person to answer the action, who has warranted the title to the tenant who has been sued. If the vouchee appeared, he was made defendant instead of the vouching tenant. ${ }^{3}$

\section{Article IV.}

Imparlance.

Sec. 234. Imparlance.

SEc. 234. Imparlance. After appearance, the defendant was entitled to an indulgence or delay from the court, before responding to the action, which was known by the name of imparlance. Primitively it signified a leave to confer (licentia loquendi) with the opposite party, with the view of an amicable settlement of the controversy. To effect this time was required, and the word itself came to represent the time given by the court to either party to respond to the pleading of his opponent, in which time he was furnished with an opportunity to settle the suit if he could do so.

Imparlances were of three kinds: 1st, general; $2 \mathrm{~d}$, special; and $3 \mathrm{~d}$, general special. ${ }^{4}$

A general imparlance was originally granted by the court in response to a general prayer for leave to imparl, without the saving of any exceptions. After leave was granted, the party obtaining it could plead only in bar of the action. He could not plead in abatement, nor regularly to the jurisdiction of the court. Neither could he plead tender, or make claim of conusance, or demand oyer of a deed. ${ }^{5}$ In the course of time this imparlance, which was always granted, came to be entered by the attorneys as a matter of course, and operated as a continuance of the cause to the next term.

I 4 Minor, Inst. 607; Booth, 3741.

24 Minor, Inst. 608; 3 Bl. Com. 300 ; Booth, 60-64.
34 Minor, Inst. 608; Booth, 43$60 ; 3$ Bl. Com. 300 .

4 Chit. Pl. 436.

51 Tidd, Pr, 463; 1 Chit. Pl. 437. 
A special imparlance was granted in answer to a prayer for imparlance which reserved the right to make dilatory pleas in abatement to the writ, bill, or count, but not to the jurisdiction of the court, unless the pleas were founded on a personal privilege. ${ }^{1}$ This imparlance could be granted only by leave of court in the King's Bench, or by the court or prothonotaries in the Common Pleas, and it operated as an extension of time for pleading to some day in the same term or to the first four days of the next term. ${ }^{2}$

A general special imparlance was distinguished from the imparlances heretofore defined, by saving to the applicant the right to make any exceptions whatsoever to the writ, bill, or declaration. ${ }^{3}$ He could plead in abatement of the writ, bill, or count, and to the jurisdiction of the court as affected by personal privilege. It could be obtained only by leave of court, ${ }^{4}$ and it operated as a continuance in like manner with special imparlances.

The effect of imparlances was in most cases to extend the time of pleading to the next term, and sometimes even to a third term. ${ }^{5}$ It was held by a conference of all the judges that imparlances were impliedly annulled by the Uniformity of Process Act of $2 \mathrm{Wm}$. IV., c. 39 , s. 11 , in all personal actions. ${ }^{6}$ The Hilary rules of $4 \mathrm{Wm}$. IV. reg. 2, practically abolished entries of imparlances on court rolls, and prohibited the entry of continuances by way of imparlances. ${ }^{7}$

11 Chit. Pl. 437.

21 Tidd, Pr. 462.

31 Tidd, Pr. 463 ; 1 Chit. Pl. 438.

41 Tidd, Pr. 463; 1 Chit. Pl. 438.
53 Chit. Gen. Pr. 103, 700.

3 Chit. Gen. Pr. 700.

73 Chit. Gen. Pr. 701; 1 Chit. Pl. 438. 


\title{
CHAPTER IX.
}

DEFENCES.

Article I. Classification of Defences. | Article II. Demurrer.

\author{
Article I. \\ Classification of Defences.
}

Sec. 235. Classification of Defences.

SEc. 235. Classification of Defences. Under the general head of defences I will consider the form and nature of the pleadings, whether of law or fact, employed by the defendant to defeat the plaintiff's claim, or by the plaintiff to overcome the defendant's plea. All these defences may be conveniently grouped as follows :-

1. Defences by way of demurrer.

2. Defences by way of dilatory pleas.

3. Defences by way of pleas in bar.

The subdivisions of this classification will be indicated when I come to discuss the respective divisions in their proper places.

The term defence as used in connection with common law pleading related to an averment in the pleading which originally prefaced the statement of every defence made by the defendant in a case. This averment consisted in a general assertion introductory to his statement, indicating that he intended to resist the action brought against him. This general and indefinite assertion, which followed the statement of his appearance, was extended and maintained by averments in the body of the pleading disclosing the character of his defence. ${ }^{1}$ The presence of this formal averment of defence in every plea seems to be a relic of the ancient denial, or no, which raised the issue for trial by battle or wager of law prior to special pleas or trial by jury. ${ }^{2}$

The defence, as indicated in the introductory averment, was to be, according to the language used, either a full defence or a half defence. 
If he intended to make a full defence, he used language by which he impliedly waived all exceptions to the jurisdiction of the court, and to the legal competency of the plaintiff to sue. ${ }^{1}$

Full defence, as used in the introductory statement, ran as follows : "And the said C. D. [defendant] by E. F. his attorney comes and defends the wrong and injury when and where it shall behoove him, and the damages and whatsoever else he ought to defend." 2

By signifying his willingness to defend when and where it shall behoove him, the defendant was considered as impliedly acknowledging the jurisdiction of the court. By his offer to defend the "damages and whitsoever else he ought to defend," he was considered as virtually admitting the plaintiff's competency to sue. ${ }^{3}$ If the defendant intended in his plea to deny the jurisdiction of the court or the legal competency of the plaintiff to sue, his plea was prefaced with language indicating that his defence would not be in the nature of a full or whole defence, and which ran as follows: "And the said C. D. by E. F. his attorney comes and defends the wrong and injury," omitting the averments of "when" and "where," and the allusion to "damages," which were considered as operating as a waiver of objections to jurisdiction or to the competency of plaintiff to sue. This latter prefatory statement was known as half defence. ${ }^{4}$

Half defence was used in connection with dilatory pleas; full defence, in connection with pleas to the merits. ${ }^{5}$ According to Gould, full defence could be used in all dilatory pleas, except those going to the jurisdiction of the court, or the legal competency of the plaintiff to sue. ${ }^{6}$ These formal defences were also used in connection with demurrers. ${ }^{7}$

So essential were these formal statements of defence considered in early times, that the erroneous use of a defence which was not adapted to the plea, or an entire omission of it, was fatal to the declaration, although the plea was in other respects sufficient. ${ }^{8}$ The defect came to be aided by general demurrer. ${ }^{9}$

The requirement of a general statement of defence, which had to be circumstantially extended and amplified, was arbitrary and

1 Gould, Pl. c. ii. s. 6, 9.

2 Gould, Pl. c. ii. s. 6; 2 Saund. Dig. Abatement, $1,16$. 209 (ed. 1802).

3 Gould, Pl. c. ii. s. 10.

- Gould, Pl. c. ii. s. 10.

5 Gould, Pl. c. ii. s. 10, 12 ; Com.

${ }_{6}^{6}$ Gould, Pl. c. ii. s. 11.

72 Chit. Pl. 678, ed. 1809.

81 Chit. Pl. 428.

91 Chit. Pl. 429.

ifartix Civil Procenure-19 
superfluous. In the progress of time it was evaded by the practice of adding to the phrase constituting half defence the words "when, etc.," which addition did not affect it as a half defence, when such defence was suited to the plea, but which implied a full defence when the latter was necessary to the plea. ${ }^{1}$ Under this practice the distinction between half and full defence became obsolete. ${ }^{2}$

It was ordered in the rules of Hilary term, 1834, that no formal defence be required in a plea, and that it should be commenced as follows: "The said defendant by his attorney says that," etc."

It will be noticed that these rules omit the statement of appearance, which was expressed in the word venit (comes); a suggestion which has not been invariably followed in modern pleadings, which usually contain the ancient allegations of appearance.

\section{Article II.}

\section{Demurrer.}

Sec. 236. Defined.

" 237. History.

" 238. Causes for Demurrer.

“239. Effects and Consequences.
Sec. 240. Effect of pleading over without l)emurrer.

“ 241. Judgments on Demurrer.

" 242. Demurrer to Evidence.

SEc. 236. Defined. After having received the declaration and exercised or waived his right to demand oyer and further particulars, it became the duty of the defendant, within the time limited by the rules of court, to determine whether the declaration was sufficient in law to disclose a cause of action, and thus impose on him the obligation to plead to it. The formal mode of disputing the sufficiency in law of the pleading of an adversary, either as to form or substance, was called a demurrer, which word is derived from the Latin word demorari and the French word demeurer. Primarily it signified a delay or pause in the progress of the action upon a point of law, which must be determined by the court before any further proceedings can be had therein." It was in substance a declaration that the party demurring would "go no further," because the other party had not shown sufficient matter against him that he was bound to answer, and praying judgment of the court in

18 T. P. 633; Alexander v. Mawman, Willes, 40 ; 2 Sáund. 209 c.

22 Chit. Pl. 410, note o, ed. 1809.
3 Reg. Gen. Hil. Term, $4 \mathrm{Wm}$ IV. reg. 10.

4 Mansel on Demurrer, 1. 
his favor, for want of a sufficient declaration. ${ }^{1}$ This challenge of law could be interposed not only to the declaration but to any subsequent plea or replication. The effect of it was to admit the facts pleaded and to refer the question of their legal sufficiency to the decision of the court. ${ }^{2}$ While a demurrer in ancient as well as in modern usage constitutes a pleading, because it raises and presents to the court an issue of law decisive of the case, it is not referred to as a plea, which latter word, in a technical sense, embraces only such pleadings as contain allegations of fact. ${ }^{3}$ It has always been treated and classified as a proper defence to an action, and the form of it until recent times contained the prefatory recital of "formal defence" in like manner with pleas. ${ }^{4}$

SEC. 237. History. The demurrer, as a defence, would naturally receive recognition after actions and pleas had assumed definite forms in common law procedure.

Accordingly it will be found that the separation of law from fact in English procedure worked its way to perfect recognition quite slowly. The office of a demurrer is frequently shadowed forth in the twelfth and thirteenth centuries, but a regular joinder in demurrer, which implied that both pleaders desired the judgment of the court on an issue of law, is said to appear very rarely if at all on the early rolls. ${ }^{5}$ In the reigns of Henry VI. and Edward IV. of the fifteenth century the disposition of a case by demurrer became well established in English procedure. ${ }^{6}$

By a general demurrer, which first came in use, the party demurring could, under the simple declaration that the pleading of his adversary was insufficient in law, urge in its support any defect in substance or form which might occur to him, except the single defect of duplicity, which he was required to mention specially; ${ }^{7}$ and this was the only special demurrer required at common law. ${ }^{8}$ This use of the demurrer continued until the judges were required by the statutes of 27 Elizabeth and of $4 \& 5$ Anne to give judgment on joinder in demurrer, "according to the very right of the cause and matter in law," without regarding any imperfection, defect, or want of form, except those only which the party demurring should

11 Chit. Pl. 661; 2 Chit. Pl. 678, ed. 1809 .

21 Chit. Pl. 662.

3 Sec. 14.

42 Chit. Pl. 678; Mansel, Demurrer, 201.
5 2 Pol. \& Mait. 637, 638.

62 Reeves, 648.

7 Mansel, Demurrer, 2; Powdick $v$. Lyon, 11 East, 565.

${ }^{8} 1$ Tidd's Pr. 694. 
"specially and particularly set down and express in connection with his demurrer as causes of the same." 1 In pursuance of these statutes, demurrers came to be divided into two classes, designated as general and special.

The general demurrer remained in the general and indefinite form of the primitive demurrer until it was somewhat simplified by the Hilary rules. It consisted in the general declaration that the pleading against which it was directed was insufficient in law. Under this demurrer only objections on matter of substance could be made. Its scope was limited to a consideration of matters of substance only.

If the pleader wished to take advantage of defects of form alone or in commection with matters of substance, it was necessary that he should speeify such defeets or omissions, otherwise they could not be noticed by the court.

The form of a special demurrer will be found to contain : first, the allegations which constitute a general demurrer; second, a specification of any defects in form which the demurrant desires to bring to the attention of the court, and which constitute the grounds of his special demurrer. ${ }^{2}$

Under a general demurrer, as stated above, only objections on matters of substance could be taken. Under a special demurrer the demurrant could urge not only the objections on matters of form, which he had specially set forth, but also any objections on matters of substance. This resulted from the fact that every spocial demurrer included in truth, as well as in form, also a general demurrer. ${ }^{3}$

It seems that the statutory requirement which confined the general demurrer to matters of substance was not construed as applying to demurrers to pleas in abatement, but that under a general demurrer to such pleas, objections of form as well as substance could be taken as before the statute. ${ }^{4}$ This construction of the statutes resulted from the nature of pleas in abatement, which were dilatory and did not go to the merits of the action. ${ }^{5}$ On this account they were not favored in the law and were held not to be within the spirit of the statutes, which were made, as expressed in their title, "for the furtherance of justice." 0

127 Eliz. c. $5 ; 4$ \& 5 Anne, c. 16 ; 1 Chit. Pl. 663, 664.

2 Steph. Pl. 45. 664.
4 Lloyd v. Williams, 2 M. \& S. 484 ; Walden $v$. Holman, 2 Ld. Raymond, 1015; 1 Chit. Pl. 664.

51 Tidd, Pr. 638.

${ }^{6}$ Ileard i. Baskerville, Hob. 232. 
By the pleading and practice rules of Hilary Term, 1834, the demurrer was simplified in form by omission of the recital of appearance, recital of formal defence, and the superfluous verbiage of the ancient pleader. The demurrant was also required to state in the margin of his demurrer at least one arguable objection in law, under penalty of having his demurrer set aside for failure to comply with the requirement. At the time of the argument he was at liberty to urge any further matters of law brought to the notice of the court in the usual way. 1

In other respects the general and special demurrer continued in use as before.

By the Common Law Procedure Act of 1852, special demurrers were abolished, and in place thereof was substituted a motion to strike out or amend any pleading which was "so framed as to prejudice, embarrass, or delay the fair trial of the action." By the same act a party might, by leave of court or a judge, granted upon a showing supported by affidavit, plead and demur to the same pleading. ${ }^{2}$ By this act the general demurrer was retained in a form similar to that prescribed by the Hilary rules, but which emphasized its use for reaching defects of substance only. ${ }^{3}$

By the orders adopted under the Supreme Court Judicature Act of 1873 the demurrer was abolished, and objections of law and matters of fact can be urged in the same pleading. ${ }^{4}$ It remains very generally in the United States. ${ }^{5}$

SEc. 238. Causes of Demurrer. There were held to be two indispensable requisites to all good pleadings: 1 . That the facts alleged be sufficient in law to disclose a maintainable cause of action, plea, or replication, as the case might be; and 2 . That they be alleged according to the forms of law which have been established for the conduct of judicial proceedings. For omission of either of these requisites the pleading was insufficient in law. To meet the two essential requisites the pleading had to be sufficient not only in substance, but in form. ${ }^{6}$ An insufficiency in either respect furnished a good cause of demurrer. ${ }^{7}$

1 Hilary Term, 4 Wm. IV ; 1 Chit. Pl. Appendix, 733, 737 ; 3 Chit. Gen. Pr. 755, 758, 760.

2 Common Law Procedure Act, 1852 ; 15 \& 16 Vict. c. 76 , sec. 50,51 , 52,80 .

8 15 \& 16 Vict. c. $76,89$.
4 Order 25.

5 See Forms of general and special demurrer in Appendix, Forms 44 and 45; and joinder in demurrer, Form $45 \mathrm{a}$.

6 Gould, Pl. c. jii. s. 1.

7 Gould, Pl. c. ix. s. 14. 
It is thus seen that the causes of demurrer were commensurate with the domain of substantive law, and involved the technical forms as well as the general principles of pleading. Probably on account of this latitude in the employment of the demurrer, the old authors on pleading never attempted any classification of the causes for demurrer, outside of that which is implied in the definitions of general and special demurrer.

The distinction between these two kinds of demurrers was more easy to express than to apply in actual practice, - a difficulty which admonished the pleader to use the special demurrer when he entertained any reasonable doubt about the nature of the defect which he wished to take advantage of. It has been laid down as a rule "that if the matter pleaded be in itself insufficient without reference to the manner of pleading it, the defect is substantial; but that if the only fault is in the form of alleging it, the defect is but formal." 1

Sec. 239. Effects and Consequences of Demurrer. Certain effects at common law attended the employment of a demurrer, either general or special.

First. It admitted all such matters of fact as were sufficiently pleaded. If the facts were not sufficiently pleaded as to substance or form, the demurrer at common law was no admission of their truth. ${ }^{2}$ After enactment of the statutes of Elizabeth and Anne already referred to, the rule of non-admission of the truth of matter insufficient in substance remained the same as at common law. If, however, the matter was sufficient in substance, but was defectively or informally pleaded, it was held by the courts that by virtue of the statutes the truth of it was admitted by a demurrer, unless the demurrer expressly and specially assigned the defects of form for cause of demurrer. ${ }^{3}$ A general demurrer thereafter was held to be an admission of all material facts though informally pleaded, in like manner as if formally pleaded. ${ }^{4}$

In applying this rule of admission there was one exception, and three cautionary directions which have been by some authors erroneously classified as exceptions.

1st. A general demurrer does not admit the allegations of a material fact or facts of which the court must take judicial cognizance. Whatever the court as a judicial tribunal must know to be untrue

1 Gould, Pl. c. ix. s 18.

2 Gould, Pl. c. ix. s. 21.

4 Steph. Pl. 143 ; Gould, Pl. c. ix.

3 Gould, Pl. c. ix. s. 21. s. 21 . 
or impossible cannot be established or taken to be true by any implied admission of the parties. An averment contrary to what previously appears certain of record, or one which the pleader is estopped from making, is not admitted by a general demurrer.

2 d. An immaterial allegation is not admitted by a general demurrer, for the reason that the rule of admission applies only to material allegations.

3d. Neither does a general demurrer admit a conclusion of law. It is superfluous to state a conclusion of law from facts, although it may often be proper for advising the court of the legal attitude of the party pleading it. It is the province of the court to draw. the necessary conclusions of law, and its action in that respect cannot be forestalled or overcome by the implications of a demurrer. Neither does it admit conclusions of fact, which the pleader may have seen fit to draw and express in his pleading, obviously deduced from other facts expressed in the pleading. Such conclusions of fact belong as a general rule to the province of the jury. ${ }^{1}$

4th. The admissions of fact implied by a general demurrer are only for the purpose of argument of the demurrer, and do not constitute evidence in the trial of any issue in the same or in any other case.

Second. Another effect of a demurrer consists in the rule that the court in determining it will examine the whole record, and give judgment on the demurrer for the party who on the whole record appears to be entitled to it. ${ }^{2}$

In following this rule, the court reviews the whole record, commencing with the declaration, and gives judgment in the cause against the party who is found to be first in default according to the pleadings. By whole record is meant the pleadings which commence with the declaration and terminate with the demurrer. Should they also terminate in another issue of fact, the demurrer would not open up such other record.

To this rule of opening up the whole record there were some exceptions and qualifications, which may be briefly noted.

1. In a demurrer to a plea in abatement the court will not go back of the plea and consider the sufficiency of the declaration, but will render judgment of respondeat ouster if the demurrer should be sustained. Having the right under this judgment to respond to the declaration again by plea or demurrer, the defendant was

1 Lindley $v$. Miller, 67 Ill. 244.

2 Steph. Pl. 144. 
not deprived of any privilege by restricting the examination to his plea. ${ }^{1}$

2. Though on the whole record the right may appear to be with the plaintiff, the court will not adjudge in favor of such right unless the plaintiff has put his action on that ground in his declaration. ${ }^{2}$

3. If a demurrer to a declaration be too broad in pointing to all the counts of a declaration, where one of them only is defective, the court will give judgment for the plaintiff generally, notwithstanding the defective count. ${ }^{3}$

4. The court, in examining the whole record in pursuance of a denurrer, will consider only the right in matter of substance, and not in respect of mere form such as should have been the subject of a special demurrer. ${ }^{*}$

5. The plaintiff is deprived of the benefits of the rule when he has suffered what is called in pleading a discontinuanee, - that is, when he has omitted to take judgment for failure of answer to part of the declaration. Having omitted to take judgment when the error occurred, he was not permitted on a subsequent demurrer to go back and demand judgment for the error thus passed by him. ${ }^{5}$

SEC. 240. The Effect of pleading over without Demurrer. A party by failing to demur, and by pleading over, as it is called, does not as a general rule admit that his adversary's pleadings are sufficient in law and undemurrable. In some cases this is the effect, and in some it is not. Advantage may occasionally be taken of demurrable defects by motion in arrest of judgment, or motion for judgment non obstante veredicto, or motion for a repleader, or by writ of error, according to the circumstances of the case.

1st. Demurrable faults of form were as a general proposition aided or waived by merely pleading over. ${ }^{6}$

2d. Demurrable faults, whether in substance or form, were cured by verdict, when it must be presumed by reasonable intendment that the disposition of the issue joined necessarily required, on the trial, proof of the facts imperfectly stated or omitted. ${ }^{7}$ In other words, after verdict everything will be intended which the averments of the record required to be proved. ${ }^{8}$

1 Steph. Pl. 144.

2 Steph. Pl. 144, 145.

3 Steph. Pl. 145.

1 Steph. Pl. 145.

Steph. Pl. 216, 217.

6 Steph. Pl. 147.
- Steph. Pl. 149.

84 Minor's Inst. 897; Nerot ". Wallace, 3 T. R. 25; Barber v. Fox, 2 Saund. 136; Stennel $v$. Hogg, 1 Saund. 228, note 1 . 
3d. At certain stages of the cause all faults of pleading in matters of form were cured by the different statutes of Jeofaile and amendments $;^{1}$ and could not be urged in motion to arrest judgment.

4th. That the declaration totally omits to state a cause of action was a demurrable fault, which was not cured or aided by judgment. In such case there could be no presumption that the cause of action was proved, as in the case of a defective statement of a good canse of action. $^{2}$

SEc. 241. Judgments on Demurrer. To bring a deinurrer before the court for its determination, it was necessary that there should be a formal joinder in demurrer, in which the language of the demurrer was traversed or contradicted by simply alleging the sufficiency of the declaration or plea demurred to. ${ }^{3}$

A judgment on demurrer regularly followed the nature of the pleading demurred to, or the prayer of the demurrant. If it was a demurrer to a plea in abatement, and the demurrer was overruled because the plea was good, the judgment was that the writ be quashed. ${ }^{4}$ This is all that the defendant asked for in his plea. If the demurrer was sustained, because the plea was bad, judgment of respondeat ouster was rendered, - that is, that the defendant make answer to the declaration. ${ }^{5}$ This is all the plaintiff prayed for in his demurrer to such a plea. The reason for these judgments, which were indecisive of the action, was that a plea in abatement does not go to the merits of the action, but only to put off or delay a trial on the merits; and that the parties therefore ought not to be concluded by a final judgment which did not result from a trial of the merits of the action. ${ }^{6}$ It may be mentioned here that when the issue on a plea in abatement was raised, not by demurrer but by a replication of fact, and the issue was found for the plaintiff, the judgment was final on the merits of the cause, as hereinafter explained. ${ }^{7}$

When a demurrer was joined on any of the pleadings in chief or other pleadings which went to the action and not in mere abatement thereof, the judgment was, if for the plaintiff, that he should recover (quod recuperet); if for the defendant, that he should go without day (quod eat sine die). ${ }^{8} \quad$ It was a general rule, that on a

11 Steph. Pl. 150.

22 Tidd, Pr. 919.

81 Chit. Pl. 667.

4 Gould, Pl. c. ix. s. 41.
5 Gould, Pl. c. ix. s. 41 ; 1 Chit Pl. 666 .

6 Gould, Pl. c. v. s. 158.

7 Sec. 255.

8 Gould, Pl. c. ix. s. 42. 
demurrer to any of the pleadings which go to the action, as distinguished from those of a dilatory nature, which operate only to delay and put off the action, the judgment for either party should be the same as it would have been on any issue in fact joined upon the same pleading and found in favor of the same party. ${ }^{1}$ Such judgment on demurrer was equally conclusive of the facts in issue, as if rendered on a verdict of a jury. ${ }^{2}$

The foregoing judgment on the merits of the case was either interlocutory on its first rendition and afterwards made final upon assessment of damages, or final in the first instance when rendered on a liquidated demand, requiring no assessment of damages. ${ }^{3}$

It may be added here that the courts formerly denied amendment after demurrer, without the consent of the adverse party. ${ }^{4}$ The demurrant had to submit to the judgment suited to the nature of the issue. This harsh rule, which there is good reason to believe grew up in derogation of the simplicity of the ancient law, came to be relaxed in more recent times. According to the settled rules of modern practice, irrespective of the statutes of amendments, either party after demurrer or joinder in demurrer was at liberty to amend as a matter of course, while the proceedings were on paper and before recording. 5 In like manner the demurrant was allowed to withdraw his demurrer after argument and plead to the merits. ${ }^{6}$ But after the proceedings were entered of record, the action of the courts in allowing amendments was governed by the statutes of amendments, ${ }^{7}$ and was exercised in obedience to judicial discrétion. By the Common Law Procedure Act of 1852, the courts were vested with ample authority to allow amendments in furtherance of justice at any stage of a case, thereby relieving the parties from the injurious consequences of the strict rule at common law directing judgment on demurrer. ${ }^{8}$

SEC. 242. Demurrer to Evidence. According to common law a party could demur to the facts shoun in evidence as well as to the facts alleged in the pleadings. ${ }^{9}$ In some cases when the pleadings terminate in an issue of fact which is being tried by a jury, the party, whether plaintiff or defendant, who holds the negative side of the issue might demur to the evidence exhibited by the adverse

1 Gould, Pl. c. ix. s. 42.

2 Gould, Pl. c. ix. s. 43, 44.

8 Steph. Pl. 105, 106.

41 Tidd, Pr. 709.

51 Tidd, Pr. 709.

- 1 Tidd, Pr. 710, 711.

71 Tidd, Pr. 712.

815 \& 16 Vict. c. 76, sec. 222.

92 Tidd, Pr. 865; Bac. Abr. Pleas, note 7. 
party in support of the affirmative of the issue. ${ }^{1}$ The effect of this proceeding, when permitted by the court, was to withdraw the examination of the cause from the jury, and to substitute an issue of law for determination of the court in place of the issue of fact being tried by the jury. ${ }^{2}$ This demurrer confessed the truth of the evidence, and made the question of its relevancy the sole point on which the issue of fact is to be determined. A determination of the demurrer in law operated as a determination of the issue of fact, for which it had been exchanged; so that a decision on the demurrer in favor of either party was in effect a finding of the issue in fact in favor of the same party who received final or interlocutory judgment, according to the nature of the case. ${ }^{3} \quad$ The jury discharged from the trial of the issue might be retained to assess the damages conditionally, or they might be discharged entirely from the cause, and inquiry of damages, if necessary, ordered before another jury. ${ }^{4}$

The mode of presenting a demurrer to evidence depended upon the nature of the evidence demurred to. If the evidence, whether written or oral, was submitted to prove a definite fact, the opposite party, by admitting the fact itself of record, could compel his adversary to join in his demurrer, or to waive the evidence. ${ }^{5}$ If parol evidence submitted in support of an issue was certain and direct, the opposite party, by entering the evidence on record together with an admission that it was true, could in like manner compel the party submitting it to join in a demurrer or waive the evidence. ${ }^{6}$ If the evidence submitted was loose and indetcrminate, the adverse party, by stating it upon the record as certuin and determinate, and admitting it in that form to be true, could compel a joinder in his demurrer, or force a waiver of the evidence.

If the evidence submitted was circumstantial, only the party demurring, by admitting on the record every fact and conclusion of fact in favor of the opposite party, which the evidence conduces to prove, could compel a joinder in demurrer or waiver of the evidence. ${ }^{8}$

The whole proceeding of demurrer to evidence was under the direction and control of the judge or judges trying the case. Of course, if the proper statement of the evidence and necessary ad-

1 Gould, Pl. c. ix. s. 47.

2 Gould, Pl. c. ix. s. 47.

3 Gould, Pl. c. ix. s. $49 ; 2$ Tidd, Pr. 866, 867.

12 Tidd, Pr. 866, 867; Gould, Pr. 866 .
5 Gould, Pl. c. ix. s. 62.

6 Gould, Pl. c. ix. s. 63.

7 Gould, Pl. c. ix. s. 64.

8 Gould, Pl. c. ix. s. $65 ; 2$ Tidd, Pl. c. ix. s. 73 . 
missions required by the foregoing rules were not entered of record, the right to demur would be disallowed. ${ }^{1}$ And even when they were entered, the opposite party could always demand the judgment of the court as to whether he was bound to join in the demurrer. And if no colorable or plausible cause of demurrer was apparent, it was the duty of the court to disallow it. ${ }^{2}$ When a demurrer was disallowed by the trial judge, it was his duty, at the request of the party claiming it, to sign a bill of exceptions, upon which the correctness of his action might be reviewed. ${ }^{8}$

This practice of demurring to evidence became unusual and obsolete. ${ }^{4}$ It was supplanted by the more modern practice of the judge reserving a point of law dependent on his admission or exclusion of evidence against objection, accompanied with leave to the objecting party to move for a nonsuit or a verdict, as. the case might be. ${ }^{5}$

1 Gould, Pl. c. ix. s. 72.

1 Kerr on Actions, 281.

2 Gould, Pl. c. ix. s. 71.

5 Kerr on Actions, 282.

3 Gould, Pl. c. ix. s. 74 ; 2 Tidd, Pr. 866. 


\section{CHAPTER X.}

\section{DEFENCES BY WAY OF DILATORY PLEAS.}

Article I. Prefatory.

"II. Pleas to the Jurisdiction.
Article III. Pleas in Abatement.

" IV. Conclusion of and Judgment on Dilatory.

\section{Article I.}

\section{Prefatory.}

Sec. 243. Introductory.

I Sec. 244. Defined and Classified.

SEc. 243. Prefatory. Having considered the form and nature of the pleading by which the defendant was permitted to take advantage of the insufficiency of the plaintiff's cause of action, as appearing in the declaration, it will be next in order to consider the various forms in which he was required to make his defence when it did not appear in the declaration.

What I have to say will relate to the forms of defence in personal actions, and such mixed actions as have superseded the ancient real actions. The term plea, in a general sense, may be said to include the allegations of both sides. But it was applied in ordinary use to matters of fact or denial alleged by the defendant in response to the declaration. The orderly parts of pleading, when extended to the utmost limit known in practice, were as follows :-

The declaration or count by the plaintiff; the plea by the defendant; the replication by the plaintiff; the rejoinder by the defendant; the rebutter by the plaintiff; the surrebutter by the defendant.

The most material of these pleadings were the declaration and the plea; and the plaintiff had to prevail, if at all, upon the facts contained in his declaration, and the defendant upon the matters alleged in his plea. All the subsequent pleadings were required to be consistent with and in support of the declaration on one side, and the plea on the other. 
Pleas on the part of the defendant are divided into two general classes: First, pleas dilatory; second, pleas to the action, which were denominated pleas peremptory by Chitty and Stephens, ${ }^{1}$ and which were inore commonly known as pleas in bar.

SEC. 244. Defined and Classified. Dilatory pleas were such as "tend to merely delay or put off the suit," 2 or, as Gould more correctly says, "such as tend to delay the plaintiff"s eventucul rem$e d y . " ~{ }^{*}$ They are pleas "in which the defendant seeks to delay the plaintiff's remedy by showing that there is an objection to the action founded on principles of remedial law as distinguished from substantive law." ${ }_{4}$ The effect of them when sustained was to defeat the present suit, but to leave the cause of action undetermined on its merits. It was a characteristic requirement of the plea that it should indicate or suggest how the cause of action might in some other court, suit, or proceeding be prosecuted. ${ }^{5}$

Dilatory pleas may be conveniently divided into three classes: First, pleas to the jurisdiction of the court; seeond, pleas in suspension of the action; third, pleas in abatement.

Pleas to the jurisdiction have by some authors been classed under the head of abatement, ${ }^{6}$ but they are more generally assigned to a distinct head of their own among dilatory pleas. ${ }^{7}$ They are not technically pleas in abatement, because they do not pray for abatement of the writ or action, but ask judgment as to whether the defendant should make answer, or the court take cognizance of the case.

Some authors insert a class denominated pleas to the disability of the parties plaintiff, in which exception is taken to the competency of the plaintiff to sue. ${ }^{8}$ But as such pleas do not tend to deny the right of action itself, and their effect, when sustained, is to abate the action, ${ }^{9}$ they have been by other authors classed and treated under the head of abatement, ${ }^{10}$ a practice followed in our classification.

In a few instances matter pleaded by way of abatement on ac-

11 Chit. Pl. 441 ; Steph. Pl. 46.

$23 \mathrm{Bl}$. Com. 301.

3 Gould, Pl. c. ii. s. 33.

418 Am. \& Eng. Encyc. Law, 519.

61 Chit. Pl. 445, 446; Gould, Pl. c. v. s. 67 .

- Comyn, Nig. Abatement, c. 1;
71 Chit. Pl. 440.

83 Bl. Com. 301 ; Gould, Pl. c. v. s. 10 .

9 Steph. Pl. 50; 3 Bl. Com. 303.

10 Steph. Pl. 48; 1 Saund. Pl. \& Ev. 2; 1 Chit. Pl. 447. Jacobs, Dict. Abatement. 
count of disability of plaintiff, as outlawry or alien enmity happening after institution of suit, operated only to postpone or suspend the action without absolutely abating it, a result which has suggested a classiiication of such pleas as distinct from pleas in abatement, under the head of pleas in suspension of the action. ${ }^{1}$ The plea concludes with a prayer that the pleading may be stayed until the ground of disability be removed. ${ }^{2}$ In many real actions brought against an infant, and in the action of debt against him as heir to a deceased ancestor, either, party might suggest the nonage of the infant and pray that the proceedings may be deferred till his full age, - in legal phraseology, that the parol may demur, which operated as a suspension of the action till the minor reached his majority. $^{3}$ The parol demurrer was abolished in the reign of William IV. ${ }^{4}$ Aid prayer and excommunication of plaintiff were regarded as subjects for pleas in suspension. ${ }^{5}$ But as the number of these pleas is small and the suspension of the action is equivalent to an abatement of the suit until some future and contingent event, the distinction has not been always accepted as sufficient to eliminate them from pleas in abatement. ${ }^{6}$ Nevertheless I have retained them under a separate classification, because they ask for a suspension of the action instead of an abatement of it; thus following the classification of Stephens.

\section{ARticle II.}

\section{Pleas to the Jurisdiction.}

Sec. 245. Defined and Classified.

| Sec. 246. Requirements.

Sec. 245. Defined and Classified. In a plea to the jurisdiction the defendant alleges matter in denial of the jurisdiction of the court to try the cause of action.

Pleas to the jurisdiction of the court were either, 1st, that the person of the party making the plea, or $2 \mathrm{nd}$, the cause of action, was not the subject of the court's jurisdiction. ${ }^{7}$

Pleas under the first head were of a limited class, and consisted in a

1 Steph. PI. 46, 47.

2 Steph. Pl. 47.

83 Bl. Com. 300; Comyn, Dig. Abatement, B. 1; 1 Chit. Pl. 447.

$11 \mathrm{Wm}$. IV. c. 47 , s. 10 .

5 Steph. Pl., Appendix, note 21.
61 Chit. Pl. 447 ; 1 Saund. Pl. \& Ev. 2; Hutchinson $v$. Brock, 11 Mass. 119 ; Comyn, Dig. Abatement, B. 1 .

$$
7 \text { frould, Pl. c. v. s. } 14 .
$$


right of the defendant by which he was privileged to be exclusively sued in some other court, - a right which was accorded at different times to attorneys and officers of courts and scholars of universities. The conclusion of such pleas would seem to class them with pleas to the jurisdiction, ${ }^{1}$ where we have placed them; but they have been classed with pleas in abatement to the person of defendant by some courts and authors. ${ }^{2}$ Pleas challenging the right of the plaintiff to sue on account of any disability are not properly classed with pleas to the jurisdiction. They more properly belong to a class of pleas in abatement as hereinafter treated.

Under the second head are classed:-

1st. What may be determined privilege of tenure, under which fall pleas of ancient demesne;-ancient demesne being a species of privileged tenure cognizable only in the court of the manor of which the land sued for is held. ${ }^{3}$

$2 \mathrm{~d}$. Causes of action arising out of the local limits of the court's jurisdiction, as in counties palatine or other inferior courts of local jurisdiction. ${ }^{4}$

3d. Want of power in the court to take jurisdiction over the subject matter of the action. When the objection to the jurisdiction of the court is that it has no cognizance of the subject matter of the suit, - that is to say, that the nature of the action is such as the court is under no circumstances competent to try, it may, but need not, be raised by plea to the jurisdiction. ${ }^{5}$ The objection may be successfully urged in almost any form by plea or motion at any stage of the case. It may be pleaded in bar or taken advantage of under the general issue. Whenever a court becomes satisfied that it has no jurisdiction of the subject matter of the suit, it becomes its duty to dismiss the proceeding ex officio ${ }^{6}$.

SEc. 246. Requirements. In general, pleas to the jurisdiction were required to be pleaded in person and not by attorney. It was necessary also that the plea should indicate another jurisdiction in which the suit could be prosecuted. ${ }^{7}$ They required only half defences $;^{8}$ formal commencements were omitted $;^{9}$ and they

1 Wilkes $v$. Williams, 8 T. R. 631 .

2 Hunter $v$. Neck, 3 Scott, N. R. 448 ; 3 M. \& G. 181; Jacobs, Dic. Abatement, 1.

3 Gould, Pl. c. v. s. 15.

41 Chit. Pl. 443, 444 ; Comvn, Dig. Plea to Jurisdiction, D. ; Gould, Pl. c. v. s. 17.
5 Gould, Pl. c. จ. s. 25; 1 Chit. Pl. 442.

6 Gould, Pl. c. v. s. 25.

7 Mostyn $v$. Fabrigas, Cowp. 172.

81 Chit. Pl. 444.

9 Steph. Pl. 394. 
concluded to the cognizance of the court by praying judgment, if the court will take or have further cognizance of the suit. ${ }^{1}$

Pleas to the jurisdiction, except such as denied jurisdiction over the subject matter of the suit under any circumstances, were required to be pleaded first in order and were considered as waived by pleading to the merits of the suit which necessarily admitted jurisdiction. In an action brought in a court of limited jurisdiction it was required that every fact should appear in the declaration necessary to sustain the jurisdiction. It could not be helped out with presumptions. ${ }^{2}$ When the jurisdiction did not thus appear, advantage could be taken by demurrer. In courts of general jurisdiction the rule was otherwise; and jurisdiction was presumed, unless the declaration showed that the action occurred in some exclusive jurisdiction; in which latter event a demurrer would lie. But if no fact rebutting jurisdiction appeared in the declaration, the objection could be taken only by plea; and the plea, to meet the requirements of good pleading, had to negative every fact from which jurisdiction might be presumed. ${ }^{3}$

They differed from pleas in abatement, 1st, in being always pleaded in person; $2 \mathrm{~d}$, in always requiring half defence, while some pleas in abatement were said to be good with full defence; $3 \mathrm{~d}$, in praying judgment, if the court will take further cognizance of the suit. In other respects they were essentially the same, as they abated the writ or action. ${ }^{4}$ All of them have been by some authors classed with pleas in abatement, as already stated, ${ }^{5}$ while many of them are treated variously by authors under both heads. $^{6}$

\section{Article III.}

Pleas in Suspension.

SEc. 247. Pleas in Suspension of the Action. These pleas, as already stated, were of a very limited number, such as outlawry or alien enmity of plaintiff happening after institution of the suit. ${ }^{7}$ They also occurred in many real actions brought against an infant

1 Gould, Pl. c. v. s. 29.

21 Saund. Pl. \& Ev. 1.

3 Diblee $v$. Davison, 25 Ill. 486 (original ed.).

Martin Civil Procedule-14
41 Saund. Pl. \& Ev. 17.

5 Sec. 244.

6 See Plea to Jurisdiction, form 46.

7 Sec. 244; Gould, Pl. c. v. s. 33. 
and in the action of debt against him as heir of a deceased ancestor. when upon suggestion of his nonage the action was stayed till he has reached his majority. Aid prayer, and excommunication of the plaintiff were regarded as proper subjects for pleas in suspension of the action. The distinguishing feature which separated these pleas from pleas in abatement consisted in the effect of suspending the action instead of abating it. ${ }^{1}$ They were greatly limited in number by abolishment of the parol demurrer in suits against infants. ${ }^{2}$ They usually concluded with the prayer that the plaint remain without day. ${ }^{3}$

\section{ARticle IV.}

\section{Pleas in Abatement.}

Sec. 248. Defined and Classified.

“ 249. Pleas to the Person of Plaintiff.

“ 250. Pleas to the Person of Defend- “ 252. Pleas to the Writ or Bill. ant.

253. Statutory Restrictions.

SEc. 248. General Nature and Classification. By a plea in abatement the defendant shows matter to the court why he should not be impleaded or sued; or if impleaded, not in the manner and form employed by the plaintiff; and praying that the writ or plaint may abate. ${ }^{4}$

The writ was abatable not only by plea formally attacking its sufficiency but by a plea to the person suing or to the person sued, showing that no writ should have been issued in favor of the plaintiff or against the defendant.

In accordance with this broad view, pleas in abatement were very generally divided into the following groups: 1st. Pleas relating to the disability of the person suing or the person sued; $2 \mathrm{~d}$. Pleas relating to the count or declaration; $3 \mathrm{~d}$. Pleas relating to the writ, as to the form of it and to the action of it. ${ }^{5}$

SEC. 249. Pleas in Abatement on account of disability of the person of the plaintiff. They consisted originally in pleas denying the existence of the plaintiff as a person; setting up his

1 Sec. 244, 250; 1 Chit. Pl. 447.

21 Chit. Pl. 447.

31 Chit. Pl. 461. - Jacobs, Dict. Abatement; Steph. Appendix, form 48.
Pl. 47 ; Comyn, Dig. Abatement, B. 1. 61 Chit. Pl. 447, 448; 1 Saund. Pl. \& Ev. 2. See Plea in Abatement, 
disability to sue by reason of his being an alien in amity, ${ }^{1}$ or in enmity, ${ }^{2}$ his outlawry upon mesne or final process; his attainder of treason or felony, his infancy when appearing otherwise than by guardian or next friend, and his death. ${ }^{3}$ Coverture of female plaintiff was pleadable in abatement, when she sued otherwise than as co-plaintiff with her husband. ${ }^{4}$

SEC. 250. Pleas in Abatement on account of the disability of the person of the defendant. They consisted in the coverture or infancy of the defendant. The plea of coverture did not assume to deny the liability of the defendant in the cause of action, which might be contested in a plea in bar, but only her liability to be sued apart from her husband. ${ }^{5}$ Anciently, infancy of defendant was pleadable in suspension in certain real actions, and in debt when the infant was sued as heir on the specialty of his ancestor, in which cases it was held that the parol may demur, that is that the pleadings may be stayed until he had attained his full age. ${ }^{6}$ But this right never extended to an infant devisee; and it was finally altogether abolished. ${ }^{7}$

SEc. 251. Pleas in Abatement on account of defects in the count or declaration. Anciently, various matters could be pleaded in abatement of the count or declaration in suits commeaced by original writ. ${ }^{8}$ Pleas of this kind were founded principally upon some defect, mistake, or informality, appearing in the recital of the writ in the declaration, which was deemed necessary in all cases, or upon a variance between the writ as recited and the count or declaration. Thus it seems that although the plea was formally directed against the count or declaration, and was called a plea to the count or declaration, it had reference to the writ as therein recited. ${ }^{9}$

By rule of court adopted by the Common Pleas in 1654, it was ordered that declarations in actions on the case, and upon general statutes, other than debt, should not repeat the original writ, but only the nature of the action. ${ }^{10}$ The rule was somewhat extended by practice, and it resulted in abolishing pleas to the count or

1 Gonld, Pl. c. v. s. 46.

2 Gould, Pl. c. v. s. 42.

8 Gould, Pl. c. v. 54.

41 Saund. Pl. \& Ev. 2 ; Gould, Pl. c. v. s. 50 .

51 Chit. Pl. 449.

- 1 Chit. Pl. 449 ; 3 Bl. Com. 300.
$71 \mathrm{Wm}$. IV. c. 47 , s. $10 ; 1$ Chit. Pl. 449:

8 Gould, Pl. c. v. s. 64 , note 9 ; 3 Bl. Com. 301, 302 ; Com. Dig. Abatement, G. 1 ; 1 Chit. Pl. 450.

9 Gould, Pl. c. v. s. 64 , note 9.

10. 1 Saund. 318 a. 
declaration founded on what appeared only in the recited writ. The objection of variance between the writ and declaration could not thereafter be taken, except by obtaining oyer of the writ. ${ }^{1}$ By a later rule of Common Pleas and King's Bench, adopted in the reigns. of George II. and George III., oyer of the original writ was denied, the effect of which was to abolish all pleas in abatement founderl on a variance between the declaration and the writ, ${ }^{2}$ and all other pleas in abatement which could not be verified without oyer of the writ. ${ }^{3}$ This effect would not apply to suits commenced by bill. ${ }^{4}$ Thus it came to be laid down that there was no plea to the declaration alone independent of the writ, except in bar. ${ }^{5}$

SEc. 252. Pleas in Abatement to the Writ or Bill. Pleas in abatement to the writ as anciently entertained ceased to be possible after oyer of the writ was denied. Similar pleas continued to be termed pleas in abatement rather from their effcet upon the writ than from any direct attack upon it, as in former times. ${ }^{6}$ But if the defect in the writ be carried also into the declaration, or rather if the declaration, which is presumed to correspond with the writ, be incorrect in respect of some extrinsic matter, it is then open to the defendant to plead in abatement to the writ through the medium of the declaration. ${ }^{7}$

Pleas in abatement to the form of the writ consisted principally in misnomer, nonjoinder, misjoinder, and that plaintiffs or defendants suing or being sued as husband and wife are not married. ${ }^{8}$ Death of a party, plaintiff or defendant, is more properly classed under pleas to the person. ${ }^{9}$ Pleas in abatement to the action of the writ are that the action is prematurely brought; that there is another action pending for the same cause of action in the same or in any other Superior Court. ${ }^{10}$ The objection that the action is misconceived, although pleadable in abatement, may be taken advantace of on demurrer, if the mistake appears on the face of the declaration, and if not, then under the general issue. ${ }^{11}$

Sec. 253. Statutory Restrictions on Dilatory Pleas. At common law neither pleas to the jurisdiction nor in abatement were

1 Com. Dig. Abatement, H. ; Gould, Pl. c. v. s. 64 , note $9 ; 1$ Chit. Pl. 450 .

2 Gould, Pl. c. v. s. 64 , note 9.

${ }^{3}$ Gould, Pl. c. v. s. 82, 101.

4 Gould, Pl. c. v. s. 84.

- 1 Chit. Pl. 450: 2 Siumd. 207 d.

- 1 Chit. Pl. 450 ).
71 Chit. Pl. 450 ; Gould, Pl. c. v. s. 83 .

81 Chit. Pl. 451-453.

9 Gould, Pl. c. v. s. 138, note 16 a.

101 Chit. Pl. $453,454$.

11 Goull, I'l. c. v. s. 137. 
required to be verified. But by the statute of $4 \& 5$ Anne, c. 16, s. 11, affidavit of their truth was required. ${ }^{1}$ By the 9 Geo. IV. c. 14 , s. 2 , it was enacted that in a joint action a plea in abatement as to one defendant should not prevent recovery against the other. By the $3 \& 4$ Wm. IV. c. 42 , s. 8 , it was enacted that no plea in abatement for the nonjoinder of any person as a co-defendant shall be allowed, unless it appears from the plea that such person resides within the jurisdiction, and his residence is set out in the affidavit verifying the plea. By the ninth section of the same Act, a discharge in bankruptcy might be pleaded in reply to a plea of nonjoinder of another person. By the eleventh section of the same Act, pleas in abatement for misnomer were abolished in all personal actions. The remedy substituted was by summons to compel plaintiff to amend by inserting the right name founded on affidavit. ${ }^{2}$

By the Common Law Procedure Act of 1852, pleas in abatement for nonjoinder and misjoinder could be responded to by amendment. ${ }^{3}$

The effect of abatement, and the liability to abate by reason of death, marriage, and bankruptcy, were relieved against by certain sections of the same Act, which provided a way in which the suit might be continued in all cases in which the cause of action survived against or for the benefit of others. ${ }^{4}$

\section{Article V.}

Conclusion of, and Judgment on, Dilatory Pleas.

Sec. 254. Conclusion of Dilatory Pleas. | Sec. 255. Judgment on.

Sec. 254. Conclusion of Dilatory Pleas. As dilatory pleas were not favored by the courts, great certainty and precision were required in framing them. The least inaccuracy or defect was fatal to their validity. ${ }^{5}$

The character of a plea was said to depend upon the nature of the judgment which it prays in its commencement and conclusion. A prayer for judgment in the formal commencement was not held necessary either in pleas to the jurisdiction or in abatement, provided it was contained in the conclusion. ${ }^{6}$ The concluding prayer was generally regarded as the controlling test of the plea.

11 Chit. Pl. 462, 463.

23 Chit. Gen. Prac. 711, 712.

315 \& 16 Vict. c. 76, s. 34 to 39 .

415 \& 16 Vict. c. 76 , s. 135 to
5 Gould, Pl. c. v. s. 66.

61 Chit. Pl. 460, 461; 2 Saund. 209 a, note 1 ; Gould, Pl. c. v. s. 142 . 
Pleas to the jurisdiction should conclude with the prayer "si curia cognoscere velit" - if the court will take cognizance - when the subject matter of the plea related to the cause of action; and with the prayer "respondere non debet" - that he ought not to answer - when the objection to the jurisdiction consisted in a personal privilege to be sued in some other court. ${ }^{1}$ A conclusion in bar to the action would admit jurisdiction.

Pleas in abatement on account of the disability of the plaintiff to sue, or of the defendant to be sued, and not merely on account of the nonjoinder of another party, should conclude with the prayer: "if the plaintiff ought to be answered," or "whether the defendant should be compelled to answer." When the disability operates only as a temporary suspension of the suit, instead of an abatement of it, they should conclude with the prayer: "that the plaint remain without day." 2 When the death of the plaintiff since issue of the writ is pleaded, the plea should conclude: "if the court will further proceed." 3

Pleas 'in abatement to the writ, must conclude by "praying judgment of the writ, and that the same may be quashed." 4 Since oyer of the writ has been denied, a plea in abatement of the writ must in general be pleaded of the writ and declaration when the latter continues and discloses the objection to the writ. ${ }^{5}$ When the action is by bill, the plea must conclude by praying judgment of the bill. ${ }^{6}$ Pleas in abatement on' account of coverture of plaintiff or defendant, as the objection goes rather to the nonjoinder of the husband than to the disability of the feme, should conclude with a prayer of judgment as to the writ. ${ }^{7}$

Sec. 255. Judgment on Dilatory Pleas. If a plea to the jurisdiction or in abatement is determined in favor of the defendant, either upon an issue of law or fact, the judgment was that the writ or bill, as the case might be, should be quashed or abated. If the plaintiff prevailed upon a demurrer to the plea, the judgment was interlocutory - respondeat ouster - that defendant answer over. ${ }^{8}$ If an issue of fact was joined on the plea and the issue was found in favor of the plaintiff, final judgment was awarded .

11 Chit. Pl. $445-461$.

21 Chit. Pl. 461.

81 Chit. Pl. 461.

41 Chit. Pl. 461.

b 1 Chit. Pl. 461.

61 Chit. Pl. 461.
1 Chit. Pl. 461 ; 1 Saund. Pl. \& Ev. 4 ; 2 Saund. 9 , note 10 ; contra: Gould, Pl. c. v. 8. 143.

81 Chit. Pl. 446; Gould, Pl. c. v. s. 159 . 
ART. V.] DEFENCES DILATORY. - CONCLUSION AND JUDGMENT. 215 in his favor on the merits $;^{1}$ and nothing remained to be done in the case but to assess the damages. The plaintiff thus obtained judgment on the merits of his case, without any trial of the issues tendered in the declaration. This rule of court was adopted to discourage false dilatory pleas $;^{2}$ and it must be admitted that it would naturally tend to such a result.

1 Gould, Pl. c. v. s. 159 ; 1 Chit. $\quad 2$ Gould, Pl. c. v. s. 159. P1. 464. 


\section{CHAPTER XI.}

\section{DEFENCES IN BAR BY WAY OF TRAVERSE.}

Article I. Defined and Classified.

"II. General Traverse.
| Article III. Specific Traverse.

\section{Article I. \\ Defined and Classified.}

Sec. 256. General Nature of Pleas in Bar. Sec. 258. General Traverse Defined.

“ 257. Specific 'Traverse Defined.

SEc. 256. General Nature of Pleas in Bar. Pleas in bar go to the merits of the case, and deny that the plaintiff has any cause of action, and do not, like pleas in abatement, give a better writ. ${ }^{1}$ A plea in bar is "a substantial and conclusive answer to the action." 2 It is distinguished from dilatory pleas in impugning the cause of action altogether, and foregoing all objections arising out of merely remedial law. ${ }^{3}$

Assuming that a cause of action is stated in the declaration, a good plea in bar must, 1st, "either deny all or some cssential part of the averments of fact in the declaration; or, $2 d$, admitting them to be true, allege new facts which obviate or repel their legal effect" ; ${ }^{4}$ or, $3 \mathrm{~d}$, without admitting or denying the facts alleged, set up new facts which operate to prevent the plaintiff from making the allegations of the declaration. "In the first class the defendant is said, in the language of pleading, to traverse the matter of the declaration; in the second class, to confess and avoid it "; ${ }^{5}$ in the third class, without admitting or denying the declaration, to interpose matters of fact which operate to estop and prevent the plaintiff from asserting the facts constituting his cause of action. ${ }^{6}$ Pleas in bar are consequently divided into pleas by way of traverse, pleas by way of confession and avoidance, aud pleas by way of estoppel.

11 Chit. Pl. 469.

2 Steph. Pl. 51, 52.

8 Steph. Pl. 51.
4 Steph. Pl. 52.

5 Steph. Pl. 52.

6 Gould. Pl. c. ii. s. 39. 
Pleas in bar by way of traverse or denial may be conveniently grouped under three heads :-

1st. Pleas by way of specific traverse.

2 d. Pleas by way of general traverse.

3d. Pleas by way of special traverse.

SEC. 257. Specific Traverse Defined. This is a plea in which the defendant denies all or some essential part of the matter alleged in the declaration in the specific language in which it is alleged. Denial and traverse are synonymous terms. The plea must consist in the denial or traverse of one or more facts contained in the declaration, without which the plaintiff would have no cause of action. This is the most primitive and natural traverse, and has been designated by Stephens and Gould as the common traverse, ${ }^{1}$ and confusedly included by Chitty in his definition of the general traverse. ${ }^{2}$

In selecting facts for specific denial, it was necessary that they should not constitute the whole substance of the declaration; otherwise the form of a general traverse hereafter defined would have to be used. ${ }^{3}$ This rule tended to discourage the specific traverse, which nodern pleading has aimed to restore. The specific traverse was generally negative in form, because it was almost always in response to affirmative averments in the declaration, which were naturally traversed by a direct denial. But when the averments in the declaration were negative in their form, the traverse of them might be in the affirmative. As this traverse contained no inducement, and is not connected with new matter of any kind, it leaves nothing to be answered by the adverse party. It therefore always tendered an issue and concluded to the country.

SEc. 258. General Traverse Defined. This form of traverse was used in most of the personal and mixed actions. It differed from the specific or common traverse, in that its denial was not in the specific language of the declaration, but in some general compendious phrase, which came to be regarded as putting in issue all the material allegations of the declaration or the principal fact upon which it was founded. The issue raised by it was known as the general issue, because it was of a more general and comprehensive kind than that usually tendered by the specific or common trav-

1 Steph. Pl. 153, 154; Gould, PI. c. vii. s. 11,12 .

21 Chit. Pl. 605
3 Gould, Pl. c. vi. s. 89 ; Steph. Pl. 419.

4 Gould, P1. c, vii. s. 16. 
erse $;^{1}$ and the plea was better known by that name than by the name of general traverse. ${ }^{2}$

By the practice of the courts it came to have in the course of time technical names, according to the forms of action in which it was used. Its scope and extent as a defence in the respective actions depended upon the construction of the courts, which for a long time tended to give it in many actions a more general and comprehensive meaning than would naturally be inferred from the words of the technical phrase in which it was clothed. But in more recent times this broadelled scope has been greatly reduced by express rules of the court, thus bringing it back to its primitive import. $^{3}$

It was characteristic of the general traverse (or general issue) that it was not prefaced with any inducement, - that it tendered an issue and concluded to the country. ${ }^{4}$

There is a peculiar general traverse, known as the replication de injuria, which will be defined and treated at the conclusion of our remarks on the general traverse.

SEc. 259. Special Traverse Defined. This traverse-highly technical in form - was known under the various designations of special traverse, ${ }^{5}$ special technical traverse, ${ }^{6}$ and formal traverse. ${ }^{7}$ It is more generally known and treated under the name of special traverse. It differs from the general and the specific traverse, heretofore defined, in containing affirmative new matter, constituting what was called an inducement to the traverse, but which differed materially from an inducement to a declaration. This matter composing the inducement was in its nature an indirect denial of some material allegations in the opposite pleading, being in contradiction thereof, by reason alone of inconsistency or repugnancy.

The special traverse also contains a direct denial or traverse of the same allegations. This direct negation was prefaced with the technical phrase absque hoc (without this), that is, without this: (that there is any truth in the particular matter alleged as a cause of action or defence, as the case might be). It could be used in a plea, ${ }^{8}$ replication, ${ }^{9}$ or other subsequent pleading.

1 Steph. Pl. 155.

2 Steph. Pl. 162.

8 Gen. Reg. Hil. T 4 Wm. IV.

4 Gould, Pl. c. v. s. 19 ; Steph.

Pl. 155,156 .
6 Steph. Pl. 165.

6 Gould, Pl. c. vii. s. 6.

71 Chit. Pl. 619.

8 Steph. Pl. 167, 168.

- Steph. Pl. 172. 
If in an action of debt on a bond the defendant should plead that he executed the bond by duress, the plaintiff may reply alleging new matter by way of inducement, to the effect that the defendant executed it of his own free will and for a valuable consideration without this: that he executed it by duress. ${ }^{1}$ Instead of the phrase absque hoc (without this), the pleader was at liberty to use the phrase et non (and not), which was recognized as equivalent to it, ${ }^{2}$ by which it was understood that the defendant (in the case supposed) had executed the bond for a valuable consideration and not by duress. ${ }^{3}$

This traverse originally differed from the other traverses in concluding with a verification, by which the issue was not formally tendered, but postponed to the next stage of the pleadings, 4 at which the opposite party, if the traverse was undemurrable, had no choice but to tender issue by reaffirming in a rejoinder the matter denied by the absque hoc clause; and concluding to the country. Under this obligatory consequence of a special traverse, it is apparent that the issue is substantially though not technically tendered by the party pleading the traverse, and it has been so expressed by some authors.

\title{
ARTICLE II.
}

\section{General Traverse - Application thereof.}

\author{
Sec. 260. In Debt \\ “ 261. In Covenant. \\ “ 262. In Assumpsit. \\ “ 263 In Account. \\ “ 264. In 'Trespass \\ Sec. 265. In Trespass on the Case. \\ “ 266. In 'Trover. \\ “ 267. In Detinue. \\ “ 268. In Replevin. \\ “ 269. In Ejectment.
}

Secs. 270, 271 General Traverse De Injuria by way of Replication.

SEC. 260. In Debt. In considering the application of these traverses to the different forms of actions, it will be more convenient to take up first the general traverse, next the specific, and lastly the special.

The general traverse tendering the general issue in the action of debt on simple contract was called " nil debet," - that the defendant "owes nothing." As it spoke of a fact in the present tense, it became adapted under construction of the courts to any kind of a defence that tends to deny an existing debt. ${ }^{5}$ Under

- 1 Gould, Pl. c. vii. s. 7.

: Bennett $v$. Filkins, 1 Saund. 201

8 Gould, Pl. c. vii. s. 8.
4 Gould, Pl. c. vii. s. 13.

5 Steph. Pl. 162, note 20. 
this plea the defendant could submit evidence tending to prove not only that no debt had ever been contracted, but that it had been released or satisfied. Hardly any matter of defence to an action of debt on simple contract could be excluded under the plea of nil debett, because almost all defences resolve themselves into a denial of the debt. ${ }^{1}$ It has been said that bankruptcy, statute of limitations, and tender are the only defences which could not be proved under the plea of nil debet. ${ }^{2}$

In an action of debt on a specialty the plea of general traverse was "non est factum" (not his deed). Under this plea the defendant could prove that he never executed the deed, or such facts as showed that it was void in law. ${ }^{3}$

In an action of debt on a judgment or recognizance the general traverse was "nul tiel record" (no such record); in the trial of which the existence or nonexistence of the record was the sole issue. $^{4}$

In debt for rent on a demise, "rien en arrere" (nothing in arrear), as well as " nil debet," was a good general traverse.

In debt on a penal statute, while the more appropriate general traverse is " nil debet," because it accords with the form of the action, the plea of " not guilty" may be substituted, because the action is to enforce the penalty for an offence. ${ }^{6}$

By the Hilary Rules of 1834 the plea of nil debet was abolished in all actions. The plea of "nunquam indebitatus" (never indebted) was substituted for it in actions on simple contract other than notes and bills. The same effect was given to this latter plea as to the plea of non assumpsit in "indebitatus assumpsit," which will be presently mentioned. All matters in confession and avoidance were required to be pleaded specially as directed in actions of assumpsit.

In other actions of debt in which the plea of nil debet had been theretofore used, including those on bills and notes, the defendant was required to deny specifically some particular matter of fact in the declaration, or to plead specially in confession and avoidance. ${ }^{7}$

In debt on specialty the plea of " non est factum" was declared to operate as a denial of the execution of the deed in point of

1 Steph. Pl. 162, note 20.

24 Minor, Inst. 641.

3 See plea of non est factum in Appendix, form 49 .

4 Gould, Pl. c. vi. s. 10.
5 Gould, Pl. c. vi. s. 10.

6 Gould, Pl. c. vi. s. 10.

7 See plea of nil debet in Appendix, form 50 . 
fact only, and all other defences were required to be specially pleaded, including matters which made the deed absolutely void as well as those which made it voidable. ${ }^{1}$

SEc. 261. In Covenant. The only plea in the nature of a general traverse in the action of covenant is the plea of "non est factum," as in debt on a bond. ${ }^{2}$ This plea is of limited scope as compared with the general traverse in assumpsit case and debt on simple contract, confining the issue to the existence of the deed in fact and in law, all other defences being required to be pleaded specially. So narrow is its scope that Saunders and Chitty have denied to it the characteristics of a general traverse. ${ }^{3}$ It would seem to resemble more nearly the specific traverse, because raising an issue on a single material averment of the execution of an instrument. The reason why such a narrow issue was approved in this action is the simple truth that in ancient times there could be no defences to a sealed instrument outside of its conditions, except such as tended to show that it had not been executed or that the cause had been released under seal. Anciently, fraud, want of consideration, illegality, unless on the face of the instrument, and release, unless under seal, constituted no defence. ${ }^{4}$ No defence in pais outside of non-performance of conditions, except duress, would be entertained. ${ }^{5}$

Under this plea the defendant was at liberty to prove any state of facts which showed that the deed never had a valid existence in fact or in law; as, that it was not signed or delivered by the defendant; that it was delivered in escrow only; that the defendant, at the time of its execution, was a lunatic or a female under coverture $;^{6}$ or that its execution was obtained by such a fraud upon defendant that he was deceived as to the identity or nature of the instrument.' But matters showing it merely voidable, not void, as infancy, duress, usury, gaming, and fraud inducing an execution of the instrument without deceiving the defendant as to its identity or actual terms, were required to be specially pleaded, when in the course of time they came to be recognized as valid defences at law.

In may be proper to mention in this connection that under the

11 Chit. Pl. 518.

21 Chit. Pl. 486, 487.

31 Saund. Pl. \& Ev. 393; 1 Chit. Pl. 486.

48 Harvard Law Rev. 49.
58 Harvard Law Rev. 49.

62 Greenl. Ev. s. 246, 300.

7 Mason $v$. Ditchbourne, 1 Moody \& Rob. 460 ; 2 Cr. M. \& R. 720, note a. 
common law, as prevailing down to very recent times, fraud was no defence at law to an action on a sealed instrument. ${ }^{1}$ The same is true of the defence of a want or failure of consideration. ${ }^{2}$ Illegality, unless apparent on the face of the instrument, was likewise no defence at law prior to 1767.3 Neither was payment, unaccompanied with release under seal, a valid defence in England until it was made so by statute in 1707.4 To the general rule of the common law prohibiting the avoidance of sealed instruments by defences in pais, there was an exception in the case of duress, which was always, and still remains, a valid defence at law; but which must be affirmatively pleaded; and is not admissible under the general issue. ${ }^{5}$

In fraud, illegality, payment without release under seal, and failure of consideration, the courts of equity in very early times furnished relief by injunction. Their action in this respect has been generally followed by the courts of law in modern times, admitting such defences in actions at law, either from a change in judicial opinion or in pursuance of statutes. ${ }^{6}$

Although the general traverse in covenant was of limited scope as compared with it in some other actions, the effect of it was further limited by the Hilary rules of 1834 , which left it to operate as a denial of the deed in point of fact only, requiring all defences avoiding it in point of $l a w$ to be specially pleaded. ${ }^{7}$

Performance of the covenant by defendant, excuse for non-performance, non-performance of condition precedent by plaintiff, discharge in bankruptcy, and accord and satisfaction, were always valid defences at law, but were required to be pleaded specially. ${ }^{8}$ The plea of non est factum denied the existence of the deed in point of fact only.

SEc. 262. In Assumpsit. The general traverse tendering the general issue in the action of assumpsit is "non-assumpsit" (did not promise). ${ }^{9} \quad$ On strict construction of the language of this plea it would naturally operate only as a denial in fact of the express con-

1 Wright $v$. Campbell, 2 F. \& F. 393 ; George $v$. Tate, 102 U. S. 564 ; Montgomery $v$. Tipton, 1 Mo. 446 ; $\mathrm{s}$ Harvard Law Rev. 49.

2 Collins $v$. Blantern, 2 Wils. 347. Parker $v$. Parmlee, 20 Johns. 130.

3 Collins $v$. Blantern, 2 Wils. 347.

4 \& 5 Anne. c. 16 , s. 11.

5 Whelpdale's Case, 5 Rep. 119.

- In confirmation of these conclu- sions, the reader is referred to the able article of Professor Ames in 8 IIarv. Law Review, 49, and to the cases cited therein.

71 Chit. Pl. $51 \mathrm{~s}$.

81 Saund. Pl. \& Ev. 393; 1 Clit. Pl. 488.

9 See plea of non-assumpsit in $\mathrm{Ap}$ pendix, form 51 . 
tract or promise, where one is alleged, or of the matters of fact from which the contract or promise may be implied by law. ${ }^{1}$ But by an early relaxation of this prinitive implication, and by a contrary construction of the courts, the plea came to be employed as a very broad one. The defrudant in special as well as in general assumpsit was at liberty to prove, not only that no contract was in fact made, but that having been made, it was not binding upon him by reason of "infancy, coverture, drunkenness, or other mental incapacity, duress, want of consideration, illegality, alteration of written contract, former recovery, performance, excuse for nonperformance, and discharge." 2 Thus it seems that under this plea the defendant could submit in evidence matters showing that the plaintiff never had a cause of action, and also most matters tending to show that his cause of action na ceased to exist before the beginning of the suit. ${ }^{3}$ The bankruprcy ot defendant, tender, set off, and statute of limitations were required to be pleaded specially. ${ }^{4}$

By the Hilary rules of 1834 this misapplication and abuse of the general issue was put an end to. They proviac that in all actions of assumpsit (except on bill of exchange and promissory notes) the plea of non-assumpsit shall operate only as a denia: in fact of the express contract or promise alleged, or of the matter of fact from which the contract or promise alleged may be implied Ly law. ${ }^{5}$ It will be observed that this rule applies to general as well as special assumpsit. In compliance with the rule, it was declared that in actions of indebitatus assumpsit for goods sold and delivered or for money had and received, the plea of non-assumpsit should operate only as a denial of the sale and delivery or of the receipt of the money to plaintiff's use. ${ }^{6}$

In actions on notes and bills the general issue was inadmissible. A plea in denial was required to traverse same matter of fact alleged in the declaration, such as making, drawing, indorsing, accepting, presenting, or giving of notice. In this regulation is perceived a substitution of the specific for the general traverse.

In every species of assumpsit all matters in confession and avoidance, including not only those by way of discharge, but those which show the transaction to be either void or voidable in point of law,

12 Greenl. Ev. s. 135.

22 Greenl. Ev. s. 135; 1 Chit. Pl. 478,479 ; McKryng $r$. Bull, 16 N. Y. 297.

31 Chit. Pl. 478.
42 Greenl. Ev. s. 135.

51 Chit. Pl. 513.

61 Chit. Pl. 514.

71 Chit. Pl. 515. 
on the ground of fraud or otherwise, were required to be specially pleaded. ${ }^{1}$

By the Common Law Procedure Act of 1852, and the regulations made in pursuance of it, the plea of nunquam indebitatus was substituted for non-assumpsit on the common counts, which operated as a denial of the facts from which the liability of defendant arises. ${ }^{2}$ The plea "that he did not promise as alleged" is the form given as responsive to other declarations on simple contract, excepting bills and notes, to which the traverse had to be specific under the Hilary rules of $1834 .^{3}$ By the weight of authority evidence of unexpired credit could be given under the general issue in indebitatus assumpsit. ${ }^{4}$

SEc. 263. In Account. In the common law action of account render there was no plea in the nature of a general traverse. The traverse had to be specific or the plea special. ${ }^{5}$

SEc. 264. In Trespass $\nabla \mathbf{i}$ et armis. The general traverse tendering the general issue in this action is "not guilty." 6 This plea put in issue the facts and acts of the trespass alleged in the declaration. All matters of justification and excuse constituting a defence had to be specially pleaded.

In an action for assault upon the person of plaintiff, it operated to put in issue all the facts constituting a trespass of that nature which did not depend upon any inducement in the nature of title or ownership.

In trespass to personal property, it operated to put in issue the material facts and acts necessary to maintain the action, viz.: the possession of plaintiff and the physical acts of defendant in disturbing that possession. If, however, the goods were carried away, and the action was in form of trespass de bonis asportatis, the plea puts in issue the right of property (or the right of possession) as between the plaintiff and defendant. ${ }^{8}$ If defendant is entitled to possession of the goods, his right of possession draws to him the legal possession, and he is not liable for the mere act of dispossessing the plaintiff of them. ${ }^{9}$

In trespass upon realty it had a similar effect, in putting in issue

11 Chit. Pl. 515.

2 Com. L. P. Act, 1852, Schedule form 52.

B. 36 .

Schedule B. 37.

4 See secs. 273. 293, 297.

61 Chit. Pl. 488.
6 See plea of not guilty in Appendix,

7 Bird v. Randall, 3 Burr. 1353.

8 Steph. Pl. 162, note 20; Fuller v. Rounceville, 29 N. II. 554.

- Dane $v$. Gilmore, 49 Me. 173. 
not only the physical acts of defendant in entering upon the land, but also the fact of actual possession of plaintiff or his lawful possession as against the superior title of the defendant. ${ }^{1}$

It will be seen that the original meaning of the issue had not been much abused in its application to this action. Nevertheless, the scope of the issue was materially restricted by the Hilary rules of 1834 , which provided that in trespass de bonis asportatis the plea of not guilty should not put in issue the plaintiff's property in the goods which had been carried off; and that in trespass quare clausum fregit it should not put in issue the plaintiff's actual possession or right of possession of the place in which the trespass was alleged to have been committed. ${ }^{2}$ These facts were required to be specifically traversed, or specially pleaded to. ${ }^{3}$ When a person was authorized by statute to plead the general issue and give the special matter in evidence, he was not disabled by the Hilary rules from doing so, with like effect as before the rules. ${ }^{4}$

SEC. 265. In Trespass on the Case. The general traverse in this action is "not guilty." As trespass on the case was originally regarded as in the nature of a bill in equity, and the plaintiff was required "to recover upon the justice and conscience of his case, and on that only," 5 great latitude of proof was tolerated under the general issue analogous to that in assumpsit. It operated to put the plaintiff upon proof of the whole charge in the declaration, including matters of inducement, as well as matters constituting the gist of the action. Not only evidence in discharge of the cause of action, but evidence in justification and excuse, were admissible under it. ${ }^{6}$ The scope of the plea resembled that in assumpsit, in thus admitting in evidence matters of confession and avoidance, which do not fall within the strict principle of the plea. While the defendant was at liberty to prove such defences (of confession and avoidance) under the general issue, he was not obliged to take that course in either case or assumpsit, but might bring forward by way of special plea all matters which confess what is adversely alleged, but repel or obviate its legal effect. ${ }^{7}$

1 Steph. Pl. 162, n. 20 ; 1 Chit. Pl. 500, 502 ; Argent $v$. Durrant, 8 T. R. 403 ; Dodd $v$. Kyffin, 7-T. R. 354; Badkin v. Powell, Cowp. 478.

21 Chit. Pl. 520.

3 Jnnes $v$. Chapman. 18 L. J. Rep. N. s. 456 (Part 2)

Martin Crvil Procedure-15
$43 \& 4$ Wm. IV. c. 42 , s. 10 ; ?

Selw. N. P. 1334 (Wheaton).

5 Bird v. Randall, 3 Burr. 1353 ; 1 Chit. Pl. 491.

61 Chit. Pl. 491.

7 Steph. Pl. 162, n. 20, Heard. 
An exception to the extraordinary latitude of proof tolerated under the general issue was established and enforced by the judges in actions for defamation. Chief Justice Raymond is authority for the statement that, at a meeting of all the judges upon a case that arose in the Common Pleas, a large majority of them determined that, in the future, evidence of the truth of the defamatory matter charged in the declaration should not be admissible under the general issue, but should be pleaded specially. ${ }^{1}$ This determination of the judges became a general rule, which extended to all kind of words whether importing a charge of felony or not. ${ }^{2}$

Another exception to the relaxation prevailing in practice consisted in the statute of limitations, which it was always necessary to plead specially. ${ }^{3}$

The scope of the plea was greatly limited by the Hilary rules of 1834. They provided that the plea of general issue "shall operate as a denial only of the breach of duty or wrongful act alleged to have been committed by the defendant, and not of the facts stated in the inducement; and no other defence than such denial shall be admissible under that plea; all other pleas in denial shall take issue on some particular matter of fact alleged in the declaration." In an action for slander to plaintiff in his office, profession, or trade, it will "not operate as a denial of the fact of the plaintiff holding the office or being of the profession or trade alleged." 4 All matters in confession and avoidance shall be pleaded specially as in actions of assumpsit. ${ }^{5}$ The reform was a very important one, as will appear in the examples following the rule.

By inducement is meant those facts and circumstances which were usually necessary to be stated in every action of the case to disclose a right in the plaintiff, which existed at the time of the wrongful act of the defendant, and independant of it. The wrongful act of the defendant consisted in an invasion or infraction of such right, and the plea operated to admit the inducement or right of plaintiff and to deny the infraction of it by defendant. ${ }^{6}$ In case for injury by defendant's dogs the scicnter alleged is part of the wrongful act, and not inducement. ${ }^{7}$ The defence of privileged communication can likewise be proved under the general issue. ${ }^{8}$

Underwood $v$. Sparks, 2 Stra. 1200 [1744].

2 Ibid.

81 Chit. Pl. 497.

1 Chit. Pl. 519.

51 Chit. P1. 518, 519.
6 Frankum $v$. Earl of Falmouth, 2 Ad. \& E. 452.

7 Thomas v. Morgan, 2 Crompt. M. \& R. 496.

${ }^{8}$ Lillie $v$. Price, 5 Ad. \& E. 645. 
SEc. 266. In Trover. We have seen that trover is a species of trespass on the case. ${ }^{1}$ The general issue is "not guilty," and it operated anciently to put the whole declaration in issue, in like manner as in other actions of trespass on the case. Any defence upon the merits could be given in evidence, except the statute of limitations and a release. ${ }^{2}$ Matters in excuse were properly admissible under the pleas because they tended to show that the supposed conversion was not wrongful, and therefore no conversion. ${ }^{3}$

Trover, being an action on the case, fell within the reforming rule of the Hilary term, 1834, relating to such actions. Under thic rule, as heretofore stated, the plea of not guilty operated to deny the wrongful act of the defendant as distinguished from the facts of right in the plaintiff, although the facts of right may constitute in some degree a part of the description of the wrongful acts. ${ }^{4}$ In the examples given for illustration of the rule, it is declared that, "in an action for converting the plaintiff's goods, the conversion only, and not the plaintiff's title to the goods," is denied by the plea. ${ }^{5}$

It has been said by Chitty and Greenleaf that this plea under the Hilary rules put in issue only a conversion in fact, irrespective of its character. $^{6}$ But it would seem that the decisions giving countenance to that view liave been receded from, and that the term conversion as used in the rules means a wrongful conversion as before the rules, and that there can be no such thing as a rightful or justifiable conversion. ${ }^{7}$

Under the Hilary rule the defendant is at liberty to prove under this plea anything tending to show that the act complained of was not a wrongful act, and therefore not a conversion, admitting the plaintiff's title (which constitutes the sole inducement in trover) to be true. ${ }^{8}$ It has been held that evidence of a lien is inadmissible under this plea, ${ }^{9}$ for the reason that it questions the plaintiff's possession or right of possession, which is now admitted by the plea. ${ }^{10}$

1 Sec. 98.

21 Chit. Pl. 161; 2 Greenl. Ev. 648.

s Yelverton, 174 a.

4 Frankum v. Earl of Falmouth, 4 Nev. \& Man. 330 ; S. C. 2 Ad. \& E. 452 .

5 1 Chit. Pl. 518, 519.

(7 Am. ed.) 536; Stancliffe $v$. Hardwick, 2 Cr. M. \& R. 1.

7 Young $v$. Cooper, 6 Exch. 259; Whitmore $v$. Green, 13 M. \& W. 104.

8 See Remarks of Alderson, B., in

Lewis $v$. Alcock, 3 M. \& W. 188.

9 White $v$. Teale, 9 L. J. (Q. B.)

6 2 Greenl. Ev. 648; 1 Chit. Pl. 102 Wheat. Selw. 1380. 
SEc. 267. In Detinue. The plea of "non detinet" represented the general traverse in this action, and raised what was treated as the general issue, although falling short of putting in issue all the material elements of the action. ${ }^{1}$ Formerly this plea put in issue the actual fact of adverse detention, and the plaintiff's right of property or possession. ${ }^{2}$ The wrongful character of an actual adverse detention could hardly be repelled under this plea, except by proof that the plaintiff had no right of possession to the goods. Under this plea the defendant was allowed to disprove the plaintiff's right of property or possession, which showed that the defendant did not wrongfully detain. Evidence strictly in excuse or justification; that is to say, evidence admitting the wrongful detention, but avoiding it, was inadmissible.

It was, however, held that evidence of a lien or pledge was inadmissible at common law under this plea, and that such fact should be pleaded specially. ${ }^{3}$

If the lien or pledge gives the defendant the right to detain the property as against the plaintiff, it would seem to defeat the plaintiff's right of property or possession, and be properly admissible under the general issue; but the weight of authority seems to be the other way.

The scope of the plea was greatly limited by the Hilary rules of 1834, and the construction placed upon them by the courts. They provided that this plea should operate as a denial of the detention of the goods by the defendant, but not of the plaintiff's property therein; and that no other defence than such denial should be admissible under that plea. ${ }^{4}$

It is thus seen that the only defence admissible since the rules under the general traverse of non detinet is the fact of detention. All evidence controverting plaintiff's title is excluded by the rules, not excepting evidence of title in defendant by pledge or lien. ${ }^{5}$ But however limited this may be, it has been held, after some conflict of anthority, that the detention contemplated by the rules is an adverse and wrongful one. ${ }^{6}$

11 Chit. Pl. 488. See form 53 in Appendix.

21 Chit. Pl. 488; Steph. Pl. 162, n. 20.

31 Chit. Pl. 488; 1 Co. Litt. 283 a; Phillips $v$. Rohinson, 4 Bing. 106; Mason v. Farnell, 12 M. \& W'
674; Richards $v$. Frankum, 6 M. \& W. 420 .

41 Chit. Pl. 518.

5 Richards $v$. Frankum, 6 M. \& W. 420.

${ }^{6}$ Clements $r$. Flight, 16 M. \& W. 42. 
The finding or bailment contained in the declaration ceased to be traversable before the Hilary rules, and remained so after them.

SEC. 268. In Replevin. The plea of non cepit modo et forma, as used in this action, has been classed with pleas of general traverse, raising the general issue. ${ }^{\cdot}$ But it is a plea of such limited scope that its classification with general traverses may well be questioned. ${ }^{2}$ It operates to put in issue only the facts of the taking of the goods, and the place of taking or having them. ${ }^{3}$ Under this plea property in and possession of the goods by plaintiff is admitted. ${ }^{4}$ The sole issue raised is whether the defendant seized the goods at all, or at the place mentioned in the declaration. The traverse is clearly in the form and nature of a specific traverse, and should be so classified.

If the defendant wishes to put in issue the plaintiff's property in the goods, he could do so by pleading property in himself or in a stranger. ${ }^{5}$

If the defendant wished to justify the taking as landlord, his plea to that effect was called an avowry or cognizance, which has been explained in our sketch of the action. ${ }^{6}$ This plea avowed or acknowledged the seizure, and set up the facts of a tenancy and of arrearage in rent, asking for return of the property. It necessarily admitted that the goods seized belonged to the plaintiff. As it was in the nature of a declaration, the plaintiff was required to plead to it like a defendant in other cases. In doing this, he invoked the plea of riens en arrere (nothing in arrear), which was recognized as the general traverse for rent due on a demise. This plea, which was presented in the form of a replication, was of limited scope, admitting the defendant's title as stated in the avowry, and operating only to deny that any rent was in arrear. ${ }^{8}$ In its nature and form it is more closely allied with the specific than the general traverse. The Hilary rules of 1834 contained no change relating to the action of replevin. ${ }^{9}$

SEC. 269. In Ejectment. Bearing in mind that ejectment was originally a personal action of trespass, in which a lessee sued for

11 Chit. Pl. 499 ; Gould, Pl. c. vi. s. 9.

2 See form 54 in Appendix.

3 Steph. Pl. 161.

4 Dover $v$. Rawlings, 2 Moody \& Rob. 544 .
5 Gilb. Rep. 127.

6 Sec. 112.

7 Sec. 260.

8 Hill $v$. Wright, 2 Esp. 669.

9 Dover $v$. Rawlings, 2 Moody \& Rob. 544. 
damages for being ejected from his term, ${ }^{1}$ the plea of not guilty constituted a general traverse, as in other actions of trespass. It put in issue all the material facts alleged in the declaration, constituting the right to let, the actual lease, the entry, and the ouster. But, as may be seen in our Appendix, ${ }^{2}$ the scope of the general issue in this action was greatly limited by the consent rule. The actual tenant was compelled by this rule to plead not guilty, and to admit the lease, entry, and ouster, in order to be substituted as a defendant in place of the casual or fictitious ejector. By these admissions, the only question left open for trial under the issue was the right of the alleged lessor by virtue of his title to give lease and entry to the lessee in whose name the suit was brought. ${ }^{3}$

So favorably was the general traverse regarded, that it was prescribed by statutes of Parliament as a proper or sufficient plea by certain officers and other persons in actions against them for acts done by virtue of their office or in pursuance of certain statutes. Special matter might be given in evidence under the general issue thus authorized by Parliament. ${ }^{4}$

SEC. 270. General Traverse of De injuria, by way of Replication to a Plea. - Definition and Origin. This peculiar traverse being more in the nature of a general traverse, for the reason that it puts in issue by a compendious phrase (and not by denial in the words alleged as in specific traverse) the substance of a particular plea, may properly be considered in this connection. It differs from the special traverse by reaffirming the wrong complained of, and in not introducing any new matter by way of inducement. ${ }^{5}$ It has been designated at times as the general replication. ${ }^{6}$ By some it has been styled the general technical traverse, as distinguished from the special technical traverse. ${ }^{7}$

The full form of the phrase constituting the traverse is "de injuria sua propria absque tali causa" (of his own wrong withont such cause). It was used only in a replication wherein the plaintiff alleged that the defendant of his own wrong and without any such cause as in his plea alleged did the wrong complaincd of in the

1 Sec. 166.

2 Note 4.

3 Note 4, Appendix.

41 Chit. Pl. 506, 507.
5 Steph. Pl. 163 ; Gould, Pl. c. vii. s. 9 .

6 See form 55.

7 Gould, Pl. c. vii. s. 5. 
declaration. It appears in the early reports, ${ }^{1}$ and received its characteristic features mostly from the resolutions of the court in the leading case of Edward Crogate. ${ }^{2}$

It originated and was first used in actions of trespass and trespass on the case for torts independent of contract. When the defendant in such actions responded by a plea disclosing matters of excuse for the act of trespass complained of, the plaintiff was permitted by this replication to deny the matters pleaded in excuse, and to reaffirm the charge of wrong contained in his declaration. This replication operated to put in issue all the material matters of excuse which constituted the substance of the plea, however numerous they might be, provided they all supported the issue of excuse. ${ }^{3}$ It put in issue the cause of the excuse, and not its character or extent. ${ }^{4}$ The authorities on this point are divided. ${ }^{5}$

When a plea in excuse contained matters to which the replication de injuria is inapplicable, the plaintiff might expressly except and admit those matters, and in this manner confine his replication to the remainder of the plea, in which case he substituted the phrase "absque residuo causce" for "absque tali causa." 6

SEC. 271. Replication De injuria, continued. Exceptions and Extensions. There were three well settled exceptions to the general rule governing the use of this replication as laid down in the text, ${ }^{7}$ which are sometimes embodied as qualifications in general language incorporated in the rule. ${ }^{8}$ The replication will not apply to a plea of excuse :-

1. When the excuse is founded on matter of record, because this would result in an improper submission to the jury of matters of record along with matters of fact. ${ }^{9}$

2. When the excuse is founded on an authority derived mediately or immediately from the plaintiff. The reason for this latter qualification rests in the obvious justice of compelling the plaintiff to plead specially matters lying equally within his own knowledge,

1 Under the law French, de son tort demesne sans tiel cause. Com. Dig. Pleader, F. 18.

28 Co. Rep. 66 [1608]; 1 Smith's Ld. Cas. 53.

3 O'Brien v. Saxon, 2 Barn. \& C. 908 ; Jones v. Kitchin, 1 Bos. \& Pul. 76 ; Isaac $v$. Farrar, 1 M. \& W. 65; 1 Chit. Pl. 605; Steph. Pl. 264.
4 Penn v. Ward, 2 Cr. M. \& R. 338.

5 See Ames's Cases, note 1, p. 173.

- Renno $v$. Bennett, 3 Gale \& D.

54 ; Crogate's Case, 8 Rep. 66; Steph. Pl. 265.

7 Steph. Pl. 164.

81 Chit. Pl. 606.

9 Fursden $v$. Weeks, Leviuz, 65; Crogate's Case, 8 Rep. 66. 
such as authority or license from himself, and not put the defendant to proof of them on a general traverse. ${ }^{1}$

3. When the excuse is founded in whole or in part on a title or interest in land belonging to the defendant, or to some one other than the plaintiff under whom he acted. ${ }^{2}$ This exception was announced in Crogate's Case, and probably rests upon the importance attributed in ancient times to every issue involving title to land; discouraging all controversy about it, unless definitely presented. Chief Justice Tindal gives for this exception the same reason assigned by him for the second exception; viz. that when the defendant justifies by claim of title or interest in land, "such interest must have been granted originally by the plaintiff himself or those to whom he is privy in estate." 3 This third exception does not apply to cases in which the title or interest in land is alleged only as an inducement to the defence, or when the claim of damages is collateral to the title. ${ }^{4}$

When the plea in excuse involves only a title to personalty, the better opinion is that the replication will apply; the resolution in the Crogate Case purporting to confine the exceptions to cases in which an interest or title to land was pleaded. Its extension to replevin was approved in $1832 .^{5}$

After the Hilary rules of 1834 materially narrowed the general issue in debt and assumpsit, and special pleas became of everyday occurrence in assumpsit, it was desirable that the plaintiff who had but one replication should be enabled to put in issue several of the numerous allegations which the special pleas were found to contain, by the general traverse de injuria. The question of its applicability to actions ex contractu came before the courts, and after some dissent the use of it was approved in assumpsit. ${ }^{6}$ It was finally permitted in debt. ${ }^{7}$

The term injuria, in its generic sense, represents the wrong involved in the infraction of acquired as well as natural rights; and there would seem to be no good reason to deny the replication

1 Purchell v. Salter, 1 Q. B. 197; Crogate's Case, 8 Rep. 66.

2 Crogate's Case, 8 Rep. 66 ; Cockrill $v$. Armstrong, Willes, 99 ; Jones $v$. Kitchin, 1 Bos. \& Pul. 76.

8 Purchell $v$. Salter, 1 Q. B. 197.

4 Taylor v. Markham, Cro. Jac. 224 ; Vivian $v$. Jenkins, 3 A. \& E. 741; Sampson $v$. Henry, 11 Pick. 379.
5 Selby $v$. Bardons, 3 B. \& Ad. 1 , cited in note to Crogate's Case in Smith's Ld. Cas. 53.

6 Isaac $v$. Farrar, 1 M. \& W. 65; Griffin v. Yates, 2 Bing. N. C. 579; Leigh's N. P. 176.

7 Purchell $v$. Salter, 1 Q. B. 197 ; Cowper v. Garbett, 13 M. \& W. 33. 
in all actions ex contractu in which a plea of excuse or justification is permitted, subject, of course, to the exceptions which were settled in Crogate's Case. ${ }^{1}$

\section{Article III.}

\section{Specific Traverse. - Application thereof.}

\author{
Sec. 272. General Rule. \\ " 273. In Debt. \\ “ 274. In Covenant. \\ “ 275. In Assumpsit. \\ “ 276. In Account Render.
}

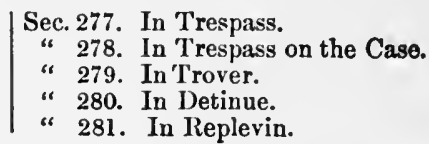

SEc. 272. General Rule. I will refer briefly to the application of the specific traverse to the different actions, which the student will readily understand, if he bears in mind that such traverse was nothing more than an express denial or contradiction of some one or more allegations in the declaration or plea which were material to the cause of action or the defence, as the case might be, in the language in which they are made; and that it must not amount to a denial of all the material allegations asserted in the adverse pleading, otherwise it would be objectionable as usurping the office of the general traverse, the use of which has just been considered.

SEc. 273. In Debt. It will be observed that the declaration in this action continued to conform with its ancient proprietary character, in which it was alleged in terms that the defendant owes to the plaintiff a certain sum of money which he unjustly detains. There would seem to be no room for a specific traverse to debt on simple contract without invading the province of the general traverse of nil debet, as heretofore explained..$^{2}$

If the defendant denied merely that he owed the debt, the plea would be bad, as amounting to the general traverse of "nil debet." If he denied merely that he detained the debt, this is no longer a distinct or material issue in the modern action of debt. Having admitted the debt to be owing, his detention and failure to pay is impliedly admitted in the existence of the debt itself. If payment of the debt was postponed by a subsequent agreement not appearing in the declaration, this could be proved only under a

1 Isaac $v$. Farrar, 1 M. \& W. 65;

2 Section 260. 
special plea. If, however, an unexpired credit was given in the terms of the contract ereating the debt, this could be shown under the general issue, because no actionable debt exists until it is due. ${ }^{1}$

It is true that in all cases the deelaration contained a description of the contraet or agreement, express or implied, out of which the debt arose, and an averment that no part of the money had been paid. But while such averment was generally said to be necessary to the sufficiency of the declaration, the fact of non-payment was held to be non-traversable. ${ }^{2}$ The burden of proving payment was on the defendant, and a special plea in bar to that effect was required to admit the defence.

SEc. 274. In Covenant. On account of the limited scope of the general issue of non est factum in this action there remained ample room for specific traverses, which were generally employed in denial of the breach alleged in the declaration. ${ }^{3}$ In doing this it was incumbent on the defendant to contradict expressly the material facts alleged by the.plaintiff as constituting the breach. He could select only one material fact for such purpose. ${ }^{4}$ But when the facts constituting the breach or breaches were numerous, he incurred the risk of leaving out some material fact, which might prove fatal if not responded to by plea or traverse. On this account the specific traverse was not very generally employed except in connection with other pleas. In most cases of covenant, the defendant met the breach by affirmative plea of performance or excuse for non-performance. ${ }^{5}$

A traverse by defendant of the general allegations of non-performance, which usually precede a statement of the facts constituting the breach by a negative averment (non infregit conventionem) that he has not broken his covenant in inanner and form as alleged, is demurrable as being too indefinite, except perhaps in a case in which the breach consists of a single act or fact. ${ }^{6}$

If the instrument contained a condition precedent to the liability

1 " There is no debt till the credit has expired." Alderson, B., in Broomfield $v$. Smith, 1 M. \& W. 542. See Sections 262, 293, 297.

2 Goodchild $v$. Pledge, 1 M. \& W. 363 ; People $v$. Rowland, 5 Barb. 449 ; Utter $v$. Vance, 7 Blackf. 514.

3 Steph. Pl. 52.
4 Gould, Pl. c. vii. s. 49.

51 Chit. Pl. 487 ; Wheat. Selw. 547 ; 5 Enc. Pl. \& Pr. 380.

6 Roosevelt $v$. Fulton, 7 Cow. 71 ; 1 Wheat. Selw. 545; 1 Chit. Pl. 487; Pett $v$. Russell, 3 Lev. 19 ; Houston $v$. Spruance, 4 Har. (Del.) 129; Marshall r. Haney, 9 Gill (Md.), 251. 
of the defendant on his covenant, it was necessary for the plaintiff to plead it, and to plead performance or compliance with it. If he did not plead the condition, he could not prove it under the plea of non est factum. If he pleaded the condition and performance of it, the plea of non est factum admitted the performance. It was necessary therefore to traverse the performance of the condition specifically to admit that defence, or to plead the fact of non-performance by affirmative plea. ${ }^{1}$

SEc. 275. In Assumpsit. As the general issue of non-assumpsit was narrowed in this action by the Hilary rules of 1834 so that it operated to put in issue only the fact or facts of the promise, whether express or implied, it became necessary to traverse specifically the performance of the contract by the plaintiff, and the happening of conditions precedent to the plaintiff's right of recovery, or to plead specially to them, otherwise they would be adinitted by the general issue. ${ }^{2}$

It was necessary in like manner to traverse the breach or nonperformance of the contract by defendant as alleged in the declaration, if such facts were to be controverted at the trial. ${ }^{3}$

In indebitatus assumpsit the only breach alleged is the fact of non-payment. But as this negative fact is not a necessary part of the plaintiff's case, it is not put in issue under the Hilary rules by a mere denial, ${ }^{4}$ but must be met by an affirmative plea of payment. ${ }^{5}$

In assumpsit on bills and notes the general issue was abolished by the Hilary rules, and all pleas in denial were required to specifically traverse some matter of fact, such as the drawing, making, indorsing, accepting, presenting, or giving of notice of dishonor. ${ }^{6}$

A specific traverse was always available by way of replication to a plea of the statute of limitations. It was in the nature of an affirmative traverse putting in issue the negative averment that the action had not accrued within the period of time fixed by the statute for bringing the action. ${ }^{7}$

SEC. 276. In Account Render. There being no general trav-

1 McCall v. Welsh, 3 Bibb, 289; Parker $v$. Parmlee, 20 Johns. 30; President, \&c. v. Rife, 2 Ind. 316.

${ }^{2}$ De Pinna $v$. Polhil, 8 Car. \& 515. P. 78 .

${ }^{3}$ Smith v. Parsons, 8 Car. \& P. 518. 199.
4 Goodchild v. Pledge, 1 M. \& W. 363.

${ }^{5}$ Hilary rules, 1834 ; 1 Chit. Pl.

${ }^{6}$ Hilary rules, 1834 ; 1 Chit. Pl.

7 Steph. Pl. 154. 
erse in this action, the defendant could by specific traverse deny the allegation of his being a receiver, or his being a tenant in common, from which his liability to account resulted. A plea that he had fully accounted would seem to be in the nature of a specific traverse to the allegation that he had not accounted, although in the affirmative.

SEC. 277. In Trespass vi et armis. In trespass to one's person there never was any room for a specific traverse, for the reason that the declaration contained no allegations or inducement of right necessary to constitute the cause of action. His rights of person were implied in the mention of his person, and were judicially recognized by the court. His body could not belong to another, so as to deprive him of his right of action for injuries to it. Therefore the general traverse of not guilty traversed all the facts of the trespass, which facts necessarily consisted of injuries only to his person resulting directly from the projection of force.

But in respect to trespass to his personal or real property, his right to the property, which consisted in actual possession and the right to such possession, was involved, because it was possible that the possession and the right of possession might belong to another. It was therefore invariably held prior to the Hilary rules of 1834 that the general traverse of not guilty put the plaintiff to proof of the title to the property necessary to maintain trespass, as well as the physical acts of force by which his property was disturbed or interfered with. ${ }^{1}$ Therefore, there was no necessity for a specific traverse or special plea to put in issue the right of property, which could be controverted under the general issue. Nevertheless the specific traverse of "not possessed" in trespass to personalty, and " not his close" in "trespass clausum fregit," was sometimes employed instead of the general issue. These traverses admitted the taking or physical interference with the personalty and the entry in trespass upon land, narrowing the issue to the necessary title to maintain trespass in respect to the personal property or land, as the case might be. But after the Hilary rules of 1834 provided that the general traverse should no longer put in issue the plaintiff's property in the goods, in trespass de bonis asportatis, or the plaintiff"s possession or right of possession in

1 Argent $v$. Durrant, 8 T. R. 403 ; Jones v. Chapman, 18 L. J. R. 456 (P. 2); Collet v. Flinn, 5 Cow. 466 ;
Lyon $v$. Fairbanks, 79 Wis. 455 ; IIarris $v$. Miner, 28 Ill. 135 ; Lambert $v$. Stroother, Willes, 222. 
trespass clausum fregit, ${ }^{1}$ the specific traverses of "not possessed" and "not his close," or special plea to the same effect, became necessary and frequent. These traverses after the new rules, although formally addressed to mere possession, were held to put in issue the right of property and possession in such actions. ${ }^{2}$

In an action of trespass for wrongs to a wife, child, or servant, by reason of which the plaintiff was damaged in the loss of services and incurment of expenses, an inducement was necessary in the declaration consisting of an allegation of the existing relationship, which, after the Hilary rules and in obedience to their spirit, could be specifically traversed. ${ }^{3}$ It is obvious that this traverse would be equally proper if the action was in form of trespass on the case. ${ }^{4}$

SEc. 278. In Trespass on the Case. On account of the varied circumstances giving rise to this action, it would not be practicable to indicate in detail the specific traverses available by the defendant. Although the general traverse anciently put in issue the inducement as well as the gist of the action, there was no valid objection to the defendant denying facts in the inducement by specific traverse. But the absence of any necessity in doing this tended to discourage the practice.

After the Hilary rules of 1834 restricted the general traverse to a denial only of the gist of the action, and left the facts of the inducement uncontroverted, a specific traverse of such facts became necessary, and the rules directed that all other pleas in denial should take issue on "some particular matter of fact alleged in the declaration." 5 In an action of nuisance to the occupant of a house, the occupation would have to be denied specifically. In an action for obstructing a right of way, the right of way would be admitted unless specifically traversed. In case for malicious prosecution it has been held that the necessary allegation of a termination of the prosecution is matter of inducement, and must be traversed specifically. $^{6}$ In case against a sheriff for false return of an execution to the effect that the defendant in the execution had no goods subject to levy, the defendant cannot prove under the general issue that he had no goods, but must traverse the fact of ownership specifically. ${ }^{7}$

1 Sec. 264.

2 .Jones $v$. Chapman, 18 L. J. R. (Exch.) 456 ; Heath $v$. Milward, 2 Bing. N. C. 98 ; Harrison $v$. Dixon, 12 M. \& W. 142.
3 Torrence $v$. Gibbins, 5 Q. B. 297.

4 Sec. 278.

5 Sec. 265.

6 Watkins $v$. Lee, 5 M. \& W. 270.

7 Lewis $v$. Alcock, 3 M. \& W. 188. 
SEc. 279. In Trover. After the Hilary rules of 1834 the general traverse put in issue the wrongful act of conversion, but not the title to the property, which was not in issue unless the allegations of ownership were traversed specifically. This was done by the plea " not possessed," under which the defendant could contest the plaintiff's actual possession, or right of possession, but was excluded from giving evidence bearing on the defendant's wrongful act, outside of the plaintiff's possession or right of possession. ${ }^{1}$ The plea has been held appropriate and necessary when the defendant claimed possession by virtue of a lien or license from plaintiff. ${ }^{2}$ This traverse could be joined with the general traverse of not guilty. ${ }^{3}$

SEc. 280. In Detinue. The specific traverse most often used in this action is the plea of " not possessed," which put in issue only the plaintiff"s right of possession. Evidence of a lien giving to defendant the right of possession seems to be admissible under this traverse on principle, supported by good authority, ${ }^{4}$ but there is some good authority to the contrary, holding that it is inadmissible under this traverse, as it was under the general traverse, which before the Hilary rules put the right of property in issue. ${ }^{5}$

SEc. 281. In Replevin. Specific traverses to the declaration in this action are unusual, because the defendant usually desired a return of the property, and to secure this he had to plead an avowry or cognizance or property in himself or a stranger. ${ }^{6}$ A mere traverse of the allegation of property in the plaintiff, unaccompanied with any designation of the owner of the property, was demurrable for defect in form rather than in substance. To make the traverse good in form, the defendant was required to preface or conclude it with the averment of property in himself, or in a stranger, naming him. ${ }^{8}$ This additional averment robbed the plea of its character as a specific traverse, and gave to it the inducement of a special traverse, which should be followed by the direct traverse. ${ }^{9}$ But as to the necessity of adding the direct traverse to

1 Owen $v$. Kinight, 4 Bing. N. C. 54.

2 Owen $v$. Knight, 4 Bing. N. C. 54 ; Ringham v. Clements, 12 Q. B. 260 ; Leake $v$. Loveday, 4 M. \& G. 972 ; Gregg $v$. Wells, 10 Ad. \& E. 90; (see sec. 279).

3 See form 56.

4 Lane $v$. Tewson, 1 Gale \& D. Q. B. 584; Dirks v. Richards, 4 M. \&
G. 574 ; Barnewall $v$. Williams, $7 \mathrm{M}$. \& G. 403 ; 1 Wheat. Selw. 665.

5 Mason $v$. Farnell, 12 M. \& W. 674 ; see sec. 267.

6 Com. Dig. Pleader, 3 K. 11.

7 Dermott $v$. Wallach, 1 Black, U. S. 96 .

8 Anstice v. Holmes, 3 Den. 244 ; Whitwell $v$. IVells, 24 Pick. 25.

9 Hammond, N. P. 485. 
make it a good plea, the authorities are divided. ${ }^{1}$ The plea of property in the defendant or in a stranger was good in abatement or in bar. ${ }^{2}$

\section{Article IV.}

\section{Special Traverse. - Application thereof.}
Sec. 282. History.
" 283. Essential Requisites. “ " 286. Conclusion of it.
Sec. 285. Special Traverse, abnormal Form.
“ 284. Rules for determining its “ 287. Practice resulting from defect- Sufficiency. ive 'Traverse.
Sec. 288. Principles relating to Traverses in general.

SEc. 282. History. Argumentative pleading was common in the reign of Edward III. $;^{3}$ a very natural vice, ${ }^{4}$ which led to the rule that every affirmation in pleading should be answered by an express negative. In compliance with this rule, the pleader, after statement of his argumentative matter, added a direct denial of his adversary's affirmative allegation by an absque hoc or sans ce clause. ${ }^{5}$ The objects to be attained in employing this method of traverse have never been very satisfactorily explained. ${ }^{6}$ It has been said that a direct denial in some cases might be held improper as in violation of a possible estoppel, and that this objection could be obviated by an explanatory denial. ${ }^{7}$ It has also been urged with some plausibility that it furnished a convenient form for presenting the facts in support of the denial on record, so that the issue might be determined by the court as an issue of law upon demurrer. ${ }^{8}$ But whatever may have been the object had in view by the pleader, the practice of introducing into pleadings evidential facts in support of express denials therein was so common in ancient times that the special traverse became a part of the common law system of pleading. ${ }^{9}$

It would seem to be a manifest departure from the simplicity and singleness of issue, for the production of which that system was

1 Loveday $v$. Mitchell, Comyn Rep. Case, 137.

2 Loveday $v$. Mitchell, Comyn Rep. Case, 137.

32 Reeves, Hist. 624.

4 This method of controverting a point by argument occurs in everyday disputation. Any person inexperienced in pleading would naturally meet the point of duress in the example mentioned in sec. 259 , by saying in behalf of the plaintiff (if the facts were at his command), "the plaintiff paid full value to the defendant for the bond, which is a fact inconsistent with and repugnant to the pretended fact of duress, and therefore I say it was not executed under duress."

52 Reeves, Hist. 624, 625.

6 Steph. Pl. 175, 176.

7 Steph. Pl. 176.

8 Steph. Pl. 177 ; Beckman $v$. Knight, 4 Bing. N. C. 243.

9 Steph. Pl. 179; 1 Chit. Pl. 619. 
invented; and the courts in more recent times have discouraged the use of it, first in the forms in which no new matter is alleged but only old matter repeated, and finally in the normal form which contains new matter. ${ }^{1}$ While it became less and less used, nevertheless its legality so far as its original and normal form is concerned has never been questioned where the common law system of plead. ing prevails; and its existence was expressly recognized in the Hilary rules of 1834 , directing a change in its conclusion.

It is not easy to conceive of a case in which a special traverse is absolutely necessary, and in which a specific traverse could not be used. In support of this conclusion, it is only necessary to refer to the fact that, to make a special traverse good, a direct traverse under the absque hoc clause, has to be added as a necessary part of it, ${ }^{2}$ and that the issue is made on this direct traverse when it is in proper form. The subordinate and inconsequential nature of the indirect denial in the inducement, as compared with the direct denial in the absque hoc clause, is shown, not only in the fact that it could not be pleaded to, but in the further fact that the party pleading it was not restricted to it at the trial, but could give in evidence any other competent facts in support of the denial in the absque hoc clause. ${ }^{3}$

SEc. 283. Essential Requisites. The special traverse originally consisted of three requisites of form: 1st. An inducement containing the averments of new matter, constituting an indirect denial of some material allegation in the adverse pleading. $2 \mathrm{~d}$. The absque hoc clause constituting a direct denial of the same material allegation in the language in which it is made. $3 \mathrm{~d}$. The conclusion in which the party pleading averred that he was ready to establish the truth of the matters set forth in his plea, and which went by the name of averment or verification.

To make a special traverse good in form it was necessary that it should contain all the foregoing requisites. It was also necessary in general that the indirect denial contained in the inducement, and the direct denial in the absque hoc clause, should relate to the same matter in the adverse pleading. ${ }^{4}$ It may be observed that it was only a logical conclusion, from the nature of a special traverse, that the direct denial of the absque hoc clause was always a negative

11 Chit. Pl. 619 ; Robinson v. Rayley, 1 Burr. 320 ; Steph. Pl. $1 \cong 2$.

2 Fortescue $v$. Holt, 1 Vent. 213.
3 Cross Keys Co. v. Rawlings, 3 Bing. N. C. 71 .

4 Gould, Pl. c. vii. s. 14, 64. 
averment, which necessarily required the party pleading to it to do so by repeating his affirmative averment and tendering issue thereon. ${ }^{1}$

The special traverse, like other pleadings, might be defective in form or in substance. When its validity was tested on demurrer, the action of the court was governed by the following rules: 1st. If it was defective in form, in either the inducement or in the absque hoc denial, the whole traverse would be held bad on special demurrer. ${ }^{2} 2 \mathrm{~d}$. But if it was good in substance in either the inducement or the absque hoc denial, the whole traverse would be held good on general demurrer, which fails to reach mere matters of form. ${ }^{3} \quad$ This latter rule indicates the dual nature of the special traverse, as disclosed in its two essential parts. If one of them was good in substance, a substantial issue was raised, although it was contained in a defective form.

Whether a wrong conclusion of a traverse is a fault of substance or of form only, opinions differ. By most of the authorities it was regarded as a defect in substance, and was fatal in general as well as special demurrer. ${ }^{4}$ But as the conclusion is nothing more than a technical form of closing the pleadings or keeping them open, this rule has been justly questioned on principle. ${ }^{5}$

SEC. 284. Rules for determining the sufficiency thereof. There were three well recognized rules for determining the sufficiency of a special traverse as heretofore defined and described:-

1st. The inducement should in itself amount to a sufficient answer in substance to the last pleading. In other words, the indirect denial was required to contain, without aid of the absque hoc clause, an answer in substance to the opposite pleading, although argumentative in form. ${ }^{6}$

2d. The answer thus contained in the inducement could be of no other nature than that of an indirect denial. The inducement was bad if it consisted of a direct denial. ${ }^{7}$

3d. Neither could the answer contained in the inducement be in the nature of a confession and avoidance, or coupled with matter

1 Gould, Pl. c. vii. s. 41,64 .

5 Gould, Pl. c. vii. s. 25 ; Clue v.

2 Anon., 3 Salk. 353; Courtney $v$. Bdily, 1 Vent. 240.

Satchwell, 1 Stra. 694 .

8 Horn $v$. Lewin, 2 Salk. 583.

4 Gould, Pl. c. vii. s. 25; 1 Saund. Cro. Eliz. 754.

103, note 3 ; Anon, 3 Mod 203.

Martin Civil Procedure-16 
in avoidance. ${ }^{1}$ In such case it would be a plea in confession and avoidance, and not a traverse. To add a traverse to such a plea would make the pleading demurrable. ${ }^{2}$ It could be nothing more than matter explanatory of the direct denial in the absque hoc clause.

To these rules may be added a fourth one, which was more distinctively a rule of practice, resulting logically from the nature of an inducement as heretofore defined:-

4th. An inducement contained in a special traverse, good in form and substance, could not be traversed by the opposite party. No choice was left but to tender issue after reaffirming the matter denied in the absque hoc clause. ${ }^{3}$ The reason of this was that an inducement is itself a traverse, although an indirect one, and falls under the rule which applies to all traverses and forbids a traverse upon a traverse. ${ }^{4}$ Neither could it be answered by way of confession and avoidance for the same reason. ${ }^{5}$ No choice was left but to tender issue, as just indicated. ${ }^{6}$ If the inducement alone was bad, it could be reached only on demurrer. ${ }^{7}$

SEc. 285. Special Traverse. - Abnormal Form. After the special traverse had become established in the common law system of pleading, it grew so much in favor as to be adopted occasionally in cases to which the original reasons of the form were inapplicable; as in cases where the inducement contained no new explanatory matter, but consisted in a mere repetition of the original complaint. ${ }^{8} \mathrm{As}$, for instance, in cases of assault, when the defendant pleaded a warrant of arrest in justification of his act, the plaintiff was permitted to reply that the defendant of $h$ is own wrong made the assault, without this, - that he had any warrant of arrest to justify his act. ${ }^{9}$

This form, although a manifest departure from the essential requirements of a special traverse, as defined by the best authorities, was passed and impliedly approved by the courts. ${ }^{10}$ Its use, however, was occasional only $;^{11}$ and in modern times it has been almost entirely superseded by the specific or common traverse. ${ }^{12}$

1 Steph. Pl. 185; Palmer v. Ekins, 2 Ld. Raym. 1550.

21 Saund. 22, note 5, 209, note 8; Oystead $v$. Shed, 13 Mass. 520.

s Steph. Pl. 186.

4 Steph. Pl. 186; Thorn v. Shering, Cro. Car. 586.

5 Steph. Pl. 188.
6 Steph. Pl. 189.

7 Steph. Pl. 189.

8 Steph. Pl. 180.

9 Steph. Pl. 180.

10 Stennel $v$. Hogg, 1 Saund. 223;

Mayor v. Richardson, 4 T. R. 437.

11 Steph. Pl. 181.

12. Steph. Pl. 181. 
SEC. 286. Conclusion thereof. In former times it was very generally held that every special traverse proper - that is, a traverse with an absque hoc followed or preceded by an inducement of new matter - should conclude with an averment or verification. ${ }^{1}$ This rule may be said to have prevailed anciently with some varying exceptions.

It was said that the reason of the rule was to leave an opportunity for the adverse party to answer the new matter, notwithstanding there were already complete affirmative and negative allegations of record constituting a perfect issue, which rendered it wholly unnecessary to conclude with a verification. ${ }^{2}$ There never was any good reason for postponing the tender of issue. ${ }^{3}$ If the special traverse was good, the opposite party could not answer the new matter, but was compelled to tender issue by reaffirming the truth of the matter denied in the absque hoc clause. If the traverse was bad, he could demur to it irrespective of the conclusion. The fact that he might in some cases, as we shall presently see, when the inducement was defective, treat it as something else than the component part of a special traverse, and plead to it as to a common plea, must be accepted as a very illogical, if not whimsical, reason for a rule governing the special traverse proper.

There was not even a shadow for the rule in the class of abnormal traverses in which no new matter was alleged, but only a reaffirmation in general terms of old matter; and accordingly the application of the rule was very generally denied in such cases and a conclusion to the country was approved. ${ }^{4}$

But the more modern authorities qualified the rule in special traverses proper with this distinction, that when the whole of the matter of the opposite pleading was denied by the plea or replication, it must conclude to the country, notwithstanding it has an introductory inducement and formal traverse with an absque hoc; but when a particular fact alleged is denied, the replication must conclude with a verification. ${ }^{5}$ But the rule that a special traverse

1 Gould, Pl. c. vii. s. 18 ; Co. Litt. 126 a; 1 Saund. 103 note 3; Carth. 337 ; 2 Stra. 871; Roberts $v$. Marriett, 2 Saund. 189.

23 Chit. Gen. Pr. 719.

31 Saund. $103 \mathrm{~b}$, note 3, Williams.

41 Saund. $103 \mathrm{a}$, note c ; Calvert $v$. Gordon, 1 Mann. \& Ry. 497 ; Low $v$.
Burrows, 4 Nev. \& Man. 367 ; Skinner $v$. Kilby, Carth. 87; Roberts $v$. Marriett, 2 Saund. 189 ; Trapaud $v$. Mercer, 2 Burr. 1022.

51 Saund. 103 a, note c ; Gould, Pl. c. vii. s. 19,20 ; Haywood $v$. Davies, 1 Salk. 4 ; Robinson $v$. Rayley, 1 Burr. 317; Boyce $v$. Whitaker, 1 
of only a part of what is alleged on the other side must conclude with an averment, was never universal, and the courts approved the anomalous practice of permitting the pleader in many cases to conclude his traverse either way. ${ }^{2}$

The conflict of judicial opinion in respect to the conclusion of the special traverse was terminated by one of the Hilary Rules of 1834 , which required that "all special traverses or traverses with an inducement of affirmative matter, shall conclude to the country," but that this regulation should "not preclude the opposite party from pleading over to the inducement when the traverse is immaterial. ${ }^{2}$

SEc. 287. Practice consequent upon defective Special

\section{Traverses.}

1st. It was held that if the direct traverse under the absque hoc clause was good in substance, and the inducement bad, the responding party was required either to demur specially or plead to the direct traverse by tendering issue upon it before the Hilary rules, or joining in the issue tendered by the other side after the making of those rules.

$2 \mathrm{~d}$. When the direct traverse in the absque hoc clause was defective in substance, as being taken on immaterial matter, the opposite party was at liberty to demur or to treat the defective direct traverse as surplusage, and plead to the matter in the inducement by traverse, or by confession and avoidance, according to the nature of the case. ${ }^{3}$ Under these circumstances the adverse party was allowed to treat the matter in the inducement as if it occurred in a pleading disconnected with any absque hoc denial, and to traverse or confess and avoid it, irrespective of its intended character as an inducement. His right to do this is instanced as an exception to the rule that a traverse could not be taken upon a traverse.

The exception is more apparent than real, since the immaterial denial in the absque hoc clause in such case operated to divest the pleading of its intended character as a special traverse, at the

Doug. 94 ; Smith $v$. Dovers, 2 Doug. 428,429 , note 1 ; Hedges $v$. Sandon, 2 T. R. 442.

1 Gould, Pl. c. vii. s. 22 ; Sanford v. Rogers, 2 Wils. 113 ; 1 Saund. $103 \mathrm{c}$; IIedges $v$. Sandon, 2 T. R. 442; 1 Chit. Pl. 616.
23 Chit. Gen. Pr. 717.

3 Steph. Pl. 187, 188; Richardson v. Mayor of Oxford, $2 \mathrm{H}$. Bl. 186; King qui tam $v$. Bolton, 1 Stra. 117; Breck v. Blanchard, 20 N. H. 333. 
option of the adverse party. His right to do so was preserved by the Hilary rules of 1834 , as already mentioned. ${ }^{1}$

$3 \mathrm{~d}$. When the traverse of the absque hoc clause could be treated as immaterial, and passed by, is not very definitely settled.

If the inducement was defective for the reason that it contained matter in confession and avoidance, it was generally held that the pleader could not also add a traverse of any kind to the matter so confessed and avoided, even though the matter traversed was material. If added, it would naturally be waived by the confession and avoidance. ${ }^{2}$ In such case there would seem to be no good objection to the practice of allowing the adverse party, if he did not choose to demur, to pass the traverse by as immaterial, and plead to the matter in confession and avoidance, as if it was disconnected with any traverse. ${ }^{3}$

If the inducement was defective for the reason that it contained a direct denial of material matter, resembling in this respect a specific or common traverse, whether the addition of another traverse under the absque hoc clause could be treated as immaterial is a question not so easily answered. If the two traverses are to the same allegations, there would seem to be no substantial reason against joining issue on the specific traverse and ignoring the absque hoc clause as superfluous. "For when a matter is expressly pleaded in the affirmative which is expressly pleaded by the other party in the negative, there a traverse is needless, because there is a sufficient issue joined, as 36 Hen. VI. pl. 15." 4

But if they go to different allegations of the adverse pleading and both are material, as neither denial waives the other, while the plea would be demurrable for doubleness, serious results might follow in joining issue on one, and allowing the other to go unanswered.

SEC. 288. Principles relating to Traverses in general. In

1 Sec. 286.

2 King $v$. Coke, Cro. Car. 384; Bennett $v$. Filkins, 1 Saund. 20; Hob. 104; Bedell v. Lull, Cro. Jac. 221; Bedell $v$. Lull, Yelv. 151 ; Anon., 3 Salk. 353; Pearson v. Rogers, 9 Ad. \& E. 303 .

8 In Bennett $v$. Filkins, 1 Saund. 20, Mr. Saunders as counsel, after admitting the general rule forbidding a traverse upon a traverse, said, “ But where the first traverse is idle and not well taken nor pertinent to the matter, but is of that which was sufficiently confessed and avoided before, there the other party may take another traverse after such immaterial traverse taken before."

- Huish v. Philips, Cro. Eliz. 754. 
concluding the subject of traverses, it will be proper to notice certain principles relating to traverses in general.

1st. A traverse should deny the allegation pleaded to in the manner and form in which it is made. ${ }^{1}$ The opposite party is required to prove that his allegation, in substance at least, is accurately true. A failure to traverse in manner and form as alleged subjects the party making it to the danger of variance between pleading and proof.

The negative traverses non est factum and replication de injuria are exceptions to the rule requiring traverses to be pleaded modo et forma. ${ }^{2}$

2d. A traverse must not be taken upon matter of law alone, for a denial of law is only an exception to the sufficiency of the pleading in point of law, and should therefore be urged by way of demurrer, and not by traverse. ${ }^{3}$ It may be taken upon mixed matter of law and fact. ${ }^{4}$

3d. A traverse should not be taken upon matter not alleged. This rule is subject to the qualification that it may be taken upon matter which, though not expressly alleged, is necessarily implied. ${ }^{5}$

4th. A party to a deed who traverses it must plead non est factum, and should not plead that he did not grant, did not demise. $^{6}$ In other words he must deny the evidential fact of the grant or demise, when that fact is pleaded by his adversary. If he admits that he made the deed he is estopped from denying its operation and effect as a grant or demise. The rule is based on the doctrine of estoppel.

There are some other rules relating to traverses which will be noticed in connection with the grouping and recital of general rules governing pleadings. ${ }^{7}$

1 Steph. PI. 189.

2 Steph. Pl. 191.

3 Steph. Pl. 191.

1 Saund. 23, note 5; Grocery Co.

v. Archbishop, 3 Wils. 234.
5 Steph. Pl. 193, 195.

- Steph. Pl. 196.

7 See form 57. 


\section{CHAPTER XII.}

\section{DEFENCE IN BAR BY WAY OF CONFESSION AND AVOIDANCE.} Article I. Defined, Classified, and Ex-
plained.

Article III. Pleas by Estoppel.

Article I.

Defined, Classified, and Explained.

Sec. 289. Defined and Classified. . Sec. 291. Confession or Color expressed. " 290. Confession or Color implied. " 292. Pleas in Discharge defined. Sec. 293. Pleas in Justification or Excuse defined.

SEC. 289. Defined and Classified. Pleas by way of confession and avoidance are such as admit expressly or impliedly the facts of the declaration constituting the cause of action, and then proceed to allege new facts, which so qualify and affect the facts admitted as to show that the plaintiff never had a cause of action, or that a cause of action once possessed by him has ceased to exist. The new facts pleaded are said to be in avoidance of the right of action asserted by the adverse party.

Pleas in confession and avoidance are divided into two classes, viz. pleas in discharge, and pleas in justification or excuse, ${ }^{1}$ which will be defined and distinguished further on. They are not susceptible of this division when occurring in subsequent pleadings, except in replications to a set-off, which is virtually a new cause of action. $^{2}$

SEc. 290. Confession or Color implied. It was essential that all pleas in confession and avoidance should expressly or impliedly admit the truth of the averments which were to be avoided by the new matter pleaded. The forms anciently used wonld seem to indicate that an express admission was usual ${ }^{3}$ but an implied or

1 Steph. Pl. 198, 199.

3 Steph. 1'. 200.

2 Davies v. Benton, 6 B.\& C. 216. 
indirect admission was approved at a very early day. ${ }^{1}$ The nature and extent of the admission came to be defined and qualified by the rule which required that all pleadings by way of confession and avoidance should give color. By this was meant that the pleading should indirectly or impliedly at least concede to the plaintiff, either a previous cause of actions now discharged, or an apparent or prima facie cause of action for the purpose of the plea, - something in the nature of an admitted cause of action in his behalf but for the new matter pleaded, which operated to avoid or neutralize it. This latent admission, which naturally inheres in the structure of all pleas in confession and avoidance, and which might be indirectly expressed, went by the name of implied color. ${ }^{2}$ An allusion to the plaintiff's right of action in language which did not question it as the prima facie effect of the facts alleged, was generally accepted as giving the required color. An allusion to the promises of a declaration "if any such were made," or to a cause of action "if any such there be," has been denied by the courts as a sufficient giving of color, being regarded as a hypothetical admission. $^{3} \quad$ It might be passed in a plea in abatement which need not traverse or confess and avoid all matters alleged. ${ }^{4}$ A similar allusion was passed in a plea to an assault, but without any comment by the court. ${ }^{5}$ But a reference to the plaintiff's statement, as "the supposed causes of action" has been accepted and very generally approved as giving sufficient color. ${ }^{6}$ The necessity for inserting any indirect admission of a prima facie case is not apparent in face of the formal rule, "that every pleading is taken to confess such traversable matters alleged on the other side as it does not traverse." 7 The better view is that such indirect admission has never been considered necessary to the validity of a plea which contains facts in avoidance, and remains silent in other respects as to the facts constituting the plaintiff's cause of action. This silent admission would seem to give sufficient color to preserve the plea, in obedience to the maxim Qui non negat fatctur. ${ }^{8}$

1 Year Book, 49 Edw. III. 23.

2 Steph. Pl. 205, 206.

3 Gould v. Lasbury, 1 Cr. M. \& R. 254; Margetts $v$. Bays, 4 Ad. \& E. 489 ; 1 Chit. Pl. 526.

4 Gould v. Lasbury, 1 Cr. M. \& R. 254.

5 Wise $v$. Hodsoll. 11 A. \& E. 816.
6 Evestaff v. Russell, 10 M. \& W. 365 .

7 Steph. Pl. 217.

8 Hudson $v$. Jones, 1 Salk. 91; Strong $v$. Smith, 3 Caines, 164 ; Briggs v. Dorr, 19 Johns. 95 ; People v. Gray, 72 Ill. 343. 
SEc. 291. Confession or Color expressed. The term express color came to have a technical signification, which distinguished it sharply from implied color, which was sufficiently pleaded by an unambiguous reference. It came to represent an intricate and subtle fiction, which was originally employed in the mixed actions of assize and writs of entry in the nature of assize, and in the personal action of trespass. After abolition of the mixed actions mentioned, it remained in trespass alone. It has been defined to be " a feigned matter pleaded by the defendant in an action of trespass, from which the plaintiff seems to have a good cause of action, whereas he has in truth only an appearance or color of cause." 1

As an illustration: In an action for trespass upon land, if the plaintiff pleaded merely a seisin in a third person and a demise for years from such person to himself, by reason whereof he entered upon the close, as he had lawful right to do, the plea would be bad for the reason that this defence could be proved under the general issue, it being strictly in support of a denial of the plaintiff's possession, or right of possession, as against defendant. If the defendant made use of the general issue, he would be compelled to prove his whole title to justify his entry. Accordingly he was permitted, after setting out his title, to allege expressly that the plaintiff had a prior charter of demise from the same person for the term of his life, by virtue of which he (plaintiff) had entered upon the close, but that nothing in the said close ever passed into his possession by virtue of said charter (which implied some insufficiency in law, as that the charter was not a feoffment and was unaccompanied with livery of seisin); and that thereupon defendant entered into said close and upon the said plaintiff's possession, as it was lawful for him to do. It was held by the courts that this express averment of a defective title in plaintiff gave a semblance of right to his case, which was sufficient color for the purposes of the plea. The matter of color thus given was not traversable, and when the plaintiff's turn for reply came, he was obliged, under the rules of pleading which forbade taking issue upon more than one decisive point, to admit the seisin of the third party or the demise from him to defendant. In this manner the issues were narrowed by the pleadings which relieved the defendant from proving his whole title. If the plaintiff should deem the plea insufficient in law, the 
validity of the defendant's title could be decided by the court on demurrer without resort to a trial by jury. The sole issue to be tried by either court or jury consisted in the defendant's right to enter by virtue of the title pleaded by him.

It was never necessary to give this express color when the nature of the plea itself disclosed implied color. Feigned color would be out of place in connection with such a plea.

This extreme subtlety of the rule governing express color consisted in the two requirements: first, that the plea should give an apparent right of action to the plaintiff; second, that it should not give an actual or valid right. If it failed to give a feigned right, it was bad. If it gave an actual or valid right, it went too far, and operated as a confession which could not be contradicted by the matter pleaded in avoidance. ${ }^{1}$

The practice of giving express color obtained only in pleas, and did not extend to subsequent pleadings. ${ }^{2}$. Neither was it usual to employ other than the well known fictions of a defective charter of demise in trespass to land, and the delivery of goods to a stranger who delivered to plaintiff from whom defendant took them in trespass for taking chattels. ${ }^{3}$

All pleas in confession and avoidance were required to conclude with a verification, for the reason that they contained new matter. ${ }^{4}$

SEc. 292. Pleas in Discharge defined and enumerated. A plea in discharge must allege a discharge or release from the liability asserted in the declaration. The effect of it is to show that, although the plaintiff once had a cause of action, it has been released, discharged, or satisfied by some subsequent act or matter. ${ }^{5}$ The plea impliedly confesses the existence at some time of a cause of action in alleging a release or discharge therefrom. The facts of avoidance give sufficient color, without any express indirect allusion to that effect, or appeal to the formal rule that what is not denied is confessed.

Pleas of this class were limited in number and quite well defined in name. They were, as a general rule, applicable to all personal actions, and most real and mixed actions. They were known as pleas of accord with performance or satisfaction $;^{6}$ of arbitrament

- 1 Steph. Pl. 214 ; Radford $v$. Harbyn, Cro. Jac. 122.

2 Steph. Pl. 213.

3 Steph. Pl. 214.
4 Steph. PI. 199 ; Goodchild $v$. Pledge, 1 M. \& W. 363.

-6 Steph. Pl. 199.

6 Comyn, Dig. Accord. 
with performance $;^{1}$ of payment $;^{2}$ of release $;^{3}$ of discharge under laws of bankruptcy or insolvency $;^{4}$ and of tender in some cases. ${ }^{5}$

Evidence of many of these defences was admissible under the general issue in assumpsit, debt on simple contract, and case, prior to the Hilary rules of 1834 , but this fact never forbade pleading them specially in bar even in those actions for the purpose of narrowing the issues. ${ }^{6}$ After the Hilary rules it became necessary to plead them specially.

Sec. 293. Pleas in Justification or Excuse defined. Pleas by way of justification or excuse contain a statement of new matter, which constitutes a legal justification or excuse for the matters complained of in the declaration. The effect of them is to show that, on account of the new matter disclosed in the plea, the plaintiff never had a cause of action; because, when considered in connection with such new matter omitted from the declaration, the act complained of therein was lawful. ${ }^{8}$

Pleas in justification and pleas in excuse are the same in effect, although differing from each other in the general nature of the facts contained in them. A plea in excuse, in a strict sense of the word, discloses some act or conduct in pais of the plaintiff, which legally excuses the defendant from all liability on account of the matters complained of in the declaration; while a plea in justification discloses some legal title, right, interest, or authority in the defendant, which in law justifies him in the act or omission complained of. In an action for assault and battery, a plea that the plaintiff first assaulted the defendant, and that the defendant did no more than was necessary to defend himself from such assault, is an example of a plea in excuse. ${ }^{9}$ In an action for trespass by cattle, a right of common in the owner of the cattle may be pleaded in justification of the trespass. ${ }^{10}$ So also in an action of trespass de bonis asportatis, a plea of taking under authority of a writ of execution is a good plea in justification of the act complained of.

1 . Comyn, Dig. Accord, D.; Yingling v. Kohlhass, 18 Md. 148; Brown $v$. Perry, 14 Ind. 32.

${ }_{2}$ Goodchild $v$. Pledge, 1 M. \& W. 363.

3 Brooks v. Stuart, 9 Ad. \& E. 854.

4 Gould $v$. Lasbury, 1 Cr. M. \& R. 254.

51 Chit. Pl. 479 ; Comyn, Dig. Saund. 27.
Tender; 1 Leigh, N. P. 699 ; Heskett $v$. Fawcett, 11 M. \& W. 356 .

61 Chit. Pl. 480, 526; Gould, PI.

c. vi. s. $54,5 \overline{5}, 56,9 \overline{5}$.

7 See form 58.

${ }^{8}$ Steph. Pl. 199.

9 Wise v. Hodsoll, 11 Ad. \& E. 816.

${ }^{10}$ Earl of Manchester $v$. Vale, 1 
It may be observed, however, that the term excuse is very often applied to facts which constitute justification within the meaning given above. ${ }^{1}$

Pleas in justification and excuse may be said to include all pleas by way of confession and avoidance except those in discharge of the liability. They have no assignable limit in number, neither are they distinguishable by well known names, like pleas. in discharge. It is not within the scope of this treatise to consider the great variety of pleas in justification or excuse which have been recognized at common law. It will be sufficient to indicate the general nature and form of them, as employed in response to the ordinary personal actions, which will be done in the next article.

\section{Article II.}

Pleas in Justification or Excuse applied.

Sec. 294. In Debt.

695. In Covenant.

“ 296. In Special Assumpsit.

“ 297. In General Assumpsit.

Sec. 302. In Case.

Sec. 298. In Trespass.

" 299. In Trover.

“ 300. In Detinue.

“ 301. IL Replevin.

SEc. 294. In Debt. The plea of justification or excuse must directly or indirectly admit the facts which prima facie constitute the debt, but which tend to avoid it. ${ }^{2}$ In debt on a sealed instrument we have seen that the plea of non est factum under the Hilary rules put in issue only the existence of the deed in point of fact. All other defences had to be specially pleaded, - those tending to show it was either void or voidable. ${ }^{3}$ Pleas therefore in justification or excuse admitted only the making of the bond, and set forth new matters which avoided the bond as a legal obligation, - such as infancy or coverture of defendant, fraud, duress, limitations, usury, and non-performance by plaintiff of conditions subsequent, $\&$ c. $^{-}$

In debt on simple contract we have seen that the general issue of nil debet, with the latitude of defence admissible under it, was

1 Ames's Cases, 50-76.

2 See form 59.

3 Sec. 260.

41 Chit. Pl. 480, 518 ; Evestaff $v$.

Russell, 10 M. \& W. 365; Hinton $v$.
Rossey, 3 Mod. 35 ; Mc Alester $v$. Reab, 4 Wend. 483; King $v$. Jones, $2 \mathrm{Id}$. Raym. 1525; Phelps v. Decker, 10 Mass. 267. 
abolished by the Hilary rules, and that the general traverse of nunquam indebitatus was substituted therefor, except in actions on bills and notes. ${ }^{1}$ It was further provided in these rules that the general traverse of nunquam indebitatus should have the same operation as the plea of non assumpsit in indebitatus assumpsit, and that all matters in confession and avoidance should be pleaded specially as in actions of assumpsit. ${ }^{2}$

To understand the nature of pleas in justification and excuse in debt on simple contract, it is only necessary to consult them as approved in indebitatus assumpsit, to which the student is referred. ${ }^{3}$ Debt on simple contract and indebitatus assumpsit are the same in effect. Both are grounded on the fact of a debt, and the consideration of the debt must appear in the declaration of both cases. ${ }^{4}$ Until the debt is due, the action of debt cannot be maintained. Neither can indebitatus assumpsit be maintained, because the law will not raise a promise to pay before the debt is due. It has therefore been held that an unexpired credit given in the contract or facts creating the debt can be proved under the plea of nunquam indebitatus, and need not be pleaded in excuse or justification. ${ }^{5}$ By the weight of authority the same is true in indebitatus assumpsit. ${ }^{6}$

In an action of debt for rent, an eviction from the premises by the lessor or claimant under paramount title was a good plea in excuse. ${ }^{7}$ Before the Hilary rules it was optional with the tenant to plead it specially or give it in evidence under the general issue of nil debet. ${ }^{8}$ After the rules it was required to be pleaded specially in excuse or justification. ${ }^{9}$

SEc. 295. In Covenant. In the action of covenant, as in the action of debt on covenant, the general issue of non est factum after the Hilary rules of 1834 admitted only the execution of the covenant or deed in point of fact, - leaving all defences tending to show that it was void or voidable to be pleaded specially.10

It was peculiar to the action of covenant that the plaintiff was required to set out only the covenants of the defendant for breach

1 Sec. 260.

2 Hil. Rules, II. Cov. and Debt, s. 3.

8 Sec. 297.

41 Chit. Pl. 114. 542.

6 Broomfield v. Smith, 1 M. \& W.

6 Sec. 297.
71 Chit. Pl. 482, 591.

8 Anon., 1 Mod. 35; Browne's Case, 1 Mod. 118; 1 Saund. 204, note 2 .

9 Waddilove $v$. Barnett, 2 Bing. N. C. 538 ; S. C. 2 Scott, 763.

10 Sec. 261. 
of which he complained, and that he was excused from noticing conditions subsequent, leaving breach of them by plaintiff to be urged by defendant. ${ }^{1}$

He was also relieved from stating any consideration unless the performance of the consideration constitutes a condition precedent to the defendant's liability on his covenant, the seal of the instrument in nearly all other cases operating to impose liability on the covenanting parties. ${ }^{2}$ If however there existed a condition precedent to defendant's liability on his covenant, it was invariably necessary to state such condition, and the fact of performance or compliance with it by plaintiff. ${ }^{3}$ If he omitted stating it, the omission could be taken advantage of under the plea of non est factum. If he stated the condition and omitted to state the fact of performance, the omission would prove fatal on general demurrer, and very often in arrest of judgment. ${ }^{4}$ If the condition was stated as also the fact of performance, the defendant might contest the issue by a specific traverse $;^{5}$ the traverse of non est factum being too restricted to raise an issue as to the performance. But when the facts of performance were numerous, the specific traverse was not regarded as suitable, for the reason that it was adapted to the denial of a single material fact. This embarrassment led to the practice of allowing the defendant to plead specially the facts wherein the plaintiff had failed to perform the condition precedent. ${ }^{6}$

Such plea would not seem to be strictly a plea in justification or excuse, because it does not admit there ever was a prima facie cause of action in favor of the plaintiff. It has however been treated as in the nature of such a plea, on the pretence that the defendant is excused from fulfilling his covenant if the plaintiff has failed to perform a condition precedent to defendant's liability. ${ }^{7}$

Undoubtedly a contract may be of such a character that non-

1 Hotham v. East Ind. Co., 1 T. R. 638.

21 Chit. Pl. 114, 366.

81 Wheat. Selw. 527; 1 Chit. Pl. 120, 367 ; Parks $v$. Heman, 7 Mo. App. 14.

4 Dakin $v$. Williams, 11 Wend. 70; Collins $v$. Gibbs, 2 Burr. 899 ; Huy $v$. Brown, 12 Wend. 591; Justice $v$. Vermilion County, 2 Blackf. 149 ; Bailey $r$. Clay, 4 Rand. 346.

5 Turnpike Co. v. Rife, 2 Ind. 316;
McCall $v$. Welsh, 3 Bibb, 289; Traver $v$. Halstead, 23 Wend. 67 ; Joslyn $v$. Taylor, 33 Vt. 471; Potts $v$. Point Pleas, Id. Ca. 47 N. J. L. 476 ; Miles v. Ringo, 13 Ark. 229.

6 Glazebrooke $v$. Woodrow, 8 T. R. 366 ; Parker v. Parmlee, 20 Johns. 130 ; 1 Chit. Pl. 488.

71 Chit. Pl. 488; Glazebrooke $v$. Woodrow, 8 T. R. 366; Parker v. Parmlee, 20 Johns. 130. 
performance by one party may operate as an excuse for non-performance of the other. ${ }^{1}$ And so may many other acts of the plaintiff result in the same effect. But when the performance by the plaintiff is a condition precedent to any right of action on the contract, a plea of non-performance denies that there ever was a right of action, and would seem to render it unnecessary for the defendant to urge the fact by way of justification or excuse.

But notwithstanding these objections, an affirmative plea of nonperformance is not only permitted, but very generally required to be pleaded. Where performance consists of a single material fact like the tender of a deed or dismissal of a suit, a specific traverse would seem to be an unexceptionable mode of raising the issue. ${ }^{2}$

When the allegation of performance of a condition precedent is defective, or it is not made at all, the defendant was always at liberty to set up non-performance by special plea. ${ }^{3}$

A plea of performance of his covenant by defendant is not a plea in excuse or justification. It is in its nature a plea in denial, although in affirmative form something in the nature of a special traverse $;^{4}$ for if the defendant has performed his covenant, the plaintiff never had any cause of action. Where non-performance consists of a single breach and a single material fact, there would seem to be no good reason against a specific traverse of the fact constituting non-performance. But the authorities are unanimous in the general practice of permitting, and in most cases requiring, the defence of performance to be urged by affirmative plea of a special or general nature. ${ }^{5}$

A plea of offer to perform and a waiver of the particular required performance is a good plea in excuse. ${ }^{6}$ All excuses or justifications for non-performance must be specially pleaded, as they are in confession and avoidance. ${ }^{7}$

1 Warner $v$. Smith, 8 Conn. 14.

2 Miles $v$. Ringo, 13 Ark. 229 ; Turnpike Co. $v$. Rife, 2 Ind. 316.

${ }^{3}$ Ireland $v$. Chauncy, 4 Ind. 224; Dakin v. Williams, 11 Wend. 70 ; Gibbs $v$. Stone, 7 T. B. Mon. 302.

4 Wilkinson $v$. Turnpike Co., 6 Penn. 398; Farmers', \&c. Turnpike Co. v. McCullough, 25 Penn. 303 ; Bender $v$. Fromberger, 4 Dall. U. S. 436.

5 Sterenson v. Lambard, 2 East, 575 ; Comyn, Dig. Pleader, 2 V. 13 ; 1 Wheat. Selw. 546 ; 5 Enc. Pl. \& Pr. 380 .

${ }^{6}$ Colgan v. Sharpe, 4 Mo. 263; Dickhut $v$. Durrel, 11 III. 72 ; Johnson v. Clay, 7 Taunt. 486.

7 Scraggs $v$. Hill, 37 W. Va. 709; S. C. 17 S. E. 185 ; Stone v. Dennis, 3 Port. (Ala.) 231; Jones $v$. Johnson, 10 Humph. 184. 
In the action of covenant for rent, eviction by the lessor or by a stranger holding paramount title is a good plea in excuse $;^{1}$ so also is the plea of surrender of lease. ${ }^{2}$

Whenever want or failure of consideration can be urged in defeat of a covenant in a court of law, such fact must be specially pleaded, like all other facts of avoidance.

Conditions subsequent and clauses of defeasance must be pleaded specially by defendant. ${ }^{3}$

SEC. 296. In Special Assumpsit. A plea in justification or excuse admits the promise, consideration, and breach of the contract as pleaded, and sets forth new facts going to show that there was nothing wrongful in the defendant's failure or refusal to keep his promise. A plea that defendant never made the promise or received the consideration, or that he has kept his promise, would be in denial, and not averrable in justification or excuse. ${ }^{4}$ Disability of the plaintiff as an alien enemy accruing after the promise was made, ${ }^{5}$ illegality of the promise, and the statute of frauds, ${ }^{6}$ were pleas in excuse or justification. ${ }^{7}$ But the defence of the statute of frauds was and continued to be admissible under the general traverse.

Any collateral agreement or stipulation, by which the liability of defendant for breach of his promise is limited as to time or amount, is pleadable in excuse under the Hilary rules. ${ }^{8}$

If it is in the nature of a condition subsequent limiting or avoiding the liability of defendant on his promise, it should be pleaded in excuse. ${ }^{9}$

If, however, the agreement or stipulation is in the same contract, and is a mere qualification of the defendant's promise and not a substantial or collateral contract or condition, it should not be pleaded in excuse, but is admissible under the plea of non-assumpsit. ${ }^{10}$ A plea which merely sets forth the contract or promise in different terms from what is alleged in the declaration is erroneous as amounting to the general issue. ${ }^{11}$

11 Saund 204, note 2; Pendleton v. Dyett, 4 Cow. 581; 1 Chit. Pl. 487.

21 Chit. Pl. 488; Glazebronke $v$. Woodrow, 8 T. R. 366 ; Vermont University $v$. Joslyn, $21 \mathrm{Vt}$. 52.

8 See form 60.

4 Lyall v. Higgins, 4 Q. B. 528.

b Harman $v$. Kingston, 3 Camp. 152.

- Gardner v. Weber, 17 Pick. 407.
71 Chit. Pl. 479, 480.

8 Latham v. Rutley, 2 B. \& C. 20; Smart $v$. Hyde, 8 M. \& W. 723.

9 Clarke v. Gray, 6 East, 564; Syms v. Chaplin, 5 Ad. \& E. 634; Holtham v. East Ind. Co., 1 T. R. 638; Smart $v$. Hyde. 8 M. \& IV. 72:3.

10 Brind v. Dale, 2 M. \& W. 775.

11 Morgan v. Pebrer, 3 Bing. N. 
The plea of non-assumpsit in assumpsit, unlike the plea of non est fuctum in covenant, put in issue the consideration as alleged when it was necessary to allege a consideration. Therefore a want of consideration was a fact in denial of the promise, and should not be pleaded in excuse. ${ }^{1}$ Non-performance by plaintiff of a condition precedent to his right of recovery can be shown under a general or specific traverse, and should not be pleaded in excuse. ${ }^{2}$ In such case performance of the condition precedent goes to the promise, and to the consideration of the promise, and should be responded to by denial.

Non-performance of his promise by defendant must be alleged in the declaration. It is therefore traversable. A plea of performance by defendant would be, not a plea in excuse, but in denial. ${ }^{3}$

Nevertheless the Hilary rules of 1834 enumerated performance as a defence necessary to be specially pleaded in this action. ${ }^{*}$

An offer to perform and prevention by plaintiff is a good plea in excuse.

SEc. 297. In General Assumpsit. In this form of action the promise sued on is implied from the facts which constitute a debt; the promise is fictitious, and is based solely on implication of law. A plea in excuse necessarily admits the facts upon which the debt is based, also the non-payment of it, and discloses new facts showing that the non-payment is justifiable. In indebitatus assumpsit pleas in excuse are quite as restricted as in the action of debt. This results from the fact that the promise on which the action is brought is based on a debt express or implied, and is raised by implication of law, and not by express undertaking. The law will not raise the fictitious promise to pay a debt, in face of a stipulation giving credit for a specified time, until that time has expired. The fact of credit being given in the contract defeats the promise until it has expired. A plea of credit unexpired in this form of action is not a good plea in excuse; and such fact should be taken advantage of by traverse. ${ }^{5}$

C. 457 ; Nash $v$. Breeze, 11 M. \& W. 352.

${ }^{1}$ Lyall v. Higgins, 4 Q. B. 528; Breech v. White, 12 Ad. \& E. 668 ; Sutherland v. Pratt, 11 M. \& W. 296; Weedon $v$. Woodbridge, 13 Q. B. 470 , 481.

2 Kernble v. Mills, 1 M. \& G. 757. Martin Crvil Procedure-17
770 ; Sesson $v$. Willard, 25 Wend. 373.

3 As to when the plea may be general or special, see Steph. Pl. 334$-337$.

4 Chit. Pl. 515.

"Hayselden $v$. Staff, 5 Ad. \& E. 153. 
The Hilary rules of 1834 , which apply to general as well as special assumpsit, unquestionably broadened the scope of pleas in confession and avoidance to action of assumpsit, by providing that the general traverse of non-assumpsit should operate only as a denial in fact of the express contract or promise alleged, or of the matters of fact from which the contract or promise alleged may be implied in law. ${ }^{1}$ Thereafter in every species of assumpsit all matters in confession and avoidance, including not only those by way of discharge, but those which show the transaction to be either void or voidable in point of law on the ground of fraud or otherwise, were required by the rules to be specially pleaded.2 The rules enumerated infancy, coverture, release, payment, performance, illegality of consideration, drawing, indorsing, accepting bills or notes by way of accommodation, set-off, mutual credit, unseaworthiness, misrepresentation, concealment, and deviation as facts in discharge or in confession and avoidance, which must be specially pleaded. ${ }^{3}$

SEc. 298. In Trespass $\nabla i$ et armis. A plea in justification or excuse to an action of trespass for injuries to the person admits the commission of the physical acts as alleged in the declaration, and proceeds to disclose new matters to show that the defendant was justified or excused in committing them; as in self-defence, ${ }^{4}$ or in execution of a warrant of arrest. ${ }^{5}$ In trespass for negligently colliding with plaintiff's carriage, contributory negligence on the part of the plaintiff was a good plea in excuse. ${ }^{6}$ In trespass for the taking of goods a defence that the goods belonged to defendant, being in justification, had to be specially pleaded after the Hilary rules of $1834 .^{7}$ In trespass for a wrongful entry on land, the usual pleas of justification consisted in a right of way, right of common, license from plaintiff, and right of freehold. ${ }^{8}$

When several acts of trespass are set forth in the declaration, the plea must justify them all, otherwise it will be demurrable. ${ }^{9}$ But if the plea justifies as to all, and it is found on trial to be a justification only as to some of the acts, the jury was permitted under the Hilary rules of 1834 to find for the defendant in respect of such of

11 Chit. P1. 513.

21 Chit. Pl. 515, 517.

81 Chit. Pl. 515 a.

-Wise $v$. Hodsol, 11 Ad. \& E. 816.

5 See form 61. 6 Knapp v. Salsbury, 2 Camp. 500. Saund. 27.
7 Jones $v$. Brown, 1 Bing. N. C. 484 ; 1 Chit. Pl. 520.

81 Chit. Pl. 505; see plea of liberum tenementum, form 62 .

9 Earl of Manchester v. Vale, 1 
the acts of trespass proved as shall be justified, and for the plaintiff in respect of the trespasses not so justified. ${ }^{1}$

That a trespass was involuntarily committed by defeudant is no plea in excuse or justification. Such defence can be admitted only under a plea of not guilty. ${ }^{2}$

SEc. 299. In Trover. As trover consists in the wrongful conversion of the goods of the plaintiff, it is evident that there is no reason for a plea in justification or excuse. If the act complained of is wrongful, and it must be such to constitute a cause of action, it cannot be justified or excused. The two necessary elements of the action consist in the fact of property in the plaintiff, and a taking or detention by defendant without or against plaintiff's consent. We have seen that these issues were met by general or specific traverses. The general traverse anciently operated in denial of both elements. ${ }^{3}$ After the Hilary rules of 1834, it operated only to deny the taking or detention without plaintiff's consent. If the plaintiff's title was to be put in issue it required the specific traverse of not possessed.

Facts tending to show that the taking was not wrongful - as for instance a seizure by a sheriff at defendant's request under judgment and execution - could not be set up by plea in excuse or justification. They constituted a denial of the cause of action, and were properly admissible under the plea of not guilty. ${ }^{4}$ A retention of the goods as security for a debt could not be pleaded in excuse. It was matter in denial of the plaintiff's right of possession, and after the Hilary rules could be made available only by the specific traverse of not possessed. ${ }^{5}$ There would seem to be no pleas in confession and avoidance in this action except pleas in discharge.

SEC. 300. In Detinue. A plea in justification or excuse would have to admit the plaintiff's right of possession, and the defendant's adverse or wrongful detention. It would therefore seem that there is no more room for a plea in justification or excuse in this action than in trover. It may be proper to repeat in this connection that the facts necessary to constitute a cause of action in detinue will

11 Chit. Pl. 520, Hil. rules. 38.

2 Gibbons v. Pepper, 1 Ld. Raym.

8 See sec. 266.

4 Young $v$. Cooper, 6 Exch. 259.

5 Dorrington v. Carter, 1 Exch.
566 ; Owen $\imath$. Knight, 4 Bing. N. C. 54 ; Isaac $v$. Belcher, 5 M. \& IV. 139 ; Ringham $v$. Clements, 12 Q. B. 260 ; White v. Teal, 9 I. .J. R. [Q. B.] 377 ; Jackson v. Cummins, 5 M. \& W. 342, 349. See sec. 279. 
usually support trover; and that on this account alone it was possible for trover to supersede detinue.

Any fact tending to show a right in the defendant to retain the goods is in effect a denial of the plaintiff's right of possession, and does not support a plea in excuse or justification, which to be good must impliedly admit the plaintiff's right of possession. The right to detain the goods by virtue of a pledge or lien would logically constitute a denial of the plaintiff's right of possession, and should be admissible under a specific traverse. ${ }^{1}$ Decisions such as Mason $v$. Farnell, 12 M. \& W. 674, requiring such a defence to be pleaded in excuse, cannot be approved on principle, although possibly supported by some good authority. ${ }^{2}$

Neither is the fact that the defendant offered to give the goods up a plea in justification or excuse. It tends to show that there was no adverse detention at the time it took place; and it is therefore properly adinissible under the general traverse of non detinet. ${ }^{3}$

SEC. 301. In Replevin. Defences of justification or excuse were very common in this action, although they did not always go by that name. The pleadings took their form from the original use of the action in cases of distress for rent.

In his response to the declaration in replevin, the landlord could admit the fact of taking the tenant's property, justify his act by alleging that it was taken for rent due and in arrears, and ask that the property be returned to him, in order that it might remain in his hands as security for the rent. This answer was known by the name of an avowry, and was' not classed among pleas, being in its effect something in the nature of a counter declaration. But by whatever name it was known, it is evident that it contained a complete justification for the act complained of; and this aspect of it is not changed by the fact that it went further, and asked for affirmative relief. An avowry therefore performed the functions of a plea in justification, although it was not classified with pleas of any kind. ${ }^{4}$

There were certain pleas in replevin which passed under the denomination of pleas in justification or excuse. One of ancient date was known as a plea merely in justification. It was employed

1 Lane $v$. Tewson, 1 Gale \& D. 584; Dirks v. Richards, 4 M. \& G. 574; Barnewell $v$. Williams, 7 M. \& G. 403. See sec. 279.

2 See sec. 280.
8 Clements $v$. Flight, 8 Law Times, 166; S. C. Ames's Cases, 66; Anderson $v$. Smith, 29 L. J. Exch. 460, Part 2.

4 See plea in arowry, form 6:3. 
by a landlord who had distrained for homage due, and not for rent. Upon the death of tenant after distress, his executor replevies the goods on the ground that the landlord's right to retain for homage expired with the death of the tenant, who alone could do the homage.

In this plea the original taking was justified; the death of the tenant and affirmance of title in the executor operated to excuse the defendant from damages. No affirmative relief in return of the goods to defendant was asked. ${ }^{1}$

When the defendant in replevin confessed caption of the goods and pleaded property in himself or a stranger, his plea was said to be in justification, although it entitled him to a return of the property without an avowry. ${ }^{2}$ Manifestly this was not a good plea in justification, because it failed to confess the necessary elements of the action, which consisted of a right of property in the plaintiff and a taking and adverse detention by the defendant. It was never pretended that it confessed anything more than the gist of the action, which was the taking and detention. ${ }^{3}$

A plea of property in the defendant or in a stranger is not new matter, but is in denial of the allegation of property in the plaintiff. It was perhaps peculiar to this action that the defendant was disabled from putting the plaintiff's right of property in issue by a specific traverse simply denying it, but was required to plead of record the name of the owner. This requirement furnished a proper notice of the real issue to be tried, and clearly indicated the right of return as incident to the plea. The plea on principle, however, was not in justification, but in denial, and contained the elements of a special traverse, and was so very generally regarded, especially in modern times. ${ }^{4}$

SEC. 302. In Case. A plea in excuse in this action is on principle impossible. As it has to confess all the facts contained in the inducement and statement of the wrongful act, nothing remains for a plea but matter in release or discharge. Having admitted the wrong, there would seem to be no room for a plea in justification or excuse. Facts which tend to support such a. defence must, as a general rule, be in denial of the wrong, and are

11 Roscoe, Ac. 632 ; Wilkinson, Replev. 49.

2 Wilkinson, Replev. 48 ; Gilbert, Replev. 167, 168.
8 Wilkinson, Replev. 48. 244. 
therefore properly admissible under a traverse of some kind. Thus, in an action for malicious prosecution, the existence of reasonable or probable cause is not a good plea by way of justification or excuse, for the reason that a want of probable cause is a necessary part of the plaintiff's case and must be expressly alleged. Facts tending to show probable cause are therefore admissible under a general traverse, being strictly in denial, and not in justification. ${ }^{1}$ In an action against a common carrier for loss of goods delivered to him for carriage, the bailment as set forth in the declaration is composed of allegations necessary to the cause of action. If the carrier wishes to prove that the goods were bailed to him under conditions not appearing in the declaration which have not been complied with, such matter is not pleadable by way of justification or excuse. It is in denial of the bailment alleged, and is admissible under the general issue. To permit the defendant to set up a different bailment, and offer to show that he was not liable on it would be entertaining a defence to a cause of action of which the plaintiff had not complained. ${ }^{2}$

Anciently, in a civil action for libel or slander, the defendant was permitted to prove the truth of the words under the general issue. On principle this practice was correct, for the plaintiff is required to allege the falsity of the charge in his declaration. A general denial would seem to put the plaintiff on proof of the falsity, or at least admit the defendant to repel the presumption of falsity by proving the truth. But at a meeting of the judges, some time prior to 1744 , it was determined by a majority of them that in the future truth as a defence must be specially pleaded. ${ }^{3}$ Ever since this determination it has been held that the truth must be specially pleaded wherever it constitutes a justification for the utterance or publication. ${ }^{4}$

The fact that the defendant merely repeated the words of another constitutes no excuse or justification. ${ }^{5}$

It has been held that contributory negligence on the part of the plaintiff is not a good plea in excuse in an action of case for damages resulting from the negligence of the defendant. It was said to be only an argumentative denial of the wrongful act complained

1 Cotton $v$. Browne, 3 Ad. \& E. 312.

2 Crouch v. London \& N. IV. Ry. Co., 7 Exch. 705.

3 Underwood v. Sparks, 2 Stra. 1200 ; see sec. 265.
11 Chit. Pl. 494 ; see form 64.

5 M'Pherson $v$. Daniels, 10 B. \& C. 263. 
of. If the plaintiff is guilty of negligence causing the injury, then the defendant's act, which the plaintiff has helped to make effective, is not wrongful so far as he is concerned. Evidence of contributory negligence tends to support a denial, and should be offered under such a plea. ${ }^{1}$

It is otherwise, as we have seen in trespass vi et armis, in which the physical act complained of constitutes the prima facie cause of action, irrespective of its wrongfulness. ${ }^{2}$

It may be added that, according to the weight of modern authority, contributory negligence is required to be specially pleaded in actions of case or in the nature of case, as an avoidance of the prima facie liability of the defendant. Especially is this true under code pleading. ${ }^{3}$

\section{ARticle III.}

\section{Pleas in Bar by Way of Estoppel.}

SEc. 303. Estoppel. A plea in estoppel is not in form or substance a plea in bar of the action. ${ }^{4}$

It is not a denial or traverse. Neither does it admit or confess the allegations pleaded to. It resembles a plea in avoidance of the declaration in that it alleges new matter. But the new matter is not in form or substance an avoidance of the cause of action; it operates merely to preclude the plaintiff from availing himself of the allegations of his declaration by reason of inconsistency therewith under the law of estoppel. ${ }^{5}$ It is treated as an exception to the rule of pleading that a party must dermur or traverse or plead by way of confession and avoidance. ${ }^{6}$

The plaintiff may or may not have a good cause of action in his statement, but he has done something previous to his pleading which disables him in law from making or proving the allegations of his pleading in any court. ${ }^{7}$ It served the purpose of finally and permanently ending the proceeding, and for that reason it may be properly classed with pleas in bar. It had to be particularly pleaded and specially relied on in the conclusion of the plea by

1 Bridge $v$. Grand Junction Ry. Co., 3 M. \& W. 244.

${ }^{2}$ Knapp $v$. Salsbury, 2 Camp. 500.

35 Fncyc Pl. \& Pr. 10.

5 Gould, Pl. c. ii. s. $42 ; 1$ Saund. Pl. \& Ev. 325 a.

6 Steph. Pl. 219.

74 Minor, Inst. 908.

4 See form 6 o. 
way of estoppel, to be available. ${ }^{1}$ The commencement and conclusion of the plea differed from pleas in bar, in saying in the commencement that the plaintiff ought not to be admitted or received to make the allegations of his declaration, because of the previous acts or matters upon which the estoppel pleaded is supposed to arise, and which the defendant offers to verify.

Then followed the conclusion of the plea, in which the defendant prays judgment if the plaintiff ought to be admitted or received to make his said allegations against the matter pleaded in estoppel. ${ }^{2}$

The Hilary rules of 1834 , while abolishing formal prayers in the conclusion of pleas in bar, excepted the plea in estoppel, and left the prayer for judgment as before the rules. ${ }^{3}$ 915 .

11 Chit. Pl. 559; 4 Minor, Inst. $\quad{ }^{2}$ Steph. Pl. 220 ; 4 Minor, Inst. 915.

${ }^{3}$ Reg. 9 Hil. Rules, 1834. 


\section{CHAPTER XIII.}

\section{RULES OF PLEADING.}

Article I. Introductory.

"II. Rules which tend simply to the Production of an Issue.

" III. Rules which tend to secure the Materiality of the Issue.

“ IV. Rules which tend to produce Singleness or Unity of the Issue.

“ V. Rules which tend to produce
Certainty or Particularity of the Issue.

Article VI. Rules which tend to Prevent Obscurity or Confusion in Pleading.

“ VII. Rules which tend to Prevent Prolixity and Delay in Pleading.

“ VIII. Certain Miscellaneous Rules.

\section{ARticle I.}

\section{Introductory.}

Sec. 304. Introductory.

SEc. 304. Introductory. I have thus far considered the nature and characteristics of the various pleadings in an action at law. In doing so it has been necessary to assume and explain many fundamental principles by which the parties to a suit are governed in making their statements of fact, and in challenging the sufficiency in law of such statements. These fundamental principles did not originate in legislative enactment, but arose gradually from the practice and usage of the courts. They received their binding force from the sanction and enforcement of the courts. Some of them will be found applicable alone to the technical system of common law pleading under which they originated, while others will be recognized as proper and necessary aids in any system of procedure which aims to bring before a court for its decision the matters in actual dispute between the parties litigant.

These principles have been so admirably grouped and discussed by Mr. Stephen under seven general heads, with subdivisions thereto, that his achievement in that behalf has been very generally accepted as the most lucid and complete exposition of them to be found in the literature of remedial common law.

Having already explained and applied the most important of 
these rules in our treatment of declarations, demurrers, pleas, and replications, it will not be necessary to discuss them again in connection with the formal and orderly announcement of them by Mr. Stephen, which is mostly adopted here and repeated for the benefit of the student.

The reason and necessity of many of these rules must be so obvious that they will be easily understood, without explanation or comment. It is not within the scope of this treatise to consider particularly the qualifications and illustrations of these rules which are given at length by Mr. Stephen; but to indicate brietly their general nature and import, with an occasional example or illustration when that is deemed necessary. In most cases a recurrence to their application to the different pleadings, as contained in the previous pages of this treatise, will be sufficient.

\section{Article II.}

Rules which tend simply to the Production of an Issue.

Sec. 305. Recital of the Rules and Pur-|Sec. 307. Manner of Reaching an Issue pose of them.

" 306. Form of producing an Issue by

Demurrer or Traverse.

by Plea in Confession and Avoidance.

Sec. 309. Exceptions to Rule I.

SEC. 305. Recital of the Rules and Purpose of them.

Rule I. After the Declaration the Parties must at each Stage demur or plead by Traverse, or by way of Confession and Avoidance.

\section{Rule II. Upon a Traverse, Issue must be tendered.}

Rule III. Issue when well tendered must be accepted.

The object of all pleading is to ascertain and disclose to the court the points of controversy for its decision. The main object of the common law system of pleading was to ascertain and disclose a single and material point in controversy in respect to each subject of suit for the decision of the court. This object was attained by compelling the parties to make alternate allegations so as to produce an issue in respect of each single claim in suit. ${ }^{1}$ The production of a single issue by the allegations of the parties themselves is the distinguishing feature of common law pleading, which marks it as differing from all other known systems. ${ }^{2}$

1 Steph. Pl. 130-132.

2 Steph. Pl. 124, 125. 
This immediate object of the system was attained in practice by a rigid adherence to the foregoing rules. Indeed, the whole system rests on these rules, and Mr. Stephen devotes about one third of his admirable treatise to their application and illustration. It is in connection with, and under the caption of, this first group of rules that he develops the nature, form, and characteristics of the demurrer, pleas dilatory, pleas in bar'by way of the specific, the general, and the special traverse, and by way of confession and avoidance.

I have thought it best to attempt the same thing under the respective names of these subsequent pleadings, - following an account of the various actions in which they are used. It only remains for me in this connection, after recital of the formulated rules, to briefly indicate the practical working of them and note well recognized exceptions, referring the student to our previous treatment of the nature of the different pleadings subsequent to the declaration.

SEC. 306. Form of producing an Issue by Demurrer and Traverse. Upon receipt of the declaration by defendant, which never took place till his appearance of record, it was imperative on him to respond to it in some of the modes indicated by these rules. If he deemed it insufficient in law, he could challeuge its sufficiency by demurring to it, either generally or specially.

If his demurrer was in proper form, it tendered an issue of law which the plaintiff was bound to accept, or suffer the consequences of a nonsuit. This issue when made was sharply defined in the demurrer and joinder. In the demurrer the defendant was required to say "that the said declaration and the matters therein contained in manner and form as the same are above stated and set forth are not sufficient in law for the said A. B. to have and maintain his aforesaid action thereof against him, the said C. D., and that he, said C. D., is not bound by the law of the land to answer the same," \&c..$^{1}$ This challenge the plaintiff had to accept in a joinder in demurrer or give up his action. In the joinder the plaintiff was required to say: "That the said declaration and the matters therein contained in manner and form as the same are above stated and set forth are sufficient in law for him, the said A. B., to have and maintain his aforesaid action thereof against him, the said C. D., and the said A. B. is ready to verify and prove the same as the court shall direct and award, wherefore," \&c. ${ }^{2}$ It

12 Chit. Pl. 678, ed. 1808 .

22 Chit. P1. 682, ed. 1808. 
will be noticed that a single issue of law is raised by the alternate allegations of the parties in which the defendant says that the declaration is not sufficient in law, and the plaintiff joins issue by averring that it is sufficient in law.

If the court decided this issue of law in favor of the defendant, final judgment was entered for him and he was discharged without day; if in favor of the plaintiff, judgment was entered for him on the merits of the case, with an order for assessment of damages by a jury, when from the nature of the case the court could not compute the amount of damages without evidence. The nature and effect of demurrers will be found treated very fully in the chapter on Demurrers.

If the defendant deemed the declaration sufficient in law, he had the alternative of responding to it by a traverse of it in the nature of a denial, or by a plea confessing and avoiding its effect. There were three forms of traverse as already explained. ${ }^{1}$ If the defendant used the common or specific traverse, or the general traverse, he was regarded as simply denying some material part of the declaration, or the whole declaration, according to the nature of his traverse. These traverses concluded as follows: "And of this the said defendant puts himself on the country." 2

If the traverse for any reason was insufficient in law, the plaintiff might demur to it, in which case the defendant was bound to join issue. This joinder raised an issue of law at one stage later than when the demurrer was interposed to the declaration. In this issue the plaintiff alleged the insufficiency of the traverse as a defence, and the defendant asserted its sufficiency. If the traverse was decided to be insufficient in law, judgment was entered for plaintiff, with like effect as upon an ineffectual attack upon the declaration. If decided for the defendant, final judgment against the plaintiff was entered, and the defendant was discharged without day.

If, however, the traverse was deemed sufficient in law, the plaintiff had to accept the issue of fact as tendered, which he did by a joinder in issue under a form known as the "similiter," which ran as follows: "And the plaintiff as to the plea of the said defendant above pleaded, and whereof he hath put himself upon the country, doth the like." 3 In this manner the pleadings ended in an issue of fact, which was sent to be tried by a jury. This issue was raised

1 Chap. XI. Art. 1.

s 2 Chit. Pl. 592, ed. 1808.

2 Sec. 258. 
by an affirmation, or certain affirmations in the declaration, and a denial thereof in the plea.

If the defendant employed what was known as a special traverse, 1 which involved the introduction of new matter by way of inducement to the traverse, the conclusion was by way of verification, and the issue was postponed to some other stage of the pleadings. ${ }^{2}$ This was the ancient practice, but the dilatory effect of it led to the rule adopted at Hilary term, 1834, providing that its conclusion should be to the country in most cases. If the inducement of the special traverse was insufficient in law, the plaintiff could demur, but if it was sufficient and the traverse good in form, the plaintiff had to join issue, and the pleadings were at an end. There was no traverse upon a traverse, and no pleading to it by way of confession and avoidance.

SEC. 307. Manner of reaching an Issue by Plea in Confession and Avoidance. If the defendant employed a plea by way of confession and avoidance, (the nature and different kinds of which have already been considered, $\left.{ }^{3}\right)$ the conclusion was invariably with a verification, because it contained averments of new matter to which the plaintiff was at liberty to plead. He might raise an issue of law by interposing a demurrer, if the plea was insufficient in law. If it was good in law, he could traverse or confess and avoid the new matter, in like manner and with like effect as in case of the defendant responding to a declaration. His pleading to that effect was known as a replication. Issue was reached sooner or later according to the nature of the replication and the response to it.

If the replication was insufficient in law, the defendant might demur, and raise an issue of law. If good in law, he might respond to it by a rejoinder. In like manner the rejoinder could be responded to by demurrer, if insufficient in law ; if sufficient, by plea, which was called a surrejoinder. The surrejoinder could be followed by a demurrer or rebutter, and the rebutter by demurrer or surrebutter.

It is not easy to conceive of a case which would justify an extension of the pleadings to such a length. But the logic of the system required that the pleadings should go on until an issue of law was raised by demurrer, or an issue of fact by traverse. When such

1 Sec. $259,282$.

s See Chapter XII.

2 Sec. 286. 
issue was reached, no further pleading was allowed. If a point decisive of the case was missed in the issue joined, which sometimes happened when joinder was made on immaterial matter, the court might on motion award a repleader, in which the court orders the parties to plead de novo for the purpose of obtaining a better issue. ${ }^{1}$ Under this order the new pleadings begin at the stage of the first fault or defect. ${ }^{2}$ It was not customary to award a repleader upon issue joined on demurrer, because the court could upon a demurrer go back and give judgment against the first party in default. ${ }^{3}$

It is thus seen how the issue to be tried was developed by the pleadings made by the respective parties.

Sfc. 308. Subordinate Rules. There were two subordinate rules applying to pleadings by way of traverse or confession and avoidance, an observance of which aided in attaining the object of this first group of rules.

1st. Every pleading must be an answer to the whole of what is adversely alleged. ${ }^{4}$

Failure of a party to respond to a material part of a pleading justified the opposite party in signing judgment by nil dicit against him in respect to the part unanswered, or in demurring to the whole plea. ${ }^{5}$

2d. Every pleading is taken to confess such traversable matters alleged on the other side as it does not traverse. ${ }^{6}$ This admission is extremely strong, and is not like the implied admission of a demurrer, which is in the nature of admissions for the purpose of the demurrer alone. It concludes the party from proving and the jury from finding anything contrary to the admission. Formerly the admission concluded the party suffering it, not only in the suit in progress, but in any subsequent suit between the same parties, unless coupled with a formula of protestation.

The practice of protestation in pleading was introduced to counteract the effect of the admission in subsequent actions. But upon abolishment of the formula of protestation, the admission ceased to be conclusive in subsequent actions. ${ }^{7}$

SEC. 309. Exceptions to Rule 1. There were three exceptions to the first rule in this group, which required the parties to demur or plead by way of traverse or confession and avoidance.

1 Steph. Pl. 98, 100.

2 Staple $v$. Hayden, 2 Salk. 579.

8 Parnham v. Pacey, Willes, 532; Stafford $v$. Mayor of Albany, 6 Johns. 1 .
4 Steph. Pl. 215.

5 Steph. Pl. 216.

6 Steph. Pl. 217.

7 Steph. Pl. 217, 218. 
ART. III.] RULES OF PLEAdiNg. - to MAteriality OF ISSUE. 271

1st. A dilatory plea is not within the rule, because it is not a plea to the merits of the declaration and it need not therefore traverse or confess or avoid its allegations. ${ }^{1}$ Such pleas are interposed on account of defects in form or in abatement of the suit. ${ }^{2}$ The rule however obtains in respect to replications and subsequent pleadings, whether in response to pleas in bar or in abatement. ${ }^{3}$

2d. Pleadings in estoppel were not within the rule, because they did not in their nature either deny or admit and avoid the cause of action, but merely disclosed matter which disabled the opposite party from alleging or proving the facts of his declaration, to which the plea was addressed. ${ }^{4}$

$3 \mathrm{~d}$. The right to make a new assignment was also an exception.

In doing this the pleader adopted the expedient of stating more definitely his cause of action, so that his adversary could not escape responding to it. It was nothing more than a correction of the indefiniteness and generality of the declaration. ${ }^{5}$

\section{Article III.}

Rules which tend to secure the Materiality of the Issue.

Sec 310. Rule. All pleadings must con- Sec. 311. Subordinate Rules. tain matter pertinent and material.

SEc. 310. Rule. - All Pleadings must contain Matter pertinent and material. ${ }^{1}$ This rule in an enlarged sense may be regarded as embodying a reasonable requirement incidental to all proceedings, whether in courts, legislative assemblies, or popular convocations. When a person attempts to introduce matter not pertinent or material to the issue or motion under consideration in any such proceedings, he is out of order.

In a legal proceeding a party thereto is protected from objections in so far as he keeps within the settled forms of pleading, although they may contain matter which he is not required to prove, and which is not traversable. He violates the rule only when he includes in his pleading statements which are foreign to the settled forms of pleading, and not pertinent or material to the issue involved in the case.

1 Steph. P1. 219.

2 Steph. Pl. 219.

Steph. P1. 219.

4 Steph. Pl. 219 ; see sec. 303.

6 Steph. Pl. 220.

6 Steph. Pl. 240. 
The consequences of including impertinent or immaterial matter depend upon the nature of the matter, and the mode in which the opposite party has treated it in his response, which are considered elsewhere.

SEC. 311. Subordinate Rules. The operation of the rule is most pointedly illustrated in its application to pleadings by way of traverse, and is disclosed in the formulation of two subordinate rules, as follows:-

1st. A traverse must not be taken on an immaterial point. ${ }^{1}$

This subordinate rule was violated not only by taking a traverse on a point wholly immaterial, but also :-

1. When taken on matter the allegation of which was premature, though in itself not immaterial to the case. The system of common law pleading, unlike pleading in equity, forbade anticipation of defences. ${ }^{2}$

2. When taken on matter of inducement, which was in general explanatory of the material allegations. But when the inducement was not merely explanatory, but of the substance of the cause, it might nevertheless be put in issue by a proper traverse. ${ }^{8}$

3. When taken on matter of aggravation of the wrong complained of, and which only furnished ground for increase of damage without affecting the right of action itself. ${ }^{4}$

It was always optional with the pleader to traverse any one of several material allegations. ${ }^{5}$

2d. A traverse must not be too large.

1. It was too large when it put in issue those parts of the allegation traversed which were immaterial to the merits of the case. A traverse ought not to include more of the allegation traversed than is material to the cause of action or defence, as the case may be. Matters of time, place, quantity and quality, and surrounding circumstances, when not essential features of the cause of action or defence, ought not to be specially traversed. ${ }^{6}$

2. A traverse may be too large when taken in the conjunctive, instead of the disjunctive, when it is not material that the allegation traversed should be proved conjunctively. ${ }^{7}$

In qualification of this subordinate rule it may be added that a

1 Steph. Pl. 241.

2 Steph. Pl. 242.

3 Steph. Pl. 243.

- Steph. Pl. 243.
5 Steph. Pl. 243.

6 Steph. Pl. 245.

7 Steph. Pl. 246. 
party may generally traverse a material allegation of title or estate to the extent to which it is alleged, though it need not have been alleged to that extent without incurring the risk of violating the rule. ${ }^{1}$

3d. A traverse must not be too narrow.

A traverse is too narrow when it fails to answer fully the whole substance or material parts of the adversary's allegation which it undertakes to answer. ${ }^{2}$ It may be too narrow when it responds to part only of a material and indivisible allegation, such as that of a grant or prescription. ${ }^{3}$

\section{Article IV.}

Rules which tend to produce Singleness or Unity of the Issue.

Sec. 312. The Vice of Duplicity.

“ 313. Extent of Rule I.

“ 314. Subordinate Rules.

“ 315. Cumulative 'Traverses.

Sec. 318. Rule II. Against Pleading and Demurring to the same Matter.

SEc. 312. The Vice of Duplicity. There are two rules under this grouping, one of which is invoked to prevent duplicity in pleading, the other to prevent a party from pleading and demurring to the same matter.

Rule I. Pleadings must not be Double. Mr. Stephen gives us to understand that, while this rule is directed in its terms against doubleness, it is equally applicable to cases of trebleness. ${ }^{4}$ If doubleness in pleading is a vice, trebleness would seem to be an aggravation of it, since nothing is treble which is not also double, in obedience to the axiom that the greater always includes the less.

In discussing the vice of duplicity in common law pleading, I will consider this rule first as it existed in ancient common law pleading, with the subordinate rules adopted for enforcing it; next, the evasions of it, which were tolerated in practice along with the statutes and judicial construction thereof, which resulted in limiting its application. The rule against doubleness is coexistent with the origin and growth of common law pleading, and purports to advance the main object of the system, which was to eliminate from the alternate allegations of the parties a single material is-

1 Steph. Pl. 247.

2 Steph. Pl. 249, 250.

Martin Civil Procedure-18
3 Steph. Pl. 250.

4 Steph. P1. 252. 
sue decisive of the controversy. It applied both to the declaration and to subsequent pleadings. "Its meaning with respect to the former is that the declaration must not, in support of a single demand, allege several distinct matters, by any one of which that demand is sufficiently supported. With respect to the subsequent pleadings, the meaning is that none of them is to contain several distinct answers to that which preceded it; and the reason of the rule in each case is that such pleading tends to several issues concerning a single claim. ${ }^{1}$

When a person had several grounds for the same recovery, the ancient common law required him to make his election between them, and to rest his case on the one so selected. The same was equally true in respect to defences. The rule against duplicity was enforced with great severity, as will be seen from the cases cited in the note. ${ }^{2}$

\section{SEc. 313. Determinations on the Extent of the Rule.}

1. This rule was never construed as prohibiting the joinder (when proper) of two or more distinct demands or causes of action in the same declaration. In such case two or more distinct recoveries were asked for, and the plaintiff was at liberty to allege distinct matters respectively in support of each demand or cause of action. $^{3}$ In debt, covenant, and detinue, and the real and mixed actions, these distinct demands or causes of action could be included in one count by enlargement of the claim in point of sums and quantities, while in trespass, case, and assumpsit they had to be stated in separate counts. ${ }^{4}$

2. In like manner, the plea was not objectionahle on account of duplicity, because it contained distinct answers applicable to each demand or cause of action. ${ }^{5}$

3. Neither was it objectionable for containing distinct answers, respectively to such parts of a declaration as relate to different matters of claim or complaint, ${ }^{6}$ although the rule would be vio-

1 Steph. Pl. 251.

2 Humphreys $v$. Bethily, 2 Vent. 198, 222; Hart $v$. Longfield, 7 Mod. 148 ; Cornwallis $v$. Savery, 2 Burr. 773; Saunders v. Crawley, 1 Rolle, 112 ; Galway $v$. liose, 6 M. \& W. 291; Harrison v. Cotgreave, 5 D. \& L. 169 ; Humphreys v. Churchman, Rep. Temp. Hard. 289; Trevelian $v$. Sec- comb, Carth. 8 ; Clearwater v. Meredith, 1 Wall. 25; Kipp $v$. Bell, $86 \mathrm{Ill}$. 577 ; Steph. Pl. 271.

3 Steph. Pl. 255.

4 Comyu, Dig. Pleader, 2 V. 23; Steph. Pl. 131, 255, 268, 269; 1 Chit. Pl. 586.
5 Steph. PI. 256.
6 Steph. P1. 256. 
lated if it contained several answers to the declaration as a whole. ${ }^{1}$

In alleging in a plea distinct matters in answer respectively to such parts of a declaration as relate to different claims, care should be taken that neither of the matters so alleged would alone be a sufficient answer to the whole. ${ }^{2}$

4. If there were several defendants, the rule against duplicity was never carried so far as to compel each of them to make the same answer to the declaration. Each was at liberty to use such plea as he might think proper for his own defence; and they might either join in the same plea or sever at their discretion. ${ }^{3}$

SEC. 314. Subordinate Rules guiding the Application of the Rule against Duplicity.

I. A pleading will be double that contains several answers, whatever lie the class or quality of the answer.

It will be double if it contains several matters in abatement, or several in bar, or one in abatement and another in bar. The same will be true in respect to pleas by way of traverse and pleas in confession and avoidance. ${ }^{4}$

2. Matter may suffice to make a pleading double, though it be ill pleaded.

To give occasion for application of this rule both matters pleaded must be material, - one of such material matters being ill pleaded. ${ }^{5}$

3. Matter immaterial cannot operate to make a pleading double. ${ }^{6}$

Immaterial matter, though well pleaded or ill pleaded, cannot make a pleading double, because no issue can properly be taken upon it. It does not therefore tend to a separate issue in violation of the rule against duplicity. ${ }^{7} \mathrm{It}$ is otherwise in respect to material matter ill pleaded, because, if the plaintiff waives the formal objection of ill pleading, by taking issue on the substance of the plea, the issue will have to be tried as if it was well pleaded, in which event the vice of double pleading would be apparent. ${ }^{8}$

4. No matter will operate to make a pleading double that is pleaded only as necessary inducement to another allegation.

By this rule Sergeant Stephen may be understood as declaring that when matter which might in itself be a defence is pleaded by

1 Steph. Pl. 256.

2 Steph. PI. 257.

3 Steph. Pl. 257.

4 Steph. Pl. 258.
5 Steph. Pl. 259.

8 Steph. Pl. 259.

7 Steph. Pl. 260.

8 Steph. Pl. 261. 
way of necessary inducement to other matter pleaded as a defence, the plea is not objectionable for duplicity. Whether the rule is violated in such case depends upon how the supposed double matter is pleaded, whether independently as a defence, or as matter explanatory of, or as a necessary ingredient of, another matter of defence. $^{1}$

5. No matters, however multifarious, will operate to make a pleading double that together constitute but one connected proposition or entire point. ${ }^{2}$

This rule is illustrated by reference to a defence to an action for assault and imprisonment, to the effect that the arrest was made on suspicion of a felony. In stating his cause of suspicion he may recite any number of circumstances of suspicion, though each circumstance alone may be sufficient to justify the arrest; for all of them taken together amount to one connected cause of suspicion. ${ }^{3}$

SEC. 315. Traverses apparently cumulative authorized under Subordinate Rule 5. This qualification of the rule against duplicity as expressed in the subordinate rule number 5 is said by Mr. Stephen to apply not only to pleading by way of confession and avoidance, but to traverses also; so that a man may deny as well as affirm on pleading any number of circumstances that together form but a single point or proposition. ${ }^{4}$

The qualification is illustrated by the case of Robinson $v$. Rayley, 1 Burr. 316, in which Lord Mansfield justified an apparent departure from the rule against cumulative traverses, holding " that you must take issue upon a single point, but it is not necessary that this single point should consist only of a single fact." The distinction does not seem to have been successfully preserved. ${ }^{5}$

In applying the qualification, the principal difficulty occurs in determining whether a certain number of facts constitutes a single cause of action or a single defence. ${ }^{6}$

The replication de injuria was in its nature a species of cumulative traverse, in which the plaintiff alleged that the defendant did the act of his own wrong and without the cause alleged, - a phrase which put in issue the cause, although it consisted of several connected circumstances. This general traverse, as we have seen, could

1 Steph. Pl. 262.

2 Steph. Pl. 262.

3 Steph. Pl. 262.

4 Steph. Pl. 263.
5 Dewolf $v$. Bevan, 13 M. \& W. 160 ; Bonzi v. Stewart, 7 M. \& G. 746.

6 Clearwater $v$. Meredith, 1 IVall. 25; Stearns $v$. Stearns' Adm'r, $32 \mathrm{Vt}$. 678; Wiley $v$. Carpenter, 64 Vt. 212. 
not be used against matter of title, interest, commandment, authority from the adverse party, or matter of record. Such matter was required to be traversed separately. If this replication was used at all, as against pleas containing such matter, it had to be confined to other matters in the plea. ${ }^{1}$

It is said by Mr. Stephen that this restriction of the traverse in the replication de injuria applies in principle to all cases of cumulative traverse; so that it may be said to be generally true that where matter of title, interest, commandment, authority from the adverse party or record, is pleaded in connection with other circumstances, it is not a case in which it is competent to the other party to traverse cumulatively; and that, if he include all these circumstances in the same traverse his pleading will be double. ${ }^{2}$

The general issue which was raised by a general traverse partook of the nature of a cumulative traverse in certain cases, as in trespass, case, assumpsit, and debt on simple contract. Under this compendious traverse the defendant had the advantage of putting in issue all the material averments in the declaration, without indicating any particular one upon which he might ground his defence.

\section{SEC. 316. Relaxations of the Rule against Duplicity in the}

Declaration. It may be repeated here that including in one writ or declaration two distinct causes of action never constituted a violation of the rule forbidding duplicity in pleading. The joinder was of course subject to rules confining it to demands somewhat allied in their nature and form. ${ }^{3}$

This right of joining two distinct causes of action in one declaration suggested a practice of ancient date, by which the pleader ingeniously evaded the rule against double pleading by including in his precipe and declaration different statements of his single demand or cause of action. He was always careful to designate each one as referring to a cause of action distinct and separate from the others. In this manner he overcame the objection of duplicity when urged on demurrer. It was only after submission of the evidence that the identity of the causes of action became apparent. Under the ruling of the court he could have but one judgment. But he was entitled to it if any one of the statements was supported by the evidence adduced on trial. He was thus enabled frequently to protect himself against failure of evidence, surprise, and the consequence of variance between allegation and proof.

1 Steph. Pl. 265 ; supra, sec. 271.

3 Steph. Pl. 267, 268.

2 Steph. Pl. 266. 
These different statements were in most cases complete and separate counts in the declaration. But in debt, assumpsit, covenant, and detinue it was the practice to enlarge the claim in point of sums and quantities, including all the causes of action in one count. ${ }^{1}$

This practice of varying the statement gave rise to the use of the common counts, which were used in the actions of debt and assumpsit, as heretofore mentioned. ${ }^{2}$ Under rule of court it was permissible to condense the common counts into one count. ${ }^{3}$ But notwithstanding this they were regarded as distinct and separate counts within the meaning of the reformed rules forbiding the use of several counts. ${ }^{4}$ Several breaches of a covenant could be stated in one count at common law, ${ }^{5}$ an exception which was permitted by the Hilary rules. ${ }^{6}$

SEC. 317. Relaxation of the Rule against Duplicity in Pleas. The rule against duplicity in pleas never prevented the defendant from giving distinct answer to different complaints on the part of the plaintiff. To several counts or to distinct parts of the same count he might plead several pleas, one to each. ${ }^{7}$ These pleas to different counts or distinct parts of the same count need not be of the same kind, but may be some in bar and others in abatement. 8

But by the common law the defendant was prohibited from giving distinct answers to the same claim or cause of action. He was compelled to rely upon one alone, and in making his selection he sometimes incurred the risk of founding his defence upon the weaker plea. The severity of this rule led to legislative enactment, by which it was greatly relaxed. The statute of Anne directed that it should "be lawful for any defendant or tenant in any action or court, or for any plaintiff in replevin in any court of record, with the leave of the court, to plead as many several matters thereto as he shall think necessary for his defence." 9 This statute did not extend to replications or subsequent pleadings. ${ }^{10}$ The privilege of making several pleas being subject to the discretion of the court, it was thought that a sufficient safeguard against abuse was thus furnished by the statute; and the judges at first were disposed

1 Stepl. Pl. 269; Andrews's Steph. Pl. 151.

2 Sec. 55.

8 Hil. T. 2 Wm. IV.

4 Reg. 5 Hil. T. $4 \mathrm{Wm}$. IV.

5 Comyn, Dig. Pleader, 2 V. 2, 3.
$64 \mathrm{Wm}$. IV. reg. 5.

7 Steph. Pl. 269, 270.

8 Steph. Pl. 271.

94 Anne, c. 16 , s. 4 and 5.

101 Chit. Pl. 228. 
to reject nearly all inconsistent pleas. ${ }^{1}$ But the courts in a great measure surrendered the discretion vested in them, and indulged the bar in permitting a multiplicity of pleas, resulting in obstruction and delay of justice. ${ }^{2}$

In modern English practice the only pleas perhaps which have been uniformly disallowed on the mere ground of inconsistency are those of the general issue and a tender. ${ }^{3}$ 'The defendant was permitted by different pleas to state as many substantially different grounds of defence as he thought proper, provided they could be determined by the same mode of trial, although they might appear contradictory of, or inconsistent with, one another. ${ }^{4}$ The general issue came to be pleaded along with special pleas. The right, however, was held not to include dilatory pleas. $^{5}$

The excuse for several varying pleas, which consisted in the necessity of avoiding a variance, was in a great measure removed by extending to the judges the power of amendment during trial. Thereafter the judges thought it arlvisable to qualify the liberty of pleading several pleas, by rule of Hilary term, $1834 .^{6}$

But this rule in its terms purported only to forbid stating the same subject matter of defence, by merely varying the staternent, description, or circumstances, leaving the defendant, as before, to plead as many pleas of different matters of defence as may be reasonable. ${ }^{7}$ Inconsistent pleas were not forbidden. ${ }^{8}$ By the Common Law Procedure Act of 1852, while the privilege was extended to subsequent pleadings, it was reasonably restricted by requirement of an affidavit from the applicant, and by designation of certain pleas which could be used without leave of court. ${ }^{9}$

It may be added here that objection for duplicity could be taken only in the form of demurrer.

SEc. 318. Rule II. It is not allowable to Plead and to Demur to the same Matter. ${ }^{10}$ This rule is nothing more than an extension of the general rule against the use of several pleas. The same reason which forbade the use of several pleas applied with

1 Steph. Pl. 274.

21 Chit. Pl. 563; Com. Law Proc. Act, 1852 , p. 299 , note a, Morris and Finlason.

8 Steph. Pl. 274, 275.

41 Chit. Pl. 561, 562 ; Steph. Pl. $274,275$.

5 Steph. Pl. 276.
6 Hil. T. 4 Wm. IV. reg. 5.

71 Chit. Pl. 564.

81 Chit. Pl. 564.

9 Com. Law Proc. Act, 1852, sec. $81,82,83,84$, Morris and Finlason, 300, note $b$.

10 Steph. Pl. 278. 
equal force to the use at the same time of a demurrer and a plea to a single claim.

The statute of Anne, which allowed several pleas, was construed as furnishing no authority for demurring and pleading at the same time to the same cause of action, so that the practice in this respect remained as at common law.

No substantial reason is apparent for restricting the right to pleas only. ${ }^{1}$

\section{ARticle V.}

Rules which tend to produce Certainty or Particularity in the Issue.

Sec. 319. Rule I. The Pleading must have Certainty of Place.

“ 320. Rule II. The Pleadings must have Certainty of 'Time.

“ 321. Rule III. The Pleadings must specify Quality, Quantity, aud Value.

“ 322. Rule IV. The Pleadings must specify the Names of Persons.

“ 323. Rule V. 'The I'leadings must slow Title.

" 324. How to allege Title in himself or another whose Authority he Pleads.
Sec. 325. Exceptions.

" 326. How to allege Title in an $\mathrm{Ad}$ versary.

“ 327. Exceptions.

“ 328. Rule VI. The Pleadings must show Authority.

“ 329. Rule VII. In general, whatever is alleged in Pleading must be alleged with Certainty.

“ 330. Subordinate Rules limiting and restricting the general Rules which tend to Certainty.

\section{SEC. 319. Rule I. The Pleading must have Certainty of}

Place. This rule is disclosed in the necessity of alleging venue in the declaration. In treating of the venue as a part of the declaration, I have considered in what cases it must be alleged in the margin of the declaration, and in what cases it must be alleged in the body of the declaration; and what has been said upon it is now referred to without repetition. ${ }^{2}$ The principle governing venue in the body of the declaration, prior to the Hilary rules of 1834 , applied to affirmative traversable allegations in the plea, replication, and subsequent pleadings. By those rules the venue in the margin of the declaration was not repeated in the body or subsequent pleadings, except when place was of the description of the action. Defects in venue could be taken advantage of by demurrer, plea in abatement, or motion for nonsuit. ${ }^{3}$

SEc. 320. Rule II. The Pleadings must have Certainty of Time. Time is as necessary to a perfect pleading as place. The common law required the pleader to allege the time as well as place to every traversable allegation. Certainty of time was required in
I 4 Minor, Inst. 951, 952.
31 Chit. Pl. 279.
2 Sec. 30 .
4 Steph. Pl. 292. 
personal actions only. This requirement was complied with by stating the day, month, and year. In the ancient real and mixed actions it was sufficient to state in what King's reign the matter of complaint arose. ${ }^{1}$

While time, like venue, was a necessary element of every pleading, correctness of date was not considered in general as forming a material part of the issue; so that one time might be alleged and another proved. The pleader was at liberty as a general rule to assign any time that he pleased to a given fact. ${ }^{2}$ The latitude of this rule was subject to three restrictions :-

1st. If the pleader did not wish to be held strictly to the time alleged, he should lay it under a videlicet, prefacing the date, which permitted him to prove any other date or time consistent with the nature of his case. ${ }^{3}$

$2 d$. The time laid should not be intrinsically impossible or inconsistent with the fact to which it relates. This, however, would not be objectionable if it did not relate to a traversable fact, or if it was unnecessarily made. ${ }^{4}$

3d. When, as in some instances, time forms a material point in the merits of the case, the true time should be alleged. If in such cases a traverse be taken, the time laid is of the substance of the issue, and must be strictly proved, just as in statements of local description it is necessary to prove the alleged place. ${ }^{5} \mathrm{~A}$ failure to prove the time as alleged results in a variance, and the insertion of a videlicet will give no help. ${ }^{6}$

The restriction that true time need not be stated when it is immaterial, as in most cases, is subject to the rule that the plea and subsequent pleadings should follow the day alleged in the writ or declaration. But where in the plea or the subsequent pleadings the time happens to be material, it must be alleged correctly, even though the pleader be obliged to depart from the day mentioned in the writ or declaration.?

SEc. 321. Rule III. The Pleading must specify Quality, Quantity, and Value. In any action for the recovery of real property, its quantity should be specified. It was also necessary in general that its quality should be shown, as whether it consists of houses,

1 Steph. Pl. 295.

2 Steph. Pl. 292, 293.

8 As to the meaning and effect of a videlicet, see 1 Chit. Pl. 317, 318; Heard, Steph. Pl. 293, note u.
4 Steph. Pl. 293.

5 Steph. Pl. 293, 294.

6 Stepl. Pl. 294.

7 Steph. Pl. 295. 
lands, or other hereditaments; and in general it was necessary to state whether the lands were meadow, pasture, or arable. ${ }^{1}$ In personal actions upon contracts relating to goods and chattels, and for injuries to them, their quality, quantity, and value or price should be stated. Likewise in an action for injuries to real property, the quality should be shown, as whether it consists of houses, lands, or other hereditaments. ${ }^{2}$

Value should be specified with reference to the current coin of the realm. Quantity should be specified by the ordinary measures of extent, weight, or capacity. ${ }^{3}$

This rule was not so strictly construed in actual practice as to exclude the specification of quality and quantity in a loose and general way, especially in the actions of trover and trespass. ${ }^{4}$ It was relaxed in the actions of debt and indebitatus assumpsit, if the debt was claimed in respect of goods sold, by entirely omitting the quality, quantity, or value of the goods, and stating the amount of the debt or sum of money due upon the sale. ${ }^{5}$ Exact quantity and value were not, in general, material points in the issue of the case, so as to require the proof to correspond with the averment. The pleader might in general allege any quantity and value, (at least if it be laid under a videlicet,) without risk of incurring the consequence of a variance in the event of a different amount being proved, not exceeding the amount claimed. ${ }^{6}$

Quantity and value may in some instances, like time, form a part of the substance of the issue, and then they must be strictly proved as laid.? The averment of quality was as a general rule required to be strictly proved as laid, because it generally is matter of description. ${ }^{8}$

Sec. 322. Rule IV. The Pleadings must specify the Names of Persons. The requirements of this rule apply to parties to the suit, and to persons not parties to the suit of whom mention is made in the pleading.

1. In Relation to Parties to the Suit. It was necessary that the names of both plaintiff and defendant should be accurately set forth in the writ and declaration. Each had to be described by his Christian name and surname, and by his name of dignity, if any;

1 Steph. Pl. 296.

2 Steph. Pl. 296.

8 Steph. Pl. 298.

4 Steph. Pl. 299.

6 Steph. Pl. 300.
6 Steph. Pl. 300.

7 Rivers $v$. Griffiths, 5 Barn. \& Ald. 630 ; Steph. Pl $300,301$.

8 Steph. Pl. 301. 
and any omission or mistake in this respect furnished ground for plea in abatement only, and could not be objected to for variance at trial.

By statute in the reign of William IV., pleas in abatement for misnomer of parties were not allowed in any action; but the declaration on defendant's motion, and on affidavit of the true name; was amended by inserting it. ${ }^{1}$

2. In Relation to Third Persons not Parties to the Suit. The same accuracy was required as in the case of parties. But a mistake in the name of a person not a party, unlike mistakes as to parties, subjected the pleading to the effects of a fatal variance, when the proof did not correspond with the averment. Advantage of the mistake was taken in the same way as in any other variance.

SEc. 323. Rule V. The Pleadings must show Title. When, in pleading, any right or authority is set up in respect of property personal or real, some title to that property must of course be alleged in the party, or in some other person from whom he derives his authority. So if a party be charged with any liability in respect of property, personal or real, his title to that property must be alleged. ${ }^{2}$ This is Mr. Stephen's declaration of the general rule requiring pleadings to show title.

Bearing in mind the axiomatic truth, that a statement of every cause of action must disclose a right in the plaintiff and an invasion or infraction of that right by defendant, it will simplify our understanding of this rule to consider and treat the term title as merely representing certain manifestations or phases of right. When rights take on certain phases and forms, we find them designated by the term of title.

By ancient usage some of the rights of property, such as are implied in the fact of possession, were not included in the classification of titles, because of their temporary and provisional existence. ${ }^{3}$ But it is more convenient to recognize the right of possession springing solely from the fact of actual and peaceable possession as a species of title.

The general requirement of showing title may be considered, first, where it is alleged to be in the party making the allegation; second, where it is alleged to be in his adversary.

SEC. 324. Rule V. continued. - I. Where a Party alleges Title in himself or in another whose Authority he pleads. Titles being

$13 \& 4$ Wm. IV. c. 42.

2 Steph. Pl. 304.

${ }^{8}$ Sec. 121. 
various in kind and extent, in pleading them as the basis of a right of action it is only necessary to allege such title, or so much title as may be susceptible of the infraction and wrong complained of: The mode of doing this has gravitated into certain expressions and forms, which have long been clothed with the binding force of precedent.

a. When the title implied by peaceable possession has been invaded or violated by the defendant, it is sufficient to allege the fact of possession in order to admit evidence of the wrongful act affecting the implied right of possession.

If the action related to goods and chattels, the plaintiff was permitted to allege that he "was lawfully possessed of them, as of his own property," or that they were the "goods and chattels of plaintiff." If the action related to land, it was sufficient to allege that the plaintiff was "lawfully possessed of a certain close," or that the close describing it was the close of plaintiff. These expressions were regarded as broad enough to admit proof of title sufficient to maintain trespass against any one who could be made liable to plaintiff in such action. ${ }^{1}$ If the defendant was a stranger, the right of property implied in the fact of peaceable possession was sufficient. As against the rightful owner, such right of possession would not be sufficient.

The form of alleging title to an incorporeal hereditament was somewhat technical and strained, and consisted in alleging possession of the corporeal thing to which the incorporeal right attached, and averring that by reason thereof the plaintiff was entitled to the right or easement claimed. ${ }^{2}$ By a statute of William IV., this rule was changed, at least in so far as it related to incorporeal rights claimed by prescription: thereafter it was sufficient to allege the enjoyment of the way, common or other easement, as of right by the occupier of the tenement in respect whereof the right is claimed for such period of time as gives the right by prescription. ${ }^{3}$

It is unnecessary to repeat in this connection the various actions which may be brought on the strength of a title by possession, or the cases in which it may be pleaded as a defence. ${ }^{4}$ I may remark that the rule permitting plea of possession did not prevail in replevin. ${ }^{5}$ Neither did it apply to real or mixed actions, in which an injury to possession was seldom alleged. ${ }^{6}$

1 Sec. 77.

2 Steph. Pl. 305.

$82 \& 3$ Wm. IV. c. 71.
4 Steph. Pl. 319.

5 Steph. Pl. 321.

6 Steph. Pl. 322. 
b. In pleading titles superior to those of possession, there was a marked distinction preserved between estates in fee simple and particular estates. In general, it was sufficient in fee simple 'estates to allege a seisin in fee simple, viz. that the party "was seised in his demesne, as of fee of, and in a certain messuage," without showing the derivation or commencement of the estate. ${ }^{1}$

This rule prevailed in all cases except where in the pleading the seisin has already been alleged in another person from whom the present party claims. In such case, it must of course be shown how it passed from one of these persons to the other. ${ }^{2}$

In pleading particular estates the general rule was that the commencement of the particular estates must be shown. ${ }^{3}$ This rule did not apply when the title of the particular estate was alleged by way of inducement. ${ }^{4}$

c. In pleading derivative titles the following additional rules were recognized and enforced:-

Firstly. Where a party claims by inheritance, he must in general show how he is heir; viz. as son or otherwise, and if he claims by mediate, not immediate, descent, he must show the pedigree. ${ }^{5}$

Secondly. Where a party claims by conveyance or alienation, the nature of the conveyance or alienation must in general be stated, as whether it be by devise, feoffment, \&c. ${ }^{6}$

Thirdly. The nature of the conveyance or alienation should be stated according to its legal effect, rather than its form or words.' This was nothing more than an application of the general rule, to be noticed hereafter; viz. "that things are to be pleaded according to their legal effect or operation."

Fourthly. Where the nature of the conveyance is such that it would at common law be valid without deed or writing, there no deed or writing need be alleged in the pleading, though such document may in fact exist; but where the nature of the conveyance requires 'at common law a deed or other written instrument, such instrument must be alleged. ${ }^{8}$

SEc. 325. Rule $\mathbf{V}$. continued. - Exceptions. While the foregoing rules apply to the allegation of title in general, there are certain excepted cases in which different and less precise modes of laying title are permitted. ${ }^{9}$

1 Steph. Pl. 305, 306.

2 Steph. P]. 307.

3 Steph. Pl. 308.

4 Steph. Pl. 309.

5 Steph. Pl. 310.
6 Steph. Pl. 310, 311.

7 Steph. Pl. 311.

8 Steph. Pl. 312.

o Steph. Pl. 314. 
1. It is occasionally sufficient to allege what may be called a general freehold title. ${ }^{1}$ Such is the case in response to an action of trespass quare clausum fregit, and in an avowry in replevin; if the defendant claim an estate of freehold in the locus in quo he is allowed to plead generally that the place is his "close, soil, and freehold." This was known as the plea or avowry of libcrum tenementum..$^{2}$

2. It is often sufficient to allege a title of mere possession. ${ }^{3}$ This exception or qualification has been considered in connection with the rule relating to the manner in which titles should be alleged, possession being treated as implying and representing a species of title.

SEc. 326. Rule V. continued. - II. Where a Party alleges Title in his Adversary.

The general rule under this head may be announced as follows:-

That it is not necessary to allege title more precisely than is sufficient to show a liability in the party charged, or to defeat his present claim. ${ }^{4}$

In pleading the title of an adversary it is not in general necessary to plead it with as much precision as in the case where the pleader is stating his own title. ${ }^{5}$ The commencement of particular estates need not be shown, and the derivations of title may be alleged with less precision.

Allegations of title, unlike allegations of time, quantity, and value, were required to be proved as alleged being ordinarily of the substance of the issue. ${ }^{6}$

SEC. 327. Rule V. continued. - Exceptions. To the general rule requiring title to be shown, an exception was recognized when the opposite party was estopped from denying title. The pleader in such case was relieved from alleging or proving it. ${ }^{7}$ It was sufficient that the fact or relation which constituted the estoppel appeared in the pleading. By a statute passed in the reign of George II. the defendant was enabled to avow or make cognizances in more general terms, without particularly setting forth the grant, tenure, demise, or title of the landlords, lessors, or owners of the manor. ${ }^{8}$

Sec. 328. Rule VI. The Pleading must show Authority. In general, when a party has occasion to justify under a writ,

1 Steph. Pl. 314.

2 Steph. Pl. 315.

8 Steph. Pl. 317.

Steph. Pl. 322.
5 Steph. Pl. 324.

6 Steph. Pl. 326.

7 Steph. PI. 327.

811 Geo. II. c. 19, s. 22. 
warrant, or precept, or any other authority whatever, he must set it forth particularly in his pleading. And he ought also to show that he has substantially pursued such authority. ${ }^{\text {I }}$

The degree of particularity depends somewhat upon the nature of the case, involving important distinctions.

1. It is not necessary that any person justifying under judicial process should set forth the cause of action in the original suit in which the process issue. ${ }^{2}$

2. If the justification be by the officer executing a writ, he is required to plead such writ only, and not the judgment on which it was founded. It is otherwise when the justification is pleaded by a party to a suit, or by any stranger; the judgment as well as the writ must be set forth. ${ }^{3}$

3. When an officer justifies under a writ, he must show that the writ was returned, if it was his duty to make return. In general, writs of execution need not be returned. But a return must be shown of any prior writ necessary to justify issue of the writ under which justification is made. ${ }^{4}$ It has been held that a subordinate officer is entitled to justify under a writ without making return.

4. In justifying under a judgment of a superior court, the judgment alone may be shown without setting forth any of the previous proceedings. ${ }^{5}$

5. When justification is founded on process issuing out of an inferior English court, or a court of foreign jurisdiction, the nature and extent of the jurisdiction of such court ought to be set forth; and it should also appear that the cause of action was within that jurisdiction. ${ }^{6}$ Where an authority may be constituted verbally and generally, it is allowable to plead it in general terms. ${ }^{7}$

The allegation of authority, like that of title, must in general be strictly proved as alleged.

SEC. 329. Rule VII. In general, whatever is alleged in Pleading must be alleged with Certainty. ${ }^{3}$ This general rule is illustrated by examples relating to the performance of conditions or covenants in which the party pleading performance was required to show the time, place, and manner of performance. ${ }^{9}$ In other

1 Steph. Pl. 329.

2 Steph. Pl. 331.

3 Steph. Pl. 331.

4 Steph. Pl. 332.

5 Steph. Pl. 332.
6 Steph. Pl. 332.

7 Steph. Pl. 333.

8 Steph. Pl. 334.

9 Steph. Pl. 334. 
words; he was required to plead the facts constituting performance, instead of the ultimate conclusion of performance. A general plea of performance, however, was permitted in certain cases instanced by Mr. Stephen. ${ }^{1}$ The general rule is illustrated in a variety of other cases mentioned by him, to which the student is referred. ${ }^{2}$

SEC. 330. Subordinate Rules limiting and restricting the General Rules which tend to Certainty.

1. It is not necessary in Pleading to state that which is merely Matter of Evidence. ${ }^{3}$

This rule is based on the distinction between issuable facts and evidential or probative facts, requiring the pleader to state the former, and leaving him to bring forward the latter only at the trial.

2. It is not necessary to state Matter of which the Court takes Notice ex officio. ${ }^{4}$

The court takes judicial cognizance of the law of the land governing the facts pleaded, and no allusion to it need be made; although it is often permissible and proper to allude generally to the law or statute for the convenience or intelligibility of the statement of fact. ${ }^{5}$ Many facts of a public kind will be officially noticed by the court, and need not be pleaded. Such facts are determined by the law of evidence, and need not be considered here.

3. It is not necessary to state Matter which would come more properly from the other Side. ${ }^{6}$

The meaning of this rule is that it is not necessary to anticipate the answer of the adversary. ${ }^{7}$ But where the matter is such that its affirmation or denial is essential to the apparent or prima facic right of the party pleading, there it ought to be affirmed or denied in the first instance, though it may be such as would otherwise properly form the subject of objection on the other side. ${ }^{8}$ An exception to this rule exists in pleading estoppels. The facts of estoppel must be pleaded with certainty in every particular; in other words, the plea of an estoppel must meet and remove by anticipation every possible answer of the adversary. ${ }^{9}$ The same requirement was said to apply to the plea of alien enemy.

1 Steph. Pl. 336.

2 Steph. Pl. 337.

3 Steph. Pl. 342.

4 Steph. Pl. 346.

5 Steph. Pl. 347, 348.
6 Steph..Pl. 350.

7 Steph. Pl. 350.

8 Steph. Pl. 352.

9 Steph. Pl. 353. 
4. It is not necessary to allege Circumstances necessarily implied. ${ }^{1}$

If a feoffment be pleaded, it is not necessary to allege livery of seisin, for it is implied in the word " enfeoffed." So if a man plead that he is heir to $A$. he need not plead that $A$. is dead, for it is implied.

5. It is not necessary to allege what the Law will presume. ${ }^{2}$

The presumptions of the law are contained in the law of evidence, to which the student is referred.

6. A general Mode of Pleading is allowed where great Prolixity is thereby avoided. ${ }^{3}$

This rule is somewhat indefinite, but its extent and application nna be collected with some degree of precision from the examples by which it is illustrated in the books, and by considering the limitations which it necessarily receives from the rules tending to certainty as enumerated in a former part of this article.

7. A general Mode of Pleading is often sufficient, where the Allegation on the other side must reduce the Matter to Certainty. ${ }^{4}$

The application of this rule is illustrated in pleading performance in actions of debt on bond, in the plea of non damnificatus in an action on an indemnity bond, or on bond conditioned " to keep the plaintiff harmless and indemnified," or where the condition of the bond sued on is for the performance of covenants or other matters contained in an indenture or other instrument collateral to the bond, and not set forth in its condition. ${ }^{5}$

S. No greater Particularity is required than the Nature of the Thing pleaded will conveniently admit. ${ }^{6}$

The nature of each case must be considered in determining the application of this limitation or qualification. The relaxation permitted arises from the difficulty and inconvenience of particularizing losses which happen to a multitude or great variety of goods.

9. Less Particularity is required when the Facts lie more in the Knowledge of the opposite Party than of the Party pleading. ${ }^{7}$

This rule is exemplified in the general mode in which it is permitted to allege title in an adversary. ${ }^{8}$

10. Less Particularity is necessary in the Statement of Matter of Inducement or Aggravation, than in the main Allegation. ${ }^{9}$

1 Steph. Pl. 353.

2 Steph. Pl. 354.

3 Steph. Pl. 355, 356.

4 Steph. Pl. 359.

5 Steph. Pl. 363.
${ }^{6}$ Steph. Pl. 367, 368.

7 Steph. Pl. 370.

8 Sec. 326.

9 Steph. Pl. 372.

Martin Civil Procedure-19 
This rule is exemplified in the exception to the general rule requiring the commencement of a particular estate to be shown; permitting the estate to be alleged generally, if the title is mentioned in the inducement. ${ }^{1}$

11. With Respect to acts valid at Common Law, but regulated as to the Mode of Performance by Statute, it is sufficient to use such Certainty of Allegation as was sufficient before the Statute. ${ }^{2}$

This rule is illustrated in setting forth causes of action which were good at common law, but which were required to be in writing by the statute of frauds. It was for the defendant to take advantage of the statute, and the plaintiff continued to plead as before the statute. But when the defendant sought to found his defence on a contract by pleading it in bar, if the statute of frauds required the contract to be in writing, it was necessary for him to so plead it. ${ }^{3}$

\section{Article VI.}

Rules which tend to prevent Obscurity and Confusion in Pleading.

Sec. 331. Rule I. Pleading must not be Sec. 335. Rule V. Pleadings must not be Insensible or Repuginant.

"332. Rule II Pleading must not be Ambignous or Doubtful, and when two different Meanings present themselves that Construction shall be adopted which is most unfavorable to the Party pleading.

- 333. Rule III. Pleading must not be A rgumentative.

“ 334. Rule IV. Pleading must not be Hypothetical or in the Alternative. by way of Recital, but must be Positive in their Form.

" 336. Rule VI. Things are to be pleaded according to their legal Effect or Operation.

“ 337. Rule VII. Pleadings should observe the known and ancient Forms or Expressions, as contained in approved l'recedents.

“ 338. Rule VIII. Pleadings should have their proper formal Commencements and Conclusions.

Sec. 339. Rule IX. Pleading which is Bad in Part is Bad altogether.

SEc. 331. Rule I. Pleadings must not be Insensible or

\section{Repugnant.}

A statement which is unintelligible does not answer the purpose of a pleading, and is subject to successful attack in various ways.

Again, if a pleading be inconsistent with itself or repugnant, this is ground of demurrer. The rule is subject to this exception: that if the second allegation which created the repugnancy is merely superfluous and redundant, so that it may be rejected from the pleading without materially altering the general sense and effect, it shall in that case be rejected, at least if laid under a videlicet,

1 Steph. Pl. 372.

2 Steph. Pl. 373, 374.
8 Steph. Pl. 376.

4 Steph. Pl. 377. 
ART. VI.] RULES OF PLEAdING. - TO PREVENT OBSCURITY, ETC. 291

and shall not vitiate the pleading; for the maxim is utile per inutile non vitiatur. ${ }^{1}$

Repugnancy in a pleading which was thus forbidden must be distinguished from independent and inconsistent pleas, which came to be very generally allowed. ${ }^{2}$

SEC. 332. Rule II. Pleading must not be Ambiguous or doubtful in Meaning; and when two different Meanings present themselves, that Construction shall be adopted which is most unfavorable to the Party pleading. ${ }^{3}$

In the enforcement of this rule, a pleading is not objectionable as ambiguous or obscure if it be certain to a common intent, that is, if it be clear enough according to reasonable intendment or construction, though not worded with absolute precision. ${ }^{4}$

It is under this head of ambiguity that the doctrine of negatives pregnant appears most properly to range itself. ${ }^{5}$ A negative pregnant is such a form of negative expression as may imply or carry within it an affirmative. As, for instance, in trespass for entering the plaintiff's house, the defendant pleaded that the plaintiff's daughter gave him license to do so, and that he entered by that license. The plaintiff replied that he did not enter by her license. It will be observed that this traverse might imply or carry within it that a license was given, though the defendant did not enter by that license. It is therefore, in the language of pleading, said to be pregnant with that admission, viz. that a license was given. At the same time, the license is not expressly admitted, and the effect therefore is to leave it in doubt whether the plaintiff means to deny the license, or to deny that the defendant entered by virtue of that license. It is this ambiguity which constitutes the fault. ${ }^{6}$

This rule, however, against a negative pregnant has not, in modern times at least, been very strictly applied, that form of expression having been frequently held free from objection upon various grounds of distinction from the general rule. ${ }^{7}$

Sec. 333. Rule III. Pleadings must not be Argumentative. ${ }^{8}$

In other words, they must present their positions of fact in an absolute form, and not leave them to be collected by inference and

1 Steph. Pl. 378.

21 Chit. Pl. 554 ; Steph. Pl. 274, 275 ; sec. 317.

3 Steph. Pl. 378.

5 Steph. Pl. 381.

6 Steph. Pl. 382.

7 Steph. Pl. 383.

8 Steph. PL. 384.

4 Steph. Pl. 380. 
argument only. ${ }^{1}$ This argumentativeness was a vice which left the pleadings destitute of a precise issue on the face of the record. To put in issue the matter of fact asserted on one side, it was necessary for the other side to deny it in direct terms of denial; the statement of another fact from which it must be inferred that the fact responded to is untrue, was not sufficient. The direct denial following the inducement in the special traverse was an illustration of the rule requiring a formal issue on the record, and was a concession of the rule against argumentativeness. ${ }^{2}$

It is a branch of this rule that two affrmatives do not make a good issue. The reason is that the traverse attempted in the second affirmation is argumentative in its nature. ${ }^{3}$ Another branch of the rule against argumentativeness is that two negatives do not make a good issue. 4

SEc. 334. Rule IV. Pleadings must not be Hypothetical, or in the Alternative. ${ }^{5}$

Thus, in an action of debt against a jailer for escape of a prisoner, it was held that the defendant could not plead hypothetically that, if there has been an escape, there has also been a return. ${ }^{6}$

Sec. 335. Rule V. Pleadings must not be by Way of Recital, but must be Positive in their Form. ${ }^{7}$

The facts constituting the cause of action should as a general rule be alleged positively and directly, and not by way of recital or narration. When a deed is pleaded in support of a grant, the pleader should allege that the party granted, and not that it is witnessed in the deed that he granted. ${ }^{8}$

When the recital is by way of inducement introductory to some other direct allegation, it is not objectionable. ${ }^{9}$

SEc. 336. Rule VI. Things are to be pleaded according to their legal Effect or Operation. ${ }^{10}$

The meaning is that in stating an instrument or other matter in pleading it should be set forth, not according to its tenor, but according to its effeet in law; and the reason seems to be that it is under the latter aspect that it must principally and ultimately be considered; and therefore to plead it in terms or forms only is an indirect and circuitous method of allegation. ${ }^{11}$

1 Steph. Pl. 384.

2 Steph. Pl. 179.

3 Steph. 1'. 386.

4 Steph. Pl. 386.

5 Steph. Pl. 387.

6 Steph. Pl. 387.
7 Steph. Pl. 388.

8 Steph. Pl. 389.

- Steph. Pl. 389.

10 Steph. Pl. 387.

11 Steph. Pl. 390. 
The rule in question is in its terms often confined to deeds and conveyances. It extends, however, to all instruments in writing and contracts written or verbal; and indeed it may be said generally to all matters or transactions whatever which a party may have occasion to allege in pleading, and in which the form is distinguishable from the legal effect. ${ }^{1}$

An exception to the rule exists in the case of a declaration for written or verbal slander, where (as the action turns on the words themselves) the words themselves must be set forth; and it is not sufficient to allege that the defendant published a libel containing false and scandalous matter in substance as follows, \&c., or used words to the effect following, \&c. ${ }^{2}$

\section{SEC. 337. Rule VII. Pleadings should observe the known and ancient Forms or Expressions as contained in ap- proved Precedents. ${ }^{3}$}

It may be remarked, however, with respect to this rule, that the allegations to which it relates are of course only those of frequent and ordinary recurrence; and that even as to these it is rather of uncertain application, as it must be often doubtful whether a given form of expression has been so fixed by the course of precedents as to admit of no variation. ${ }^{4}$

SEC. 338. Rule VIII. Pleadings should have their proper formal Commencements and Conclusions. ${ }^{5}$

This rule is connected in some measure with the preceding one, and is apparently referable to the same object. ${ }^{6}$ This rule applied only to the commencement and conclusion of pleadings subsequent to the declaration. ${ }^{7}$ The commencement and conclusion have the effect of defining the class and character of the plea, as being either to the jurisdiction, in suspension, in abatement, or in bar. ${ }^{8}$ They have like effect in respect to the replication, serving to show whether the pleading be intended as in confession and avoidance or estoppel; and whether intended to be pleaded to the whole or to a part. ${ }^{9}$ The usual commencements and conclusions of pleadings have been considered in connection with the forms of pleas and replications.

1 Steph. Pl. 391.

2 Steph. Pl. 391.

3 Steph. Pl. 392; Dyster v. Battye, 3 Barn. \& Ald. 448; 3 Reeves, Hist. 463,464 .

4 Steph. Pl. 393.
5 Steph. Pl. 393

6 Steph. Pl. 393.

7 Steph. Pl. 394.

8 Steph. Pl. 405, 406.

9 Steph. Pl. 406. 
A restatement of them along with the changes effected by the Hilary rules of 1834 will be found in Mr. Stephen's exposition of this rule. ${ }^{1}$

SEc. 339. Rule IX. Pleading which is Bad in Part is Bad altogether. ${ }^{2}$

The meaning of this rule is, that, if any material part of a pleaking, or in reference to any of the material things which it undertakes to answer, or to either of the parties answering, the pleading be bad, though in other respects to be free from objection, the whole of it is open to demurrer; so that if the objection be good, the whole pleading is overruled, and judgment given accordingly. ${ }^{3}$

This rule applies only to material allegations; for where the objectionable matter is mere surplusage, and unnecessarily introduced (the answer being complete without it), its introduction does not vitiate the rest of the pleading. ${ }^{4}$

It is said that this rule results from Rule VIII., already considered, which requires each pleading to have its formal commencement and conclusion. For by those forms, it will be observed, the matter which any pleading contains is offered as an entire answer to the whole of that which last preceded. ${ }^{5}$ But as the declaration contains no commencement or conclusion of the kind to which Rule VIII. applies, so on the other hand the $d c c l a-$ ration does not fall within the rule now in question.

Therefore, if a declaration be good in part, though bad as to another part relating to a distinct demand divisible from the rest, and the defendant demur to the whole, instead of confining his demurrer to the faulty part only, the court will give judgment for the plaintiff. This result may happen in respect to a declaration consisting of a single count, but containing several demands or grounds of action divisible from each other, as two or more chattels in trover, or two or more breaches in covenant. ${ }^{6}$

1 Steph. Pl. 394, 407.

2 Steph. Pl. 407.

8 Steph. Pl. 407.

4 Steph. Pl. 409.
5 Steph. Pl. 408.

61 Saund. 286, n. 9 (ed. 1799); Powdick $v$. Lyon, 11 East, 565. 


\section{Article VII.}

Rules which tend to prevent Prolixity and Delay in Pleading. $\begin{aligned} & \text { Sec. 340. Rule I. There must be no De- } \\ & \text { parture in Pleading. }\end{aligned} \mid \begin{aligned} & \text { Sec. 341. Rule II. Where a Plea } \\ & \text { aimounts to the General Is- } \\ & \text { sue, it should be so Pleaded. }\end{aligned}$ Sec. 342. Rule III. Surplusage is to be avoided.

SEC. 340. Rule I. There must be no Departure in Pleading. ${ }^{1}$

A departure takes place when in any pleading the party deserts the ground that he took in his last antecedent pleading, and resorts to another. ${ }^{2}$ The rule is evidently necessary to prevent the retardation of the issue. For, if a new ground be taken in any part of the pleadings, a new state of facts is introduced, and the result is consequently postponed. ${ }^{3}$

A departure obviously can never take place till the replication, and it more frequently occurs in the rejoinder to the plea. ${ }^{4}$

It is also a departure if the pleader puts the same facts on a new ground in point of law; as if he relies on the effect of the common law in his declaration, and on a custom in his replication; or on the effect of the common law in his plea, and a statute in his rejoinder. ${ }^{5}$ When the declaration discloses an action in contract and the replication sounds in tort, there is a departure. ${ }^{6}$

No departure occurs when the subsequent pleading merely supports the preceding pleading of the same party. ${ }^{7}$ There is no such thing as a departure from an immaterial averment. ${ }^{8}$ Advantage of a departure could be taken on general demurrer.

SEc. 341. Rule II. Where a Plea amounts to the General Issue, it should be so Pleaded. ${ }^{9}$

The form, nature, and office of the general issue have been considered in preceding parts of this treatise, ${ }^{10}$ as also the existence and application of this rule, which need not be further noticed. The meaning of the rule is, that if, instead of traversing the dec-

1 Steph. Pl. 410.

2 Steph. Pl. 410.

3 Steph. Pl. 418.

4 Steph. PI. 411.

5 Steph. Pl. 413. 836 .

- Bartlett $v$. Wills, 1 Best \& Smith,

7 Mole $v$. Wallis, 1 Lev. 81.

8 Cole $v$. Hawkins, 1 Strange, 21; Steph. PI. 417.

9 Steph. Pl. 418.

10 Chapter XI. Art. II. 
laration in the compendious form of the general issue, the party pleads specially matter which is constructively and in effect the same as the general issue, such plea will be bad, and the general issue should be substituted. ${ }^{1}$ The true object of the rule was to avoid prolixity; and it assumed that the matter pleaded was sufficient in substance. ${ }^{2}$ A breach of the rule was more properly taken advantage of by motion to set aside the special plea and enter the general issue in place thereof; ${ }^{3}$ but according to some authorities a special demurrer might be employed for that purpose. ${ }^{4}$

\section{SEC. 342. Rule III. Surplusage is to be avoided.}

Surplusage in its large sense includes all unnecessary matter of whatsoever description. ${ }^{5}$ The greatest possible brevity consistent with the requisite certainty and precision is now considered as the perfection of pleading. ${ }^{6}$

The rule against surplusage may be considered in three aspects :-

1st. As preseribing the omission of matter wholly foreign.

2d. As preseribing the omission of matter which, though not wholly foreign, is not required to be stated by the pleader; such as matter of evidence, law, or anything which the court officially notices; also matter more properly coming from the other side, or necessarily implied in the statements made.

3d. As prescribing generally the cultivation of brevity or avoidance of prolixity in the manner of statement. A terse style is encouraged under this aspect of the rule, and is recommended by the best practitioners. ${ }^{\top}$

The vice of surplusage could not be reached by demurrer. ${ }^{8}$ It was usually corrected by motion made with the view of having tho redundant matter stricken out. ${ }^{9}$

1 Steph. Pl. 419.

5 Steph. Pl. 422.

2 Steph. Pl. 422.

- Steph. Pl. 422.

3 Steph. PI. 421; Gould, Pl. c. vi.

7 Steph. Pl. 424. s. 86,87 .

8 Steph. Pl. 424.

4 Gould, Pl. c. vi. s. 86,87 .

9 Steph. Pl, 424. 


\section{Article VIII.}

\section{Of Certain Miscellaneous Rules.}

Sec. 343. Prefatory.

" 344. Rule I. Declaration must conform with the Writ.

“ 345. Rule II. Declaration must have proper Commencement, and in its Conclusion lay Damages and Production of Suit.

" 346. Rule III. Pleas must be pleaded in due Order.

" 347. Rule IV. Pleas in Abatement - must give the Plaintiff a better Writ or Declaration.

" 348. Rule V. Dilatory Pleas must be pleaded at a Preliminary Stage of the Suit.

Sec. 349. Rule VI. All affirmative Pleadings which do not conclude to the Country must conclude with a Verification.

“ 350. Rule VII. Profert inust be made of a Deed alleged in the Pleading.

“ 351. Rule VIIİ. All Pleadings inust be properly entitled.

“ 352. Rule IX. All Pleadings must be True.

Sec. 353. Rule X. Which relates to Exceptions in Statutes and Contracts.

SEc. 343. Prefatory. The rules indicated under this head relate to the declaration and plea, or to pleading in general. Most of them have been considered already in previous parts of this work, and need not be noticed again except in a formal way. Such as have not been thus noticed will be explained briefly.

SEc. 344. Rule I. The Declaration must be conformable to the original Writ.

It usually contained in its commencement a brief recital of the original writ, or of its tenor. Anciently this was deemed a necessary requisite of a declaration; and although the rule ceased to be of any practical importance, declarations continued for a long time to be framed in conformity with the supposed original writ. ${ }^{1}$

The way in which the rule first became relaxed, or ceased to have effect, after the abolishment of the original writ, is explained in previous parts of the work, to which the student is referred. ${ }^{2}$

SEC. 345. Rule II. The Declaration should have its proper Commencement, and should in Conclusion lay Damages and allege Production of Suit.

As to commencement, see Sec. 31, and Stepl. Pl. 426, note 33, 34 .

As to conclusion and production of suit, see Sec. 33, and Steph. Pl. 428, 429 .

SEc. 346. Rule III. Pleas must be pleaded in due Order. The order as finally established was as follows:-

1. To the jurisdiction of the court.

1 Steph. Pl. 427.

2 Sec. 31. 252 ; see also notes 33 \& 34, Steph. Pl. 426. 
2. To the disability of the person of plaintiff.

3. To the disability of the person of defendant.

4. To the count or declaration.

5. To the writ.

6. To the action itself, in bar thereof. 1

SEc. 347. Rule IV. Pleas in Abatement must give the Plaintiff a better Writ or Declaration.

This rule required that the plea in abatement should correct the mistake or defect against which it was directed by suggesting how the writ or declaration should be framed. The rule was adopted to prevent a repetition of merely dilatory pleas which were discouraged. $^{2}$ This condition of requiring the defendant to suggest a better writ or declaration was often followed as a criterion to distinguish whether matter should be pleaded in abatement or bar. ${ }^{3}$

The student is referred to Sec. 246 in relation to this feature as applicable to pleas to the jurisdiction.

SEc. 348. Rule V. Dilatory Pleas must be pleaded at a Preliminary Stage of the Suit.

This rule is nothing more than a logical consequence of Rule III., which in prescribing the order of pleas implies that any of these pleas is accepted as waiving all pleas of a kind prior in the series. ${ }^{4}$

After oyer, which is a preliminary step to a plea in bar, and after a plea in bar a dilatory plea is out of place..$^{5}$

SEC. 349. Rule VI. All affirmative Pleadings which do not conclude to the Country must conclude with a Verification. .

In explanation of this rule, it is sufficient to say that, according to the doctrine of the ancient law, every pleading aftirmative in its nature was required to be supported by an offer of some mode of proof; which offer went by the name of verification; and the reference to a jury, who were originally in the nature of witnesses to the fact in issue, was considered as an offer of proof, within the meaning of the doctrine. ${ }^{6}$

When the proof proposed was that by jury, the offer originally made viva voce in Norman French was, after translation into Latin, entered in the record as "et hoc paratus est verificare" (and this he is prepared to verify).

When other modes of proof were intended, the offer alluded to

1 Steph. Pl. 430, 431.

+ Steph. Pl. 431.

2 Steph. Pl. 432.

5 Steph. Pl. 433.

3 Steph. Pl. 432.

6 Steph. Pl. 435. 
them, or was made broadly so as to invite other modes of proof than by jury.

While these were the forms generally observed, there was a well defined exception, viz. that on the attainment of an issue to be tried by jury, the pleadings marked that result by a change of phrase, and substituted for the verification a conclusion praying that the truth of the issue might be inquired of by the country, - meaning a jury of the country. ${ }^{1}$ This exception prevailed as a rule in all cases in which an issue is tendered to be tried by a jury. ${ }^{2}$ If the issue was tendered by the defendant the offer was contained in the phrase "and of this the defendant puts himself upon the country." 3

Thus it is seen that all affirmative pleadings must conclude either with a verification or to the country, - the latter conclusion being employed when an issue was reached. ${ }^{4}$

This rule requiring verification applied only to affirmative pleadings. If the pleading was merely negative in its nature, no verification was necessary. But it was customary to conclude with a verification all negative as well as affirmative pleadings that do not conclude to the country.

While the rule has no longer any value or meaning as regards the object it originally proposed, it remains as a rule of form serving to mark whether the pleading was intended to make a tender of issue. ${ }^{5}$

SEC. 350. Rule VII. In all Pleadings where a Deed is alleged, under which the Party claims or justifies, Profert of such Deed must be made. ${ }^{6}$

The existence, application, and qualification of this rule have been expressed in connection with the doctrine of profert. ${ }^{7}$

SEC. 351. Rule VIII. All Pleadings must be properly entitled. ${ }^{8}$

This rule has been considered in our treatment of the entitlement of the declaration. ${ }^{9}$

SEC 352. Rule IX. All Pleadings ought to be true. ${ }^{10}$

This rule would seem to be a cautionary direction against falsehood and fraud. A violation of it was denounced as sham pleading.

1 Steph. Pl. 435.

2 Steph. Pl. 230.

3 Steph. Pl. 230, 231.

4 Steph. Pl. 435.

Steph. Pl. 436.
- Steph. Pl. 436.

7 Chapter I. Art. IX.

8 Steph PI. 441.

9 Sec 29.

10 Steph. Pl. 441. 
The temptation to resort to it consisted in the delay achieved by the pleader. Not having a true plea or defence, he made use of a false one which was expected to serve the purpose of a true one until the trial. In the ordinary course of things the falsity of the plea would not become apparent to the court until trial, and when that day came, the purpose of the plea had been accomplished.

The practice of sham pleading was discouraged in some cases, both by statute and rules of court requiring affidavits and particularity of statement. ${ }^{1}$

The court, of course, has the inherent power in all cases to censure and punish for sham pleading. But some difficulty is met with in ascertaining the utter falsity of a plea before the issue is tried.

But when it can be clearly inferred from the improbable matter of the plea, and the frame of it, that it is pleaded for a dilatory purpose, it was the practice of the court, on motion supported by affidavit of its falsehood, to allow judgment to be signed as for want of a plea, and to make the defendant or his attorney pay the costs.

A well settled exception to the rule was recognized in the employment of certain recognized fictions inhering in the ancient forms which the pleader was justified in using, such as the finding in trover and the demise in ejectment. ${ }^{2}$

SEc. 353. Rule X. Relating to Exceptions in Statutes and Contracts:- If a statute or contract contains a general clause and afterwards a separate and distinct clause relating to matter which otherwise would be included in the general clause, a party relying upon the general clause in pleading may set out that clause only, without noticing the separate and distinct clause which operates as an exception. But if the exception itself be incorporated in the general clause, then the party relying upon the general clause must, in pleading, state it with the exception, and show that the opposite party is not within the exception. ${ }^{3}$

The foregoing rule has not been included in Mr. Stephen's collection of miscellaneous rules, although it perhaps may be deduced from one of his subordinate rules of a more general application. ${ }^{4}$

14 Anne, c. 16, s. 11; Rule Hil. 4 Axen, 1 Ld. Raym. 119 ; Spieres $v$. Wm. IV.

2 Steph. Pl. 443.

Parker, 1 T. R. 141; Vavasour $v$.

31 Chit. Pl. 223, 224; Jones $v$ Ormrod, 6 B. \& C. 430.

4 Steph. Pl. 350-352. 
It is, however, well settled in the adjudications, and has met with the recognition and approval of Mr. Chitty and other authors. On account of the great length and increased number of conditions and provisos of modern statutes and contracts, the rule is believed to be more important than formerly.

It relieves the pleader from encumbering his pleading with conditions, provisos, and qualifications which do not constitute any essential or descriptive part of his prima facie case or defence.

In like manner, if the law raises an exception to a general right it need not be stated in pleading. ${ }^{1}$

The same necessity exists for noticing and negativing an exception when it is made a part of the general clause by reference, as when it is expressly incorporated in the language of that clause. ${ }^{2}$

11 Chit. Pl. 224 ; Cro. Eliz. 485 ; Carrett $v$. Smallpage, 9 East, 330, 339. 430.

${ }^{2}$ Vavasour $v$. Ormrod, 6 B. \& C. 


\section{CHAPTER XIV.}

\section{TRIAL, VERDICT, JUDGMENT, AND EXECUTION.}

Article I. Trial.

" II. Verdict. $\mid \begin{aligned} & \text { Article III. Judgment. } \\ & \text { " IV. Execution. }\end{aligned}$

\section{ARticle I.}

\section{Trial.}

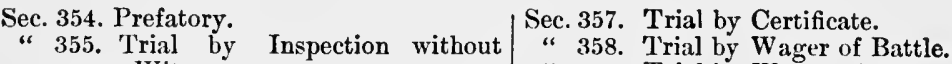

Wituesses. “ 356. Trial by Witnesses without “ 360 . Trial by Record.
Jury.

Sec. 362. Trial by Jury ordinary.

SEc. 354. Prefatory. There were seven modes of trial at common law, all of which except two have either been abolished or become obsolete. Those modes which no longer exist will be first noticed, and dismissed with brief explanation.

SEC. 355. Trial by Inspection of the Judges, without the Assistance of Witnesses. Cestain facts were regarded in the common law as susceptible of so easy and speedy determination by ocular inspection of the judges and personal examination, that it was not deemed necessary to refer them to a jury; - facts, such as nonage or infancy of a party to a record; the existence and identity of a party plaintiff to a suit alleged by defendant to be dead; calendar of dates of events ; appeals of mayhem, \&c. ${ }^{1}$ The matter in dispute, being the object of sight, was decided by the judges upon the evidence of their senses.

The parties might, by consent, refer the question to a jury. ${ }^{2}$ If the judges after inspection were in doubt on the facts, they had the discretion of taking proof, or of sending the parties to a trial by jury. ${ }^{3}$ This form of trial passed out of use after the abolishment of real actions.

13 Bl. Com. 330.

83 Bl. Com. 331.

2 Bac. Abr. Infancy, L. 10. 


\section{SEC. 356. Trial by Witnesses without the Intervention of}

a Jury. This mode of trial, in which the judge determines the fact upon the credit of witnesses, was permitted in only a few cases, as in a writ of dower when the tenant pleads that the husband is not dead. Being regarded in the nature of a dilatory plea, it was allowed to be tried in this mode. In a real action the pretence that the defendant was not duly summoned was disposed of in the same manner. The same was true in respect to the validity of a challenge to a juror. ${ }^{1}$ This was the method of trial which prevailed in the civil law, and in Chancery, where the testimony of the witnesses was read from their depositions, but which until in recent times has not prevailed in the courts at common law, except in the disposition of motions and objections incidental or consequent to the trial of the main issues. When exercised by the judges in modern times in trial of the main issues of an action at law, it is invariably with the consent of the parties, upon waiver of jury trial.

SEc. 357. Trial by Certificate. Trial by certificate was allowed in a few cases, in which the evidence of the person giving the certificate was regarded as the only proper criterion of the fact in dispute. ${ }^{2}$ Such as the fact of a person's presence in the army outside of the realm, proved by certificate of the marshal ; imprisonment in a foreign town under English control, proved by certificate of the mayor; citizenship of London proved by certificate of the sheriff; marriage, excommunication, general bastardy, and orders proved by certificate of the bishop; customs and practice of courts, proved by certificate of the proper officers thereof. ${ }^{3}$

SEC. 358. Trial by Wager of Battle. In this primitive mode of trial the issue was determined by personal combat between the champions of the respective parties, which transpired in the presence and under the supervision of the judges, who gave judgment in accordance with the result of the combat. In civil cases it was confined to trials of the writ of right, and was the only mode of trial in such cases, until the trial by grand assize was introduced in the reign of Henry II., a peculiar species of trial by jury, after which the tenant had his choice of the one or the other. ${ }^{4}$ Trial by wager of battle fell into general disuse, but was not expressly abolished till the passage of the statute of 59 Geo. III. c. $46 .^{5}$

$13 \mathrm{Bl}$. Com. 336.

$23 \mathrm{Bl}$. Com. 333.

$33 \mathrm{Bl}$. Com. 336.
43 Bl. Com. 341.

5 Ashford $v$. Thornton, 1 B. \& Ald. 405. 
SEc. 359. Trial by Wager of Law. In a trial by wager of law, the defendant appeared in court, and brought with him eleven of his neighbors, who were called compurgators. He took an oath that he did not owe the debt or detain the goods sued for. Upon his eleven compurgators taking an oath to the effect that they believed him, he was entitled to judgment as upon the verdict of a jury in his favor. ${ }^{1}$ So long as the custom of producing the secta or suit or witnesses to give probability to the plaintiff"s demand continued, the defendant was not put to wage his law unless the secta was first produced and their testimony was foumd consistent. ${ }^{2}$

This mode of trial was admitted only where an action was brought for the enforcement of a liability, which the defendant may be reasonably supposed to have voluntarily assumed and discharged, without being able to prove it. It therefore could be invoked in debt on simple contract, and in detinue, which anciently originated in a voluntary bailment, and in account. It seems to have been permitted in a real action where the tenant alleges that he was not legally summoned to appear. ${ }^{3}$ It fell into general disuse by resort to forms of action in which it could not be invoked. It was expressly abolished by statute in the reign of William IV. ${ }^{4}$

SEc. 360. Trial by Record. When a matter of record was pleaded as a ground of recovery in an action, or as a defence in a plea, if the opposite party desired to dispute the existence of the record, he did this by a plea of nul tiel record, by which he averred that there was no such record. He tendered issue on this averment, praying verification instead of putting himself on the country. The opposite party was compelled to accept the issue, which he did in his replication by reaffirming that there was such a record, and offering to verify his affirmation by a certain record of the court of a certain term and roll, and praying that the term and roll aforesaid may be seen and inspected by the court. Joinder in issue followed. Upon production of this issue, the court rendered an interlocutory order giving a certain day to the parties to hear the judgment of the court thereon.

If the record was of another court, the party relying on it was commanded in the interlocutory order to produce it, or a certificate of

13 Bl. Com. 343.

23 Bl. Com. 344.

83 Bl. Com. 345.
43 \& 4 Wm. IV. c. 42 ; King $v$. Williams, 2 B. \& C. 538. 
the tenor thereof, at the time fixed for the hearing. ${ }^{1}$ Whether the record was of the same court or produced from another, the court entertaining the plea determined the issue by comparing the record with the statement of the plea, and gave judgment accordingly. It may be added that nothing complied with the meaning of the term record except the record of a court of justice. No other mode of trial of this issue was permitted at common law, and it may be said to prevail in modern times.

In designating this as a trial by record, the old writers made use of a misleading phrase. The trial was in reality a trial by the judges, and the record constituted the kind of evidence upon which they decided the issue. The judges, and not the record, tried the issue. The mode of trial received its name rather awkwardly from the manner of proof. ${ }^{2}$

The same criticism applies to trials by inspection, by witnesses, and by certificate. These were all trials by the judges upon the evidence submitted to them, and are improperly classed as different modes of trial, so far at least as the triers of the issue are concerned.

SEc. 361. Trial by Jury extraordinary. Trials by jury in civil causes were of two kinds, - extraordinary and ordinary.

The extraordinary trial by jury is that of the grand assize, which was instituted by Henry II. in Parliament by way of alternative to trial by battle in determining the mise (issue) in a writ of right. The grand assize in trials under the writ of right consisted of at least sixteen knights of the county, and might contain twenty-four or more. ${ }^{3}$ This mode of trial fell into disuse along with the real actions in which it was employed, and was expressly abolished in the reign of William IV.

Another species of extraordinary trial by jury was conducted before a jury of twenty-four of the best men of the county, which was known as the grand jury of attaint, to distingnish it from the ordinary jury of twelve men. This trial lay to inquire whether a jury of twelve men had given a false verdict, so that the judgment following thereupon might be reversed. It lay at common law only upon writs of assize.

This tribunal must be distinguished from the grand assize, which was used in trying the issue of mere right in a writ of right.

12 Tidd, Pr. 745 ; Tidd's Appendix, 302 (ed. 1819).

24 Minor, Inst. 922. Martin Civil Procedure-20 s 3 Bl. Com. 351 ; Bl. Com. Appendix, No. 1; Booth, 92 note, 96.

$43 \& 4$ Wm. IV. c. 42 , s. 16. 
In proceedings of attaint, this grand assize was said to be turned into an inquest or jury; that is, that the issue should be tried by them as by a common jury of inquest, and not by them as recognitors of assize. The effect of their verdict was to reverse the verdict of the previous jury, and to punish the jurors with forfeitures and fines.

By statutes passed at different times the remedy was extended to all pleas whatsoever, except pleas to the writ of right, in which the mise or issue was joined on the mere right. ${ }^{1}$

The practice of setting aside verdicts upon motion, and granting new trials, so far superseded proceedings in attaint that few instances of them appear later than the sixteenth century.

SEc. 362. Trials by Jury ordinary. The ordinary jury for the trial of civil causes which has come down to modern times consisted of twelve men of the county in which the cause of action was supposed to have arisen.

The process for furnishing this tribunal varied at different times, and by reason of the statutes and rictions and practice of the courts it involves so much complexity that a brief sketch thereof cannot fail to be of material assistance to the student.

Anciently the trial of all causes commenced in the Superior Courts was held before the bar of the court in which they were commenced, wherever the court might be sitting. The jury was brought before the court from the county in which the venue was laid by a writ of venire facias juratores. ${ }^{2}$ Originally only actions of weight and importance were brought in the Superior Courts, all trifling suits being disposed of in the Court Baron, hundred, or county court. But when, on account of the more certain and perfect administration of justice in the Superior Courts, the usage began of bringing actions of a trifling nature and amount in those courts, it was found to be an intolerable burden to compel the parties, witnesses, aud jurors to attend the trial from a distant county. Accordingly, a practice grew up at a very early day of continuing such causes from term to term in the court above, provided the Justices in Eyre did not come into the county where the cause of action arose; and if it appeared that they arrived there during the continuance, the whole cause was removed from the jurisdiction of the Superior Court to that of the Justices in Eyre. ${ }^{3}$

11 Edw. I. c. $38 ; 1$ Edw. III. c. 6 ; 5 Edw. III. c. 7 ; 28 Edw. III. c. 8 ; 34 Edw. III. c. 7.
2 Smith, Ac. 248.

3 Bract. c. 11, s. 8 ; 2 'Tidd, Pr. 747. 
When the Court of Common Pleas had become stationary at Westminster Hall, by virtue of Magna Charta (1215), the practice of conducting trials before the bar of the court in cases which could not be properly removed therefrom was fraught with much hardship to the parties, witnesses, and jurors whose attendance was necessary. ${ }^{1}$ This hardship led to the statute of $13 \mathrm{Edw}$. I. c. 30, by which the power was conferred upon the justices of assize, who had superseded the Justices in Eyre, to try common issues in trespass and other less important suits, with directions to return them when tried into the court above, where alone judgment couid be rendered. As only the trial, and not the determination of the whole case, was now intended to be had in the lower court, the clause of nisi prius was left out of the conditional continuances, and was directed by the statute to be inserted in the writs of venire facias, that is, "that the sheriff should cause the jurors to come to Westminster (or wherever the King's courts should be held) on such a day in Easter and Michælmas terms (nisi prius), unless before that day the justices assigned to take assizes shall come into his said county." As the justices in assize were certain to come into the county before the return day of the writ in the upper court, the sheriff by virtue of the statute summoned the jurors to appear in the court of the judges of assize, and there the trial was had during vacation of the upper court. This statute was commonly designated as the statute of nisi prius, and the same name was given to the trials had in pursuance of it before the justices of assize.

An inconvenience attended the practice under the statute, arising principally from the fact that the sheriff made no return of the jury to the upper court, by reason of which the parties remained ignorant of the names of the jurors until they were called at the trial, and were not ready with their challenges or exceptions. This inconvenience led to the statute of $42 \mathrm{Edw}$. III. c. 11, by which the method of trials at nisi prius was altered; and it was enacted that no inquest (except of assize and jail delivery) should be taken by writ of nisi prius till after the sheriff had returned the names of the jurors to the court above.

To carry out the intention of the statute and to bring the issue to a speedy trial, the practice of the courts was changed. The clause of nisi prius was dropped out of the writ entirely, and a writ was

1 Smith, Ac. 121. 
issued commanding the sheriff to cause the jury to appear in the upper court at the last return day of the term at which the issue was joined. This venire facias was like the one used before the statute. The sheriff in compliance with the statute returned the names of the jury only on a panel annexed to the writ, purposely failing to summon them; and the court, assuming fictitiously that the jurors were in default, made an entry of record to the effect that the jury was respited through the defect of the jurors till the first day of the next term, then to appear at Westminster unless before that time, viz. on a day fixed, the justices appointed to take assizes in that county shall have come to the place assigned for holding assizes. Thereupon the court issued compulsory process against the same jurors, which took the form of a writ of distringas in the King's Bench and a writ of habeas corpora juratorum in the Common Pleas. In the first mentioned writ, the sheriff was commanded to distrain the jurors by their lands and goods, so as to compel their appearance at the subsequent day, either before the court itself, or before the judges of assize, if they should previously come to sit in the county.

The writ in the Common Pleas run to the same effect, except that it commanded the sheriff to have the bodies of the jurors there. ${ }^{1}$ It may be observed that the precise phrase of nisi prius is not used in these writs, but that they contain alternative commands which have the same effect. ${ }^{2}$ As the judges of assize were certain to come, the sheriff, in obedience to the writs, returned the jury to appear before them where the trial of the issue is had. Among the judges of assize were usually two judges of the courts at Westminster. It is thus seen that two distinct writs were required to furnish a jury in the trial at nisi prius, the venire facius, and either the distringas or habeas corpora, although nothing was done under the first writ. To enable the judges of assize to try the issue intelligently, a record was made in the court above and transmitted to the court below, reciting the pleadings, the respite of the jury, and award of compulsory process, which was known in practice as the nisi prius record. ${ }^{3}$

In jury trials at nisi prius, or before the bar of the court, the testimony of all witnesses was submitted viva voce in the presence of the jury. The parties and all interested in the event of the suit, were disqualified to act as witnesses.

1 Steph. Pl. 80.

${ }^{3}$ Steph. Pl. 78, 79.

2 Smith, Ac. 250, 251. 
While trial by the judge without a jury has come to be the normal mode of trial in England, the right of either party to a jury is still preserved in purely common law actions. ${ }^{1}$

In the United States the right of trial by jury as used in common law actions has been preserved by a provision to that effect in the Federal Constitution and most of the State Constitutions. Able and exhaustive historical statements of the origin and development of trial by jury will be found in the Harvard Law Review. ${ }^{2}$

\section{Article II.}

\section{Verdict.}

Sec. 363. Form and Tenor.

" 364. Variance.

“ 365. Demurrer to Evidence.

“ 366. Special Verdict.

“ 367. Special Case.

Sec. 372. Motion for Repleader.

Sec. 368. Exceptions.

“ 369. Motion for New Trial.

“ 370. Motion in Arrest.

“ 371. Motion for Judginent non obstante veredicto.

SEc. 363. Form and Tenor. The verdict must be responsive to the issue submitted for trial. It is usually in general terms "for the plaintiff," or "for the defendant." When for the plaintiff, it contains a finding of the amount of damages to which they think him entitled, when damages are claimed in the action. When separate and distinct issues are submitted for trial, there should be a finding on each one of them. The jurors must all agree to the verdict; and after it was rendered it was entered on the back of the nisi prius record and was called the postea, from the name in Latin with which the recital began. ${ }^{3}$

SEc. 364. Variance. It' was incumbent on the party upon whom the burden of proof rested to establish the substance of the issue in his favor by competent evidence to that effect. If there was a total 'failure of proof, it was the duty of the jury to find the issue in favor of the opposite party. When there was a disagreement or discrepancy between the allegations of the issue and the proof in some particular point or points only, the disagreement was called a variance. Such variance was at common law as fatal to the party on "whom the proof lies as a total failure of evidence, the jury being bound upon variance to find the issue against him. (1883.)

1 Regulations 2-7; Order 36. Thayer; 10 Harv. Law Rev. 150,
25 Harv. Law Rev. 249, 295, 357, ${ }^{3}$ Steph. Pl. 87. 
The serious consequences of a variance at common law have been greatly obviated in modern times by statutes allowing amendment of the pleadings at the trial in cases where the variance is not material to the merits of the cause, and where there is no reason to believe that the opposite party has been prejudiced by the mistake. ${ }^{1}$

SEC. 365 Demurrer to Evidence. When a party disputed the legal effect of evidence offered, he was at liberty to demur to the evidence, which was analogous to a demurrer in pleading. Upon joinder in this demurrer by the opposite party, the jury was generally discharged absolutely or conditionally ; and the demurrer, being entered of record, was argued and decided in the court in bank. As to the nature, tenor, and consequences of a demurrer to evidence, the student is referred to a fuller statement, following our treatment of the subject of demurrer in the pleadings. ${ }^{2}$

ScE. 366. Special Verdict. Another and more common course to determine the legal effect of the evidence was to obtain from the jury a special verdict in lieu of the general one which has been described. ${ }^{3}$

The jury have an option, instead of finding the negative or affirmative of the issue as in a general verdict, to find all the facts of the case as contained in the evidence before them, and after so setting them forth to conclude to the following effect: "that they are ignorant in point of law on which side they ought upon these facts to find the issue; that, if upon the whole matter the court shall be of opinion that the issue is proved for the plaintiff, they find for the plaintiff accordingly, and assess the damages at (a stated sum); but if the court is of an opposite opinion, then vice versa." 4 After the jury has found the facts, the form of verdict is adjusted by the court without further interference of the jury, and is entered of record. ${ }^{5}$ If the decision of the judges is not satisfactory to the losing party, he is at liberty to prosecute a writ of error. Whether the jury shall render a general or special verdict is entirely within the discretion of the jury; and the party asking for a special verdict may be driven to a demurrer to the evidence if he wishes to put his objection on record for the purpose of a writ of error.

SEC. 367. Special Case. If, however, the objecting party does

1 Steph. Pl. 86.

2 See Sec. 242.

8 Steph. Pl. 91.
4 Steph. PI. 91.

5 Steph. Pl. 91. 
not wish to put the legal question raised by his objection on record with a view to a writ of error, but desires merely to obtain the decision of the court in bank, he may omit demurring to evidence or asking for a special verdict, but submit to a general verdict subject to a special case; that is, to a written statement of all the facts of the case, drawn up for the opinion of the court in bank by the counsel and attorneys on either side, under direction of the judge at nisi prius, according to the principle of a special verdict, as just explained. The party for whom the general verdict is so given is of course not entitled to judgment till the court in bank has decided on the special case; and according to the result of that decision the verdict is ultimately entered either for him or his adversary. ${ }^{1}$ A special case is not like a special verdict entered on record; and consequently a writ of error cannot be brought on this decision. ${ }^{2}$ The settlement of the facts of a special case depends upon the agreement of the counsel of the respective parties. If they fail to agree on the facts no special case can be certified to the court in bank. ${ }^{3}$

SCE. 368. Exceptions. In the progress of a trial it is the province of the judge to decide on the admissibility of evidence, and on its legal effect, when objection is taken by either of the parties. If either of the parties is dissatisfied with the decision, and is content to refer it to the Superior Court in which the issue was joined, he is at liberty to do so by means of a motion for a new trial, which will be presently considered. But if he desires to obtain the revision of some court of appellate jurisdiction, it is necessary that the question of law be put on record in accordance with the provisions of an early statute $;^{4}$ and this is done pending the trial by means of a bill of exceptions, that is, a statement in writing of the objection to the decision, to which statement, if truly made and tendered to the judge, he is bound to set his seal in confirmation of its accuracy. The allowance and sealing of the bill make it a part of the record in the cause for use only in the appellate court. $^{5}$ The cause then proceeds to verdict as usual, and the opposite party for whom the verdict is given is entitled as in the common course to judgment upon such verdict in the court in bank, for that court takes no notice of the bill of exceptions. ${ }^{6}$ But after

1 Steph. Pl. 93.

2 Steph. Pl. 93.

3 \& 4 Wm. IV. c. 42 , s. 25.
4 Westm. II., 13 Edw. I. c. 31.

52 'Tidd, Pr. 864, 8€̋.

5 Steph. Pl. 89. 
judgment the whole record is removed into the appellate court by writ of error, where the questions disclosed in the bill of exceptions are reviewed and decided by the latter court.

SEc. 369. Motion for New Trial. If, however, the objecting and defeated party is content with a review of the disputed points by the same court in which the issue was joined, he may after verdict bring them to its attention by a motion for a new trial. He may likewise make this motion when he thinks the evidence against him is not sufficient in law to justify the verdict, even where no adverse opinion has been expressed by the judge. This motion in a case sent below for trial is made in the Superior Court within four days after the return of the record there. If in a case tried at bar, it should be made within four days from the date of the trial; it being the practice of the upper court, in which only the judgment can be rendered on the verdict, to hold up the entry of judgment during that time, and until the disposition of the motion. ${ }^{1}$ It is not within the scope of this treatise to consider in full the grounds upon which a motion for a new trial will lie. When the ground of the motion does not appear of record, it was usual to establish it by affidavits. A motion for a venire facias de novo, which lies when by reason of some irregularity or defect in the practical course of proceedings on the first venire or the trial, rather than on the merits, the proper effect of that writ has been frustrated or the verdict become void in law, is in substance a motion for a new trial, and is properly classed with such motions. ${ }^{2}$

SEC. 370. Motion in Arrest of Judgment. This motion differs distinctively from a motion for a new trial, although, like that motion, it must be made in the court in which the issue was joined and within the same period of time. It was only an unsuccessful defendant who could make the motion. It was in form a motion that the judgment for the plaintiff be arrested or withheld, on the ground that some error appeared on the face of the record which vitiated the proceedings culminating in the verdict. It was necessary that the error should be manifest on the face of the record, and that it should be (after passage of the statutes of amendments and jeofails) an error in the substance of the proceedings, and not in the form. ${ }^{3}$ For a full consideration of the nature and scope of

1 Steph. Pl. 94.

3 Steph. Pl. 96.

2 Steph. Pl. 100. 
this motion, which is involved in the law of pleading as well as in that of practice, the reader is referred to Steph. Pl. 97, note 7, Second Appendix by Mr. Heard; and to Gould's Pl., c. x.

SEC. 371. Motion for Judgment non obstante veredicto. This motion was always made by the plaintiff, and nearly always when the verdict was for the defendant. It was a motion that the court in which the issue was joined should render judgment in favor of plaintiff without regard to the verdict obtained by defendant. It was made in cases where, after a pleading by the defendant in confession and avoidance, as, for example, a plea in bar and issue joined thereon, and verdict found for the defendant, the plaintiff, on retrospective examination of the record, conceives that such plea was bad in substance, and might have been made the subject of demurrer on that ground. 1 If the plea was substantially bad in law, the verdict, which merely shows it to be true in fact, could not justify a judgment in defeudant's favor, while on the other hand the plea, being in confession and avoidance, involves a confession of the plaintiff's declaration, and shows that he was entitled to maintain his action. ${ }^{2}$ In other words, the matter of the plea in defence is bad, while the confession which it implies is good; and for that reason the plaintiff on the face of the record is entitled to judgment as upon confession. In such case the court gave judgment for plaintiff without regard to the verdict. It was also called a judgment as upon confession. ${ }^{3}$

Sometimes it is expedient for the plaintiff to move for judgment non obstante veredicto, even though the judgment be in his favor; for if, when the matter of defence in the plea of confession and avoidance is bad, he takes judgment as upon the verdict, it has been held that such judgment would be erroneous, and that the only safe course is to take it as upon confession, - that is, on the pleadings, and not on the verdict. In such case the verdict is ignored in like manner as if it was against him.

SEC. 372. Motion for a Repleader. This motion may be made by the unsuccessful party, whether plaintiff or defendant, when he conceives that the issue joined was an immaterial issue, that is, not taken on a point proper to decide the action. ${ }^{5}$

Either of the parties may, from misapprehension of law or over-

1 Steph. Pl. 97.

2 Steph. Pl. 98.

8 Steph. Pl. 98.
4 Steph. Pl. 98.

5 Steph. Pl. 98. 
sight, have passed over without demurrer a statement on the other side insufficient and immaterial in law; and an issue of fact may have been ultimately joined on such immaterial statement; and so the issue will be immaterial, though the parties have made it the point in controversy between them. ${ }^{1}$

It is obvious that this result might often happen in a system of pleading which required the parties to eliminate from their controversy all material issues except one.

If the issue joined be on a fact immaterial to the decision of the action, it is evident that, whether this issue be found for the plaintiff or the defendant, it will remain equally uncertain whether the plaintiff is entitled or not to maintain his action. In such case, therefore, the court, not knowing for whom to give judgment, will award a repleader, that is, will order the parties to plead de novo for the purpose of obtaining a better issue. ${ }^{2}$

It was a well settled rule that a repleader will not be awarded except when complete justice cannot be otherwise obtained.

Although joinder may have been taken on an immaterial issue, yet a repleader will not be awarded if it appear from the record that, had the pleadings been correct, the decision must nevertheless be the same. ${ }^{3}$

\section{ARTICLE III.}

\section{Judgment.}

Sec. 373. Prefatory.

“ 374. Defined.

“ 375. Interlocutory Judgments.

“ 376. Final Judgments.
Sec. 377. Signing and Enrolment.

" 378. Audita Querela.

“ 379. Writs of Error.

" 380. Writs of Error, continued.

SEc. 373. Prefatory. In discussing the nature of the different actions and defences, it has been necessary to consider in connection with them the kinds of judgment applicable to or resulting from them; and therefore it is believed that it will be sufficient in this place to enumerate and briefly define the various kinds of judgments, and to explain more fully the features common to final judgments in ordinary actions at common law.

SEc. 374. Defined. In defining a judgment the authors and jurists of ancient times affected to represent it as the determination

1 Steph. Pl. 99.

2 Steph. Pl. 100.

3 For the law governing repleader, see 4 Minor, Inst. 774 ; Gould, Pl.

c. x. s. $29-32,36-42,47-52$. 
and sentence of the law, and not the determination or sentence of the judge pronouncing it, ${ }^{1}$ believing that it would more effectually command the obedience of suitors and the approbation of the com. munity if it was regarded as the act of the law, which was acknowledged to be binding on all, rather than the act of judges, who were known to be fallible like other men. Accordingly, we find this representation embodied, not only in the ancient definition of a judgment, but also in the style and form of it. "Judgments are the sentence of the law, pronounced by the court upon the matter contained in the record." 2 "Judgment is the conclusion of law upon facts found or admitted by the parties, or upon their default in the course of the suit." 3

In the style of the ancient judgment, all mention of it or the action of the judges is avoided; it is not decreed or resolved by the court, but it " $i$ s considered by the court" (consideratum est per curiam) that the plaintiff do recover his damages, his debt, his possession, and the like; which implies that the judgment is none of their own, but the act of law, pronounced and declared by the court. ${ }^{4}$

It is needless to remark that this view of the nature of a judgment is not strictly accurate; if it were, there never could be an erroneous judgment. In consequence of this, the old definition has undergone a slight modification in modern times. A judgment is the official and authentic decision of a court of justice upon the respective rights and claims of the parties to an action or suit therein litigated and submitted to its determination. ${ }^{5}$

This definition represents what is commonly meant by the word judgrnent when it is used without any qualifying terms, that is, a final judgment. The fact that it is often used as applying to decisions which determine rights of the parties upon pleadings and issues before final disposition of the case, or disposition on trial of its merits, furnishes the ground for dividing judgments into two general classes, viz. interlocutory judgments and final judgrnents.

SEC. 375. Interlocutory Judgments. An interlocutory judgment is one given in the progress of a cause upon some plea, proceeding, or default, which is only intermediate, and does not finally determine or complete the suit. ${ }^{6}$ This definition includes what

13 Bl. Com. 396.

23 Bl. Com. 395.

82 Tidd, Pr. 930.

3 Bl. Com. 396.
- Black's Dict. Judgment ; Whitwell $v$. Emory, 3 Mich. 84, 88 .

6 3 bl. Com. 396. 
may be called interlocutory judgments proper; that is, judgments which dispose of issues but do not terminate the suit, as in subdivision 9 of this section. The term has also been applied to judgments occurring in the progress of the cause which terminate the suit, without reaching the trial of an issue on the merits, as in the other subdivisions. There is quite a variety of these judgments, some rendered before issue joined, some after issue joined and before trial of issue, and others after trial of issue.

They are as follows:-

1. Judgment by Default of Appearance. In a real (though not in a personal) action, if the defendant fails to appear after service of process, judgment of default may be given against him for his default, and the plaintiff was awarded recovery of the estate sued for. ${ }^{1}$ In personal actions judgment on the merits could not be given upon default of appearance in ancient times. When such judgments came to be given in personal actions, they were interlocutory in the first instance, and the court or jury at the same time or afterwards, according to the nature of the demand, assessed the damages for a final judgment of recovery. ${ }^{2}$

2. Judgment by nil dicit. In actions real, mixed, or personal, if after appearance, the defendant neither pleads nor demurs; or if after plea, he fails to maintain his pleading till issue joined, by rejoinder, rebutter, \&c., judgment will be given against him for want of a plea, which is called judgment by nil dicit. The same judgment of recovery follows as in case of a default of appearance. ${ }^{3}$

3. Judgment by non sum informatus. If instead of a plea, defendant's attorney says he is not informed of any auswer to be given to the action, judgment will be given against him, which is called judgment by non sum informatus; and includes or is followed with a judgment of recovery as in defaults. ${ }^{4}$

4. Judgment by Confession. Instead of a plea the defendant may choose to confess the action, or after pleading he may at any time before trial confess the action and withdraw his plea or other allegations; and the judgment against him in either case is called a judgment by confession. In the latter case, it is said to be by confession relicta verificatione. ${ }^{5}$ Final judgment of recovery follows.

1 Booth, 232.

2 See judgment in debt, sec. 44.

3 Steph. Pl. 108.
4 Steph. Pl. 108.

- Steph. Pl. 108. 
5. Judgment of non prosequitur. This judgment may be given against the plaintiff in any class of actions for not declaring, or replying, or surrejoining within the period of time allotted to him for that purpose by the law or rules of the court. ${ }^{1}$ The effect of such judgment is to abate the suit.

6. Judgment of nolle prosequi. This judgnent is entered against the plaintiff when he does not merely neglect to plead, but when without previous failure in that respect he appears and declares that he will not further prosecute his suit. Upon this declaration being made, an entry is made on the roll in the nature of a judgment of a direction that all further proceedings be stayed, which was called a stet processus; that is, that the process may stand. If he declares that he withdraws his suit, the judgment is called a judgment of retraxit. If he asks that his writ (breve) or declaration (narratio) be quashed after plea in abatement, the judgment entered is called a judgment of cassetur breve or cassetur narratio. A judgment of retraxit operates as a voluntary renunciation of his claim, and constitutes a bar to any other suit or action on it. These judgments may be suffered at any stage of the proceedings before verdict or trial of the issue. ${ }^{2}$

7. Respondeat ouster. When the court sustained a demurrer going to the merits of the action, or decided on an issue of law, any other dilatory plea in favor of the plaintiff, the judgment upon it was respondeat ouster; that he answer over to the action. ${ }^{3}$ This was clearly an interlocutory judgment in the sense that it determined an issue in the progress of the suit; but only for the purpose of allowing another issue to be taken to the same matter. If the defendant failed or refused to raise an issue of fact, then a judgment on the issue was awarded, which would be interlocutory again or final, according to the nature of the issue.

8. Judgment of Nonsuit. This judgment is given against the plaintiff when on trial by jury the plaintiff, on being called at the instance of defendant to be present in court while the jury give their verdict, fails to make his appearance. ${ }^{4}$ Judgment of nonsuit is also given when, after the cause is called for trial, the plaintiff fails to appear upon call of the court made upon demand by defendant. ${ }^{5} \quad$ So if, after issue is joined, the plaintiff neglect to

1 Steph. Pl. 109.

2 Steph. Pl. 109.

3 Steph. Pl. 104, 105.
4 Steph. Pl. 109.

52 Tidd, Pr. 868. 
bring such issue on to be tried in due time, as limited by the course and practice of the court in the particular case, judgment will be given against him for his default in that respect; which is called judgment as in case of nonsuit. ${ }^{1}$ A similar judgment can also be directed by the court at nisi prius, when the plaintiff's evidence clearly fails in point of law to sustain the issue. ${ }^{2}$

9. Judgment that the Plaintiff ought to recover his Damages. This is the interlocutory judgment which is usually meant by that name. When any interlocutory judgment of the foregoing classes is intended, the technical names of them as judgments by default, nil dicit, \&c., were usually employed. This judgment was rendered only in cases in which an issue of law or fact was joined and tried by the court without a jury, and was found for the plaintiff, and it became necessary to call a jury, to assess the damages in order to. fix the amount of recovery for a final judgment. It was anciently rendered only in actions sounding in damages, and was out of place in suits for the specific recovery of lands, goods, or liquidated sums of money, as in actions real or mixed, or in debt or detinue. When the court tried an issue of law or fact for the plaintiff, if the issue was of such a character that it could compute or fix the amount of recovery with'out the aid of a jury, it rendered final judgment thereon; otherwise, it directed a writ of inquiry to be issued to the sheriff of the proper county, commanding him to inquire into the amount of damages sustained by a jury of the county. There were changes in the law and practice which enlarged the right of the judges in respect to entering final judgment. ${ }^{3}$

If the issue be one of fact and is tried by a jury, then the jury at the same time that it tries the issue assesses the damages, upon which final judgment is rendered. ${ }^{4}$

There were two other interlocutory judgments proper, very similar in their effect, but known under different names, which may be mentioned here.

Judgment quod partitio fiat. This judgment ordered that a partition be made in the common law action of partition, while the final judgment confirmed the partition after it had been made and reported to the court. Partition was the only real action in which an interlocutory judgment proper was given. ${ }^{5}$ In all other of the

1 Steph. PI. 109.

22 Tidd. Pr. 868.

See judgment in debt, sec. 44.
4 Steph. Pl. 106.

- 1 Roscoe, 326; Freeman, Judg. s. 8. 
ancient real actions proper, the judgment was final upon default, demurrer, confession, or verdict, because the thing demanded was certain. $^{1}$ In mixed actions for the recovery of land and damages also, it is necessary to have a writ of inquiry upon default, confession, \&c., to ascertain the damages. ${ }^{2}$

Judgment quod computet. This judgment' ordered that the defendant account with the plaintiff. A final judgment of recovery for the balance found due to the plaintiff in the accounting followed it.

SEC. 376. Final Judgments. A final judgment properly so called is the determination and completion of the issues, finally disposing of the case. It is distinguished from an interlocutory judgment proper in that it leaves nothing further to be done to end the litigation.

1. Judgments for Plaintiff. - Quod recuperet clause. If the action does not sound in damages, a decision of the issue whether by court or jury is followed by a final judgment that the plaintiff recover seisin, \&c., or the debt, \&c.

If the action sounds in damages, the final judgment given on assessment of damages by the jury trying the issue or assessing the damages on a writ of inquiry is that the plaintiff do recover his damages in the sum assessed by the jury. In mixed actions, if the decision is by the court, it is interlocutory in the first instance, and final after assessment of damages. If tried by a jury, assessment is usually made at the same time, and final judgment follows; if damages are not assessed at that time, it follows after inquiry and assessment of damages.

The quod recuperet clause, to the effect that the plaintiff do recover the thing sued for or the damages assessed by the jury, was the distinguishing feature in a judgment in an ordinary common law action. Without it the judgment would be without effective force, and would not justify any process of execution.

2. Judgments for Defendant. If the issue tried was decided in favor of the defendant, the final judgment depended upon the nature of the issue as raised by the plea. If the issue, whether of law or fact, arise on a dilatory plea, the judgment is that the writ or declaration be quashed upon such pleas as are in abatement of the writ or bill, and that the suit be stayed or respited until a fixed time upon such pleas as are in suspension only; the effect in

12 Roscoe, 326.

22 Roscoe, 326. 
the first case of course being that the suit is defeated, but with liberty to begin another in more correct form; in the second, that the suit is suspended until the objection is removed. These judgments, although not conclusive of the merits, nevertheless dispose of the suit, and may be ranked as final. ${ }^{1}$ If the issue rise upon a declaration or peremptory plea to the action, the judgment for the defendant is in general that the plaintiff take nothing; \&c., and that the defendant go thereof without day, which is called a judgment of nil capiat. ${ }^{2}$

3. Costs. At common law neither party was entitled to costs. ${ }^{3}$ The right to recover costs rested upon statutes. ${ }^{4}$ Judgment in most personal and mixed actions, whether upon issue or by default, confession, \&c., contains as a part of the adjudication a recovery of costs against the defeated party, which are taxed by an officer of the court. ${ }^{5}$

4. Capiatur and Misericordia. Another feature which anciently attended all judgments at law was that the defeated party was regarded as having become liable to punishment as for an offence; and this liability was incorporated in the judgment. ${ }^{6}$

If the plaintiff failed in his suit of any description whatever, he and his pledges for prosecution could be, and invariably were, amerced in a small pecuniary sum for having made a false claim. He could be imprisoned by the King if he failed in the endeavor to reduce a freeman to villenage. ${ }^{7}$ He might also be fined in case of fraud or deceit to the court, or for malicious or vexatious suits.

If the defendant failed in his defence, and verdict went against him, he was punished with fine or amercement according to the nature of the action. In all actions in courts of record sounding in force, or of falsehood in denying his own deed, or unjustly claiming property in replevin, or of contempt in disobeying the command of the King's writ, or the express provision of any statute, he was adjudged to be liable to arrest until he paid a fine to the King; and the judgment contained the award of a capias pro fine. In all other cases he was liable to amercement, which was a more merciful punishment in the form of a small pecuniary penalty assessed by the jury. This punishment was contained in the

1 Steph. Pl. 107.

2 Steph. Pl. 107.

32 Inst. 288.

46 Edw. II. c. 1 , s. $2 ; 8 \& 9$ Wm.

III. c. $11 ; 7$ Hen. VIII. c. $4 ; 21 \mathrm{Hen}$.
VIII. c. 19 , s. 3 ; 23 Hen. VIII. c. 15 , s. 1.
5 Steph. Pl. 110.
6 Pol. \& Mait. 517.
72 Pol \& Mait. 517. 
phrase which declared that he had offended, and that he be in mercy (misericordia) to the King, or lord, as the case might be.

These fines and amercements, which anciently were important and very numerous, by virtue of statutes and the practice of the courts, ceased to be actually imposed.1 The judgments, however, long after this continued to recite the old phrases of capiatur and misericordia, and they have been very generally regarded as disclosing the proper test for determining the right of joinder in common law actions. ${ }^{2}$

SEC. 377. Signing and Enrolment. Judgments, like the pleadings, were formerly pronounced in open court, and are still always supposed to be so. But by a relaxation of practice there is now, in general, except in the case of an issue of law, no actual delivery of judgment in court or elsewhere. ${ }^{3}$ When the cause is in such a state in the court having authority to give judgment that by the course of practice the plaintiff or defendant is entitled to judgment, he obtains the signature or allowance of the proper officer of the court, expressing generally that judgment is given in his favor; and this is called signing judgment, and stands in the place of the actual delivery thereof by the judges themselves. ${ }^{4}$ Upon authority of this allowance, the attorney enters the judgment for his client on a roll of parchment, which includes all the proceedings up to that point, and is completed by that entry, and is called the judgment roll. ${ }^{5}$ This roll is deposited in the treasury of the court.

SEc. 378. Audita Querela. When, after rendition of judgment, anything took place which operated as a discharge or release of judgment, but which did not appear of record, the defendant was at liberty to sue out of Chancery, or out of the court where the record remains, a writ of audita querela ${ }^{6}$ This writ is in the nature of a bill in equity. It is directed to the court, or returnable to the court, where the record remains, statiug that the complaint of the defendant has been heard (audita querela defendentis), setting out the matter of the complaint, and directing the court to call the parties before it, and, having heard their allegations and proofs, to cause justice to be done between them. ${ }^{7}$ The use of this writ has

1 Steph. Pl. $110 ; 3$ Bl. Com. 399

2 Gould, Pl. c. iv. s. 38, 79, 80.

3 Steph. Pl. 110.

4 Steph. Pl. 110.

Martin Civil Procedure-21
5 Steph. Pl. 111, 112, 113. 114.

63 Bl. Com. 406; 2 Sel. Pr. 254.

73 Bl. Com. 406. 
been superseded by the practice of the courts in granting summary relief against the injustice complained of on motion made before thein.

SEC. 379. Writs of Error. - 1. The Writ of Error in General, as it is called, is an original writ sued out of Chancery, directed to the judges of a court of record in which judgment has been given, commanding them to send the record to another court of appellate jurisdiction; and is in the nature of a commission to the judges of the appellate court, by which they are authorized to examine the record, in order that some alleged error in the proceedings may be corrected. ${ }^{1}$ The object of the writ is to reverse or modify the judgment for some error of law of a substantial kind appearing on the face of the record. Matters not appearing on record constituted no ground of error in the judges, not being supposed to have entered into their consideration of the case. ${ }^{2}$

The judges were, in contemplation of law, bound to examine the whole record before giving final judgment, and then to adjudge either for the plaintiff or defendant, according to the legal right as it may on the whole appear, - notwithstanding, or without regard to, the issue in law or fact that may have been raised and decided between the parties; and this because the pleader may from misapprehension have passed by a material question of law without taking issue upon it. Therefore whenever, upon examination of the whole record, right appears on the whole not to have been done, and judgment appears to have been for one of the parties when it should have been for the other, this will be crror in law within the meaning of the writ for correction of errors. ${ }^{3}$ And it will be equally error in law, whether it was developed by demurrer or on an issue of fact, or in the absence of an issue. ${ }^{4}$ The entry of a judgment in a wrong form inappropriate to the case will be error in law. Writs of error suggesting error in the proceedings of any one of the three Superior Courts were made returnable in the Court of Exchequer Chamber, which consisted of the judges of the other two courts. For error of the Exchequer Chamber the writ of error was returnable to the House of Lorads.

SEC. 380. Writs of Error, continued. - 2. Writ of Error coram nobis or coram vobis. This ancient writ differed from the writ of error proper, both in substance and form. In the first place, it

1 Steph. Pl. 117; 2 Tidd, Pr. 1134.

2 Steph. P1. 121.
3 Steph. Pl. 120.

4 Steph. Pl. 120 
issued to correct errors of fact, and not errors of law. Moreover, the errors of fact capable of being corrected through it were of a very limited class, which will be presently described. In the next place it commissioned the judges to whom it was addressed to correct the error of fact which preceded the entry of their own judgment. It was not returnable to any appellate court. The record was not sent to such court, but remained in the court where the judgment was rendered, for correction of the error by the judges of the court in pursuance of the command of the writ. When it was addressed to the judges of the King's Bench, it was called a coram nobis, because the record was stated to remain before us (the King), that being the court in which the King himself theoretically dispensed justice. If it was addressed to the judges of the Common Pleas, it was called a coram vobis, because the record was stated to remain before you (the judges of the Common Pleas), where the. King's actual presence was not contemplated by law. ${ }^{1}$

The character of the facts constituting error within the meaning of this writ will have to be defined. It should be borne in mind, as formerly observed, that no appeal in the English law from the decision of an issue of fact was allowed, except in the way of motion for a new trial; and that this motion was addressed to, and heard by, the judges of the court in which the issue was joined, and by whom judgment on the verdict was to be rendered. A wrong decision of this motion was not error of the court in that technical sense to which a writ of error refers. The granting or refusal of a new trial was in English practice treated as an act within the discretion of the judges of the court in which the issue was joined, and was not subject to review by the appellate court. That court corrected errors of law only as they appeared on the record proper, or in a bill of exceptions which had been allowed as part of the record. If a matter of fact, such as a lease, should exist which was not brought into issue, but which if brought into issue would have led to a different judgment, the existence of such fact does not, after judgment, amount to error in the proceedings, and consequently cannot furnish any ground for the action of a court of error." But there are certain facts which affect the validity and regularity of the legal proceeding itself; such as the defendant having, while under age, appeared in the suit by attorney, and not by guardian, or the plaintiff or defendant having been a married woman when the suit was

12 Tidd, Pr. 1136, 1137.

2 Steph. Pl. 119. 
commenced. Such facts as these, however late discovered and alleged, are errors in fact, and sufficient to reverse the judgment upon writ of error. To such cases the writ of error coram nobis or coram vobis applies, because the error in fact is not an error of the judges, but a mistake or oversight of the parties which vitiates the judgment. ${ }^{1}$

In obedience to this writ, the judges themselves corrected the error of fact by reversing the judgment. As the same result could be obtained on a motion for a new trial, the latter method of redress practically superseded the writ, and it became quite obsolete in English practice.

The mere issue and delivery of the writ of error entitled the plaintiff in error to a supersedeas of final process in execution of the judgment. ${ }^{2}$ The inconvenience which resulted to the defendant in error from the issue of groundless writs led the courts to adopt the practice of withholding a supersedeas until some manifest error was shown to the justices of the court in the record of the case. ${ }^{3}$ It was afterwards provided by statutes passed at different times, and applying to most cases, that a supersedeas should not be granted until a good and sufficient bond was furnished by the plaintiff in error to prosecute the writ with effect, and in case of affirmance to pay the debt, damages, and costs awarded on the former judgment, and the costs and damages to be awarded for the delaying of execution. ${ }^{4}$

The proceedings and practice attending the prosecution of a writ of error are not within the scope of this treatise; and for a full treatment of them as prevailing at common law the student is referred to Tidd's Practice. ${ }^{5}$

\section{ARTICLE IV.}

\section{Execution.}

Sec. 381. Defined.

"382. Execution for the Recovery of formance of some special thing. Sec. 383. Executions in Actions for the Recovery of Money.

SEc. 381. Defined. An execution in the usual legal sense is a judicial writ grounded on the judgment of the court from which it issues; and is supposed to be granted by the court at the request of

1 Steph Pl. 119.

22 Tidd, Pr. 1149.

s 2 'Tidd, Pr. I149.
12 Tidd, Pr. 1149, 1150 ; Steph. Pl. 117, note 2 .

52 Tidd, Pr. 1134-1187. 
the party at whose suit it is issued, to give him satisfaction on the judgment standing in his favor. ${ }^{1}$ Therefore an execution cannot be sued out of one court upon a judgment obtained in another. While supposed to be actually awarded by the judges in court, no such award is in general actually made. The successful party having a right to an execution upon the judgment rendered, as a matter of course, unless a stay or supersedeas has been granted, sues it out of the proper office in the form adapted under the law to the form of action and nature of the judgment to be carried into effect. Accordingly, we find exccutions falling properly into two general classes, following the nature of the judgments to be enforced.

1st. Those in which some specific thing, real or personal, is recovered, or some speciai thing to be done.

2d. Those in which money only is recovered, as a debt or damages.

I think it will be sufficient for the purposes of this treatise to mention the different kinds of execution by the technical names by which they were generally designated, and to indicate briefly their nature.

SEC. 382. Executions in Actions for the Recovery of specific real or personal Property from the Defendant, or to compel him to do or render some special Thing which the Judgment requires him to do or render.

1. Writ of Habere facias seisinam. This writ issued only in the ancient real actions in which a freehold was recovered. It was a command to the sheriff that he cause the demandant to have seisin of the land recovered. Under this writ the sheriff invested the demandant with the freelold he had recovered by giving him actual possession of the land. ${ }^{2}$ Being put in actual possession, he is deemed to hold it in pursuance of the judgment giving him a freehold estate. If after judgment he should succeed in acquiring possession by entry, the judgment will be regarded as executed, and he will be invested with the freehold. ${ }^{3}$

2. Writ of Habere facias possessionem. This writ issued to the sheriff upon a judgment for plaintiff in ejectment, commanding that he cause the plaintiff to have possession of the term recoverel by him. It was executed like the writ for seisin, by giving plaintiff possession of the land described in the leasehold term, which under

1 Impey's K. B.

32 Roscoe, 341.

2 Watson on Sheriffs, 237-239. 
the judgment he had the right to possess for the unexpired part of the term. ${ }^{1}$

3. Writ of Clerico admittendo. This writ issued to the plaintiff upon his recovery of a benefice in a quare impedit or assize of darrein presentment. It is directed, not to the sheriff, but to the bishop or archbishop, requiring him to admit and institute the clerk of the plaintiff; which being done operates as a removal of the wrongful incumbent, who is thus said to be removed in due manuer after judgment given in the action. ${ }^{2}$

4. Writ to abate a Nuisance. This writ issued in the ancient real actions of assize of nuisance and quod permittat prosternere, where, besides recovery of damages, the judgment in the former is that the plaintiff have the nuisance abated; in the latter, that the defendant permit the plaintiff to abate it. ${ }^{3} A$ writ issues to the sheriff to abate or remove the nuisance or hindrance at the charge of the defendant when he fails to abate it or to permit the plaintiff to do so. ${ }^{4}$ These ancient actions having been displaced by actions on the case, in which no abatement can be adjudged, or by bill in equity, the writ of execution at law to abate a nuisance has become obsolete. ${ }^{5}$

5. Writ De retorno habendo. This writ issued in favor of the defendant in the action of replevin, when the plaintiff was defeated and judgment was rendered in favor of defendant that he have return of the property replevied by the plaintiff. ${ }^{6}$ If the sheriff could not find the property, and made return that it was eloigned and removed to places unknown, the defendant was entitled to the writ of capias in withernam, directed to the sheriff, commanding him in effect to take in withernam (by way of reprisal) the cattle, goods, and chattels of plaintiff to the value of the property replevied, to be delivered to the defendant to be kept by him till the sheriff can cause the replevied goods to be returned. ${ }^{7}$ But on the plaintiff tendering the damages expressed in the judgment, which represented the arrearages of rent to the extent of the value of the goods distrained, and submitting to a fine, the process in withernam was stayed..$^{8}$

6. Writ of Distringas in Detinue. Although the plaintiff in detinue, when the issue terminated in his favor, obtained a judgment

12 Roscoe, 341.

22 Roscoe, 344.

3 Bl. Com. 221, 222.

43 Bl. Com. 413 ; Barnet v. Ihrie, 1 Rawle, 44.
$53 \mathrm{Bl}$. Com. 222.

6 Wilkinson, Replevin, 109.

7 Wilkinson, Replevin, 110.

82 Leon. 174. 
that he recover the personal property sued for, or the assessed value thereof if he cannot have the property, ${ }^{1}$ the writ of execution issued on the judgment at common law to the sheriff did not assume to place the plaintiff in possession of his property. A writ of distringas issued to the sheriff, commanding him to compel the defendant to deliver the goods to plaintiff by repeated distresses of his chattels. If the defendant continued obstinate, then the sheriff, under the alternative order of the writ, made the assessed value of the goods out of the person and goods of the defendant, as authorized by law in the execution of money demands. ${ }^{2}$

It thus appears that in both detinue and replevin, if the wrongdoer be very perverse, the process may fall short of compelling him to restore the identical goods taken or detained; but that he has his election to deliver the goods or their value. ${ }^{3}$

As to modern enactments to enforce delivery of specific chattels, see section 85 .

\section{SEC. 383. Executions in Actions for the Recovery of Money.}

1. Writ of Capias ad satisfaciendum. This writ issued to the sheriff commanding him to take the body of the defendant and have it in court on a certain day for the purpose of satisfying the plaintiff of the debt or damages recovered. The effect of it was to deprive the defendant of his liberty until he made satisfaction of the debt or damages and costs. ${ }^{4}$ It issued only in cases in which the defendant could have been held to bail on mesne process. ${ }^{5}$ Privileged persons, peers or members of Parliament, and executors and administrators were exempt from this process. ${ }^{6}$ This writ unight be sued out against the defendant's bail given in mesne process after it appeared in a scire facias that the defendant had failed to surrender himself as a prisoner, and his sureties had failed to pay the debt and costs. ${ }^{7}$ It was a writ of so high a nature that, when a person was once taken on execution of this writ, no other process could be sued out against his lands or goods. ${ }^{8}$ When imprisonment for debt was abolished, the writ went out of use.

2. Writ of Fieri facias. In this writ the sheriff is commanded that he cause to be made (fierifacias) of the goods and chattels of

11 Chit. Pl. 125.

23 Bl. Com. 413.

83 Bl. Com. 413.

$\div 3$ Bl. Com. 414.
53 Bl. Com. 414.

63 Bl. Com. 414.

73 Bl. Com. 416.

$83 \mathrm{Bl}$. Com. 414. 
the defendant the sum of damages, or the debt recovered. ${ }^{1}$ This writ was issuable against privileged persons, peers, \&c., as other common persous; and against executors and administrators, in which latter case the sheriff was commanded to make the debt or damages from the goods of the deceased.2 All tangible goods and ehattels were subject to seizure under this writ, also chattels real, including estates for years, which were regarded as personal property at common law. ${ }^{3}$ The true test of availability of personal property under this writ for satisfaction of debts is the existence of the right of voluntary transfer by the owner as enjoyed by him at common law. ${ }^{4}$

3. Writ of Levari facias. This writ issued at common law, commanding the sheriff to levy the plaintiff's debt on the lands and goods of the defendant. As the lands themselves were not subject at common law to execution for debts, the sheriff in executing this writ levied on only the goods of the debtor and the profits and rents of his land. ${ }^{5}$ There being no fixed return day to the execution, the sheriff had authority to continue taking or receiving the rents and profits of the land until satisfaction of the judgment was accomplished. ${ }^{6}$ To execute the writ, the sheriff had the right to enter upon the defendant's lands for the purpose of seizing his goods and chattels, securing his growing crops, and collecting his rents and profits. But he could not take possession of the land, or displace the ownership or possession of the defendant in respect to the same. ${ }^{7}$

This writ was practically superseded by the writ of elegit, given by statute.

3. Writ of Elegit. This writ was authorized by an early statute, ${ }^{8}$ for execution of a judgment for debt or damages; or upon forfeiture of a recognizance taken in the King's Court. ${ }^{9}$ It was called an elegit because it rested in the choice or election of the plaintift whether he would sue out this writ or one of the former.

By virtue of this writ the sheriff seized the goods and chattels of the defendant, had them appraised, and (except oxen and beasts of the plough) then delivered them to plaintiff at such reasonable appraisement and price in part satisfaction of his debt. ${ }^{10}$ If the goods

13 Bl. Com. 417.

23 Bl. Com. 417.

33 Bl. Com. 417.

4 Freeman, Exec. 110.

5 Bl. Com. 417.
63 Bl. Com. 418.

3 Bl. Com. 418.

8 Westm. II., 13 Edw. I. c. 18.

9 3 B1. Con. 418.

103 Pl. Com. 418. 
and chattels were not sufficient, then one half of his freehold lands, after their annual valie was found by a jury, was set out by metes and bounds, and also delivered to the plaintiff to hold till out of the rents and profits thereof the debt was satisfied, or till the defendant's interest in the land expired. ${ }^{1}$ During this period the plaintiff is called tenant by elegit. The admeasurement, valuation, and delivery of lands under this writ was known as cxtending the execution of the writ over the lands subject to execution. This extent was effected by virtue of the writ of elegit without the aid of any further process. ${ }^{2}$ This execution or seizing of land by clegit is of so high a nature that after it the body of the defendant could not be taken upon any other writ; but if the elegit could not be executed by delivery of lands because the defendant had none, and the goods levied upon were not sufficient to satisfy the judgment, a writ of capias ad satisfaciendum may then be had after the elegit. ${ }^{3}$ Body and goods may be taken in execution, or land and goods, but not body and land too, upon any judgment between subject and subject in the course of the common law." The King alone was always entitled to sue out execution against the body, lands, and goods of his accountant or debtor. ${ }^{5}$

5. Writ of Extendi facias. This was an ancient prerogative writ for obtaining satisfaction of debts due or assigned to the King, or found due to the King on an inquisition $;^{6}$ and it issued only from the equity side of the Court of Exchequer. ${ }^{7}$ Its execution was directed against the body, lands, and goods of the Crown debtor. ${ }^{8}$ By this writ he was directed to inquire by a jury what lands and goods the defendant was seised of, and to appraise and extend them, and to take and seize the same into the King's hands. ${ }^{9}$ He was prohibited from selling the goods and chattels until further commanded, and he was without authority to sell the lands. For the purpose of effecting a sale of the goods and chattels and lands, it was necessary that he should obtain for that purpose a further writ called a venditioni exponas, or an order in the nature of snch writ.

There grew up a practice in the Court of Exchequer which was recognized and controlled by statutes, according to which a debtor of the Crown could invoke in his behalf the writ of extendi facias

$13 \mathrm{Bl}$. Com. 419.

2 Watson on Sheriffs, 208.

33 Bl. Com. 419.

43 Bl. Com. 419.

5 Bl. Com. 420.
6 Watson on Sheriffs, 246.

72 Tidd, Pr. 1048.

8 Watson on Sheriffs, 246, 249.

92 Tidd, Pr. 1088. 
for the purpose of collecting a debt of equal amount due him from any subject. The benefit of the writ was accorded him upon the suggestion or showing that the Crown would be in danger of losing its demand against him if he was not assisted by this writ to collect the debt due him from his debtor. It also could be invoked by a surety of a debtor to the Crown who had paid the debt of the Crown debtor. ${ }^{1}$ When this assistance was invoked in behalf of a debtor to the Crown for the enforcement of his debt against other subjects, or in behalf of a Crown debtor's surety, it was called a writ of extendi facias in aid. ${ }^{2}$ When employed only to collect debts directly due the Crown, it was called a writ of extendi facias in chief. The student is referred to Tidd's Practice, in which will be found full particulars of the nature of these writs, and of the proceedings under them. ${ }^{3}$

In modern times writs for the collection of debts or damages are in the nature of the common law writ of ficri facias, and are directed against both lands and goods.

12 Tidd, Pr. 1059, 1060.

82 Tidd, Pr. 1043-1083.

22 Tidd, Pr. 1059, 1060. 


\section{CONCLUSION.}

Sec. 384. Conclusion. In the foregoing pages I have endeavored to present the main principles and leading features of Civil Procedure at Common Law.

It is apparent that the most important and difficult part of it is contained in its pleadings.

In closing this work I have thought it proper to mention, in a general way, some of the reasons accounting for the changes to which its system of pleading was subjected, whether emanating from the courts or from Parliament; also for its final overthrow in the country in which it originated, and where it prevailed for more than seven hundred years.

It is obvious that every system of pleading must aim to ascertain as definitely as possible the substantial matter in controversy between the litigants, so that it may be decided by the mode of trial furnished by its procedure for that purpose.

Certainly the oral or written statements of the litigants must be accepted as the basis of every system of pleading. In all other systems, except that of the common law, the court at some stage of the proceedings is compelled to collect and declare from these statements the substantial points in issue between the litigants. It was peculiar to the common law system that the parties litigant were compelled by the courts so to make their statements in court as to disclose the matter in dispute between them.

Anciently the parties were required to rest their claims and defences on a single fact or state of facts sufficient to sustain them. While a party might have several grounds for the same recovery or for the same defence, it was assumed by the courts that one ground was sufficient, and he was required to select the best one at his peril. It will be seen that the issue thus raised between the litigants was single and certain. The tribunal in deciding this issue was relieved from considering anything else in the case. 
Another feature which characterized the system in its origin and early development was that the pláintiff and defendant were relieved from stating with particularity, in the first instance, all the material'facts of the claim or defence.

It was sufficient for the plaintiff to state the ground or foundation of his action, - some matter prima facie sufficient to impose on the defendant the obligation to respond. The gist of the action was disclosed with sufficient certainty, while the inducement was briefly alluded to, or in many cases entirely omitted, - being implied as it were in the act of bringing the suit. The gist of an action on covenant consisted in the breach of it by defendant, and the plaintiff was relieved from alleging performance on his part of a condition precedent, that fact being left for the defendant to plead, if it were true. ${ }^{1}$ Special certainty or preciseness was deemed useless until it was seen whether the defendant would deny, in which event it could be supplied at the next stage of the pleading if necessary. In like manner, it was necessary for the defendant only to meet the gist of the count. By a mere denial he could not put in issue more than the gist or gravamen of the action, and then only in substance. Under such denial, special or affirmative defences were not allowable. And in making an affirmative defence it was sufficient to allege the foundation of it in substance, sufficient to enable the plaintiff to reply to it. Thus in covenant a general plea of performance was good, and imposed on the plaintiff the duty of particularizing the breach or breaches relied on, which he was excused from setting forth in the first instance in his declaration.

Explanatory denials, which are as natural in pleadings as in ordinary conversation, were permitted free from the technicality and subtlety of the special traverse, as established in subsequent times. Litigants were required to plead truthfully, and to refrain from putting each other to proof of subordinate or incidental facts which were known by both parties to be true. An observance of this and other proper requirements was enforced by the harsh rule prevailing in the early age of civil procedure, to the effect that the plaintiff should pay a fine to the King for prosecuting an unfounded claim, and the defendant should be amerced in penal damages for making a false defence.

1 Pole $v$. Tocheff, 48 Edw. III., f. 6. 
It must be admitted that the system as thus defined was admirably adapted to the trial of issues of fact by a jury.

Neither can any better system be conceived of to serve the necessities of a rude people for a fair and intelligible trial.

It is believed to have reached its perfection as a system in the reign of Edward III. We have the declarations of eminent jurists to that effect. Lord Coke says that in the reign of Edward III. and upwards, the pleadings were plain and sensible, "ever more having chief respect to matter and not to forms of words," 1 and that in the reign of Edward III. "pleadings grew to perfection both without lameness and curiosity." ${ }^{2}$ The declarations of Sir Matthew Hale and Lord Brooke are to the same effect. ${ }^{3}$

According to the admissions and complainings of the same and other authors, this primitive system of pleading commenced soon after the reign of Edward III. to lose its truth and simplicity in the corrupt practice of the bar, which grew up with the assent of the judges.

The vicious results of this departure from the primitive system of pleading became very pronounced in the reign of Henry VIII., and are alluded to in the statutes of that and some of the subsequent reigns, which were passed with the manifest purpose of correcting some of the mischiefs.

In a statute of Henry VIII., passed in 1540, it is recited "that parties in actions and suits real and personal at the common law of this realm have been before this time greatly delayed and hindered in their suits and demands, by reason of the crafty, subtle, and negligent pleadings of the plaintiffs or defendants to the great hurry, delay, and hindrance of the said plaintiffs or the vexation of the said defendants." 4 In a statute of the reign of Elizabeth, passed in 1585 , occur the following recitals: "that excessive charges and expenses, and great delay and hindrance of justice, have grown in actions and suits between the subjects of this realin by reason that upon some small mistakings, or want of form in pleading, judgments are often reversed by writs of error, and oftentimes upon demurrers in law given otherwise than the matter in law and the very right of the cause doth require, whereby the parties are con-

1 Co. Litt. 304 a.

2 Co. Litt. 304 b.
3 IIale, Hist. 173, 176 ; Brooke, Abr. Count, 3.

432 Hen. VIII. c. 30. 
strained either utterly to lose their right, or else after long time and great trouble and expenses to renew again their suits." 1

It will add to the intelligent apprehension of the student to state very briefly some of the departures from the primitive simplicity which prevailed in the reign of Edward III. First. The ancient rule excusing the plaintiff from stating at all, or stating with particularity in the first instance, matters outside of the foundation fact of the declaration or plea was entirely reversed. Unless the litigant stated every fact material in law, although not actually material in the particular case, and stated it correctly in form as well as in substance, his pleading was adjudged imperfect. The ancient distinction between form and substance had disappeared in the scholasticism and pedantry of the reigus of Henry VIII. and Elizabeth. Second. The ancient rule, that a pleading was sufficient if it was certain to the most common understanding, ${ }^{2}$ was disregarded, and it was required to be certain to every intent, and if two intents were possible, the one against the pleader's interest was to be accepted. ${ }^{3}$ Third. A litigant was allowed to attack the sufficiency of the pleading of his adversary in matters of mere form by a general demurrer, which contained no intimation of the defect to be urged in the argument. Fourth. Under the general issue, the defendant was permitted to give in evidence affirmative defences in debt on simple contract, assumpsit, case, and trover, contrary to the ancient rule, which required such defences to be pleaded specially in order to admit evidence thereof. By such construction of the general issue, the plaintiff was not only put to proof of every fact technically material to make out a cause of action, but was required to meet affirmative defences of which he had no notice in the plea. Fifth. The license of stating the same cause of action in more than one count, which grew up in derogation of the primitive system, was abused by the employment of many counts, thus multiplying the issues and adding greatly to the labor and costs of a trial. Sixth. Immaterial variances between pleading and proofs were permitted to defeat the rights of the parties on the merits of the case.

I might recite other departures from the simplicity of the early procedure, but these will answer our purpose in this connection.

I think I may safely say that in no age is the bench superior

127 Eliz. c. 5.

3 Straddling $v$. Morgan, 1 Plow.

2 Colthirst $v$. Bejustin, 1 Plow. 28. 202. 
to the bar, or in advance of it, in the administration of justice. The judges of the courts seem to have accepted (with perhaps an occasional murmur of dissent) all the subtleties and intricacies of the perverted system, as disclosed in dilatory pleas, general deinurrers, special traverses, and immaterial variances, by means of which important controversies were constantly disposed of without reaching a fair trial on their merits.

Morris and Finlason, in their introductory essay to the Common Law Procedure Act of 1852, refer to Saunders's reports as embodying a climax of the perverted system, which had grown up in violation of the course of the common law, as follows: "It is a work in which all is technical and untruthful; in which forms are systematically established for substance; in which there is not one single broad legal principle enunciated, and which might be read through without a glimpse or a guess at the existence of such a thing as moral justice in the universe." 1

It is further remarked by the same writers: "The difference between Coke and Saunders is simply this, that in the former the sound principles of the ancient and honest system of pleading are to be clearly traced amongst the corruption that had commenced, and in the latter they are not to be traced amidst the perversion that was complete." 2

While there is much to sustain these severe criticisms, I am inclined to regard them as somewhat partial in ignoring the chief merits of the system, which in a great measure continued, notwithstanding the abuse and perversion complained of.

Right here an inquiry naturally presents itself to the modern jurist: If the ancient system originated in the courts, and reached perfection under their directing precedents, what was there to prevent them at any time from staying or correcting the abuse and perversion of the system, which was a creation of their own? This inquiry is easily answered. In those times the distinction between remedial law and substantive law was not felt or recognized by the bench or bar. When a practice had grown up in the courts in relation to the pleadings before them, that practice was deemed part of the common law governing the litigants, like any other part of the common law bearing on their substantive rights and liabilities. The right to an essoin, or formal excuse from pleading at the

1 Com. Law Proc. Act, by Morris \& 2 Ibid. Finlason, 76. 
regular time, was deemed a valuable right of the subject, and was to be protected in like manner with his rights of property. Long established practices, however pernicious, were regarded as immutable so far as the courts were concerned, having become common law, and therefore above the power of abrogation or reform except by act of Parliament. The courts acknowledged themselves helpless, in the face of long established abuses, to reform or correct what they had ignorantly or negligently permitted.

Acts of Parliament were passed, which for the most part should be construed as efforts to correct the prevailing abuses, and to restore pleading to its ancient simplicity. By the act of Henry VIII., already referred to, it was ordered that, if any issue be tried, the judges should give their judgment in the case notwithstanding "any mispleading or insufficient pleading, or any other default or negligence, of the parties." By a technical construction this statute was held not to apply to declarations. Its reforming effect was restricted to waivers effected by verdict only, leaving the mischief untouched in all other cases. ${ }^{1}$

By the act of Elizabeth heretofore alluded to, it was ordered that the judges should give judgment on demurrers according as the "very right of the cause and matter in law shall appear to them, without regarding any imperfection, defect, or want of form in any writ, return, plaint, declaration, or other pleading process or course of proceeding whatsoever, except those only which the party demurring shall specially and particularly set down and express, togther with his demurrer." 2 The effect of this statute was to preserve and continue objections to form by requiring the demurrant merely to specify them in his demurrer. The idea of abolishing such objections as ground of demurrer was beyond the spirit and conception of the age.

In construing this statute, the courts held very divergent views in respect to the proper distinction between substance and form. Accordingly, a statute in the reign of Anne was passed, explaining and extending the statute of Elizabeth, and reciting particular defects as matters of form, which had been before the statute deemed substantial in their nature, and which thenceforth would be aided on general demurrer. ${ }^{3}$

These statutes were only partial in their effect on the perversions

132 Hen. VIII. c. 30.

34 \& 5 Anne, c. 16.

227 Eliz. c. 5. 
of pleading in vogue, and they were interpreted and applied by the courts with an illiberal and hostile spirit. Their most serious effect, however, was to recognize the perversions of the ancient system of pleading as constituting "the course and order of the common law," thus legalizing them in every respect except in so far as repealed by Parliament.

The next reforming statutes were passed in the reign of William IV., of which the one relating to pleadings must be noticed. ${ }^{1}$

This statute, which was passed in 1833 , recites that it would greatly contribute to the diminishing of expenses if the pleadings were in some respects altered, "and the questions to be tried by the jury left less at large than they now are according to the course and practice of pleading in several forms of action." The act further recites that this cannot be done conveniently otherwise than by rules or orders of the judges. After declaring that doubts may arise as to the power of the judges to make the alterations without the authority of Parliament, the act then goes on to confer the requisite power upon the judges. By virtue of this statute the judges promulgated the famous rules of Hilary term, 1834, which mark a decided return to the simplicity of the ancient system.

The commissioners who made report to Parliament on the condition of pleading, and upon whose representations the statute was passed, confined their recommendations principally to a restriction of the scope of the general issue; and it is seen that the statute and the rules adopted by the judges do not in the main purport to effect many other material reforms in respect to the pleadings. The act contains a provision intended to mitigate the serious results of immaterial variances, and it directed some salutary changes in the practice and procedure of a cause outside of the pleadings proper. But it failed to bring the system back to its primitive simplicity, and it is apparent that such an achievement was not suited to the age in which the act was passed.

As civilization progresses and commerce extends, the transactions of men become more varied and complicated. The rule of disposing of controversies by reducing them to the determination of a single material fact becomes impracticable. This was felt and acknowledged in the use of several counts which grew up in face of the primitive rule forbidding the plaintiff to state his case in more than one form. It was also acknowledged by the statute of Anne,

$23 \& 4$ William IV. c. 42.

Martin Civil Procedure-222 
in which the defendant was permitted by leave of court to plead more than one defence. ${ }^{1}$ It has been found necessary in the American States where the Code system prevails to permit the practice of employing in some cases a double statement of the same cause of action, while the defendant is at liberty to make as many defences as he may have.

The Common Law Procedure Act of 1852 accomplished much towards simplifying common law procedure in many respects, which have been occasionally alluded to in this treatise, and which need not be repeated in this connection.

In none of the legislation or regulations made in pursuance of it was the plaintiff relieved from stating all the allegations necessary to constitute his cause of action. He cannot stand in the first instance on the foundation fact or gravamen of lis action or defence as he could anciently at common law. Neither has the system been brought back to the singleness of issue required in early times.

It will be seen that the reforms introduced by the Hilary rules and subsequent regulation and legislation all tend to the establishment of a system of special pleading as distinguished from general pleading. It has been found that every system of general pleading which fails to discluse quite definitely the issues of the controversy must be supplemented at the trial before a jury with hypothetical instructions or directions particularizing the precise issue of facts for them to determine. These instructions, drawn and given in the hurry of the trial, are often erroneous and misleading, and fail to serve successfully the purpose of definite and well considered pleadings prepared with care and deliberation, and possibly settled by the court before the trial.

I may properly remark in this connection that the common law system of pleading, in its origin and in its normal development, rested upon the actual separation between law and equity which existed in English jurisprudence. It was not suited to trials in equity proceedings. This separation was accidental and unnatural. It was bound to come to an end at some time.

As the business transactions, of the community inereased in volume and complexity, the principles of equity jurisprudence became more dominant and controlling. The common law courts were compelled to recognize them more aud more, and to adopt them frequently in the disposition of legal issues. Equitable de- 
fences came to be authorized in actions at law. The two methods of procedure were approaching each other year after year, with aggressive influence and increasing jurisdiction on the part of the tribunal of equity. When the two merged in one system, it is apparent that the common law system of procedure would have to give way, as not suited to the new condition of things, and that the pleadings adopted would more nearly approximate the simplicity and informality of equity procedure.

This is precisely what has taken place in England under the Supreme Court Judicature Act of 1873 and amendments thereto. The administration of law and equity is merged in one tribunal and one mode of procedure, and it is declared that in all trials the issues shall be determined according to the principles of equity, when applicable to the facts disclosed.

The reforms enacted in England after the independence of the Colonies were not generally followed in the American States. In some States other contrivances were adopted to guard against the perversions alluded to. A revolt against the system as prevailing in the United States was inaugurated in New York in 1848, which culminated in the adoption of a system of procedure in which both law and equity are administered in the same tribunal and same case, and which is known as the Code of Civil Procedure. It was next adopted in the State of Missouri, and has been substantially adopted by a majority of the American States.

It is not within the scope of this treatise to consider or criticise the merits of the American Code system, nor of the new system adopted in England in 1873. The merits of the New York Code will have to be diligently sought for in nearly four thousand sections of statute law, burdened with a gloss of countless decisions. Although the new English system of procedure has been in force only half as long as the Civil Code of New York, its merits will have to be ascertained from the Annual Practice conpila. tion, which presents to the student an intricate and tangled net of statutory provisions, court orders, and judicial interpretations. The expectations of the founders and friends of these systems have not been fulfilled; and the increasing complaints against them would seem to indicate that the best method of presenting and determining the issues between litigants in modern jurisprudence remains to be developed. 



\section{AP PENDIX.}

\section{NOTE I.}

\section{GENERAL ASSUMPSIT FOR PART PERFORMANCE OF EXPRESS CONTRACTS.}

UxDER what circumstances general assumpsit may be maintained, notwithstanding the existence of an express executory contract relating to the same subject matter, is a question about which there is great conflict of opinion.

It will not be possible in this note to consider in detail the full merits of the controversy. I shall content myself with referring the student to some of the best sources of information and formulating some general conclusions, which it is hoped may assist him in his examination of the conflicting authorities.

It may be observed that anciently the courts were very liberal in allowing actions to be maintained on contracts, notwithstanding a failure on the part of the plaintiff to perform the contract on his side. Langdell, Sum. Cont. 178. But the injustice to which this indulgence led induced the courts to import into contracts, in which performance on one side constituted a consideration for performance on the other, the implied condition precedent that the contract must be fully performed on the part of plaintiff before he could maintain an action on the contract for non-performance on the part of defendant. Kingston $v$. Preston (Ld. Mansfield), cited in Jones $v$. Barkley, 2 Dougl. 684; Langdell, Cas. Cont. 901; Boone v. Eyre, 1 Hen. Bl. 273 ; S. C. 2 Wm. Bl. 1312 ; Thorp $v$. Thorp, 12 Mod. 455 ; Dakin $v$. Williams, 11 Wend. 67 ; Hulle $v$. Heightman, 2 East, 145; Gordon $v$. Martin, Fitzgibb. 303.

But the courts did not stop with the rule that no action could be maintained on the express contract so long as it remained open and unperformed, but announced the further rule, that no action could be brought in general assumpsit for anything done under the express contract while it remains open and to be performed. Gordon $v$. 
Martin, Fitzgibb. 303 ; Hulle $v$. Heightman, 2 East, 145; Dermot $v$. Jones, 23 How. 233; Felton $v$. Dickinson, 10 Mass. 287; Kelley v. Foster, 2 Binn. 4 ; Camp v. Barker, 21 Vt. 460 ; Christy v. Price, 7 Mo. $430 ; 2$ Smith's Ld. Cas. 10.

It is this latter extension of the rule which engages our attention just now, and which may be stated as follows: While a special contract remains open and unperformed, no action in general assumpsit can be brought for anything done under it. The action must be special if at all. See the cases collected in 5 Century Dig. Assumpsit, sec. 15. What I have to say in regard to it will be expressed in the form of exceptions to the rule as announced, although I am satisfied that the exceptions are so material and numerous that they leave little more than a mere shadow of the rule at the present time.

1st Exreption. When the express contract is substantially identical with the implied contract, it will not operate to defeat an action on the implied contract. This may happen in a few cases: as when a surety has paid the demand for which he was surety, he may sue the principal for what he has paid in indebitatus assumpsit notwithstanding he may have a special parol promise of indemnity from him. Gibbs $v$. Bryant, 1 Pick. 118; MeWilliams $v$. Willis, 1 Wash. (Va.) 199 ; Princeton Company $v$. Grelick, 1 Harr. 161 (N. J.).

$2 d$ Exception. If an express contract has been completely performed on the part of plaintiff, and nothing remains on the part of defendant but to pay in money the consideration price, an action can be maintained for it on an implied assumpsit or on the express contract, at the option of the plaintiff. 1 Chit. Pl. 348; Cooke $v$. Munstone, 1 B. \& P. 354; Alcorn v. Westbrooke, 1 Wils. 117; Bank of Columbia $v$. Patterson, 7 Cranch, 333 ; Felton $v$. Dickinson, 10 Mass. 292 ; Mansur $v$. Botts, 80 Mo. 652 ; Williams $v$. R. R., 112 Mo. 463; Moore $v$. Gaus \& Sons Mfg. Co., 113 Mo. 98 ; Kennerly $v$. Summerville, 64 Mo. App. 75; Begole $v$. McKenzie, 26 Mich. 470 ; 5 Century Dig. Assumpsit, sec. 17. But if the consideration price consists in the payment or delivery of specific property instead of money, it has been held that no such option exists, and that the plaintiff is confined to an action of special assumpsit on the contract. Boone $v$. Eyre, $1 \mathrm{H}$. Bl. 287; Read $v$. Hutchinson, 3 Camp. 352; Cochran $v$. Tatum, 3 T. B. Mon. 405; Wilt $v$. Ogden, I3 Johns. 56; Shearer $v$. Jewett, 14 Pick. 232 ; Thomas Co. $v$. Watson, 27 Atl. 176 (Me.); Hunneman $v$. Grafton, 10 Met. (Mass.) 454; Sendicor v. Leach, 10 Ala. 330; 1 Chit. Pl. 346; Bernard v. Dickens, 22 Ark. 351; Mitchell v. Gile, $12 \mathrm{~N}$. H. 390 ; Weart $v$. Hoagland, 2 Zabr. 518 ; Harrison $v$. Luke, 14 M. \& W. 138. But it is believed that this qualification will not apply, if the defendant is in default and the time has expired for delivery of 
the property or security. 1 Chit. Pl. 347; Baylies v. Fettyplace, 7 Mass. 325, 329; Elkinton $v$. Fennimore, 13'Penn. 173; Clark $v$. Fairchild, 22 Wend. 576; Way $v$. Wakefield, 7 Vt. 223, 228; Stone $v$. Stone, 43 Vt. 180 ; Fitch $v$. Casey, 2 Iowa, 300.

$3 d$ Exception. In contracts for work or materials to be done or furnished in conformity with requirements contained therein for a stipulated price, if all the work has been done and all the materials furnished, but not in quality or value according to the requirements of the contract, the party thus performing the contract may maintain an action of implied assumpsit for the true value of what he has done or furnished, provided the work or materials have been retained by the defendant and are of benefit to him. The defendant is permitted in such action to reduce the amount of recovery against him to the extent of the damages suffered by him in the depreciation of the consideration; or to express it in another way the plaintiff is permitted to recover for only so much as the defendant is benefited by the work and material. Basten $v$. Butter, 7 East, 479; Farnsworth $v$. Garrard, 1 Camp. 38; Thornton $v$. Place, 1 M. \& Rob. 219; Denew $v$. Daverell, 3 Camp. 450 ; Choppel v. Hicks, 2 C. \& M. 214 : Deatherage Lumber Co. $v$. Snyder, 65 Mo. App. 568; Grant $v$. Button, 14 Johns. 377. The same rule has been applied to contracts containing express warranties where the defect of consideration constitutes a breach of the warranty. Poulton $v$. Lattimore, 9 B. \& C. 259 ; Street $v$. Blay, 2 B. \& Adol. 456 ; King $v$. Boston, 7 East, 481 n.; McAlister $v$. Reab, 4 Wend. 483; Batterman $v$. Pierce, 3 Hill (N. Y.), 172 ; Mixer v. Coburn, 11 Met. (Mass.) 559. It may be remarked in this connection, that prior to Basten $v$. Butter, the courts had recognized the distinction between a failure in the value or quality of the consideration, and a failure to do or furnish in specie or amount all the consideration. The failure in the latter case was regarded as only a part performance, which defeated recovery on the contract, while a failure in the former case did not constitute non-performance so as to defeat the action. The failure in quality and value was not regarded as going to the essence of the contract, and therefore not a fatal nonperformance of it.

In compliance with this view the courts allowed the plaintiff to recover on the contract, when performed in specie and amount as above stated, and denied to the defendant the right to reduce the amount of recovery by proof of inferiority. in value or quality, but drove him to a cross action. Browne $v$. Davis, cited in 7 East, 479 ; Templar $v$. McLachlan, 2 N. R. 136 ; Mills $v$. Bainbridge, cited in 2 N. R. 136 ; Read $v$. Ran, 10 B. \& C. 439 ; Everett v. Gray, 1 Mass. 101. 
The inconvenience and hardship of this circuity of actions led to the doctrine of Basten $v$. Butter, in which the defendant was permitted to prove depreciation in the consideration in reduction of damages. He was permitted to do this in this class of actions whether they were founded on the express contract or on the implied assumpsit; Mondel $v$. Steel, 8 M. \& IV. 870 ; Harrington $v$. Stratton, 22 Pick. (39 Mass.) 510; Bicker $v$. Vrooman, 13 Johns. 302; McAlister $v$. Reab, 4 Wend. 483 ; Spalding $v$. Vandercook, 2 Wend. 431 ; Davis $v$. Hedges, 6 L. R. Q. B. 687 ; and the option to sue in either form was generally conceded; the only difference being that when the suit was founded on the special contract, previous notice of the matter in reduction might be required; Burton $v$. Stewart, 3 Wend. 236; when founded on the general assumpsit, the matter of reduction was involved in the nature of the claim, and no notice was required. Basten $v$. Butter, Lord Ellenborough ; Harrington $v$. Stratton, Dewey, J.

In the growing tendency to maintain general assumpsit for part performance of express contracts, this distinction is not recognized very generally as limiting the action, but recovery is permitted in other failures than such as relate to quality and value, on equitable principles, which underlie the nature of the action. White $v$. Oliver, 36 Me. 92. See cases collected in 5 Century Dig. Assumpsit, sec. 17.

But the cases permitting recovery on the contract, notwithstanding failure as to quality and value, must be distinguished from those eases in which there has been a substantial and bona fide compliance on the part of the plaintiff with all requirements; when he will be allowed to recover on the contract, notwithstanding some slight imperfection for which the defeulant may be compensated in damages. Noble $v$. James, 2 Grant's Cases, 278 (Penn.); Phillip $v$. Gallant, 62 N. Y. 256 (17 Sick.) ; Glacius v. Black, 50 N. Y. 145 (5 Sick.).

$4 t h$ Exception. If the promises or undertakings of the respective parties to an express contract are not dependent upon each other in the sense of the performance on one side being a condition precedent to performance on the other side, an action on the contract may be maintained for what has been done under the contract by one party and retained by the other. Campbell $v$. Jones, 6 T. R. 570 ; Franklin $v$. Miller, 4 A. \& E. 599 ; Stavers $v$. Curling, 3 Bing. N. C. 355 ; Pordage $v$. Cole, $1 \mathrm{Wm}$. Saund. 320 , n. 4 ; Butler $v$. Manny. 52 Mo. 497. If an action can be maintained under such an express contract for part performance, it must follow that a general assumpsit will lie for so much as has been performed, if it has been retained and is beneficial to the defendant. The express contract of independent undertakings or promises will not operate to defeat the general assumpsit, although it may well operate to limit or reduce 
the amount of recovery. Indeed, the general rule prohibiting general assumpsit in the face of an unperformed express contract has never been considered as applying to contracts in which the covenants or undertakings of the respective parties are independent of each other in the sense hereinbefore mentioned. Perkins $v$. Hart, 11 Wheat. 237 ; Leonard $v$. Dyer, 26 Conn. 177 ; Roberts $v$. Havelock, 3 B. \& Ad. 404 ; Scott v. Parker, 1 Q. B. 810.

5th Exception. If a person has performed in part an express contract, he may recover in general assumpsit for the value of what he has performed, and which has been retained by the defendant, when the special contract is merely void, or the defendant is disabled from suing on it by reason of its being within the statute of frauds. 'Tucker $v$. Groves, 60 Wis. 240 ; Moses $v$. Stephens, 2 Pick. 332 ; King $v$. Welcome, 5 Gray, 41 ; Lockwood $v$. Barnes, 3 Hill (N. Y.), 128; Clark $v$. Terry, 25 Conn. 395 ; Ray $v$. Young, 13 Tex. 550; Sims $v$. McEwen, 27 Ala. 184; Cohen $v$. Stein, 61 Wis. 508 ; Mills $v$. Joiner, 20 Fla. 479; Sullivan $v$. Campbell, 2 Hall, 271; Sherman $v$. N. Y. Cent. R. R., 22 Barb. 239 ; Rice $v$. Peet, 15 Johns. 503; Eno $v$. Woodworth, 4 Coms. 249 ; Buckingham $v$. Ludlum, 39 N. J. Eq. 137; Frazer $v$. How, 106 Ill. 563 ; Tंhurston $v$. Percival, 1 Pick. 415; MicCord $v$. Crooker, 83 Ill. 556; Gwin $v$. Smur, 49 Mo. App. 361 ; Nelson v. Shelby Company, 96 Ala. 515. In such case there is practically no contract to assert against the plaintiff's right to recover in general assumpsit.

6th Exception. If the plaintiff has performed part of an express contract entire and unapportionable, and has been prevented or excused from performing the residue, by act or consent of the defendant, by legal enactment, or by the occurrence of any event by reason of which he is expressly or impliedly excused from further performance, he may maintain an action on an implied assumpsit for the reasonable value of the part performed by him, provided it has been beneficial to the defendant, and has been retained by him; and the special contract cannot be set up to defeat the implied assumpsit. Planche $v$. Colburn, 8 Bing. 14 ; Lilley $v$. Elwin, 11 Q. B. 742, 755; Archard $v$. Horner, 3 C. \& P. 349 ; Smith $v$. Hayward, 7 A. \& E. 544 ; Algeo $v$. Algeo, 10 S. \& R. 235 ; Moulton v. Trask, 9 Met. (Mass.) 577 ; Derby $v$. Johnson, 21 Vt. 18 ; Wright $v$. Haskell, 45 Me. 489 ; Leonard $v$. Dyer, 26 Conn. 172 ; Lockwood $v$. Barnes, 3 Hill (N. Y.), 129; Glover $v$. Henderson, 120 Mo. 367 ; Rude $v$. Mitchell, 97 Mo. 365 ; Fitzgerald $v$. Hayward, 50 Mo. 516; Kelly $v$. Rowane, 33 Mo. App. 440; Ahern $v$. Boyce, 26 Mo. App. 558; Marsh $v$. Richards, 29 Mo. $99 ; 5$ Century Dig. s. $17 b$.

In this class of cases it is assumed that the plaintiff has been 
legally excused from further, or full performance according to the law of the jurisdiction. What constitutes a legal excuse is a question of substantive law, not within the purview of this discussion.

It may be remarked that in cases of wrongful prevention by the defendant, the plaintiff is at liberty to treat the contract as still binding on the defendant, and to found his action on the contract for a breach thereof. By offering to perform, he substitutes a constructive performance which enables him to maintain his action on the contract as if actually performed. Pond $v$ Wyman, 15 Mo. 175; Nearns $v$. Harbert, 25 Mo. 352 ; Halpin v. Manny, 57 Mo. App. 59 ; McCullough v. Baker, 47 Mo. 401.

7th Exception. Disputed. It has been held in many cases, which seem to be increasing in number, that if a party has performed part of an express contract, entire in its nature, and fails or refuses to perform the residne without legal excuse for his action, he may nevertheless recover on an implied assumpsit for the reasonable value of what he has performed, if the same is upon the whole beneficial to the defendant, and has been retained by him. The express contract in such case will not operate as a bar to the implied assumpsit, although it may be employed to show that, npon the whole the defendant has been damaged and not benefited by the part performance. He may recoup in damages or maintain a counter claim for plaintiff's breach of contract. Britton $v$. Turner, 6 N. H. 482 ; Yeats $v$. Ballentine, 56 Mo. 530 ; McFarland $v$. Lyon, $23 \mathrm{~S}$. W. (Tex.) 5554 ; Vicksburg Water Supply Co. $v$. Gorman, 11 So. R. 680 ; Mugan $v$. Regan, 48 No. App. 461; Duncan $v$. Baker, 21 Kan. 99 ; Parcell $v$. Comber, 11 Neb. 200; Hillyard $v$. Crabtree, 11 Tex. 264; Fenton $v$. Clark, 11 Vt. 560; McClay $v$. Hedge, 18 Iowa, 66; Bedow $v$. Tonkin, 59 N. W. 222 (S. Dak.); MeMillan $v$. Malloy, 10 Neb. 228; Studdy $v$. Saunders, 5 B. \& C. 628 ; Strutter $v$. Harlock, 1 Bing. 34 ; Halpin $v$. School Dist., 54 Mo. App. 371; Lee $v$. Ashbrook, 14 Mo. 278; 58 Mo. App. 480 ; Williams $v$. R. R., 112 Mo. 463 ; Linnenkohl $v$. Winkelmeyer, 54 Mo. App. 570 ; Fleischman $v$. Miller, 38 Mo. App. 177; Heman v. Compton Hill Imp. Co., 58 Mo. App. 480; Freeman $v$. Ayler, 62 Mo. App. 613; Gregg v. Down, 38 Mo. App. 283.

In some States the foregoing exception is conceded when it appears that the plaintiff has failed after having endeavored in good faith to complete performance; Hayward $v$. Leonard, 7 Pick. 181; Atkins $v$. Barnstable, 97 Mass. 428; Blood $v$. Williams, 141 Mass. 25; Blakeslee $v$. Holt, 42 Conn. 226 ; White $v$. Oliver, 36 Me. 92 ; Beha $v$. Ottenberg, 6 D. C. 348 ; Kelly $v$. Bradford, 33 Vt. 55 ; but is denied when the failure to complete the performance is wilful. Angel $v$. Hanna, 22 Ill. 431; Stark $v$. Parker, 2 Pick. 267; Malbon $v$. Birney, 11 
Wis. 112; Pullman $v$. Corning, 14 Barb. 174; Neville $v$. Frost, 2 E. D. Smith (N. Y.), 62 ; Timberlake $v$. Thayer, 24 I. R. A. 231 (Miss.); 5 Century Dig. Assumpsit, s. $17 d$.

It may be questioned whether the distinction is practicable or defensible. McKinney $v$. Springer, 3 Ind. 59.

Whether the plaintiff has wilfully and dishonestly abandoned his contract after part performance, or has abandoned it without legal excuse after an honest endeavor to perform it, would seem to be about the same thing to the defendant. The defendant's cause of action or defence for non-performance is the same in both cases, - failure to perform without legal excuse.

It has been said that it would encourage parties to break their contracts to admit recovery in cases of wilful abandonment, after part performance, and that recovery in such cases should be prohibited on grounds of public policy. In answer to this objection, reference may be made to the nature of the action in which the plaintiff is permitted to recover for part performance, - an action entirely equitable in its nature, in which the plaintiff must face the damages resulting from his breach of contract, and receive judgment, if at all, for the benefit received by the defendant after taking into consideration the damages suffered by the plaintiff's default. It is not easy to perceive any substantial encouragement for the breaking of contracts in such a result. On the other hand, how does it comport with public policy to help the defendant to retain valuable benefits to the enrichment of his estate, without compensation or payment of any kind?

In one State the exception is conceded in all contracts except those for personal services; Schnerr $v$. Lemp, 19 Mo. 40 ; White $v$. Wright, 16 Mo. App. 551; while in some other States such contracts are the first in which an implied assumpsit for part performance has been approved. Hare \& Wallace, in 2 Smith's Ld. Cases, 47 (5th Am. ed.).

It must be admitted that the law in England and in many of the American States refuses to admit the exception, and asserts the reverse of it. The American decisions are collected in the notes of Hare and Wallace to Cutter $v$. Powell, in Smith's Leading Cases. Cutter $v$. Powell, 2 Smith's Ld. Cases, 51 (5th Am. ed.); see 2 Encyc. Pl. \& Pr. 1011; 1 Wait, Ac. \& Def. 386 ; 5 Century Dig. Assumpsit, s. $17 d$; 24 L. R. A. 231.

In view of the great number of exceptions to the old rule as stated by us, and the few instances in which it holds good, it is apparent that it has lost much of its force as a general rule. I am inclined to believe that a declaration in reverse of the rule, with one or two exceptions, will more perfectly represent the present condition of the law, or at least the condition which is growing in favor in the courts. 
The general rule should be this: When the plaintiff has performed part of an express contract existing between himself and the defendant, and the part which has been performed has been accepted or retained by the defendant, and is of value or benefit to him, he (the plaintiff) is entitled to recover in general assumpsit the reasonable value of his part performance to the defendant under the circumstances of the case; and the express contract will not operate to defeat his right of action, but may be used to reduce or limit the amount of recovery.

To this general rule two well recognized exceptions may be noted.

1st Exception. Where it expressly appears from the language of the contract, or is necessarily implied from the terms and nature of it that the actual intention of the parties was that complete performance was a condition precedent to the payment of all or any part of the consideration stipulated for, or, in other words, that nothing was to be paid for part performance, however beneficial it might be to the defendant, the express contract will operate to defeat the implied assumpsit. Nearly all authorities are agreed that such actual intention of the parties must govern in denying the right of action. Leonard $v$. Dyer, 26 Conn. 177; Todd $v$. Summers, 2 Grat. 167 ; Lenenkohl $v$. Winkelmeyer, 54 M o. App. 570; Huntingdon $v$. Claflin, 10 Bosw. 262 ; S. C. 38 N. Y. 182 ; Monkman $v$. Shepherdson, 11 Ad. \& El. 411 ; Hunter $v$. Gibson, 3 Rich. (S. C.) 161; Partington $v$. Wamsutta Mills, 110 Mass. 467; Naylor v. Fall River Iron Works, 118 Mass. 317 ; Preston $v$. Am. Lin. Co., 119 Mass. 400.

In such case the benefits of part performance, whether great or small, are forfeited by the plaintiff's default. Such was the result in Cutter $v$. Powell, - a result which Kenyon, C. J. declared came from the express stipulation of the parties. 2 Smith's Ld. Cas. (5th Am. ed.).

Earnest money and deposits are forfeited upon default of the plaintiff, because loss or forfeiture of them is within the contemplation of the parties. Crews $v$. Garneau, 14 Mo. App. 505 ; Ludwig $v$. Knippenger, 13 Mo. App. 593. But where full performance is made a condition precedent by implication of law, and not by actual intention of the parties, the express contract should not operate to defeat the implied assumpsit, which is equitable in its nature. In such case the action does not run counter to the intention of the parties. The bare implication of the law is quite another thing, and should give way to the equity of general assumpsit. Keener, Quasi Cont. 225, 231.

$2 d$ Exception. When the express contract is void for illegality, the policy of the law will not permit recovery for part performance of it either on the contract or in implied assumpsit. Burt $v$. Place, 6 Cow. 431; Honnegger $v$. Wettstein, $94 \mathrm{~N}$. Y. 252. It may be added here that in some legal contracts the principle of forfeiture has been 
applied against a party whose breach of contract consists in a serious tort against the other party, as embezzlement by an agent or servant. Wanton desertion by a seaman is punished with forfeiture of wages on grounds of public policy. Webb $v$. Duckingfield, 13 Johns. 390; Edward $v$. Trevellick, 4 E. \& B. 59.

In elosing this note I may remind the student that much of the confusion met with in the cases has arisen from two misapprehensions as to the nature of general assumpsit.

1st. The first consists in the erroneous impression that when general assumpsit is brought for part performance of a special contract, the contract is in some degree or to some extent the ground of the plaintiff's right of recovery. Such is never the case. The action is either on another contract found as a matter of fact, or on a liability raised by implication of law. This misapprehension has led to a multitude of erroneous decisions, and is emphasized by Hare and Wallace in their commentaries on the case of Cutter $v$. Powell, 2 Smith's Ld. Cas., p. 51, ed. 1855.

2d. The second consists in confining the general assumpsit in such cases to a subsequent contract implied from the acts and conduct of the defendant to pay for the benefit he has received, and to deny the right of action in the absence of facts or evidence tending to show that the defendant has actually agreed to pay for them.

The right of action should be recognized for the enforcement of the legal obligation to pay for benefits received, irrespective of any promise or declaration to that effect. It should be considered as resting on a legal liability springing out of consideration or benefits actually received and retained. 2 Smith's Ld. Cas., p. 51, ed. 1855 . The declaration or intention of the defendant alone cannot relieve him from the legal obligation. Proprietors $v$. Taylor, 6 N. H. 499. Only when his intention is concurred in by the plaintiff can he be relieved from the liability of general assumpsit, which draws its support from equity and conscience. 


\section{NOTE II.}

\section{PROCEEDINGS IN REPLEVIN AFTER ISSUE OF WRIT OR MAKING OF PLAINT.}

The nature of this complicated action at common law, and as modified by statutes, will most clearly appear in connection with the proceedings which took place subsequent to the issue of the writ or making of the plaint, which will now be briefly rehearsed. In doing so it may be necessary to repeat in this note some matters stated in the text.

Upon receiving this writ, the sheriff, after exacting pledges or security from the plaintiff, as required by the common law, to the effect that he would prosecute an action to determine the legality of the distress, proceeded to execute the first command of the writ by taking the property from the distrainer and returning it to the plaintiff. At this stage of the proceedings the attitude of the parties to each other was somewhat changed. The plaintiff was repossessed of his goods, and the defendant was most interested in compelling him to declare, so that the legality of the original taking could be determined, and a return of the property adjudged. Accordingly no summons was in the first instance made on the defendant. He was permitted to appear at any time and have a rule of court compelling the plaintiff to declare. If he did not appear and obtain such rule, the plaintiff might, of his own accord, come into court and declare; after which the defendant was, by summons or attachment, brought into court to plead. 1 Espin. N. P. 349. In entering the rule to plead, and in determining the legality of the distress in his court, the sheriff executed the second and final command of the writ which commissioned him to do justice between the parties.

Notwithstanding these prompt proceedings of the sheriff, the tenant, while applying to chancery for a writ, suffered an inconvenience in being deprived of his property, which often consisted of living cattle required in his daily occupation.

This inconvenience was obviated by the statute of Marlbridge, 52 Hen. III. c. 21 (1267), by which the sheriff acquired jurisdiction in replevin of any value in like manner as possesserl by him under an original writ. Wilks. Repl. 78 . 
The jurisdiction was exercised upon plaint made to him by plaintiff, in pursuance of which a precept to his bailiff, to take the property from the defendant, and deliver it to the plaintiff, and to summon the defendant to answer in the county court an action for the unlawful taking and detention.

It has been seen that the plaintiff, as in all cases, was required at common law to furnish pledges for the prosecution of his action. But these pledges of plaintiff at common law were responsive to the King for bringing a false complaint, if he did not prevail. Wilks. Repl. 10; Gilbert, Repl. 97; 1 Espin. N. P. 347. Neither did the defendant have any lien at common law for his protection on the goods distrained, after they had been taken from him and delivered to plaintiff. Bradyl $v$. Ball, 1 Bro. C. C. 429 . But by the statute of Westminster II. c. 2 (1285), the sheriff, whether acting in pursuance of a writ, or a plaint to him under the statute of Marlbridge, was required, before delivering the property to plaintiff, to exact from him, in addition to the common law pledges for prosecution, security also for a return of the property to defendant, if the plaintiff was defeated in his suit, and a return was adjudged.

The amount and sufficiency of these pledges were entirely within the discretion of the sheriff, - an imperfection which was remedied in cases of distress for rent, by the statute of 11 Geo. II. c. 19 (1738), by which the sheriff was ordered "to take a bond with two sureties in a sum double the value of the goods distrained, conditioned to prosecute the suit and to return the goods, if a return is awarded; which bond may be assigned to the defendant, and if forfeited may be sued in the name of the assignee." This bond took the place of the pledges. $2 \mathrm{H}$. B1. 550 .

After the passage of the statute of Marlbridge in 1267, replevin by original writ became less and less frequent; the last instance occurring, it is said, in 1743. Anon., 2 Salk. 237; Wilks. Repl. 7. All suits of replevin in case of distress for rent in arrear and damage feasant, must be brought in the new County Court without writ. $9 \& 10$ Vict. c. 95, s. 119.

If, in executing a writ or precept of seizure in pursuance of a plaint, the sheriff was notified that the defendant claimed the property as his own, or as that of a third person, his jurisdiction to proceed further in the case was arrested at once, for the reason that he could not without the King's writ to that effect try the right of property.

If the replevin was by plaint, and the defendant claimed the property, the plaintiff might, if he desired, proceed further in the case by suing out of Chancery, or from the King's Bench (Bacon, Abr. E. 4), the writ de proprietate probanda, for the purpose of inquiring into 
the right of property before the sheriff. 1 Espin. N. P. 352; Wilks. Repl. 16, 17. This inquiry was known by the name of inquest of office. If this inquest resulted in favor of the plaintiff, the sheriff replevied and made deliverance at once, and the suit proceeded in the sheriff's court. 2 Roscoe, 626 ; Browne, 450 ; 1 Espin. N. P. 352.

The finding of the sheriff for plaintiff was not conclusive against the defendant, who might contest the right of property by plea, after the cause was removed, as hereinafter mentioned. 2 Roscoe, 627 ; Wilks. Repl. 17.

If the finding at the inquest was in favor of the defendant, no deliverance could be made by the sheriff, and the suit by plaint was at an end. Wilks. Repl. $17 ; 1$ Espin. N. P. 352; 2 Roscoe, 627. He was at liberty, however, to bring a new replevin by writ, and the finding of the sheriff was no bar to its prosecution. Wilks. Repl.17.

If the replevin was by writ, and the defendant claimed the property, the sheriff could not make deliverance any more than he could upon the plaint; but if the writ was an alias or pluries returnable to the Superior Court, which came to be issued at the same time with the original writ, and contained the clause vel causam nobis significes, it was the duty of the sheriff to make return of the claim made by defendant, as a reason for his failure to replevy the property. Jacob, Law Dict. Repl. V. ; Morris, Repl. 56; 2 Roscoe, 626.

According to Coke, the Superior Court had authority to try the issue rendered necessary by this return. Co. Litt. $145 b$.

The plaintiff might however sue, if he wanted possession of his goods, from Chancery the writ de proprietate probanda, in like manner as in case by plaint. which authorized the sheriff to determine the right of property by inquest of office, and to make deliverance if the right was found in favor of plaintiff. 2 Dyer, 172. If so found, the sheriff made deliverance of the property to the plaintiff and gave the defendant a day in court. The plaintiff declared for the unjust caption, and subsequent unlawful detention. The defendant was not barred by the inquest which had been held, but was at liberty to plead.property in himself, and have it determined by a verdict, which was conclusive on both parties.

If the inquest held by the sheriff resulted in favor of the defendant, this ended the suit of replevin by writ, which implied a redelivery to the plaintiff (Morris, Repl. 57), or at'least a continuing right in the sheriff to redeliver, - a right which could not be exercised in face of the finding.

After this finding, the plaintiff was not by his pledges expected or required to declare, and the defendant, having the property, had no interest or occasion to appear and plead. 
If the sheriff, in executing a pluries writ of replevin, made return that the chattels had been eloigned to places unknown so that he could not deliver them, the plaintiff could sue out of Cha acery the writ of capias in withernam directed to the sheriff, commanding him to take the cattle and goods of defendant, of equal value to those of the plaintiff distrained by him ; and to detain them until the distrained goods were restored. In this manner distress was met by distress, by way of reprisal. Fitz. N. B. 69; Jacob, Law Dict., Repl. V.; 3 Bl. Com. 148. Goods thus taken in obedience to the writ of capias in withernam were irrepleviable until the original distress was forthcoming.

In like manner, if the sheriff acted in pursuance of a plaint and not a writ, and his return of a pluries precept is to the effect that the cattle or goods have been eloigned, the plaintiff was entitled to a precept in the nature of a writ of withernam, by which the goods of defendant could be seized in lieu of the goods distrained aud withheld from the plaintiff. Wilks. Repl. 20 .

It was however optional with the plaintiff to have such writ or precept if the goods were withheld, or to proceed with the cause and recover damages to the full amount of the goods, as well as for the detention; Wilks. Repl. 20; Fitz. N. B. 60 ; in which latter case the defendant's appearance to the suit was enforced by summons and at tachment. Gilb. Repl. 83; 2 Roscoe, 627.

In this proceeding, without further efforts to obtain possession, the declaration was said to be in the detinet because the detention was a continuing wrong at the time of declaring.

If the sheriff had succeeded in delivering the property, the declaration which was demandable was said to be in the detinuit, because the detention was terminated, and only damages for the taking and past detention were given. This difference in the declaration did not affect the cause of action, but related only to the anount of damages, which was not considered material.

It ceased to be observed when replevin by writ became obsolete. 1 Chitty, Pl. 162; Browne, Ac. 447; Bull. N. P. 52. In other words, under a declaration in the detinuit, the plaintiff in the course of time was allowed to recover for the value of the goods, if they were still detained by defendant; otherwise, he could recover only for the taking and detention. There was no material variance in allowing the plaintiff to prove a continued detention under au allegation of a previous taking and an actual detention in the past.

While the plaintiff could anciently proceed in the detinet, when the goods were not delivered, and compel defendaut's appearance to the action, it is evident that he was thenceforth prosecuting nothing

Martin Civil Procedure-23 
more than an action of trespass de bonis asportatis; and it became customary either to attempt another replevin or institite some other action.

The advantage of going on with the remainder of the replevin case, instead of resorting to an independent action of trespass de bonis asportatis, consisted in his right, when the goods were eloigned, to compel the defendant to make immediate delivery, or furnish gage of deliverance, if the property was repleviable, and the defendant pleaded an avowry, which conceded property in the plaintiff; 1 Espin. N. P. 379 ; Bull, N. P. 52 ; Jacob, Law Dict. Repl. III.; 2 Sellon, Pr. 154; or he might have a writ of withernam, commanding the sheriff to take other property of defendant. 2 Sellon, Pr. 154.

As the cause could not proceed in the County Court when the defendant claimed property, or the freehold came in question, and as the advantages of the writ of second deliverance extended only to proceedings in the Superior Courts, it came to be the usual practice at a very early day to remove the cause in the first instance into one of the Superior Courts. 2 Roscoe, Ac. $627 ; 3$ Bl. Com. 149. If the suit was commenced by writ, it could be removed by either plaintiff or defendant by a writ called the pone loquelam, which became obsolete with the original writ of replevin. WVilks. Repl. 26.

If it was commenced in the County Court by plaint, either party could remove it by writ of recordari fucias loquelam. Wilks. Repl. 27. From other inferior courts, not of record, including courts in ancient demesne, the parties could remove by writ of accedas ad curiam, which was a species of recordari. Wilks. Repl. 56. From inferior courts of record the cause could be removed by writ of certiorari.

All these writs (except the certiorari in some cases) issued out of Chancery. Wilks. Repl. 27. It is said by Gilbert that formerly good cause had to be shown for the removal. Gilb. Repl. 135, 136. But it was afterwards held that the plaintiff might remove without cause shown. Wilks. Repl. 28.

While the defendant had to show cause, he was held to have com. plied with the requirement, by insertion in the writ of recordari and in the accedas ad curiam of a possible but fictitious cause. Wilks. Repl. 28.

According to some authorities, neither plaintiff or defendant conld remove it from the Barons Court, except on cause shown. Wilks. Repl. 28 ; Fitz. N. B. 70.

The cause alleged in the writ was not traversable, except perhaps in removals from the Barons Court. Browne, Ac. 451 ; 2 Inst. 339. These writs of removal either enjoined a summous of the opposite 
party, or gave him a day and an opportunity to appear in the court above. Fitz. N. B. 70; Wilks. Repl. 31, 32, 151, 154. The County Courts now having become courts of record, the action of replevin is removable therefrom by either party by writ of certiorari upon certain cause shown and bond given to prosecute the suit without delay, according to requirements of the modern statute. $9 \& 10$ Vict. c. 95 , sec. 121.

In responding to the declaration, the defendant was permitted, as already stated, to plead, by way of justification, property in himself or in a third person. If the issue arising from this plea was decided in his favor, he was entitled to a judgment of return. Wilks. Repl. 48. The plea of non cepit put in issue ouly the caption and detention, and was devoid of any suggestion for a return, and consequently there could be no judgment for a return on this plea. Wilks. Repl. 49,50 .

The most usual plea of justification was known by the name of avowry or cognizance. In these pleas the defendant alleged a demise of certain premises, a default in the payment of rent, and a distraint of the goods in question on the demised premises. 'This plea when put in by the landlord in his own right was called an avowry; when put in by any one having authority from him, it was called a cognizance. Wilks. Repl. 52, 53; 3 Bl. Com. 149. A return of the property replevied was always prayed for in the pleas. Wilks. Repl. 165.

If the issue was determined in favor of plaintiff, he, already having received his goods, could have nothing more than a judgment for the damages of a taking and detention. $3 \mathrm{Bl}$. Com. 149 . If it was determined in favor of defendant upon verdict or demurrer, he was entitled to a judgment of return irrepleviable, which was conclusive on the plaintiff. $3 \mathrm{Bl}$. Com. 149.

But when the plaintiff's case terminated in a nonsuit, and the issue raised by the plea was not disposed of upon its merits, while the defendant was entitled to a judgment of return, the property when thus returned to him was repleviable again; and the plaintiff not being concluded on the merits, was at liberty to sue out another writ or make another plaint for recovery of the same property. Wilks. Repl. 135, 136.

The mischief of the plaintiff suffering a nonsuit and replevying again became so prevalent that Parliament interfered, and by the statute of Westminster II. c. 2, restrained the plaintiff, when nonsuited, from suing out a fresh replevin, but in lieu thereof gave him a judicial writ issuing from the court having cognizance of the cause, called a writ of second deliverance, by virtue of which the sheriff, on exact- 
ing the like security as before, redelivered the property to the plaintiff after it had been returned to the defendant.

In this writ the defendant was given a certain day in court, and if the plaintiff suffered nonsuit again, or if return of the property was awarded again to the defendant, it become irrepleviable, and the plaintiff could have no further writ of deliverance. Wilks. Repl. 137; 3 Bl. Com. 148, 149; Morris, Repl. 51, 52. Upon judgment of return in favor of defendant after avowry or cognizance, he was entitled to writ of execution de retorno habendo. If the cattle or goods were eloigned by the plaintiff so that the sheriff could not deliver them, upon return to that effect the defendant was entitled to the writ of capias in withernam, by which the sheriff was commanded to take in withernam other goods of the plaintiff equal in value to those before taken and now withheld by him, which were delivered to defendant to be held by him until the sheriff could make return of the goods called for in the writ. 2 Roscoe, 650 .

The sheriff was also commanded to put, by gages and safe pledges, the plaintiff to answer for his contempt, as well as to respond in damages to the defendant for the injury done him. 2 Roscoe, Real Ac. 650, 651 .

The writ of second deliverance operated as a supersedeas to the writ de retorno habendo, which was given to defendant when a return was awarded, and it was executed by the sheriff only when he had made return of the goods before receiving it, in which event it was executed like a new replevin. Wilks. Repl. 138, 139 . It did not operate as a supersedeas to the writ of inquiry of damages under the statute of 7 Hen. VIII. c. 4, and 21 Hen. VIII. c. 19, nor to the writ of inquiry under the statute of $\mathbf{1 7}$ Car. II. c. 7 ; it being the opinion of eminent lawyers that the latter statute in effect took away the writ of second deliverance in cases of distress for rent. Wilks. Repl. 138, 139.

The right of distress being exercised without process was liable to an abuse which gave rise to the writ of recaption. The abuse consisted in the defendant, after the sheriff had replevied the property, seizing it again or other property of the plaintiffs for the same rent or service, without waiting for a determination of the replevin suit, thus vexing the plaintiff with repeated seizures of his property for the same rent, although sufficiently secured for his rent by the pledges of return furnished by the plaintiff in obtaining a replevin of the property first seized. To correct this abuse the writ of recaption from Chancery was framed, by virtue of which the sheriff was commanded to make deliverance to plaintiff of the property taken by defendant in his second seizure. 
If convicted of such second taking, the defendant was fined to the King. Neither could he justify by avowry or cognizance to this second caption as to the first. If he justified, it had to be as in trespass. Fitz. N. B. 72. Neither was the plaintiff required in suing out this writ of recaption to give pledges of return; nor was the defendant entitled to return of the property. His right to a return was reserved to him in the replevin suit, and could not be invoked again in the proceedings of recaption. Wilks. Repl. 131, 132.

The design of the writ was to prevent a second distress for the - same rent or duty. Wilks. Repl. 138. 


\section{NOTE III.}

\section{WRITS ABOLISHED BY 3 \& 4 WM. IV. c. 27 , sec. 36}

"No writ of right patent, writ of right quia dominus remisit curiam, writ of right in capite, writ of right in London, writ of right close, writ of right de rationabili parte, writ of right of advowson, writ of right upon disclaimer, writ de rationabilibus divisis, writ of right of ward, writ de consuetudinibus et servitiis, writ of cessavit, writ of escheat, writ of quo jure, writ of secta ad molendinum, writ de cssendo quietum de tolonio, writ of ne injuste vexes, writ of mesne, writ of quod permittat, writ of formedon, in descender, in remainder, or in reverter; writ of assize of novel disseisin, nuisance, darrein presentment, juris utrum, or mort d'ancestor; writ of entry sur disseisin in the quibus, in the per, in the per and cui, or in the post; writ of entry sur intrusion, writ of entry sur alienation, dum fuit non compos mentis, dum fuit infra otatem, dum fuit in prisona, ad communem legem ; in casu proviso, in consimili casu, cui in vita, sur cui in vita, cui ante divortium, or sur cui ante divortium, writ of entry sur abatement, writ of entry quare ejecit infra terminum, or ad terminum qui proeteriit, causa matrimonii proelocuti, writ of aiel, besaiel, tresaiel, cosinage, or nuper oliit, writ of waste, writ of partition, writ of disceit, writ of quod ei deforceat, writ of covenant real, writ of warrantia charto, writ of curia claudenda, or writ per quoe servitia, and no other action, real or unmixed, (except a writ of right of dower, or writ of dower unde nihil habet, or a quare impedit, or an ejectment,) and no plaint in the nature of any such writ or action except a plaint for free bench, or dower, shall be brought after the 31st day of December, 1884." 
NOTE IV.

\section{PROCEEDINGS IN EJECTMENT.}

ThE modern action of ejectment is a signal illustration of the philosophy of evolution as applied to legal procedure.

In the earlier periods of English history estates for years were unknown. Where the right to a determinate period was first given to the vassals to stimulate their industry, they were not construed as transferring any title to the land. Adams, Eject. 2. This demise was construed to be a contract or covenant relating to the enjoyment of the rents and profits by the lessee, who occupied the relation of bailee to the lessor, not tenant. If his lease was under seal, he could recover compensation for a breach of it by the lessor. Hammond, N. P. 412. His term or interest in the contract was only a chattel. Ham. N. P. 414.

As opposed to freeholds, terms for years were treated as personal property, and they devolved after the manner of personal estates.

It was the duty of the lord to defend and protect his tenant for years in the possession and enjoyment of the land, both as against hinself as well as strangers.

If the tenant was evicted by the lessor himself, the ancient law furnished a sufficient remedy for his redress in the writ of corenant, a personal writ, by which the lessor was compelled by judgment of the court to restore the unexpired term to his tenant, and to pay damages for the wrongful eviction. $3 \mathrm{Bl}$. Com. 157; Fitz. N. B. $145 \mathrm{M}$, sec. 46. In such a case it was unnecessary to resort to equity.

If the lessee was evicted by a stranger, claiming under an older title from the lessor, his sole remedy at law was by action on the covenant against the lessor for damages; Fitz. N. B. 342 ; in which he recovered damages only, without restitution of his term. This action proceeded upon the theory that the lessor by his grant, previous or subsequent, had broken his covenant. There was no remedy at all by covenant against the lessor, when the lessee was dispossessed of his land by act of a stranger, not claiming under the lessor. Adams, Eject. 3. Neither was there any action in the tenant's name against such a stranger, prior to the reign of Henry III. Bracton, b. 4, f. 220. This remedy by covenant was therefore often inadequate and fruitless. None other was at his command prior to that reign. He could 
not recover possession in any of the real actions against the stranger, because he was not possessed of the freehold. His right under the lease was a subordinate right of contract merely, dependent upon the right of freehold in his lessor.

It was ordinarily in line with the lessor's interest to vindicate his right of freehold by suit against the stranger for its restoration. A recovery of the freehold enabled the lessor to keep good his contract with his lessee by restoring him to his rights in the enjoyment of the land. The only way in which the lessee could recover his term from the evicting stranger was by persuading the lessor to bring a real action against him, and, after recovery, to admit him again to possession. If the lessor refused or neglected to do this, the condition of the lessee was felt to be so remediless at law that suitors began resorting to equity by bill against the lessor to compel specific performance of his contract of lease by restoration of the possession, when it was apparent that he could do so; and by bill against the stranger for perpetual injunction to quiet possession. Gilb. on Eject. 2, 3, 4 ; Adams, Eject. 8 ; Runnington, Eject. 5. In administering this equity of quiet possession, the court also compelled restoration of possession to the injured party. This resort to equity quickened the courts of law in devising a better remedy for the wrongful eviction of lessees for years. In doing this they only availed themselves of the suggestions and analogies contained in well known proceedings going on every day before them, as follows.

In the reign of Henry III. (1216-1272) the writ of quare ejecit infra terminum had been introduced, by which the lessee, upon eviction by the lessor, or a stranger claiming under him, could recover back his term along with damages for the eviction. But this writ, as we have seen, lay in favor of the lessee only when the stranger claimed to have acted by virtue of sale from or under contract with the lessor. 1 Roscoe, Real Actions, 99 ; Adams, Eject. 5 ; Gilb. Eject. 123. This limitation, which has been overlooked by erudite writers like Reeves (2 Reeves, Hist. Eng. Law, 136), greatly reduced the usefulness of the remedy. Adams, Eject. 7. Blackstone remarks that it did not lie against the lessor, but only against his feoffee or other person claiming under him. $3 \mathrm{Bl}$. Com. 199. If the lessor ejected the lessee, the latter had, as we have seen, a limited remedy on the covenant. But it may be questioned whether this action would not also lie against the ejecting lessor himself. Adans, Eject. 4. Notwithstanding the limited number of eases to which the writ applied, it contained the important element of restoring to the lessee possession of the land for his unexpired term.

It was not a writ of trespass vi et armis, but has been classed with 
real actions of the possessory kind; and was subject, of course, to the delays and burdens which attended such actions.

In the early part of the reign of Edward III. (1326-1377), possibly as early as the reign of Edward I., there appeared a new personal writ, by which a lessee for years could recover damages as in trespass against any one who, without claiming under the lessor, evicted him. $44 \mathrm{Edw}$. III. f. 22, pl. 26. It came to be known in later times as the writ of ejectione firmce. Originally no restitution of the premises was adjudged or given, although it has been strenuously maintained by Mr. Finlason in his edition of Reeves's History, that restitution was always given. 2 Reeves, 549 ; 3 Reeves, 177, 178, 179, 759. Baron Gilbert infers that it must have been given prior to the reign of Henry VII. (1485-1509). Gilb. on Eject. 4. Runnington is of the same opinion, and cites Blackstone in support. $3 \mathrm{Bl}$. Com. 201; Runnington, 5. However this may be, the first reported ease, in which the lessee in this action was allowed to recover his term, as well as damages, is found in the reign of Henry VII. in 1499. 14 Henry VII.; Rast. Ent. f. 252 ; 2 Reeves, Hist. Eng. Law, 549, note.

This decision constitutes the most important link in the history of modern ejectment. It furnished in a personal action a remedy existing almost exclusively in real actions, and it furnished it to a suitor who could not invoke in his behalf the remedial benefits of any real action. It has been said that in doing this the courts of law only followed the practice of the courts of equity, inspired by jealousy at their growing jurisdiction. $3 \mathrm{Bl}$. Com. 200. But the nature and extent of this equitable jurisdiction does not appear to be definitely disclosed by any of the writers mentioning it, and its indefiniteness may well have added to the jealousy and apprehension of the courts of law.

It is probable that the courts of law followed the analogy furnished by the writ of quare ejecit infra terminum, in which restitution was given to the lessee, whenever he could maintain that action, rather than follow the uncertain and undefined practice of the Courts of Equity in restoring the possession.

The writ of ejectione firmo, as thus employed, existed only in favor of an actual lessee to recover back his term and obtain damages from the actual ejector. It continued with this limitation till after the reign of Henry VII. How it came to be employed by the freeholder and lessor to obtain possession of the land is interesting from an historical point of view, but by no means surprising in a system of procedure which abounded in forms and fictions. In the transformation which took place nothing was done which had not been done or been suggested in other proceedings, to which allusion is now made. 
The action of forcible entry, which had been created and enlarged by the statutes of Richard II. and Henry VI., was an attempt at providing a more summary and effective remedy for dispossession of the freehold than contained in the possessory writ of novel disseisin. 15 Rich. II. c. $2 ; 8$ Hen. VI. c. 9 . As extended, it embraced a wrongful and forcible withholding, although the entry had been peaceable. The large number of cases it applied to tended to discourage resort to many of the real actions. It differed from the real actions in that it assumed to redress the wrong of dispossession by restoring the possession to the one who had been actually disturbed, without inquiring into the titles of the parties. But this remedy was held to exist only in favor of freeholders by virtue of the statutes creating it. In the reign of Henry VII. the courts held that, while the remedy did not exist in favor of the lessee for years, he nevertheless would be permitted to have the benefit of it, if he prosecuted it in the name of his lessor, who was a freeholder.

It was but a short step from this holding of the courts, and entirely in line with it, to permit the freeholder, when his tenant was ousted, to invoke in his tenant's name the writ of ejectione fivma, which existed only in favor of a lessee for years. This step was finally taken by the courts, and thereafter the possessory action of ejectment came to be used by freeholders as well as tenants for years. It lay for them not only where the land had been forcibly taken, but where it was wrongfully withheld irrespective of actual force.

But it will be noticed that the freeholder who invoked its use had also to be a lessor for years, and that he could sue only in the name of his lessee. The remedy was so efficacious and popular that, when he wished to avail himself of its advantages, if he had no lessee, he went to work and manufactured one for the occasion. Runnington, Eject. 12. Having the right of entry, he made actual clandestine entry on the land, and while in possession made a lease for years to some one who was in accord with his intentions. This secret lessee being on the land then suffered an actual ouster from the person in occupation, or a clandestine ouster from another friend of the freeholder, who came to be known in the proceeding as the casual ejector. 3 Bl. Com. 201. This supposed stranger or casual ejector was then made defendant in the case, and the writ, which ran in the name of the friendly lessee, was directed to and served on the casual ejector. This casual ejector was sure to suffer default.

Originally, the courts upon this default rendered judgment of restitution of the land, by which the actual occupant of it was turned out, and in order to regain his possession he was compelled to sue in ejectment. 3 Reeves, Hist. Eng. Law, 179. 
The manifest injustice of this practice led to the establishment of a rule of court, that no plaintiff in ejectment should recover the land against a casual ejector, unless notice of the suit was first given to the tenant in possession, if any there were, by the casual ejector. 3 Bl. Com. 202; Runnington, 3. This notice consisted of a delivery of the declaration in the case, with a statement by the ejector that he had no interest in the land, and that, unless the party so notified appeared and defended the astion, judgment would be suffered by default and he would be turned out. If upon affidavit of service the party so served or notified failed to appear and defend, judgment went against the casual ejector, and the occupant of the land was evicted in like manner as he had been evicted before the courts required notice to be given him. If he appeared and interposed a defence, the plaintiff was compelled to establish four propositions of fact: 1st, that his lessor had a good title; $2 \mathrm{~d}$, that his lessor having such title made the lease for the unexpired term to plaintiff; $3 \mathrm{~d}$, that plaintiff took possession under the lease; $4 \mathrm{th}$, that the defendant ejected him. If the plaintiff succeeded in establishing all these propositions he obtained judgment, which dispossessed the tenant so defending and all entering under or after him. If the plaintiff failed to establish any one of them, the judgment went for the defendant.

This seems to have been the practice in the action of ejectment, from the reign of Henry VII. to the time of the Protectorate of Cromwell, - about 150 years.

As much inconvenience attended the formalities of actual lease, entry, and ouster (Adams, Eject. 17), while the substantial issue involved only the right of the lessor to make a lease, the courts took another and final step in moulding the proceedings under this writ to answer the purposes of a real action, without the delays and embarrassments incident to it. In 1652, or a few years before that time, Chief Justice Rolle is accredited with introducing into practice a rule of the court which is known as the consent rule, by which the issue to be tried was confined to the right of the lessor to make the lease described by the plaintiff in his declaration. Styles, Rep. 368. By this rule the true tenant, after appearing in pursuance of notice of the casual ejector, was required, as a condition upon which he was permitted to defend, to enter into an agreement that he would confess at the trial the lease, entry, and ouster as alleged by the plaintiff, and take issue only on the title or right of the lessor to make the lease.

A further condition was imposed on him, by which he consented that, if he did not at the trial keep his engagement of confession, he would pay all costs of suit, and allow judgment to be entered against 
the casual ejector. Such a judgment when executed would dispossess him as before the rule.

When the terre tenant in possession had to admit lease, entry, and ouster in order to defend, these facts might as well be fictitious as real or collusive; and such under this rule and by sanction of court they eventually became.

The attorneys framed a declaration as if preceded by an original writ, and introduced the name of John Doe as lessee and plaintiff, and the name of Richard Roe as defendant and casual ejector, alleging a fictitious ouster by him. After notice to the terve tenant or occupant, which consisted of delivery to him of the declaration with a warning to defend or be ousted, as the result of a judgment of default, he was permitted to defend the action upon entering into the consent rule mentioned, and upon receiving without writ or process a new declaration, with his own name substituted as defendant in the place of Richard Roe, the fictitious ejector and former defendant.

In this form the action continued down to comparatively recent times, superseding nearly all the real and possessory actions known to the common law. By $3 \& 4 \mathrm{Wm}$. IV. c. 27 , s. 39 , it was enacted that no descent cast, discontinnance, or warranty shall hereafter defeat any right of entry or action for the recovery of any lauds. This enactment converted all titles into possessory titles, and thus made the remedy by ejectment of universal application. Tyler, Eject. 89.

By section 36 of chapter 27 of the same statute all real actions were expressly abolished except four, one of which is ejectment; the other three - quare impedit and the two writs in dower - involving rights which it was supposed could not be enforced in that action.

The action of ejectment as between landlord and tenant and mortgagor and mortgagee was subjected to some necessary modifications by the statute of $4 \mathrm{Geo}$. II. c. 28, and the Common Law Procedure Act of 1852 ( $15 \& 16$ Vict. c. 76 ), relating to the right of entry and the method of enforcing it by that action. By an amendment of the Common Law Procedure Act of 1852, parties to real actions were allowed to arbitrate their claims and enter judgment on the award. $17 \& 18$ Vict. c. 125 , s. 16 . 


\section{FORMS IN PLEADING.}

\section{FORM (1).}

\section{Writ in DebT.}

George the Third, \&c. To the sheriff of —_ greeting: Command C. D., late of - that justly and without delay he render to A. B. the sum of $\mathfrak{E} \longrightarrow$ of good and lawful money of Great Britain, which he owes to, and unjustly detains from him, as it is said: and unless he shall so do, and if the said A. B. shall make you secure of prosecuting his claim, then summon by good summoners, the said C. D. that he be before us, on — wheresoever we shall be in England, (or, in C. P. before our justices at Westminster, on -, ) to shew wherefore he hath not done it, and have there the names of the summoners, and this writ. Witness ourself, \&c. L. S.

- Tidd's Appendix, 20.

\section{FORM (2).}

\section{Declaration in Debt for Goons sold and Delivered.}

In the Common Pleas.

The 12th day of June, 1845 .

Somersetshire, to wit. - Jonathan Gregory (the plaintiff in this suit), by Abraham Elliot, his attorney, complains of James Johnson (the defendant in this suit), who has been summoned to answer the said plaintiff in an action of debt, and he demands of the said defendant the sum of $£ 500$, which he owes to and unjustly detains from the said plaintiff. For that whereas the said defendant heretofore, to wit, on the first day of December, in the year of our Lord 1844, was indebted in $£ 500$, for goods then sold and delivered by the said plaintiff to the said defendant, at his request, to be paid by the said defendant to the said plaintiff on request. Whereby, and by reason of the non-payment thereof, an action hath accrued to the said plaintiff to demand and have of and from the said defendant the said sum of $£ 500$, above demanded. Yet the said defendant, although often requested, hath not paid the said sum of $£ 500$, above demanded, or any part thereof, to the damage of the said plaintiff of $£ 50$, and therefore he brings this suit, \&c.

Warren, Law Studies, 583. 
FORM (3).

\section{Declaration in Debt on Bond.}

In the Queen's Bench.

The — day of — in the year of our Lord 18-.

London, ? A. B. by X. Y. his attorney, complains of C. D., who has to wit: $\}$ been summoned to answer the said A. B. in an action of debt, and he demands of him the sum of $£ 1000$, which he owes to and unjustly detains from him. For that whereas the said C. D. heretofore, to wit, on the —_ day of —_, in the year of our Lord — by his certain writing obligatory, sealed with his seal, and now shown to the Court of our said Lady the Queen, before the Queen herself here, the date whereof is the day and year aforesaid, acknowledged himself to be held and firmly bound unto the said A. B. in the said sum of $£$ - above demanded, to be paid to the said A. B. Yet the said C. D. (although often requested so to do) hath not as yet paid the said sum of $£ 1000$ above demanded, or any part thereof, to the said A. B., but hath hitherto wholly neglected and refused, and still neglects and refuses so to do. To the damage of the said A. B. of ten pounds, and therefore he brings his suit, \&c.

$$
\text { J. W. Smith, Actions, } 120 .
$$

\section{FORM (4). \\ Writ on Covenant.}

George the Third, by the grace of God of the United Kingdom of Great Britain and Ireland King, Defender of the Faith. To the sheriff — greeting: Command C. D., late of — that justly and without delay he keep with $\mathrm{A}$. B. the covenant (or covenants) made by the said C. D. with the said A. B. according to the force, form, and effect of a certain indenture (or deed-poll, or articles of agreement) in that behalf made between them, as it is said; and unless he shall so do, and if the said A. B. shall make you secure of prosecuting his claim, then summon by good summoners the said C. D. that he be before us, on - wheresoever we shall then be in England, (or, in C. P. before our justices at Westminster, on - $\longrightarrow$ ) to shew wherefore he hath not done it; and have there the names of the summoners, and this writ. Witness ourself at Westminster, the __ day of __ in the —_ year of our reign.

Tidd's Appendix, 19.

FORM (5).

\section{Declaration on Covenant.}

In the K. B. (or C. P.).

London, to wit (venue). C. D. was summoned to answer A. B. of a plea, that he keep with him the covenant made by the said C. D. with 
the said A. B., according to the form and effect of a certain indenture (or " deed-poll," \&c., according to fact) made between them (according to fact) ; and thereupon the said A. B., by his attorney, complains, for that whereas, \&c. (state the deed and breaches, \&c., and conclude thus): Wherefore the said A. B. saith that he is injured, and hath sustained damage to the amount of $\mathcal{1} \longrightarrow$, and therefore he brings his suit, \&c. (no pledges).

Saund. Pl. \& E., 483.

FORM (6).

Writ in Assumpsit.

In the King's Bench.

William the Fourth, by the grace of God, of the United Kingdom of Great Britain and Ireland King, Defender of the Faith, to the Sheriffs of London [the venue], greeting: If A. B. shall make you secure of prosecuting his claim, then put by gages and safe pledges, C. D. sate of [London, merchant], that he be before us on the Morrow of All Souls [the return] wheresoever we shall then be in England, (or in C. P. before our justices at Westminster, on, \&c.) to show, For that whereas, \&c. (Here state the cause of action as in a declaration) and have there the names of the pledges and this writ. Witness ourself at Westminster, the — day of — in the — year of our reign. 2 Chitty, Pl. 7 (ed. 1872).

\section{FORM (7).}

\section{Ancient Writ of Trespass on the Case on Promises.}

(This writ resembled the general writ of trespass on the case; alleging that the defendant had agreed or undertaken with the defendant to do something in his behalf, and that he had wrongfully failed and refused to carry out his agreement, by reason of which plaintiff had been damaged.) See 2 Chit. Pl. 7 (ed. 1872); 1 Rich. C. P. 81 ; F. N. B. 94.

FORM (8).

Declaration in Assumpsit.

In the Queen's Bench.

The - day of - in the year of our Lord 18-.

London, \} A. B. by X. Y. his attorney, complains of C. D., who has to wit. $\}$ been summoned to answer the said A. B. in an action on promises for that, whereas the said C. D. heretofore, to wit, on the - day of — in the year of our Liord 18-, was indebted to the said A. B. in $£ 100$ for money found to be due from the said C. D. to the said A. B. on an account then stated between them, and the said C. D. afterwards, on the day and year aforesaid, in consideration 
of the premises respectively promised the said A. B. to pay the said several moneys respectively to the said A. B. on request. Yet the said C. D. hath disregarded his promises, and hath not paid any of the said moneys, or any part thereof, to the damage of the said A. B. of $£ 200$ and thereupon he brings his suit, \&c.

J. W. Smith, Ac. 117.

\section{FORM (9).}

Writ in Account Render.

The King to the sheriff, \&c. Command A. that he render to B. a reasonable account for the time in which he was receiver of the money of him the said A. or bailiff of him the said A. and unless he will do it, and the aforesaid A. shall make you secure of prosecuting his claim, then summon the aforesaid B. that he be before our justices at Westminster in fifteen days of Easter, \&c., to shew wherefore he will not do it: And have there the summoners and this writ, \&c.

F. N. B. 268.

FORM (10).

\section{Declaration on Account Render.}

In the Common Pleas.

- Term, — Will. IV.

London, (to wit). A. S. was summoned to answer to W. S. in a plea that she render to the said W. S. a reasonable account for the time during which she was bailiff to the said IV. S. in the parish of [St. Botolph, Bishopsgate Street,] in the [city of London]. And thereupon the said W. S. by - his attorney, saith, that whereas, heretofore, to wit, on the —_ day of —_, in the year of our Lord - , and from thence for a long space of time, to wit, hitherto the said plaintiff was lawfully possessed of one undivided moiety or half part, the whole in moieties to be divided [or if the plaintiff was seized in fee, say, "the said plaintiff was seized in his demesne as of fee, of and in one undivided, \&c."] of and in a certain messuage, with the appurtenances, situate, \&c., for the rest and residue of a certain term, to wit, the terin of six years, commencing, \&c. with the said defendant, during all that time held the said tenement, with the appurtenances, together with the said plaintiff, as tenants in common; [or if the seisin was in fee, say, "and the said defendant and divers other persons whose names are to the said plaintiff unknown, during all that time held the said tenements with the appurtenances, together with the said plaintiff, as tenants in common;"] and the said defendant had also, during all that time, the care and management of the whole of the said premises with the appurtenances, to receive and 
take the rents, issues, and profits thereof, as bailiff of the said plaintiff, of what she received more than her just share and proportion thereof to render a reasonable account thereof to the said plaintiff and his said share thereof, when the said defendant should be thereunto afterwards requested, according to the form of the statute, \&c.; and although the said defendant during the time aforesaid, at, \&c. (venue) aforesaid, received more than her just share and proportion of the rents, issues, and profits of the said tenements with the appurtenances, and the said plaintiff's share thereof, that is to say the whole of the rents, issues, and profits of the said tenements with the appurtenances; yet the said defendant, although she was afterwards, to wit, on, \&c. at, \&c. (venue) aforesaid, requested by the said plaintiff so to do, hath not yet rendered a reasonable account to the said plaintiff of the said rents, issues, and profits so received as aforesaid or either of them, or any part thereof, or of the said share of the said plaintiff, or any part thereof, but hath hitherto wholly neglected and refused so to do contrary to the form of the statute in that case made and provided, to wit, at, \&c. (venue), aforesaid; wherefore the said plaintiff says he is injured, and hath sustained clamage to the amount of $£$ - and therefore he brings his suit, \&c.

\section{Chit. Pl. 1297.}

FORM (11).

\section{Common Pleas.}

Writ in Annuity.

Command A. that justly, \&c. he render to B. one hundred marks and the moiety of three garments with costly fur, and of two garments with fine linen, which are in arrear to him, of the yearly rent of ten marks, and the moiety of one garment with fur and of one garment with fine linen, which he oweth to him, \&c., and unless, \&c.

F. N. B. 357 .

\section{FORM (12).}

\section{Declaration in Annuity.}

- (to wit) A. B. complains of C. D. being in custody of the marshal of the Marshalsea of our lord the now King, before the King himself, of a plea, that he render unto the said A. B. the sum of of lawful money of Great Britain, which he is in arrear to the said A. B. of a certain annuity or yearly rent of — and which the said C. D. owes to the said A. B. For that whereas, \&c. Wherefore the said plaintiff saith that he is injured, and hath sustained damage to the amount of $\&$ - and therefore he brings his suit, \&c. 


\section{FORM (13).}

\section{WRIT OF SCIRE FACIAS.}

George the Third, \&c. To the sheriff of - greeting: Whereas A. B. lately in our court before us at Westminster, by bill without writ, and by the judgment of the same court, recovered against C. D. $£$ - for his damage, which he hath sustained as well on occasion of the not performing certain promises and undertakings then lately made by the said C. D. to the said A. B. as for his costs and charges by him about his suit in that behalf expended; whereof the said C. D. is convicted, as appears to us of record. And now on behalf of the said A. B. in our said court before us, we have been informed that although judgment be thereupon given, yet execution of the damages aforesaid still remains to be made to him; wherefore the said A. B. hath humbly besought us to provide him a proper remedy in this behalf. And we being willing that what is just in this behalf should be done, command you, that by honest and lawful men of your bailiwick, you make known to the said C. D. that he be before us at Westminster, on — next after — to shew if he has or knows of anything to say for himself why the said A. B. ought not to have his execution against him of the damages aforesaid, according to the force, form, and effect of the said recovery, if it shall seem expedient for him so to do; and further to do and receive what our said court before us shall then and there consider of him in this behalf; and have there then the names of those by whom you shall so make known to him, and this writ. Witness Sir Charles Abbot Knight, at Westminster the — day of — in the —_ year of our reign.

Tidd's Appeudix, 527.

\section{FORM (14).}

\section{Writ in Trespass vi et Armis.}

The King to the sheriff, \&c. If A. shall make you secure, \&c., then put by gages and safe pledges $B$. that he be before us on the morrow of All Souls, wheresoever we sliall then be in England, to shew wherefore with force and arms he made an assault upon him the said $\mathrm{A}$. at $\mathrm{N}$. and beat, wounded, and ill treated him, so that his life was despaired of, and other enormous things to him did, to the great damage of him the said A. and against our peace. And have there the names of the pledges and this writ. Witness, \&c.

F. N. B. 196. 


\section{FORM (15).}

\section{Declaration in Trespass vi et Armis.}

In the Queen's Bench.

On the - day of — in the year of our Lord 18-.

London A. B. by X. Y., his attorney, complains of C. D. who has to wit. $\int$ been summoned to answer the said A. B. in an action of trespass. For that the said C. D. heretofore, to wit on, \&c. with force and arms, \&c., made an assault on the said A. B., and beat, bruised, wounded, and ill treated him, insomuch that his life was thereby greatly despaired of, and other wrongs to the said A. B. he the said C. D. then did against the peace of our Lady the Queen, and to the damage of the said A. B. of fifty pounds, and therefore he brings suit, \&c.

$$
\text { J. W. Smith, Ac. } 119 \text { [244]. }
$$

\section{FORM (16).}

\section{Writ in Detinue.}

The King to the sheriff, \&c. Command A. that, \&c. he render to B. a certain writing by which $\mathrm{B}$. hath given and granted all his goods and chattels lately being in the manor of $\mathrm{N}$. to I. of L. which he unjustly detains from him, \&c.

\section{FORM (17).}

$$
\text { F. N. B. } 323 \text {. }
$$

\section{Declaration in Detinue.}

In the Exchequer of Pleas.

The 15th day of June, in the year of our Lord 1845.

Berkshire, to wit. - Anthony Brown (the plaintiff in this suit), by Peter Black, his attorney, complains of Augustus White (the defendant in this suit), who has been summoned to answer the said plaintiff in all action of Detinue. For that whereas the said plaintiff heretofore and before the commencement of this suit, to wit, on the 12th day of February, in the year of our Lord 1845, had delivered to the said defendant certain goods and chattels, to wit, twenty pipes of wine of the said plaintiff, of great value, to wit of the value of $£ 2,000$, to be redelivered by the said defendant to the said plaintiff when the said defendant should be thereunto afterwards requested; yet the said defendant, although he was afterwards, to wit, on the first day of March, in the year aforesaid, requested by the said plaintiff so to do, hath not as yet delivered the said goods and chattels, or any of them, or any part thereof, to the said plaintiff, but so to do hath hitherto wholly refused, and still refuses, and still unjustly detains the same from the said plaintiff, to the damage of the said plaintiff of $£ 800$, and thereupon he brings his suit, \&c. 


\section{FORM (18).}

\section{Writ in Trespass on the Case.}

The King to the sheriff, \&e. If A. shall make you secure, then put \&c. T. of D., \&c. that he be, \&c. to show wherefore, whereas the aforesaid $\mathrm{T}$. of $\mathrm{D}$. contriving deceitfully to defraud him, the said $\mathrm{A}$. and to extort divers sums of money from the same A. excited and procured the said $\mathrm{A}$. to play at dice with him the said $\mathrm{T}$. at a certain game called the dozen for divers sums of money at Burton upon Trent, and the said $\mathrm{A}$. there played with him at dice at the game aforesaid, the aforesaid $\mathrm{T}$. certain dice truly titled delivered to him the said $\mathrm{A}$. to throw, and when the said dice happened to come to the hands of him, the said T., he, the same T., falsely and fraudulently, threw certain other false dice, and deceitfully titled, which he knew would turn up number twelve at every throw, by which he, the said A., lost great sums of money to him, the said T., at that game, and the said T. falsely and deceitfully took and carried away those sums under color of gain, to the damage of him, the said A., of five pounds, as it is said. And have you there the names of the pledges and this writ. Witness, \&c.

F. N. B. 95 .

\section{FORMI (19).}

\section{Declaration in Trespass on the Case.}

In the Queen's Bench.

The 15th day of June, in the year of our Lord 1845.

Lancashire (Southern Division), to wit. - Thomas Moody (the plaintiff in this suit), by Frederick Jones, his attorney, complains of William White (the defendant in this suit), who has been summoned to answer the said plaintiff in an action of trespass on the case. For that whereas the defendant before, and at the time of the commencement of this suit, and of the injury and damage occurring, as hereinafter mentioned, was the possessor and occupier of a certain messuage, vault, cellar, and premises, with the appurtenances, situate in the town of Liverpool, in the county of Lancaster, and near to a certain common and public footway there, and in which vault and cellar there was a certain hole or aperture opening into the said public footway. Yet the defendant, well knowing the premises, whilst he was so the possessor and occupier of the said messuage, vault, cellar, and premises, with the appurtenances, and whilst there was such hole as aforesaid, here. tofore, to wit, on the first day of May, in the year of our Lord 1845, wrongfully and unjustly, and contrary to his duty in that behalf, per. mitted the said hole to be, and continue, and the same was then so badly, insufficiently, and defectively covered, that, by means of the 
premises, and for want of a proper and sufficient covering to the said hole, the plaintiff, who was then lawfully passing in and along the said footway, then slipped and fell into the said hole, and thereby the left leg of the plaintiff was then fractured and broken, and greatly damaged; and the plaintiff became and was sick, sore, lame, and disordered, and so remained and continued for a long time, to wit, thence hitherto, during all which time the plaintiff thereby suffered and underwent great pain, and was prevented from attending to and transacting his lawful affairs and business, by him during that time to be performed and transacted; and was also, by means of the premises, forced and obliged to pay, lay out, and expend, and did pay, lay out ${ }_{2}$ and expend a large sum of money, to wit, the sum of $£ 60$ in and about the endeavoring to be healed and cured of the wounds, lameness, sickness, and disorder so occasioned as aforesaid, to the plaintiff's damage of $£ 200$, and thereupon he brings suit, \&c.

Warren, Law Studies, 588.

\section{FORM (20).}

\section{Declaration in Trover.}

In the Common Pleas.

The 1st day of June, in the year of our Lord 1845.

Staffordshire, to wit.- Emanuel Clifton (the plaintiff in this suit), by Titus Trueman, his attorney, complains of William Waller (the defendant in this suit), who has been summoned to answer the plaintiff in an action of trover. For that whereas the plaintiff heretofore, to wit, on the 17th day of January, in the year of our Lord 1845 , was lawfully possessed, as of his own property, of a certain balloon of great value, to wit, of the value of $£ 500$, and being so possesssed thereof, the plaintiff afterwards, to wit, on the day and year aforesaid, casually lost the same out of his possession, and the same afterwards, to wit, on the day and year aforesaid, came to the possession of the defendant by finding; yet the defendant, well knowing the said balloon to be the property of the plaintiff, and of right to belong and appertain to him, but contriving and frandulently intending to deceive and defraud the plaintiff, hath not as yet delivered the said balloon to the plaintiff (although often requested so to do); and afterwards, to wit, on the day and year aforesaid, converted and disposed of the same to his, the defendant's, own use, to the damage of the plaintiff of $£ 200$, and therefore he brings suit, \&c.

Warren, Law Studies, 589. 


\section{FORM (21).}

\section{Writ of Replevin.}

George the Fourth, by the grace of God, of the United Kingdom of Great Britain and Ireland King, Defender of the Faith, to the sheriff of - greeting: We command you, that justly and without delay you cause to be replevied to A. B. his cattle, goods, and chattels, which C. D. hath taken and unjustly detaineth, as he saith, and after cause him to be brought to justice for the same; that we hear no more complaint for want of justice. Witness ourself at Westminster, the — day of — in the —_ year of our reign.

Wilkinson, 143.

\section{FORM (22).}

\section{Declaration in Replevin.}

In the Exchequer of Pleas.

The 21st day of April, in the year of our Lord 1845 in Easter Term, in the 8th year of the reign of Queen Victoria.

Sussex, to wit. - Charles Dupper (the defendant in this suit) was summoned to answer Archibald Brudenall (the plaintiff in this suit) of a plea, wherefore he took the cattle of the said plaintiff, and unjustly detained the same against sureties and pledges, until, \&c.; and thereupon the said plaintiff, by Henry Blunt, his attorney, complains : For that the said defendant heretofore, to wit on the 1st day of February, in the year of our Lord 1845, at Lewes, in the county of Sussex, in a certain place there called Chalkey Hill, took the cattle, to wit, one gelding, of the said plaintiff, of great value, to wit of the value of $£ 50$, and unjustly detained the same, against sureties and pledges, until, \&c.: wherefore the said plaintiff saith that he is injured, and hath sustained damage to the value of $£ 100$, and therefore he brings his suit, \&c.

Warren, Law Studies, 589.

\section{FORM (23).}

\section{Writ of Right Patent.}

"Charles, \&c. to T. M. greeting: We command you that without delay you do full right to $T$. I3. of one messuage and ten acres of land with the appurtenances in B. which he claims to hold of you by the free service of one penny per annum for all service; of which. J. S. deforceth him; and unless you will do this, let the sheriff of C. do it, that we may hear no more clamor thereupon for want of right. Witness, etc." 
FORM (24).

Count on a Writ of Rigit Patent.

Middlesex, to wit. - Francis John Tyssen, Esq., by John Vernon, his attorney, demands against George Clarke ten messuages, ten gardens, one shop, two coach-houses, three stables, and two acres of land with the appurtenances, in the parish of Saint John Hackney, as his right and inheritance by writ of the lord the King of right, and thereupon he saith that Francis Tyssen, Esq., father of him the said Francis John, was seised of the tenements aforesaid, with the appurtenances in his demesne as of fee and right in the time of peace in the time of the lord George the First, late King of Great Britain, to wit, within years now last past, by taking the esplees thereof to the value, \&c., and from the said Francis John, the father, the right descended to the said Francis John, who now demands as son and heir of the said Francis, his father, and that such is his right he offers, \&c.

Booth, 92, note.

FORM (25).

\section{Writ of Right Close.}

The King, \&c. to the mayor and sheriffs of London, greeting: We cominand you, that without delay you do full right to E. of N. of one messuage and two shops with the appurtenances in London, which he claims to hold of us by free service, \&c. whereof W. deforceth him, that we may hear no more clamor thereupon for want of right. Witness, \&c.

Booth, 116.

FORM (26).

\section{Writ of Right of Advowson.}

The King, \&c. to the sheriff of $\mathrm{C}$. greeting: Command A. that justly, \&c. he render B. the advowson of the church of S. from which he unjustly deforces him as he says; and unless, \&c.

Booth, 122.

\section{FORM (27).}

\section{WRIT OF RIGHT OF DOWER.}

The King to A. greeting: We command you, that without delay you do full right to B., who was the wife of C., of a third part of ten acres of land with the appurtenances in W. which she claims to hold of you in dower by the free service of a third part of one penny per annum for all service whereof C. unjustly deforceth her, \&c.

Booth, 118. 


\section{FORM (28).}

\section{Writ of Dower Unde Nihil Habet.}

The King to the sheriff, \&c. Command A. that justly, \&c. he render to B., who was the wife of C., her reasonable dower which falls to her share, of the freehold which was the aforesaid C.'s, some time her husband in $\mathrm{N}$. whereof she nothing hath, as she saith, and whereof she complains that the aforesaid $\mathbf{A}$. unjustly deforceth her, and unless, \&c.

Booth, 166.

\section{FORM (29).}

\section{Writ of Formedon in Descender.}

The King to the sheriff, \&c. Command A. that, \&c. he render to B. the manor of N., with the appurtenances which C. gave to D. and E. his wife, and the heirs of the bodies of them the said D. and E. issuing, and which after the death of the aforesaid D. and E. ought to descend to the aforesaid B. the son and heir of the aforesaid D. and E., by the form of the gift aforesaid, as he saith, and unless, \&c. Booth, 142.

\section{FORM (30).}

\section{Writ of Ne Injuste Vexes.}

The King to A., greeting: We command you, that you unjustly vex not, or permit to be vexed, B. concerning his free tenement, which he holds of you in J., nor therefore require or permit to be required of him customs or services which he oweth not, nor is used to do for the same; and unless you will do this, the sheriff of Lincoln shall cause the same to be done, that we may hear no more clamor thereupon for want of right.

Booth, 126.

FORM (31).

\section{Writ of Assize of Novel Disseisin.}

The King to the sheriff, \&c. A. hath complained unto us that $B$. unjustly and without judgment hath disseised him of his freehold in C. within thirty years last past, and therefore we command you that if the aforesaid $A$. shall make you secure to prosecute his claim, then cause that tenement to be reseized, and the chattels which were taken in it, and the same tenement with the chattels to be in peace until the first assize, when our justices shall come into those parts, and in the 
mean time cause twelve free and lawful men of that visne to view that tenement, and their names to be put into the writ, and summon them by good summoners, that they be before the justices aforesaid, at the assize aforesaid, ready to make recognizance thereupon, and put by gages and safe pledges the aforesaid B., or, if he shall not be found, his bailiff, that he may be then there to hear that recognizance, \&c. And have there the summoners, the names of the pledges, and this writ, \&c.

Booth, 211.

\section{FORM (32).}

\section{Writ of tile Assize of Nuisance.}

The King to his beloved, \&c. Know ye, that we have constituted you our justices to take the assize which $\mathrm{B}$. hath arraigned before you by our writs against $\mathrm{N}$. touching a certain pool heightened in $\mathrm{C}$. in the county of $\mathrm{S}$. to the nuisance of his freehold in L. in the county $\mathrm{H}$. And therefore, \&c. that at a certain day, \&c. in the confines of the counties aforesaid which you shall appoint for this purpose, you take that assize, doing thereon what to justice belongs; for we have commanded our sheriffs in the counties aforesaid, that at a certain day and place in the confines of the said counties, whereof you shall give them notice, they cause that assize to come before you: In witness whereof we have caused these our letters to be made patents. Witness, \&c.

Fitz. N. B. 183.

FORM (33).

\section{Writ of Assize Mort D'Ancestor.}

The King to the sheriff of S. greeting: If A. shall make you secure, \&c. then summon, \&c. twelve free and lawful men of the neighborhood of $\mathrm{N}$. that they be before our justices at the first assize, when they shall come into those parts, or before our justices at Westminster on the octave of, \&c., or before our beloved and faithful D. and E. and those whom we have associated unto them, at a certain day and place, whereof they the said $\mathrm{D}$. and $\mathrm{E}$. shall give you notice ready to recognize by oath, if $W$. father of the aforesaid $A$. or mother, sister, brother, uncle or aunt, was seised in his (or her) demesne as of fee, of one messuage with the appurtenances in N., the day whereupon he died, and if he died after the coronation of lord King Henry; and if the same $A$. be his next heir: and in the mean time let them view the said messuage and land, and cause their names to be put in the writ, and summon by good summoners B., who now holds the aforesaid messuage and lands, that he may be there to hear that recognizance; and have there the summoners and this writ. Witness, \&c. 


\section{FORM (34).}

\section{Writ of Entry in Nature of an Assize on the Ancestor's} SEISIN.

That justly, \&c. he render to $B$. one messuage in $L$. which he claims to be, \&c. whereof the said A. unjustly and without judgment hath disseised $\mathrm{C}$. (the father or mother or other ancestor) of the said B. whose heir he is within twenty years now last past, as he says, \&c. and unless, \&c.

Booth, 175.

\section{FORM (35).}

Writ of Entry in Nature of an Assize or Writ of Entry in De Quibus in Seçond Degree.

Command A. that, \&c. he render to B. one messuage with the appurtenances in $\mathrm{N}$. which he claims to his right and inheritance, and into which the same A. hath not entry, but D. the father (or mother or other ancestor) of the aforesaid B. whose heir he is, who demised it to him for a term which is past, as he says, and unless he will do it, \&c.

Booth, 172.

\section{FORM (36).}

\section{Writ of Aiel and Besaiel.}

The King to the sheriff, \&c. Command A. that justly, \&c. he render to $\mathrm{B}$ one messuage with the appurtenance in $\mathrm{E}$. of which W., the grandfather of the said B. or grandmother of the said B. or greatgrandfather, or great-grandmother of the said B., whose heir he is, was seised in his (or her) demesne as of fee, npon the day on which he died, as he saith, and unless he will do it, and the aforesaid $B$. shall make you secure, \&c. then summon, \&c. the aforesaid A., \&c.

The count is as follows:-

And whereupon he saith, that the said W., the grandfather, \&c. was seised of the messuage, \&c. in his demesne as of fee in time of peace, in the time of the lord the now King, by taking thereof the esplees to the valne, \&c. and from the said W. the grandfather, \&c. descended the right, \&c. to the said C. who now demands as cousin and heir of the said W., to wit, the son of 'T. the son of the said W., \&c. from whom, \&c. and thereof he brings suit, \&c. 
FORM (37).

\section{Writ of Entry sur Intrusion.}

The King to the sheriff, \&c. Command A. that justly, \&c. he render to $\mathrm{B}$. one ploughland, with the appurtenances in $\mathrm{N}$., which he claims to be his right and inheritance, and into which the same A. hath not entry but by the intrusion which he made into it after the death of C. who was the wife of $\mathrm{D}$. who held it in dower of the gift of the aforesaid D. sometime her husband, the father or brother of the aforesaid B., whose heir he is, as he saith, and unless, \&c. Booth, 181.

\section{FORM (38).}

\section{Writ of Quare Eject Infra Terminum.}

The King to the sheriff, \&c. If A. shall make you secure, \&c. then summon B. that he be, \&c. to shew wherefore he deforceth the aforesaid A. of one messuage with the appurtenances in N. which C. demised to him for a term which is not yet passed, within which term the same C. sold that messuage to the aforesaid $B$. by reason of which sale he the said B. hath ejected the aforesaid A. from the messuage aforesaid, as it is said. And have, \&c.

\section{F. N. B. 458.}

\section{FORM (39).}

\section{WRIT OF QUARE IMPEDIT.}

The King, \&c. to the sheriff greeting: Command A. that justly, \&c. he permit B. to present a fit person to the church of $\mathrm{N}$. which is vacant, and belongs to his gift as he says. And whereof he complains that the said A. unjustly hinders him. And unless he will do it, summon by good summoners the said $A$. that he be before our justices of Chester at Chester, on the first day of the next session of the county court of Chester, to be held at Chester, to shew iwherefore he hath not done it. And have there the summoners and this writ. Witness.

Booth, 226.

FORM (40).

\section{Writ of Waste.}

The King to the sheriff of - If $A$. shall make you secure, \&c. then summon by good summoners B. that he be before onr justices at Westminster, on, \&c. Wherefore sceing that it is provided 
by the Common Council of our realm of England, that it shall not be lawful for any person to commit waste, sale, or destruction of lands, houses, woods, or gardens, the same B. hath committed waste, \&c., of the lands, houses, woods, and gardens in L. which the aforesaid A. demised to him, \&c.

2 Sellon, 236.

FORM (41).

Writ of Ejectione Firme.

The King to the sheriff, \&c. If A. shall make you secure, \&c. then put, \&c. B. that he be before our justices, \&c. to shew wherefore with force and arms he entered into the manor of I. which T. demised to the said A. for a term which is not yet passed, and the goods and chattels of him the said $\mathbf{A}$. to the value of, \&c. found in the same manor, took and carried away and ejected him the said $\mathbf{A}$. from his farm aforesaid, and other wrongs to him did, to the great damage of, \&c.

F. N. B. 220.

\section{FORM $(41 a)$.}

\section{Originat Writ in Ejectment.}

Geo. the Third, \&c. (403). To the sheriff of - greeting: If John Doe shall give you security of prosecnting his claim, then put by gages and safe pledges Richard Roe, late of —_ yeoman, that he be before us, on - wheresoever we shall then be in England, (or, in C. P. "that he be before our justices at Westminster, on -,") to shew wherefore, with force and arms, he entered into - messuages, \&c. (721) with the appurtenances in which A. B. hath demised to the said John Doe, for a term which is not yet expired, and ejected him from the said farm; and other wrongs to the said John Doe there did, to the great damage of the said John Doe, and against our peace: And have you there the names of the pledges, and this writ.

Witness ourselves at Westminster, the - day of - in the - year of our reign.

Tidd's Appendix, 720.

FORM (41 $a$, continued).

Declaration in Ejectment.

In the King's Bench.

- Term, in the - year of the reign of King William the Fourth. To wit, C. D. was attached to answer John Doe of a 
plea of trespass and ejectment, and thereupon the said Jolin Doe, by _- his attorney, complains :- For that whereas A. B. heretofore, to wit, on the — day of — in the year of our Lord —_, had demised to the said John Doe — messuages, — stables, _ yards, and — gardens, situate and being 'in the parish of —-, in the county of - to have and to hold the same to the said John Doe and his assigns, from the — day of — in the year aforesaid, for and during and unto the full end and term of - years from thence next ensuing, and fully to be complete and ended. By virtue of which said demise, the said John Doe entered into said tenements, with the appurtenances, and became and was thereof possessed for the said term so to him thereof granted as aforesaid. And the said John Doe being so thereof possessed, the said C. D. afterwards, to wit, on the — day of — in the year aforesaid, with force and arms entered into the said tenements, with the appurtenances, in which the said John Doe was so interested, in manner, and for the term aforesaid, which is not expired, and ejected him the said John Doe out of his said farm, and other wrongs to the said John Doe then and there did, against the peace of our said lord the King, and to the damage of the said John Doe of — pounds ; and therefore he brings his suit, \&c.

Stephen Pl. 33.

\section{Notice to a Person in Possession to Appear.}

Mr. C. D.

I am informed that you are in possession of, or claim title to the premises, in this declaration of ejectment mentioned or some part thereof; and I, being sued in this action as a casual ejector only, and having no claim or title to the same, do advise you to appear in next _ term, (or, in London or Middlesex, "on the first day of next term,") in his Majesty's Court of King's Bench, wheresoever his said Majesty shall then be in England, (or, in the Common Pleas, "in his Majesty's Court of Common Bench at Westminster,") by some attorney of that Court; and then and there', by rule of the same Court, to cause yourself to be made defendant in my stead; otherwise I shall suffer judgment therein to be entered against me by default, and you will be turned out of possession.

Yours, \&c.

Richard Roe. Tidd's Appendix, 722. 


\section{FORM (42). \\ Writ of Deceit.}

The King to the sheriff of Lincolnshire, greeting:

If A. shall make you secure, \&c., then put, \&c., P., \&c. as well to answer us as the aforesaid A., wherefore he fraudulently and maliciously in our Court of Chancery obtained our certain writ by a fine of twenty shillings, taken for our use, for the writ aforesaid, in the name of the aforesaid A., who was wholly ignorant of this, in deceit of our court, to the great damage of the said A. And have you there the names and pledges on this writ.

Fitz. N. B. 96.

Writ of deceit lies where the sheriff returns the tenant summoned when he was not summoned, by which he loseth his land. - The writ lies against him who recovered, and the sheriff for false return; and the tenant shall be restored.

Fitz. N. B. 97.

\section{FORM (43).}

\section{Writ of Partition.}

George the Third, by the grace of God, of Great Britain, France, and Ireland King, Defender of the Faith, and so forth, To the sheriff of - greeting: If A. B. and C. D. shall give you security, that their suit shall be prosecuted; then summon. by good summoners, E. F. that he be before our justices at Westminster, on the morrow of All Souls, to show wherefore, whereas the said A. B., C. D., and E. F. hold together and undivided the manor of in the parishes of - and - , of which the said E. F. denieth partition to be made between them according to the form of the statute made and provided, and unjustly permitteth not the same to be done. And contrary to the form of said statute, as they say; and have you there the summoners, and this writ. Witness ourself at Westminster, the — day of — reign.

2 Sellon, 214.

\section{FORM (44).}

\section{General Demurrer.}

C. D.) And the said C. D. by E. F. his attorney, comes and defends ats. $\}$ the wrong and injury, when, \&c., and says that the said A. B. declaration (or "the said first count of the said declaration ") 
and the matters therein contained in manner and form, as the same are above stated and set forth, are not sufficient in law for the said A. B. to have or maintain his aforesaid action thereof against him, the said C. D. and that he the said C. D. is not bound by the law of the land to answer the same, and this he is realy to verify; wherefore, for want of a sufficient declaration or ("first count of the said declaration ") in this behalf, the said C. D. prays judgnent, and that the said A. B. may be barred from having or maintaining his aforesaid action thereof against him, \&c.

2 Chit. Pl. 678.

\section{FORM (45).}

\section{Special Demurrer}

When the causes of demurrer are stated, as is in general advisable, proceed as in the above precedent to the end, and then as follows: And the said C. D., according to the form of the statute in such case made and provided, states, and shews to the court here, the following causes of demurrer to the said declaration, (or "to the said first count of the said declaration,") that is to say, that, \&c. (here state the particular causes, and conclude thus: and also that the said declaration or "first count of the said declaration") is in other respects uncertain, informal, and insufficient, \&c.

2 Chit. Pl. 678.

FORM (45a).

JoINDER in DemurRer.

A. B. And the said A. B. saith, that the said declaration, (or "first agst. Count," or "replication,") and the matters therein contained C. D. in unanner and form as the same are above stated, and set forth, are sufficient in law for him the said A. B. to have and maintain his aforesaid action thereof against him the said C. D., and the said A. B. is ready to verify and prove the same as the Court here shall direct and award; wherefore, inasmuch as the said C. D. hath not answered the said declaration, (or "first count," or "replication,") nor hitherto in any manner denied the same, the said A. B. prays judgment, and his damages, by reason of the not performing of the said several promises and undertakings in the said declaration mentioned, to be adjudged to him, \&c. 
FORM (46).

Plea to the Jurisdiction.

In the King's Bench.

The _- day of _-, in the year of our Lord

C. D. And the said defendant, in his proper person says that the ats. Said County of Durham is, and, from time whereof the A. B. memory of man is not to the contrary, hath been a county palatine; and there now are, and for all the time aforesaid have been justices there; and that all and singular pleas for the recovery of manors, messuages, and tenements, lying and being within the said county, have been for all the time aforesaid, and still are pleaded and pleadable within the said County of Durham, before the justices there for the time being, and not here in the Court of our lord, the King, before the King himself. And this he is ready to verify. Wherefore, since the plea aforesaid is brought for recovery of the possession of the manors, messuages, lands, and hereditaments aforesaid, within the said county palatine, the said defendant prays judgment if the Court of our lord, the King, here will or ought to have further cognizance of the plea aforesaid.

Steph. Pl. 46.

FORM (47).

\section{Plea in Suspension.}

(This plea resembled other dilatory pleas in its general form. It recited the facts justifying suspension of the suit and concluded with a prayer that the parol may demur, - that is, that the suit be stayed.) See 4 Minor's Inst. 627; Steph. Pl. 47 ; Pearl v. Wells, 6 Wend. 294.

\section{FORM (48).}

\section{Plea in Abatement.}

In the K. B. (or C. P.).

C. D. And the said C. D. in his person, (or "by G. H. his attorats. $\}$ ney,") comes and defends the wrong and injury, when, \&c., and A. B. prays judgment of the said bill (or "writ") of the said A.; because he says that the said $A$., before and at the time of the commencement of this suit, was and still is married to one E. F., then and yet her husband, who is still living, to wit, at, \&c., aforesaid; and this he the said C. D. is ready to verify; wherefore, because the said E. F. is not named in the said bill (or "writ") of the said A., the said C. D. prays judgment of the bill (or "writ") aforesaid and 
the same may be quashed, \&c. (Add affidavit of the truth in substance.)

2 Chit. Pl. 414.

\section{FORM (49).}

Plea of Non est Factum.

In the King's Bench.

C. D. )

vs.

- Term, — Will. IV.

A. B. And the said defendant by E. F. his attorney, comes and defends the wrong and injury, when, \&c. and says that the said indenture (or "articles of agreement," or "deed poll," as in the declaration) is not his deed.

And of this the said defendant puts himself upon the country, \&c. 3 Chit. Yl. 1001 (ed. 1872).

\section{FORM (50).}

Plea in Bar by way of General Traverse, in Debt.

$\left.\begin{array}{c}\text { C. D. } \\ \text { ats. }\end{array}\right\}$ And the said C. D. by E. F. his attorney, comes and defends A. B. the wrong and injury, when, \&c. and says that he does not owe the said sum of money, (or "the said sum of $\mathcal{E}-$ ") above demanded, or any part thereof, in manner and form as the said A. B. hath above thereof complained against him, and of this he the said C. D. puts himself upon the country, \&c.

2 Chit. Pl. 459.

\section{Same Plfa under Hilary Rules of 1834.}

And the said defendant, by - his attorney, says, that he never was indebted in the manner and form as in the declaration alleged. And of this he puts himself upon the country.

Steph. Pl. 156.

FORM (5i).

Plea of Non Assumpsit.

In the Common Pleas.

C. D. And the said defendant by E. F. his attorney, comes and $v s$. $\}$ defends the wrong and injury when, \&c. and saith that he did A. B. not undertake or promise in manner and form as the said plaintiff hath above thereof complained against him, and of this he puts himself upon the country, \&c.

Martin Crvil Procedure-25

3 Chit. Pl. 908 (ed. 1872). 
FORM (52).

Plea of Not Guilty.

And the said defendant by — his attorney, says that he is not guilty of the said trespasses or in case ["the premises"] above laid to his charge or any part thereof, in manner and form, as the said plaintiff hath above complained. And of this the said defendant puts himself upon the country.

Steph. Pl. 157.

FORM (53).

Plea in Bar by Way of General Traverse, in Detinue.

C. D. And the said C. D. by E. F. his attorney, comes and defends ats. $\}$ the wrong and injury, when, \&c. and saith, that he doth not A. B. detain the said goods and chattels in the said declaration specified, or any part thereof, in manner and form as the said A. B. hath above thereof complained against him, and of this he the said C. D. puts himself upon the country, \&c.

2 Chit. Pl. 495.

\section{FORML (54).}

\section{Plea of Non Cepit.}

In the King's Bench.

C. D. And the said defendant by E. F. his attorney, comes and $v s$. $\}$ defends the wrong and injury when, and, \&c. And says that A. B. he did not take the said (cattle, goods, and chattels) in the said declaration mentioned, or any or either of them, or any part thereof, in manner and form as the said plaintiff hath above complained against him.

And of this the said defendant puts himself upon the country, \&c. 3 Chit. Pl. 1042 (ed. 1872).

\section{FORM (55).}

\section{Replication de Injuria.}

And the said plaintiff as to the said plea of the said defendant by him above pleaded as to the said several trespasses in the introductory part of that plea mentioned, and therein attempted to be justified, saith, that the said plaintiff by reason of anything by the said defendant in that plea alleged, ought not to be barred from having and maintaining 
his aforesaid action thereof against the defendant, because he saith that the said defendant at the said time when, \&c. of his own wrong and without the cause by him in his said plea alleged, committed the said several trespasses in the said plea attempted to be justified, in manner and form as the said plaintiff hath above in the said count of his said declaration complained against the defendant.

And this the said plaintiff prays nay be inquired of by the country, \&c.

3 Chit. Pl. 1202 (ed. 1872).

FORM (56).

Plea in Bar by Way of Spectfic ol Common Traverse. In Covenant, on Indenture of Lease, for not Repairing.

The day of —-, in the year of our Lord

C. D. ) And the said defendant by - his attorney, [or, in perats. $\}$ son, ] says that the windows of the said messuage or tenement A. B. were not in any part thereof ruinous, in decay, or out of repair, in manner and form as the said plaintiff hath above complained against him, the said defendant.

And of this he puts himself upon the country.

Steph. Pl. 52.

\section{FORM (57).}

\section{Plea in Bar by Way of Special Traverse.}

And the said defendant, by - his attorney, says that the said E. B. deceased, at the time of the making of the said indenture, was seised in demesne, as of freehold for the term of his natural life, of and in 'the said demised premises, with the appurtenances, and continued so seised thereof until and at the time of his death; and that after the making of the said indenture, and before the expiration of the said term, to wit, on the __ day of __, in the year of our Lord —, at — aforesaid, the said E. B. died; whereupon the term created by the said indenture wholly ceased and determined: Withont this, that, after the making of the said indenture, the reversion of the said demised premises belonged to the said E. B. and his heirs, in manner and form as the said declaration alleged. And of this the defendant puts himself upon the country. 


\section{FORM (58).}

\section{Plea in Bar by Way of Confession and Avoldance. - Discirarge.}

C. D. And the said C. D. by E. F. his attorney, comes and defends the ats. Wrong (or in trespass or ejectment, say "force," and injury, A. B. when, \&c. and says, that the said A. B. ought not further to have or maintain his aforesaid action thereof against him, because he says, that, after the making of the said several promises and undertakings in the said declaration mentioned, and before the exhibiting of the bill of the said A. B. against him the said C. D. in his behalf, or if by original or in C. P. " before the commencement of this suit,") to wit, on, \&c. at, \&c. aforesaid, he the said C. D. delivered to the said A. B. one pipe of wine, of great value, to wit, of the value of $£ 100$ in full satisfaction and discharge of the said several promises and undertakings in the said declaration mentioned, and which said pipe of wine he the said A. B. then and there accepted and received of and from the said C. D. in full satisfaction and discharge of the said several promises and undertakings, in the said declaration mentioned. And this the said C. D. is ready to verify; wherefore he prays judgment if the said A. B. ought to have or maintain his aforesaid action thereof against him, \&c.

\section{Chit. Pl. 434.}

For old forms of pleas in confession and avoidance, see 2 Chit. Pl. 424-588 (ed. 1809). For modern pleas in confession and avoidance, see 2 Chit. Pl. (ed. 1876).

\section{FORM (59).}

\section{Justification For Removal of Goods.}

And for a further plea in this behalf the said defendant by leave, \&c. (actio non, \&c. as in previous forms) because he saith that before and at the said time when, \&c. he the said defendant was lawfully possessed of a certain close called —- situate at, \&c. And becausc the said goods and chattels in the said last count mentioned before and at the said time when, \&c., in the said last mentioned count, were wrongfully in and upon the said close or parcel of land, encumbering the same, and doing damage there to the said defendant, he the said defendant at the said time, \&c. in the said last mentioned count, seized and took the said goods and chattels and removed and carried away the same to a small and convenient distance and there left the same for the use of the said plaintiff, doing no unnecessary 
damage to the said goods and chattels on the occasion aforesaid, and as he lawfully might for the cause aforesaid, which are the same supposed trespasses of which the plaintiff hath above thereof complained against him the said defendant. And this, \&c. - (Conclude with a verification.)

3 Chit. Pl. 1094 (ed. 1872).

FORM (60).

\section{Plene Administravit.}

Because he says, that he the said defendant hath fully administered all and singular the goods and chattels which were of the said $\mathbf{E}$. F. deceased at the time of his death, and which have ever come to the hands of the said defendant, as executor as aforesaid to be administered aforesaid, and that he the said defendant hath not nor on the day of exhibiting the bill of the said plaintiff in this behalf, or at any time since had any goods or chattels which were of the said E. F. deceased, at the time of his death in his hands to be administered.

And this he the said defendant is ready to verify, wherefore he prays judgment if the said plaintiff ought to have or maintain his aforesaid action thereof against the defendant, \&c.

$$
3 \text { Chit. Pl. } 945 \text { (ed. 1872). }
$$

\section{(FORM 61).}

\section{Plea of Justification in Trespass under a Warrant of Arrest.}

(After enumerating the trespass intended to be justified, if necessary so to do, actio non, as in usual form.)

Because he says, that just before the said times when, \&c. in the said declaration mentioned, to wit, on the said, \&c. at, \&c. (venue), the said plaintiff, with force and arms, \&c., (Here state the cause for which the warrant was taken out, which in the case in question was as follows:) made an assault upon the said defendant, and then and there beat and ill treated the said defendant, in breach and violation of the peace of our lord, the now King, whereupon the said defendant afterwards to wit, on, \&c. at, \&c. duly applied to C. Esq., he then and there being one of the justices of our said lord the King, assigned to keep the peace of our said lord the King, in and for the said County of M. and then and there duly made oath of the said last-mentioned trespasses committed by the plaintiff on the said defendant as last aforesaid; and thereupon the said C. so being such justice aforesaid, 
afterwards to wit, on the day and year last aforesaid at, \&c. duly made and issued his said certain warrant under his hand and seal bearing date to wit, the day and year last aforesaid, directed to all constables and his Majesty's officers of the peace, whom the said warrant might concern and thereby commanded them (Here insert the language of the warrant and the delivery of it to the constable or other officer of the peace) by virtue of which said warrant he the said (constable) and the said defendant in his aid and assistance and by his command afterwards, to wit, at the said time when, \&c. that is to say, on, \&c. gently laid their hands on the said plaintiff in order to take, and did then and there take the said plaintiff into the custody of the said (constable), until the said plaintiff afterwards, and as soon as conveniently could be, was carried in the said County of M. to and before the said C. then being one of his Majesty's justices aforesaid to keep the peace in and for said County of M. for examination concerning the premises, and on that occasion the said plaintiff was necessarily and unavoidably imprisoned, and kept and detained in prison for the said space of time in the said declaration mentioned, and the said defendant committed the said supposed trespasses in the introductory part of his plea mentioned, and whereof the said plaintiff hath above thereof complained, which are the said several supposed trespasses in the said declaration mentioned, and whereof the said plaintiff hath above complained against him; without this that the said defendant was guilty of the said supposed trespasses in the said declaration mentioned, or any or either of them, elsewhere than in the said County of M. and in taking and carrying the said plaintiff in the said County of $\mathbf{M}$. to and before the said $\mathrm{C}$. as aforesaid, or at any time there, on the said —_ day of — and in execution of the said warrant. And this, \&c. (Conclude with a verification).

3 Chit Pl. $1091 a$ (ed. 1872).

\section{FORM (62).}

\section{Plea of Liberum Tenementum in Trespass Quare Clausum Fregit.}

And for a further plea in this behalf as to the breaking and entering the said close in which, \&c., in the said declaration mentioned, and with feet in walking, treading down, trampling upon, consuming and spoiling, the grass and herbage then and there growing, the said defendant says, that the said plaintiff ought not to have or maintain his aforesaid action thereof against him; because he says, that the said close in the said declaration mentioned and in which he, \&c., 
now is, and at the several times when, \&c., was the close soil ani freehold of him the said defendant. Wherefore he the said defendant at the said several times when, \&c., broke and entered the said close in which, \&c., and with feet in walking trod down, trampled upon, consumed, and spoiled the grass and herbage then and there growing, as he lawfully might for the cause aforesaid, which are the same trespasses, in the introductory part of this plea mentioned, and whereof the said defendant is ready to verify. Wherefore he prays judgment if the said plaintiff ought to have or maintain his aforesaid action thereof against him.

Steph. Pl. 315. 2 Chit. Pl. 551 (1st ed.).

\section{FORM (63).}

\section{Plea of Avowry in Repleyin.}

And the said defendant, by $\longrightarrow$, his attorney, comes and defends the wrong and injury, when, \&c., and well avows the taking of the said cattle, goods, and chattels, in the said declaration mentioned, in the said close and dwelling-house (as in declaration) in which, \&c., and justly, \&c., because he says that the said plaintiff, for a long time, to wit, for the space of — years next before, and ending on the - day of —, A. D. — and from thence until, and at the said time, when, \&c., held and enjoyed the said dwelling-house, in which, \&c., with the appurtenances, as tenant thereof, to the said defendant, by virtue of a certain demise thereof to him, the said plaintiff, therefore made, at and under a certain yearly rent, to wit, the yearly rent $£-$, payable quarterly, on, \&c. (the days of payment,) in every year, by even and equal portions; and, because the sum of $\mathfrak{E}$ - , of the rent aforesaid for the said space of - , ending, as aforesaid, on the said —_ day of __, in the year aforesaid, and from thence until and at the said time, when, \&c., was due and in arrear from the said plaintiff to the said defendant, he the said defendant, well avows the taking of the said goods and chattels in the said dwelling-house, in which, \&c., and justly, \&c., as for and in the name of a distress for the said rent, so due and in arrear to the said defendant as aforesaid, and which is still in arrear and unpaid. And this he, the said defendant, is ready to verify; wherefore he prays judgment and a return of the said goods and chattels, together with his damages, \&c., according to the form of the statute in such case made and provided, to be adjudged to him, \&c.

2 Saunders, Pl. \& Ev. 763, 764. 


\section{FORM (64).}

\section{Plea of Truth in Justification of Slander or Libel CHARGING TheFT.}

And for a further plea in this behalf as to the speaking and publishing of the said several words of and conceruing the said plaintiff as in the said declaration mentioned, the said defendant by leave of the court here for this purpose first had and obtained, according to the form of the statute in such case made and provided, saith that the said plaintiff ought not to have or maintain his aforesaid action thereof, against him, because he says that the said plaintiff, before the speaking and publishing of the said several words of and concerning the said plaintiff as in the said declaration mentioned, to wit, on, \&c. at, \&c. (venue) did feloniously steal, take, and carry away certain goods and chattels, to wit, - of one E. F. of great value, to wit of the value of $£$. Wherefore, he the said defendant afterwards, to wit, at the said several times when, \&c., in the declaration mentioned at, \&c. (venue) aforesaid, did speak and publish the said words of and concerning the said plaintiff as in the said declaration mentioned as he lawfully might for the canse aforesaid. And this, \&c. (Conclude with a verification.)

3 Chit. Pl. 1031 (ed. 1872).

\section{FORMI (65).}

\section{Plea in Estoppel by Replication.}

And the said plaintiff saith that the said defendant ought not to be admitted or received to plead the said plea by him (secondly) above pleaded, as to so much wherein he alleges that (stating the part to which the estoppel relates) because he says that, \&c. (Here state the ground of estoppel whether by pleadings, record, bond, or other matter of estoppel and conclude as follows): And this he the said plaintiff is ready to verify, wherefore he prays judgment if the said defendant ought to be admitted or received against the said record (or otler matter of estoppel) to plead the plea by him above pleaded in this suit, that, \&c. (stating. and concluding with the allegation in that part of the plea to which the estoppel relates).

3 Chit. Pl. 1144 (ed. 1872). 


\section{TABLE OF ENGLISH REGNAL YEARS.}

Sovereign.

Time of Reign.

Length of Reign (Years).

William I • . . . . Oct. 14, 1066 - Sept. 26,1087 • . . . . 21

Villiam II . . . . . Sept. 26,1087 - Aug. 5, 1100 . . . . . 13

Henry I . . . . Aug. 5, 1100-Dec. 26, 1135 . . . . . 35

Stephen . . . . Dec. 26, 1135 - Dec. 19, 1154 • • . . . 19

Henry II . . . . . Dec. 19, 1154- Sept. 3, 1189 . . . . . 35

Richard I . . . . . Sept. 3, 1189 - May 27, 1199 . . . . . . 10

John . . . . . May 27, 1199 - Oct. 28, 1216 . . . . . . 17

Henry III . . . . . Oct. 28, 1216- Nov. 20, 1272 . . . . . 56

Edward I . . . . Nov. 20, 1272 - July 8, 1307 . . . . . 35

Edward II . . . . . July 8, 1307 - Jan. 25, 1326 . . . . . . 19

Edward III - • . . Jan. 25, 1326-June 22, 1377 • • • . . 51

Richard II . . . 。 . June 22, 1377-Sept. 30,1399 . . . . . 22

Henry IV . . . . . Sept. 30, 1399 - March 21, 1413 . • . . 14

Henry V . . . . . March 21,1413-Sept. 1,1422 . . . . . 9

Henry VI . . . . . Sept. 1, 1422-March 4,1461 . . . . . 39

Edward IV . . . . March 4,1461 - April 9,1483 . . . . . 22

Edward V . . . . April 9, 1483 - June 26,1483 . . . . . .

Richard III . . . . June 26,1483-Aug. 22, 1485 . . • . . 2

Henry VII . • . . Aug. 22, 1485 - April 22, 1509 . • . . . 24

Henry VIII . . . . April 22, 1509-Jan. 28, 1547 . . • . 38

Edward VI . . . . Jan. 28, 1547 - July 6, 1553 . . . . . . 6

Mary . . . . July 6, 1553-Novi. 17, 1558 • • • • . 5

Elizabeth . . . . Nov. 17, 1558-March 24, 1603 . . . . 45

James I • 。 . . . March 24, 1603-March 27, 1625 . • . 22

Charles I . . . . . March 27, 1625-Jan. 30,1649 . . . . . 24

Commonwealth . . . Jan. 30, 1649 - May 29, 1660 . . . . . 11

Charles II 。 . . . May 29, 1660-Feb. 6, 1685 . . . . . . 25

James II . . . . . Feb. 6, 1685 - Feb. 13, 1689 • • • • . 4

William and Mary . . Feb. 13, 1689 - Dec. 28, 1694 . . . . . 5

William III . . . . Dec. 28, 1694-March 8, 1702 . . . . . 8

Anne . . . . . March 8, 1702-Aug. 1, 1714 . . . . 12

George I . . . . . Aug. 1, 1714-June 11, 1727 . . . . . 13

George II • . . . . June 11, 1727- Oct. 25, 1760 • • • . 33

George III . . . . Oct. 25, 1760-Jan. 29,1820 . . . . . 60

George IV . • . . . Jan. 29, 1820 - June 26, 1830 . • . . . 11

William IV • . . . June 26,1830-June 20,1837 • . • . . 7

Victoria . . . June 20, 1837 - 



\section{N D E X.}

[The references are to sections except when otherwise expressed.]

A.

ABATEMENT OF NUISANCE, 382.

ABATEMENT, PLEAS IN.

(See Pleas in Abatement.)

ABOLISHMENT OF ORIGINAL WRITS, 11.

of ancient real actions, 124 .

(See Note III.)

ABU'TTALS, IN TRESPASS CLAUSUM FREGIT, 79.

ACCOUNT, 61 .

history, 62 .

nature and characteristics, 63.

action of case for refusal to account, 64 .

assumpsit on account stated, $\mathbf{6} \overline{\mathbf{5}}$.

judgment in, 67.

general traverse in, 263.

ACTIONS,

(See Writ and Declaration, Forms 9 and 10.)

definition and classification, 7, 8, 9 .

local and transitory, 30.

AFFIRMATIVE AVERMENTS,

two affirmations do not make a good issue, 333 .

AFFIRMATIVE PLEADINGS,

should conclude with a verification, 349 .

AFFIRMATIVE TRAVERSE, 257.

AGENTS, AS PARTIES, 187, 202, 218.

AGGRAVATION,

matter in aggravation not traversable, 311.

AIDER BY VERDICT, 239.

AID-PRAYER, 233.

AMBIGLOUS OR DOUBTFUI, PLEADING, 332.

AMERCEMENTS, 376.

ANCIENT REAI, ACTIONS, 117-161.

definition and history, 118, 119 .

classification of, 120 . 
[The references are to sections except when otherwise expressed.]

ANCIENT REAL AC'TIONS,--continued.

theory of rights in land, 121, 122.

distinction in, 123, 124.

possession and property, 121, 122, 123, 129.

abolishment of, Note III., p. 358.

ANNE, STATU'TE OF, 237, 317.

ANNUITY, 68.

history of, 69 .

nature and characteristics, 70 .

judgment in, 71 .

(See Writ and Declaration, Forms 11 and 12.)

APPEALS, 18, 379.

APPEARANCE, 12.

change in the law of appearance, 13.

ARGUMENTATIVE PLEADING, 333.

ARREST OF JUDGMENT, 370.

ASSESSMEN'T OF DAMAGES, 44.

ASSIGNEES, AS PAR'TIES, 186, 197, 204, 222.

ASSIZE OF DARREIN PRESENTMENT, 141.

ASSIZE OF JURIS UTRUM, 142.

ASSIZE OF MORT 1'ANCESTOR, 143.

ASSIZE OF NUISANCE, 140.

ASSIZE, WRIT OF, 138.

ASṠUMPSIT, 51.

history, 52, 53 .

nature and features, 54 .

general assumpsit, 55, 56, 57, 58, Note I.

special assumpsit, 54.

pleas in justification or excuse, 296, 297.

declaration in, 59.

judgment in, 60 .

general traverse in, 262.

specific traverse in, 275 .

writ and declaration.

A'T'AIN'T,

(See Forms 6, 7, and 8.)

grand jury of, 361 .

ATTORNEYS AND BARRISTERS,

origin, 24.

general duties, 25.

qualifications. etc., 26.

sergeants and barristers, 26 .

discipline, 26.

AUDITA QUERELA, 378.

AUTHORITY,

must be shown in pleading, 328.

AVOIDANCE.

(See Conffision and Avoidance.)

AVOWRY AND COGNIZANCE, 112, Note II. 
BAILEES, AS PARTIES, 77, 102, 194.

BAILMENT.

(See Trespass and Trover.)

(See Trover and Detinue.)

BANKRUP'TCY, PLEA OF, 260, 292.

BARRISTERS.

(See Attorneys and Barristers.)

BATTLE, WAGER OF, 358.

BILL OF EXCEPTIONS, 368.

BILL OF MIDDLESEX, 18.

BOND,

declaration in debt on, p. 366 .

BREACH,

of covenant or condition, 49 .

of contract, 59,87 .

of duty, 92, 265.

C.

CAPIAS AD RESPONDENDUM, 12, 18, 19.

CAPIAS AD SATISFACIENDUM, 383.

CAPIAS IN WITHERNAM, 111.

CAPIATUR, 376.

CASE.

CAUSA DEBENDI, 41.

(See Trespass on the Case.)

CERTAINTY OF ISSUES, of place, quantity, quality, and value, 319-330.

(See Chapter XIII., Art. V.)

CERTIFICATE, TRIAL BY, 357.

CERTIORARI, IN REPLEVIN, pp. 354, 355.

CHANGE OF VENUE, 30.

CIVIL ACTIONS,

defined, 7 .

general classification, 8 .

personal actions classified, 9 .

mixed actions, 8 .

CLERICO ADMITTENDO, execution of, 382 .

COGNIZANCE.

COLOR, 291.

(See Avowry.)

COMMENCEMENT OF DECLARATION, 31, 338.

COMMISSION OF ASSIZE, 21.

COMMON BAR.

(See Liberum Tenementum.) 
[The references are to sections except when otherwise expressed.]

COMMON COUN'TS, 55, 56, 57, 58. (See General Assumpsit.)

COMMON PLEAS COURT, 19.

CONCLUSION OF DECLARATION, 33, 338, 345.

CONCLUSION OF PLEADINGS, 33, 338, 349.

CONCLUSION OF THE TREA'TISE, 384.

original simplicity of common law pleading, 384 .

perversion of it, 384 .

statutes restorative, 384 .

reasons of its discontinuance and abolishment, 384 .

CONDITION,

performance of, how pleaded, 274, 295, 296, 329 .

CONFESSION AND AVOIDANCE, 289, 302.

(See Defences in Bar by Way of Confession and Avoidance.)

CONFESSION, JUDGMENT OF, 375.

CONSENT RULE IN EJECTMENT, 363.

CONSIDERATION, 40, 41, 43, 48, 49, 54, 55, 56, 57, 59.

CONSTRUCTION OF PLEADINGS, 384 .

CONTINUAL CLAIM, 122.

CONTRA, PACEM, 79, 87, 89.

CONTRACT, 40, 43, 52 .

CONTRIBUTORY NEGLIGENCE, 212.

admissible under a denial, 302.

CONVERSION, 100, 101, 102, 103.

CONVEYANCE,

(See Trover.)

must be shown by party claiming under, 324 .

CORAM NOBIS, IVRIT OF, 380.

CORAM VOBIS, WRIT OF, 380.

CORPORATIONS, AS PARTIES, 188, 208, 223.

COSTS, 376.

COUNT, 118.

(See Common Counts.)

COUNTRY, CONCLUSION TO THE, 33, 338, 345.

COURTS,

prefatory, 17.

King's Bench, 18.

common pleas, 19 .

exchequer, 20.

commission of assize, 21.

county court, 22 .

courts baron, 23 .

COVENANT, 45.

history of, 46,47 .

essential features of, 48 .

declaration in, 49 .

judgment in, 50 .

general traverse in, 261.

specific traverse in, 274 .

pleas of justification or excuse, 295.

(See Forms 4 and 5 in Appendix.) 
[The references are to sections except when otherwise expressed.]

CREDIT UNEXPIRED, 294, 297.

CUMULATIVE TRAVERSES, 315.

CURIA CLAUDENDA, WRIT OF, 137.

CUSTOM, DEBT ON, 39.

D.

DAMAGE, 4.

actual, 6 .

implied, 5 .

DAMA GES, 59, $375,376$.

(See Judgmant and Declaration in each action.)

DAMNUM ABSQUE INJURIA, 4.

DEBT, ACTION OF,

defined, 39 .

history of, 40,41 .

essential features, 42 .

declaration in, 43.

judgment in, 44 .

inquiry of damages, 44.

general traverse in, 260.

specific traverse in, 273.

pleas of justification or excuse in, 294.

DECEI'T, WRIT OF, 157.

DECLARATION,

defined, 27.

title of court. 28.

entitlement of term, 29.

venue, 30 .

commencement, 31 .

statement, 32.

conclusion, 33 .

DECLARATIONS, FORMS OF.

DEEDS,

(See Forms in Appendix.)

how pleaded, 324 .

how traversed, $260,261$.

DEFAUIT, JUDGMENT OF, 395.

(See Profert.)

DEFENCES, CLASSIFICATION OF, 235.

DEFENCES, DILATORY.

(See Dilatory Pleas.)

DEFENCES IN BAR BY WAY OF CONFESSION AND AVOID.

ANCE, 289-303.

defined and classified, 289.

confession or color implied, 290.

confession or color expressed, 291 . .

pleas in discharge defined, 292.

pleas in justification or excuse, 293.

in debt, 294.

in covenant, 295.

in special assumpsit, 296.

in general assumpsit, 297. 
[The references are to sections except when otherwise expressed.]

DEFENCES IN BAR,-continued.

pleas in trespass, 298.

in trover, 299.

in detinue, 300 .

in replevin, 301 .

in case, 302 .

defence in bar by estoppel, 303.

DEFENCES IN BAR BY WAY UF TRAVERSE, 256-288. general nature of pleas in bar, 256 .

specific traverse defined, 257.

general traverse defined, 258.

special traverse defined, 259.

general traverse in debt, 260.

in covenant, 261.

in assumpsit, 262.

in account, 263.

in trespass, 264.

in case, 265.

in trover, 266.

in detinue, 267.

in replevin, 268 .

in ejectment, 269 .

de injuria, $270,271$.

specific traverse, general rule, 272.

in debt, 273 .

in covenant, 274 .

in assumpsit, 275 .

in account, 276 .

in trespass, 277 .

in case, 278 .

in trover, 279.

in replevin, 281.

special traverse, history, 282.

requisites, 283.

rules therefor, 284 .

abnormal, 285 .

conclusion, 286 .

when defective, practice resulting therefrom, 287 .

traverses in general, principles of, 288 .

DEFENDANTS IN ACTIONS EX CONTRACTU, 201-211. general rule, 201.

as to agents, 202.

as to trustees, etc., 203.

as to assignees, 204.

as to executors and administrators, 205.

as to heirs and devisees, 206.

as to infants, 207.

as to corporations, 208.

as to joinder of defendants, 209, 210, 211.

as to husband and wife, 211.

DEFENDANTS IN AC'TIONS EX DELICTO, 212-224.

general rule, 212.

as to absolute rights, 213.

as to relative rights, 214 .

as to land, 21:.

as to personal chattels, 216 .

as to negligence in control and use of property, 217. 
[The references are to sections except when otherwise expressed.]

DFFENDANTS IN ACTIONS EX DELICTO,-continued.

as to principal and agent, 218 .

as to husband and wife, 219.

as to infants and the insane, 220 .

as to executors and administrators, 221.

as to assignees, 222.

as to corporations, 223 .

as to joinder of defendants, 224.

DEEENDANTS IN REAL ACTIONS, 227.

DE INJURIA, replication of, $270,271$.

DEMAND OF OYER, 231.

DEMAND OF PARTICULARS, 232.

DEMURRER, 236-242.

defined, 236.

history of, 237.

causes of, 238.

effects and consequences of, 239 .

effect of pleading over without demurrer, 240 .

judgments on, 241.

demurrer to evidence, 242,365 .

(See Forms if Demurrer, p. 382.)

DEPARTURE IN PLEADING, 340.

DE PROPRIETATE PROBANDA, 11.

DE RATIONABILE PARTE, 129.

DESCENT CAST, 122, 124.

DETINUE, 81.

history, 82 .

nature and features, 83 .

declaration in, 84 .

judgment on, 85 .

general traverse in, 267.

specific traverse in, 280.

pleas in justification or excuse, 300 .

writ and declaration. (See Forms 16 and 17.)

DETRIMENT, as a consideraticn, 54.

DII.ATORY PLEAS, 243-255.

defined and classified, 244.

to the jurisdiction, $245,246$.

in suspension, 247.

in abatement, 248, 249, 250, 251, 252, 253.

conclusion in, 254 .

judgment in, 255.

DISCHARGE, pleas in, 272.

DISSEISIN, 121, 122, 145.

election of, 138.

DISTRESS. (See Replevin.)

DISTRINGAS, 13.

IOOWER, writ of, ancient, 131.

writ of, modern, 176.

J)UPLICITY IN PLEADING, 314, 318

DUTIES, 2.

Martin Civil Procenure-26; 


\section{E.}

ECCESIASTICAL COURTS, 40.

EJECIT INFRA TERMINUM, 153.

EJECTIONE FIRM 156.

EJECTMENT, 165-171.

causes leading to it, 166, Note IV.

action defined, 167 .

declaration in, 168 .

judgment in, 169 .

recent changes in England, 170.

ejectment in United States, 171.

proseedings in, Note IV.

history of, Note IV.

ELECTION OF ACTIONS, 230.

ELEGIT EXECUTION, 383.

ELIZABETH, STATUTE OF, 237.

ENTIRETY OF CONTRACT, Note I.

ENTRY UPON LANDS, J22, 123, 162, 163.

ENTRY, WRITS OF, 144.

sur disseisin, 145.

sur alienation, 146.

sur abatement, 148.

sur intrusion, 147 .

ad terminum, 149 .

eausa matrimonii, 150 .

as affected by feoffment and descent, 151 .

ERROR, writs of, 379,380 .

ESPLEES. (See Count in Writ of Right, Form 24.)

ESTOPPEL, pleas in, 303.

ESTREPMENT, writ of, 137.

EVIDENCE, demurrer to, 242.

EXCEPTIONS, at trial, 368.

when to be pleaded, 353 .

EXCHEQUER, court of, jurisdiction of, 20.

EXCUSE, pleas in, 293.

(See Pleas 1x Justification or Excuse, 294-302.)

EXECUTION, 381.

defined, 381 .

habere facias seisinam, 382 .

habere facias possessionem, 382.

clerico admittendo, 382 .

abatement of nuisance, :38.

de retorno habendo, 382 , p. 356 .

distringas in detinne, 382. .

capias ad satisfaciendum, 383 .

fieri facias, 383 .

levari facias, 383.

elegit, 383.

extendi facias, 383 . 
[The references are to sections except when otherwise expreased.]

EXECUTORS AND ADMINISTRATORS,

as parties, 189, 198, 205, 221.

EXTENDI FACIAS, 383.

EXTRA-JUDICIAL ENTRY, 122, 123, 162, 163.

i.

\section{FIERI FACIAS,}

executions of, 383.

FORCE. (See Trespass.)

FORCIBI,E ENTRY AND DETAINER, 160-164.

defined, 161.

forcible entries at common law, 162.

history after Statute 5 Rich. II., 163.

history continued, 164.

modern, 178, 179.

characteristic features, 179.

FORMS OF DEFENCES, pp. 382-392.

general demurrer, p. 382.

special demurrer, p. 383.

joinder in demurrer, p. 383.

plea to the jurisdiction, p. 384.

plea in suspension, p. 384.

plea in abatement, p. 384.

plea of non est factum, p. 385 .

nil debet, p. 385.

non assumpsit, p. 385 .

not guilty, p. 386 .

non cepit, p. 386.

de injuria, p. 386.

specific traverse, p. 387.

special traverse, p. 387.

confession and avoidance, p. 388.

justification, pp. 388, 389 .

liberum tenementum, p. 390.

avowry, p. 391.

plea of truth in slander, p. 392.

plea of estoppel, p. 392 .

FORMS OF WRITS AND DECLARATIONS,

(See Appendix, pp. 365-392.)

writ and declarations in debt, pp. $365,366$.

writ and declaration in covenant, p. 366.

writs and declarations in assumpsit. p. 367.

writ and declaration in acconnt render, p. 368.

writ and declaration in annuity, p. 369.

writ of scire facias, p. 370 .

writ and declaration in trespass, pp. 376, 371.

writ and declaration in detinue, p. 371.

writ and declaration in trespass, p. 372.

declaration in trover, p. 373.

writ and declaration in replevin, p. 374.

writ and count of right patent, pp. 374, 375.

writ of right close, p. 375 .

writ of right of advowson, p. 375.

writ of right of dower. p. 375 .

writ of dower unde nihil habet, p. 376 . 
[The references are to sections except when otherwise expressed.]

FORMS OF WRITS AND DECLARATIONS, - continued. writ of formedon, p. 376.

writ of novel disseisin, p. 376.

writ of assize of nuisance, p. 377 .

writ of mort d'ancestor, p. 377.

writs of entry, pp. 378,379 .

writ of aiel and besaiel, p. 378 .

writ of quare ejecit infra terminuin, p. 37y.

writ of quare impedit, p. 379 .

writ of waste, p. 379.

writ of ejectione firmæ, p. 330 .

writ in ejectment, p. 380.

declaration in ejectment, p. 580 .

notice in ejectinent, p. 381 .

writ of deceit, p. 382.

writ of partition, p. 382 .

FRANCHISES, injuries to, 94 .

FRAUD, as a defence.

(See Pleas in Confession and Avoidance.)

G.

GENERAL ASSUMPSIT, 55, 56, 57, 58.

for part performance of express contracts, pp. 341-349.

the general rule, p. 341.

exceptions, pp. 342-346.

present general rule, p. 348.

exceptions, pp. 348,349 .

misapprehensions, p. 349.

GENERAI ISSUE.

(See General Traverse.)

GENERAL TRAVERSE, 258, 341.

(See Traverse, General.)

GIST,

of certain actions, $77,83,98,100,103,384$.

GRAND ASSIZE, 361.

GRAND JURY OF ATTAINT, 361.

H.

HABEAS CORPORA, 362.

HABERE FACIAS POSSESSIONEM, 382.

HABERE FACIAS SEISINAM, 382.

HEIR,

how to plead heirship, 324 .

HEIRS AND DEVISEES AS PARTIES, 206.

HILARY RULES OF 1834, 384.

(See General Issue in each action.)

HOUSE OF LORDS, APPEAL TO, 18.

HUSBAND AND WIFE,

as parties to actions, 190, 200, 211, 219 .

HYPOTHETICAL PLEADING, 334. 
IMPARLANCE, 234.

IMPLIED ASSUMPSIT, (See Common Counts, and Geteral Assumpsit.)

INCONSISTENT PLEAS, 317.

INCORPOREAL HEREDITAMENTS, 94, 127, 138.

INDEBITATUS ASSUMPSIT, 56, 57.

INDUCEMENT, 32, 95, 98, 265, 278, 306. mode of pleading it, 330 .

INFANTS AS PARTIES, 207, 220.

INJURIA SINE DANINO, 5.

INJURY, 344.

INQUEST, 163, 164, p. 352.

INQUIRY, 44.

(See Judgment.)

INSIMUL COMPUTASSENT, 56, 57.

INSPECTION, TRIAL BY, 355.

INTERLOCUTORY JUDGMENTS, 375.

by default of appearance, 375 .

by nil dicit, 375 .

by non sum informatus, 375 .

by confession, 375 .

INTRUSION, 122, 147.

ISSUE, 16.

how made up, 362 .

(See Articles 2, 3, 4, 5, Cimapter XiII.)

ISSUE, GENERAL.

(See General Traverse.)

J.

JEOFAILS, STATUTES OF, 240.

JOINDER IN DEMURRER, 306.

JOINDER IN ISSUE, 306.

JOINDER OF ACTIONS 228, 229.

JOINDER OF DEFENDANTS IN ACTIONS EX CONTRACTU, 209, $210,211$.

JOINDER OF DEFENDANTS IN ACTIONS EX DELICTO, 224. JOINDER OF PARTIES DEFENDANT. IN REAL ACTIONS, 227.

JOINDER OF PARTIES PLAINTIFF IN REAL ACTIONS, 225, 226. JOINDER OF PLAIN'TIFFS IN ACTIONS EX CONTRACTU, 190. JOINDER OF PLAINTIFFS IN AC'IIONS EX DELICTO, 200.

JUDGIENT DEFINED, 373, 374. interlocutory judgment, 375 .

(See JudgMeNT in each action.)

JUDGMENT, FINAL, $376,377,378,380$. 
JUDGMENT, how pleaded, 360.

JUDGMENT NON OBSTANTE VEREDICTO, 371.

JURISDICTION, PLEAS TO.

(See Pleas to the Jurisdiction.)

JURY EXTRAORDINARY, 361.

JURY ORDINARY, 362.

JURY, TRIAL BY, 361, 362.

JUSTIFICATION, PLEAS IN, 293.

(See Defences in Bar.)

K.

KING'S BENCH, 18.

LAND, theory of rights in, 121-129.

LAW,

defined, 1.

issue of, 306.

matter of, need not be alleged, 330 .

wager of, $3 \tilde{9} 9$.

LE'TTERS TESTAMENTARY, profert to be made, 36 .

LEVARI FACIAS, execution, 383.

LIBEL, justification in, 265, p. 392.

LIBERUM TENEMENTUM, plea of, 162, 298, p. 390.

LIMITATIONS, plea of statute, 294.

LIVERY OF SEISIN, how pleaded, 324 .

LOCAL AND TRANSITORY ACTIONS, 30.

M.

MAIICIOUS PROSECUTION, 88, 224.

MARLBRIDGE, statute of, 108.

MERCY, 376.

MESNE PROFITS, action for, 116.

definition and nature, 116.

MISE,

issue in writ of right, 361 .

MISERICORDIA, 376.

MISNOMER, 322.

MIXED ACTIONS, 8. 
[The references are to soctions except when otherwise expressed.]

MODERN REAL ACTIONS, 165-173.

ejectment, 166-171.

trespass to try title, $172,173$.

writs of entry, 174.

writs of disseisin, 175 .

dower, 176.

partition, 177.

forcible entry and detainer, 178, 179.

MODO ET FORMA, 288.

MONEY COUNTS, 56.

MIOR'T D'ANCESTOR, 143.

MOTION FOR JUDGMENT, 371.

MOTION FOR NEIV TRIAL, 369.

MOTION FOR REPLEADER, 372.

MOTION IN ARREST, 370.

MO'TIVE,

not essential in trover, 90, 102.

N.

NAMES,

of persons to be specified, 322 .

when omission excused, 322.

NEGA'IIVE AVERMENTS, two do not make an issue, 333.

NEGATIVE PREGNANT, 332.

NEGLIGENCE, 217.

\section{(See CASE.)}

NEGOTIABLE INSTRUMENTS, 37, 42, 59.

NE INJUSTE VEXES, writ of, 137.

NEW ASSIGNMENT, 309.

NEW TRIAL, motion for, 369.

NIL CAPIAT, 376.

NIL DICIT, judgment of, 375.

NISI FECERIS, in writs, 10.

NISI PRIUS, 362.

(See Forms of Writs.)

NON ASSUMPSIT, 262.

NON CEPIT, 268.

NON DETINET, 267.

NONEEASANCE.

(See Assumpstr.)

NON OBSTANTE VEREDICTO, 371

NON PROS., judgment of, 375 .

NONSUIT, judgment of, 375 .

NON SUM INFORMATUS, 375.

NOT GUILTY, 264, 265, 266.

NOT POSSESSED, 279, 280. 
NOVEL DISSEISIN, writ of, 139.

NUISANCE, writ of, 140.

(See Writ, Form 32.)

NUL TIEL RECORD, 260, 261.

NUNQUAM INDEBITATUS, 260.

OFFICERS,

O.

when exempt from liability, 212.

ORAL PLEADING, 15.

ORDER OF PLEAS, 346.

ORIGINAL WRITS, 10-11.

OYER,

demand of, 231.

P.

PAROL DEMURRER, 247.

PARTICULAR ESTATE,

how to be pleaded, 324 .

PARTICULARITY OF ISSUE.

(See Art. V., Ch. XIII.)

PARTICUI,ARS, demand of, 222.

PARTIES IN REAL AC'TIONS, 225, 226, 227.

PARTIES TO ACTIONS PERSONAL.

(See Plaintiffs and Defendants in Actions ex Contractu, also Ex DeLICTO.)

PARTITION, modern, 177.

PARTITION, writ of, 158.

PAYMEN'T, plea of, 292.

PENALTY, 44.

PEREORIIANCE OF CONDITIONS, how pleaded, 329 .

(See Condjtion, Performance of.)

PERSON, pleas to the, 249. 250.

PERSONAL ACTIONS, classified, 9.

PLACE,

when to he stated, 319 .

in replevin, 115.

(See Venuf and Avowry.)

PLAINTIFFS IN ACTIONS EX CONTRACTU, 180-190. general rule, 181.

as to bonds and deeds, 182, 183.

as to simple contracts, 184 .

as to contracts of carriers, 185 .

as to assignees of choses, 186 .

as to agents, 187 .

as to corporations, 188.

as to executors and administrators, 189 .

as to joinder of plaintiffs, 190 .

as to husband and wife, 190. 
[The references are to sections except when otherwise expressed.]

l'LAIN'TIFFS IN ACTIONS EX DELICTO, 191-200.

general rule, 191.

as to absolute rights, 192 .

as to relative rights, 193 .

as to personal chattels, 194.

as to real property, 195 .

as to real property incorporeal, 196.

as to assignees, 197.

as to executors and administrators, 198.

as to assignees in bankruptcy, 199.

as to joinder of plaintiffs, 200 .

as to husband and wife, 200 .

P'IAINTIFES IN REAL ACTIONS, 225, 226.

P'LEA, definition of, 243.

l'LEA AND DEMURRER, not permitted, 318.

PLEADING, defined, 14.

l'LEADING BAD IN PART, 339.

PLEADINGS,

defined, 14.

history of, 15 .

immediate object of, 16.

PLEAS,

conclusion of, $254,255$.

Forms of. (See Forms, pp. 365-392.)

PLEAS IN ABATEMEN'T, nature and classification, 248.

on account of disability of plaintiff, 219 .

on account of disability of defendant, 250 .

on account of defects in count or declaration, 251 .

to the writ or bill, 252 .

statutory restrictions, 253.

conclusion in, 254.

judgment in, 255.

PLEAS IN BAR, 256, 303.

(See Defences in Bar.)

PIEAS IN CONFESSION AND AVOIDANCE, 289, 302.

PLEAS IN ESTOPPEL, 303.

PLEAS IN SUSPENSION, 247.

PLEAS TO THE JURISDICTION,

defined and classified, 245.

requirements of, 246 .

conclusion and judgment in, 254, 255.

I'LEDGES OF PROSECUTION, 33.

POSSESSION AND PROPERTY, 121, 122, 123, 124.

POSSESSION AS TITLE, 268, 323.

POSSESSORY ACTIONS REAL, 138.

writs of assize, 138.

novel disseisin, 139.

assize of nuisance, 140 .

assize of darrein presentment, 141 .

assize of juris utrum, 142 .

assize of mort d'ancestor, 143.

writs of entry, 144. 
[The references are to sections except when otherwise expressed.]

POSSESSORY ACTIONS REAL,-continued.

entry sur disseisin, 145 .

entry sur alienation, 146.

entry sur intrusion, 147.

entry sur abatement, 148.

entry ad terminum, 149.

causa matrimonii, 150 .

entry as affected by feoffment and descent, 151 .

writs ancestral possessory, 152.

writ of quare ejecit, 153.

writ of quare impedit, 154 .

writ of waste, 155 .

writ de ejectione firmæ, 156.

writ of deceit, 157.

writ of partition, 158.

writs of warrantia chartæ, 159.

writ of curia claudenda, 159.

POSTEA, 363.

PRECEDEN'TS IN PLEADING, should be followed, 337 .

PRACIPE IN CAPITE, 126.

PRESCRIPTION, TITLE BY, how pleaded, 324 .

PRIMORDIAL CONCEPTIONS, 1-6.

PROCEEDINGS IN REPLEVIN, Note II.

Marlbridge, statute of, p. 350 .

pledges in, p. 357.

writ de proprietate probanda, pp. 351, 352 .

capias in withernam, p. 353.

declaration in the detinuit and detinet, pp. 353, 354.

removal of action, p. 354 .

Stat. Westm. II. c. 2, p. 355.

second deliverance, p. 356 .

PROCESS, 12, 13.

PRODUCTION OF SUIT, 33.

PROFERT,

defined, 34.

relaxation of rule, 35 .

extension of rule, 36 .

qualification of rule, 36 .

limitation of rule, 37 .

effect of, 38.

PROLIXITY, RULES TO PREVENT.

(See Art. VII., Ch. VIII.)

PROMISE EXPRESS OR IMPLIED.

(See Assumpsit.)

PROPRIETARY ACTIONS REAL, 125-137.

writs of right proper, 126.

right patent, 126.

quia dominus remiset, 126.

precipe in capite, 126.

right patent in London, 126.

writs in nature of writs of right, 127.

writ of right close in, 127.

ancient demesne, 128. 
[The references are to sections except when otherwise expressed.]

PROPRIETARY ACTIONS REAL, - continued.

writ of de rationabile parte, 129 .

right of advowson, 130 .

right of dower, 131.

dower unde nihil habet, 132.

quod permittat, 133 .

writs of formedon, 134.

quod ei deforceat, 135 .

other writs, 136.

writ of ne injuste vexes, 137 .

curia claudenda, 137 .

monstraverunt, 137.

warrantia chartæ, 137.

estrepment, 137.

PROTESTATION IN PLEADING, 308.

PROVISO,

when to be pleaded, 353 .

Q.

QUALITY, should be specified, 321.

QUANTITY, should be specified, 32 i.

QUANTUM MERUIT, 56.

QUANTUM VALEBANT, 56 .

QUARE CLAUSIM FREGI'T, 78, 79, 192.

QUARE EJECIT, writ of, 153, p. 360.

QUARE IMPEDIT, writ of, 154 .

QUASI CONTRACTS, 54, 56, 92, Note I.

QUI NON NEGAT FATETUR, 290.

QUID PRO QUO, 54.

QUO MINUS, writ of, 20.

QUOD BREVE CASSITUR, 254.

QUOD EI DEFORCEA'T, writ of, 135.

QUOD PERMITTAT, writ of, 133.

QUOD RECUPERET, judgment of, 376.

R.

REAL ACTION, 118.

REBUTTER, 307.

(See Ancient Real Actions.)

RECI'TAL,

pleadings should not be by way of recital, 335 .

RECORD,

trial by, 360 .

REGISTER OF WRITS, 10.

REJOINDER, 307.

RELEASE, 292.

REPLEADER, 307. 
[The references are to sections except when otherwise expressed.]

REPLEADER, motion for, 372.

REPLEVIN, 105.

history of, 106, 107, 108, 109, 110, 111, 112.

characteristic features, 113.

declaration in, 114, Note II.

judgrnent in, 115, Note II.

general issue in, 268 .

specific traverse in, 281 .

pleas in justification or excuse, 301, p. 355.

proceeding in, Note II., pp. 350-356.

recaption, p. 356.

REPLICATION,

(See Forms 21, 22.)

conclusion of plea in, 338 .

REPLICATION DE INJURIA, 270, 271 .

REPUGNANCY IN PLEADING, 331.

RESPONDEAT OUSTER, 241, 255.

RETORNO HABENDO.

RIENS EN ARRERE, 268.

(See Note II.)

RIGITS, 2.

RIGHT CLOSE IN ANCIENT DENESNE, 128.

RIGHT PATEN'T, 126.

RIGHT OF ADVOWSON, 130.

RIGH'T OF DOWER, 131.

RIGHT OF DOWER UNDE, etc., 131.

S.

SCIENTER IN CASE, 265.

SCIRE FACIAS, 72.

definition and history, 72.

(See Form 13.)

SELF-HELP, 122, 123, 162, 163.

SEVERAL COUNTS.

SEVERAL ISSUES.

(See Common Counts.)

(See Duplicity and Joinder of Action.)

SEVERAL PLEAS, $3 i 7$.

(See Duplicitr.)

SEVERANCE IN PLEAS, 313.

SHAM PLEADING, 352.

SIGNING AND ENROLMENT OF JUDGMENTS, 377.

SIGNING OF DECLARATION, 33.

SIMILITER, 306.

SINGLENESS OF ISSUE, 314-317.

SLANDER,

the words must be pleaded, 336 . 
[The references are to sections except when otherwise expressed.]

SON ASSAULT DEMESNE, plea of, 285.

SOU'TH CAROLINA, trespass to try title,172.

SPECIAL ASSUMPSIT, 54.

SPECIAL CASE, 367.

SPECIAL PLEADERS, 25, 26.

SPECIAL PLEAS.

(See Justification, Excuse, and Discharge.)

SPECIAL TRAVERSE.

$$
\text { (See Traverse, Special.) }
$$

SPECIALTY, 34, 37, 45.

(See Covenant.)

SPECIAL VERDICT, 366.

SPECIFIC TRA VERSE.

(See Traverse, Specific.)

STATUTE OF FRAUDS, 330.

STATUTE OF LIMITATIONS, plea of, 294.

STA'TUTE OF MARLBRIDGE, 108.

STATUTE OF WESTM. II., 109.

STATUTES : what statutes need not be pleaded, 330 .

SUI'T, production of, 33.

SURPLUSAGE, 342.

SURREBUTTER, 307.

SURREJOINDER, 307.

SUSPENSION, Pleas in.

(See Preas in Suspension.)

T.

TENDER, 260, 295, 296.

TENDER OF ISSUE, 258, 259, 286, 305, 306.

TEXAS,

(See General, Specific, and Special Traverses.)

trespass to try title, 173.

TIME,

certainty of, 320 .

TITLE,

how pleaded, $323,324,325,326,327$.

TORT,

waiver of, 55 .

qualification of, 102.

TRANSITORY AND IOCAL ACTIONS, 30.

TRAVERSE, specific traverse defined, 257. general traverse defined, 258. special traverse defined, 259. general traverse in debt, 260. in covenant, 261. 
[The references are to sections except when otherwise expressed.1

TRAVERSE, - continued.

general traverse in assumpsit, 262.

in account, 263.

in trespass, 264.

in case, 265 .

in trover, 266.

in detinue, 267.

in replevin, 268.

in ejectment, 269.

de injuria, 270, 271.

specific traverse, general rule, 272.

in debt, 273.

in covenant, 274 .

in assumpsit, 275 .

in account render, 276.

in trespass, 277.

in case, 278.

in trover, 279.

in detinue, 280.

in replevin, 281 .

special traverse, history, 282.

requisites of, 283.

rules governing, $28 t$.

abnormal form, 285.

conclusion, 285.

practice when defective, 287.

principles relating to traverses in general, 288.

conjunctive and disjunctive, 272.

affirmative, when, 257.

TRESPASS ON THE CASE, 86.

history, 87.

nature and features, $88,89,90,91,92,93,94$.

as to rights of person, 88 .

rights in the person of others, 89 .

as to personal chattels, 90 .

as to contracts, $91,92,93$.

as to real property, 94 .

declaration in, 95 .

judgment in, 96 .

general traverse in, 265.

(See Forms 18, 19.)

specific traverse in, 278.

pleas in justification or excuse, 302.

TRESPASS TO TRY TITLE, 172, 173.

in South Carolina and Alabama, 172.

in Texas, 173.

TRESPASS VI ET ARMIS, 73.

history, 74.

nature and characteristic features, $75,76,77,78$.

declaration in, 79 .

judgment in, 80 .

clausum fregit, $\mathbf{7 8}, \mathbf{7 9}$

(See Forms 14 and 15.)

general traverse in, 264.

specific traverse in, 277.

pleas in justification or excuse, 298. 
TRIAL, 354 .

by inspection, 355 .

by witnesses, 356 .

by certificate, 357 .

by wager ot battle, 358 .

by wager of law, 359 .

by record, 360 .

by jury extraordinary, 361.

by jury ordinary, 362 .

TROVER, 97.

history of, 98, 99, 100, 101.

qualifications and distinctions, 102.

declaration in, 103.

judgrnent in, 104.

general traverse in, 266.

specific traverse in, 279 .

pleas in justification or excuse, 299.

(See Form 20.)

TRUSTEES AS PARTIES, 203.

TRUTH OF PLEADINGS, 352.

UBI JUS IBI REMEDIUM, 5.

UNEXPIRED CREDIT, 294, 297.

USE AND OCCUPATION, 56.

U.

VALUE,

V.

when to be alleged, 321 .

VARIANCE, 251, 364.

VENIRE FACIAS, 362.

de novo, 368 .

VENUE, 30, 319, 362.

VERDICT, form and tenor of, 363 .

variance, 364.

special verdict, 366 .

special case, 367.

exceptions, 368 .

motion for new trial, 369 .

motion in arrest, 370 .

motion for judgment, 371 .

motion for repleader, 372.

VERIFICATION, 283, 286, 349.

VIDELICET, 320, 331.

VIEIVS, 233.

VOUCHER OF WARRANTY, 233.

IV.

WAGER OF BATTLE, TRIAL BY, 368.

WAGER OF LAW, TRIAL BY, 359. 
WARRANTIA CHARTE, 137, 159.

WARRANTY, VOUCHER OF, 233.

WASTE, WRIT OF, 150.

WESTM. II., STATUTE OF, 87.

WITNESSES, TRIAL BY, 356.

WORK AND LABOR.

(See Common Counts, also Note I.)

WRITS, ANCIENT, abolished.

(See Note III. p. 358.)

WRITS, FORMS OF.

$$
\text { (See Forms.) }
$$

- WRITS,

original, 10,11 .

judicial, 11, 12, 13.

WRITS OF ERROR, 379, 38 .

WRONGDOER.

WRONGS,

(See Trespass, Trover, and Case.)

defined, 3. 

